\title{
MIROSŁAW PRZYGODA
}

\section{Atrakcyjność inwestowania w regionach słabo rozwiniętych}

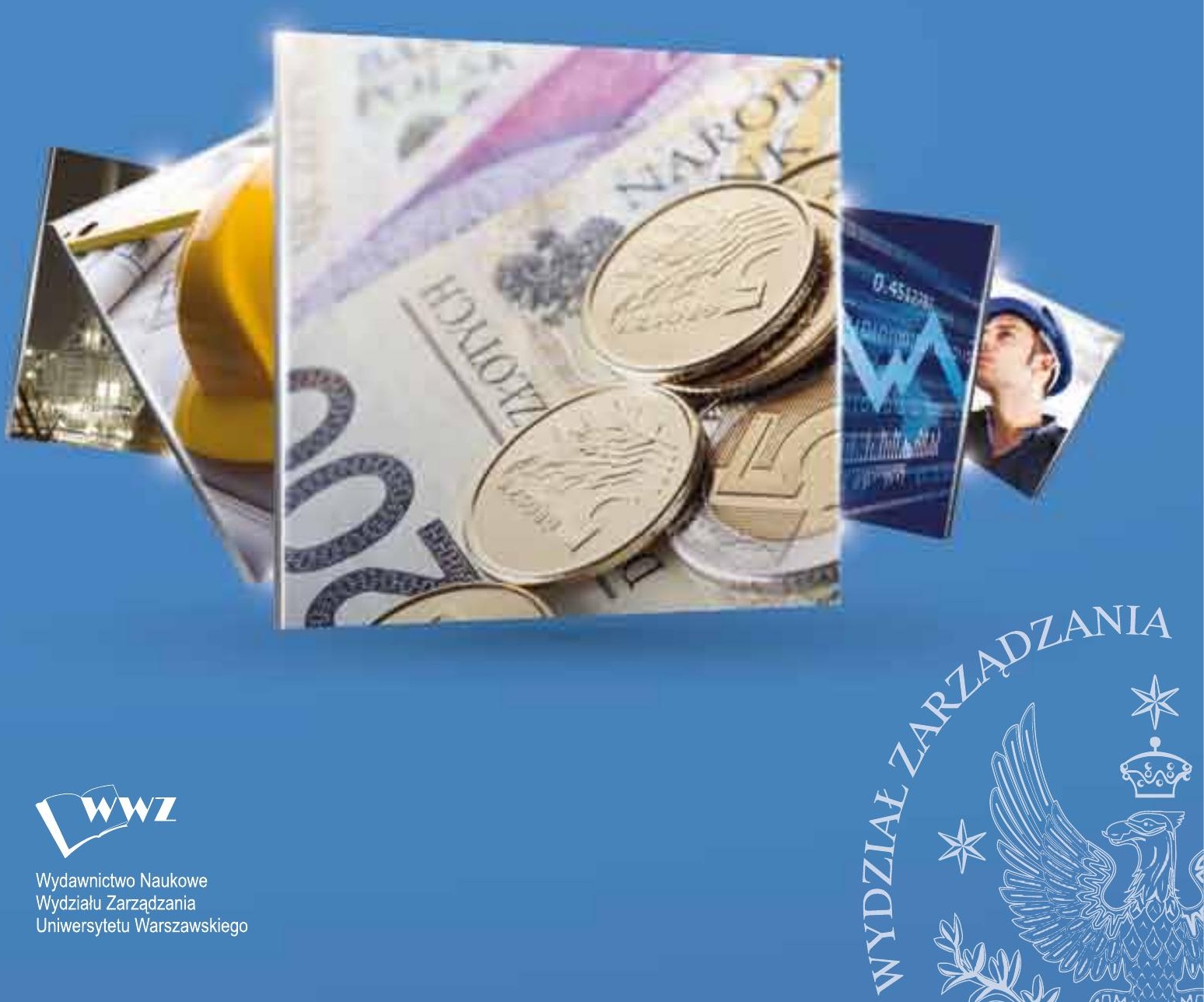


Atrakcyjność inwestowania w regionach słabo rozwiniętych 



\section{Atrakcyjność inwestowania}

Mirosław Przygoda

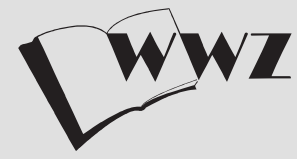

Wydawnictwo Naukowe Wydziału Zarzadzania Uniwersytetu Warszawskiego

\section{w regionach \\ słabo rozwiniętych}

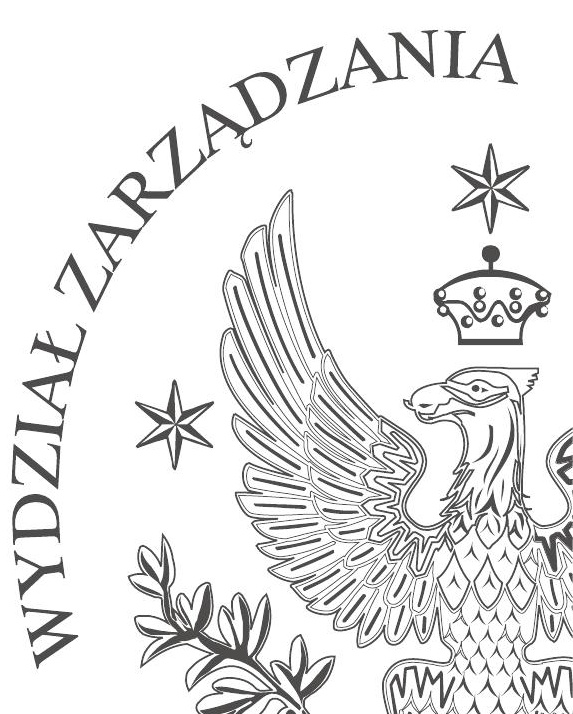


Recenzja

prof. zw. dr hab. Jan Śliwa (Wydział Zarządzania UW)

prof. ALK dr hab. Witold Bielecki (Akademia Leona Koźmińskiego)

Red a kcja

Anita Sosnowska

Projekt okładki

Agnieszka Miłaszewicz

(C) Copyright by Wydawnictwo Naukowe Wydziału Zarządzania Uniwersytetu Warszawskiego

Warszawa 2013

ISBN 978-83-63962-33-3

ISBN 978-83-63962-34-0 (online)

DOI: 10.7172/2013.wwz.9

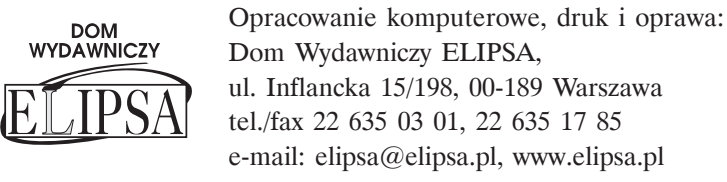




\section{Spis treści}

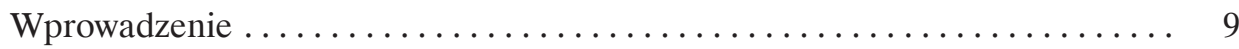

Rozdział I. Geneza regionów. ...................... 15

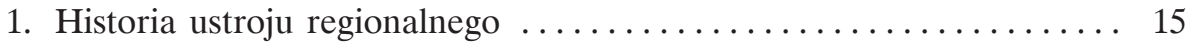

2. Pojęcie regionu ........................... 20

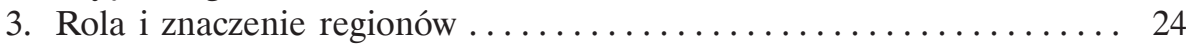

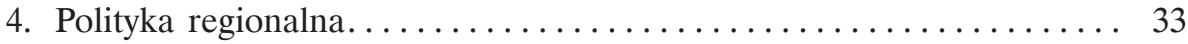

5. Zarządzanie na poziomie regionalnym i lokalnym ............ 34

ROZDZIAŁ II. Czynniki determinujące powstanie regionów......... 36

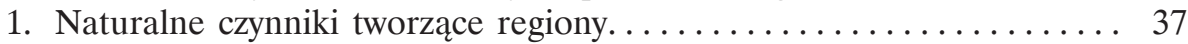

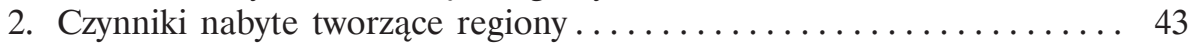

3. Regionalizm i regionalizacja ..................... 66

Rozdział III. Wybrane teorie rozwoju regionalnego $\ldots \ldots \ldots \ldots \ldots \ldots \ldots$

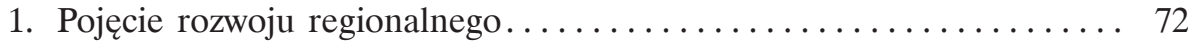

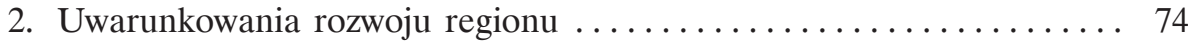

3. Koncepcje rozwoju regionalnego .................. 76

3.1. Klasyczne teorie lokalizacji . . . . . . . . . . . . . . 77

3.1.1. Teoria przewagi absolutnej Adama Smitha............ 77

3.1.2. Teoria kosztów komparatywnych Davida Ricardo ........ 78

3.1.3. Teoria sfer rolniczych Heinricha von Thünena ... . . . . . 79

3.1.4. Teoria lokalizacji przemysłu Alfreda Webera.......... 79

3.1.5. Istotne czynniki wpływające na lokalizację ......... 80

3.1.6. Teoria ośrodków centralnych Waltera Christallera ...... 83

3.2. Wczesne teorie rozwoju regionalnego ............... 85

3.2.1. Teoria okręgów przemysłowych Alfreda Marshalla...... 85

3.3. Neoklasyczne teorie rozwoju regionalnego ............ 87

3.4. Modele fazowe rozwoju regionalnego ................ 88

3.4.1. Teoria długich cykli Nikołaja Kondratiewa.......... 88

3.4.2. Teoria życia produktu.................. 90

3.4.3. Teoria cyklu życia regionu Walta Rostowa ........... 93

3.5. Model Keynesowski .......................... 96

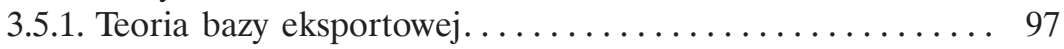


3.6. Teorie zrównoważonego rozwoju regionalnego ............ 99

3.6.1. Teoria zrównoważonego wzrostu Ragnara Nurkse’a ...... 99

3.6.2. Teoria „wielkiego pchnięcia” Paula Rosensteina-Rodana... 101

3.6.3. Teoria nieograniczonych zasobów pracy Arthura Lewisa . . . 102

3.7. Teorie niezrównoważonego wzrostu regionalnego . . . . . . . . 103

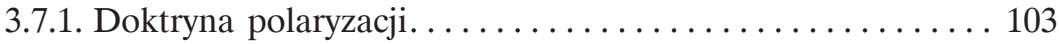

3.7.2. Teoria biegunów wzrostu François Perroux .......... 103

3.7.3. Koncepcja okrężnej i kumulatywnej przyczynowości Gunnara Myrdala................................ 104

3.7.4. Koncepcja polaryzacji sektorowo-regionalnej Alfreda

O. Hirschmana .......................... 105

3.7.5. Teoria centrum-peryferia Raula Prebischa ........... 106

3.8. Urbanistyczne teorie wzrostu regionalnego. . . . . . . . . . . . 107

3.8.1. Teoria City Limits Paula Petersona . . . . . . . . . . . . 108

3.8.2. Teoria „maszyny wzrostu” Johna Logana i Harvey'a

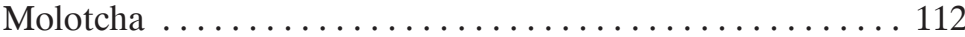

3.8.3. Teoria „maszyny rozrywki” Terrego N. Clarka . . . . . . . . 113

3.8.4. Teoria reżimów Clarence Stone'a............... 115

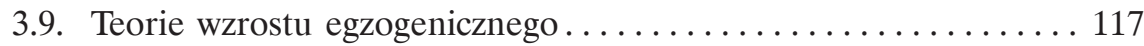

3.10. Teorie wzrostu endogenicznego. . . . . . . . . . . . . 117

3.11. Koncepcja rozwoju regionalnego oparta na klastrach

przemysłowych ......................... 119

4. Najnowsze koncepcje rozwoju regionalnego . . . . . . . . . . . 122

Rozdział IV. Polityka regionalna Unii Europejskiej............... 123

1. Geneza polityki regionalnej w Unii Europejskiej . . . . . . . . . . . . 123

2. Główne etapy w kształtowaniu się polityki regionalnej UE . . . . . . 126

3. Cele realizowane $w$ ramach polityki regionalnej.............. 130

4. Europejskie Fundusze Strukturalne. . . . . . . . . . . . . . . . . . . . . . 137

4.1. Fundusze jako element budżetu Unii Europejskiej...... . . . . 137

4.2. Fundusze strukturalne $\mathrm{w}$ ramach perspektyw finansowych UE. . 139

4.3. Europejski Fundusz Rozwoju Regionalnego (EFRR). . . . . . . . 140

4.4. Europejski Fundusz Społeczny $($ EFS) . . . . . . . . . . . . . . 142

4.5. Fundusz Spójności (FS) . . . . . . . . . . . . . . . . . 143

4.6. Europejski Fundusz Rolny na rzecz Rozwoju Obszarów Wiejskich

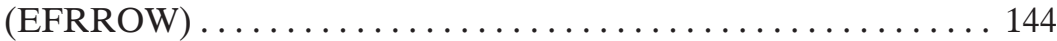

4.7. Europejski Fundusz Orientacji i Gwarancji Rolnej (EFOiGR). . 145

Rozdział V. Rozwój Polski Wschodniej .................... 147

1. Charakterystyka Polski Wschodniej...................... 148

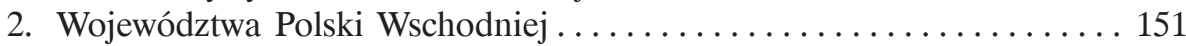

2.1. Województwo lubelskie. ...................... 151

2.2. Województwo podkarpackie.................... 154 
2.3. Województwo świętokrzyskie................... 156

2.4. Województwo warmińsko-mazurskie ................ 159

2.5. Województwo podlaskie ...................... 162

3. Polska Wschodnia w kontekście unijnej polityki spójności ......... 165

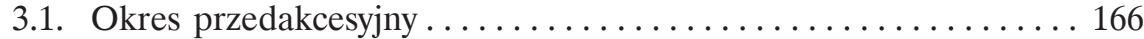

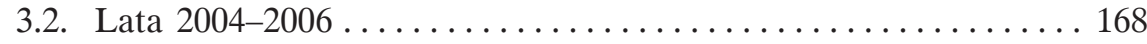

3.3. Czwarta perspektywa finansowa obejmująca lata 2007-2013 . . . 173

3.4. Poszczególne programy operacyjne ................. 178

3.4.1. Regionalne Programy Operacyjne (RPO). . . . . . . . . . 178

3.4.2. Program Operacyjny Infrastruktura i Środowisko (PO IiŚ) . . 179

3.4.3. Program Operacyjny Kapitał Ludzki (PO KL) ......... 181

3.4.4. Program Operacyjny Innowacyjna Gospodarka (PO IG). . 184

3.4.5. Program Operacyjny Europejska Współpraca Terytorialna

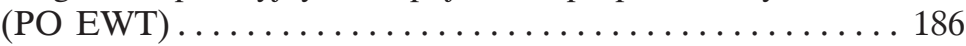

3.4.6. Program Operacyjny Pomoc Techniczna (PO PT). . . . . . 189

4. Program Operacyjny Rozwój Polski Wschodniej (PO RPW) . . . . . . . 190

Rozdział VI. Atrakcyjność inwestycyjna regionów . . . . . . . . . . . . . 197

1. Atrakcyjność $\mathrm{w}$ podstawowym znaczeniu . . . . . . . . . . . . 197

2. Pojęcie atrakcyjności inwestycyjnej regionu . . . . . . . . . . . . . . 198

3. Ocena atrakcyjności inwestycyjnej Polski Wschodniej ............. 199

3.1. Analiza SWOT ... . . . . . . . . . . . . . . . . . . . . . 199

3.2. Atrakcyjność regionu mierzona poziomem inwestycji ........ 208

3.3. Atrakcyjność polskich regionów według raportów Instytutu Badań nad Gospodarką Rynkowa.......................... 214

4. Atrakcyjność Polski Wschodniej jako miejsca inwestycji . . . . . . . . 221

Rozdział VII. Możliwości zwiększenia atrakcyjności inwestycyjnej regionów

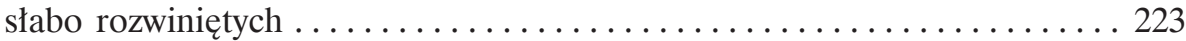

1. Wybrane wskaźniki opisujące sytuację gospodarczo-społeczną regionów słabiej rozwiniętych $\mathrm{w}$ Polsce . . . . . . . . . . . . . . . . . . . . . . 224

2. Ocena zmian w atrakcyjności inwestycyjnej regionów Polski Wschodniej. . 234

3. Sposoby na zwiększenie atrakcyjności inwestycyjnej regionów słabiej

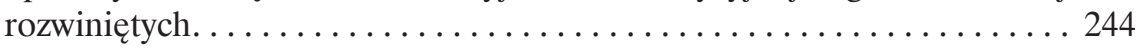

4. Bezpośredni udział społeczeństwa w kierowaniu rozwojem regionu . . 246

Rozdział VIII. Koncepcja zwiększenia bezpośredniego udziału obywateli

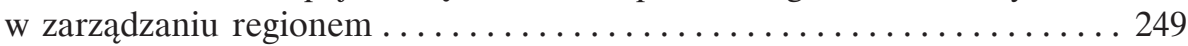

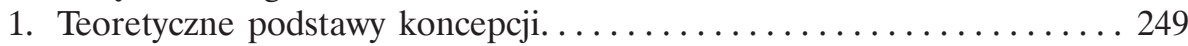

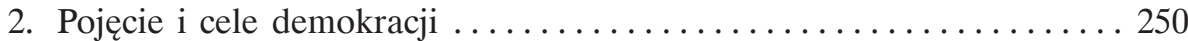

2.1. Cykliczność zmian demokratycznych ............... 253

2.2. Potencjalna zdolność obecnego systemu demokratycznego do

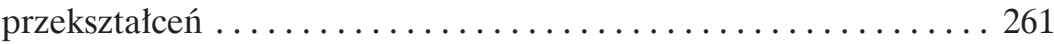


2.2.1. System demokracji pośredniej.................. 261

2.2.2. Ustrój polityczny w Polsce................... 262

2.2.3. Demokracja bezpośrednia .................. 265

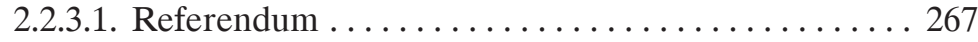

2.2.3.2. Plebiscyt ..................... 269

2.2.3.3. Obywatelska inicjatywa ustawodawcza ........ 271

2.2.3.4. Weto ludowe .................... 272

2.2.3.5. Budżet partycypacyjny. . . . . . . . . . . . . 274

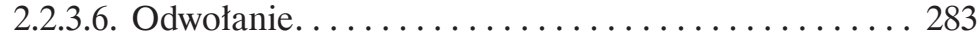

2.2.4. Zalety demokracji bezpośredniej na tle systemu demokracji

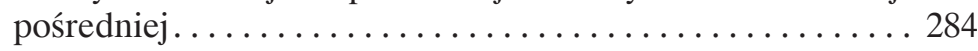

2.2.5. Kierunki zmian we współczesnej demokracji ......... 287

3. Wzmocnienie atrakcyjności inwestycyjnej regionów słabiej rozwiniętych . . 291

4. Zarys koncepcji zwiększenia udziału obywateli w zarządzaniu regionem. . 296

Rozdział IX. Współudział mieszkańców w zarządzaniu regionem na tle wybranych

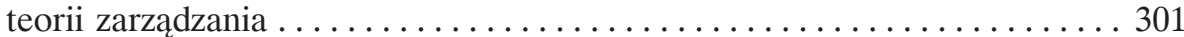

1. Nauki o zarządzaniu . . . . . . . . . . . . . . . . . . . . 301

2. Koncepcja „obywatelska” na tle wybranych teorii zarządzania...... 302

3. Znaczenie wybranych teorii zarządzania dla koncepcji zwiększonego udziału obywateli w zarządzaniu regionem ............... 308

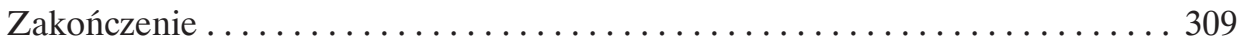

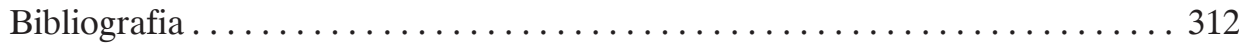

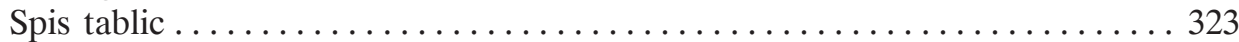

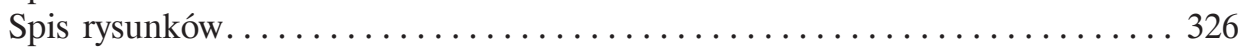




\section{Wprowadzenie}

Niniejsza monografia została poświęcona zagadnieniom związanym z atrakcyjnością inwestowania na terenach słabo rozwiniętych. Wybór tematu był następstwem zauważalnego procesu zwiększania się znaczenia regionów i kreowania związanej z nimi polityki zarówno w Polsce, jak i na świecie. Obecnie rola regionów polega $\mathrm{w}$ dużej mierze na zagospodarowaniu potencjału, jaki skumulowany jest w społeczeństwie i wykorzystaniu go jako instrumentu służącego zagwarantowaniu ciągłego i niezakłóconego postępu. Chodzi tutaj między innymi o wykazywaną przez mieszkańców: przedsiębiorczość oraz innowacyjność w szukaniu rozwiązań, inicjatywę obywatelską, zaangażowanie w realizację zaplanowanych projektów i chęć polepszenia warunków własnego życia. Oblicze danego terytorium stanowi odbicie dążeń i ambicji zamieszkującej go populacji ludzkiej realizowanych w miarę istniejących możliwości. Odzwierciedla także specyfikę i związane z tym unikalne cechy danej zbiorowości.

Niestety, nie wszystkie obszary dysponują jednakowymi warunkami umożliwiającymi osiągnięcie pożądanego sukcesu. W praktyce, w granicach każdego państwa istnieją tereny mające większe i mniejsze szanse rozwojowe. Na stan taki składa się wiele różnorodnych czynników. Część z nich ma pochodzenie naturalne związane z klimatem, zasobami surowcowymi, ukształtowaniem terenu, położeniem geograficznym oraz odmiennością występującej lokalnie flory i fauny. Pozostałe to czynniki nabyte, stawiające na pierwszym planie określone struktury: etniczne, administracyjne i gospodarcze. Bogactwo, połączone ze sprzyjającą konfiguracją czynników naturalnych stawia tereny, na których występują, w uprzywilejowanej sytuacji w stosunku do innych obszarów. Jednakże przy właściwym i przemyślanym wykorzystaniu możliwości czynników nabytych istnieje szansa na zniwelowanie międzyregionalnych różnic społeczno-gospodarczych. Ma to bardzo istotne znaczenie szczególnie w odniesieniu do terenów uważanych za zacofane, uboższych w zasoby naturalne i słabo nasyconych infrastrukturą przemysłową.

Dzisiaj w ostry sposób zarysował się podział terytoriów na lepiej i słabiej rozwinięte. W większości przypadków można z dużą precyzją zaznaczyć granice, w jakich się zamykają. Tworzą regiony, w których opłaca się prowadzić życie i inwestować oraz takie, na których zamiera aktywność gospodarcza oraz 
odpływają ludzie i kapitał. Fakt ten odbija się negatywnie na sferze ekonomicznej każdego kraju, ponieważ pojawiają się zjawiska wysoce niekorzystne, takie jak: bezrobocie, powstawanie sfer ubóstwa i obszarów problemowych, niekontrolowane migracje ludzkie, niezadowolenie społeczne, niewykorzystanie istniejącej infrastruktury gospodarczej czy też brak nowych inwestycji gwarantujących rozwój.

Zagadnienie rozwoju regionalnego opartego na inwestycjach ma zasadnicze znaczenie. Regiony, do których napływa kapitał krajowy i zagraniczny, gdzie realizowane są nowe projekty, rozbudowywana jest istniejąca już baza przemysłowo-usługowa są bardziej atrakcyjne dla inwestorów niż inne. Stwarza to sytuację, w której regiony zaawansowane pod względem ekonomicznym rozwijają się dużo szybciej od tych posiadających słabsze warunki. Inwestycje dają siłę rozwojową oraz możliwość zaistnienia pozytywnych zmian zwiększających potencjał danego obszaru i roztaczających przed nim nowe perspektywy. Brak inwestycji przekreśla szanse na wzrost gospodarczy, rozwój i polepszenie standardu życia obywateli.

Problem nierównomiernego rozwoju regionalnego został dostrzeżony już przez „ojców ekonomii klasycznej”: Adama Smitha i Dawida Ricardo. Stworzyli oni podwaliny pod gałąź nauki, jaką jest teoria rozwoju regionalnego. Od początków XVIII wieku aż do czasów współczesnych ich następcy próbowali w dziesiątkach zaprezentowanych koncepcji znaleźć odpowiednią metodę postępowania, która pozwalałaby sterować i zarządzać procesem pożądanych zmian regionalnych. Istniejące teorie i koncepcje zostały pogrupowane według różnorodnych kryteriów, stawiających na pierwszym planie: ich cechy, poruszane zagadnienia i problemy, szczegóły ujęcia, a czasem nawet drobne detale. W zależności od autora koncepcji i kraju, zmieniał się punkt widzenia na aspekty determinujące powstawanie różnic między regionami. Według Alfreda Webera najważniejsza była lokalizacja przemysłu, według innego niemieckiego badacza - Waltera Christallera - najistotniejszy czynnik stanowiła dostępność dóbr i usług oferowanych przez ośrodki centralne. Na uwagę zasługują także: teoria długich cykli Nikołaja Kondratiewa, teoria cyklu życia regionu Waltera Rostowa, koncepcja „wielkiego pchnięcia” Paula Rosensteina-Rodana czy też teoria biegunów wzrostu François Perroux. Wśród badaczy podejmujących wysiłek zgłębienia trudnego tematu pojawia się długi szereg zasłużonych nazwisk, takich jak: Gunnar Myrdal, Alfred Marshall, Arthur Lewis, Paul Peterson, John R. Logan, Harvey Molotch, Terry N. Clark, Clarens Stone, Ragnar Nurske, Raul Prebisch, Alfred Hirschman, Charles Tiebout, Douglas C. North, Michael E. Porter, czy współcześnie żyjący Adam Dąbrowski z Uniwersytetu Lódzkiego. Aby można było przejść do rozważań nad istotą zmian zachodzących w regionach, niezbędnym staje się chociaż pobieżne zapoznanie się z głównymi ideami olbrzymiego dorobku naukowego w tej dziedzinie. 
Obecnie dominuje przekonanie, że stworzenie zupełnie nowej teorii w dziedzinie rozwoju regionalnego nie jest już praktycznie możliwe. Nowe koncepcje mają raczej charakter adaptacji „starych” poglądów do nowych uwarunkowań lub zapożyczania i łączenia elementów istniejących wcześniej teorii w celu zbudowania jednolitej wizji nowo zaobserwowanych zjawisk. Co więcej, w poczynania dzisiejszych specjalistów z dziedziny polityki regionalnej wdarł się pewien schemat $\mathrm{w}$ podejściu do związanych $\mathrm{z}$ tym zagadnień. Zdecydowanie większą wagę przywiązuje się do rozwiązań opartych na egzogenicznym wzroście określonych obszarów niż do jego endogenicznego odpowiednika, co skłania do bliższego przyjrzenia się temu problemowi.

Wnikliwa analiza dostępnych źródeł wykazała, że zupełnie nie eksplorowanym jeszcze polem dociekań naukowych jest możliwość zwiększenia atrakcyjności inwestycyjnej słabo rozwiniętych obszarów za pomocą metod endogenicznych. W przypadku potwierdzenia się takiego założenia, dawało to paletę nowych rozwiązań zapobiegających występowaniu niekorzystnych zjawisk w wymiarze regionalnym. Aby jednak mogło dojść do stworzenia nowej koncepcji, należało najpierw potwierdzić występowanie zjawiska, jakim jest istnienie określonej atrakcyjności inwestycyjnej regionów słabo rozwiniętych. Temu schematowi myślowemu został podporządkowany układ niniejszej pracy, składający się na nią materiał został zaś ujęty w strukturze dziewięciu rozdziałów.

W pierwszym rozdziale zajęto się genezą regionów. Złożyły się nań: historia ustroju regionalnego od starożytności po czasy najbardziej współczesne, zdefiniowanie pojęcia regionu, etymologia samego słowa, rola i znaczenie tego typu terytoriów oraz zadania polityki regionalnej w ujęciu klasycznym i współczesnym. Ostatni punkt pierwszego rozdziału został poświęcony rozgraniczeniu pojęciowemu zjawiska zarządzania na poziomie regionalnym i lokalnym.

W rozdziale drugim zostały wymienione, a następnie przeanalizowane czynniki determinujące powstawanie regionów. Dla każdego z nich starano się znaleźć przykład występowania w rzeczywistości i w praktyce, opisując jego wagę, rolę i działanie. W ostatnim punkcie tej części pracy wyjaśniono często dziś używane pojęcie „regionalizmu”, nie zapominając również o zjawisku „regionalizacji”. Dokonane zostało zdefiniowanie i rozgraniczenie obu pojęć.

Rozdział trzeci stanowi obszerną prezentację wybranych teorii rozwoju regionalnego. Zostało w nim skonkretyzowane samo pojęcie rozwoju regionalnego oraz jego uwarunkowania, a następnie w kilkudziesięciu podpunktach, opisano najważniejsze powstałe dotychczas na świecie koncepcje i teorie uszeregowane według wspólnych kryteriów. Zapoznanie się z tą częścią pracy stanowi niejako warunek zrozumienia przeprowadzonych dalej dociekań.

W rozdziale czwartym została opisana polityka regionalna prowadzona przez Unię Europejską. Wymieniony temat stanowi ważny aspekt przeprowadzonych rozważań, ze względu na jego bezpośrednie oddziaływanie w kierunku ukształto- 
wania oblicza współczesnej Europy oraz wpływu na sprawy polskie. W części tej opisana została geneza polityki regionalnej UE, główne etapy jej tworzenia, cele jakie stawiane są przed nią do realizacji oraz instrumenty, jakimi się posługuje - w formie funduszy europejskich. Ze szczególną uwagą potraktowane zostały: cel pierwszy w czwartej perspektywie czasowej (2007-2013), czyli konwergencja obszarów najbardziej zacofanych z lepiej zagospodarowanymi oraz zadania, jakie ma przed sobą do zrealizowania Fundusz Spójności. Zaprezentowane zostały kolejne wspólnotowe perspektywy finansowe wraz z opisem funkcjonujących w ich ramach funduszy strukturalnych.

Rozdział piąty został poświęcony scharakteryzowaniu aktualnego poziomu rozwoju Polski Wschodniej. Stanowi ona bowiem wyodrębniony obszar znajdujący się na północno-wschodnich i południowo-wschodnich terenach państwa. Obejmuje rubieże Rzeczypospolitej oraz jeden region położony bliżej jej centrum. W sumie tzw. Polskę Wschodnią tworzy pięć województw: lubelskie, podkarpackie, podlaskie, świętokrzyskie i warmińsko-mazurskie. Wszystkie one charakteryzują się dużo niższym poziomem rozwoju społeczno-ekonomicznego w stosunku do reszty jednostek podziału administracyjnego na ich szczeblu. Do niedawna były także najbardziej zacofanymi obszarami w całej Europie. Stanowily wprost idealny, na potrzeby niniejszej pracy, przykład regionów słabo rozwiniętych. Zagadnienie ich dostosowania do poziomu, prezentowanego przez pozostałe tereny naszego państwa, stanowi od wielu dziesięcioleci poważny problem natury polityczno-społecznej i gospodarczej. Każde z pięciu problemowych województw zostało dokładnie scharakteryzowane z punktu widzenia: położenia, powierzchni, liczby ludności, najważniejszych zasobów naturalnych, zaplecza edukacyjnego, posiadanych atrybutów oraz wiodącej/ych gałęzi gospodarki. Następnie opisane zostało miejsce Polski Wschodniej w kontekście unijnej polityki spójności. To zagadnienie zostało rozbite na: okres przedakcesyjny, lata 2004-2006 i aktualną perspektywę czasową 2007-2013. Środki finansowe postawione do dyspozycji Polski przez Unię Europejską zostały określone w sposób ogólny, ich rozdysponowanie na poszczególne województwa oraz podział na pojedyncze programy operacyjne. Dane ukazano w postaci tablic i w ujęciu kwotowo-procentowym. Potem w szczegółowy sposób opisane zostały po kolei wszystkie Regionalne Programy Operacyjne. Przytoczone zostały stworzone dla nich osie priorytetowe, zawarte w nich główne cele oraz potencjalni beneficjenci wymienionych programów.

We wstępie rozdziału szóstego sprecyzowano pojęcia atrakcyjności inwestycyjnej regionu. Następnie, za pomocą trzech najbardziej popularnych stosowanych obecnie metod, przeprowadzono proces empirycznej oceny atrakcyjności inwestycyjnej Polski Wschodniej oraz pięciu należących do niej województw. Dla przeprowadzania analiz posłużono się danymi i informacjami zaczerpniętymi z oficjalnych źródeł Głównego Urzędu Statystycznego w Warszawie (GUS) oraz 
istniejącymi raportami Instytutu Badań nad Gospodarką Rynkową (IBnGR). W ostatnim, czwartym punkcie tego rozdziału przedstawione zostały wnioski dotyczące poziomu atrakcyjności Polski Wschodniej jako miejsca dla inwestycji.

Siódmy rozdział stanowi istotną część pracy, dotyczy bowiem rozważań nad możliwościami zwiększenia atrakcyjności inwestycyjnej regionów słabo rozwiniętych. Za pomocą danych ujętych w postaci rysunków (wykresów, map, schematów) i tablic starano się w nim wykazać, że dotychczas zastosowane metody egzogenicznego pobudzenia rozwoju regionów Polski Wschodniej nie przyniosły spodziewanych efektów w wymiarze krajowym. Aby bez konieczności dalszych wielomiliardowych nakładów zrealizować zadanie zwiększenia spójności i konwergencji tych terenów z resztą Polski, należy zastosować mniej doceniane koncepcje wzrostu regionalnego oparte na czynnikach endogenicznych. Końcową część tego rozdziału stanowi wprowadzenie do nowej teorii (koncepcji) dotyczącej rozwoju regionalnego.

Rozdział ósmy został poświęcony prezentacji Koncepcji zwiększenia bezpośredniego udziału obywateli $w$ zarzadzaniu regionem. Przedstawiono w nim teoretyczne podstawy idei współuczestnictwa mieszkańców w kierowaniu określonym terytorium stanowiącym ich miejsce pracy i życia. Opisano również narzędzia, jakimi można się posłużyć, aby zapisy teorii przenieść w praktyce do rzeczywistości. Ponadto rozdział zawiera rozważania dotyczące zalet demokracji bezpośredniej wobec systemu demokracji pośredniej oraz kierunki zmian we współczesnej demokracji. Dalej zostały w nim zidentyfikowane czynniki, które mają wpływ na podniesienie atrakcyjności inwestycyjnej regionów przy zastosowaniu nowego podejścia. Ostatnia część tego rozdziału, została poświęcona przedstawieniu w zarysie zupełnie nowej koncepcji rozwoju regionalnego na podstawie teorii endogenicznych. Przedstawione w niej rozwiązania moga zostać zastosowane zarówno w odniesieniu do obszaru pięciu województw Polski Wschodniej, jak i innych regionów słabo rozwiniętych.

Dziewiąty rozdział pracy, zajmuje się umiejscowieniem zjawiska zwiększonego udziału (współuczestnictwa) obywateli regionów w zarządzaniu zamieszkanym przez nich terenem. Odbywa się to na tle dotychczasowego dorobku nauk o zarządzaniu. Całość rozpoczyna się zdefiniowaniem zarządzania jako jednej z trzech głównych dyscyplin należących do dziedziny nauk ekonomicznych. Następnie odszukane i przedstawione zostają elementy wybranych teorii zarządzania mające odbicie w przedstawionej Koncepcji zwiększenia bezpośredniego udziatu obywateli w zarzadzaniu regionem. Ostatni rozdział podkreśla i eksponuje zarazem ścisły związek treści pracy z naukami o zarządzaniu. 



\section{ROZDZIA}

\section{Geneza regionów}

Konieczność stworzenia efektywnie funkcjonującej administracji, chęć osiągnięcia wysokiej ściągalności podatków, a także troska o zapewnienie bezpieczeństwa mieszkańcom określonego terenu leżały u podstawy działania każdej władzy państwowej. Postępujący rozwój kulturowy i terytorialny najstarszych cywilizacji uwidocznił, że sprawne zarządzanie pozostającym we władaniu obszarem możliwe jest tylko poprzez scedowanie przywilejów ośrodka centralnego na podległe mu niższe szczeble władzy. Przy istniejących bowiem w przeszłości słabych możliwościach przesyłania informacji oraz trudnościach w pokonywaniu istniejących odległości drogą wodną i lądową nie można było zabezpieczyć żywotnych interesów państwa.

Zwłoka w podjęciu ważnych decyzji, hierarchiczność organizacyjna i opieszałość w działaniu mogły doprowadzić do utraty cennych ziem i narazić ich mieszkańców na dotkliwe straty. Tylko władza lokalna odnosząca się do ograniczonego terenu umożliwiała przezwyciężenie tego typu zagrożeń. Dlatego już od czasów starożytności zorganizowane organizmy państwowe powoływały do życia jednostki władzy terytorialnej, które z dzisiejszego punktu widzenia można porównać do regionów.

\section{Historia ustroju regionalnego}

W XXI wieku integrująca się Europa podejmuje wysiłek znalezienia, głównie własnymi siłami, najlepszych rozwiązań, które sprostałyby współczesnym wyzwaniom i potrzebom. Starania te dotyczą często bardzo różnych dziedzin i zagadnień. Dotyczą również spraw zasadniczych, jak: wspólna polityka zagraniczna, rolnictwo, rybołówstwo, zagadnienia obronności, wymiar sprawiedliwości i rolnictwo oraz rzeczy mniej istotnych z ogólnego punktu widzenia, do których można zaliczyć: normy jakości wyrobów, wielkość warzyw i owoców, kwoty mleczne czy wysokość diet parlamentarzystów. Proces twórczy odnosi się również do polityki regionalnej, która jako sprawny instrument powinna wspierać rozwój jednoczących się państw. 
W oddalonych czasowo epokach działania mające charakter aktywności polityczno-ekonomicznej na szczeblu regionalnym miały jednak zgoła inny wymiar. Funkcjonujące w praktyce rozwiązania były wypadkową działań militarnych, sojuszy politycznych, wpływów dynastycznych, doktryn religijnych oraz zmysłu i talentu organizacyjnego jednostek sprawujących władzę. Obszar, na jakim były wcielane, rozciągał się na znacznie większej przestrzeni niż obecnie. W czasach starożytnych wzorce dość swobodnie przenoszone były przez ludzi w obrębie wybrzeży Morza Śródziemnego: na okalających je terenach Afryki Północnej, Azji Mniejszej i Europy Południowo-Zachodniej.

Prapoczątków budowy regionalnej państwa można dopatrywać się w strukturze organizacyjnej kraju faraonów. W latach 2850-2650 p.n.e. za czasów panowania I i II dynastii, doszło do scalenia ziem Górnego i Dolnego Egiptu w jednolity organizm. Obie części zostały podporządkowane jednemu władcy, jednakże w wyniku oddzielnej administracji zachowały aż do końca istnienia państwa zauważalną odrębność ekonomiczną i kulturową. Bogatszy, Dolny Egipt z głównym ośrodkiem w Memfis, obejmował najbardziej żyzne tereny położone w delcie Nilu. Dogodne warunki naturalne sprzyjały rozwojowi hodowli i rolnictwa oraz wpłynęły na wysoką gęstość zaludnienia. Uboższy, Górny Egipt był znacznie większy terytorialnie. Rozciągał się on wzdłuż wąskiej doliny środkowego Nilu, aż do pierwszej katarakty. Ludność tego obszaru, mniej liczna, ale bardziej zróżnicowana etnicznie, zajmowała się obok uprawy zbóż także łowiectwem oraz handlem $\mathrm{z}$ terenami położonymi na południu. Najważniejszym ośrodkiem miejskim dla tego obszaru były starożytne Teby.

Dużo później, ale jeszcze przed rokiem 1000 p.n.e. na terenie ówczesnej Grecji, zaczęły tworzyć się polis (państwa-miasta). Ośrodki te wraz z przyległymi terenami podzieliły starożytną Helladę na trzy zasadnicze części. Sfera kultury doryckiej swój wiodący ośrodek miała w Sparcie, strefa jońska - w Attyce, a część achajska - w Arkadii. Wszystkie trzy obszary wniosły odmienne wzorce i wartości do kultury europejskiej.

Sytuacja zmieniła się zasadniczo, gdy w roku 336 p.n.e. władzę objął Aleksander Macedoński. Po poskromieniu buntujących się greckich polis, zdolny strateg rozpoczął szybką ekspansję terytorialną państwa. W wyniku kolejnych podbojów stworzył imperium rozciagające się od terenów południowej Europy i Afryki Północnej, aż po północno-zachodnie Indie. Przedwczesna śmierć dotknęła władcę w wieku zaledwie 33 lat, przerywając dzieło zjednoczenia całego znanego wówczas świata. Imperium Aleksandra Wielkiego, które przetrwało około pół wieku po jego odejściu, zostało podzielone pomiędzy dowódców jego wojsk, zwanych diadochami. W obrębie dotychczasowego organizmu państwowego stworzono siedem regionów utrzymujących jeszcze przez jakiś czas wspólną monetę i jednakowe obciążenia podatkowe ludności. Podejmowano także pewne wysiłki w celu przywrócenia jedności imperium. Narastające anta- 
gonizmy pomiędzy diadochami oraz krwawe wojny pomiędzy nimi przesądzity jednak o ostatecznym upadku kraju. W miejsce jednego państwa powstały trzy silne monarchie: Macedonia z królestwem Antygonidów, Egipt z dynastią Ptolemeuszów oraz Azja Przednia (Syria) rządzona przez Seleukidów.

W III wieku p.n.e. ekspansja militarna Rzymu umożliwiła nowe, rozległe zdobycze terytorialne, które znajdowały się poza terenem Italii. By nimi zarządzać stworzono jednostkę administracyjną zwaną prowincją. Liczba prowincji szybko rosła. Ich obszar zmieniał się w zależności od prowadzonej przez rządzących polityki zewnętrznej. W momencie największego rozkwitu, w II wieku n.e., Imperium Rzymskie i jego prowincje zajmowały obszar: Europy Zachodniej wraz z południowymi terenami Wielkiej Brytanii, Afrykę Północną i dużą część dzisiejszego Bliskiego Wschodu w Azji, Morze Śródziemne stanowiło zaś wewnętrzny akwen tego państwa.

W 395 roku cesarz Teodozjusz Wielki podzielił państwo rzymskie pomiędzy dwóch synów. Powstało cesarstwo zachodniorzymskie ze stolicą w Rzymie i wschodniorzymskie ze stolicą w Konstantynopolu. Datę tę uważa się za początek średniowiecza w Europie. Upadek części zachodniej nastąpił w 476 roku.

W średniowieczu na terenie starego kontynentu istniało wiele ważnych w świecie chrześcijańskim państw. Najznamienitsze z nich to: Królestwo Francji, Rzesza Niemiecka, Królestwo Anglii, Królestwo Burgundii, Królestwo Polskie i Królestwo Węgier. We wszystkich wymienionych krajach przebiegały zasadniczo podobne do siebie procesy. Władza monarsza słabła na korzyść parlamentu i możnowładców, a ci ostatni szczególnie rośli w siłę dzięki coraz liczniej przyznawanym im przywilejom. Skutkiem tych poczynań było duże usamodzielnienie się regionów zarządzanych przez książęta i pomniejszych panów feudalnych. Nierzadko dysponowali oni majątkiem większym niż królewski, własną armią oraz prawem do prowadzenia odrębnej polityki zagranicznej i nakładania lokalnych podatków.

Cesarstwo wschodniorzymskie przetrwało ponad tysiąc lat dłużej niż zachodniorzymskie i jako Cesarstwo Bizantyjskie funkcjonowało do 1453 roku. W odpowiedzi na narastający napór ludów pochodzenia azjatyckiego wypracowało swój własny ustrój, opierający się na specyficznych jednostkach administracji państwowej, w których władza cywilna została ściśle połączona $z$ organizacją wojskową. Nowe struktury (temy) zastąpiły dotychczasowe prowincje. Im bardziej pogarszało się położenie polityczno-ekonomiczne Bizancjum i kurczyło terytorium państwa, tym szybciej rosła liczba tem, ograniczając możliwości skutecznej reakcji zarządzających nimi namiestników na nadciągające wydarzenia.

Drugą połowę XV wieku uważa się za schyłek średniowiecza na starym kontynencie. Nadchodzący po nim renesans zmienia zasadniczo mapę tej części świata. Od XVI wieku na terenie Europy powstaje wielka liczba 
księstw i królestw wchodzących przejściowo lub na stałe w strukturę większych tworów państwowych. Powstają nowe ośrodki władzy, zawiązują się sojusze i ligi o charakterze przede wszystkim militarno-obronnym. Procesom tym podlegają Niemcy, Francja, Anglia, Hiszpania, Włochy i Skandynawia. Dotyczy to także Królestwa Polskiego, które jako Korona w 1569 roku łączy się z Wielkim Księstwem Litewskim. Na mocy unii lubelskiej powstała Rzeczpospolita Obojga Narodów. Zawarta na sejmie w Lublinie umowa, ratyfikowana w tym samym roku przez króla, przewiduje dla powołanego do życia organizmu: wspólnego monarchę, jeden herb i sejm, wprowadza jednolitą walutę i zobowiązuje obie części nowego państwa do prowadzenia wspólnej polityki zagranicznej oraz obronnej. Wzorem podobnych rozwiązań europejskich obaj sygnatariusze umowy zachowują odrębne urzędy, sądownictwo, skarb oraz armię.

Procesy scalania i rozpadu istniejących państw, trwają przez całe dzieje nowożytne, to znaczy od początków renesansu, aż do wybuchu rewolucji francuskiej. Następujące po tej epoce czasy najnowsze, obejmujące załamanie się epoki napoleońskiej, kongres wiedeński, Wiosnę Ludów, rewolucję przemysłową oraz I i II wojnę światową przybliżają zasadniczo obraz Europy i jej podziału do tego jaki istnieje obecnie. Po I wojnie światowej znikają z mapy trzy wielkie monarchie będące żandarmami całego kontynentu: Rosja, Prusy i Austro-Węgry. Na ich dotychczasowych terenach odbudowują niepodległość liczne twory państwowe, które przyjmują jako wzorce bardziej demokratyczne rozwiązania ustrojowe, jak również administracyjne. Po II wojnie światowej mają jeszcze miejsce ważne wydarzenia, które dotyczą usamodzielnienia się dotychczasowych regionów państw związkowych i federacyjnych. W wyniku ruchów odśrodkowych rozpada się w dramatycznych okolicznościach Jugosławia. W sposób całkowicie pokojowy dzieli się Czechosłowacja. W rezultacie kryzysu w Rosji niepodległość odzyskują trzy kraje bałtyckie oraz Białoruś i Ukraina. W Wielkiej Brytanii szeroką autonomię uzyskują: Szkocja, Walia i Irlandia Północna. Na półwyspie Iberyjskim podobnie dzieje się w odniesieniu do Katalonii i Kraju Basków. Pomimo wyraźnej niechęci władz w Madrycie, obie hiszpańskie prowincje uzyskują niezależność w wielu dziedzinach życia, pozostając w dotychczasowych strukturach państwowych.

Wszystkie te wydarzenia zostały jednak zdominowane w XX wieku przez proces jednoczenia się Europy. Po zakończeniu II wojny światowej przywódcy państw starego kontynentu pragnęli raz na zawsze zażegnać zagrożenie wybuchem nowego konfliktu militarnego i jednocześnie zapewnić stabilność ekonomiczną Europie Zachodniej. Rozwiązaniem miała być kontrola Francji nad odradzającym się potencjałem gospodarczym Niemiec, przy jednoczesnym włączeniu gospodarki kraju nad Renem w struktury gospodarcze odbudowującej się Europy. 
Kroki integracyjne rozpoczęło zawarcie w kwietniu 1951 roku Traktatu Paryskiego. Na jego mocy powołano do życia Europejską Wspólnotę Węgla i Stali. Traktat zaczął obowiązywać od lipca następnego roku i obejmował sześć państw sygnatariuszy: Francję, Niemiecką Republikę Federalną, Belgię, Holandię i Luksemburg oraz Włochy. Porozumienie zostało podpisane na okres pół wieku, a na jego datę finalną został wyznaczony 2002 rok.

$\mathrm{Na}$ mocy dwóch umów międzynarodowych podpisanych w stolicy Italii w 1957 roku, zwanych traktatami rzymskimi, od 1 stycznia 1958 roku, zaczęły funkcjonować: Europejska Wspólnota Energii Atomowej (Euratom) oraz Europejska Wspólnota Gospodarcza (EWG). Do organizacji tych weszło sześć państw: Francja, Niemcy, Włochy oraz kraje Beneluksu. Zadaniami Euratomu były: współpraca w warunkach pokoju w dziedzinie rozwoju technologii jądrowych przy jednoczesnym tworzeniu przemysłu nuklearnego. Natomiast naczelnym celem Europejskiej Wspólnoty Gospodarczej było stworzenie w ciągu 12 kolejnych lat wspólnego rynku gospodarczego opierającego się na jednolitej polityce rolnej, transportowej i celnej. Zakładane procesy integracyjne przebiegały jednak relatywnie powoli.

Słaby wzrost ekonomiczny oraz wysokie bezrobocie były największymi problemami ugrupowania integracyjnego w latach siedemdziesiątych i osiemdziesiątych XX wieku. Brak dominującej idei politycznej, niedowład struktur administracyjnych oraz stagnacja gospodarcza stały się powszechnie odczuwalne. Możliwości wyjścia z zastoju zaczęto upatrywać w radykalnych reformach. Miały się one skoncentrować na połączeniu wspólnego rynku i wprowadzeniu w jego obrębie jednej waluty.

Jednakże dopiero ostatnia dekada XX wieku stała się momentem przełomu. Zmiany zostały zapoczątkowane podpisaniem Traktatu o Unii Europejskiej (TUE) w holenderskim mieście Maastricht. Była to międzynarodowa umowa parafowana w grudniu 1991 roku, a sygnowana w lutym roku następnego. Porozumienie, które podpisały: Belgia, Dania, Francja, Grecja, Hiszpania, Holandia, Irlandia, Luksemburg, Portugalia, RFN, Wielka Brytania i Włochy, weszło w życie w listopadzie 1993 roku. Na podstawie Traktatu, dotychczasowa EWG stała się Wspólnotą Europejską (WE). Traktat ustanawiał także Unię Europejską, która miała w przyszłości stanowić gospodarczo-polityczny związek demokratycznych państw europejskich. Unia Europejska jako organizacja międzynarodowa zastąpiła Wspólnotę Europejską w 1 grudnia 2009 r., przejmując jej obowiązki i kompetencje (Przygoda, 2012, s. 495-496).

Państwa decydujące się na integrację w ramach UE wypracowały wspólny system podziału terytorialnego, na podstawie którego funkcjonuje w tej chwili ich administracja, prowadzona jest statystyka i badania porównawcze oraz rozdysponowywane są środki finansowe pochodzące $\mathrm{z}$ unijnego budżetu. Przeprowadzony w ramach ugrupowania integracyjnego podział stał się spraw- 
nym i użytecznym instrumentem, umożliwiającym szybsze, lepsze i bardziej precyzyjne dotarcie ze wsparciem i pomocą do wszystkich objętych utworzoną strukturą obszarów.

\section{Pojęcie regionu}

Słowo region znalazło swoje miejsce w informacjach, które za pośrednictwem mediów docierają codziennie do opinii publicznej. Środki masowego przekazu, takie jak prasa, radio i telewizja donoszą niestrudzenie o najważniejszych wydarzeniach rozgrywających się w kraju i na świecie. Można zatem usłyszeć: o regionach objętych klęskami żywiołowymi, takich na których panuje dotkliwy głód lub wybuchła pociągająca ofiary śmiertelne epidemia, regionach zapalnych politycznie lub już ogarniętych zamieszkami czy wojną. Region jest w tym kontekście synonimem problemów i sytuacji wymagających najczęściej szybkiej interwencji międzynarodowej.

Te same media używają jednak pojęcia region również w zamyśle zainteresowania mas społecznych i skupienia uwagi określonych grup do wyselekcjonowanych zagadnień. W takich przypadkach mówi się o regionach, które odznaczają się ponadprzeciętnym stopniem rozwoju gospodarczego, są atrakcyjne dla inwestorów, mają moc przyciągania szerokich rzesz turystów swoją unikalną przyrodą, historią i atrakcjami. W odniesieniu do tego rodzaju przekazu region jawi się jako nośnik pozytywnych sygnałów, emitujący zachęcające hasła.

Środki masowego przekazu, rozpowszechniając informacje i relacjonując wydarzenia, nie starają się o bliższe określenie samego pojęcia region. Z punktu widzenia mass mediów jest to wzmianka o znaczeniu drugo- lub nawet trzecioplanowym. Rezultatem takiego podejścia jest relatywnie nieścisłe rozumienie samego określenia w codziennej praktyce.

Pojęcie „region”, pochodzące bezpośrednio od łacińskiego słowa: regio, etymologicznie zawiera w sobie dwa znaczenia - pierwsze, to ruch w ustalonym kierunku, drugie zaś to przestrzeń. Ich połączenie daje: „kierunek wyznaczający przestrzeń". W najprostszym tłumaczeniu oznacza: krainę, okręg, rejon lub dzielnicę. Znaczenie odnoszące się do obszaru zdominowało z biegiem czasu potoczne rozumienie tego wyrazu i obecnie pojęcie to używane jest najczęściej do zdefiniowania jedynie pewnego obszaru (Korenik, Zakrzewska-Półtorak, 2011, s. 12). Niektórzy sięgają znacznie głębiej w historię, wywodząc termin „region” od zapisanych w indyjskim sanskrycie słów: rajach (król), rji (królowa) oraz rjati (on tu rządzi). Takie ujęcie wskazuje na ważny kontekst powiązania określonego terytorium z obowiązującym prawem pochodzącym od osoby panującej (Morris, 1975, s. 1095). 
Na potrzeby dalszych rozważań można przyjąć, że w najszerszym znaczeniu region to: „wyodrębniony z otoczenia, stosunkowo jednorodny obszar, odróżniający się od terenów przyległych naturalnymi lub nabytymi cechami, na którego powstanie miały wpływ dające się określić czynniki”. Jednakże potrzeby badań statystycznych, sporządzanie planów zagospodarowania przestrzennego, zamierzenia i projekty ekonomiczne, przeprowadzenie zmian otoczenia poprzez realizację dużych inwestycji rzeczowych wymagają uściślenia pojęcia „region”. W tej chwili istnieje, niejako równolegle do siebie, kilka ujęć dookreślających szerokie podejście. Jedna z definicji na pierwszy plan wysuwa dwa czynniki ustanawiające region (Chojnacki, 1997, s. 12):

- zbiorowość ludzką,

- zajmowane terytorium.

Można się bez zastrzeżeń zgodzić, że to właśnie te dwa zasadnicze elementy w większości przypadków wyznaczają region. Szczególnie ważne wydaje się być wymienienie zbiorowości ludzkiej jako konstytuującej pewien obszar poprzez objęcie w posiadanie, zasiedlenie, a następnie ustalenie obowiązujących norm oraz dostosowanie go do własnych specyficznych potrzeb.

Profesor Ann Markusen - wykładowczyni Uniwersytetów w Colorado i Berkeley -obok terytorium i zbiorowości ludzkiej, widzi jeszcze trzy dodatkowe czynniki ustanawiające region (1987, s.16-17):

- kulturę,

- politykę,

- warunki ekonomiczne, w jakich żyje dana społeczność.

Również w tym przypadku trudno się nie zgodzić ze słusznością prezentowanego podejścia. Jednakże takie ujęcie dotyczyć może raczej zaawansowanego cywilizacyjnie, kulturowo i ekonomicznie społeczeństwa posiadającego już pewne doświadczenie i wystarczająco długą historię w dziedzinie parlamentaryzmu oraz zaangażowanych politycznie obywateli. Odnosi się bardziej do rozwiniętych demokracji typu anglo-saksońskiego niż do młodych, powstałych często w wyniku rewolucyjnych przemian i będących ciągle jeszcze na etapie przeobrażeń, ustrojowych struktur terytorialnych.

Profesor Ohio State University - Edward J. Malecki, wybitny specjalista od zagadnień rozwoju i polityki regionalnej - określa trzy wyznaczniki, które pozwalają zrozumieć istotę regionu (1997, s. 7):

- homogeniczność takich obszarów pod względem cech fizycznych, ekonomicznych i społecznych,

- konieczność występowania na danym terenie wiodącego ośrodka miejskiego,

- istnienie centrum władzy o charakterze administracyjnym. 
Według wspomnianego autora, dopiero jednoczesne zaistnienie wymienionych wyżej trzech czynników umożliwia w sprzyjających warunkach stworzenie stabilnie funkcjonującego regionu. Nowym elementem „regionalnej układanki” jest w tym ujęciu zwrócenie uwagi na nieodzowność istnienia, w granicach obszaru o takim charakterze, rozwiniętego ośrodka o cechach dużego miasta lub aglomeracji.

Ceniony autor zajmujący się poruszaną problematyką, prof. Stanisław Korenik z Uniwersytetu Ekonomicznego we Wrocławiu, zwraca uwagę, że wszelkie próby zdefiniowania mają pewne cechy wspólne, ujmujące region jako obszar przestrzennie zwarty o następujących cechach (2004, s. 53):

- w jego skład wchodzą wzajemnie podobne jednostki elementarne,

- w ramach każdego regionu można wyróżnić powiązania wewnętrzne i zewnętrzne,

- powiązania wewnętrzne są z reguły silniejsze,

- region odznacza się określoną specjalizacją,

- ma ukształtowany zespół sił wytwórczych,

- charakteryzuje się pewnym stopniem domknięcia,

- w jego obrębie funkcjonuje przynajmniej jeden ośrodek miejski będący czynnikiem integrującym,

- poszczególne elementy składające się na konstrukcję regionu położone są relatywnie blisko siebie.

Jednocześnie polski badacz podkreśla, że regionu nie można traktować jedynie jako struktury gospodarczej i przestrzennej. Aby prawidłowo go opisać, należy do wymienionych cech obowiązkowo dodać jeszcze zamieszkującą go społeczność, posiadającą poczucie własnej tożsamości oraz zarysowaną odrębność etniczną, kulturową i ekonomiczną. Społeczność tę charakteryzują: długoletnia tradycja, codzienne przyzwyczajenia, przyjęte i wyznawane wzorce zachowań, stanowiące z jednej strony czynnik integrujący, z drugiej zaś - element odróżniający ją od otoczenia.

$\mathrm{Na}$ potrzeby natury teoretyczno-badawczej odniesiono pojęcie „region” do czterech kategorii, z którymi się łączy (Korenik, Zakrzewska-Półtorak, 2011, s. 17):

- otoczenia,

- rynku,

- funkcji,

- potencjału.

Aby zrozumieć to podejście, należy krótko określić każdą z kategorii. Region stanowi otoczenie dla działających na jego terytorium ludzi, gospodarstw domowych, podmiotów gospodarczych, wszelakich instytucji oraz organów admini- 
stracji publicznej. Jako rynek, region jest miejscem spotkania się sił podaży i popytu na określone usługi oraz dobra w określonym czasie. Kategorię funkcji należy przede wszystkim rozumieć jako specjalizację i zróżnicowanie struktury gospodarczej występujące na danym terenie. Ostatnia kategoria zwraca uwagę, że region to także tkwiący w nim szeroko rozumiany zasób możliwości instytucjonalnych, ekonomicznych, cywilizacyjnych i kulturowych itp.

Tych kilka przytoczonych wcześniej przykładów ukazuje, że określenie regionu jest wielowymiarowe i niejednoznaczne już w istocie samego pojęcia. W praktyce trudno jest znaleźć, nawet tylko zbliżony do idealnego, przykład regionu. W rzeczywistości brakuje takich obszarów, które spełniałyby z równym natężeniem i jednocześnie wszystkie zaprezentowane przesłanki definicyjne. Próby znalezienia satysfakcjonującego wyjaśnienia i znaczenia terminu „region” podejmowane są $\mathrm{w}$ dalszym ciągu.

Unia Europejska stworzyła własną definicję klasyfikującą obszary leżące w jej granicach. W celu umożliwienia porównań danych statystycznych, w 1988 roku została wprowadzona prawem wspólnotowym Nomenklatura Jednostek Terytorialnych do Celów Statystycznych - NUTS (fr. Nomenclature des Unites Territoriales pour des besoins Statistique, ang. Nomenclature of Units for Territorial Statistics).

W roku 2003 zostało wydane Rozporządzenie Parlamentu Europejskiego i Rady Unii Europejskiej określające zasady klasyfikacji NUTS. W 2005 roku natomiast miała miejsce nowelizacja wymienionego Rozporządzenia. W styczniu 2008 roku została dopisana poprawka do tego dokumentu, a kolejna poprawka - w styczniu 2012 roku.

NUTS stanowi jednolity i spójny schemat podziału struktur terytorialnych wszystkich krajów członkowskich ugrupowania integracyjnego. Wykorzystywany jest do gromadzenia i analizowania danych statystycznych oraz efektywnego prowadzenia polityki regionalnej. Obok stworzenia porównywalnych struktur administracyjnych, wprowadzenie tego systemu umożliwiło przede wszystkim włączenie szczebla lokalnego oraz regionalnego władz samorządowych w aktywny proces integracji europejskiej. Obecnie wszystkie podstawowe dokumenty programowe Unii Europejskiej przygotowywane są w odniesieniu do zasad przyjętych w NUTS.

Na podstawie zestawień opartych na Nomenklaturze Jednostek Terytorialnych wykonywane są między innymi: szacowanie wielkości subwencji ze środków funduszy strukturalnych na rzecz regionów wymagających wsparcia oraz identyfikacja obszarów najsłabiej rozwiniętych lub mających problemy $\mathrm{w}$ procesie restrukturyzacji.

Klasyfikacja NUTS uwzględnia pięć poziomów, które z nielicznymi odstępstwami, składają się z całych jednostek stworzonych według podziału administracyjnego poszczególnych państw. Trzy poziomy mają charakter regionalny, 
są to: NUTS - 1, NUTS - 2 i NUTS - 3. Dwa pozostałe: NUTS - 4 oraz NUTS - 5 odnoszą się do poziomów lokalnych. Dodatkowo stworzony został jeszcze poziom krajowy, określony jako NUTS -0 .

Nomenklatura Jednostek Terytorialnych do Celów Statystycznych jest klasyfikacją opartą na zasadzie budowy hierarchicznej. Określona liczba jednostek statystycznych NUTS - 5 tworzy jednostki statystyczne wyższego szczebla NUTS - 4. Te z kolei tworzą jednostki na poziomie NUTS - 3. Z jednostek na poziomie NUTS - 3, składają się jednostki NUTS - 2, a te tworzą poziom NUTS - 1 .

Za najważniejsze, a przez to wyróżnione przez Rozporządzenie Parlamentu Europejskiego i Rady Unii Europejskiej w sprawie klasyfikacji NUTS, uważane są dwa z poziomów: NUTS - 2 oraz o NUTS - 3, służące identyfikacji obszarów kwalifikujących się do wsparcia w ramach polityki strukturalnej UE. Na poziomie NUTS - 2 wsparciem objęte zostały obszary problemowe o niskim stopniu rozwoju. Następny poziom NUTS - 3 dotyczy obszarów wymagających restrukturyzacji oraz regionów przygranicznych (Przygoda, 2009, s. 37-38).

Według nomenklatury Unii Europejskiej za region uważana jest największa jednostka podziału administracyjnego danego państwa członkowskiego, charakteryzująca się wybieralną władzą, posiadająca podmiotowość prawną i funkcjonująca w oparciu o własny budżet (Zaucha, 1997, s. 56).

Obecnie podejście oparte na wzorcach ugrupowania integracyjnego jest jedynym tak dopracowanym w założeniach i sprawdzonym przez wiele lat w praktyce rozwiązaniem, umożliwiającym klasyfikację regionów na naszym kontynencie. Jest ono zarazem elastyczną metodą pomiaru i analizy, uwzględniającą ewentualne zmiany, jakie mogą zajść w wyniku zmian granic państwowych i regionalnych w przyszłości. Poprzez swoją przejrzystą strukturę i zasady, jakie w niej obowiązują, Nomenklatura Jednostek Terytorialnych do Celów Statystycznych (NUTS) przyczynia się do bardziej wszechstronnego i dynamicznego rozwoju krajów członkowskich Wspólnoty.

\section{Rola i znaczenie regionów}

Współcześnie rola regionów polega w istotnej mierze na stworzeniu odpowiedniego klimatu dla pożądanych postaw obywatelskich i społecznych. Dotyczy również wzmocnienia, a nawet na kreacji określonych zachowań. Stanowią one egzemplifikację dążeń i ambicji populacji ludzkiej zamieszkującej wyznaczone obszary, do stworzenia własnych struktur oddających najlepiej specyfikę i unikalną mentalność zbiorowości, z którą są związane. Odzwierciedlają próbę utrzymania wyznawanych wartości w obliczu przemian zachodzących w skali zarówno najbliższego otoczenia, jak i globalnej. Niektórzy autorzy korzeni takiego podej- 
ścia upatrują w katolickiej nauce społecznej, powołując się przy tym na zasadę subsydiarności, zwaną również zasadą pomocniczości. Termin „subsydiarność” pochodzi bezpośrednio od lacińskiego słowa subsydium, które oznacza: pomoc, wsparcie lub też działanie oparte na zaangażowaniu dodatkowych sił.

Kościół w swoim przekazie do wiernych opiera się na wybranych zapisach ze Starego Testamentu, jak również na naukach samego Jezusa Chrystusa zawartych w Nowym Testamencie. Ważnym źródłem w opisywanej materii jest doktryna filozoficzna świętego Tomasza z Akwinu, który czerpiąc swoje inspiracje z pism świętego Pawła Apostoła, postrzegał społeczność jako układ hierarchiczny. Był on jednak przekonany, że społeczności wyższe powinny powstawać i wyrastać ze społeczności niższych i nie dążyć do ich zdominowania. Wyraźne odniesienia do tej zasady zawierają także encyklika Rerum Novarum, ogłoszona w 1891 roku przez papieża Leona XIII oraz encyklika Quadragesimo Anno z 1931 roku wydana przez papieża Piusa XI. Autor ostatniego z dwóch wymienionych watykańskich dokumentów stwierdza: „Co jednostka z własnej inicjatywy i własnymi siłami może zdziałać, tego jej nie wolno wydzierać na rzecz społeczeństwa; podobnie niesprawiedliwością, a nawet szkodą społeczną i zakłóceniem ustroju jest zabieranie mniejszym i niższym społecznościom tych zadań, które mogą spełniać i przekazywanie ich społecznościom większym i wyższym. Każda akcja społeczna z racji swojego celu i ze swej natury posiada charakter pomocniczy; winna pomagać członkom organizmu społecznego, a nie niszczyć ich lub wchłaniać" (Gawlikowska-Hueckel, 2003, s. 127-128). Obecnie zasada subsydiarności, wzbogacona o treść doktryn liberalnych, uważana jest za jedną podstaw każdego nowoczesnego systemu demokratycznego. Wyrazem tego przekonania jest powołanie się na nią jako obowiązującą normę w Traktacie o Wspólnotach Europejskich z 1957 roku oraz powtórzenie jej w Traktacie o Unii Europejskiej. Według podejścia przyjętego za obowiązujące w Unii Europejskiej zasada subsydiarności oznacza, że władze niższego szczebla (regionalne lub lokalne szczebla podstawowego) są odpowiedzialne za zagadnienia rozwoju oraz sprawy publiczne społeczności zamieszkującej dany teren. Podstawowe potrzeby obywateli powinny być zaspokajane na najniższym z możliwych poziomów władzy. Dopiero wtedy, gdy niższy szczebel z różnych względów nie jest w stanie tej funkcji wypełnić, wyższy szczebel władzy może przejąć aktywność w sferze spraw publicznych (Wojtaszczak, 2004, s. 17-18). Dzięki nadrzędności prawa unijnego nad krajowym, zasada pomocniczości została skutecznie i sprawnie wprowadzona jako podstawowa reguła do systemu legislacyjnego wszystkich państw członkowskich ugrupowania integracyjnego.

Nie należy jednak rozumieć kultywowania przyjętych zwyczajów jako niechęci do korzystania ze zdobyczy nauki czy dezaprobaty dla postępu cywilizacyjnego. Można pogodzić opieranie się na utartych historycznie wzorcach przy jednoczesnej możliwości czerpania z najlepszych, dostępnych współcześnie rozwiązań. 
Te ostatnie należy jedynie w odpowiedni sposób zaadaptować do własnych potrzeb. Takie podejście przynosi często zadziwiająco pozytywne efekty. Przykładami tego typu zjawisk w dużej skali są sukcesy na arenie gospodarczej i politycznej państw azjatyckich: Japonii, Korei Południowej, Chin Ludowych, Tajwanu, a w ostatnim czasie - Indii. Przywiązanie do tradycji i istniejące od setek lat struktury społeczne nie przeszkadzają tym krajom dynamicznie się rozwijać i zmieniać na lepsze. W odczuwalnie mniejszej skali - regionalnej można również zauważyć podobne zjawiska. Należy odwołać się tutaj chociażby do ewenementu szybkiego, ekonomicznego rozwoju: Wysp Hawajskich w USA, regionów Scanii i Blekinge w Szwecji, Okręgu Kaliningradzkiego w Rosji czy też obszaru Szkocji w Wielkiej Brytanii.

Pozostałe zjawiska obserwowane w ramach regionów mają najczęściej pochodny w stosunku do ich społecznej funkcji charakter. Wykorzystanie zaangażowania mieszkańców danego obszaru w dziele budowy i poszukiwania własnych rozwiązań rzutuje na osiągnięcia realizowane w dziedzinach nie tylko ekonomicznej, ale także politycznej, gospodarczej, edukacyjnej, naukowej, kulturalnej czy handlowej. Przebiegający na tej drodze proces jest czynnikiem postępu i niejednokrotnie główną siłą napędową dla funkcjonowania wyodrębnionego terytorium.

W ścisłej korelacji do inicjatyw i aktywności oddolnej pozostaje urzeczywistnianie tzw. polityki intraregionalnej. Jest ona prowadzona przez wybrane w sposób demokratyczny władze regionalne, które za pomocą posiadanych kompetencji i dostępnych im środków oddziałują na mechanizmy społecznogospodarcze obszarów podlegających ich jurysdykcji. Poszczególne samorządy terytorialne, korzystając z nadanych im uprawnień i posiadanych środków finansowych, mogą samodzielnie decydować o formie i zakresie działań dynamizujących rozwój gospodarczy. Regiony są w tym układzie w dużej mierze prawnie, jak również funkcjonalnie uniezależnione od państwowych władz centralnych (Fajferek, 1999, s. 272). Obok niewątpliwych zalet, stosowanie tej polityki niesie za sobą pewne zagrożenia. Największym z nich jest tendencja do pojawienia się różnic rozwojowych i dysproporcji międzyregionalnych w skali kraju lub nawet ugrupowań integrujących się ze sobą krajów. To zróżnicowanie może stać się poważnym problemem, którego władze lokalne nie będą w stanie samodzielnie przezwyciężyć. W rezultacie może powstać układ terytorialny o wadliwej strukturze. Najczęściej dochodzi wtedy do widocznej asymetrii rozwoju. Regiony rozwinięte gospodarczo konsekwentnie wzmacniają swoją pozycję, natomiast regiony słabo rozwinięte narażone są na pozostanie w stanie dotychczasowego niedorozwoju ekonomicznego, obarczonego najczęściej stagnacją lub odczuwalną depresją (Wojtaszczak, 2004, s. 60).

W opozycji do polityki intraregionalnej stoi tzw. polityka interregionalna. Jest ona wyrazem polityki władz centralnych w stosunku do regionów. Naczelne 
władze państwa podejmują decyzje o wyborze regionów, które będą preferowane, jeśli chodzi o różne formy pomocy i wsparcia. Władze centralne decydują o kierunkach i priorytetach w rozwoju wybranych regionów. W ślad za tym przyznawane są środki finansowe i wyznaczane zadania, które będą realizowane. Jednostki samorządowe są w ten sposób ściśle uzależnione finansowo i decyzyjnie od władz krajowych. Takie podejście najczęściej stoi jednak w sprzeczności z zasadami wolnej gospodarki rynkowej (Fajferek, 1999, s. 271). W tablicy 1 zostały zestawione zalety obu opisywanych rodzajów polityki.

Tablica 1. Zestawienie zalet stosowania polityki intraregionalnej i polityki interregionalnej

\begin{tabular}{|c|c|}
\hline Polityka intraregionalna & Polityka interregionalna \\
\hline $\begin{array}{l}\text { - niezależność decyzyjna i finansowa od } \\
\text { władz centralnych } \\
\text { - skrócenie drogi decyzyjnej } \\
\text { - } \text { szybsza realizacja zaplanowanych } \\
\text { przedsięwzięć } \\
\text { - osiaggnięcie mocniejszej pozycji } \\
\text { konkurencyjnej wobec innych regionów } \\
\text { - tworzenie potencjału wykonawczego } \\
\text { dostosowanego do własnych potrzeb } \\
\text { - lepsze rozpoznanie istniejących } \\
\text { problemów lokalnych } \\
\text { - możliwość synergii z dotychczasową } \\
\text { działalnością w regionie }\end{array}$ & $\begin{array}{l}\text { - ujęcie danego regionu w strategicznych } \\
\text { kierunkach rozwoju kraju } \\
\text { - wykorzystywanie środków budżetu } \\
\text { centralnego dla inwestycji lokalnych } \\
\text { - możliwość czerpania z potencjału } \\
\text { wykonawczego innych obszarów } \\
\text { - możliwość realizacji dużych } \\
\text { przedsięwzięć } \\
\text { - bardziej dynamiczne tempo rozwoju } \\
\text { - szybkie zwiększenie potencjału } \\
\text { ekonomicznego } \\
\text { - mniejsza wrażliwość na zjawiska } \\
\text { kryzysowe gospodarki }\end{array}$ \\
\hline
\end{tabular}

Źródło: opracowanie własne.

Należy od razu zaznaczyć, że wybór określonej polityki wiąże się również z pewnymi niedogodnościami, ponieważ zarówno polityka intraregionalna, jak i polityka interregionalna mają pewne wady i mogą nieść istotne zagrożenia, o których należy wspomnieć (tab. 2).

Obecnie przyjmuje się wyższość podejścia intraregionalnego w odniesieniu do interregionalnego. Uważa się, że stosowanie pierwszego z wymienionych podejść jest bardziej efektywne i skuteczniejsze w ramach polityki regionalnej. Podkreśla się, że na szczeblu regionalnym władze samorządowe są w stanie lepiej zidentyfikować najpilniejsze potrzeby i określoną specyfikę własnego terenu. Naprzeciw realizacji zamierzeń wychodzi w tym podejściu rozwiązanie kwestii finansowych. Przeniesienie na poziom budżetów regionalnych środków finansowych z budżetu centralnego sprzyja racjonalności ich wykorzystania - pieniądze 
Tablica 2. Zestawienie wad i zagrożeń związanych ze stosowaniem polityki intraregionalnej i polityki interregionalnej

\begin{tabular}{|c|c|}
\hline Polityka intraregionalna & Polityka interregionalna \\
\hline $\begin{array}{l}\text { - możliwość wystapienia niedostatku } \\
\text { własnych środków finansowych } \\
\text { - mniejsza skala i ilość realizowanych } \\
\text { przedsięwzięć } \\
\text { - konieczność wypracowania własnego } \\
\text { know-how } \\
\text { - możliwość wystąpienia braku odniesienia } \\
\text { do strategicznego planu rozwoju danego } \\
\text { państwa } \\
\text { - istnienie wielu grup nacisku o różnych } \\
\text { interesach i zwalczających się nawzajem } \\
\text { lobby } \\
\text { - duża wrażliwość na sytuację rynkową }\end{array}$ & $\begin{array}{l}\text { - wysokie uzależnienie się decyzyjne } \\
\text { i finansowe od władz centralnych } \\
\text { - możliwość realizacji projektów } \\
\text { niespójnych z charakterem regionu } \\
\text { - wydłużenie czasu i drogi przy } \\
\text { podejmowaniu istotnych decyzji } \\
\text { - możliwe problemy integracji technicznej, } \\
\text { organizacyjnej, personalnej i kulturowej } \\
\text { - brak dobrych ofert we właściwym czasie } \\
\text { - przejmowanie zbędnego potencjału } \\
\text { i łączących się z tym problemów } \\
\text { - ograniczona przejrzystość decyzyjna } \\
\text { i związane z tym ryzyko }\end{array}$ \\
\hline
\end{tabular}

Źródło: opracowanie własne.

są lepiej wydatkowane. Trudny wybór jednej z przedstawionych metod prowadzenia polityki regionalnej wywołuje jednocześnie skomplikowany problem określenia większej lub mniejszej roli sektora publicznego w kreowaniu skutecznej polityki regionalnej (Paczoski, 2010, s. 21-22). Polityka intraregionalna lepiej sprawdza się w warunkach rynkowych i na etapie rozwoju i dojrzałości cyklu koniunkturalnego. Jest stosowana na szeroką skalę przez państwa członkowskie Unii Europejskiej. Natomiast polityka interregionalna lepiej sprawdza się w warunkach kryzysu i przy wychodzeniu z depresji. Jej zalety doceniane są przez kraje rozwijające się, ze słabiej rozwiniętą gospodarką, chociaż stosowana jest także przez państwa oparte na centralnie sterowanej gospodarce rynkowej, takie jak: Korea Południowa, Japonia i Chiny Ludowe.

Należy jednakże zwrócić uwagę na pewną prawidłowość polegającą na tym, że często wysokie zorganizowanie struktur społecznych i administracyjnych w regionie rzutuje bezpośrednio na dynamiczny poziom rozwoju danego terenu. W wyniku takiego procesu powstaje wyjątkowo prężny, przodujący zarówno gospodarczo, jak i kulturowo, obszar w ramach struktury państwa. Gdy osiagnie już wystarczający stopień rozwoju, jego dokonania rzutują w odczuwalny sposób na graniczące z nim tereny. Poprzez swoją dominującą pozycję, staje się on odniesieniem i wzorcem przy wyborze kierunków polityki społeczno-gospodarczej dla innych regionów w granicach całego kraju. Jako ośrodek centralny czerpie także wymierne korzyści ekonomiczne - staje się biegunem wzrostu 
ściągającym z zewnątrz na swoje terytorium: siłę roboczą i obce kapitały. Obszar ten przyczynia się również do powstawania nowych inwestycji, wzrostu obrotów handlowych, zwiększenia konsumpcji oraz podniesienia poziomu życia lokalnego społeczeństwa. Chęć utrzymania uprzywilejowanej pozycji wyzwala mocne tendencje dośrodkowe. Jeśli jest to dodatkowo ośrodek centralny, to prowadzi do scalania narodu i rodzenia się postaw patriotycznych. Jeśli jest to ośrodek inny niż siedziba władz państwowych albo region peryferyjny lub też konkurencyjny do głównego bieguna wzrostu, można zauważyć tendencję do zachowań odśrodkowych. Tendencje odśrodkowe stanowią poważne zagrożenie dla centrum i są przezeń zwalczane z dużą konsekwencją i determinacją. Przykładem głównego bieguna wzrostu jest Republika Serbii w byłej Jugosławii. Pozostałe republiki, w tym szczególnie: Chorwacja, Słowenia oraz Okręg Autonomiczny Kosowo, w ostatnich latach istnienia Federacji Jugosłowiańskiej zdecydowanie dążyły do uwolnienia się spod władz w Belgradzie i uzyskania niepodległości. Cel, jakim było doprowadzenie do rozpadu Jugosławii, został osiągnięty w następstwie wojny domowej, która pochłonęła dziesiątki tysięcy ofiar.

Nie wszystkie ruchy o charakterze odśrodkowym, mające na celu uzyskanie pełnej niezawisłości, są rozwiązywane po myśli aspirujących do wolności regionów. Przykładem uzyskania przez region niepodległości tylko na relatywnie krótki czas, a następnie jej utraty i ponownego wcielenia w granice dotychczasowego państwa, jest przypadek Republiki Czeczenii, wchodzącej w skład Federacji Rosyjskiej. W czasie rozpadu Związku Socjalistycznych Republik Radzieckich (ZSRR), w 1991 roku nacjonaliści czeczeńscy wykorzystali słabość Moskwy i ogłosili niepodległość swojego kraju. Następnie konsekwentnie realizując politykę niezawisłości, w 1992 roku Czeczenia kategorycznie odmówiła podpisania umowy stowarzyszeniowej z Rosją. Mocarstwo nie uznało tej decyzji i w 1994 roku wszczęło krwawą wojnę z maleńką, byłą republiką położoną na północnym Kaukazie. Ku zaskoczeniu wszystkich, Czeczenii tę wojnę udało się wygrać, a działania militarne zostały zakończone w 1996 roku. Konflikt odnowił się po objęciu prezydentury przez Władimira Putina w 1999 roku. Władze rosyjskie ogłosiły całkowite zwycięstwo w 2002 roku i przywróciły uprzedni stan rzeczy, co doprowadziło do całkowitego zniszczenia obszaru republiki. W roku 2003 w Republice Czeczenii odbyło się referendum konstytucyjne, w którym ponad $96 \%$ biorących w nim udział osób opowiedziało się za powtórnym włączeniem terytorium tego górzystego regionu w granice Federacji Rosyjskiej. Zdania w sprawie Czeczenii są w tej chwili podzielone. Część światowej opinii publicznej uważa, że Rosja miała niezaprzeczalne prawo do obrony integralności swojego terytorium. Inni obserwatorzy opisywanych wydarzeń są zdania, że wyniszczająca wojna na Kaukazie miała czysto kolonialny charakter, a jej głównym narzędziem były zakrojone na szeroką skalę czystki etniczne i taktyka 
spalonej ziemi. Podkreślają przy tym niczym niezbywalne prawo górali z Czeczenii do posiadania własnego państwa i samookreślenia.

Innym przykładem, także pochodzącym z Rosji, jest stosunkowo mało znana sprawa dążeń separatystycznych Uralskiego Okręgu Federacyjnego. Jeszcze w strukturach ZSRR był jednym z najbogatszych i najbardziej uprzemysłowionych obszarów kraju. Położony w całości po wschodniej stronie Uralu, stanowił najbardziej wysunięty na zachód okręg azjatycki. Areał tego tworu jest większy niż łączna powierzchnia Francji, Hiszpanii, Niemiec i Wielkiej Brytanii. W jego granicach znajduje się około $6 \%$ światowych zasobów ropy naftowej i aż ponad $26 \%$ globalnych zasobów gazu ziemnego. Obserwując zakończone powodzeniem uniezależnienie się od władz moskiewskich: Litwy, Lotwy i Estonii, Armenii, Azerbejdżanu, Białorusi, Gruzji, Kazachstanu, Kirgistanu, Mołdawii, Tadżykistanu, Turkmenistanu, Uzbekistanu i Ukrainy władze w stolicy regionu - Jekaterynburgu - postanowiły latem 1993 roku ogłosić niezależność Uralu. Duży wpływ na tę decyzję miały również niepowodzenia militarne Rosji w Czeczenii. Na jesieni 1993 roku Republika Uralska, która powstała w miejsce Okręgu Federacyjnego, posiadała już własną konstytucję. Na większości urzędów powiewały narodowe biało-zielono-czarne flagi. Działał przywódca państwa oraz parlament. W obiegu funkcjonowała własna waluta - uralskie franki. Republika istniała tylko 131 dni. Już na początku listopada 1993 roku ówczesny prezydent Rosji - Borys Jelcyn - rozwiązał parlament w Jekaterynburgu, odwołał przywódcę Republiki - Edwarda Russela - i zakończył jej krótki żywot przy pomocy urzędników oddanych Federacji. Na Uralu nie było protestów. Wszyscy wiedzieli w jaki sposób władza nieco wcześniej rozprawiła się ze zbuntowanym parlamentem w Moskwie przy pomocy brutalnej interwencji dywizji pancernej (Kacewicz, 2012, s. 66-67). Rosja za pomocą tzw. inwigilacji czystej, opartej na pokazie siły i wywołaniu strachu, uniknęła całkowitego rozpadu. Nie wystąpił „wariant jugosłowiański”, którego powtórzenia tym razem w większej skali obawiali się przywódcy na Kremlu.

Aktualnie bardzo wyraźnie widoczne są tendencje odśrodkowe w Hiszpanii. Centralnie położony region Kastylii (na którą składają się: Stara i Nowa Kastylia) stanowi od samego początku serce i duszę tego kraju, natomiast stolica tej historycznej prowincji - Madryt, tworzy dzisiaj własny, silny okręg autonomiczny. Jest najważniejszym ośrodkiem przemysłowym, a zarazem siedzibą władz państwowych i miejscem, w którym znajdują się najważniejsze instytucje o znaczeniu ogólnokrajowym. W stolicy państwa na Półwyspie Iberyjskim można spotkać się z największą ilością przejawów i symboli świadczących o głębokim przywiązaniu do wielowiekowej tradycji i jedności Hiszpanii. W opozycji do scalających dążeń Kastylijczyków stoją poczynania mieszkańców Katalonii. Własne: flaga, herb, hymn, język, prezydent, rząd, parlament i kluby piłkarskie są najważniejszymi przejawami zjawisk odśrodkowych tej prowincji. Popularną 
maskotką w Katalonii jest osioł, który symbolizuje własne zdanie oraz spokojne i uparte dążenie do obranego celu. Jego wizerunek można często zobaczyć na ulicach Barcelony w witrynach sklepów, na murach lub na szybach samochodów. Zwierzę to stanowi przeciwieństwo dla byka symbolizującego zjednoczoną Hiszpanię. W obliczu kryzysu gospodarczego zachowania mieszkańców Katalonii uległy zradykalizowaniu. Rząd wspólnoty autonomicznej wystąpił z wnioskiem do władz centralnych o zgodę na przeprowadzenie w 2014 roku referendum w sprawie niepodległości prowincji. Pomysł ten jest skutecznie, jak do tej pory, blokowany przez władze w Madrycie, a rząd centralny stoi na stanowisku, że nacjonaliści katalońscy muszą przestrzegać konstytucji. Wedle zapisów w niej zawartych (słynny paragraf 22), przeprowadzenie plebiscytu w sprawie niepodległości jakiejkolwiek części Hiszpanii jest sprzeczne z obowiązującym powszechnie prawem. Lokalne wybory do regionalnego parlamentu w Katalonii, w listopadzie 2012 roku, dały zwycięstwo partiom separatystycznym. Fakt ten pokazuje, że dążeń niepodległościowych społeczeństwa regionu nie da się po prostu rządowi centralnemu zignorować.

W Polsce najbardziej jaskrawym przejawem regionalnych dążeń odśrodkowych są, mające wieloletnia tradycję, ruchy polityczno-społeczne w obrębie Górnego Śląska. Główne ugrupowanie tego nurtu - działający od 1990 roku Ruch Autonomii Śląska - powołuje się na istniejący w okresie dwudziestolecia międzywojennego ważny precedens. Funkcjonująca w formie oficjalnego stowarzyszenia organizacja za koronny przykład podaje posiadanie autonomii w okresie II Rzeczypospolitej przez ówczesne województwo śląskie. Podobnie jak władze w Madrycie w stosunku do Katalończyków, także kolejne ugrupowania rządzące w Warszawie odnosily się i odnoszą sceptycznie do idei szerzonych przez organizację Ślązaków. Dążenia do autonomii nie są już w tej chwili na Górnym Śląsku tak radykalne, jak wcześniej, ze względu na utratę przez ten region znaczenia gospodarczego w skali kraju oraz trwający wiele lat masowy exodus ludności tego obszaru do Republiki Federalnej Niemiec. Jednakże pewne zintensyfikowanie autonomicznych zachowań daje się zauważyć w ostatnich latach na obszarze Śląska Opolskiego (województwa opolskiego). Dwie nazwy: Śląsk Opolski oraz Opolszczyzna są bardzo często używane w potocznej mowie zamiennie i traktowane jako wzajemnie równoważne synonimy. Popularne określenie: Opolszczyzna stanowi de facto rusycyzm, użyty po raz pierwszy w mediach dopiero w 1960 roku (Smolorz, 2012, s. 249). Oznacza ono teren w obrębie historycznego Górnego Śląska, który nabrał, w wyniku głębokich procesów historycznych i administracyjnych, charakteru różniącego go od jego wschodniej wysoko uprzemysłowionej części (Pysiewicz-Jędrusik, Pustelnik, Konopska, 1998, s.13). Zachowania autonomiczne na Opolszczyźnie przejawiają się w dążeniach miejscowej ludności do ustawowego uregulowania sprawy języka śląskiego i niemieckiego jako obowiązujących oficjalnie w szko- 
łach powszechnych oraz różnych innych dziedzinach życia codziennego. Wybór mowy uzależniony jest od tego czy obszar zdominowany jest przez ludność śląską, czy też mniejszość niemiecką w Polsce. W wielu powiatach województwa wprowadzona została także dwujęzyczność wszelkich tablic, niektórych dokumentów i napisów informacyjnych. Tak zdeterminowane postawy ludności autochtonicznej wywołują reakcje uzasadnionego sprzeciwu u ludności napływowej tego regionu, posługującej się na co dzień językiem polskim.

Tworzenie samodzielnych regionów podparte jest przeświadczeniem, że władze samorządowe odpowiedniego szczebla lepiej rozpoznają i zrozumieją potrzeby lokalnej społeczności. Nie należy przy tym jednak zapominać, że regiony nie posiadają tak skutecznych instrumentów polityki gospodarczej, jakie mają do swojej dyspozycji władze państwa. Z jednej strony, mają w znacznie mniejszym zakresie możliwości prowadzenia polityki wymiany handlowej, polityki monetarnej, polityki podatkowej czy kreowania polityki konkurencji. Z drugiej zaś - regiony są bardziej otwarte i elastyczne niż państwo w przypadku przepływów towarowych, migracji ludzkich i ruchu kapitału (Richardson, 1973, s. 73-74). Przebywając w sposób fizyczny na bezpośrednio podległym sobie terenie, lokalne gremia decyzyjne są w stanie zauważyć najbardziej pilne zadania do realizacji oraz inwestycje mające na celu poprawę warunków życia mieszkańców. Skuteczniej i szybciej mogą też reagować na wszelkie objawy niegospodarności i marnotrawstwa. Także wyboista droga obywatela do administracji ulega w takim wypadku wydatnemu skróceniu. Przekonanie o uzasadnionej słuszności takiego podejścia implikuje daleką decentralizację uprawnień i przekazanie jej organom znajdującym się na najniższych $\mathrm{z}$ istniejących poziomów władzy (Wallance, Ridley, 1985, s. 26-29). Przy ograniczonych środkach finansowych wymienione czynniki mają pozytywny wpływ na bardziej przemyślane i racjonalne wydatkowanie pieniędzy, niż w przypadku centralnego ich rozdzielnictwa w skali całego kraju. Niestety, ograniczony zasób pieniędzy, jakie mają do swojej dyspozycji władze regionalne, należy najczęściej rozumieć jako ich niedostatek. Wtedy realizacja słusznych w zamyśle planów i projektów staje się w praktyce utrudniona lub wręcz niewykonalna. Nie oznacza to stworzenia złych założeń opartych na fałszywych przesłankach, nie jest też objawem słabości struktur samorządowych. Jest ona raczej wyrazem niemożności sprostania zbyt trudnym, obiektywnym warunkom, przy niewystarczających środkach i braku odpowiednich instrumentów. Zaistnienie takiej sytuacji podważa wiarygodność władz lokalnych w oczach miejscowej ludności i skłania do odejścia od samej koncepcji społeczeństwa i ustroju regionalnego. 


\section{Polityka regionalna}

Polityka regionalna stanowi zespół koncepcji wzbogaconych modelami teoretycznymi oraz opartych na nich działań, odnoszących się do rozwoju wydzielonych obszarów w obrębie organizmów państwowych. W połączeniu ich zastosowanie ma za zadanie efektywnie wpływać na wielkość i kierunki oraz tempo rozwoju regionalnego.

Rozwiązania, wprowadzane za pomocą rozwiązań politycznych i uregulowań prawnych, mają na celu przeprowadzenie zmian w istniejącej strukturze społeczno-gospodarczej i w układzie przestrzennym danego terytorium (Strzelecki, 2008, s. 78).

Zarówno zakres, jak i charakter polityki regionalnej ulegały na przestrzeni wielu lat głębokim zmianom ze względu na ciągłe przeobrażenia zachodzące w skali globalnej oraz z osobna w każdym kraju. Zmieniały się priorytety stawiane przed polityką regionalną, a także cele i zadania, w zależności od kontynentu oraz realizującego ją państwa przy uwzględnieniu panującego w nim ustroju (Secomski, 1982, s. 45).

Można wyróżnić dwa ujęcia dotyczące opisywanego zagadnienia w odniesieniu do problematyki, jakiej dotyka polityka regionalna:

- ujęcie klasyczne, określające politykę regionalną jako skuteczny instrument interwencjonizmu państwowego, prowadzony na szczeblu centralnym i ukierunkowany na wyrównywanie istniejących różnic rozwojowych pomiędzy poszczególnymi obszarami;

- ujęcie współczesne (szerokie), określające politykę regionalną jako zaplanowany w dłuższym okresie proces, mający na celu rozwój określonego obszaru przy aktywnym wykorzystaniu jego bogactw, zasobów, posiadanej infrastruktury ekonomicznej oraz istniejących struktur społecznych; nacisk w tym podejściu kładzie się na wyzyskanie wewnętrznego potencjału, jakim dysponuje dane terytorium oraz pobudzanie takich pożądanych zjawisk, jak innowacyjność stosowanych rozwiązań czy zwiększanie konkurencyjności; w ujęciu współczesnym opisywane działania mogą być prowadzone na szczeblach: lokalnym (podstawowym), regionalnym, międzyregionalnym, krajowym (centralnym), a także ponadnarodowym (na przykład w ramach UE).

Kształt aktualnie prowadzonej polityki regionalnej nawiązuje z natury do szeregu wcześniejszych doświadczeń i osiągnięć na tym polu. Jednakże uważa się, że w każdym przypadku powinna ona zapewniać harmonijny i dynamiczny rozwój terenów, których dotyczy. Coraz mocniej podkreśla się, że polityka regionalna powinna w efektywny sposób dążyć do wykorzystania posiadanych 
zasobów i unikatowego dobra, jakie tworzy kapitał ludzki, aby zrealizować wyznaczone cele.

Polityka regionalna to przede wszystkim rozstrzygnięcia ekonomiczne i społeczne dotyczące szczebla niższego niż ogólnokrajowy. W jej obrębie dochodzi do wyboru najważniejszych celów i wyznaczenia sposobów ich realizacji. Określone zostają także warunki, w jakich ma dojść do urzeczywistnienia ważnych dla określonych obszarów planów, projektów i zamierzeń. W zależności od koniunktury, systemu politycznego, świadomości mieszkańców czy grupy sprawującej aktualnie władzę, polityka regionalna może ewoluować w różnych kierunkach.

\section{Zarządzanie na poziomie regionalnym i lokalnym}

W praktyce bardzo często pojęcie „polityki regionalnej” stosuje się wymiennie z pojęciem „zarządzania regionalnego”. Faktem niezaprzeczalnym jest, że pomiędzy tymi terminami istnieją daleko idące powiązania, a w wielu przypadkach opierają się one na wspólnych elementach. Utrudnia to w zasadniczy sposób proces przeprowadzenia ich dokładnej delimitacji. Pomimo tego, przytoczona para pojęć nie jest ze sobą tożsama (Kudłacz, 2011, s. 3). Zarządzanie regionalne zawarte jest bowiem w obszarze polityki regionalnej, a oba pojęcia odnoszą się do procesu rozwoju określonych obszarów.

Polityka regionalna dotyczy w przeważającej mierze sfery wzajemnych powiązań podmiotów biorących udział w procesie rozwoju regionalnego oraz zakresu związanych z tym regulacji ustrojowych i prawnych. Ma charakter koncepcyjny, planistyczny i organizacyjny, wyznaczający określone cele do realizacji.

Zarzadzanie regionalne odnosi się natomiast do sfery procesów i czynności praktycznych mających charakter realny i ciągły wtedy, kiedy rozpocznie się już ich realizacja. Wymienione procesy oraz czynności, stanowią zespół skoordynowanych działań służących optymalnemu lub możliwie najbardziej efektywnemu wykorzystaniu istniejących w regionie: zasobów ludzkich, bazy surowcowej, infrastruktury przemysłowej czy też sprzyjających warunków naturalnych. Wszystkie posunięcia urzeczywistniane są na bazie organizacyjnej jednostek samorządu terytorialnego poszczególnych szczebli przy aktywnej współpracy i współudziale reprezentantów środowisk społecznych i gospodarczych oraz instytucji i organizacji pozarządowych. Zamysłem tych poczynań, jest realizacja celów wyznaczonych wcześniej w ramach polityki regionalnej. Najważniejszy z nich stanowi zapewnienie rozwoju danego obszaru.

Rozwój jest tutaj rozumiany jako proces zaistnienia pozytywnych zmian, które obejmują wzrost ilościowy i zarazem poprawę jakościową. Najbardziej pożądany dla regionu jest rozwój zintegrowany mający wymiar wszechstronny, 
dynamiczny i wewnętrznie zgodny charakter. Wszechstronny wymiar oznacza zespolenie czynników gospodarczych i społecznych, wliczając w to także ważny element środowiska, w którym cały proces ma miejsce (Skrzeszewski, 1976, s. 64-65). Rozwój regionalny powinien odbywać się jednocześnie w pięciu równoległych do siebie płaszczyznach (aspektach), które tworzą (Wojtasiewicz, 1997, s. 8-16):

- zaspokajanie podstawowych potrzeb ludności,

- optymalne wykorzystanie istniejących zasobów,

- skuteczne i efektywne funkcjonowanie wszystkich podmiotów w ramach danej jednostki terytorialnej,

- stały postęp w sprawności działania instytucji o charakterze publicznym,

- niezawodność w wypełnianiu założonych czynności przez ogół istniejących systemów oraz ich właściwe i niezakłócone zasilanie w zasoby wytwórcze.

Należy jeszcze rozgraniczyć dwa inne ważne pojęcia: zarządzanie na poziomie regionalnym i zarzadzanie na poziomie lokalnym. Podobnie jak to było w przypadku polityki regionalnej i zarządzania regionalnego, są one bardzo często używane zamiennie, chociaż dotyczą innego zakresu pojęciowego.

Zarządzanie na poziomie regionalnym oznacza realizację obranych celów dla wyznaczonych jednostek administracyjnych znajdujących się jeden stopień niżej niż poziom krajowy. W przypadku Polski jest to zarządzanie dotyczące każdego z poszczególnych szesnastu województw.

Zarządzanie lokalne swoją skalą obejmuje gminę, grupę gmin lub powiat. W takim ujęciu skala lokalna tworzy podsystem regionu, a zarazem samodzielny system dla tworzących ją jednostek, np.: miast lub sołectw (Wiatrak, 2006, s. 9).

Wszelkie procesy obserwowane na poziomie lokalnym mogą stanowić proste odbicie zjawisk występujących na szczeblu regionalnym, jednakże w znacznie okrojonym zakresie i na dużo mniejsza skalę. Mogą także tworzyć zupełnie niezależne, nowe i oryginalne rozwiązania wynikające $\mathrm{z}$ ograniczonej, miejscowej specyfiki oraz mentalności mieszkańców danego obszaru. Zarządzanie regionalne staje się coraz ważniejszym elementem polityki nie tylko krajowej, lecz także ponadpaństwowej i w wymiarze globalnym. 


\section{ROZDZIA}

\section{Czynniki determinujące powstanie regionów}

Według „podejścia sprawczego" można wymienić czynniki będące przyczyną powstania regionów. Biorąc ten aspekt pod uwagę: „Region to względnie jednorodny, umownie wydzielony z otoczenia obszar, którego powstanie mogło nastąpić w wyniku wystąpienia określonych czynników naturalnych lub nabytych”. Do najważniejszych czynników naturalnych, można zaliczyć: fizycznogeograficzne, klimatyczne i zoogeograficzne. Natomiast do najistotniejszych czynników nabytych, można zaliczyć: etniczne (kulturowe), gospodarcze (przemysłowe, rolnicze) oraz administracyjne.

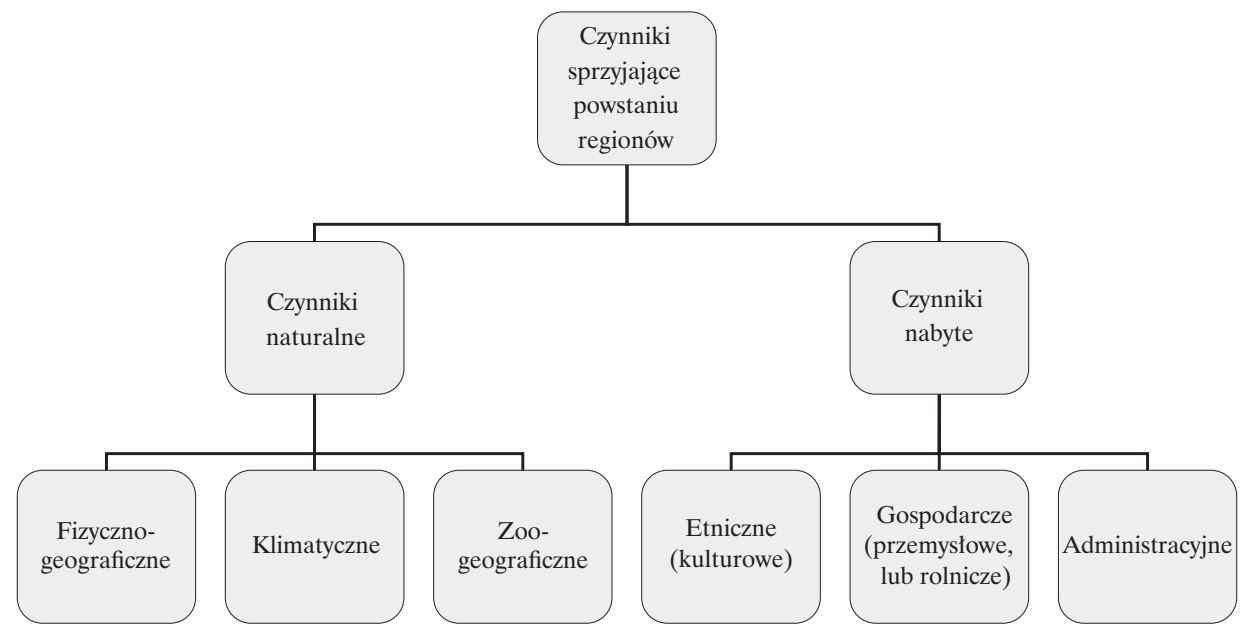

Rysunek 1. Czynniki sprzyjające powstawaniu regionów

Źródło: opracowanie własne.

Oczywiście takie podejście jest jedynie punktem wyjścia do zdefiniowania palety możliwych przyczyn formowania się regionów. 


\section{Naturalne czynniki tworzące regiony}

Czynniki fizycznogeograficzne odnoszą się przede wszystkim do ukształtowania przestrzeni, która określa region. Rzeźba terenu w wielu wypadkach tworzy łatwo widoczne granice, które w naturalny sposób determinują charakter objętego nimi obszaru. Wyraźnie widać to w odniesieniu do: gór, wyżyn, półwyspów, wysp oraz kanionów i dolin. Powierzchnia każdego obszaru może być kształtowana ze względu na procesy endogeniczne, które pochodzą z wnętrza naszego globu, takie jak: lądotwórcze i górotwórcze ruchy tektoniczne skorupy ziemskiej, procesy wulkaniczne i trzęsienia ziemi. Do wyglądu terenu mogą przyczynić się także procesy egzogeniczne, które spowodowane są głównie czynnikami zewnętrznymi, takimi jak: słońce, woda i wiatr, lodowce oraz pływy morskie.

Jako przykład obszaru stworzonego przez góry może posłużyć leżący w Azji Region Zakaukaski (Zakaukazie) obejmujący w byłym Związku Radzieckim trzy republiki: Gruzję, Azerbejdżan, Armenię. W wyniku rozpadu ZSRR wcześniejsze republiki powstały lub odzyskały niepodległość jako państwa. Granicą wyznaczającą ten region było główne pasmo gór Kaukazu. Innym przykładem jest Region Tybetu w obecnych Chinach, zajmujący obszar Wyżyny Tybetańskiej. Należy również zwrócić uwagę, że to głównie warunki naturalne stworzyły w przeszłości możliwość istnienia (aż do 1950 roku) niezależnego Państwa Tybetańskiego.

Półwysep Synaj, wchodzący w skład Arabskiej Republiki Egiptu, tworzy osobny region wyznaczony wodami Zatoki Akaba, Morza Czerwonego wraz z Kanałem Sueskim oraz Morza Śródziemnego. Geograficznie przynależy do Azji, chociaż Egipt w większości swojego obszaru położy jest w Afryce. Ciekawostkę stanowi fakt, że aby dostać się z Półwyspu Synaj do części afrykańskiej Egiptu, trzeba starać się o specjalną wizę wjazdową. Dotyczy to zarówno mieszkańców kraju pod piramidami, jak i turystów.

Półwysep Krymski tworzy region autonomicznej republiki, w ramach której tylko stolica tego obszaru - Sewastopol, jako miasto wydzielone, wchodzi bezpośrednio w skład Ukrainy i podlega władzom centralnym w Kijowie. Półwysep połączony jest ze stałym lądem wąskim Przesmykiem Perekopskim, który oblewają wody Morza Czarnego i Morza Azowskiego. Od Rosji oddzielony jest Cieśniną Kerczeńską. Krym został uroczyście przekazany Ukrainie przez Moskwę 19 lutego 1954 roku dekretem prezydium Rady Najwyższej Związku Radzieckiego. Nastąpiło to w związku z 300. rocznicą ugody perejasławskiej, która historycznie zjednoczyła „na wieczne czasy” Ukrainę z Rosją. Obwód krymski został wyłączony ze składu Rosyjskiej Socjalistycznej Republiki Radzieckiej, do której należał, i włączony następnie w skład Ukraińskiej Socjalistycznej Republiki Radzieckiej.

Wyspy w sposób najbardziej naturalny wyznaczają granice regionalne. Najbliższym nam przykładem jest wyspa Bornholm położona o około $120 \mathrm{~km}$ od 
północnego wybrzeża Polski. W Danii stanowi najbardziej na wschód wysunięty okręg administracyjny tego kraju o randze województwa (duń. Amtskommune). W oficjalnych dokumentach określa się go jako „gminę regionalną” (duń. Bornholms Regionskommune).

Innymi europejskimi przykładami obrazującymi istnienie regionów jako wynik czynników fizycznogeografinych wyznaczonych przez wyspy są: we Włoszech: Sycylia i Sardynia; we Francji podobny status autonomicznego regionu posiada Korsyka; w Grecji przykładem jest piąta co do wielkości wyspa na Morzu Sródziemnym - Kreta.

W Stanach Zjednoczonych osobny, a zarazem najmłodszy stan tworzy archipelag Wysp Hawajskich, położony na Oceanie Spokojnym i oddalony od zachodniego wybrzeża kontynentalnej części kraju o około 4 tys. kilometrów.

Dolina Aosty stanowi autonomiczny region administracyjny na północy Włoch. Jest obszarem otoczonym przez najwyższe partie Alp włoskich, francuskich i szwajcarskich, przez których szczyty przebiega granica państwa. Na jej terenie możliwa jest uprawa żyta, kukurydzy, ziemniaków i winorośli. Od północy Dolina Aosty graniczy ze Szwajcarią, od zachodu z Francją. Od wschodu i południa $z$ włoskim regionem Piemont.

Dolina Valais (niem. Wallis) w Szwajcarii położona jest na obu brzegach przepływającej przezeń rzeki Rodan. Posiada liczne mniejsze odnogi, których większość jest zamieszkana. Otoczona jest najbardziej malowniczymi fragmentami Alp Zachodnich łącznie ze szczytem Matterhorn (4478 m n.p.m.), u którego stóp leży znana na całym świecie stacja narciarska Zermatt. Obszar doliny wraz z górującymi nad nią wierzchołkami tworzy w państwie Hellwetów trzeci pod względem wielkości kanton o nazwie Valais. Region graniczy z Francją na zachodzie, z Włochami na południu i południowym wschodzie, na północy z kantonami Berno i Vaud, natomiast na wschodzie z kantonami Ticino (niem. Tessin) i Uri.

W drugiej połowie XX wieku podjęto wysiłek stworzenia klasyfikacji obszarów ze względu na czynniki fizycznogeograficzne, które je wyznaczają. Dzięki temu powstał dziesiątkowy system oznaczania regionów geograficznych. Polegał on na ustaleniu układu jednostek hierarchicznie sobie podporządkowanych, z których każda otrzymywała zakodowany numer. Na przykład makroregion - Pobrzeże Szczecińskie oznaczony został w tym systemie jako: 313.2. Jego niższy szczebel mezoregion składający się z Wysp Wolin i Uznam, legitymuje się w tej nomenklaturze kodem: 313.21. Opracowany system stosowany jest dzisiaj w obszarze nauk związanych z geografią (Kondracki, 1995, s. 349-354).

Czynniki klimatyczne - stanowią podstawę określającą całokształt warunków pogodowych charakterystycznych dla danego obszaru. Do głównych z nich można zaliczyć: promieniowanie słoneczne (nasłonecznienie), temperaturę powietrza, ciśnienie atmosferyczne (wysokość na jakiej położony jest 
teren), wilgotność powietrza, występujące wiatry, zachmurzenie oraz osady i opady atmosferyczne. W połączeniu determinują one klimat występujący w granicach przyjętych dla określonego regionu. Obok nich występują jeszcze istotne czynniki klimatotwórcze, do których należą: szerokość geograficzna, wielkość powierzchni lądu, specyfika ukształtowania terenu i jego pokrycia szatą roślinną, prądy morskie, odległość od akwenów wodnych, takich jak: rzeki, jeziora i morza. W połączeniu czynniki klimatotwórcze i klimatyczne tworzą pięć stref klimatycznych, które układają się w sposób równoleżnikowy wokół kuli ziemskiej. Są to strefy klimatów: równikowych, zwrotnikowych, podzwrotnikowych, umiarkowanych oraz okołobiegunowych. W każdej ze stref istnieją jeszcze obszary charakteryzujące się swoistymi cechami pogodowymi, odróżniającymi je od innych terenów. Wyznaczają one granice regionów objęte charakterystycznym klimatem, przykładowo: wysokogórskim, pustynnym, kontynentalnym, śródziemnomorskim czy monsunowym, które z kolei wyznaczają regiony: wysokogórskie, pustynne, półpustynne, stepowe, tundry, śródziemnomorski i monsunów. Znajomość i poprawna analiza czynników klimatycznych umożliwia człowiekowi podejmowanie określonych kroków mających na celu jak najbardziej efektywne wykorzystanie zamieszkałych przez niego obszarów. Brak takiej wiedzy może prowadzić do katastrofalnych skutków, czego przykładem może być wykorzystywanie w starożytności przez greckie polis drewna pochodzącego z najbliższego otoczenia jako budulca dla statków i okrętów. Rosnące na zboczach pobliskich gór lasy sosnowe oraz występujące liczne dęby i cedry zostały wycięte. Doprowadziło to do prawie całkowitego ogołocenia terenów Hellady z drzew. To pociągnęło za sobą wyjałowienie ziem, erozję skał oraz znaczne podwyższenie panujących temperatur. Przyczyniło się również do wyginięcia niektórych gatunków specyficznych dla opisywanego terenu, jak lwy i miniaturowe słonie leśne. Jedyną pamiątką po tych zwierzętach są współczesne znaleziska archeologiczne oraz wzmianka w mitach greckich o zabiciu przez Heraklesa - lwa nemejskiego, który siał spustoszenie i trwogę na północ od Myken. Dzisiaj większość górzystych terenów wysp i Grecji kontynentalnej przypomina prawie księżycowy krajobraz. Lasy udało się utrzymać na zaledwie $20 \%$ obszaru.

Innym przykładem jest występujący na obszarze południa Europy, w zachodniej części Bliskiego Wschodu oraz Afryki Północnej, łagodny rodzaj klimatu podzwrotnikowego. Od akwenu, na którym panuje, przyjął nazwę klimatu śródziemnomorskiego, tworząc także region o tej samej nazwie. Już od starożytności cały jego obszar znany jest z wyjątkowo korzystnych warunków do uprawy winorośli i produkcji wybornych win. Europejczycy, którzy osiedlili się w Republice Południowej Afryki (region Kapsztadu), Chile (region Valparaiso i Santiago), w USA (Kalifornia) oraz w Południowo-Zachodniej Australii (okolice miasta Adelaide oraz regiony Great Southern, South West, nadmorska 
część regionu Wheatbelt) zauważyli, że występujący tam klimat zbliżony jest do śódziemnomorskiego. Dało to asumpt do prób uprawy winorośli, które zakończyły się wielkim sukcesem. Obecnie wina z Australii, Chile, Kalifornii i Południowej Afryki na stałe zagościły w Europie. Skutecznie wypierają w dobrych restauracjach i gospodarstwach domowych szlachetne trunki, pochodzące dotychczas z regionu śródziemnomorskiego.

Interesującym faktem w kontekście napojów alkoholowych jest, utrzymujące się jeszcze w Europie do XX wieku, zróżnicowanie regionalne dotyczące preferencji w ich wyborze. $\mathrm{W}$ regionie śródziemnomorskim, obejmującym południe starego kontynentu, zawsze najchętniej pite było wino. W Europie Zachodniej, gdzie nie sięgała uprawa winorośli, pragnienie zaspokajało piwo, pochodzące $\mathrm{z}$ latwych do uzyskania na tym terenie chmielu lub jęczmienia. Natomiast w Europie Wschodniej, obejmującej Polskę, Ukrainę, Białoruś i Rosję, ze względu na trudne warunki klimatyczne najbardziej popularne, wobec wysokich cen innych napojów, były trunki wysokokaloryczne, takie jak wódka. W Skandynawii, gdzie panują najsurowsze w Europie warunki życia, społeczeństwo również chętnie sięgało po najmocniejsze napoje alkoholowe (słynna okowita). Na początku XX wieku sytuacja w krajach położonych w tym regionie groziła wręcz degeneracją biologiczną Szwedów, Norwegów i Finów, a zaradziły temu jedynie radykalne środki i zsynchronizowane działania rządów. Ograniczenia dotyczące dystrybucji mocnych alkoholi, zniechęcająca polityka wysokich cen oraz mała ilość punktów ich sprzedaży, także dzisiaj mają być gwarancją na powstrzymanie mieszkańców Skandynawii przed powtórnym popadnięciem w niebezpieczny nałóg.

Zbiorniki wód słodkich w postaci rzek oraz jezior, jak również wód słonych w postaci, oceanów, mórz i słonych jezior wpływają na klimat czasem nawet bardzo rozległych terenów. Oddziaływanie to zależy od wielkości zbiornika (w przypadku rzek: od wielkości dorzecza, długości całkowitej oraz wielkości przepływu), odległości obszaru lądu od danego akwenu, szerokości geograficznej oraz rozkładu prądów morskich i oceanicznych.

Wielkie rzeki, takie jak: Amazonka, Nil, Kongo, Niger, Jangcy, Huang-ho, Ganges i Brahmaputra, Missisipi, Mckenzie, Parana, Wołga, Ob, Jenisej, Darling i Murray czy wreszcie Dunaj umożliwiają rozkwit flory i fauny na obszarach leżących w ich pobliżu. Znacząco łagodzą klimat oraz nawadniają pobliskie tereny. Pozwalają też ludziom na korzystanie z ich zasobów.

Zbiorniki wody słonej, szczególnie te największe, jak oceany, istotnie wpływają na warunki pogodowe na sąsiadujących z nimi przestrzeniach lądowych. Najbardziej znany z prądów morskich - Golfsztrom, transportuje ciepłe wody z Zatoki Meksykańskiej na drugą stronę Atlantyku. W pobliżu Wysp Brytyjskich i Norwegii jego przedłużenie w postaci Prądu Północnoatlantyckiego znacząco ociepla klimat całej strefy. W efekcie, w Irlandii na zachodnich wybrzeżach 
wyspy rosną w parkach, na ulicach i w ogródkach przydomowych palmy śródziemnomorskie. Zimą temperatura powietrza w Norwegii jest średnio o ponad 20 stopni Celcjusza wyższa niż na terenach umiejscowionych na podobnej szerokości geograficznej w innych częściach świata. Położony już za kołem polarnym port w Murmańsku nie zamarza nawet w zimie. Dla porównania, na leżących na przeciwko terytoriach po drugiej stronie oceanu występuje wieczna zmarzlina i spływają lodowce w Grenlandii. W Kanadzie panują nieprzyjazne ludziom klimaty: subpolarny i polarny. Na południowej półkuli, na Półwyspie Antarktycznym, ziemię przykrywa lądolód, a cały kontynent ze względu na przeciwności klimatyczne nie został skolonizowany.

Czynniki zoogeograficzne - umożliwiają zróżnicowanie obszarów ze względu na dającą się wyodrębnić odmienność fauny w poszczególnych regionach świata. Dotyczą zarówno środowiska lądowego, jak i wodnego. Określają rozmieszczenie gatunków na kuli ziemskiej, jak również ich liczebność. Dzięki ich wyodrębnieniu możliwe jest dokładne ustalenie zasięgu i wielkości zoosfery, czyli przestrzeni życiowej zwierząt w obrębie biosfery, to znaczy - przestrzeni zamieszkałej na kuli ziemskiej przez organizmy. Pozwalają na oszacowanie zoomasy, czyli masy ciała zwierząt (łącznie z człowiekiem). Dotyczą także możliwości introdukcji, jak i przypadkowego zawleczenia określonych gatunków w odmienne środowiska. $\mathrm{Na}$ tej podstawie możliwe staje się poznanie rozmieszczenia geograficznego zwierząt i wyodrębnienie jednostek zoogeograficznych, takich jak: królestwo, podkrólestwo, region, kraina itd. (Urbański, 1962, s. 412-427).

Przykładowo, małpy szerokonose żyją wyłącznie w lasach deszczowych Ameryki Południowej i Srodkowej, ograniczając swoje występowanie zasadniczo do krainy zwanej neotropikalną. Z kolei u pingwinów proces rozmnażania i wychowania młodych odbywa się w zdecydowanej większości przypadków w granicach krainy antarktycznej. Populacja białych niedźwiedzi ogranicza swoje występowanie do położonych poza kołem polarnym rejonów Ameryki Północnej (kraina nearktyczna) oraz Europy i Azji (kraina palearktyczna). Wyspy Nowej Zelandii ze względu na faunę tworzą zupełnie osobną krainę - brak tutaj endemicznych ssaków spowodował, że jej obszar został zdominowany przez ptaki. Natomiast brak naturalnych wrogów wiele z nich uczynił nielotami. Ptaki jako gromada liczą dziś na Nowej Zelandii blisko pięć tysięcy gatunków. W przeszłości wyspecjalizowały się we wszystkich dziedzinach aktywności. Obok siebie egzystowały zarówno niewielkie kiwi, jak i przerażające swoim ogromem czterometrowe moa i orły Haasta. Kraina australijska jest ojczyzną stekowców i torbaczy. Na jej terenie nie występowały w przeszłości ssaki łożyskowe. Dopiero ingerencja białego człowieka zmieniła ten stan. Poruszając kwestię krainy australijskiej, warto wspomnieć o Linii Wallace'a, nazwanej tak od nazwiska jej odkrywcy. Ten żyjący w XIX wieku angielski badacz zauważył, że na leżących naprzeciw siebie w odległości kilku mil wyspach Bali i Lombok z Archipelagu 
Malajskiego świat zwierzęcy ogromnie się różni. Na Bali można spotkać zwierzęta charakterystyczne dla Azji (kraina orientalna), a na Lombok egzemplarze charakterystyczne jedynie dla fauny australijskiej. Jak ustalił, czynnikiem uniemożliwiającym przedostawanie się zwierząt $\mathrm{z}$ jednej wyspy na drugą były niezwykle silne prądy na otaczających je wodach.

Znajomość czynników zoogeograficznych może być sporym atutem. Daje człowiekowi sposobność na szybszą ekspansję w rejonach, które mogą potencjalnie posłużyć za jego nowe środowisko życiowe. Przykładem jest wykorzystanie do opanowania Afryki Północnej wielbłądów jednogarbnych. Zwierzęta te pochodzą z Azji i tam też zostały w dość zamierzchłych czasach udomowione. Dopiero później trafiły na czarny kontynent. W tej chwili dromadery najbardziej kojarzą się właśnie z Afryką. Udanej introdukcji dokonano z wielbłądami jednogarbnymi w Australii. Przez wiele lat służyły one jako niezawodny środek transportu przez interior. Dopiero rozwój techniki, a szczególnie motoryzacji spowodował, że przestały być potrzebne. Mieszkańcy kontynentu wypuścili dromadery na wolność, gdzie zwierzęta te zdziczały, tworząc populację tzw. wielbłąda australijskiego. Próby wprowadzenia wielbłądów w pustynnych regionach Ameryki Południowej nie powiodły się. Na pustyniach Sechura (Peru) i Atacama (Chile) żyje niewielka ich liczba, stanowiąc jednocześnie atrakcję i środek lokomocji dla turystów. Zupełnie nieudaną introdukcję stanowiło wprowadzenie w Australii królików. Europejczycy zamiłowani w polowaniach wypuścili, w okresie kolonizacji kontynentu, kilkanaście par tych szybko rozmnażających się ssaków. Trafiły one na idealne warunki do życia i nieograniczoną w praktyce przestrzeń i stały się... prawdziwą plagą. Obecnie około 300 milinów tych zwierząt czyni znaczne szkody, wypierając gatunki endemiczne oraz wyjadając ogromne ilości traw i innych roślin nadających się do spożycia.

Czynniki zoogeograficzne zostały dokładnie opisane i wyodrębnione w stosunku do przestrzeni lądowej. W odniesieniu do hydrosfery, a więc mórz, oceanów i wód śródlądowych, stworzone podziały są dopracowane w dużo mniejszym stopniu. Czynniki zoogeograficzne w ujęciu opisowym (statystycznym) i ekologicznym odgrywają obecnie największą rolę w gospodarce morskiej człowieka, a konkretnie w rybołówstwie. Przykładowo, ze względu na wyczerpywanie się zasobów żywych w Bałtyku, Unia Europejska narzuciła Polsce tak bardzo restrykcyjne limity połowowe, że doprowadziło to faktycznego załamania całego sektora rybackiego. Innym przykładem są tzw. wojny dorszowe na Północnym Atlantyku. Określenie pochodzi od tego, że najczęściej poławianą rybą w omawianym regionie jest właśnie dorsz. Zubożenie poprzez nadmierną eksploatację łowisk wokół Islandii spowodowało, że w latach pięćdziesiątych i siedemdziesiątych państwo to podjęło zdecydowane przeciwdziałania na arenie międzynarodowej. Ogłosiło poszerzenie wyłącznej strefy ekonomicznej z dotychczasowych 4 mil morskich - w roku 1958, najpierw do 12 mil, potem w roku 1972 do 50 mil, 
a w roku 1975 do 200 mil morskich. Wewnątrz wyznaczonej strefy Islandia jednostronnie zakazywała połowów rybakom z innych krajów. Chodziło głównie o wyparcie obcych kutrów z najlepszych łowisk, stanowiących podstawę gospodarki narodowej tego kraju. Brytyjczycy każdorazowo nie uznawali decyzji islandzkich i czynnie się im przeciwstawiali. Aby przeciwdziałać przecinaniu sieci rybakom i uniemożliwianiu dostępu trawlerom brytyjskim do łowisk przez islandzką straż przybrzeżną, rząd w Londynie wysłał w zapalny region własną marynarkę (Royal Navy). Doszło do wielu incydentów pomiędzy stronami konfliktu, takich jak: taranowanie okrętów, oddawanie strzałów ostrzegawczych, a nawet kilka razy zanotowano wymianę ognia. W końcu spór został zażegnany porozumieniem, na mocy którego Islandczycy uzyskali prawo Brytyjczyków do połowu w kilku miejscach wewnątrz strefy ekonomicznej. Niemniej jednak konsekwencje zapewnienia ochrony własnemu rybołówstwu są w przypadku Islandii wyraźnie widoczne do dnia dzisiejszego. Ten mały, położony na prawie nagiej wyspie kraj, pragnąc zachować przywileje dla swoich rybaków, zdecydował się nie wstępować do Unii Europejskiej. Powodem jest prawo unijne, które od samego początku nie zezwala na tego rodzaju uprzywilejowanie jakiejkolwiek ze stron.

Wobec szybkiego wzrostu populacji ludzkiej oraz zauważalnemu wyczerpywaniu się zasobów żywych mórz i oceanów, czynniki zoogeograficzne będą odgrywały coraz większą rolę. Największym i najsilniejszym krajom będzie chodziło o zapewnienie sobie wyłączności na eksploatację najbardziej obfitych w ryby i owoce morza regionów na świecie. Może stać się to przyczyną pogorszenia stosunków politycznych lub wybuchu konfliktów zbrojnych na skalę regionalną. Najbardziej narażone na taki przebieg wydarzeń będą Azja PołudniowoWschodnia oraz Ameryka Południowa i Środkowa. W dalszej przyszłości, wraz z postępującym procesem ocieplenia klimatu w skali globalnej, przedmiotem sporów międzynarodowych mogą stać się zasobne w białko zwierzęce rejony wokół Antarktydy, a także rozległe przestrzenie wodne Oceanu Arktycznego. Będą one stanowily obszar aktywnego zaangażowania politycznego i ekonomicznego położonych na jego wybrzeżach państw.

\section{Czynniki nabyte tworzące regiony}

Czynniki nabyte związane są nierozerwalnie z życiem i z działalnością człowieka. Najważniejsze z nich to: etniczne, gospodarcze oraz administracyjne. Najbardziej zróżnicowaną grupę stanowią czynniki etniczne zwane również często kulturowymi.

Czynniki etniczne obejmują wszystkie przesłanki, które warunkują tworzenie się grup ludności posiadających swoistą kulturę, kultywujących określony sposób 
życia i mających poczucie własnej odrębności. Są to składniki, na bazie których zbudowana została świadomośc, mniej lub bardziej zorganizowanych i często hermetycznych środowisk ludzkich. Środowiska te mogą być tworzone przez: grupy rodowe, klany, klasy społeczne, plemiona, ludy czy też całe narody. Więzy łączące takie grupy, oparte są zazwyczaj na mocnym zaznaczonym podłożu emocjonalnym. Każdorazowo można zauważyć poczucie wspólnoty jednostki należącej do danej grupy z własnym środowiskiem i odrębność w stosunku do ludzi spoza niego. Do czynników etnicznych warunkujących powstawanie regionów należą przede wszystkim: język, religia, historia, tradycja i obyczaje, pochodzenie, cechy antropologiczne człowieka (rys. 2).

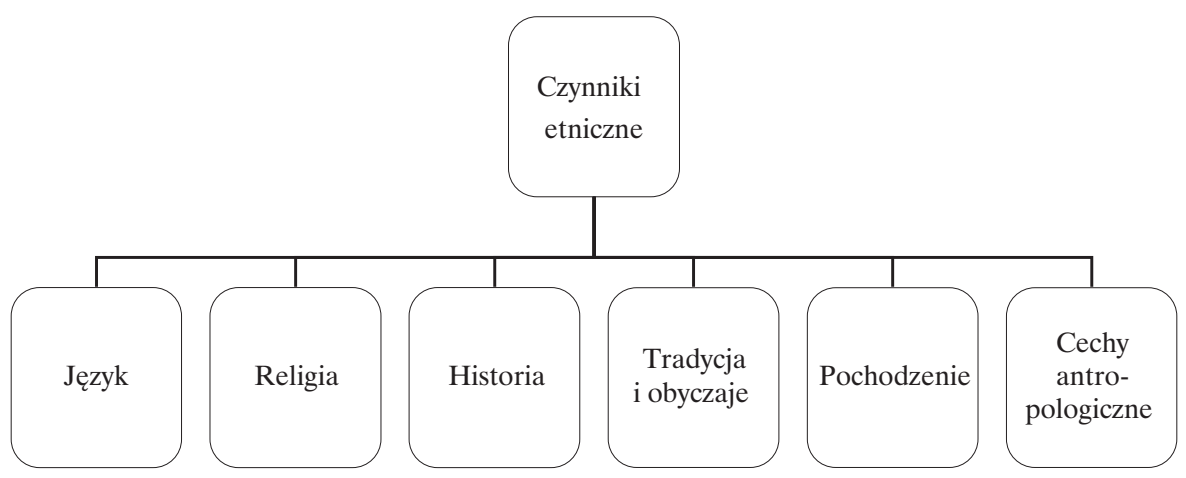

Rysunek 2. Czynniki etniczne warunkujące powstawanie regionów Źródło: opracowanie własne.

Czynniki etniczne mogą tworzyć: grupy etniczne, mniejszości narodowe, narody bez państwa i takie, które posiadają własne państwo. Przyjmuje się, że grupa etniczna nie ma rozwiniętej świadomości narodowej lub ewentualnie nie utożsamia się z żadnym narodem tworzącym inne państwo. Jako przykład moga posłużyć tutaj, rozrzuceni po całym świecie, Romowie. Egzemplifikacją z Polski będzie niewielka zbiorowość Łemków, stanowiąca ludność pochodzenia wschodniosłowiańskiego. Mniejszości narodowe egzystują w każdym państwie. $\mathrm{Na}$ Litwie tworzą je Polacy i Rosjanie, w Rumunii mniejszością narodową są głównie Węgrzy pochodzący z Siedmiogrodu, w Bułgarii najliczniejszą mniejszość narodową tworzą Turcy. W czasach kryzysu mniejszości narodowe często są wykorzystywane przez rządy wielu państw jako wygodny cel ataków medialnych w zamyśle obwiniania tych grup za wszelkie kłopoty i problemy gospodarcze. Przykładami narodów nieposiadających własnego państwa są Baskowie i Czeczeni w Europie, Kurdowie na Bliskim Wschodzie. Na subkontynencie indyjskim narodem bez państwa są Sikhowie, na Sri Lance (dawna wyspa Cejlon) 
grupę taką stanowią, pochodzący z Indii, Tamilowie. W Chinach pozbawieni kraju zostali w 1950 roku Tybetańczycy. Większość narodów bez własnej ziemi walczy za pomocą metod pokojowych i militarnych o prawo do własnego kraju. O prawie do samostanowienia mówi w rozdziale I, art. 1, pkt 2 Karty Narodów Zjednoczonych podpisanej 26 czerwca 1945 roku w San Francisco (USA), która powołała do życia Organizację Narodów Zjednoczonych. Wszyscy sygnatariusze Karty deklarują przestrzeganie jej zapisów jako obowiązującego prawa międzynarodowego. Ta jedna $\mathrm{z}$ naczelnych zasad wchodzi jednak w zdecydowany konflikt z wewnętrznymi interesami wielu krajów mających mniejszości w swoich granicach, dlatego też zupełnie się jej nie przestrzega. Jaskrawo widać to na przykładzie takich państw, jak: Chiny, Rosja, Białoruś, Litwa, Izrael, Demokratyczna Republika Konga czy Turcja. Przeszkodę na drodze do własnego państwa stanowią najczęściej bogactwa naturalne umiejscowione w danym regionie, konflikty na tle religijnym i burzliwa historia danego terenu. Jednakże nie zawsze w ramach danego organizmu państwowego większość uciska mniejszość narodową. Można znaleźć przypadki, w których to większość musi podjąć walkę ze sprawującą rządy mniejszością aby uzyskać należne sobie prawa. Tak było za czasów apardheidu, czyli do połowy lat dziewięćdziesiątych XX wieku, w Republice Południowej Afryki. Podobnie rzecz się miała w Liberii, stworzonej dla szczytnego cel,u jakim była chęć zapewnienia własnego państwa wyzwolonym niewolnikom amerykańskim. Koloniści ze Stanów Zjednoczonych (Amerykanoliberyjczycy) przez ponad sto lat wykorzystywali bez skrupułów rdzenną ludność kontynentu, odmawiając jej nawet prawa głosu. Układy wyznaniowo-plemienne bardzo często powodują sytuację ucisku większości przez mniejszość etniczną w krajach arabskich. Osoby z jednego plemienia obsadzają członkami swojej bliższej i dalszej rodziny wszystkie kluczowe resorty i intratne stanowiska w danym kraju. Aby utrzymać się przy władzy oraz czerpać z tego korzyści, wybierają jako rozwiązanie systemy totalitaryzmu i skrajnego terroru skierowane przeciwko współobywatelom. Tego rodzaju wypaczenia były głównym powodem rewolucji arabskiej w Tunezji, Libii i Syrii.

Jezzk jest stosunkowo łatwym do zidentyfikowania czynnikiem, który wyznacza region. Może opierać się na istnieniu określonych dialektów w ramach jednego języka, jak też dotyczyć zupełnie odmiennych od siebie języków. Przykładem gwary miejskiej należącej do języka angielskiego jest osławiony londyński Cockney. Ten bardzo trudny do zrozumienia język używany jest jeszcze do dziś przez mieszkańców wywodzących się z niższych warstw klasy pracującej. Dotyczy głównie robotników mieszkających w dzielnicy East End. Za „prawdziwych cockneyczków" uważają się jednakże tylko te osoby, które urodziły się i mieszkają w rejonie, w którym słychać bicie dzwonów kościoła Saint Maryle-Bow. Jest to obszar w promieniu około 1,5 kilometra od budynku świątyni (Trudgill, 1988, s. 33-49). 
Zasięg języka włoskiego wyznacza granice Kantonu Ticino (niem. Tessin). Jest to jedyny region w Szwajcarii, którego ludność posługuje się tylko i wyłącznie językiem włoskim. Jest to także język urzędowy na tym terenie. W sąsiednich kantonach: Valais, Uri i Graubinden mieszkańcy mówią po francusku i po niemiecku. Odsetek ludności posługującej się włoskim nie przekracza w tych regionach 10\% (Schaffer, 1979, s. 37-45).

Istnienie dwóch wyraźnie odrębnych stref językowych doprowadziło w 1963 roku do formalnego podziału Królestwa Belgii na trzy regiony: Flandrię z urzędowym językiem niderlandzkim, Walonię z urzędowym językiem francuskim oraz Region Brukseli, gdzie obowiązują oba języki. Ciekawostkę stanowi, że w stolicy kraju położonej w sensie geograficznym na terenie Flandrii używa się obok niderlandzkiego także języka francuskiego.

Granice Prowincji Quebec w Kanadzie również zostały wyznaczone przez czynniki językowe. Francuski jest jedynym urzędowym językiem Quebecu. $\mathrm{W}$ sąsiadujących $\mathrm{z}$ nim prowincjach używa się $\mathrm{w}$ głównie języka angielskiego lub też, tak jak w Nowym Brunszwiku, obu języków naraz. Pomimo że w prowincja ta posiada szeroką autonomię, od dawna panują w niej nastroje nawołujące do wyjścia z Konfederacji. Referendum dotyczące tego, czy Quebec ma się stać nowym, suwerennym państwem o charakterze frankofońskim na mapie Ameryki Północnej, przeprowadzone zostało w 1995 roku. Zwolennicy opcji separatystycznej przegrali o mniej niż jeden procent oddanych głosów. Dokładnie oddano 49,4\% głosów za odłączeniem się od Kanady i 50,6\% przeciw separacji (Dickinson, Young, 2003, s. 345-377).

Religia to szerokie zjawisko społeczne oparte na wierze w siły nadprzyrodzone. Jej manifestację stanowi zespół obrzędów i praktyk oraz wyznawanie określonych zasad moralnych. W sensie organizacyjnym może przyjmować formę wspólnot, takich jak zbór, parafia lub diecezja w ramach kościoła. Może też funkcjonować $\mathrm{w}$ formie wyznań religijnych zorganizowanych w strukturę hierarchiczną, takich jak protestancka Armia Zbawienia lub klasztor. Istnieją też instytucje religijne mające na celu szerzenie danej wiary, należą do nich: szkoły i uczelnie, fundacje lub należące do kościoła radio i telewizja. Mogą to być również organizacje statutowo wspierające wiernych duchowo lub materialnie, przykładowo: poradnie przedmałżeńskie lub przykościelne punkty pomocy społecznej.

Uznaje się, że we współczesnym świecie istnieją obok siebie cztery główne religie. Są nimi: chrześcijaństwo, islam, judaizm oraz hinduizm. W ramach każdej z nich istnieją dodatkowo jeszcze odłamy, wspólnoty, społeczności i grupy wyznaniowe często ze sobą poważnie skonfliktowane w odniesieniu do interpretacji podstawowych zasad wiary. W chrześcijaństwie istnieją trzy kościoły: katolicki, protestancki i prawosławny. Islam dzieli się także na trzy odłamy: sunnicki, szyicki i charydżycki. Judaizm podzielony jest na kilkanaście odmian 
i nurtów stworzonych przez rabinów o największym autorytecie. Hinduizm jako religia politeistyczna większość swoich wyznawców posiada na subkontynencie indyjskim. Zależnie od regionu uznają oni za przejaw absolutu inne bóstwo. Do najbardziej znanych bóstw należą: Brahma, Wisznu i Śiwa oraz różne postaci żeńskiego Devi. Religia zarówno w przeszłości, jak i w czasach współczesnych stanowi jeden czynników wyznaczających regiony. Ostatecznie nierzadko doprowadza do powstania nowej granicy państwa.

Irlandia Północna zamieszkana jest w większości przez protestantów, będących potomkami osadników ze Szkocji i Anglii. Powstała w wyniku decyzji o pozostaniu przy koronie brytyjskiej mieszkańców sześciu hrabstw prowincji Ulster, położonej w północno-wschodniej części „zielonej wyspy”. Opowiedzieli się za tym obywatele Zjednoczonego Królestwa, którzy nie wyobrażali sobie życia w powstałej w 1921 roku, Republice Irlandii. Głównym powodem ich decyzji był fakt, że nowoutworzone państwo miało na wskroś katolicki charakter. Jednakże to rozwiązanie nie zadowoliło wszystkich obywateli. Krwawy konflikt zbrojny o podłożu religijnym pomiędzy katolikami (republikanami dążącymi do zjednoczenia z resztą wyspy) i protestantami (unionistami wiernymi królowej) trwał w Ulsterze przez kilkadziesiąt lat, znajdując swoje zakończenie dopiero na początku XXI wieku. W dalszym ciągu jednak stosunki pomiędzy mieszkańcami Irlandii Północnej są napięte. Tradycyjnie w dniu 12 czerwca każdego roku, dochodzi do zamieszek pomiędzy zwaśnionymi stronami. Ich powodem jest prowokacyjna parada protestanckiego Zakonu Orańskiego (Oranżystów), przechodzącego przez katolickie dzielnice stolicy prowincji, Belfastu. Tym sposobem religia jest wyznacznikiem granicy pomiędzy dwoma państwami, jak również ustala linie podziału między stronami wewnątrz organizmu głównego miasta.

Innym przykładem, także z Europy, jest tragedia jaka wydarzyła się w Jugosławii. Ten kraj przypominał skomplikowaną mozaikę narodowościowo-wyznaniową. Główne narody zamieszkujące w niedalekiej przeszłości ten kraj to: Serbowie (prawosławni), Chorwaci (katolicy), Słoweńcy (w większości katolicy), Czarnogórcy (prawosławni), Bośniacy i Albańczycy (w większości muzułmanie), Macedończycy (głównie prawosławni). Granice pomiędzy poszczególnymi religiami wyznaczały jednocześnie linie podziału pomiędzy republikami połączonymi umową federacyjna w jedno państwo. Każda z pięciu związkowych republik tworzyła osobny region z własną stolicą. Pogarszająca się sytuacja gospodarcza doprowadziła do znacznego wzrostu napięć na tle narodowo-religijnym w byłej Jugosławii. Spowodowało to wybuch bratobójczej wojny w tym kraju, służącym kiedyś za przykład pokojowej koegzystencji mieszkańców. Najbardziej ucierpiała na tym ludność muzułmańska bezlitośnie eksterminowana przez Serbów, dążących do utrzymania ciągłości i jedności państwa. W niezliczonych przypadkach dochodziło do tzw. czystek etnicznych, które nie były niczym innym, jak zakrojonym na masową skalę mordowaniem współobywateli według klucza 
religijnego. Trzeba podkreślić tutaj właśnie czynnik religijny, ponieważ wyznawcami islamu w byłej Jugosławii byli również nierzadko obywatele narodowości Serbskiej i Macedońskiej. Czystki etniczne miały zapewnić dominację określonej grupy narodowościowo-wyznaniowej na wybranym terytorium. Z przykrością trzeba stwierdzić, że $\mathrm{w}$ wielu przypadkach ten zamysł został z powodzeniem zrealizowany i znalazł odbicie w przebiegu nowych granic.

W Stanach Zjednoczonych Ameryki Północnej najbardziej jednorodnym pod względem praktykowanej religii jest stan Utah. Zamieszkują go w większości wyznawcy Kościoła Jezusa Chrystusa Świętych Dni Ostatnich, potocznie zwani mormonami. Utah wszedł do Unii jako 45 stan, dopiero w 1896 roku. Jednakże dla tego wydarzenia lepiej byłoby użyć określenia: „że do Unii został w końcu przyjęty”. Pomimo wyrażanej już wiele lat wcześniej woli przyłączenia się do USA, władze Utah otrzymywały z Waszyngtonu niezmiennie odmowną odpowiedź, co było spowodowane nieskrywaną niechęcią do praktyk mormonów, którzy jako wyznawcy własnej wiary uprawiali wielożeństwo. Dopiero wprowadzenie w 1890 roku zakazu posiadania więcej niż jednej żony, spowodowało zmianę stanowiska władz w Waszyngtonie. W ten sposób religia wyznaczyła zarówno granice, jak i datę wejścia opisywanego regionu w skład Stanów Zjednoczonych Ameryki Północnej.

Najlepszym przykładem na wyznaczenie regionu przez czysty czynnik religijny jest przykład historii „Czarnych Żydów” zwanych Felaszami. Zamieszkiwali oni teren prowincji Qwara w Etiopii. Stanowi ona jednolity geograficznie obszar rozciągający od granicy dzisiejszego Sudanu Południowego, aż do północnych brzegów największego jeziora w Etiopii o nazwie Tana. Felaszowie są przedstawicielami rdzennej ludności afrykańskiej należącej do grupy kuszyckiej. Ubierają się podobnie jak pozostała ludność Etiopii, chodzą najczęściej boso. Tak jak inne społeczności żyjące w Afryce Środkowej, są czarnoskórzy. Kuszyci zamieszkują teren jeszcze kilku innych państw czarnego kontynentu, takich jak: Dżibuti, Egipt, Erytrea, Kenia, Somalia, Północny i Południowy Sudan, Tanzania oraz Uganda. Felaszowie uważają się za Żydów, którzy w czasach starożytnych zostali sprowadzeni do Etiopii. Twierdzą, że w prostej linii stanowią potomków świty Menelika I - syna królowej Saby, narodzonego ze związku z biblijnym królem Salomonem. Najprawdopodobniej nigdy nie posługiwali się językiem hebrajskim. Swoją wiarę opierali jedynie na pięcioksiagu Tory. Nie znali innych świętych ksiąg Judaizmu - Talmudu i Miszny. W tym sensie, ich wiara przypomina tradycyjne wyznanie mojżeszowe w stanie niezmienionym od dwóch tysięcy lat. W przekazie ustnym wskazywali Jerozolimę jako miejsce, z którego pochodzą, podkreślając, że kiedyś uda im się do niej powrócić. Jeszcze w XX wieku nie mieli pojęcia, że po zburzonej w zamierzchłych czasach Świątyni w Jerozolimie pozostały tylko dwa fragmenty „Ściany Płaczu”! Byli przekonani, że ciaggle stoi ona w tym samym miejscu w niezmienionym 
stanie. Stanowili hermetyczną i wyizolowaną religijnie grupę na terenie kraju zamieszkania. Powtarzające się w latach siedemdziesiątych w Etiopii, klęski głodu, terror komunistyczny i wojna domowa w latach osiemdziesiątych doprowadziły do śmierci ponad 1,5 miliona mieszkańców tego państwa. Po uznaniu w 1973 roku przez naczelnych rabinów izraelskich Falaszów za Żydów, rząd premiera Menachema Begina, podjął próbę ratowania tej ludności. Od 1977 do 2003 roku w kilku dużych falach, za pomocą mostów powietrznych zorganizowanych przez armię izraelską, przerzucono z prowincji Qwara w Etiopii prosto do Izraela całą społeczność Falaszów.

Historia jest trzecim po języku i religii czynnikiem etnicznym, dzięki któremu może zostać ukształtowany osobny region. Wspólna, często trudna lub dramatyczna przeszłość, a także przekazywane ustnie i na piśmie relacje z odległych dziejów stanowią dla danego społeczeństwa wystarczający budulec do ustalenia odrębności terytorialnej. Często też, sfabrykowane fakty historyczne mogą służyć do utworzenia nowego, autonomicznego terytorium.

Przykładem wyznaczenia granic regionu, w tym przypadku całego państwa, ze względu na czynniki historyczne są dzieje Księstwa Lichtenstein. Jest to jeden z najmniejszych organizmów państwowych położony na wschodnim brzegu Renu, w górzystym alpejskim terenie pomiędzy Austrią i Szwajcarią. Chęć posiadania większego wpływu na politykę własnego kraju zmusiła przedstawiciela jednego z najstarszych i najbogatszych rodów w Austrii do podjęcia radykalnych kroków. W roku 1608 Karol Lichtenstein otrzymał godność księcia. Jednakże był to „martwy tytuł”, ponieważ sam w sobie nie dawał prawa do zasiadania w radzie cesarskiej. Książęta Lichtenstein byli jedynie lennikami panujących Habsburgów. Aby znaleźć się w radzie, musieli być władcami terytorium pod bezpośrednim zwierzchnictwem cesarstwa. Dlatego odkupili od katastrofalnie zadłużonej rodziny Hohenemsów dwa terytoria, którymi ona władała. Były to niewielkie obszarowo, sąsiadujące ze sobą: Vaduz i Schellenberg. Po połączeniu stworzyły one Księstwo Lichtenstein, co pozwoliło jednemu z potomków Karola - Księciu Antoniemu, Florianowi Lichteistein - po ponad stu latach wysiłków całej familii wejść do rady cesarskiej. Poczucie odrębności historycznej datującej się od XVII wieku, umożliwiły utrzymanie odrębności terytorialnej Księstwu Lichtenstein aż do dnia dzisiejszego. Suwerenność polityczna, a w szczególności samodzielność ekonomiczna, zostały znacznie ograniczone na rzecz Szwajcarii (Jureczko, Wac, 2007, s. 82-83).

Innym przykładem z Europy, w którym czynniki historyczne wyznaczyły odrębność terytorialną są Wyspy Normandzkie. W sumie jest ich kilkanaście, ale zamieszkanych jest tylko osiem: Jersey, Guernsey, Alderney, Sark, Herm, Jethou, Brecqhou i Lihou. Najbliżej położona w stosunku do kontynentu europejskiego jest Alderney. Od wybrzeży francuskiej Normandii dzieli ją około 14 kilometrów w linii prostej. Niewielki archipelag tworzy dwie dependen- 
cje Korony Brytyjskiej. Oznacza to, że nie są ani terytorium Zjednoczonego Królestwa, ani też jego koloniami. Posiadają rozległą autonomię w sprawach wewnętrznych i własne rządy. W kontekście historycznym Wyspy Normandzkie należą do Korony Brytyjskiej od 1066 roku, kiedy to pochodzący z kontynentu Wilhelm Zdobywca podbił Anglię i został jej królem. Na przestrzeni wieków Anglia utraciła jednak wszystkie swoje posiadłości na terytorium Francji. Jedynymi pozostałościami po tym okresie, jest właśnie opisywany, mały archipelag. Mieszkańcy wysp mówią w przeważającej większości po angielsku. Tylko nieliczni na Guernsey używają, mającego swe korzenie w języku francuskim, dialektu Patois. Znacznie większe wpływy frankofońskie można zauważyć na Jersey. W niektórych częściach wyspy jeszcze do dziś mówi się po francusku. Francuski na Jersey był językiem urzędowym jeszcze w 1963 roku (Głuchowski, 1996, s. 191-192).

Przykładem obszaru ukształtowanego przez czynniki historyczne jest, olbrzymia powierzchniowo, Alaska na kontynencie północnoamerykańskim. Jej terytorium stanowi odrębny region geograficzny w USA, dość luźno związany z gospodarką, życiem politycznym oraz kulturalnym pozostałych częśsi państwa. Nie posiada on bezpośredniego połączenia z resztą kraju. W części lądowej zajmuje powierzchnię koło $1,5 \mathrm{mln} \mathrm{km}^{2} \mathrm{i}$ jest to największy stan należący do Unii. Leży na północno-zachodnich krańcach kontynentu amerykańskiego. Od Azji Alaska oddzielona jest stosunkowo wąską $(85 \mathrm{~km})$ Cieśniną Beringa. Pod względem ekonomicznym jest to kraina niezwykle rzadko zaludniona (tylko około 630 tysięcy mieszkańców) i słabo rozwinięta, pomimo posiadania bogatych zasobów naturalnych. Największe bogactwa tego regionu to: złoto, srebro, ropa naftowa, węgiel kamienny, rudy miedzi, cyny, rtęci, uranu, niklu i platyny (Barbag, Galon, 1967, s. 148-149).

Alaska została sprzedana Stanom Zjednoczonym w 1867 roku przez cara Imperium Rosyjskiego - Aleksandra II, za ogromną jak na owe czasy kwotę 7 milionów 200 tysięcy dolarów. Obszar regionu Alaski przetrwał do czasów współczesnych w niezmienionym historycznie kształcie. Ciekawostkę może stanowić mało znany fakt, że równolegle z Alaską Imperium Rosyjskie zaproponowało Amerykanom również zakup Kamczatki. Jednakże do zrealizowania transakcji nie doszło. Cena położonej znacznie dalej, bo aż w Azji, nieurodzajnej Kamczatki przy ówczesnych problemach logistycznych wydała się zbyt wygórowana.

Tradycja $\boldsymbol{i}$ obyczaje stanowią w sumie czynniki etniczne kształtujące regiony nie zawsze na pierwszy rzut oka łatwo dostrzegalne. Często występują w połączeniu z innymi czynnikami nabytymi o charakterze etnicznym. Tradycję można określić jako przekazywane $\mathrm{w}$ formie pisemnej lub ustnej poprzez pokolenia w obrębie określonych grup etnicznych specyficzne: przekonania, wierzenia, przesądy, podejście do spraw w życiu codziennym. Tradycja może egzempli- 
fikować się także w sposobie ubierania się, zwyczajach kulinarnych, muzyce i architekturze. Obyczaj można określić jako przyjętą przez daną wspólnotę formę zachowania, wynikającą z uznawanych przez grupę norm społecznych i nawiązującą do tradycji. Istotną cechą obyczaju jest jego niezmienność w dłuższym okresie, mogącym wynosić nawet ponad kilkaset lat.

Przykładem żywej tradycji, która wyznacza region jest Tyrol. Przejawia się ona na tym terenie przywiązaniem miejscowej ludności do religii rzymsko-katolickiej, używaniem wspólnego dialektu języka niemieckiego, tradycyjną architekturą domów i kościołów, specyficznymi dla całego regionu potrawami, odwieczną specjalizacją w hodowli bydła, unikalnym sposobem śpiewania (jodtowanie) i zestawem instrumentów (rogi alpejskie, drumle ) oraz noszeniem w święta, a nawet na co dzień, charakterystycznych krótkich spodni skórzanych (niem. Lederhosen) przez mężczyzn oraz rozłożystych spódnic z szerokim fartuchem, kaftanikiem i wystającą spod niego białą bufiastą koszulką (niem. Tracht) przez kobiety. W sensie geograficznym region Tyrolu dzieli się na cztery części: Tyrol Północny i Tyrol Wschodni, które znajdują się w granicach Austrii, oraz Tyrol Południowy i Welschtirol (wł. Region Trentino), które zostały po I wojnie światowej przyłączone do Włoch. Podział Tyrolu między Austrię i Włochy został boleśnie odebrany przez mieszkańców tego regionu.

Innym przykładem tradycji oraz obyczajów kształtujących region są zwyczaje i przekonania Amiszów. Tworzą oni w Stanach Zjednoczonych zwartą chrześcijańską wspólnotę protestancką o surowej doktrynie. Wywodzą się ze Szwajcarii, skąd przywędrowali do USA na początku osiemnastego stulecia. To co wyróżnia Amiszów to charakterystyczne, bardzo skromne i ujednolicone stroje zarówno dla kobiet, jak i dla mężczyzn, dialekt języka niemieckiego, jakim posługują się na co dzień oraz wyrzeczenie się korzystania z osiągnięć techniki, takich jak: radio, telewizja, samochody, telefony komórkowe, aparaty fotograficzne czy kamery. Amisze w XXI wieku zasadniczo nie korzystają jeszcze z elektryczności! Swoją edukację kończą w wieku 14 lat na wykształceniu podstawowym. Większość tej społeczności zajmuje się prowadzonym w sposób tradycyjny rolnictwem (przy użyciu koni i co najwyżej prostych maszyn z epoki przedprzemysłowej). Domy oraz wyroby pierwszej potrzeby tworzą we własnym zakresie. Są prawie samowystarczalni. Jedną z ich podstawowych zasad jest wzajemnie wspieranie się w wykonywanych pracach. Ponad $80 \%$ całej, światowej populacji Amiszów żyje w regionie wyznaczonym przez relatywnie wąski pas terenu w sąsiadujących ze sobą trzech stanach: Indiana, Ohio i Pensylwania.

Przykładem z pogranicza polsko-słowackiego są zwyczaje i tradycja społeczności góralskiej zamieszkującej tereny wokół najwyższego pasma Karpat, jakim są Tatry. Ludność zamieszkująca te tereny posługuje się prawie jednolitą gwarą góralską, trudni się tradycyjnie rolnictwem, hodowlą, ciesielką lub zajęciami z związanymi rzemiosłem. Jest praktykująca i głęboko przywiązana do 
wiary katolickiej (Sobczyński, Zawadzka, 1988, s. 5). Górale uznają tradycyjny podział ról w domu na męskie i kobiece oraz kultywują tradycję, specyficznej dla opisywanego obszaru, muzyki wyrażanej w tańcach (zbójnicki, krzesany) i sposobie śpiewania na głosy. Góralszczyzna obejmuje cztery regiony: Podhale, Spisz, Orawę i Liptów (Roszkowski, 1995, s. 24-37). Identyfikację górali z poszczególnych regionów umożliwia różnorodność ich strojów. Chociaż podobne w swoim charakterze, różnią się one od siebie widocznymi szczegółami, takimi jak: kształt kapeluszy i wzór parzenicy na portkach u mężczyzn oraz kolor kaftanów i spódnic u kobiet.

Pochodzenie stanowi jeden $\mathrm{z}$ wielu słabiej efektywnych czynników etnograficznych mogących wyodrębnić $\mathrm{z}$ otoczenia, zwartego obszaru o charakterze osobnego regionu. Mówiąc o pochodzeniu można mieć na myśli dwa aspekty. Pochodzenie z określonej zbiorowości narodowościowej (etnicznej). W tym przypadku można być na przykład Amerykaninem włoskiego pochodzenia lub Francuzem o arabskich korzeniach. W drugim przypadku dana jednostka może wywodzić się określonej grupy społecznej i mieć na przykład pochodzenie szlacheckie, chłopskie lub mieszczańskie. W odniesieniu do takich państw, jak Indie lub Japonia (w mniejszym zakresie) może przynależeć do istniejącej obecnie lub w przeszłości kasty społecznej.

Dobrym przykładem regionu opartego na wspólnym pochodzeniu jego mieszkańców jest Malta. Ludność tego mikroskopijnego archipelagu, składającego się z dwóch głównych wysp i pięciu mniejszych wysepek położonych na Morzu Śródziemnym w pobliżu północnego wybrzeża Afryki, jest głęboko wierząca i w przeważającej większości praktykująca. Ponad 98\% Maltańczyków jest wyznania rzymsko-katolickiego. Ten wynik lokuje wyspiarzy na pierwszym miejscu wśród rodziny katolickich narodów Europy. Mówi się, że na Malcie nie ma miejsca, w którym nie słychać byłoby dzwonów kościelnych wzywających wiernych na mszę (O’Shea, 2009, s. 259-272). Urzędowymi językami są angielski i maltański. Język angielski został wprowadzony na wyspy w okresie, kiedy Malta przez ponad sto czterdzieści lat była kolonią brytyjską. W ciągu tego czasu wyparł używane w urzędach i sądownictwie języki: włoski i francuski (Misztal, 2007, s. 346-350). Jednakże o pochodzeniu rdzennych mieszkańców świadczy drugi z oficjalnych języków, a mianowicie maltański. Maltańczycy są z pochodzenia Arabami. Świadczy o tym mowa wyspiarzy stanowiąca dialekt języka arabskiego w odmianie zachodniej. Do jej zapisywania używano początkowo alfabetu arabskiego. Dopiero, powołane przez Anglików, Towarzystwo Semickie (Xirka Xemia) opracowało w 1880 roku zasady pisowni języka maltańskiego za pomocą alfabetu przyjętego w Europie Zachodniej. W tej chwili język maltański jest jedynym językiem $\mathrm{z}$ grupy semickiej zapisywanym w alfabecie łacińskim (Misztal, 2007, s. 349). O Maltańczykach można powiedzieć, że stanowią jedyną zwartą nację arabską przyjętą do Unii Europejskiej. Umożliwiły to czynniki 
związane ze wspólnym pochodzeniem i odrębnością etniczną. W odczuciu tych więzi w 1963 roku powołana została do życia Malta jako państwo, ze wszystkimi niezbędnymi atrybutami konstytuującymi ten organizm.

Przykład tworzenia regionów ze względu na pochodzenie z określonych grup społecznych stanowi system kastowy w Indiach. System zniesiony oficjalnie w momencie uzyskania przez Indie niepodległości w 1947 roku, funkcjonuje niestety do dziś. Przy czym bardziej widoczny jest on na wsi niż w wielkich miastach (Keay, 2000, s. 489-508). Kastowość zakłada podział społeczeństwa na nieprzenikalne wzajemnie, ściśle zamknięte grupy. Przynależność do danej kasty jest dziedziczona. Nie można jej zmienić przez małżeństwo lub sukces finansowy. W obrębie kasty można podejmować się tylko określonych zawodów - inne zajęcia są zabronione. W ramach jednej grupy praktykuje się ustalone obrzędy i wyznaje wiarę w określonego boga z Panteonu bóstw hinduizmu. Kastowość jest hierarchiczna. Istnieją kasty wyższe - czyste i niższe - gorsze, a nawet takie które uważa się za „nieczyste”. Przedstawiciele kast wyższych unikają kontaktów z kastami niższymi. Przejawia się to w gestach i zwyczajach polegających na unikaniu nawet podania ręki lub spożycia posiłku przygotowanego przez przedstawiciela „gorszej” kasty. Ilustracją regionu stworzonego w wyniku dominacji jednej kasty jest Radżastan - jego obszar znajduje się w północno-zachodnich Indiach i graniczy z Pakistanem. Stolicą stanu jest liczący obecnie ponad $3 \mathrm{mln}$ mieszkańców Jaipur. W okresie poprzedzającym panowanie brytyjskie Radżastan nosił nazwę Radźputana. Władała nim społeczność rycerzy, stanowiąca istniejącą do dziś kastę Radźputów należącą do warny Kszatriji - drugą w hierarchii ważności po Braminach (Kieniewicz, 1980, s. 551-592).

Gurkowie są znanymi z waleczności góralami pochodzącymi z Nepalu. Ich własne, ustne w większości, przekazy mówią, że przybyli do tego kraju z północnych Indii i są w prostej linii potomkami Radźpunów i Braminów, zajmujących się już przed setkami lat rzemiosłem wojennym. Ich wspólnym, legendarnym przodkiem jest książę Bappa Rawal, uważany za założyciela Królestwa Nepalu. Zamieszkują tereny wokół miasta Gorkha, pomiędzy Pokharą i stolicą państwa Katmandu. Ten wyodrębniony obszar jest popularnie nazywany Gorkhkalandem. Gurkowie to w istocie kilka plemion, z których najliczniejsze to Gurungowie, Magarowie i Kirati, wszystkie spokrewnione dość blisko z Tybetańczykami (Flis, 1967, s. 281). Określenie Gurkha (spotyka się też: Gorkha) pochodzi z języka angielskiego i zostało nadane tej grupie jeszcze w czasach kolonialnych. Sama nazwa Gurkowie dotyczy tych górali i ich rodzin, których tradycyjnym zajęciem jest od wielu pokoleń służba najemna w obcych armiach (Matciniak, 1996, s. 7-26). Obecnie nepalscy górale są żołnierzami w armii brytyjskiej i indyjskiej oraz służą jako wojska najemne w Singapurze i Hongkongu. Dwa czynniki etniczne - wspólna historia oraz wykonywana profesja - były podstawą skupie- 
nia się wyodrębnionej z całej populacji grupy ludności nepalskiej na odrębnym terenie, w granicach zamieszkiwanego przezeń państwa.

Ostatnim z omawianych czynników etnicznych, mogących być przyczyną tworzenia regionów, są łatwo rozpoznawalne cechy odnoszące się do typu antropologicznego człowieka. Opierają się one wyróżnieniu dających się zauważyć odmiennych cech fizycznych, które posiadają przedstawiciele różnych odmian i typów ludzkich. Cechy takie mogą oznaczać: kolor skóry, kształt czaszki, nosa, ust, kolor oczu, wielkość fałdy ocznej, głębokość oczodołu, kolor włosów, wzrost, budowa, a także proporcje ciała (długość rąk i nóg), grubość kości.

Laponia jest regionem geograficznym w Europie, który rozciąga się na północnych krańcach czterech krajów: Norwegii, Szwecji, Finlandii i Rosji (w obrębie Półwyspu Kola). Swoją nazwę oraz umowne granice zawdzięcza Lapończykom, którzy zamieszkują ten teren już ponad 10000 lat, czyli od późnego paleolitu. Od czasu ostatniego zlodowacenia, aż do czasów całkiem współczesnych prowadzili oni koczowniczy tryb życia, zajmując się głównie hodowlą, myślistwem i rybołówstwem (Czekanowski, 1963, s. 48). Teraz coraz częściej zmuszeni są do prowadzenia osiadłego trybu życia. Lapończycy są rdzennym ludem osiadłym, który zamieszkiwał tę niegościnną ziemię jeszcze przed pojawieniem się pierwszych indoeuropejczyków. Chociaż nie stanowią już na zajmowanych przez siebie terenach etnicznej większości, to jednak ich obecność jest łatwo zauważalna. Przyczyną są noszone przez nich na co dzień barwne stroje ludowe, kultywowanie starych zwyczajów, ale przede wszystkim odmienne cechy antropologiczne. Widać to bardzo wyraźnie w kontraście do wysokich i jasnowłosych Skandynawów. W budowie ich ciała przejawiają się cechy charakterystyczne dla ludów mongoloidalnych. Lapończycy odznaczają się krępą budową ciała, przy jednocześnie niskim wzroście. Widocznymi na pierwszy rzut oka szczegółami są: okrągłe, krótkie głowy o szerokich, płaskich twarzach z wyraźnie wystającymi kośćmi policzkowymi; włosy proste i najczęściej bardzo ciemne; oczy zdecydowanie ciemne, a u małych dzieci i niemowląt bardzo często skośne (wraz z wiekiem cecha ta ulega uwstecznieniu); skóra o odcieniu żółtym lub nawet brunatno-żółtym. Region Laponii posiada własny hymn i flagę, chociaż nie oznacza to jakichkolwiek dążeń rdzennych mieszkańców tego obszaru do niezawisłości.

Niechlubnym przykładem działalności białej ludności na zajętych w trakcie ekspansji ziemiach są rezerwaty dla Indian w Ameryce Północnej (głównie w Kanadzie i w Stanach Zjednoczonych) oraz Bantustany przeznaczone dla czarnej ludności w Republice Południowej Afryki. W obu wymienionych przypadkach skazywały one rodowitych mieszkańców na życie w ściśle wyznaczonych dla nich terenach. Najczęściej rezerwaty i bantustany umiejscowione były na najgorszych i nieurodzajnych terenach. Pozbawione były także jakichkolwiek bogactw naturalnych. Nie dawało to żadnych szans, zgromadzonych tam pod 
przymusem, ludziom na prowadzenie godziwego życia. System na jakim się te obozy opierały, uniemożliwiał ich mieszkańcom wydostanie się poza wyznaczony teren. Ponieważ odznaczali się łatwymi do wychwycenia cechami antropologicznymi (rasowymi) odróżniającymi mieszkańców rezerwatów i bantustanów od białej ludności, wszyscy nieprzestrzegający zakazu opuszczania przeznaczonego dla nich terenu byli zatrzymywani i karani. Bantustany zostały zlikwidowane w Afryce Południowej wraz z dojściem do władzy czarnej większości. Rezerwaty w Stanach Zjednoczonych i w Kanadzie istnieją do dzisiaj. Mieszka w nich w sumie ponad połowa całej populacji ludności indiańskiej. Jednakże dzisiaj jest to jej wolny wybór, nie zaś skutek państwowego przymusu. W obu wymienionych krajach Indianie otrzymali bowiem w drugiej połowie XX wieku pełnię praw obywatelskich, łącznie z prawem do swobodnego poruszania się po kraju (Zimmerman, 2003, s. 141-168).

Meksyk również jest przykładem silnego zróżnicowania regionalnego ze względu na czynniki antropologiczne jego mieszkańców. W kraju tym można wyróżnić bogatszą i słabiej zaludnioną północ, której mieszkańcy wykazują cechy hiszpańsko-metyskie. Na terenie w większości biedniejszego i gęściej zaludnionego południa przeważa ludność o pochodzeniu metysko-indiańskim. Obecny stan jest wynikiem poczynań kolonizacyjnych, datujących się od początku XVI wieku. W ich wyniku słabsza ekonomicznie oraz organizacyjnie ludność indiańska została wyparta przez społeczeństwo pochodzenia europejskiego na tereny mniej urodzajne i o cięższych warunkach klimatycznych. Dotyczy to szczególnie obszaru północno-wschodniego Meksyku, gdzie kolonizatorzy stworzyli wielkoobszarowe gospodarstwa o charakterze rolno-hodowlanym lub plantacyjnym. Wraz z zabudowaniami nazywane są one w całej Ameryce Lacińskiej hacjendami (hiszp.: hacienda). W stanach na terenie Meksyku Środkowego oraz Południowego obok hiszpańskojęzycznej ludności metyskiej znaczną część społeczeństwa stanowi wielomilionowa społeczność Indian posługująca się własnymi językami. Są to w prostej linii potomkowie: Azteków, Miksteków, Zapoteków, Otomi, Tonaków i Majów (Łepkowski, 1986, s. 21-48). Szczególna sytuacja ma miejsce $\mathrm{w}$ stanie Chiapas, położonym na samym południu kraju, przy granicy z Gwatemalą, który jest najbiedniejszą częścią Meksyku. Zamieszkuje go w przeważającej większości ludność indiańska. W przeszłości obszar ten stanowił serce Imperium Majów. Mieszkańcy stanu to jednorodna etnicznie społeczność, mającą poczucie własnej odrębności językowej, kulturowej i historycznej. Odróżniają się też oni wyraźnie pod względem wyglądu od ludności hiszpańsko-metyskiej. Suma tych różnic oraz poczucie odrębności etnicznej doprowadziły do powstania ruchu na rzecz autonomii i wyzwolenia regionu Chiapas. Przybrał on wyraz czynnego sprzeciwu i nieposłuszeństwa wobec administracji państwowej, a w praktyce przyją formę prowadzonej od 1994 roku walki zbrojnej. Militarnym ramieniem powstańców jest tzw. Zapaty- 
stowska Armia Wyzwolenia Narodowego. Na wyzwolonych przez bojowników terenach budowane są zręby władzy lokalnej, powstają wzorowane na modłę socjalistyczną spółdzielnie rolnicze, tworzone jest własne szkolnictwo oraz system bezpłatnej opieki i pomocy medycznej.

Podobna sytuacja do tej w Meksyku miała miejsce w Sudanie. Także w tym przypadku, obok zjawisk o charakterze czysto antropologicznym, dodatkowo w grę wchodziły inne czynniki, takie jak: historia, religia, język i tradycja oraz ważne względy ekonomiczne. Od roku 1956 Sudan przez przeszło pół wieku stanowił jeden organizm państwowy o bardzo zróżnicowanej strukturze etniczno-społecznej. Północ kraju była zdecydowanie arabska i muzułmańska, natomiast południe było w większości chrześcijańskie (Tymowski, 1996, s. 872-883). Występowały również w szerokiej skali na jego terenie wierzenia animistyczne. Południe zamieszkiwała czarnoskóra rdzennie afrykańska ludność. Pomiędzy obiema częściami kraju już od czasów kolonialnych tliło się zarzewie konfliktu. Po wyjściu Brytyjczyków animozje między grupami kulturowo-etnicznymi uległy nasileniu. Doprowadziło to długotrwałej konfrontacji militarnej między dwiema grupami mieszkańców państwa. Polaryzację obu społeczeństw wzmocniło dodatkowo odkrycie na południu bogatych złóż ropy naftowej. Dalsza wspólna egzystencja tych społeczności okazała się niemożliwa. W lipcu 2011 roku różniące się od siebie regiony utworzyły dwa osobne państwa. Na północy powstał arabski Sudan z obowiązującym szariatem, południowa część kraju przyjęła zaś nazwę Sudanu Południowego. Zrywając z doktryną prawa islamskiego, mieszkańcy tego byłego regionu opowiedzieli się za drogą rozwoju opartą na tradycyjnych wzorcach afrykańskich.

Na przykładzie Meksyku i Sudanu widać, że do wytworzenia się wyodrębnionych terenów potrzeba najczęściej jednoczesnego działania większej liczby czynników etnicznych. Rozpatrywanie ich osobno skazuje rozważania na pewne zamierzone uproszczenia w podejściu do omawianego tematu i jest przydatne tylko z czysto teoretycznego punktu widzenia.

Czynniki gospodarcze stanowią bardzo istotną grupę wśród przyczyn stwarzających warunki do wyodrębnienia regionu $\mathrm{z}$ otoczenia. Zasadniczo można je podzielić na czynniki o charakterze rolniczym i przemysłowym.

Czynniki gospodarcze o charakterze rolniczym wystąpiły w dziejach ludzkiej cywilizacji bardzo wcześnie. Ich pojawienie się związane jest w sensie czasowym z młodszą epoką kamienia (gładzonego), zwaną neolitem. Okres ten trwał od około 10000 do około 3000 lat p.n.e. Na początek IX tysiąclecia p.n.e. datuje się moment, w którym społeczeństwo zaczęło przechodzić w swoim rozwoju od koczowniczej gospodarki zbieracko-łowieckiej do gospodarki opartej na rolnictwie w połączeniu ze stałym osadnictwem. Rolnictwo przyjęło zorganizowane formy uprawy ziemi i roślin oraz chowu i hodowli zwierząt. Pierwsze rośliny, które człowiek zaczął uprawiać to: jęczmień, proso, soczewica, groch, 


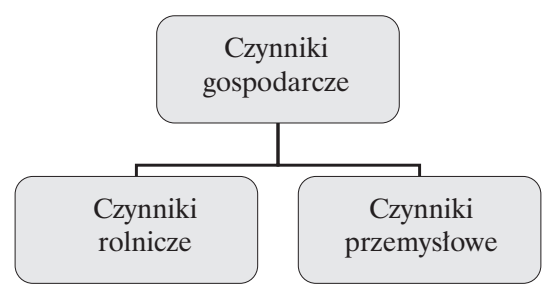

Rysunek 3. Czynniki gospodarcze kreujące regiony

Źródło: opracowanie własne.

a później żyto i pszenica. Stosunkowo szybko nauczono się również uprawy winorośli. Pierwszymi zwierzętami hodowlanymi były kozy i owce, nieco później udomowione zostały trzoda chlewna i bydło. Rolnictwo w początkowej fazie pojawiło się na terenach ku temu najbardziej sprzyjających ze względu na warunki glebowe oraz odpowiednio ciepły i wilgotny klimat. Objęło swoim zasięgiem obszar Bliskiego Wschodu od Doliny Nilu w Egipcie, poprzez dzisiejsze: Palestynę, Izrael, Syrię, południowo-wschodnią Turcję, aż po niezwykle żyzne gleby położone w dorzeczu Eufratu i Tygrysa w ówczesnej Mezopotamii (dzisiejszy Irak) (Tyloch, 1974, s. 11).

Do najważniejszych czynników warunkujących możliwość wprowadzenie rolnictwa na określonym obszarze należy zaliczyć: odpowiednie gleby, należyte nawodnienie terenu, sprzyjający klimat oraz wystarczające zasiedlenie. Czynniki te nie zmieniły się zasadniczo od czasów neolitu, aż po współczesność. Jednakże zastosowanie nawozów w celu uszlachetnienia ziemi uprawnej, wyhodowanie odmian roślin bardziej odpornych na skrajne temperatury, inwestycje melioracyjne oraz umaszynowienie rolnictwa umożliwiły rozszerzenie zasięgu tej gałęzi gospodarki na wszystkie kontynenty z wyjątkiem skutej lodem Antarktydy. Wszystkie dotychczas omówione czynniki zarówno naturalne, jak i nabyte, w sprzyjających okolicznościach mogły przyczynić się do procesu tworzenia regionu, nawet występując pojedynczo. W odróżnieniu od nich, cztery czynniki o charakterze rolniczym muszą dla osiągnięcia oczekiwanego rezultatu zaistnieć równolegle obok siebie w tym samym czasie. Jedynie natężenie poszczególnych z nich we wzajemnej relacji, może być zróżnicowane. W niektórych przypadkach może występować nawet $\mathrm{w}$ obrębie tego samego, wyodrębnionego obszaru.

Pierwszym znanym $\mathrm{z}$ historii zwartym obszarem, na którym wystąpiły sprzyjające warunki o charakterze rolniczym, umożliwiające powstanie kultury opartej na uprawie roślin i hodowli, jest Region Żyznego Półksiężyca. Łukowato wygięty od terenów, którymi płyną wody Tygrysa i Eufratu, aż do Doliny Nilu, przez długi czas nazywany był Złotym Rogiem. Pas niezwykle urodzajnych ziem, umożliwiających prowadzenie uprawy roślin i hodowli zwierząt, rozciągał się 
w czasach najdawniejszych od wschodnich wybrzeży Morza Śródziemnego aż do północnych wybrzeży Zatoki Perskiej. Obszar ten stał się kolebką największych cywilizacji starożytności: Babilonii, Egiptu, Fenicji, Izraela, Mezopotamii i Sumeru (Tschirschnitz, 1994, s. 53-66). Na jego terenie pojawiły się też kolejno trzy największe religie monoteistyczne świata: judaizm, chrześcijaństwo i islam. Ponieważ obecnie region zamieszkiwany jest w większości przez muzułmanów, zamiast nazwy Złoty Róg, stosuje się najczęściej określenie Żyzny Półksiężyc, ze względu na oczywistą konotację z jednym z najważniejszych symboli zaczerpniętych z tradycyjnego świata arabskiego.

Współczesna geografia ekonomiczna wyróżnia dwanaście głównych makroregionów rolniczych. Jerzy Kostrowicki opierając się na różnicach dominacji i współwystępowania określonych typów rolnictwa (rynkowego, spekulatywnego, specjalistycznego oraz naturalnego - mającego podstawę w samozaopatrzeniu, inaczej: subsystencyjnego) opisuje następujące globalne obszary uprawy i hodowli (Kostrowicki, Falkowski, 2005, s. 415-494):

- Makroregion Środkowopotudniowoafrykański znajdujący się na południe od Sahary. W Afryce Środkowej notuje się w nim przewagę rolnictwa pierwotnego, przeważnie subsystencyjnego (przykłady: Senegal, Gambia, Mali, Nigeria, Tanzania, Uganda). Główne uprawy wprowadzone tu jeszcze w czasach kolonialnych to: maniok, sorgo, proso, palma oleista, palma kokosowa, kawa, kakao, orzeszki ziemne. Na południu Afryki (obecnie w Republice Południowej Afryki i w Rodezji), aż połowy lat siedemdziesiątych XX wieku występowało rolnictwo intensywne rynkowe oraz uprzemysłowione.

- Makroregion Pótnocnoafrykański-Zachodnioazjatycki z przewagą rolnictwa drobnego subsystencyjnego lub małotowarowego oraz różne formy pasterstwa. Kraje występowania: Egipt, Syria, Jordania, Irak. Na relatywnie niewielkich, w stosunku do reszty opisywanego terenu, nawadnianych obszarach (w Izraelu) występuje rolnictwo intensywne, częściowo o orientacji towarowej.

- Makroregion Potudniowoazjatycki obejmujący Indie, Pakistan, Bangladesz, Birmę, Malezję, Indonezję, Kambodżę i Filipiny. Na wschodnich wybrzeżach kontynentu charakteryzuje się dużym zaangażowaniem i nakładami pracy żywej. Intensywnie nawadniany w sposób sztuczny. Przeważa tam subsystencyjne i drobno-towarowe rolnictwo, skoncentrowane na pracochłonnej uprawie ryżu. W Indonezji uprawia się również na znaczną skalę kauczuk.

- Makroregion Wschodnioazjatycki, obejmujący Japonię, Koreę Południową, Tajwan, obszar wschodnich Chin i Wietnam. Rolnictwo intensywne, tam gdzie warunki to umożliwiają - zmechanizowane i uprzemysłowione. W znacznej części sztucznie nawadniane (uprawa ryżu). W Japonii stosuje się już rolnictwo przemysłowe oparte na genetycznie zmodyfikowanych 
roślinach i uprawach hydropicznych. W Chinach i Wietnamie rolnictwo o charakterze wielkoprzestrzennym, intensywnym lecz małotowarowym, często jeszcze skolektywizowanym.

- Makroregion Środkowoazjatycki obejmujący Mongolię i zachodnie obszary Chin, ale przede wszystkim Azję Środkową z Kirgistanem, Kazachstanem, Uzbekistanem, Turkmenistanem i Tadżykistanem. Ciaggle jeszcze dominuje na tym terenie typ rolnictwa uspołecznionego, towarowego, ekstensywnego na obszarach nienawadnianych i zintensyfikowanego na terenach nawadnianych. W części zachodniej występuje rolnictwo intensywne o charakterze głównie samozaopatrzeniowym. Opiera się przede wszystkim na uprawie bawełny, herbaty, zboża i hodowli trzony chlewnej. W części zachodniej regionu przeważa forma rolnictwa ekstensywnego, czyli półkoczownicza hodowla koni, owiec, wielbłądów i kóz (w Mongolii). W Chinach, u podnóża Himalajów, znajdują się rozległe obszary plantacyjne krzewów herbaty uważanych za jedne z najsmaczniejszych gatunków tego napoju na świecie.

- Makroregion Australijsko-Nowozelandzki odznaczający się dominacją rolnictwa uprzemysłowionego, towarowego o bardzo różnych kierunkach produkcji. Przeważa rolnictwo o charakterze rynkowym, wyspecjalizowane w hodowli (głównie owiec z przeznaczeniem na wełnę, bydła) i uprawie zbóż (pszenicy, owsa, jęczmienia). W Australii Zachodniej uprawiana jest winorośl w obrębie sztucznie nawadnianych winnic.

- Makroregion Zachodnioeuropejski, na którego obszarze przeważa rolnictwo uprzemysłowione, w przeważającej większości intensywnie nawożone i wysoce zmechanizowane. Ma ono charakter wysokotowarowy typu rynkowego. Produkcja mieszana roślinna (zboża, rzepak, chmiel, tytoń, ziemniaki) i zwierzęca (bydło, trzoda chlewna, kury, kaczki i gęsi). Obejmuje ono rolnictwo: Francji, Holandii, Belgii, Luksemburga, Niemiec i Wielkiej Brytanii.

- Makroregion Środkowoeuropejski to jeden z najbardziej zróżnicowanych obszarów w odniesieniu do typów gospodarki rolnej. Od tradycyjnej rozdrobnionej i niskotowarowej, poprzez rolnictwo uspołecznione, do intensywnie rozwijającego się rolnictwa wysokotowarowego o charakterze rynkowym. Obejmuje Austrię, Czechy, Słowację, Węgry, Rumunię i Polskę. Uprawy są charakterystyczne dla strefy klimatów umiarkowanych. Najważniejsze z nich to: pszenica, żyto, ziemniaki, buraki cukrowe; dodatkowo produkcja owoców: jabłek, gruszek, śliwek i truskawek. Prowadzi się też na dużą skalę chów bydła, trzody chlewnej, owiec i drobiu. W Polsce najczęściej obok preferowanego przez władze rolnictwa wieloprzestrzennego, występuje rolnictwo o mniejszych areałach, indywidualne i drobnotowarowe o dużych walorach ekologicznych. 
- Makroregion Śródziemnomorski legitymuje się wysokotowarowym rolnictwem tradycyjnym oraz rozwiniętym typu rynkowego. Najczęściej opiera się na rozdrobnionej strukturze własności. Specjalizacja koncentrująca się głównie na plantacjach drzew oliwkowych, kulturze uprawy winorośli oraz produkcji owoców cytrusowych. Inne wytwory gospodarki rolnej to: pszenica, kukurydza, bawełna i tytoń. Występuje również ekstensywny chów bydła, owiec, kóz i drobiu. Najważniejsze kraje makroregionu w wąskim ujęciu to: Grecja, Hiszpania, Portugalia, Włochy i Turcja. W szerszym ujęciu, zaliczane są do tej grupy także: Cypr, Tunezja, Algieria i Maroko.

- Makroregion Pótnocnoeuroazjatycki obejmujący głównie rolnictwo Rosji (także Białorusi i krajów bałtyckich). Cechuje go niska towarowość i często ekstensywna gospodarka w odniesieniu do rolnictwa uspołecznionego. W efekcie transformacji ustrojowej funkcjonuje coraz więcej gospodarstw prywatnych. Kierunki produkcji można określić jako zróżnicowane. W części europejskiej duże znaczenie ma uprawa roślin i zbóż oraz hodowla bydła, trzody chlewnej i drobiu - przeważnie na własne potrzeby. W części azjatyckiej spotyka się najczęściej ekstensywną hodowlę zwierząt - owiec i kóz, rzadziej koni.

- Makroregion Pótnocnoamerykański (Angloamerykański) - na jego obszarze zdecydowanie zarysowuje się dominacja rolnictwa uprzemysłowionego, rynkowego, przeważnie wyspecjalizowanego, o różnych kierunkach produkcji. Na farmach, często o wielkiej powierzchni, prowadzona jest uprawa: pszenicy, kukurydzy, soi, sorgo, bawełny (na południowym wschodzie opisywanego obszaru) oraz tytoniu. Na dużą skalę występuje hodowla zwierzęca oparta na bydle, trzodzie chlewnej i drobiu. W Kalifornii uprawa szlachetnych gatunków winorośli. Makroregion reprezentowany jest przez dwa kraje: Stany Zjednoczone i Kanadę.

- Region Ameryki Lacińskiej (Eacińskoamerykański) charakteryzujący się przewagą rolnictwa ekstensywnego, subsystencyjnego lub małotowarowego. Obok drobnych gospodarstw produkujących na własne potrzeby, występują wieloprzestrzenne majątki ekstensywne oraz rynkowe o charakterze obszarniczym (tzw. hacjendy). Istnieją także pokaźnych rozmiarów plantacje specjalizujące się w uprawie bananów, kawy, soi, bawełny, trzciny cukrowej i tytoniu. Corocznie, przy użyciu znacznych środków finansowych i technicznych, w strefie zwrotnikowej niszczone są nielegalne pola marihuany. Główne zwierzęta hodowlane to: bydło, konie, trzoda chlewna i lamy (na obszarach górskich Ameryki Południowej). Największe kraje tego makroregionu to: Argentyna, Boliwia, Brazylia, Chile, Kolumbia, Kuba, Meksyk, Paragwaj, Peru, Urugwaj i Wenezuela. 
Makroregiony stanowią wyższy szczebel podziału odnoszący się do skali globalnej. W ich ramach wydzielone zostały mniejsze jednostki systematyczne - regiony. Najczęściej spotykane kryterium ich wyróżnienia stanowi zwykle dominacja jednej lub zespołu kilku charakterystycznych upraw roślinnych. Przykładowo w USA można wymienić (Kostrowicki, 2005, s. 418-423):

- Region wybrzeża Zatoki Meksykańskiej - zasobny w wodę i wilgotny na północy (Missisipi, Luizjana, Floryda) oraz borykający się z jej niedostatkiem w części południowo-zachodniej (Texas). Uprawy: ryż, trzcina cukrowa, owoce cytrusowe, orzeszki ziemne.

- Region zwany „pasem bawelny” - obejmujący przede wszystkim południe Stanów Zjednoczonych (Karolina Południowa, Georgia, Alabama, Missisipi, Texas). Główne uprawy to: bawełna, tytoń, soja i orzeszki ziemne.

- Region na pótnoc od „pasa bawetny” - pszenica ozima, gospodarka wielouprawowa, Obejmuje stany: Oklahoma, Kansas, Missouri, Dakota Północna, Dakota Południowa.

- Region kukurydzy - obejmuje stany: Iowa, Nebraska, Missouri, Dakota Południowa, Illinois. Hodowla to głównie bydło i trzoda chlewna.

- Region nad Wielkimi Jeziorami - warzywnictwo i hodowla o kierunku mlecznych oraz drobiarstwo i sadownictwo. Zalicza się do niego stany: Minnesota, Wisconsin, Michigan, Ohio, Pensylwania, Nowy Jork.

- Region na wybrzeżu Niziny Atlantyckiej - warzywnictwo i sadownictwo. Obejmuje: Georgię, Karolinę Południową, Karolinę Północną, Pensylwanię i Wirginię. W Massachusetts przeważa hodowla bydła, w Karolinie Południowej zaś hodowla trzody chlewnej.

- Region nad Pacyfikiem - pszenica, hodowla i gospodarka leśna. Obejmuje stany: Oregon i Waszyngton (na terenie tego stanu występuje gospodarka zbożowa wielkoobszarowa).

- Region Kalifornii - na jego obszarze przeważają: sadownictwo, warzywnictwo i uprawa winorośli. W środkowej części rolnictwo zbliżone w typie do śródziemnomorskiego. Na samej północy tego stanu, występuje również gospodarka leśna. Na południu rozpowszechniona hodowla bydła.

Można zauważyć, że klasyfikacja opierająca się na kryterium dominacji jednej lub kilku upraw nie jest ścisła i jednoznaczna. Zdarzają się bowiem stany, które zostały przypisane dwóm regionom, na przykład: Pensylwania (Region na wybrzeżu Niziny Atlantyckiej i Region nad Wielkimi Jeziorami) albo Dakota Południowa (do Regionu na północ od „pasa bawełny” i do Regionu kukurydzy). Jest to uzależnione od rozległości geograficznej wymienionych stanów i mieszanego charakteru upraw na ich terenie.

W Europie, (licząc wraz z europejską częścią Rosji) o powierzchni zbliżonej do Stanów Zjednoczonych, regiony rolnicze są zdecydowanie słabiej zróżni- 
cowane. Określając ich zasięg ze względu na kryterium dominujących kilku upraw, w sposób ogólny można wyodrębnić (Kostrowicki, 2005, s. 431-457):

- Region pótnocny. Rozciągający się umownie w górę od 50 stopnia szerokości geograficznej północnej. Południkowo od Francji (od Zatoki Biskajskiej, chociaż położona jest poniżej wyznaczonej linii), aż po Góry Ural w Rosji. Na krańcach północnych dochodzi do norweskich fiordów. $\mathrm{Z}$ przewagą upraw owsa i jęczmienia. Hodowla: bydła, trzody chlewnej i drobiu.

- Region środkowy z uprawami żyta, jęczmienia, buraków cukrowych i pszenicy, hodowlą bydła i trzody chlewnej. Rozciągający się umownie pomiędzy 50 stopniem a 45 stopniem szerokości geograficznej północnej. Obejmuje Białoruś, znaczną część Niemiec i Ukrainy, kraje Beneluksu, Polskę, Słowację i Czechy.

- Region potudniowy obejmujący kraje śródziemnomorskie, takie jak: Hiszpania, Włochy, Grecja, Chorwacja, Bośnia i Hercegowina. Zalicza się doń także niektóre państwa Europy Wschodniej: Węgry, Bułgarię, Rumunię, Mołdawię i południową część Ukrainy. Charakteryzuje się przewagą upraw pszenicy, kukurydzy, winnej latorośli i warzyw. Głównie hodowla trzody chlewnej, kóz, owiec i drobiu. Rzadziej specjalizacja w hodowli bydła (Hiszpania, Węgry, Rumunia i Włochy). W dużym przybliżeniu na południe od 45 równoleżnika szerokości geograficznej północnej.

Czynniki gospodarcze o charakterze przemystowym są najbardziej dynamiczną grupą kształtującą regiony we współczesnym świecie. Wiążą się one bezpośrednio z lokalizacją zakładów wytwórczych, takich jak fabryki, przedsiębiorstwa przetwórcze oraz zakłady wydobywające i eksploatujące bogactwa naturalne. Ich potencjalne możliwości stworzenia odrębnego regionu zależą od ilości placówek industrialnych na danym terenie, czasu ich funkcjonowania, szybkości rozwoju i następującej skali ekspansji, warunków inwestycyjnych, ilości dostępnego kapitału oraz bogactwa surowców nadających się do wykorzystania. Nieco mniejszą rolę w kształtowaniu odgrywają dostępne na ich obszarze zasoby ludzkie. Dzieje się tak dlatego, ponieważ powstające regiony o charakterze przemysłowym odznaczają się ogromną siłą przyciaggającą ludzi poszukujących stałej pracy. W przypadku braku wystarczającej ilości siły roboczej w kraju, obszary takie mają zdolność pozyskiwania zwykłych robotników oraz specjalistów wysokiej klasy nawet zza granicy.

Do najważniejszych bogactw naturalnych mogących przyczynić się do powstania odrębnych regionów należy zaliczyć surowce energetyczne, takie jak: węgiel kamienny i brunatny, ropa naftowa oraz gaz ziemny. W ostatnich kilkudziesięciu latach daje się jednak zauważyć globalną tendencję, polegającą na odchodzeniu od mało wydajnego energetycznie i szkodliwego dla środowiska węgla na korzyść 
głównie ropy naftowej i gazu. Pojawiły się dodatkowo inne - alternatywne źródła energii, uważane $\mathrm{w}$ większości za proekologiczne, w tym: wykorzystanie siły wiatru, energii słonecznej i energii wodnej. Osobny temat stanowi energetyka jądrowa, która stała się niepopularna szczególnie w kręgach obrońców przyrody. Przyczyny należy upatrywać w kilku poważnych awariach i katastrofach elektrowni atomowych, jakie miały miejsce na świecie w ostatnich kilkudziesięciu latach. Doprowadziły one do poważnych skażeń radioaktywnych wielkich obszarów, które będą się utrzymywać przez wiele dekad. Jednakże trzeba od razu stwierdzić, że alternatywne źródła energii nie zawierają w swojej istocie żadnych czynników mogących spowodować tworzenie regionów.

Górny Śląsk w Polsce oraz Zagłębie Ruhry w Niemczech są regionami, których powstanie zostało zainspirowane występowaniem na tych obszarach surowca energetycznego, jakim był węgiel kamienny. W miarę wzrostu intensywności wydobycia „czarnego złota”, tereny te miały moc przyciągania ludzi poszukujących pracy. Po osiedleniu się i zaaklimatyzowaniu w ciągu kilkuset lat wytworzyli oni unikatową kulturę przejawiającą się w specyficznym języku (gwarze), strojach, organizacji życia społecznego, instytucjach związanych z wykonywaną pracą, odrębną kuchnią regionalną oraz poczuciem odrębności etnicznej. Pomimo obecnego zmarginalizowania znaczenia węgla w życiu gospodarczym, poczucie swoistego charakteru wymienionych terenów oraz wyraźnie wyznaczone historycznie granice pozostały do dzisiaj.

Prowincja Kabinda (port. Cabinda) w Angoli, obfituje w bogate złoża ropy naftowej i gazu ziemnego. Położona jest na wybrzeżu Atlantyku, na północ od ujścia rzeki Kongo, graniczy z Demokratyczną Republiką Konga i Zairem. Jej teren nie posiada bezpośredniego połączenia z resztą kraju. „Rewolucja goździków" w połowie lat siedemdziesiątych XX wieku skierowała sprawującą nad nią pieczę - kolonialną Portugalię - na drogę demokracji. Enklawa w sierpniu 1975 roku ogłosiła niepodległość i jednocześnie niezależność od Angoli. Stała się niezawisłym państwem z własnym prezydentem, rządem, administracją i walutą. Głównym powodem próby uniezależnienia się regionu od obcych wpływów była wola jej mieszkańców. Mieli oni nadzieję wyłącznego czerpania korzyści z bogatych złóż surowców, jakie znajdowały się u wybrzeży tego obszaru. Pomimo brutalnego spacyfikowania prowincji przez wojska angolańskie i wspierających je ochotników kubańskich, w dalszym ciągu w tym regionie występują silne tendencje i ruchy narodowowyzwoleńcze.

Występowanie ropy naftowej oraz bogatych złóż gazu ziemnego było asumptem dla powstania państwa w Zatoce Perskiej o nazwie Zjednoczone Emiraty Arabskie. Obok największego w tej grupie, liczącego tylko nieco ponad 4 tys. $\mathrm{km}^{2}$ Dubaju, w jego skład wchodzi jeszcze pięć mikroskopijnych emiratów: Abu Zabi, Szardża, Adżman, Umm al-Kajwajn, Ras al-Chajma i Fudżajra. Celem, jaki przyświecał ich władcom w idei połączenia „siedmiu królestw” 
w jeden organizm państwowy, była chęć wspólnego zgromadzenia środków potrzebnych do przemysłowej eksploatacji ropy naftowej i gazu. Jednocześnie zjednoczenie dawało emiratom większe bezpieczeństwo i liczący się głos na arenie międzynarodowej. Zamierzone cele zostały w pełni osiągnięte. W tej chwili Zjednoczone Emiraty Arabskie należą do najbogatszych państw naszego globu, a z ich głosem liczą się najważniejsze organizacje międzynarodowe i największe kraje świata. Tym sposobem bogate złoża surowców energetycznych przyczyniły się do zmiany konfiguracji sił na Bliskim Wschodzie i do powstania ważnego partnera gospodarczego w skali regionu.

Powstaniem regionu ze względu na czynniki przemysłowe może poszczycić się również Polska. Chlubnym przykładem w tym względzie jest, nieukończona ze względu na wybuch II wojny światowej, budowa Centralnego Okręgu Przemysłowego (COP). Realizacja tego, największego w historii II Rzeczypospolitej, przedsięwzięcia miała miejsce w latach 1936-1939 i objęła swym zasięgiem znaczny obszar czterech ówczesnych województw, tzn. kieleckiego, lubelskiego, lwowskiego i krakowskiego. O lokalizacji zadecydowały przesłanki przede wszystkim ekonomiczne i obronne. Jednakże uwzględnione zostały również czynniki społeczne i demograficzne. COP miał stworzyć pomost między Polską A (rozwiniętym zachodem kraju) a Polską B (poważnie zacofanym gospodarczo wschodem) (Brzoza, Sowa, 2007, s. 211-218).

Tereny Centralnego Okręgu Przemysłowego miały w zamyśle stanowić surowcowe, techniczne i zaopatrzeniowe zaplecze polskiej armii w razie konfliktu zbrojnego. Wyznaczenie granic okręgu w strategicznym oddaleniu od zachodnich i wschodnich granic państwa miało zapewnić utrzymanie bieżących dostaw dla wojska w czasie przewidywanych, długotrwałych zmagań militarnych (Klusek, 1992, s. 16-52). W kontekście demograficznym chodziło o zmniejszenie panującego w tym regionie przeludnienia na wsi, przeciwdziałanie dotkliwemu bezrobociu oraz złagodzenie nastrojów niezadowolenia społecznego. W wybudowanych na obszarze COP zakładach i fabrykach do 1939 roku znalazło stałe zajęcie przeszło 100 tysięcy osób poszukujących pracy. Region stworzył model młodego, świadomego obywatela, który dzięki zatrudnieniu w przemyśle, mógł realizować swoje plany życiowe i z nadzieją patrzeć w przyszłość. Ludność w granicach Centralnego Okręgu Przemysłowego była w zdecydowanej większości rdzennie polska. $Z$ tego względu społeczeństwo, budujące na obszarze COP swoją egzystencję, było przeświadczone o niesionej misji dziejowej i głęboko patriotyczne. Budowa, niemalże od podstaw, prężnego regionu przemysłowego pochłaniała przez szereg lat większość środków budżetowych przeznaczonych na krajowe inwestycje. Prasa opozycyjna zarzucała nawet ekipie rządzącej zbudowanie „oazy szczęśliwości” kosztem niedofinansowania pozostałych części państwa. Faktycznym ukoronowaniem procesu tworzenia nowego regionu miało się stać stworzenie tzw. województwa COP. Według planów, w roku 1939, 
na mapie administracyjnej kraju, obok istniejących szesnastu, przygotowywano powstanie siedemnastego województwa: sandomierskiego. W jego granicach miały się znaleźć najważniejsze ośrodki przemysłowe skupione przede wszystkim w dynamicznie rozbudowujących się Kielcach, Rzeszowie i Radomiu (Jezierski, Leszczyńska, 2003, s. 308).

Czynniki nabyte o charakterze administracyjnym, wobec postępującej globalizacji pociągającej za sobą wzajemne przenikanie kultur i unifikację gospodarczą, stanowią w dzisiejszych czasach często jedyny sposób na wyodrębnienie regionów. Odgraniczenie w tym trybie wybranych obszarów przybiera formę całkowicie sztuczną, oderwaną od innych istotnych przesłanek. Jednakże przypisanie wyznacznika administracyjnego regionów czasom współczesnym jest zbytnim uproszczeniem. Czynnik nabyty w oparciu o decyzje administracyjne występował także w bliższej i dalszej przeszłości.

Przykładem z przeszłości, ilustrującym czynnik administracyjny, jest rozgraniczenie na gruncie polskim obszaru Warmii od Mazur. Warmia w swojej historii aż do II połowy XV wieku należała do państwa krzyżackiego. Po krótkim okresie przynależności do Rzeczypospolitej jej obszar został włączony do Królestwa Prus. Po roku 1945, wraz ze sporym kawałkiem dawnych Prus Wschodnich, znalazła się w granicach Polski. Chociaż w tej chwili terenów Warmii od terenów Pojezierza Mazurskiego nie oddzielają żadne granice i oba obszary tworzą jednolitą administracyjnie, kulturowo i przyrodniczo krainę, to jednak z punktu widzenia historii odrębność administracyjna Warmii została uszanowana. Znalazła się na mapach regionu, oficjalnych dokumentach oraz w nazwie województwa warmińsko-mazurskiego.

Innym przykładem stworzonego całkowicie sztucznie podziału regionu w sposób czysto administracyjny są należące do Królestwa Hiszpanii, położone na Oceanie Atlantyckim, Wyspy Kanaryjskie. Ten, leżący u północno-zachodnich wybrzeży Afryki, wulkaniczny archipelag składa się z siedmiu głównych wysp i towarzyszących im sześciu mniejszych. Chociaż sam w sobie jest jednorodną enklawą kultury i cywilizacji europejskiej, został podzielony na dwie prowincje skupione wokół pary największych wysp. Tworzą je ośrodki w Las Palmas de Gran Canaria i w Santa Cruz de Tenerife. Czysto administracyjny podział był uwarunkowany możliwością ubiegania się środki na rozbudowę i rozwój, pochodzące z budżetu Unii Europejskiej. W przypadku dwóch prowincji przyznana kwota pieniędzy może być dwukrotnie wyższa niż byłaby w odniesieniu do pojedynczego regionu.

W praktyce precyzyjne wyodrębnienie tylko jednego czynnika, który staje się bodźcem dla stworzenia regionu jest niemożliwe. We wszystkich przytoczonych przykładach, w sposób celowy została silnie wyeksponowana rola pojedynczej przesłanki w procesie powstawania obszaru o zauważalnie innym charakterze. Zamysłem było zwrócenie uwagi na fakt, że istnieją bardzo różniące się od 
siebie czynniki mające moc sprawczą budowania regionów. W rzeczywistości występują one równolegle do siebie, kontrastując wzajemnie tylko pod względem nasilenia lub wykazując inny czas zaistnienia. Dotyczy to zjawisk, które można zauważyć tylko w obrębie zespołu czynników naturalnych lub zespołu czynników nabytych, jak również jednoczesnego działania obu wymienionych grup na jednym polu. Można być również przekonanym co do faktu, że opisane przyczyny tworzące regiony nie zamykają listy wszystkich możliwych czynników twórczych. Ich katalog ulega nieprzerwanej ewolucji i rozbudowie. Wynika to z dynamicznych zmian politycznych na świecie. Odbywa się także dzięki postępowi technicznemu umożliwiającemu swobodne poruszanie się po naszym globie. Kolosalne znaczenie mają w tym zakresie, również: swobodny dostęp do danych i możliwość ich przechowywania dzięki rewolucji informatycznej. Jednakże przede wszystkim używanie na co dzień przez setki miliardów ludzi Internetu zmieniło świadomość i sposób podejścia do wielu spraw, w tym także sposobu postrzegania własnej odrębności.

\section{Regionalizm i regionalizacja}

Aby zrozumieć przesłanki tworzące i kształtujące regiony, niezbędne jest wyjaśnienie pojęcia „regionalizmu”. Termin ten zawiera w sobie jednak kilka różnych znaczeń.

W najczęściej rozumianym podejściu opisuje zjawisko społeczne, które należy postrzegać jako poczucie wspólnej tożsamości mieszkańców określonego regionu. W tym ujęciu zauważalne są dążenia społeczeństwa do autonomii zamieszkiwanego obszaru. W skrajnych przypadkach do głosu dochodzą nawet nastroje niepodległościowe. Pragnienie wyzwolenia się regionu z granic dotychczasowego organizmu państwowego i obranie kierunku na niepodległość i samostanowienie są słabo zaznaczone w okresie dobrej koniunktury gospodarczej. W czasach kryzysowych przybierają na sile i egzemplifikują się w postaci protestów politycznych, strajków na masową skalę, niepokojów społecznych, a nawet aktów terroru. Na obszarze Europy regionalizm odśrodkowy dążący do utworzenia własnego państwa można zaobserwować w przypadku Francji, a bezpośrednio - Korsyki. Bardziej radykalne dążenia niepodległościowe wykazują dwa regiony autonomiczne Hiszpanii, a mianowicie: Kraj Basków (stolica: Vitoria-Gasteiz ) i Katalonia (ze stolicą w Barcelonie) (Freeman, 1993, s. 43-56). Z perspektywy władz centralnych każdy regionalizm odśrodkowy ma zdecydowanie negatywny charakter i stanowi zagrożenie dla bytu państwa. Można jeszcze mówić o regionalizmie dośrodkowym. Ten typ reprezentowany jest zazwyczaj przez najsilniejszy region w kraju. Jego celem jest utrzymanie jedności państwa i zdominowanie 
cywilizacyjne oraz kulturowe obszarów peryferyjnych. Wobec sprzeciwów podległych prowincji używany jest policyjny aparat przymusu, a nawet armia. W tym układzie regionalizm może być zdefiniowany jako konflikt centrum z peryferiami. Przykładami regionów o silnym regionalizmie dośrodkowym są: Serbia z Belgradem w byłej Jugosławii oraz Madryt jako stolica połączonej Kastylii.

Najnowsza historia pokazuje, że zarówno regionalizm dośrodkowy, jak i odśrodkowy mogą być procesami wywołanymi całkowicie sztucznie, przy użyciu nie zawsze ogólnie przyjętych i akceptowanych metod oraz wbrew oczywistym interesom państwowym.

Przykładem wymuszonego regionalizmu dośrodkowego jest historia państw bałtyckich: Litwy, Lotwy i Estonii. ZSSR, na podstawie zawartych pod presją militarną umów międzynarodowych, wprowadził i utrzymywał na ich terenie już od jesieni 1939 roku silne garnizony wojskowe.

W połowie lipca 1940 roku z polecenia Stalina, pod egidą radzieckiej NKWD, zostały w państwach bałtyckich przeprowadzone „niezależne wybory” do najwyższych organów ustawodawczych. Nowo wybrani parlamentarzyści byli bądź agentami rosyjskimi, bądź też podporządkowali się już wcześniej poleceniom płynącym prosto z Moskwy. Na pierwszych posiedzeniach parlamentów podjęli oni uchwały przez aklamację o przystąpieniu swoich krajów do ZSRR. Miesiąc później Rada Najwyższa Związku Radzieckiego odpowiedziała na wystosowane pokorne prośby i wcieliła trzy niewielkie państwa do Kraju Rad jako Socjalistyczne Republiki Radzieckie: Litewską, Łotewską oraz Estońską.

Przykładem nieudanej próby wywołania procesu regionalizmu odśrodkowego jest działalność przedwojennej polskiej Ligi Morskiej i Kolonialnej w aspekcie emigracji osadniczej w Brazylii. Wychodźstwo polskie w tym kraju na początku lat trzydziestych XX wieku liczyło około 200 tysięcy osób. Regionem o najwyższej koncentracji żywiołu polskiego, był położony na południu Brazylii stan Parana. Na ogólną liczbę około miliona jego mieszkańców nasi rodacy stanowili około 100 tysięcy. Wokół stolicy tego terytorium - Kurytyby, odsetek ten przekraczał nawet 30\%. Władze Ligi Morskiej i Kolonialnej postanowiły proporcje te jeszcze zwiększyć na korzyść Polaków. W założeniach tzw. wielkiego planu delegat Ligi, generał Stefan Strzemieński, uzgodnił z rządem Brazylii, że polska organizacja zakupi na cele osadnicze $2 \mathrm{mln}$ ha ziemi oraz dokończy budowę linii kolejowej Riozinho-Guarapuava, nabywając tym samym prawo do jej wyłącznej eksploatacji na okres 60 lat. Pod koniec 1936 roku LMiK weszła w posiadanie na kontynencie południowoamerykańskim w około 30 tys. ha ziemi. Na przejęte tereny sprowadzono w tym samym roku, w pierwszym rzucie 41 rodzin, w sumie 184 osoby. Słabsza niż założono dynamika akcji osiedleńczej wiązała się z wystąpieniem w tym czasie symptomów kryzysu ekonomicznego w Polsce oraz szczupłością środków, które organizacja otrzymała decyzją Sejmu na swoje cele statutowe. Kolonizacja za sprawą Ligi Morskiej i Kolonialnej 
miała stanowić jedynie zaczątek szerszej akcji opartej na kapitale prywatnym i państwowym. Skoncentrowanie polskiego osadnictwa tylko w regionie Parany miało być pierwszym etapem realizacji dalszych koncepcji Ligi. Wychodźstwo polskie, przy czym zakładano a priori, że będzie ono posiadało szeroką autonomię w zakresie życia narodowego i gospodarczego, miało utrzymywać ścisłe kontakty kulturalno-oświatowe, a zwłaszcza być czynnikiem stymulującym rozwój polskiego handlu zamorskiego oraz producentem potrzebnych rodzimemu krajowi surowców. Stojąc na wyższym poziomie cywilizacyjnym i organizacyjnym zgromadzona w diasporze polonia, miała dokonać przejęcia w sposób pokojowy władzy w zamieszkanym przez siebie regionie. Następnie osadnicy mieli utworzyć państwo polskie o szerokim dostępie do morza, które uniezależniłoby się od Brazylii i związało ściśle z Rzeczpospolitą (Białas, 1983, s. 196-208). Na przeszkodzie tym planom stanął zamach stanu przeprowadzony przez Getulio Vargasa, który dał mu jako prezydentowi kraju praktycznie nieograniczoną władzę. Przywódca ten, stawiając na kartę nacjonalistyczną, wydał w krótkim czasie znaczną liczbę różnego rodzaju ustaw i zarządzeń wyraźnie skierowanych przeciwko osiadłym Europejczykom. Nowa konstytucja wprowadzona w listopadzie 1937 roku zapoczątkowała akcję bezwzględnej, a nawet czasami brutalnej asymilacji obcych żywiołów etnicznych. Wydane przepisy sparaliżowały całkowicie działalność kulturalną, społeczną, a nawet gospodarczą aktywnych dotąd środowisk włoskich, niemieckich oraz polskich (Lepecki, 1962, s. 181). Tak więc, wobec nieprzewidzianej i gwałtownej zmiany warunków politycznych oraz ekonomicznych, najbliższa urzeczywistnieniu, koncepcja pozyskania przez Polskę terytoriów zamorskich zakończyła się fiaskiem. Pieniądze zaangażowane w próbę wywołania procesu regionalizmu odśrodkowego na terenie Brazylii przepadły. Także materiał ludzki wysłany na teren Ameryki Południowej został bezpowrotnie utracony. Nikt z kilkuset osadników do Polski nie powrócił.

W innym podejściu regionalizm postrzegany jest jako alternatywa dla państwa lub też jako ośrodek rozwoju na poziomie niższym od ogólnopaństwowego. W tym kontekście zwolennicy regionalizmu przewidują zmierzch suwerenności i postulują zniesienie granic państwowych. Takie stanowisko wynika zazwyczaj z tworzenia się silnych związków socjalnych i ekonomicznych w obrębie regionu i wynikającego stąd nasilenia się poczucia integracji społecznej. W ten sposób powstaje tzw. integracja nieformalna, określana często jako miękki regionalizm (ang. soft regionalism). Przy takim podejściu szczególny nacisk położony jest na procesy, które prowadzą do zacieśniania współpracy gospodarczej w obrębie określonego obszaru geograficznego. Stworzone więzi ekonomiczne są silniejsze wewnątrz danego regionu niż pomiędzy nim a resztą świata. Współzależności pomiędzy działającymi podmiotami są generowane przez wspólny rynek, wymianę handlową, wzajemne inwestycje oraz określoną politykę gospodarczą. Następuje swobodny przepływ i wymiana kapitału w granicach wyodrębnionego 
obszaru, pogłębiająca się współpraca pomiędzy przedsiębiorstwami w różnych dziedzinach, jak również dochodzi do wzajemnie korzystnych przejęć i fuzji firm w układzie międzynarodowym (Gawlikowska-Hueckel, 2003, s. 119).

Zjawisko można zauważyć na gruncie Unii Europejskiej lub we współpracy podmiotów mających swoje siedziby w granicach Północnoamerykańskiej Strefy Wolnego Handlu (ang. North American Free Trade Agreement). Ten rodzaj silnie związanego z sytuacją ekonomiczną regionalizmu przeżywa swój rozkwit w okresie koniunktury rynkowej i ulega spowolnieniu lub nawet regresji w czasach kryzysu gospodarczego.

Regionalizm jako pewnego rodzaju grupowa świadomość może doprowadzić do wystąpienia tendencji ukierunkowanych na niezależność polityczną, urzeczywistnianą w ramach struktur federalnych. W ekstremalnych sytuacjach prowadzi do nacjonalizmu i separatyzmu. $\mathrm{W}$ tym znaczeniu regionalizm może być przyczyną zaistnienia, a następnie utrwalania się nierówności rozwojowych między regionami (Weyand, 1997, s. 166-182).

Na starym kontynencie zjawisko regionalizmu przyjmuje dwie zasadnicze formy - polityczną i administracyjną. Pierwsza uznaje region za wyraz upodmiotowienia wspólnoty jaka go tworzy oraz wysokiej samooceny i świadomości społeczno-politycznej jego mieszkańców. Druga uznaje istniejące podziały za niewystarczająco efektywne. Poprzez rewizję granic obszarów, ich łączenie lub podział dąży do uzyskania lepszych efektów ekonomicznych. Z punktu widzenia nowoczesnego państwa regionalizacja staje się pewnego rodzaju koniecznością. Istnieje przeświadczenie, że region jest jednostką dającą się lepiej zaplanować i efektywniej zarządzać. Rola odczuć i opinii społecznej jest w tym przypadku faktycznie zmarginalizowana (Gawlikowska-Hueckel, 2003, s. 120-121). W obu przypadkach regionalizacja jest wyrazem dążeń spójnych z założeniami i wytycznymi przyjętymi przez państwa członkowskie Unii Europejskiej. Popularne hasło: „Europa Regionów”, stworzone w latach siedemdziesiątych XX wieku, zachęcało do tworzenia w ramach struktur państwowych silnych i nastawionych na rozwój jednostek terytorialnych (Bullman, 1997, s. 3-19). Obecnie, niejako równolegle do „starej”, daje się zauważyć rozpowszechnianie nowej idei. Dotyczy ona wyższego szczebla organizacji UE i mówi o konieczności pogłębienia integracji ugrupowania zrzeszonych państw na podstawie zasad federacyjnych.

Ważnym terminem, o którym należy wspomnieć, związanym blisko znaczeniowo i etymologicznie z regionalizmem jest „regionalizacja”. Nie jest to pojęcie jednoznaczne. Ujmując sprawę ogólnie, stanowi zjawisko prawno-ustrojowe poprzez fakt bycia elementem ustroju państwa. Może też być fenomenem czysto politycznym. W praktyce oznacza zarówno czynność, jak i wynikający z niej efekt (Lemańska, 2006, s. 32-33).

Według niektórych poglądów stanowi ona zjawisko w sensie organizacyjnym, przeciwstawne do decentralizacji. Rozpatrując rzecz z tego punktu widzenia, 
regionalizację należy traktować jako formę organizacji państwa złożonego. Decentralizacja oznacza natomiast oddelegowanie kompetencji organów centralnych władzom niższych szczebli. Stanowi celową i zaplanowana politykę rządu, zmierzającą do reorganizacji terytorium państwa w celu zmniejszenia zróżnicowań i przyspieszenia rozwoju danego obszaru (Jałowiecki, 1992, s. 44).

Pogłębiając rozważania, decentralizację trzeba w tym kontekście traktować jako stworzenie podziału administracyjnego, w którym jednostki samorządu terytorialnego są szczeblem władzy podlegającym bezpośrednio rządowi centralnemu. W pewnej opozycji do takiego ujęcia istnieje pogląd, że regionalizacja nie jest skutkiem, lecz dopiero wstępnym etapem w długim procesie zmierzającym do ustanowienia pewnego porządku administracyjnego (Gawlikowska-Hueckel, 2003, s. 120). Problemem jest tutaj sposób zarządzania podzielonymi częściami oraz zakres samodzielności i stopień autonomii, na jaki władza centralna może się zgodzić (Rabska, 1992, s. 25-26).

Na gruncie europejskim można wyróżnić trzy główne, wzajemnie powiązane ze sobą formy regionalizacji. Pierwszą z nich reprezentuje regionalizacja „typu polskiego" powstała na fali zmian ustrojowych i wynikającego z nich przywrócenia samorządu terytorialnego w naszym kraju. W Polsce proces ten datowany jest od 1990 roku. W pozostałych krajach byłego bloku wschodniego nastąpiło to nieco później (Goverde, 1996, s. 72-74).

Druga forma regionalizacji to efekty szybko postępujących zjawiska rozwoju gospodarczego w szerokim wymiarze. Ta ścieżka kojarzona jest nieodłącznie z pojęciem integracyjnym w skali kontynentalnej i światowej. Mowa tu o globalizacji i dążeniach unitarnych we wspólnotach europejskich. Konkretnie chodzi o wymienioną już koncepcję „Europy Regionów”, która ma w zamyśle zagwarantować kulturową, społeczną i gospodarczą integrację starego kontynentu.

Trzecią formą jest regionalizacja związana $\mathrm{z}$ eksponowaniem przywiązania do tożsamości społeczno-kulturowej wykazywanej oficjalnie przez zorganizowane grupy ludności i instytucje na forum międzynarodowym. Przykładami są formy międzyregionalnej współpracy transgranicznej i powoływanie do życia tzw. euroregionów. Egzemplifikacją instytucjonalną jest możliwość aktywnego działania przedstawicieli regionów w Komitecie Regionów Wspólnot Europejskich (Wlaźlak, 2010, s. 26).

W dwóch pierwszych, z trzech wymienionych powyżej form, regionalizacja jest tym szybsza i przynosi tym lepsze efekty, im głębiej przebiegają i powszechniejsze są zdobycze demokratyzacji ustrojowej oraz społecznej (Gawlikowska-Hueckel, 2003, s. 121). Czynnikiem w dużym stopniu sprzyjającym temu procesowi jest także postępująca integracja ponadnarodowa w skali kontynentalnej i globalnej.

Porównując zjawisko regionalizmu i regionalizacji należy wspomnieć jeszcze o ukierunkowaniu czynników, które wpływają na wystąpienie opisywanych zjawisk. 
Regionalizm uznawany jest za tendencję „oddolną” i przede wszystkim spontaniczną w swojej istocie. Wywodzi się z obecnej i zauważalnej odrębności etnicznej popartej rozpowszechnioną tradycją społeczną. Mechanizm ten eksponuje wyjątkowość i specyfikę kultury oraz chroni tożsamość przed niechcianą unifikacją z istniejącą w otoczeniu większością.

Regionalizacja uznawana jest za tendencję „odgórną”. Stanowi oddziaływanie władz centralnych w celu zmian rozwojowych w odniesieniu do podziału terytorialnego kraju. Celem przeprowadzania zmian jest zazwyczaj dążenie do zrównoważonego wzrostu poszczególnych obszarów. Osiąga się to w praktyce poprzez określenie obowiązujących w dłuższym okresie priorytetów oraz stworzenie zadań do realizacji poprzez politykę regionalną. Urzeczywistnienie zamierzeń jest konsekwencją podejmowanych decyzji administracyjnych. Działania z zakresu regionalizacji stanowią najczęściej rezultat prac i opracowań specjalistów z wielu różnych dziedzin przy współpracy ekspertów rządowych (Sagan, 2007, s. 105). Regionalizacja stanowi długotrwały proces pogłębiania powiązań o charakterze: społecznym, administracyjnym, ekonomicznym, kulturowym, a także cywilizacyjnym, mający na celu zbudowanie silnego oraz sprawnie działającego systemu polityczno-gospodarczego.

Przyjmuje się, że w dzisiejszych czasach proces regionalizacji odbywa się równolegle na trzech poziomach (Fawcett, 2004, s. 443):

1) w danym regionie (skala krajowa),

2) pomiędzy regionami (skala krajowa i kontynentalna),

3) ponad regionami (skala kontynentalna i globalna).

Na każdym z wymienionych poziomów intensywność regionalizacji określają narastające przepływy (informacji, kapitału, siły roboczej) oraz powstające dynamicznie wzajemne zależności ekonomiczne. W dobie niezwykle szybkich przemian gospodarczych, tworzenia się świadomego swych praw społeczeństwa informatycznego, konfliktów politycznych na skalę międzynarodową oraz występowania zjawisk kryzysowych w wymiarze całego globu jesteśmy świadkami występowania obu opisanych tendencji (regionalizmu i regionalizacji) obok siebie. Ich zaistnienie i nasilenie są uzależnione od miejsca wystąpienia oraz poziomu rozwoju demokracji na danym obszarze. 


\section{Wybrane teorie rozwoju regionalnego}

Termin „rozwój” kojarzony jest najczęściej z uzyskaniem przez dany podmiot nowych i szerszych możliwości funkcjonowania. Może również oznaczać polepszenie egzystencji określonego ustroju poprzez przejście z dotychczasowego niższego poziomu na wyższy, bardziej złożony oraz mocniej zróżnicowany. Dotyczy zjawisk z różnych gałęzi nauki, techniki i praktyki społeczno-gospodarczej. Może charakteryzować procesy czysto teoretyczne lub dotyczyć zmian przebiegających w ustalonych strukturach formalnych lub też istniejących organizmach żywych. Najczęściej kojarzony jest z zauważalnym i odczuwalnym postępem w wybranej dziedzinie.

\section{Pojęcie rozwoju regionalnego}

Połączenie słowa „rozwój” ze słowem „region” albo „regionalny” daje w efekcie zaistnienie lub oczekiwanie zaistnienia pozytywnych zmian zwiększających potencjał wyznaczonego obszaru. W ten sposób zostaje określony pożądany kierunek ewolucji, którego utrzymanie stwarza szanse dalszego postępu i daje rozleglejsze perspektywy biorącym udział w całym procesie pojedynczym osobom, grupom społecznym oraz instytucjom.

Równolegle do pojęcia „rozwoju” wymienia się często pojęcie „wzrostu”. Obie kategorie mogą charakteryzować poziom gospodarki w skali regionu. Wzrost gospodarczy należy postrzegać jako kategorię ilościową, która wyraża się zwiększeniem produktu per capita. Rozwój gospodarczy jest pojęciem oznaczającym całą grupę szerszych zagadnień oraz szczegółowych aspektów życia mieszkańców danego obszaru. Powinny one prowadzić do polepszenia standardów życia społeczeństwa w granicach określonego terytorium. Wzrost należy zatem rozumieć jako zmianę czysto ilościową. Rozwój obejmuje natomiast zmiany ilościowe, jak również jakościowe. Występowanie wzajemnych zależności między wzrostem a rozwojem prowadzi w tym kontekście do stwierdzenia, że wystąpienie wzrostu stanowi zasadniczy warunek rozwoju gospodarczego regionu (Bartkowiak, 2003, s. 47). 
Dodatkowo należy zwrócić uwagę na występowanie dwóch pojęć dotyczących słowa „rozwój” w odniesieniu do zagadnień regionalnych. Występują w tym zakresie terminy: „rozwój regionu” i „,rozwój regionalny”. Rozwój regionu odnosi się do pojedynczego regionu i zjawisk, które w nim zachodzą. Natomiast rozwój regionalny opisuje zjawiska występujące w szerszej skali, na przykład w układzie kraju lub ponadnarodowym.

Takie podejście eksponuje pewne podobieństwa oraz pozwala zauważyć różnice wtedy, gdy pod uwagę branych jest kilka lub więcej wyodrębnionych obszarów jednocześnie (Gorzelak, 1989, s. 10). Wychodząc z tego założenia, wszelkie rozważania można najpierw przeprowadzić w wymiarze, który można by nazwać: „mezzoskalą” i oznacza ono odniesienie do pojedynczego regionu. Stanowiłyby one wstęp dla szerszego spojrzenia na poziomie krajowym lub transgranicznym w skali makro. Wychodząc jednak z założenia, że granica między tymi podejściami jest słabo zarysowana, a w zasadzie płynna, w dalszych rozważaniach nie będzie stosowany wyraźny podział tych zjawisk.

Rozumienie pojęcia „rozwój” należy zatem w tym miejscu zawęzić do kategorii zjawisk o charakterze pozytywnie ocenianych przeobrażen, dotyczących obserwowanego obiektu badań. Ogranicza to pojemność pojęcia, tylko i jedynie do korzystnych zmian, jednoznacznie odbieranych przez podmioty zainteresowane ogólnym przebiegiem sprawy. Jednakże trzeba mieć świadomość, że nie każdy proces rozwojowy prowadzi do pożądanych przez otoczenie przekształceń i ostatecznego sukcesu.

Przekształcenia mogą prowadzić zarówno do całościowego i zrównoważonego rozwoju, jak i do wystąpienia zaburzeń w pewnych dziedzinach, na skutek nierównomierności zamian i braku ich wzajemnego powiązania. Należy zawsze dążyć do tego, aby rozwój miał charakter integralny (zintegrowany) i wszechstronny. Daje to dużą szansę na stworzenie w każdym wypadku wewnętrznie powiązanej i złączonej całości, kształtującej życie gospodarcze i społeczne, a zarazem środowisko, w którym cały proces się odbywa (Skrzeszewski, 1976, s. 64).

W ekstremalnych przypadkach, mogą występować także patologiczne przemiany kończące się w negatywny sposób.

Poprzez analogię do diagnoz medycznych można odwołać się tu do rozwoju choroby zakaźnej, zakłócającej funkcjonowanie dotkniętego nią żywej istoty. Jej rezultatem mogą być wymykające się spod kontroli poważne następstwa. W pomyślnym układzie zaatakowany organizm może poprzez system immunologiczny uodpornić się na określony rodzaj zakażeń i infekcji. Przy niepomyślnym i bardziej dramatycznym przebiegu wypadków rozwój choroby, może doprowadzić do śmierci dotkniętego nią osobnika. Mogą też występować stany, które określane są mianem okresu inkubacji lub skrytego rozwoju choroby. Przy braku dostatecznego doświadczenia w takich przypadkach oznaczają one najczęściej brak możliwości skutecznego przeciwdziałania i niosą wielkie zagrożenie dla całego ustroju. 
Łącząc pojęcie „rozwój” z działalnością człowieka, można przyjąć, że powinno ono oznaczać zjawisko dające $\mathrm{w}$ wyniku pozytywne zmiany w systemach gospodarczych, społecznych i przyrodniczych.

\section{Uwarunkowania rozwoju regionu}

W odniesieniu do rozwoju regionu na pierwszy plan wysuwa się zdecydowanie aspekt ekonomiczny, pozostawiając $\mathrm{w}$ cieniu inne integralnie $\mathrm{z}$ nim związane zagadnienia. W tym kontekście rozwój regionu utożsamiany jest zazwyczaj z rozwojem gospodarczym, oznaczającym długofalowy proces dotyczący przeobrażeń ilościowych i jakościowych.

Do wspomnianych już zmian ilościowych, należy przede wszystkim zaliczyć: napływ kapitału, nowe inwestycje, wzrost produkcji, zwiększenie zatrudnienia, rosnącą sukcesywnie konsumpcję i podniesienie dochodów społeczeństwa. Natomiast do zmian jakościowych należy zaliczyć: osiagnięcie dynamicznego postępu techniczno-technologicznego, podniesienie wykształcenia, kwalifikacji i zaangażowania siły roboczej w pracę, postawienie nacisku na tworzenie kapitału ludzkiego, udoskonalenie systemu powiązań gospodarczych wewnątrz kraju i zagranicznych, unowocześnienie infrastruktury przemysłowej, wzrost poziomu efektywności oraz odczuwalne zwiększenie wachlarza i jakości oferowanych usług oraz produktów (Markowski, 2008, s. 13).

W szerszym ujęciu rozwój regionu to szeroki zespół zachodzących zmian, uwzględniający cele, potrzeby, priorytety oraz hierarchię wartości wyznaczoną w odniesieniu do określonego terenu. Generalnie powinien posiadać charakter uniwersalny dla wszystkich regionów. W praktyce, bardzo często można się zetknąc $\mathrm{z}$ ukierunkowaniem procesu zmian $\mathrm{w}$ z góry ustalonym i pożądanym kierunku (np. wyznaczenie rozwoju skupionego na wykorzystaniu walorów turystycznych lub bogactw naturalnych danego obszaru). Dla każdego regionu można skonstruować szczegółowe „drzewo celów”, uwzględniające jego możliwości oraz zakres związanych z tym oczekiwań (Wojtasiewicz, 1997, s. 8-9).

Główne cele rozwoju regionalnego, można rozpatrywać w czterech, powiązanych ze sobą wzajemnie płaszczyznach (Wiatrak, 2006, s. 13):

- zaspokojenia istniejących i przyszłych potrzeb lokalnego społeczeństwa;

- efektywnego wykorzystania posiadanych zasobów oraz istniejących możliwości do kreowania postępu gospodarczo-ekonomicznego;

- stworzenia sprawnego mechanizmu funkcjonowania wszystkich podmiotów i instytucji na danym terenie;

- dążenia do niezawodności działania stworzonych systemów oraz ich właściwego zasilania w zasoby wytwórcze. 


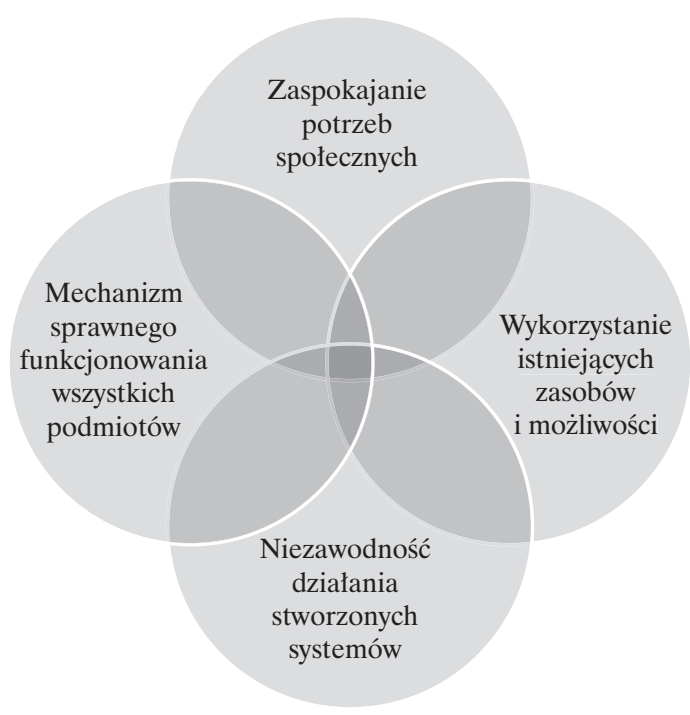

Rysunek 4. Cele rozwoju regionalnego ujęte w czterech głównych płaszczyznach Źródło: opracowanie własne.

Na bazie wymienionych celów zostają określone zadania oraz środki służące ich osiągnięciu. Zebrane są one najczęściej w oficjalne opracowania, takie jak programy działania lub strategie rozwoju dla danego terenu. Dokumenty te powinny uwzględniać czynniki sprzyjające powziętym zamierzeniom. Czynniki rozwoju dotyczą wykorzystania tak istotnych zagadnień, jak (Trojanek, 1994, s. 45-46):

- naturalnych walorów użytkowych (zasobności w bogactwa naturalne, urodzajności występujących gleb, zasoby wodne);

- walorów użytkowych stworzonych poprzez działalność ludzką (infrastruktury terenu, obiektów usługowych i produkcyjnych);

- zasobów siły roboczej (ilości rąk do pracy na lokalnym rynku, struktury wiekowej, posiadanych kwalifikacji zawodowych i wykształcenia, oczekiwań płacowych);

- rozwoju cywilizacyjnego i kultury gospodarczej (rzetelności wykonywania powierzonych zadań, punktualności, posiadanego doświadczenia i oddania dla pracy, dotychczasowej specjalizacji w dziedzinie przemysłu lub rolnictwa);

- instytucji zajmujących się rozwojem i promocją danego obszaru (banków, zakładów ubezpieczeniowych, izb gospodarczych, agencji rozwoju, zrzeszeń producentów, inkubatorów przedsiębiorczości, uczelni wyższych pracujących dla potrzeb rynku); 
- walorów przyrodniczo-krajobrazowych (stanu środowiska, zagospodarowania terenu, piękna okolicy, parków narodowych);

- walorów kulturowych (kin, teatrów, muzeów, cyklicznych imprez masowych, odrębności zwyczajów i strojów lokalnej ludności).

Uprzednie, dokładne rozpoznanie wszystkich składowych i czynników w różnych aspektach oraz płaszczyznach, staje się zatem niezbędne w procesie określenia pożądanych kierunków rozwoju regionu. Tak zorganizowane działanie umożliwia bardziej efektywne wykorzystanie istniejącego potencjału, jakim dysponuje dany teren oraz lepsze zaplanowanie warunków długotrwałego wzrostu.

\section{Koncepcje rozwoju regionalnego}

W dobrze pojętym interesie każdego społeczeństwa leży zapewnienie obszarowi, który ono zamieszkuje rozwoju ekonomicznego. Rozwój ten powinien charakteryzować zrównoważony charakter oraz długoterminowa niezmienność parametrów. W skali mikro proces taki zapewnia szansę podwyższenia poziomu życia dla uczestników gospodarstw domowych. W tej samej skali, ale dla podmiotów gospodarczych rozwój terytorium, na którym są aktywne w sensie usługowym i produkcyjnym zapewnienia funkcjonowanie oraz przetrwanie w bardziej sprzyjającym im otoczeniu, a po uzyskaniu stabilizacji połączonej ze zdobyciem przewagi konkurencyjnej, daje gwarancję generowania zysków, pomnażania majątku oraz $\mathrm{w}$ ostatecznym rozrachunku zasłużoną ekspansję rynkową. W skali makro regionalny rozwój ekonomiczny przyczynia się do stworzenia silnej gospodarki krajowej, służąc pożytkowi danego państwa. W odpowiedzi na istniejącą świadomość wagi procesów rozwojowych w skali regionalnej została wymyślona pewna liczba koncepcji opisujących, pozwalających zrozumieć i umożliwiających zastosowanie w praktyce środków i metod, które odnoszą się do zainicjowania, pobudzenia oraz akceleracji pożądanego procesu. Podstaw istniejących dziś podejść tłumaczących skomplikowane mechanizmy wzrostu i rozwoju regionalnego należy szukać w tradycyjnych oraz współczesnych teoriach ekonomii. Wśród nich stosunkowo ważną grupę stanowią teorie lokalizacji. Ich podwaliny zostały stworzone przez klasyczne teorie ekonomii Adama Smitha i Davida Ricardo. 


\subsection{Klasyczne teorie lokalizacji}

Teorie rozwoju regionalnego, związane z lokalizacją, należą do najstarszych spośród wszystkich koncepcji dotyczących czynników oraz przyczyn kształtujących oblicze obszarów wydzielonych z otoczenia. Zostały zaprezentowane światu przez „ojców ekonomii klasycznej”, Brytyjczyków - Adama Smitha (1723 - 1798) i Dawida Ricardo (1772 - 1823). Pierwszy z nich opracował Teorie przewagi absolutnej. Drugi z autorów jest zaś twórcą Teorii kosztów komparatywnych. Obie należy z całą powagą traktować jako pierwowzór, czyli klasykę późniejszych rozważań ekonomicznych, także tych związanych z dziedziną rozwoju regionalnego.

Istotnym dla dalszych rozważań zagadnieniem jest zdefiniowanie pojęcia „lokalizacji”. Przez lokalizację działalności gospodarczej należy rozumieć usytuowanie ustalonej aktywności przemysłowo-ekonomicznej w granicach pewnego terytorium. Dotyczy ona określenia rodzaju, ilości oraz wielkości funkcjonujących na danym terenie podmiotów gospodarczych. Rozpatruje także wzajemne, występujące pomiędzy nimi powiązania. Odnosić się może do jednego obiektu działającego w regionie, ich grupy lub wszelkich zarejestrowanych przejawów świadomie zorganizowanego świadczenia usług i prowadzenia produkcji. Charakteryzować może tylko jedną branżę czy gałąź, ich zbiór lub też wszystkie przejawy przedsiębiorczości występujące na danym terenie. Lokalizacja rozpoczyna się od wyboru regionu nadającego się do usług lub produkcji. Następnie w jego granicach szuka się najlepszego miejsca do podjęcia określonej działalności. $\mathrm{Na}$ końcu następuje etap polegający na rozmieszczeniu w terenie konkretnych podmiotów gospodarczych. Może się to wiązać z wyborem najbardziej optymalnych warunków jakie już istnieją lub też dostosowaniem danego terenu do specyficznych potrzeb przedsiębiorstwa.

\subsubsection{Teoria przewagi absolutnej Adama Smitha}

Teoria Adama Smitha nie jest koncepcją wyjaśniającą czynniki rozwoju regionalnego w ścisłym tego słowa znaczeniu. Odnosi się raczej do sfery międzynarodowych stosunków gospodarczych. Podejmuje próbę wyjaśnienia przyczyn uzyskiwania przewagi ekonomicznej pewnych terytoriów (krajów) nad innymi. $\mathrm{Z}$ tego względu stanowi również wyjaśnienie zjawisk, które można odnotować w odniesieniu do mniejszych obszarów będących składową poszczególnych krajów, tzn. regionów.

Adam Smith zauważył, że wydajność pracy zatrudnionych zależy w dużej mierze od specjalizacji i ustanowionego podziału pracy. Stąd wywnioskował, że wprowadzenie specjalizacji w ramach gospodarki państwa może skutkować zwięk- 
szeniem liczby produkowanych usług i towarów. Specjalizacja danego kraju wynika bezpośrednio z możliwości ekonomicznych, jakie on posiada. Warunkują je: pokłady surowców, dostępność materiałów, stopień rozwoju, posiadana infrastruktura, doświadczenie w produkcji określonego dobra. Dlatego poszczególne państwa powinny wybierać dla siebie specjalizację opierając się na zasobach, jakimi dysponują. Kryterium wyboru są tutaj absolutne różnice w kosztach wytwarzania. Wzięcie tych czynników pod uwagę stwarza możliwość podziału pracy w skali międzynarodowej. Najlepiej jest eksportować produkty, w których dany kraj się specjalizuje, natomiast importować takie, w których wytwarzaniu specjalizują się inne państwa. Teoria Adama Smitha nie uwzględnia w swoich założeniach kilku ważnych determinantów. Przykładowo, nie istnieją w niej bariery i ograniczenia w handlu międzynarodowym, takie jak: dozwolone kontyngenty dostaw, ochrona własnego rynku czy opłaty celne. Zupełnie nie bierze pod uwagę kosztów transportu. Nie zajmuje się także sytuacją krajów, w których koszty produkcji w odniesieniu do wszystkich dóbr wykazują wyższy poziom niż u potencjalnych partnerów handlowych. Pomimo tych mankamentów, teoria przewagi absolutnej stała się „kamieniem milowym” w rozwoju nauk ekonomicznych.

\subsubsection{Teoria kosztów komparatywnych Davida Ricardo}

Zapowiedzią teorii lokalizacji była ogłoszona przez Davida Ricardo w roku 1815 roku, teoria kosztów komparatywnych. Teoria ta, często określana również jako teoria korzyści (przewag) komparatywnych, została stworzona na podstawie wcześniejszych opracowań Adama Smitha. Ricardo oparł się w swojej koncepcji na przykładzie dwóch krajów. Wykazał, że każde państwo może uzyskiwać korzyści w wymianie handlowej z innymi krajami nie tylko wtedy, kiedy produkuje dobra taniej, lecz także wówczas, gdy produkuje je drożej niż ma to miejsce za granicą. Umożliwiają to dające się porównać różnice kosztów wytwarzania produktów i usług pomiędzy krajami zwane kosztami komparatywnymi. Nazwa pochodzi od angielskiego słowa compare, które oznacza porównać lub zestawić ze sobą. W założeniach autora teorii dominował pogląd, że nawet w przypadku, gdy jedno z państw wykazuje mniejszą wydajność w produkcji określonych dóbr podlegających wymianie handlowej, pomimo wszystko powinno specjalizować się w wytwarzaniu dobra, w którym jego produktywność w najmniejszym zakresie różni się od kraju wykazującego wyższą efektywność produkcji. Kooperujące ze sobą handlowo kraje będą importowały dobra, które inne państwa wytwarzają niewiele drożej od nich. Pozwoli im to na lepsze wykorzystanie potencjału wytwórczego w tych dziedzinach, w których same produkują taniej. Tym sposobem będą mogły sprzedać za granicę więcej własnych i zarazem tańszych produktów. We wnioskach Ricardo przekonywał, że przyjęcie takiej specjalizacji powinno przynosić korzyści obu zaangażowa- 
nym w wymianę krajom. W przytoczonej teorii została podkreślona odrębność terytorialna obu organizmów państwowych, co umożliwiło przetransponowanie jej założeń na skalę regionalną.

\subsubsection{Teoria sfer rolniczych Heinricha von Thünena}

Za pierwszą koncepcję lokalizacyjną z prawdziwego zdarzenia uważana jest teoria sfer rolniczych, opracowana w 1826 roku przez zdolnego agronoma Johanna Heinricha von Thünena. Autor koncepcji, zwanej również teorią kręgów Thünena, zwrócił uwagę na występowanie zależności rejonizacji oraz rodzaju działalności rolniczej od odległości od rynków zbytu. Zauważył, że istotnym warunkiem wyboru miejsca oraz charakteru produkcji rolnej jest koszt transportu płodów rolnych. Dodatkowe czynniki, które należało rozważyć, stanowiły w tej koncepcji - trwałość i wytrzymałość produktów. Ten niemiecki ekonomista, pochodzący ze znanego z produkcji piwa miasta Jever, próbował usystematyzować uwarunkowania lokalizacji działalności gospodarczej. Stwierdził, że wokół rynków zbytu tworzą się wyraźnie zaznaczone, koncentryczne pierścienie, z których każdy różni się od pozostałych sposobem i nasileniem uprawy ziemi. Produkty o niewielkim stopniu trwałości oraz te, które są stosunkowo ciężkie wytwarzane są w pobliżu miejsca ich sprzedaży w pierścieniach wewnętrznych. Jako przykład wymienia tu mleko, sery i owoce. W obrębie zewnętrznych pierścieni produkowane są wytwory rolne nadające się do dłuższego transportu i odporne na szybkie zepsucie. Jako przykład podaje tu przede wszystkim zboża. Rentowność terenów ulega zmniejszeniu wraz ze zwiększaniem się odległości od rynków zbytu. Natomiast intensywność upraw oraz stopień zaangażowania stosowanej przy produkcji technologii, największe są zawsze w pobliżu środka każdego kręgu (Słodczyk, 2003, s. 91). W teorii von Thünena miejsce zbytu stanowi usytuowany centralnie ośrodek miejski. Wokół niego odbywa się ułożona w kształcie rozszerzających się, współśrodkowych sfer produkcja rolnicza rozpostarta na dużej przestrzeni.

Koncepcję nawiązującą w pewnym sensie do ustaleń dotyczących sposobów użytkowania ziemi Heinricha von Thünena stanowi teoria lokalizacji przemysłu, opracowana przez Alfreda Webera, profesora socjologii Uniwersytetu w Heidelbergu.

\subsubsection{Teoria lokalizacji przemysłu Alfreda Webera}

Według teorii lokalizacji przemysłu Webera produkcja realizowana jest w jednym punkcie. Wokół niego, w układzie rozproszonym, rozrzucone są rynki zbytu. Decyzja o wyborze określonego miejsca pod inwestycje przemysłowe uwarunkowana jest przede wszystkim dążeniem do minimalizacji kosztów pro- 
dukcji i kosztów transportu w odniesieniu do danego przedsięwzięcia. Analiza wymienionych kosztów była jednym z najważniejszych czynników przesądzających o lokalizacji inwestycji rzeczowych.

W uproszczeniu, teoria lokalizacji zakłada, że mając na uwadze koszty transportu, należy zakład przemysłowy umiejscowić albo w bezpośrednim sąsiedztwie głównego odbiorcy, albo blisko źródeł zaopatrzenia w surowce niezbędne do produkcji. W przypadku równych (porównywalnych) kosztów transportu surowca i wyrobu gotowego, produkcja może zostać zlokalizowana pomiędzy źródłem zaopatrzenia a odbiorcą. W sytuacji, gdy źródła surowców i materiałów są dość liczne i porozrzucane, należy przy wyborze miejsca dla inwestycji zastosować w praktyce metodę mediany - czyli umiejscowienia produkcji w punkcie, w którym połowa odbiorców leży po jednej, a druga połowa po drugiej stronie lokalizacji zakładu. W przypadku rozproszenia oraz mnogości źródeł zaopatrzenia w surowce i materiały należy oprzeć decyzję o lokalizacji podmiotu gospodarczego na metodzie „wagi lokalizacyjnej”, określającej koszt transportu produktu gotowego na jednostkę odległości (Pasieczny, 2008, s. 24-25). Optymalną lokalizację w sposób szczegółowy powinny doprecyzować trzy czynniki. Po pierwsze - indeks surowców, rozumiany jako stosunek wagi surowców do wagi surowców finalnych. Po drugie - współczynnik pracy, rozumiany jako stosunek kosztów pracy wytworzenia jednej tony produktu do łącznej ceny transportu tony tegoż produktu do obszaru zbytu. Po trzecie korzyści wynikające z istnienia rozwiniętej aglomeracji (Weber, 1929, s. 24-29). Teoria wymienia jeszcze wiele innych przyczyn mogących mieć wpływ na postanowienie o wyborze miejsca rozmieszczenia majątku produkcyjnego firmy. O lokalizacji zakładów przemysłowych powinny według autora koncepcji decydować dodatkowo takie uwarunkowania, jak: cechy i dostępność surowców, koszty zatrudnienia, oczekiwania co do kwalifikacji siły roboczej, korzyści wynikające z położenia w sąsiedztwie ośrodka miejskiego, koszt dostarczenia wyrobów gotowych i towarów do punktu sprzedaży, charakter rynku zbytu.

\subsubsection{Istotne czynniki wpływające na lokalizację}

Omówione dotychczas teorie zwróciły uwagę na istnienie grupy czynników, które determinują lokalizację podmiotów gospodarczych. Wymienia się kilka istotnych zmiennych i przesłanek, mogących mieć wpływ na podjęcie decyzji dotyczących zaplanowanej lokalizacji działalności produkcyjnej zakładu przemysłowego. Według ogólnego kryterium społeczno-ekonomicznego, do najważniejszych zalicza się: środowiskowo-kulturowe, polityczne, administracyjne, przestrzenne, naukowo-techniczne, zasobowo-środowiskowe, ekonomiczne i finansowe. Zbiór wymienionych czynników wpływających na lokalizację został przedstawiony na rysunku 5 . 


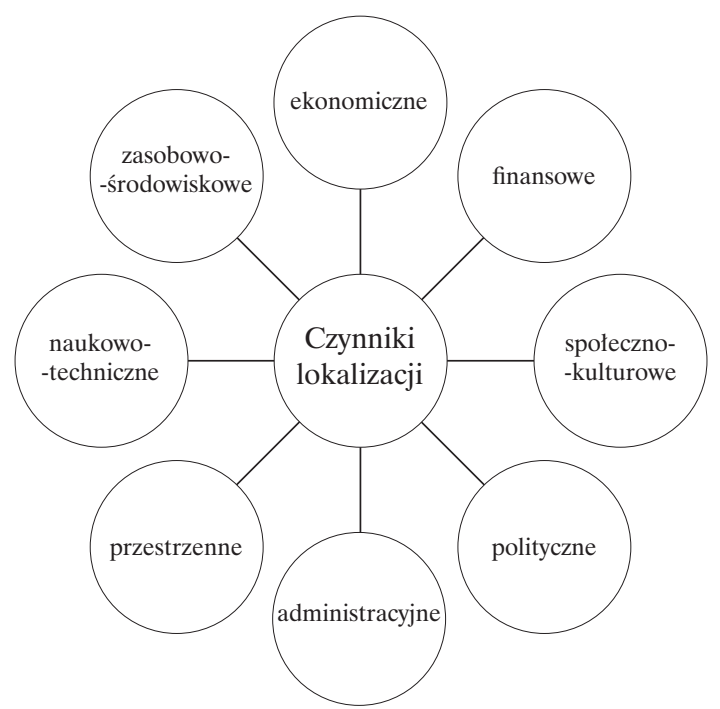

Rysunek 5. Czynniki i przesłanki mające wpływ na lokalizację inwestycji według ogólnego kryterium społeczno-ekonomicznego

Źródło: opracowanie własne.

Według ogólnego kryterium społeczno-ekonomicznego poszczególne czynniki oznaczają:

- spoteczno-kulturowe charakteryzują panujący w regionie klimat społeczny, który określony jest przez: przychylne nastawienie do ewentualnych zmian w otoczeniu społeczno-gospodarczym, poziom kulturalny i cywilizacyjny mieszkańców regionu, stan wykształcenia i kwalifikacji w społeczeństwa w danej dziedzinie, zmysł i nawyki do przedsiębiorczości, strukturę rynku pracy, poziom konsumpcji, nasilenie zjawisk migracyjnych, wykazywaną aktywność w poszukiwaniu zatrudnienia, tradycję i mentalność całego środowiska ludzkiego;

- polityczne oznaczają przede wszystkim sprawdzoną stabilność ustrojową danego terytorium, opartą na jasnych i niezmiennych przepisach prawa; zachętą może być przychylne podejście i chęć wspólpracy władz krajowych oraz regionalnych do potencjalnych inwestorów na podległym im terenie; istotna rolę odgrywa tu wiarygodność władz państwowych oraz samorządowych; ważne może okazać się występowanie w strukturach rozwiniętej demokracji aktywnie działających organizacji i instytucji; zaliczyć do nich można: związki zawodowe, izby gospodarcze i handlowe, różnorakie fundacje społeczne, związki ochrony konsumentów czy też zrzeszenia obrońców przyrody; 
- administracyjne w pewnym stopniu stanowią pochodną czynników politycznych; sprawnie funkcjonujący organizm państwowy determinuje najczęściej dobrą pracę urzędów i podległych im instytucji w terenie; elastyczność w podejściu do występujących problemów, szybkość podejmowania decyzji, brak korupcji i nepotyzmu, wysokie etyka i kompetencje urzędników, dogodne godziny pracy wszystkich instytucji, łatwy dostęp do potrzebnych informacji oraz przejrzysta struktura administracji sprzyjają wyborowi takich miejsc pod inwestycje;

- przestrzenne odnoszą się do wielkości powierzchni, jaką zajmuje dany kraj lub region; dotyczą: ukształtowania terenu i jego dostępności; nasycenia infrastrukturą komunikacyjną; położenia geograficznego w stosunku innych obszarów; odległości, jakie trzeba pokonać przy prowadzeniu działalności gospodarczej; stanu i ilości dróg oraz szlaków wodnych; połączeń lotniczych krajowych i zagranicznych;

- naukowo-techniczne dotyczą stanu technologicznego infrastruktury danego terenu; oznaczają poziom technicznej nowoczesności fabryk, zakładów przemysłowych oraz mechanizacji rolnictwa; obejmują rozwój nauki i skalę prowadzonych badań oraz jakość współpracy pomiędzy ośrodkami naukowymi a biznesem; doliczyć do tego należy jeszcze wykorzystanie nowatorskich i innowacyjnych technologii w praktyce gospodarczej; ważne jest także istnienie sieci telefonicznej i Internetu obejmujących cały obszar;

- zasobowo-środowiskowe oznaczają występowanie w środowisku geograficznym danego obszaru, surowców i materiałów potrzebnych do prowadzenia zaplanowanej działalności; wyrażają w istocie także istnienie, obok tradycyjnych, alternatywnych potencjalnie możliwych do wykorzystania źródła energii; zaliczyć do nich można: źródła geotermalne, energię wody, siłę wiatru, energię słoneczną; w odniesieniu do wszystkich czynników z tej grupy, ważne jest określenie kosztu pozyskania niezbędnych zasobów oraz opłacalność ich zastosowania w praktyce gospodarczej;

- ekonomicze dotyczą panującej sytuacji gospodarczej na danym terenie; istniejąca sytuacja może być określona przez zbiór danych, informacji i wskaźników, takich jak poziom wzrostu gospodarczego wyrażony w PKB, stopa inflacji, tempo wzrostu wynagrodzeń, nakłady kapitałowe z podziałem na źródła wewnętrzne i zewnętrzne, całkowita wielkość i pojemność rynku, panujący poziom popytu i podaży, koszty pracy, przeciętna wydajność zatrudnionych w poszczególnych gałęziach i branżach, stan zaawansowania rozwoju infrastruktury produkcyjno-usługowej, koszty transportu i ubezpieczenia, charakter gospodarki badanego obszaru, stan inwestycji, poziom życia mieszkańców, ceny nieruchomości i artykułów pierwszej potrzeby, możliwości nabycia atrakcyjnych gruntów pod inwestycje. 
- finansowe należy rozumieć jako istnienie niezbędnych instytucji na danym terenie, takich jak banki, zakłady ubezpieczeniowe, firmy asekuracyjne; ważny jest także dostęp do pomocy merytorycznej w określonej dziedzinie i usług prawnych; oznacza również przychylną politykę podatkową wzbogaconą o wiele zachęt dla inwestorów w rodzaju: ulg i zwolnień podatkowych, niskich stawek za opłaty rejestracyjne, udogodnień i wsparcia finansowego, podwyższonych stawek amortyzacyjnych, możliwości dostępu do potrzebnego kapitału, warunków swobodnego transferu zysków zagranicę.

\subsubsection{Teoria ośrodków centralnych Waltera Christallera}

Walter Christaller był niemieckim geografem ekonomicznym, a jego najbardziej intensywny okres działalności przypadł na okres II wojny światowej. Po wojnie, mieszkający w Niemieckiej Republice Demokratycznej uczony, stał się członkiem Partii Komunistycznej. W latach trzydziestych XX wieku brał jednak aktywny udział w niechlubnym opracowywaniu nazistowskiego Generalnego Planu Wschodniego (niem. Generalplan Ost). W swojej pracy był odpowiedzialny za koncepcję rozmieszczenia ośrodków administracyjnych na Wschodzie, m.in. na zajętych terenach Polski. W roku 1933 ogłosił teorię ośrodków centralnych, tłumaczącą istnienie pewnych prawidłowości w rozmieszczeniu, ilości oraz wielkości ośrodków miejskich w odniesieniu do funkcji rynku. Według autora to właśnie rynek stanowi zasadniczy element kształtujący układy osadnicze w przestrzeni geograficznej. Przedstawiona koncepcja, poprzez określenie mechanizmu lokalizacji działalności gospodarczej, podejmowała trud wyjaśnienia układu sieci miejskiej w układzie regionalnym.

Kluczowym założeniem teorii Waltera Christallera było stworzenie pojęcia dwóch rodzajów dóbr i usług centralnych (Słodczyk, 2003, s. 75):

- wyższego rzędu,

- niższego rzędu.

Taki podział uwarunkowywał występowanie hierarchii, jeśli chodzi miasta i pełnione przez nie funkcje. Wytwarzanie dóbr i świadczenie usług centralnych wyższego rzędu przypisane było tylko i wyłącznie ośrodkom wyższego rzędu. Stanowiły je duże miasta i aglomeracje. Przykładowo, chodziło tu o działalność bankową, teatralną, polikliniczną, wyższą edukację. Skorzystanie z dóbr i usług centralnych niższego rzędu możliwe było zarówno w ośrodkach niższego, jak i wyższego stopnia. Za niższy stopień uważane były małe miasta i duże wsie. Dostępne były w nich usługi podstawowe, takie jak: pieczywo z piekarni lub oferta sklepu spożywczego. Na dobra i usługi centralne występował określony popyt. Malał on wraz ze wzrostem odległości dzielącej konsumenta od większego ośrodka miejskiego. Jeśli przekraczał dystans graniczny, potencjalny nabyw- 
ca decydował się na poszukiwanie potrzebnych mu dóbr i usług na obszarze ośrodków stojących na niższych poziomach w strukturze sprzedaży. Ośrodki miejskie wyższego szczebla spełniały wszystkie funkcje przypisane ośrodkom położonym na dolnych szczeblach hierarchii. Ośrodek centralny najwyższego szczebla oferował społeczeństwu zawsze najszerszą paletę możliwych do uzyskania dóbr i usług.

Hierarchia ośrodków stworzona przez Waltera Christallera obejmująca siedem szczebli, została schematycznie ukazana na rysunku 6.

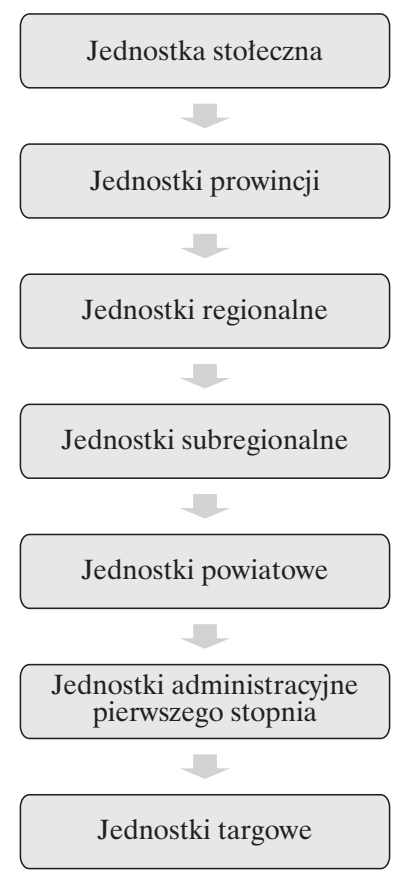

Rysunek 6. Układ jednostek w hierarchii ośrodków centralnych Waltera Christallera Źródło: opracowanie własne na podstawie: Paczoski (2010, s. 35).

Przyporządkowanie do jednego ze szczebli odbywa się na zasadzie określenia zgłaszanego popytu i zasięgu jego oddziaływania na wytwarzane dobra i usługi centralne. Czynniki graniczne zasięgu oddziaływania tworzą odległość od centralnego ośrodka miejskiego oraz rentowność podaży na danym terytorium (Sagan, 2007, s. 97). Ośrodkowi na wyższym szczeblu podporządkowana jest administracyjnie pewna liczba jednostek niższego szczebla. Wchodząc na kolejne poziomy w hierarchii, można zauważyć zwiększenie pełnionych funkcji centralnych i liczby ludności oraz wielkości obszaru, który miasto obsługuje. Ulega zmniejszeniu 
natomiast liczba najważniejszych jednostek najwyższego rzędu. Szybko stało się jasne, że teoria ośrodków centralnych sprawdza się zasadniczo tylko na terenach znacznych obszarów równinnych. Duże ośrodki miejskie powstające wzdłuż linii komunikacyjnych, porty na wybrzeżach czy centralne ośrodki wydobycia surowców w żaden sposób nie układają się w myśl przedstawionej koncepcji. Obecnie teoria ośrodków centralnych Christallera jest przydatna jedynie w wybranych przypadkach dotyczących planowania lokalizacji działalności usługowej.

\subsection{Wczesne teorie rozwoju regionalnego}

Na przełomie XIX i XX wieku zaczęły się pojawiać nowe idee ujmujące zagadnienie wzrostu regionalnego. Twórcy tych koncepcji starali się istniejące prawidłowości zidentyfikować i wstępnie usystematyzować, dostrzegali bowiem w procesach rozwoju obszarów przemysłowych pewne zauważalne prawidłowości. Ich działania miały charakter elementarnych czynności i spostrzeżeń w raczkującej dopiero dziedzinie praktyki i nauki. Najbardziej znaną koncepcją z tej grupy jest teoria okręgów przemysłowych Alfreda Marschalla. Wymienić też można w tym miejscu, powstałą w latach trzydziestych XX wieku, teorię wpływu handlu międzynarodowego i polityki interregionalnej na rozwój wydzielonych obszarów, której autorem jest szwedzki ekonomista Bertil Ohlin.

\subsubsection{Teoria okręgów przemysłowych Alfreda Marshalla}

Alfred Marshall był uznanym ekonomistą angielskim przełomu XIX i XX wie$\mathrm{ku}$. Jako profesor Uniwersytetu w Cambridge prowadził badania dotyczące funkcjonowania przemysłu na terenie Wielkiej Brytanii. Przeprowadzone obserwacje doprowadziły go do wniosku, że w rozwiniętej gospodarce można spostrzec zgrupowania firm należących do jednej branży, występujące na określonym, relatywnie niewielkim terenie. Skupiska firm należących do jednej branży nazwał w swoich rozważaniach „dystryktami przemysłowymi”. Można je było zauważyć na przykładzie wiodących ośrodków przemysłu skupionych w największych miastach Anglii. Przykładowo, Sheffield w hrabstwie South Yorkshire znane było z produkcji wysokiej jakości stalowych sztućców; Manchester oznaczał przemysł włókienniczy; Birmingham zaś przemysł zbrojeniowy; Liverpool kojarzony był przede wszystkim z przemysłem stoczniowym. Najważniejszym elementem koncepcji Marshalla było określenie tzw. korzyści zewnętrznych, które występują jako efekt skoncentrowania produkcji określonej branży w jednym miejscu. Tam, gdzie korzyści zewnętrzne występują bardziej intensywnie, daje się zauważyć większą koncentrację przestrzenną zakładów przemysłowych. Do najważniejszych korzyści zewnętrznych zaliczył: 
- wzajemne przenikanie się czynników społecznych i produkcyjnych; władze lokalne w swoich kalkulacjach biorą pod uwagę występowanie na ich terenie określonej branży przemysłu; zapewnia im to mniejsze bezrobocie, wyższy poziom życia społeczeństwa, lepszą sieć łączności, rozwój infrastruktury technicznej i komunikacyjnej, szeroko rozumiany postęp techniczny i cywilizacyjny, trwały i stabilny rozwój regionu; zakłady przemysłowe mogą jednak liczyć na korzyści w postaci: dopływu wykształconej i relatywnie taniej siły roboczej, bliskości rynku zbytu, dużej liczby potencjalnych kooperantów, niższych kosztów produkcji czy komfortu komunikacyjnego;

- przy istnieniu tylko jednej branży w regionie, następuje zaawansowana kooperacja oraz głęboka specjalizacja przedsiębiorstw współdziałających dla osiągnięcia jak najlepszego efektu końcowego.

Według autora teorii, podmioty gospodarcze są świadome istnienia określonych korzyści zewnętrznych i są w stanie je rozpoznawać. To skłania je do umiejscawiania swojej działalności we wzajemnym sąsiedztwie. Takie postępowanie tworzy coraz większe, prężniejsze i bardziej dynamicznie funkcjonujące dystrykty.

Obok korzyści zewnętrznych mogą także wystąpić zjawiska negatywne, będące ich przeciwieństwem. Powodują one tzw. koszty zewnętrzne, dotykające bezpośrednio i pośrednio podmiotów niezwiązanych z produkcją realizowaną przez dystrykty. Przyczyną ich może być: niewystarczająca ilość wykwalifikowanej siły roboczej, brak w pobliżu niezbędnych do produkcji surowców i materiałów lub też zła infrastruktura komunikacyjna. Lokalizacja okręgu przemysłowego na obszarze występowania kosztów zewnętrznych prowadzi do strat finansowych. Brak zdecydowanej reakcji władz lokalnych może w takim wypadku doprowadzić do katastrofy ekonomicznej obszaru podlegającego ich jurysdykcji.

W ramach polityki nakierowanej na rozwój regionu, zadaniem władz samorządowych powinno stać się zatem zaplanowane kreowanie korzyści zewnętrznych w uwarunkowanym możliwościami oraz kompetencjami zakresie. Stworzenie pozytywnych efektów zewnętrznych takich na przykład, jak: wprowadzenie zachęt i ulg podatkowych, zapewnienie szkolnictwa zawodowego o pożądanym w istniejącej branży profilu, zapewnienie dogodnej infrastruktury komunikacyjnej, sprawnie działająca administracja, powinny spowodować pojawienie się rzeszy nowych inwestorów (Szul, 2007, s. 115). Napływający z nimi kapitał powinien z kolei zapewnić nadejście siły roboczej oraz powstawanie potrzebnych do życia społecznego obiektów użyteczności publicznej, takich jak: szkoły, kina, teatry, szpitale, bary, restauracje, kluby fitness, obiekty sportowe itp. Powstałe instytucje, firmy usługowe oraz cała infrastruktura powinny dodatkowo wpłynąć na podwyższenie atrakcyjności turystycznej regionu. Spostrzeżenia zawarte w teorii Alfreda Marshalla stanowiły punkt wyjścia badań nad formowaniem się klastrów. 


\subsection{Neoklasyczne teorie rozwoju regionalnego}

Neoklasyczne koncepcje dotyczące procesów rozwoju regionalnego pojawiły się $\mathrm{w}$ połowie XX wieku. Wywodzą się one wprost $\mathrm{z}$ neoklasycznych teorii ekonomii, które ujrzały światło blisko wiek wcześniej. Podwaliną wszystkich tych koncepcji, w mniejszej lub większej mierze, były założenia teorii klasycznej Adama Smitha. Podkreślają one istotną rolę naturalnych mechanizmów rynkowych, w wyniku których dochodzi do optymalnego rozlokowania istniejących zasobów. Według tych idei gra wolnych sił rynkowych ma powodować zacieranie się różnic i dysproporcji w skali regionalnej, w wyniku swobodnego przepływu strumieni zawierających czynniki produkcji.

Naczelna hipoteza w podejściu neoklasycznym starała się wyjaśnić przestrzenne aspekty wzrostu regionalnego. Zakładała ona, że różnice rozwojowe pomiędzy określonymi obszarami znoszone są na skutek przemieszczania się zasobów, których użycie w procesie produkcji pozwala wytworzyć nową wartość. Rola mechanizmu rynkowego w tym procesie polegała na wyrównaniu różnic regionalnych w dochodzie per capita w obrębie poszczególnych obszarów (Dąbrowski, 1995, s. 198-202).

Model ten został oparty na twierdzeniu, że występuje bezpośrednia tendencja do wyrównywania się krańcowych wynagrodzeń czynników produkcji. Gdy wyczerpią się wolne czynniki produkcji dostępne w danym regionie, takie jak: praca, grunty czy źródła energii, ich cena wzrasta. To z kolei powoduje, że kapitał zaczyna poszukiwać tańszych lokalizacji pod inwestycje. Natomiast tania siła robocza wędruje do miejsc, w których cena pracy jest wyższa. Procesy te w naturalny sposób powinny prowadzić do wyrównywania poziomu rozwoju w przestrzeni, ponieważ zasoby kapitałowe przechodzą z miejsc wysoko zagospodarowanych, a przez to drogich, do miejsc słabiej rozwiniętych, a zarazem tańszych. Natomiast relatywnie tania siła robocza pochodząca z terenów słabiej rozwiniętych przenosi się na obszary bardziej rozwinięte, na których wyższe płace ulegają obniżeniu w wyniku napływu osób poszukujących zatrudnienia. Poziom rozwoju, a zarazem poziom życia, ulegają w ten sposób wyrównaniu za sprawą dwóch procesów:

- rozprzestrzeniania się działalności gospodarczej w miejscach słabiej rozwiniętych,

- obniżaniu się płac na obszarach dotychczasowo wyżej rozwiniętych.

Przeszkodą w realizacji opisanego procesu może być jedynie ograniczona mobilność czynników produkcji (Korenik, Zakrzewska-Półtorak, 2011, s. 38).

Przedstawicielami nurtu neoklasycznego byli Amerykanie: Robert M. Solow, Jerome L. Stein, George H. Borts i Harry W. Richardson oraz Australijczyk 
- Trevor Swan. W niektórych ich pracach wyraźnie pobrzmiewają echa teorii Keynesa. Według prezentowanej przez nich koncepcji, podstawę działalności gospodarczej stanowi generowanie maksymalnie wysokich zysków. Natomiast czynnikiem kształtującym rozwój regionów jest krańcowa efektywność czynników produkcji. Produkcja regionu i jego wzrost uzależniony jest od dostępności takich czynników produkcji, jak: kapitał i praca oraz stopień rozwoju technologicznego gospodarki regionalnej. Nadmierny wpływ państwa w sferze podziału prowadzi do zmniejszenia mobilności czynników produkcji. Ma to bezpośredni wpływ na dysproporcje w rozwoju regionalnym. Dlatego najlepszym sposobem przezwyciężenia tego zjawiska jest ograniczenie interwencjonizmu państwowego w gospodarce (Gorzelak, 1989, s. 60). Harry W. Richardson wskazuje, że wzrost ekonomiczny jednego regionu może przekładać się na wzrost w gospodarkach innych, podobnych obszarów, ponieważ otwartość gospodarki regionu jest stosunkowo wyższa niż gospodarki państwa, dając przez to lepsze warunki do niwelowania regionalnego zróżnicowania dochodów (Churski, 2005, s. 6).

\subsection{Modele fazowe rozwoju regionalnego}

Modele fazowe zakładają, że rozwój regionalny nie jest procesem stałym oraz że nie przebiega w sposób ciagły. Wykazuje się określonymi fazami, rozpoznawalnymi ze względu na ich intensywność, kierunek i zakres, jaki obejmują. Modele fazowe egzystują opierając się na tezie, że wpływ na rozwój jednostek terytorialnych różnych szczebli (miast, regionów krajów) mają czynniki nie tylko ekonomiczne, lecz także społeczne. Należą do nich przesłanki o charakterze procesów: historycznych, kulturowych, politycznych, socjologicznych, technologicznych i gospodarczych.

\subsubsection{Teoria długich cykli Nikołaja Kondratiewa}

Teoria długich cykli koniunkturalnych należy do grupy fazowych modeli rozwoju. Opisuje to zjawisko na szczeblu regionalnym i państwowym. Została stworzona przez Rosjanina, Nikołaja Kondratiewa, w latach dwudziestych $\mathrm{XX}$ wieku. Autor po raz pierwszy poruszył temat istnienia długookresowych trendów w gospodarce w swoim doktoracie w roku 1920. Teorię ogłosił w 1928 roku w pracy pt.: Wielkie cykle koniunktury gospodarczej. Natomiast rozwinął i spopularyzował teorię Kondratiewa austriacki ekonomista - Joseph Alois Schumpeter (Schumpeter, 1960, s. 88-150). Pragnieniem niezwykle zdolnego i ambitnego Schumpetera było zostanie najwybitniejszym ekonomistą na świecie, najlepszym jeźdźcem w Austrii i pierwszym kochankiem w Wiedniu. Pod koniec życia oświadczył, że udało mu się spełnić dwa z trzech wymienio- 
nych warunków. Należy przy tym wspomnieć, że na koniu nauczył się jeździć, co najwyżej przeciętnie.

Według teorii Nikołaja Kondratiewa (inny spotykany termin to teoria długiej fali), w procesach gospodarczych można zauważyć występowanie powtarzającej się regularności, przybierającej formę cykli (długich fal) trwających przeciętnie od 45 do 60 lat. Pojedynczy cykl dzieli się na dwie fazy - wzrostu i spadku koniunktury. Każda z faz trwa średnio około 25 lat. Współcześnie każdą długą falę dzieli się na trzy fazy:

- wzrostu trwającą około 20 lat,

- stabilizacji trwającą około 10 lat,

- schyłkową trwającą przeciętnie około 20 lat.

W obu krańcowych fazach - wzrostu i schyłkowej - może dochodzić do kryzysów ekonomicznych. W pierwszej załamania gospodarki mają lżejszy i krótszy charakter. W drugiej z wymienionych faz - trwają dłużej, mają cięższy przebieg i poważniejsze konsekwencje. Przyczyn występowania długich cykli Kondratiew szukał, analizując przebieg koniunktury gospodarczej w Anglii, Niemczech, we Francji i w Stanach Zjednoczonych. Jego badania objęły okres od 1780 do 1920 roku. Okazało się, że podmiotem sprawczym były: przełomowe wynalazki, wprowadzane w życie innowacje, występujące w sferze finansów zjawiska inflacyjne i deflacyjne, długofalowe zmiany w podaży złota i innych surowców, zmiany w efektywności gospodarki rolnej, ważne historycznie zjawiska polityczne i społeczne (np. wojna światowa czy rewolucja proletariacka) (Lubiński, 2004, s. 33).

Wychodząc z założeń przyjętych przez rosyjskiego ekonomistę, wyznawcy jego teorii przyjęli istnienie pięciu cykli w następujących latach (Mandel, 1995, s. 127):

- I cykl (fala): 1785-1843,

- II cykl (fala): 1844-1893,

- III cykl (fala): 1894-1939,

- IV cykl (fala): 1940-1985,

- V cykl (fala): od 1986 do dzisiaj.

Pierwsza fala (cykl) Kondratiewa trwała 58 lat. Została zapoczątkowana w Anglii wynalezieniem maszyny parowej. W czasie jej trwania na szeroką skalę rozwinął się przemysł hutniczy i włókienniczy, stworzono także gospodarkę opartą na specjalizacji i podziale pracy. Wprowadzone innowacje dały początek dynamicznemu rozwojowi miast, powstaniu obszarów przemysłowych i stworzeniu nowych klas społecznych.

Druga fala (cykl) trwała 49 lat. Była oparta na rozwoju kolei. Jej początek miał miejsce w Wielkiej Brytanii, później dotarła do Francji, a następnie 
pojawiła się w Niemczech (Prusach). W trakcie jej trwania powstała infrastruktura umożliwiająca szybki i wygodny transport ludzi oraz masowo produkowanych towarów, zapoczątkowano też powszechną erę elektryczności. Elektryfikacja miejscowości na skalę masową rozpoczęła się w latach osiemdziesiątych XIX wieku - początkowo w Stanach Zjednoczonych (uruchomienie przez Thomasa Edisona w 1882 roku pierwszej elektrowni publicznego użytku w Nowym Jorku), potem rozprzestrzeniła się w Europie: Wielkiej Brytanii, Francji, Niemczech, Polsce, Rosji. Wynalazkiem z czasu drugiej fali był również fonograf.

Trzecia fala (cykl) trwała 45 lat. Została zapoczątkowana w Stanach Zjednoczonych. Wynalazki charakterystyczne dla okresu trzeciej fali to produkcja taśmowa w zakładach samochodowych Henry'ego Forda, zastosowanie chemii w życiu codziennym gospodarstw domowych (środki piorące, mydło syntetyczne) i w rolnictwie (nawozy) oraz wynalezienie plastiku.

Czwarta fala (cykl) trwała 45 lat, a pozycję lidera w gospodarce światowej w tym okresie objęły Stany Zjednoczone. Wynalazki i innowacje charakterystyczne dla czwartej fali to: powszechna motoryzacja społeczeństwa, spopularyzowanie podróży lotniczych, wynalezienie tranzystora, wprowadzenie komputerów do gospodarki oraz zapoczątkowanie ery Internetu, a co najważniejsze umożliwienie człowiekowi podboju kosmosu.

Piąta fala (cykl) trwa od drugiej połowy lat osiemdziesiątych XX wieku do dziś. Została zapoczątkowana w Stanach Zjednoczonych Ameryki Północnej. Jej główną oś napędową stanowi informatyka. W okresie piątej fali doprowadzono do powszechnego użycia pieniądza wirtualnego (kart płatniczych), zastosowania w życiu zdobyczy nanotechnologii, biotechnologii i inżynierii genetycznej (zmodyfikowana żywność), wykorzystania energii atomowej. Po raz pierwszy w dziejach ludzkości rozwój gospodarczy nie opiera się na zasobach surowcowych i przemyśle ciężkim. Obecnie większe znaczenie zyskał dostęp do informacji, nowych technologii, sprzedaż patentów, know-how, licencji i praw autorskich.

Teoria długich cykli koniunkturalnych (długiej fali) przedstawia hipoteze wpływu procesów techniczno-technologicznych i wynikających stąd istotnych zmian o charakterze historycznym i społecznym, na rozwój jednostek terytorialnych, takich jak regiony i całe państwa. Zakłada zasadniczą rolę doniosłych wynalazków, innowacji, wydarzeń na rynku kapitałowym i pieniężnym oraz wydarzeń społecznych w kształtowaniu koniunktury gospodarczej.

\subsubsection{Teoria życia produktu}

Teoria życia produktu nawiązuje do teorii lokalizacji. Uzupełnia ją jednak i rozszerza o teorię cyklu życia przedsiębiorstwa oraz o teorię organizacji procesu produkcyjnego. Ukazuje bezpośredni związek pomiędzy procesem wzrostu gospodarczego w regionie oraz fazowością życia produktu. Bierze również 
pod uwagę poziom techniczno-technologiczny badanych obszarów wytwórczych. Zakłada ona, że intensywność oraz umiejscowienie procesów produkcyjnych są uzależnione od następujących po sobie stadiów wytwarzania produktu. Według Adama Dąbrowskiego z Uniwersytetu Łódzkiego można wyróżnić cztery etapy rozwoju produktu w regionie (Dąbrowski, 1995, s. 211):

- I etap: rozwoju i wdrażania. W praktyce odbywa się najczęściej na terenie dużego ośrodka miejskiego lub aglomeracji przemysłowej i opiera się na wykorzystaniu zaawansowanych innowacji techniczno-technologicznych. Aby mogły one zostać sprawnie wprowadzone do produkcji, a potem na rynek, przedsiębiorstwa starają się pozyskać wysoko wykwalifikowaną siłę roboczą. Nowy, innowacyjny wyrób skierowany jest głównie do wąskiej grupy zamożnych nabywców. Pobudzenie popytu na wytwarzany towar, obywa się przy użyciu sprawdzonych technik marketingowych. Zakłady wdrażające nowe produkty nie napotykają na tym etapie konkurecji w swojej branży. Niektóre firmy stają się monopolistami.

- II etap: wzrostu. W tej fazie rosną dochody przedsiębiorstwa, połączone często ze wzrostem jego potencjału wytwórczego. Innowacyjność produktu zaczyna tracić na znaczeniu na korzyść procesów produkcyjnych. Rozszerza się rynek zbytu. Jeśli produkt stanie się popularny, jest eksportowany na inne obszary i do szerszej grupy odbiorców. Później podmiot macierzysty zakłada filie i firmy córki w innych regionach i zagranicą. Wybierana jest przy tym lokalizacja oparta na jak najniższych kosztach siły roboczej, zaopatrzenia i budowy. Najlepiej do tego celu nadają się regiony słabiej rozwinięte. Produkcja przyjmuje charakter masowy. Zdobycze innowacyjne, nowe rozwiązania techniczne i know-how przenikają (są przesączane) z obszarów wyżej rozwiniętych do słabiej rozwiniętych. Mniejsze znaczenie przypisuje się kapitałowi ludzkiemu.

- III etap: standaryzacji. W tej fazie produkcję przejmują regiony o niższym poziomie rozwoju. Jeśli występuje popyt w wysoko rozwiniętym regionie macierzystym, staje się on importerem produktu, który kiedyś wprowadził na rynek. Taka sytuacja miała miejsce w przypadku produkcji ostatniego modelu Volkswagena garbusa. Zakłady produkcyjne w położone Meksyku eksportowały samochód tej marki na rynek niemiecki i europejski. Może także wystąpić sytuacja, w której region wysoko rozwinięty eksportuje wyrób już tylko na obszary zacofane, przy braku zainteresowania klientów na rynku własnym. Dzięki temu może ulec wydłużeniu cykl życia produktu. W tej fazie wyrób pojawia się na dalekich rynkach peryferyjnych. Wzrasta rozproszenie geograficzne produkcji (Budner, 2004, s. 71-72).

- IV etap: schyłkowy. Firma podejmuje wysiłki w celu zatrzymania niekorzystnych tendencji. Może szukać nieeksplorowanych dotychczas 
rynków zbytu, ratować się obniżką kosztów lub modyfikacjami cyklu produkcyjnego. Może ona także próbować swej szansy w wypuszczeniu na rynek zupełnie nowego produktu o wysokiej innowacyjności. Jako przykład można tu ponownie podać firmę Volkswagen, produkującą aż do lat siedemdziesiątych XX wieku popularnego „chrząszcza” (garbusa). Przy gwałtownie gasnącym popycie, markę uratowało wprowadzenie na rynek, zrywającego z dotychczasową tradycją i technologią, innowacyjnego modelu Volkswagen Golf. Pierwsza generacja tych aut pojawiła się w 1974 roku. W ostatniej fazie występuje widoczny spadek produkcji i usług danej firmy. Powoduje to obniżenie zysków w wyniku gwałtownie malejących przychodów.

Na rysunku 7 został przedstawiony wyżej opisany cykl życia produktu opierający się na czterech głównych etapach (fazach).

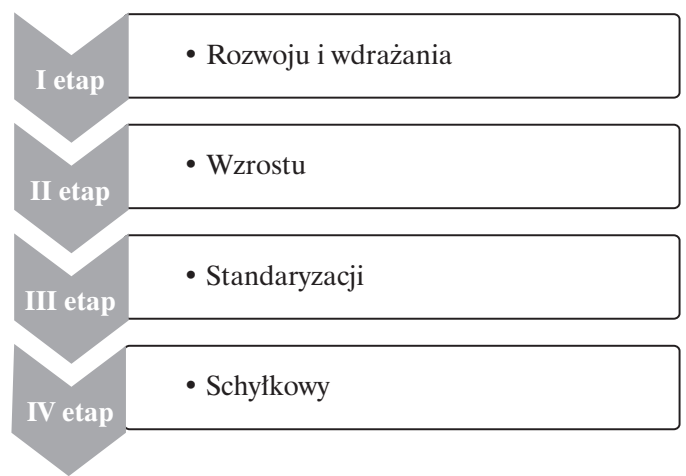

Rysunek 7. Cztery fazy (etapy) cyklu życia produktu Źródło: opracowanie własne.

Teoria cyklu życia produktu tłumaczy procesy wzrostu regionalnego poprzez uzależnienie go od innowacyjności wyrobu, zaawansowania technologii i procesów „przesycania” wiedzy i postępu techniczno-technologicznego. Jego znajomość pozwala określić, w jakiej fazie znajduje się dany obszar produkcyjny i jakie stoją przed nim perspektywy w nadchodzącej przyszłości. Teoria ta skłania do hipotezy, że rozwój pojawia się niejako „samoczynnie” tam, gdzie napotyka korzystniejsze warunki prowadzenia aktywności ekonomicznej. Można jednak zaryzykować również twierdzenie, że znajomość cyklu życia produktu składa w ręce władz samorządowych sprawny instrument ostrzegawczy przed nadciągającym kryzysem. Daje zatem niezbędny czas na podjęcie skutecznych działań zapobiegawczych. W literaturze przedmiotu można spotkać także cykle życia 
produktu (przedsiębiorstwa) opierające się tylko na trzech etapach (Veron, 1966, s. 190-207) lub też rozłożone na pięć etapów (Grzenkowicz, 2008, s. 37-41). Daje to jednak w rezultacie możliwość tylko powierzchownej lub dużo głębszej analizy omawianych procesów i zjawisk zachodzących w regionie.

\subsubsection{Teoria cyklu życia regionu Walta Rostowa}

Teoria amerykańskiego ekonomisty Walta Rostowa należy do grupy fazowych modeli rozwoju. Stanowi jedną z najważniejszych hipotez XX wieku wyjaśniających procesy wzrostu gospodarczego. Oparta została na geopolitycznej historii Stanów Zjednoczonych Ameryki Północnej i najbardziej rozwiniętych krajów Europy Zachodniej. Dlatego też w małym stopniu nadaje się do opisu zjawisk w regionach położonych na terenach Azji i Afryki (Puri, 2010, s. 127-136). Jej założenia sprawdzają się najlepiej w odniesieniu do obszarów o relatywnie dobrze funkcjonującej administracji lokalnej.

Od momentu ogłoszenia w 1960 roku została ona w stosunkowo krótkim czasie dostosowana do potrzeb zagadnień regionalnych. Teoria oparta jest na modelu wyróżniającym pięć stadiów rozwoju społeczeństwa (Rostow, 1960, s. 4-16):

- społeczeństwa tradycyjnego (ang. traditional society),

- przedwzrostowego tworzenia warunków startu (ang. preconditions for take-off),

- startu (ang. take-off) zwanego również fazą wzrostu,

- dochodzenia do dojrzałości (ang. drive to maturity),

- okresu wysokiej konsumpcji masowej (ang. age of high mass consumption).

W wyniku analizy przedmiotu, w drugiej połowie lat sześćdziesiątych XX wie$\mathrm{ku}$, zostało dodane szóste stadium - okresu pokonsumpcyjnego (ang. beyond consumption).

Na rysunku 8 ukazano pięć bazowych stadiów w klasycznym modelu Rostowa, opisujących rozwój regionalny (bez stadium pokonsumpcyjnego).

Na model Walta Rostowa, opisujący pięć stadiów rozwoju regionalnego, składają się:

- Stadium I: społeczeństwa tradycyjnego. Ludność terytorium żyje i pracuje w hierarchicznym układzie społecznym. Ten etap dotyczy regionu słabo rozwiniętego, w którym dominuje rolnictwo. Produkcja na tym obszarze zaspokaja głównie potrzeby lokalnego społeczeństwa. Nie występuje wymiana handlowa $\mathrm{z}$ innymi terenami.

- Stadium II: przedwzrostowego tworzenia warunków startu. W zauważalny sposób zmienia się struktura ekonomiczna i społeczna terytorium. 


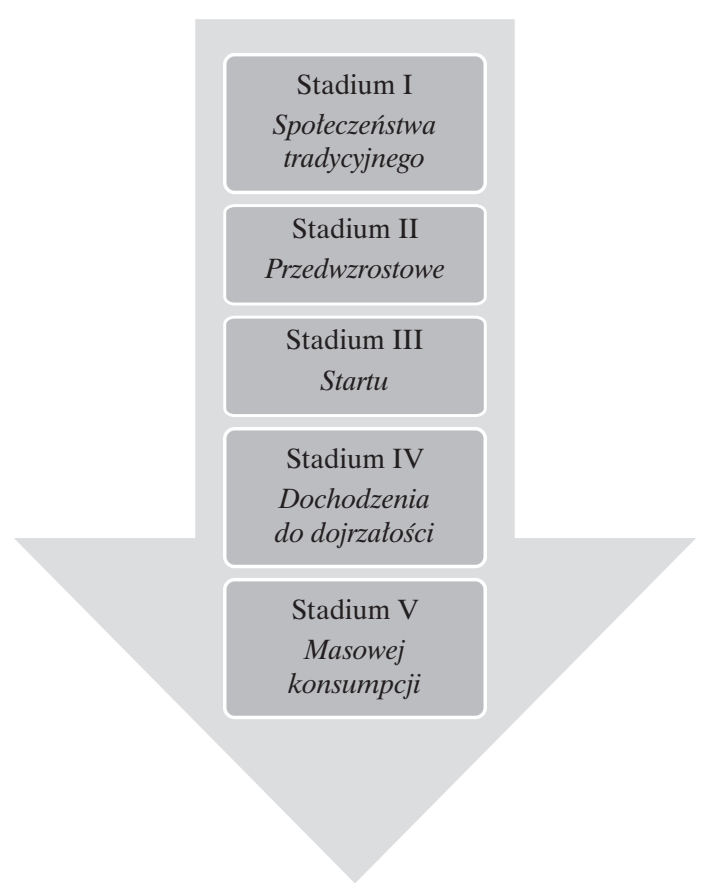

Rysunek 8. Pięć bazowych (podstawowych) stadiów rozwoju regionalnego według modelu Walta Rostowa

Źródło: opracowanie własne.

Gospodarka regionu koncentruje się jeszcze głównie na wytwarzaniu produktów podstawowych. Następuje wyraźna specjalizacja produkcji. W jej wyniku szybko występują nadwyżki produkcyjne, które stają się przedmiotem wymiany handlowej z innymi obszarami. Widoczny jest rozwój infrastruktury komunikacyjnej, postęp cywilizacyjny oraz podejmowane są inwestycje. Pojawiają się nowe, lepiej sytuowane grupy ludności. Odgrywają one coraz większą rolę w życiu społecznym i politycznym regionu. Obok powstawania własnych zasobów pracy, zaczyna napływać imigracja zarobkowa z innych obszarów. Stanowią ją kadry zarządzające oraz wykwalifikowana siła robocza. Dzięki temu rozszerzają się możliwości wytwórcze przedsiębiorstw, wzrasta ich efektywność i konkurencyjność rynkowa. Rodzi się odczucie odrębnej tożsamości regionalnej.

- Stadium III: startu zwane również fazą wzrostu. Następuje proces uprzemysłowienia regionu. Pojawiają się dynamicznie rozwijające się ośrodki i okręgi produkcyjne, starające się wykorzystać istniejące, często specyficzne uwarunkowania oraz lokalną bazę surowcową. Szeroką skalę 
przybiera proces emigracji ludności ze wsi do miast w poszukiwaniu pracy i lepszych warunków życia. Powstaje liczna klasa robotnicza i związki zawodowe. Tworzą się również bogate elity społeczno-polityczne. Ten etap może trwać od 20 do 30 lat.

- Stadium IV: dochodzenia do dojrzałości. W tej fazie bardzo wyraźnie zarysowuje się trend polegający na zwiększeniu roli i zakresu usług w gospodarce. Dzieje się to kosztem sektora rolniczego. We wszystkich działach przemysłu odnotowuje się znaczny postęp techniczny. Szeroko stosowane są rozwiązania nowatorskie i innowacyjne. Aktywność gospodarcza rozszerza się na wszystkie sfery, często nawet takie, które wymagają poważnych nakładów i wprowadzenia nowych, skomplikowanych technologii. Większość potrzebnych do życia ludności i dla funkcjonowania gospodarki wyrobów jest produkowana na miejscu w regionie. Zostaje położony nacisk na rozwój instytucji użyteczności publicznej, takich jak: szkoły, uczelnie wyższe, kina, teatry oraz ośrodki zdrowia i szpitale. Ta faza może być rozciągnięta w czasie od 50 do nawet 60 lat.

- Stadium V: wysokiej konsumpcji masowej. Widocznym symptomem tej fazy jest przejęcie przez sektor usług dominującej roli w całej gospodarce. Miejsce ma wielka dywersyfikacja i obfitość oferty sprzedaży. Produkcja lokalna regionu, skutecznie wypiera obce produkty. Następuje konsumpcja tanich wyrobów i usług na masową skalę. Pojawiają się także kosztowne dobra wyższego rzędu (luksusowe samochody, komfortowe domy i mieszkania, biżuteria, drogie restauracje). Oferta ich nabycia skierowana jest do wąskiej grupy bardzo zamożnych konsumentów.

- Stadium VI: pokonsumpcyjne (postkomsumpcyjne). W niektórych regionach daje się zauważyć ograniczenie działalności gospodarczej, spowodowane wyeksploatowaniem złóż surowcowych lub zmierzchem schyłkowych gałęzi przemysłu. Zmniejsza się konsumpcja oraz notuje się odpływ specjalistów oraz siły roboczej do innych regionów. Głównym sektorem danego obszaru pozostają jednak nadal usługi. Rodzi się świadomość oddziaływania człowieka i gospodarki na środowisko. Powstają instytucje i ruchy społeczne propagujące zachowania proekologiczne. Prowadzone są działania mające na celu zaktywizowanie regionu poprzez znalezienie dla niego zupełnie nowej specjalizacji lub dziedziny produkcji. Tego typu zjawiska można zaobserwować na przykład w dawnym regionie przemysłowym Sheffield (Anglia) i w Polsce na obszarze aglomeracji łódzkiej.

Model Rostowa dopuszcza zaistnienie odchyleń w czasie trwania poszczególnych stadiów oraz brak występowania niektórych istotnych elementów w poszczególnych etapach rozwoju gospodarczego. Brakuje w nim również precyzyjnego opisania czynników powodujących wzrost regionów. Oparty został 
na geopolitycznej historii Stanów Zjednoczonych Ameryki Północnej i rozwiniętych krajów Europy Zachodniej. Jego założenia sprawdzają się w małym stopniu w odniesieniu do regionów położonych na terenach Azji i Afryki (Puri, 2010, s. 127-136). Zawężony jest zasadniczo tylko obszarów o relatywnie rozwiniętej administracji lokalnej.

\subsection{Model Keynesowski}

Teoria Johna Maynarda Keynesa była próbą uporania się ze skutkami wielkiego kryzysu ekonomicznego, który miał miejsce w latach 1929-1933. Wskazując na niedoskonałość systemu rynkowego, postulowała ona wywołanie wzrostu gospodarczego i zwalczenie bezrobocia w sposób sztuczny. Chodziło o zainicjowanie zwiększenia globalnego popytu przez państwo. Proces pobudzenia wzrostu wydatków miał zostać według tej koncepcji osiągnięty za pomocą wybranych instrumentów ekonomicznych. Najważniejsze z nich to konsekwentnie prowadzone polityka pieniężna i polityka fiskalna.

Doktryna keynesowska zakłada zastosowanie interwencjonizmu państwowego w odniesieniu do rozległego obszaru uwarunkowań ekonomiczno-gospodarczych. Po zaadaptowaniu do skali terytorialnej, oznaczała bezpośrednią ingerencję władz krajowych w sprawy i zagadnienia regionalne. Konieczność takiego działania wynika $\mathrm{z}$ występujących tendencji do pogłębiania się różnic międzyregionalnych w ramach gospodarki wolnorynkowej. Regiony wysoko rozwinięte rozwijają się bardziej dynamicznie, stają się bogatsze i przyjmują pozycję dominującą wobec pozostałych terenów. Regiony słabo rozwinięte rozwijają się wolniej lub nawet wchodzą w stan stagnacji albo dotkliwego kryzysu. $\mathrm{Na}$ ich obszarze pojawiają się niepokojące zjawiska problemowe i niekorzystne napięcia społeczne. W takich sytuacjach niezbędne zdaniem Johna Keynesa staje się zaangażowanie państwa. W odniesieniu do skali terytorialnej interwencja powinna obejmować następujące obszary (Szlachta, 1992, s. 31):

- regiony słabo rozwinięte o położeniu peryferyjnym; najczęściej dominującym w nich sektorem produkcji jest rolnictwo; działania władz na ich obszarze powinny zmierzać do niwelowania przeszkód i barier rozwojowych oraz prowadzić do pobudzania mechanizmów wzrostowych;

- regiony tradycyjnie przemysłowe ogarnięte stagnacją ekonomiczną; dotyczy obszarów, które swoją egzystencję opierały na dwóch lub tylko jednej branży przemysłowej; z powodu posiadania schyłkowych dziedzin produkcji lub też wyczerpywania się zasobów surowcowych popadły one w stan zapaści; działania władz powinny skupić się na zdywersyfikowaniu działalności gospodarczej poprzez wspieranie innowacyjnych i konkurencyjnych dziedzin aktywności ekonomicznej oraz rozwijaniu usług; 
- regiony oparte na dużych aglomeracjach miejskich; poprzez swoją dużą skalę wywierają wpływ nie tylko na warunki w jakich same funkcjonują, lecz także na oblicze gospodarki całego kraju; najczęściej stanowią skoncentrowany i skomplikowany twór ludnościowo-ekonomiczny; działania władz powinny zapewnić tym obszarom długotrwały wzrost gospodarczy przy zachowaniu stabilnych struktur społecznych.

Teoria Keynesa postuluje różnorodne działania administracji zarówno krajowej, jak i samorządowej. Składać się na nią powinny: ulgi podatkowe, łatwo dostępne kredyty i pożyczki dla inwestorów, szkolenia mające za zadanie podwyższenie kwalifikacji siły roboczej, prace społeczne i roboty interwencyjne dla osób długotrwale pozbawionych zajęcia zarobkowego, promowanie lokalnych wyrobów, zachęcanie do inwestycji na własnym terenie, powoływanie do życia instytucji wspierających rozwój przedsiębiorczości, nakłady na oświatę i kształcenie, upowszechnianie nowoczesnych metod zarządzania i wdrażanie rozwiązań innowacyjnych w gospodarce regionu (Feser, Malizia E, 1999, s. 123-137). Zdaniem Johna Maynarda Keynesa, aktywność administracji publicznej powinna się koncentrować przede wszystkim na regionach słabo rozwiniętych i działać na rzecz ukierunkowanego zintensyfikowania ich wzrostu gospodarczego.

\subsubsection{Teoria bazy eksportowej}

Teoria opisująca bazę ekonomiczną regionu powstała w pierwszej połowie lat pięćdziesiątych XX wieku. Jest identyfikowana z amerykańską szkołą ekonomii. Została oparta na założeniach teoretycznych opisanych przez czterech profesorów uniwersyteckich - Richarda Bairda Andrewsa (Wisconsin School of Business at the University of Wisconsin), Jamesa Stemble'a Duesennberry'ego (Harvard University), Douglasa Cecila Northa (Washington University in St. Louis) oraz Charlesa Tiebouta (University of Washington). Powstała koncepcja znana jest również pod nazwą teorii bazy ekonomicznej. Za ojca teorii uważany jest Richard B. Andrews, który jako pierwszy dokładnie wyróżnił główne pojęcia, zasadnicze elementy oraz opisał metody diagnostyczne, możliwe do zastosowania w weryfikacji obserwowanych zjawisk ekonomicznych (Andrews, 1953, s. 161-167). Tym samym stworzył podwaliny nowego podejścia. Hipoteza, na której oparty został model bazy ekonomicznej zakłada, że wzrost gospodarczy regionu uzależniony jest w ścisły sposób od jego eksportu. Kluczowe znaczenie ma tutaj popyt zewnętrzny (egzogeniczny) na wytwarzane w regionie usługi i dobra. Od poziomu tego eksportu zależy bezpośrednio poziom produkcji i wielkość zatrudnienia na danym obszarze. Rozmiar i intensywność eksportu może być dodatkowo wywoływana przez zmienne zewnętrzne (egzogenne), 
do których można zaliczyć proponowane ze strony państwa: ulgi podatkowe, zachęty i przywileje ekonomiczne.

Douglas C. North poddając analizie źródła generowania dochodów w regionie, podzielił je na dwa główne rodzaje (1955, s. 243-256):

- dochód z działalności eksportowej (dochód bazowy),

- dochody z działalności skierowanej na zaspokojenie rynku wewnątrzregionalnego (dochód niebazowy).

Sektor bazowy cechuje wyższa produktywność niż pozostałe. Zasięg jego działalności ma charakter ponadregionalny. Tworząc podstawę ekonomiczną, jest najistotniejszy dla rozwoju danego regionu. Sektor niebazowy jest bezpośrednio zależny od aktywności i sukcesów gospodarczych sektora bazowego, a jego produkcja dóbr i usług trafia na rynek wewnątrzregionalny.

James S. Duesennberry określił decydujące znaczenie poziomu eksportu dla procesu wzrostu gospodarczego. Posłużył się przykładem porównawczym regionów: rozwiniętego (wysoko uprzemysłowionego) i słabo rozwiniętego (rolniczego) w Stanach Zjednoczonych. Niejako przy okazji poruszył temat korzyści, jakie czerpią podmioty gospodarcze w regionie w wyniku jego wzrostu gospodarczego (Duesennberry, 1950, s. 63-102).

Ostatni ze wspomnianych amerykańskich profesorów, Charles Tiebout, stworzył model wyjaśniający wpływ wydatków władz lokalnych na wachlarz dóbr i usług przeznaczonych na rynek wewnętrzny. Określił relację dostępności od zróżnicowania ich cen oraz wpływ na rozwój regionu (Tiebout, 1956b, s. 416-424). Rozwijając temat eksportu udowodnit, że podnosząc jego wielkość, zwiększa się import dóbr i usług do regionu oraz stymuluje nowe inwestycje na jego obszarze (Tiebout, 1956a, s. 160-164). Zwrócił też uwagę na fakt powiązania dynamiki eksportu z zatrudnieniem. Zauważył, że malejąca aktywność gospodarcza i zmniejszające się zatrudnienie w sektorze bazowym (eksporcie) powodują zmniejszenie aktywności ekonomicznej oraz zatrudnienia w sektorach niebazowych (zaspokajających potrzeby rynku wewnątrzregionalnego) (Tiebaut, 1962, s. 10-12). Stwierdził on, że ludzie w przypadku wystąpienia konfliktu ich przekonań z polityką władz na ich terenie wolą zmienić region zamieszkania i pracy, niż dążyć do zmiany władz lokalnych w demokratycznych wyborach. $\mathrm{Z}$ modelu Tiebouta wynikają bezpośrednie wskazówki na temat działania władz samorządowych. Obowiązkiem decydentów regionalnych jest dążenie do wzrostu opartego na eksporcie. Poprzez stworzenie systemu zachęt, takich jak: ulgi podatkowe, zwiększona amortyzacja, specjalne strefy ekonomiczne, rozwój infrastruktury komunikacyjnej i łącznościowej, władze powinny przyciągać na swój teren nowych inwestorów i wykwalifikowaną siłę roboczą. Teoria bazy eksportowej, implikującej wzrost gospodarczy, stanowi popularną koncepcję zapewnienia regionom ustabilizowanego i dynamicznego rozwoju. 


\subsection{Teorie zrównoważonego rozwoju regionalnego}

Wspólną cechą tych teorii jest założenie o konieczności ingerencji władz krajowych, a także samorządowych, w ożywienie wybranych obszarów. Prowadzenie aktywnej polityki gospodarczej przez wymienione gremia rządzące ma na celu w przeciwdziałanie niedoskonałości i powszechnym mankamentom mechanizmu rynkowego. Akumulacja kapitału traktowana jest $\mathrm{w}$ tych teoriach jako niezbędny warunek umożliwiający zrealizowanie zmian, prowadzący do rozwoju wydzielonych terytoriów. W wymienionych koncepcjach można zauważyć pewien wpływ idei keynesowskich. Najbardziej znanymi nazwiskami związanymi z grupą teorii zrównoważonego rozwoju regionalnego są: estoński ekonomista, wykładowca i polityk Ragnar Nurkse oraz profesor amerykańskich wyższych uczelni, Austriak polskiego pochodzenia, Paul Rosenstein-Rodan.

\subsubsection{Teoria zrównoważonego wzrostu Ragnara Nurkse'a}

Teoria zrównoważonego wzrostu Ragnara Nurkse'a (ang. Balanced Growth Theory) podkreśla fundamentalne znaczenie oszczędności gromadzonych przez społeczeństwo oraz konieczność pozyskania kapitału ze źródeł zewnętrznych. Wykorzystanie środków finansowych pochodzących z obu tych źródeł daje szansę stworzenia odpowiednich warunków dla rozwoju społeczno-gospodarczego w regionie. Ważnym elementem teorii jest tzw. błędne koło ubóstwa (ang. vicious circle of poverty) (rys. 9).

„Błędne koło ubóstwa” tłumaczy dlaczego biedne społeczeństwa nie mają możliwości wyrwania się z zaklętego kręgu nędzy i pomimo podejmowanych wysiłków nadal pozostają ubogie. Za praprzyczynę wszystkich zdarzeń autor opisywanej koncepcji uznaje niski poziom dochodów ludności danego terenu. Ilość środków pochodzących z pracy z trudnością pozwala na skromną egzystencję. Praca świadczona przez jednostki dysponujące ograniczonymi zasobami finansowymi jest słabo efektywna i mało wydajna. $\mathrm{Z}$ tej przyczyny również wynagrodzenie za pracę kształtuje się na bardzo niskim poziomie. Zaspokojenie podstawowych potrzeb i walka o przeżycie angażują całą energię i inwencję zatrudnionych. Brak nadwyżek kapitałowych uniemożliwia zgromadzenie oszczędności. Osoby posiadające stałe zajęcie zarobkowe nie mają wystarczających środków, aby sfinansować dalsze kształcenie ani nie są zainteresowane rozwijaniem swoich umiejętności zawodowych. W rezultacie zaangażowanie w pracę i wydajność siły roboczej w biednych regionach pozostaje na niezmiennie niskim poziomie. Sytuacja ta niekorzystnie rzutuje również na warunki funkcjonowania podmiotów gospodarczych na danym obszarze. Przedsiębiorstwa te nie są w stanie wygenerować wysokich zysków i wystarczającej nadwyżki 


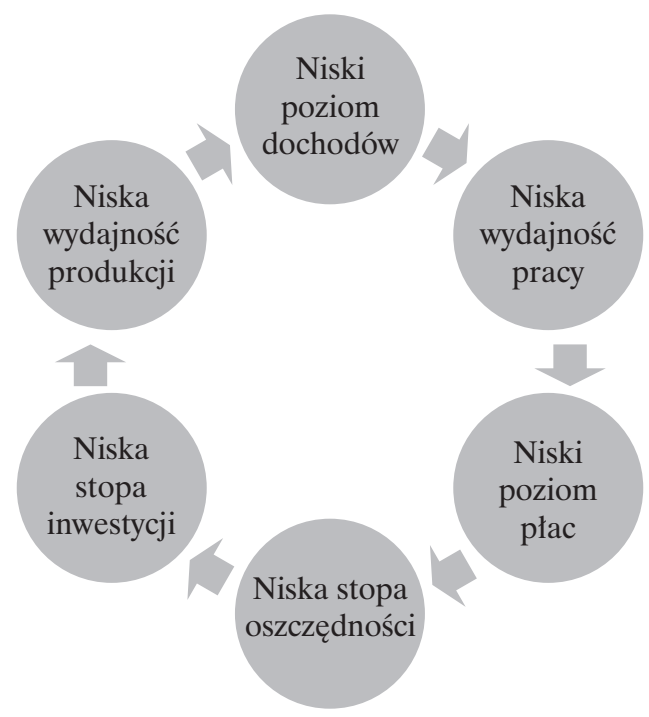

Rysunek 9. Błędne koło ubóstwa według teorii zrównoważonego wzrostu Ragnara Nurske'a

Źródło: Ziewiec (2011, s. 55).

kapitałowej. Następstwem położenia, w jakim się znalazły, jest brak możliwości wygospodarowania środków na unowocześnienie produkcji, pozyskanie nowych technologii i ewentualną podwyżkę wynagrodzeń za pracę. Ustawiczny niedostatek dochodów powoduje rezygnację z inwestycji, które są niezbędne dla samych zakładów produkcyjnych, dla regionu, a w dalszej kolejności dla państwa (Nurske, 1966, s. 28-97). Tereny słabo rozwinięte, pozostawione same sobie, zostają automatycznie skazane na „błędne koło” upokarzającej egzystencji. W obszarze koła pozostają uwięzieni ludzie i przedsiębiorstwa bez szans na przyszłość i bez jakiejkolwiek nadziei na polepszenie położenia.

Według twórcy teorii, jedynym sposobem na przerwanie „zaczarowanego kręgu" jest skłonienie inwestorów wywodzących się spoza regionu do alokacji ich pieniędzy w nadającym się do tego miejscu. Impuls w postaci dopływu obcego kapitału powinien zapoczątkować proces pozytywnych zmian dla całego obszaru i zamieszkującej go społeczności. Zapewnienie zagranicznej lub pochodzącej z innych regionów pomocy finansowej jest najważniejszym czynnikiem stabilizującym zacofaną strefę.

Na marginesie tych rozważań trzeba zauważyć, że sytuacja społeczno-gospodarcza Polski wykazuje wyraźne symptomy wchodzenia w „błędne koło ubóstwa”. Proces ten został złagodzony przez emigrację zarobkową blisko dwóch milionów Polaków. Jednakże w sytuacji nasilania się symptomów kryzysu od 
2012 roku sposób ten okazuje się niewystarczający. „Koło ubóstwa” zaczęło zataczać coraz szersze kręgi. Na pierwszy plan wysuwają się tu widoczne dramatyczne obniżenie realnych dochodów i wyczerpywanie się oszczędności ludności w naszym kraju. Dochodzą do tego problemy z zapewnieniem społeczeństwu środków finansowych wystarczających na prowadzenie godziwego życia. Najwyraźniej widać opisywane zjawisko na terenach objętych wysokim bezrobociem, położonych głównie na północnym i południowym wschodzie państwa polskiego. Należy mieć nadzieję, że odpowiedzialne za sytuację ekonomiczną władze nie dopuszczą do dalszych negatywnych zdarzeń.

\subsubsection{Teoria "wielkiego pchnięcia" Paula Rosensteina-Rodana}

Teoria „wielkiego pchnięcia” (ang. Big Push Theory lub Big Push Model) Paula Rosensteina-Rodana została ogłoszona w 1943 roku. Autor skierował jej przesłanie do krajów, których gospodarkę charakteryzował niski poziom rozwoju. Chodziło mu głównie państwa położone we wschodniej i południowowschodniej Europie oraz w Ameryce Łacińskiej. Wybitny austriacki ekonomista za najlepsze antidotum na problemy nurtujące te kraje, takie jak: wysoka stopa bezrobocia, niskie dochody i brak siły nabywczej ludności, uważał ich szybkie uprzemysłowienie (1959, s. 359-369).

Przekonywał, że najlepszym sposobem dokonania szybkiej industrializacji byłaby specjalizacja oraz integracja ze światową gospodarką. Uważał, że cały proces należy oprzeć na wykorzystaniu wielkich, międzynarodowych związków przedsiębiorstw, działających w formie koncernów, holdingów i trustów w przemyśle lekkim. Dodatkowo postulował skoncentrowanie wszystkich dużych inwestycji w jednym regionie. Inwestycje w rozwój wybranych gałęzi przemysłu stymulowane i finansowane przez państwo miały doprowadzić do wzrostu wydajności produkcji i trwałej modernizacji struktur wytwarzania. Sposobem na dopływ kapitału do wydzielonych obszarów miała być pomoc zewnętrzna, pochodząca od państwa. Według badacza naczelne władze były odpowiedzialne nie tylko za politykę industrializacji, lecz także za poniesienie wszelkich niezbędnych kosztów dodatkowych, głównie tych związanych z budową infrastruktury. Na państwie spoczywał również, według niego, obowiązek zapewnienia nowo powstałym gałęziom przemysłu odpowiednio wykwalifikowanej siły roboczej zarówno w początkowym okresie, jak i w kolejnych latach (Ziewiec, 2011, s. 54). Efekt miał być zintensyfikowany poprzez udzielenie gwarancji rządowych oraz zainicjowanie przez władze dużych projektów inwestycyjnych.

Łatwo jest zauważyć, że założenia teorii „wielkiego pchnięcia” przedstawiają dość dokładnie w ujęciu teoretycznym dokonania gospodarcze władz II Rzeczypospolitej. Mam tu na myśli budowę portu w Gdyni oraz stworzenie Centralnego Okręgu Przemysłowego. Obie te inwestycje finansowane były 
w większości z budżetu państwa polskiego. Zostały jednak zainicjowane i przeprowadzone na długo przed ogłoszeniem Modelu Rosensteina-Rodana. Należy wziąć jeszcze pod uwagę ścisłe związki urodzonego w Krakowie autora teorii oraz jego wielkie zainteresowanie sprawami naszego kraju i tej części Europy, w której jest on położony. Można zatem wysnuć przypuszczenie, że to właśnie rozwiązania zastosowane w Polsce stały się inspiracją do powstania koncepcji „wielkiego pchnięcia”. Niestety, Paul Rosenstein-Rodan nie wspomina o tym w swoich publikacjach.

\subsubsection{Teoria nieograniczonych zasobów pracy Arthura Lewisa}

Interesujący wkład do teorii rozwoju regionalnego wnosi koncepcja pochodzącego z Karaibów Brytyjczyka, Arthura Lewisa. Obszar badawczy ekonomisty stanowiły zagadnienia wzrostu gospodarczego ówczesnych państw „trzeciego świata" w okresie pierwszych dziesięcioleci po II wojnie światowej. Dociekania $\mathrm{w}$ tej materii, ze szczególnym uwzględnieniem problemów przeciwdziałania bezrobociu, oraz spostrzeżenia dotyczące dualizmu gospodarek w krajach najmniej rozwiniętych przyniosły Lewisowi Nagrodę Nobla w dziedzinie ekonomii w 1979 roku (Lewis, 1954, s. 91-139).

Lewis w swoich pracach zauważył, że obszary słabo rozwinięte opierają swoją gospodarkę przeważnie na dwóch sektorach. Pierwszy z nich, stanowi skupione na terenach wiejskich rolnictwo o niskim stopniu rozwoju i wykazujące słabą produktywność. Drugi sektor zlokalizowany w miastach, to relatywnie zaawansowany i technicznie nowoczesny przemysł. Tereny, które są zdominowane przez każdy z sektorów, różnią się zasadniczo rozwojem i warunkami życia. Rolnictwo przynosi niewielkie dochody utrzymującej się z niego ludności. Społeczność zamieszkująca ośrodki miejskie zarabia lepiej i jest w stanie uzyskać oszczędności. Dzięki akumulacji kapitału, w postaci zaoszczędzonych środków finansowych, możliwe są inwestycje tworzące rozwój. Niebagatelne znaczenie ma tutaj również wysoka konsumpcja w miastach, nakręcająca koniunkturę w usługach i innych dziedzinach gospodarki. Pogłębiające się drastycznie różnice w poziomie życia skłaniają mieszkańców wsi do migracji zarobkowych. Na zacofanych obszarach krajów rozwijających się ludność pochodzenia wiejskiego stanowi prawie nieograniczony rezerwuar nadwyżek wyjątkowo taniej siły roboczej. Właściciele środków produkcji mogą w tej sytuacji wykorzystywać dobrodziejstwo wielkiej liczby osób poszukujących pracy, a zwiększając zatrudnienie, nie są zmuszeni do podwyższania płac, przez co uzyskują wyższe zyski. Zaoszczędzone w ten sposób pieniądze mogą przeznaczać na nowe inwestycje, podjęte zaś inwestycje generują nowe, liczne miejsca pracy. Powstaje mechanizm samonapędzającego się rozwoju. System działa sprawnie dopóty, dopóki nie wyczerpią się zasoby siły roboczej albo 
pracodawcy i zarazem właściciele zakładów przemysłowych nie będą musieli podwyższać stawek wynagrodzenia.

\subsection{Teorie niezrównoważonego wzrostu regionalnego}

Główną hipotezą tej grupy teorii jest założenie zasadniczego znaczenia wysoko rozwiniętych obszarów dla procesu wzrostu regionalnego. Koncepcje te wskazują jako warunek konieczny rozwoju określonych terytoriów istnienie w gospodarce przodujących regionów posiadających prężne zaplecze przemysłowe. Do grupy teorii niezrównoważonego wzrostu zalicza się: teorię (doktrynę) polaryzacji (sektorowej i regionalnej), teorię biegunów wzrostu oraz teorię centrum-peryferia.

\subsubsection{Doktryna polaryzacji}

W połowie XX wieku pojawiły się w nauce nowatorskie koncepcje opisujące przyczyny oraz czynniki kreujące dynamikę wzrostu regionalnego, które zebrano pod wspólny szyld teorii (doktryny) polaryzacji. Swój rodowód czerpały z wcześniejszej klasycznej teorii lokalizacji. Za twórcę podstaw tej koncepcji uznaje się francuskiego ekonomistę François Perroux. Chociaż w oryginale jego teoria nie odnosiła się do zagadnień regionalnych, to jej założenia zostały później do tych celów wykorzystane. Propagatorami, a zarazem kontynuatorami dzieła Perroux byli: noblista Gunnar Myrdal oraz, pochodzący z Niemiec, profesor Alfred Otto Hirschman. Pomimo tego, że rozkwit tych teorii przypada na drugą połowę $\mathrm{XX}$ wieku, to ich ustalenia wykorzystywane są w nauce do dziś.

\subsubsection{Teoria biegunów wzrostu François Perroux}

Teoria biegunów wzrostu (ang. growth poles) została stworzona w latach pięćdziesiątych XX wieku przez profesora François Perroux, wykładowcę w College de France i University of Paris. Chociaż początkowo była koncepcją sektorową (gałęziową), odnoszącą się do zagadnień dotyczących rozwoju przemysłu, to ostatecznie otworzyła zupełnie nową sferę rozważań w odniesieniu do ekonomiki regionalnej. Koncepcja zakładała, że rozkwit całych branż i poszczególnych gałęzi przemysłu uzależniony jest od występowania przedsiębiorstw przemysłowych, które legitymują się w stosunku do innych podmiotów gospodarczych wyjątkowo dynamicznym tempem rozwoju. Biegun wzrostu tworzony jest przez jeden zakład przemysłowy lub grupę firm, mających duży udział w rynku oraz wytwarzających stosunkowo wysoki produkt brutto. Najczęściej jest on największy z notowanych w danej gospodarce. Wiodące 
przedsiębiorstwa poprzez ponadprzeciętny poziom produkcji, znaczną wielkość zbytu i wysoką aktywność gospodarczą intensywnie oddziałują na swoich kooperantów i pozostałe jednostki w regionie. Tym sposobem przyspieszony wzrost najlepszych i największych firm pociąga za sobą szybki rozwój innych, działających na danym terenie. Według Perroux zostaje wytworzone swoiste pole siłowe, które obejmuje swym zasięgiem coraz większą ilość podmiotów gospodarczych. Teoria biegunów wzrostu została następnie rozwinięta i uzupełniona przez szwedzkiego ekonomistę i polityka Gunnara Myrdala oraz Alfreda Otto Hirschmana, wykładowcę w kilku najbardziej renomowanych uczelniach wyższych w Stanach Zjednoczonych. Swoimi pracami wprowadzili oni do teorii Perroux zagadnienia związane ściśle z rozwojem regionalnym.

\subsubsection{Koncepcja okrężnej i kumulatywnej przyczynowości Gunnara Myrdala}

Gunnar Myrdal udowodnił, że szybkość rozwoju regionu lub kraju uzależniona jest od siły sprzężeń zwrotnych, jakie występują na osi pomiędzy przedsiębiorstwami przemysłowymi i gospodarką. Im silniejsze jest wzajemne oddziaływanie i im szybciej obejmuje ono kolejne obszary oraz działające w ich obrębie podmioty, tym dane terytorium odnotowuje szybszy wzrost (Myrdal, 1967). W swojej teorii Myrdal założył możliwość swobodnego przemieszczania się ludzi i kapitału. Jednakże gra sił rynkowych nie powoduje wyrównywania różnic pomiędzy poszczególnymi obszarami, a wręcz przeciwnie, prowadzi poprzez system sprzężeń zwrotnych do wzmocnienia ich intensywności. Bazując na zasadzie tzw. okrężnej przyczynowości, wywołana impulsem zmiana jednej wielkości inicjuje dalsze zmiany, które obierają ten sam kierunek. Doprowadza to do procesu skumulowanych przeobrażeń w przyjętym na samym początku kierunku. Zmiany pozytywne wyzwalają procesy rozprzestrzeniania się wzrostu regionalnego i przynoszą efekt ukierunkowanej dyfuzji (rozprzestrzeniania się) czynników wzrostu. Przykładem może być odkrycie bogatych złóż złota w 1986 r. w okolicach miasta Dawson City nad rzeką Klondike w Kanadzie. Fakt ten wywołał „gorączkę złota”, która w ciągu tylko jednego roku ściągnęła na Terytorium Jukonu ponad trzydzieści tysięcy osób. Zainicjowało to rozwój tych bardzo surowych, niedostępnych i odludnych terenów. W wyniku sprzężenia zwrotnego złotodajny obszar doznał przyspieszonego wzrostu, który w normalnych warunkach musiały trwać co najmniej kilkadziesiąt lat dłużej. Impuls inicjujący zmiany był tak silny, że efekt rozprzestrzeniania się czynników wzrostu objął swoim zasięgiem nawet miejscowości leżące w pewnej odległości od Klondike. Poszukiwacze zatrzymywali się przeważnie w Seattle, oddalonym o około 100 mil od granicy Kanady. Nabywali tam zapasy żywności, namioty oraz niezbędne narzędzia, po czym wyruszali w poszukiwaniu szczęścia dalej na północ. Następnie, jeśli im się powiodło, inwestowali lub tracili pieniądze w tym mieście. 
Zmiany negatywne, wywołane silnym niekorzystnym impulsem, powodują kumulatywny proces regresywny na danym terenie (zwany również efektem wypłukiwania czynników wzrostu). Jako przykład może posłużyć tutaj Bejrut, stolica Libanu. W okresie po II wojnie światowej metropolia ta była głównym centrum finansowym, handlowym i intelektualnym świata arabskiego. Stynęła ze swoich zabytków, teatrów, wyśmienitych restauracji, klubów nocnych, zakładów jubilerskich oraz banków. Przychylna polityka władz i niepowtarzalna atmosfera przyciągały do Bejrutu kapitały ze wszystkich części globu. Miasto bujnie rozkwitało, a z nim cały kraj. Na początku lat siedemdziesiątych XX wieku Liban nazywano: Szwajcarią Bliskiego Wschodu. Wybuch krwawej wojny domowej pomiędzy muzułmanami a chrześcijanami w 1975 roku doprowadził ten ośrodek do upadku. Całkowicie zniszczono centrum finansowe i kulturalne, które stało się ziemią niczyją. Miasto zostało podzielone na dwie wrogie sobie części, wycofano obce kapitały i wstrzymano wszelkie inwestycje. Duża liczba mieszkańców zdecydowała się na wyjazd za granicę. Pomimo zawarcia pokoju i podjęcia wysiłków stabilizujących sytuację polityczną, Bejrut utracił raz na zawsze swoją pozycję w regionie.

Przytoczone przykłady pozytywnego i negatywnego sprzężenia zwrotnego demonstrują przypadki dość ekstremalne. W praktyce do ich wystąpienia może wystarczyć zamknięcie lub zbudowanie w danym regionie dużego zakładu pracy. Myrdal dowodzi na wielu przykładach, że skumulowana siła oddziaływania efektów wypłukiwania jest zazwyczaj większa niż siła rozprzestrzeniania. Sugeruje także, że do zachwiania istniejącej równowagi gospodarczej określonego terytorium i wystąpienia korzystnych lub niekorzystnych zmian może dojść także w wyniku w niedostrzegalnych w początkowym momencie czynników.

\subsubsection{Koncepcja polaryzacji sektorowo-regionalnej Alfreda O. Hirschmana}

Alfred Otto Hirschmnan połączył pojęcia biegunowości sektorowej i biegunowości regionalnej w jedną koncepcję. Wykazał, że wzrost ekonomiczny określonego obszaru powoduje zazwyczaj zachwianie równowagi pomiędzy sektorami przemysłowymi działającymi w jego granicach. Sektory lepiej rozwinięte, kooperują jedynie z wybranymi przedsiębiorstwami zaspokajającymi ich potrzeby. Powoduje to szybszy i bardziej dynamiczny rozwój tylko wybranych gałęzi i branż. Podmioty i całe branże, które nie otrzymują tego rodzaju impulsów stymulujących, rozwijają się zdecydowanie wolniej. Zatem niezrównoważony wzrost $\mathrm{w}$ regionie nie tyle towarzyszy rozwojowi, ile stanowi jego niezbędny warunek (Hirschman, 1958, s. 32-54). W skali makroekonomicznej, twórca teorii polaryzacji odwołał się do przykładu współistnienia na naszym globie dwóch zasadniczo różniących się formacji - z jednej strony, bogatej i rozwiniętej półkuli północnej, z drugiej zaś - dużo biedniejszej, zacofanej ekonomicz- 
nie i cywilizacyjnie półkuli południowej. Wzrost gospodarczy północy wywiera bezpośredni i pośredni wpływ na warunki, w jakich funkcjonuje południe. Uprzemysłowione państwa północy, poprzez import surowców i materiałów, zakup produktów rolnych oraz zaabsorbowanie nadwyżek siły roboczej pochodzących z południa, mogą przyczynić się do zwiększenia konsumpcji per capita i wzrostu krańcowej produktywności zatrudnionych na antypodach. Stwarza to sytuację, w której regiony wysoko rozwinięte i słabo rozwinięte stają się dla siebie korzystnie działającym układem komplementarnym (Hirschman, 1958, s. 182-188). Porównując podejścia Hirschmana i Myrdala można zauważyć istotną różnicę. O ile pierwszy z wymienionych ekonomistów wskazywał na większą moc efektów wypłukiwania, o tyle drugi przekonany był o większej w praktyce sile efektów rozprzestrzeniania się.

Założenia koncepcji polaryzacji sektorowo-regionalnej Alfreda Hirschmana zostały potwierdzone na polu teorii i praktyki zjawisk zaobserwowanych w obszarze powstawania różnic międzyregionalnych na świecie. Stały się jedną z popularniejszych teorii tłumaczących mechanizmy rozwoju wybranych obszarów. Przykładem opisywanych zjawisk są istniejące różnice pomiędzy wysoko rozwiniętymi krajami Ameryki Północnej, takimi jak Kanada i USA a mniej zamożnymi państwami pozostającymi w ich cieniu, położonymi na kontynencie południowoamerykańskim.

\subsubsection{Teoria centrum-peryferia Raula Prebischa}

Za twórcę koncepcji centrum-peryferia uważany jest Argentyńczyk niemieckiego pochodzenia, Raul Prebisch. Będąc ekonomistą i politykiem, poświęcił on swoją uwagę zagadnieniom rozwoju państw Ameryki Południowej. Zręby nowej teorii stworzył w drugiej połowie lat czterdziestych XX wieku. Stała się ona następnie bazą do sformułowania popularnej w latach pięćdziesiątych i sześćdziesiątych teorii zależności (dependencji), opisującej proces bogacenia się krajów rozwiniętych (metropolii kolonialnych i mocarstw przemysłowych) poprzez pozyskiwanie dóbr i surowców z krajów rozwijających się.

Uniwersalność teorii Raula Prebischa polega na tym, że mechanizmy warunkujące zależności centrum-peryferia można zaobserwować na wszystkich poziomach w wymiarze przestrzennym. Dotyczą one szczebla: lokalnego, regionalnego, krajowego, międzynarodowego i globalnego. Głównym założeniem teorii było przekonanie, że rozwój peryferii jest zależny od rozwoju miejsc centralnych (Kundera, Szmyt, 2008, s. 101-102). Swoje wnioski autor koncepcji oparł na analizie wpływu rozwiniętej gospodarki Stanów Zjednoczonych na cały region Ameryki Południowej. Szczególnie eksponował odpływ takich elementów, jak kapitał i praca, dlatego też w kręgach naukowych uważany był czasem za neomarksistę. 
Teoria Prebischa zakłada, że centrum może oddziaływać na peryferia zarówno w pozytywny, jak i negatywny sposób. Zjawiska związane z pozytywnym i pożądanym wpływem centrum na peryferia określone zostały jako: dyfuzja (przenikanie). Natomiast zjawiska związane z niepożądanym i negatywnym wpływem określono jako: wysysanie (wymywanie). Zjawiska dyfuzyjne to przykładowo: transfer wiedzy, napływ kapitału, nowe inwestycje, postęp wiedzy, pozyskanie nowych technologii, oddziaływanie innowacji, ujednolicenie wysokich standardów, podwyższenie jakości. Dobra koniunktura i rozkwit gospodarczy miejsca centralnego wpływaja bezpośrednio wspomagająco na wyniki ekonomiczne peryferii. Obszary nawet pozbawione własnych cech i możliwości wzrostowych (peryferie) mogą liczyć na rozwój pod warunkiem wykorzystania oddziaływania pozytywnych czynników wzrostowych generowanych przez centrum. Przykładowe zjawiska wysysania to: nierówna wymiana handlowa, uzależnienie gospodarcze i polityczne, ucieczka najbardziej wykształconych i przedsiębiorczych pracowników, niekorzystny podział pracy, lokalizacja ośrodków edukacyjnych (różnych poziomów) i badawczych tylko w miejscach centralnych. Recesja i kryzys, często z pewnym opóźnieniem spowodowanym siłą inercyjną, wpływają hamująco na rozwój miejsc peryferyjnych (Szul, 2007, s. 114-115). Opisane zjawiska dyfuzji i wysysania stały się ważnymi elementami prowadzonej przez władze polityki regionalnej. Ich szybkie zdiagnozowanie pozwala władzom samorządowym na zastosowanie w praktyce skutecznych środków zapobiegających zjawiskom wysysania. Natomiast procesy dyfuzji (przenikania) powinny być wzmacniane i utrwalane przez decyzyjne gremia lokalne, ponieważ zwiększają dynamikę rozwoju regionalnego.

Koncepcje rozwoju regionalnego, przedstawione: w teorii biegunów wzrostu, teorii życia produktu oraz we wspomnianej już teorii zależności (dependencji), mają punkty styczne z opisaną teorią centrum-peryferia Raula Prebischa.

\subsection{Urbanistyczne teorie wzrostu regionalnego}

W drugiej połowie XX wieku powstało kilka teorii silnie podkreślających rolę ośrodków miejskich w procesie rozwoju regionalnego. $\mathrm{W}$ ich ramach dążono do zidentyfikowania ośrodków decyzyjnych oraz określenia czynników sprawczych, odpowiedzialnych za zmiany społeczno-gospodarcze określonych obszarów. Nowe koncepcje rozwoju podkreślały wagę wyboru jednego z dwóch opozycyjnych względem siebie sposobów zarządzania miastem. Chodziło tu o styl demokratyczny, zakładający dużą aktywność i partycypację społeczności lokalnej w sprawowaniu władzy oraz styl autorytarny, narzucający niejako odgórnie podejmowane decyzje. Powstałe teorie stworzyły zupełnie nowy nurt podejścia do zagadnień rozwoju regionalnego, silnie wiążący ten proces z przebiegiem zjawisk urbanizacji. 


\subsubsection{Teoria City Limits Paula Petersona}

Pierwszą z nowych koncepcji stanowiła teoria "publicznego wyboru” (ang. public choise) Paula E. Petersona, przedstawiona w wydanej w $1981 \mathrm{r}$. książce pt.: City Limits. Jej autor stał na stanowisku, że miejskie władze lokalne stanowią ośrodki decyzyjne niezależne od władz regionalnych i krajowych. Na ich barkach spoczywa odpowiedzialność za urzędowe (public, w tym znaczeniu - przyp. aut.) decyzje służące pożytkowi ogółu społeczeństwa zamieszkującego ośrodki miejskie.

Władze municypalne mają zatem za zadanie zabiegać w swoich poczynaniach o pozyskiwanie obcego kapitału i wysoko wykwalifikowanej siły roboczej oraz aktywnie nakłaniać do inwestycji na swoim terenie. Przy wyborze celów powinny wykorzystywać zjawisko rywalizacji pomiędzy kołami biznesu i polityki. Ich zadanie to wskazanie do realizacji tych projektów, które sprzyjają ekonomicznemu rozwojowi danego terytorium i wychodzą jednocześnie na przeciw potrzebom przedsiębiorców (Peterson, 1981, s. 23).

Peterson zwraca uwagę, że miejskie władze lokalne nie mają w swym ręku instrumentów makroekonomicznych, takich jak: polityka monetarna, polityka kursu walutowego, polityka kształtowania stopy procentowej, polityka kredytowa czy polityka cenowo-dochodowa. Jednakże mogą stosować ze zmiennym nasileniem i w różnej wzajemnej konfiguracji trzy typy tzw. polityki miejskiej. Chodzi tu o:

- polityke rozwojowa (wzrost bazy podatkowej, infrastrukturę transportową i komunikacyjną),

- politykę redystrybucyjna (służba zdrowia i opieka społeczna, mieszkania komunalne),

- polityke alokacyjna (sfera bezpieczeństwa).

Należy zaznaczyć, że w praktyce ekonomiczno-gospodarczej zakres oddziaływania poszczególnych rodzajów „polityki miejskiej” może się zazębiać i tworzyć wspólne pola działania (rys. 10).

Polityka rozwojowa z założenia powinna mieć na uwadze wzrost bazy podatkowej. Można to osiągnąć poprzez system danin i opłat lokalnych, które byłyby niższe niż w innych (konkurencyjnych lub sąsiednich) ośrodkach miejskich. Jednocześnie inwestycje w infrastrukturę transportową i komunikacyjną powinny zwiększać atrakcyjność miasta i jego okolic. Nie można przy tym alokować mniejszej ilości środków na wymienione cele, niż ma to miejsce w innych miastach o podobnej wielkości. Oddziałując wspólnie, oba czynniki umożliwiają przyciagganie na właściwe tereny kapitału i czynnika ludzkiego, czyli potencjalnie nowych podmiotów podatkowych. Właściwe i konsekwentne zastosowanie polityki rozwojowej stanowi sporą szansę przyspieszonego rozwoju dla małych 
i położonych peryferyjnie miejscowości oraz ich otoczenia w sensie geograficzno-gospodarczym. Przykładem mogą być tzw. offshore financuial centre (OFC), które oznaczają obszary przygraniczne (przybrzeżne), oferujące zainteresowanym podmiotom lepsze warunki podatkowe niż te, które obowiązują w ich kraju macierzystym przy porównywalnych warunkach życia. Takim terytorium stała się w 2012 roku Belgia, gdzie przenoszą się najbardziej zamożne, szukające azylu podatkowego, osoby z Francji.

Umiejętne stosowanie polityki rozwojowej przez władze lokalne powinno przynieść jako rezultat - utrzymanie w dłuższym okresie rozwoju ekonomicznego oraz sukcesywne zmniejszanie poziomu bezrobocia na danym obszarze.

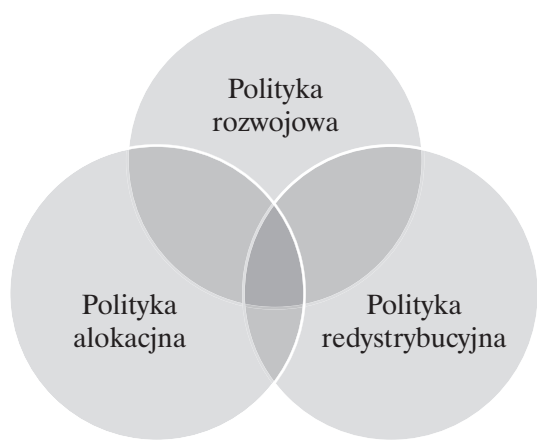

Rysunek 10. Schematyczne ukazanie wspólnych pól działania trzech rodzajów „polityki miejskiej”

Źródło: opracowanie własne.

Polityka redystrybucyjna polega na transferze dochodów od podmiotów bogatych do tych, które są w gorszej sytuacji materialnej. Jej głównym celem jest niwelowanie dysproporcji i budzących sprzeciw społeczny skrajności majątkowych. Polega ona na oddawaniu przez bogatszą część społeczeństwa części środków finansowych i przekazywaniu ich na rzecz części uboższej. Pozyskuje się je za pomocą podatków, opłat i danin lokalnych, które po ściągnięciu przeznacza się na różne cele. Przykładowo mogą one zostać spożytkowane na: opiekę medyczną, szkolnictwo i edukację, lokale komunalne czy pomoc społeczną. Przykładem polityki redystrybucyjnej w Polsce, jest osławione ,janosikowe”. Są to regulacje ustawowe nakazujące polskim województwom, wykazującym ponadprzeciętne przychody, przekazywanie części wpływów na rzecz pozostałych regionów. Kwota dotacji kalkulowana jest jako procent przychodów województwa sprzed dwóch lat, liczony w stosunku do bieżącego roku budżetowego. Jeśli chodzi o poziom podstawowy podziału administracyjnego naszego kraju, 
to opłatę taką muszą uiścić gminy, których dochody z podatków, przeliczając na głowę jednego mieszkańca, przekraczają 150\% średniej krajowej. Powiaty w Polsce wraz z miastami na prawach powiatu, które najwięcej wpłacają na tzw. fundusz solidarnościowy ukazuje tablica 3.

Tablica 3. Powiaty wraz z miastami na prawach powiatów, które są głównymi wpłacającymi na fundusz solidarności (tzw. janosikowe)

\begin{tabular}{|c|l|c|}
\hline Lp. & \multicolumn{1}{|c|}{ Powiat wraz z miastami na prawach powiatów } & Kwota w mln zl \\
\hline 1. & Warszawa & 828,0 \\
\hline 2. & Poznań & 84,0 \\
\hline 3. & Kraków & 61,5 \\
\hline 4. & Wrocław & 59,5 \\
\hline 5. & Gdańsk & 32,1 \\
\hline 6. & Katowice & 30,8 \\
\hline 7. & Lódź & 25,5 \\
\hline 8. & Powiat piaseczyński & 36,9 \\
\hline 9. & Powiat pruszkowski & 26,5 \\
\hline 10. & Razem & $\mathbf{1 . 1 8 4 , 8}$ \\
\hline
\end{tabular}

Źródło: opracowanie własne na podstawie: www.stopjanosikowe.pl.

Idea ,janosikowego" od samego momentu wprowadzenia tych uregulowań budziła duże kontrowersje. W roku 2012 władze Warszawy i Krakowa złożyły wniosek do Trybunału Konstytucyjnego o zbadanie zgodności z prawem zapisów ustawy z 13 listopada 2003 roku, o dochodach jednostek samorządu terytorialnego (Dz.U. z 2003 r. Nr 203, poz. 1966), które regulują zasady naliczania i rozporządzania środkami z ,janosikowego”. W styczniu 2013 roku Trybunał uznał jednak, że przepisy prawne nakazujące bogatym samorządom obowiązek ponoszenia opłat na rzecz biedniejszych władz lokalnych nie są niezgodne z polską ustawą zasadniczą. TK stwierdził również, że zaskarżone przez samorządowców przepisy nie naruszają zasad równości ani adekwatności wobec prawa. Za niezgodny z obowiązującymi zapisami w Konstytucji, Trybunał uznał zaledwie jeden przepis zawarty w ustawie dochodach jednostek samorządu terytorialnego.

Według oficjalnych danych Ministerstwa Finansów spośród wszystkich polskich województw w 2012 roku obciążone zostały tylko trzy regiony: 
- Mazowiecki - 659,0 mln zł,

- Dolnośląski - 26,6 mln zł,

- Wielkopolski - 1,7 mln zł.

Siedem gmin w Polsce, które wnoszą największe sumy na rzecz „janosikowego" przedstawia tablica 4.

Tablica 4. Gminy w Polsce, które w 2012 r. wpłaciły najwyższe kwoty na rzecz obciążenia ,janosikowego"

\begin{tabular}{|c|l|l|c|}
\hline Lp. & \multicolumn{1}{|c|}{ Gmina } & $\begin{array}{c}\text { Województwo (i powiat), w którym leży } \\
\text { gmina }\end{array}$ & Kwota w mln zt \\
\hline 1. & Kleszczów & łódzkie (powiat bełchatowski) & 46,5 \\
\hline 2. & Polkowice & dolnośląskie (powiat polkowicki) & 24,8 \\
\hline 3. & Nowe Warpno & zachodniopomorskie (powiat policki) & 18,0 \\
\hline 4. & Krynica Morska & pomorskie (powiat nowodworski) & 14,6 \\
\hline 5. & Płock & mazowieckie (powiat płocki) & 12,8 \\
\hline 6. & Suchy Las & wielkopolskie (powiat poznański) & 12,5 \\
\hline 7. & Tarnowo Podgórne & wielkopolskie (powiat poznański) & 10,3 \\
\hline
\end{tabular}

Źródło: opracowanie własne na podstawie: www.stopjanosikowe.pl.

Najbogatsza w Polsce gmina Kleszczów swoją pozycję zawdzięcza podatkom, które na konto samorządu wpłacają, położone na jej terenie: Elektrownia Bełchatów oraz Kopalnia Węgla Brunatnego Bełchatów. Przynoszą one opisywanej jednostce samorządu terytorialnego około $90 \mathrm{mln}$ zł dochodu w skali roku. Pozwala to m.in. na: całkowite zlikwidowanie opłat za dostarczanie wody, dofinansowywanie opieki stomatologicznej oraz wysyłanie dzieci mieszkańców gminy na bezpłatne wakacje nad Morzem Śródziemnym.

Na zakończenie praktycznego opisu polityki redystrybucyjnej w Polsce warto na chwilę powrócić jeszcze do budzących sprzeciw wysokich opłat bogatszych podmiotów na rzecz biednych. W roku 2011 powstała społeczna inicjatywa „STOP Janosikowe”. Jej pomysłodawcy zaznaczają, że nie są przeciwni samej idei wsparcia ubogich sąsiadów. Uważają jednak, że zasady rozdzielania pieniędzy pochodzących $\mathrm{z}$,janosikowego" powinny już dawno ulec zasadniczym zmianom. Ich zdaniem powinno się odejść od przyznawania pieniędzy potrzebującym gminom „w ciemno”, tak aby samorządy mogły je wydawać na dowolnie obrany przez nie cel. Wykorzystanie zgromadzonych przez budżet państwa 
środków finansowych powinno przypominać bardziej system funkcjonowania funduszy europejskich. Kwoty pomocowe powinny być przyznawane tylko na konkretne projekty inwestycje i działania prorozwojowe w gminach.

Polityka alokacyjna opiera się dwóch filarach. Pierwszy stanowią zamierzone działania władz lokalnych wpływające na pożądaną strukturę produkcji, rozlokowanie zasobów pracy oraz pozyskanie inwestycji kapitałowych na danym obszarze. Są dobrze widoczne i odczuwalne przez lokalne środowisko.

Drugi filar polega na dostarczaniu potrzebnych dóbr i usług całej społeczności lokalnej. Chociaż świadczenia te nie są najczęśsiej zorientowane na przynoszenie zysków, to stanowią niezbędne zaplecze dla działającego na terenie ośrodka miejskiego, biznesu i poczynań z zakresu polityki i mają zazwyczaj długookresowy charakter. Zaliczyć do nich można: zapewnienie bezpieczeństwa, przedsięwzięcia kulturalne, takie jak: teatr, kino, szkolnictwo o określonym profilu czy transport publiczny (Paczoski, 2010, s. 93-94).

Przykładem wspólnego oddziaływania poszczególnych rodzajów „polityki miejskiej mogą być wysiłki na rzecz rozwoju infrastruktur komunikacyjnej i transportowej, których zakres dotyczy dziedzin działania wszystkich opisanych trzech rodzajów polityki.

\subsubsection{Teoria „maszyny wzrostu” Johna Logana i Harvey'a Molotcha}

Teoria ta w sposób nieprzypadkowy ucieka się do porównania miasta do swoistej maszyny umożliwiającej postęp. Nawiązuje w ten sposób do historii wczesnoindustrialnych doświadczeń w zastosowaniu prostych urządzeń. $\mathrm{Na}$ początku rewolucji przemysłowej zauważono, że użycie narzędzi i prostych maszyn może wyznaczać wzrost oraz zakres nowych możliwości produkcyjnych. Używając przenośni - lokalne władze municypalne mogą zatem używać tkanki miasta jako „maszyny umożliwiającej wzrost” podległego im terenu. Koncepcja „maszyny wzrostu” (ang. Growth Machine) została opisana w wydanej w 1987 roku książce pt.: Urban Fortunes: The Political Economy of Place.

Jej autorzy, John R. Logan i Harvey Molotch, opisali pole konfliktu, jakie powstaje pomiędzy dwoma grupami ludzi zainteresowanymi nabyciem nieruchomości w mieście. Pierwszą z nich tworzą rezydenci, którzy traktują miejsce swojego zamieszkania jako jeden z podstawowych elementów zaspokajania potrzeb życiowych. Drugą grupą są przedsiębiorcy i inwestorzy zainteresowani zwrotem poniesionych kosztów i wzrostem wartości posiadanego majątku (Logan, Molotch, 1987, s. 2). Takie podejście determinuje konieczność rozróżnienia dwóch odrębnych wartości mogących stanowić nieruchomości położone w mieście. Dla rezydentów istotna jest przede wszystkim wartość użytkowa posiadanego mieszkania. Dla przedsiębiorców i developerów najważniejsza jest wartość wymiany i ilość pieniędzy, jakie mogą otrzymać z racji sprzedaży posiadanych 
lokali. Dlatego obie grupy będą dążyły do zapewnienia najbardziej atrakcyjnej lokalizacji dla swoich nieruchomości. Przedsiębiorcom zależy przy tym na prestiżu miejsca, w którym działa ich firma, natomiast rezydentom chodzi o wygodę i dostęp wszelkich usług. W obu przypadkach potrzeby konkurencyjnych środowisk spełnia lokalizacja w pobliżu lub nawet w samym centrum miasta. Wyobrażenia oraz zamierzenia zamożnych oraz często ustosunkowanych grup ludności stanowią impuls do zintensyfikowania rozwoju terenów śródmiejskich.

Władze miast, regionów czy nawet państwa najczęściej nie zabiegają o względy ludności. W dużo większej mierze zainteresowane są zaspokojeniem potrzeb inwestorów i posiadaczy kapitału. Problem w tym zakresie stanowi całkowita rozbieżność oczekiwań obu grup społecznych (Logan, Molotch, 1987, s. 42).

Autorzy teorii podkreślają, że poparcie władz lokalnych czy to dla lobby rezydentów, czy dla lobby inwestorów przynosi podobny efekt - dynamiczny rozwój centrum miasta. To z kolei podnosi atrakcyjność otaczających śródmieście terenów. Wokół centrum powstają nowe dzielnice przemysłowe i mieszkaniowe, a cena nieruchomości i wysokość czynszów wzrasta. W dłuższej perspektywie rozwój ośrodka miejskiego oddziałuje pozytywnie na rozkwit ekonomiczny całego regionu. Poprzez napływ ludności powstają nowe inwestycje, powstaje popyt na nowe dobra i usługi, intensyfikacji ulega wymiana handlowa, zwiększają się wpływy pochodzące z podatków. Jednakże Logan i Molotch zauważają, że instrumentalne traktowanie miasta jako maszyny służącej do osiągnięcia wzrostu może mieć pewne negatywne strony. Przykładowo, w przypadku gdy na decyzje władz miejskich duży wpływ mają grupy związane z biznesem lub polityką, do realizacji mogą być zakwalifikowane kontrowersyjne projekty niesłużące w żaden sposób lokalnej społeczności. Natomiast w sytuacji gdy przeważają pomysły rezydentów, mali i średni przedsiębiorcy mogą zostać „wypchnięci” na dalekie peryferie.

\subsubsection{Teoria "maszyny rozrywki" Terrego N. Clarka}

Twórcą interesującej teorii „miasta jako maszyny rozrywki” (ang. city as an entertainment machine) jest amerykański profesor socjologii, Terry Nichols Clark. Nowa koncepcja, zaprezentowana w 2003 roku, zakłada ścisły związek lokalnego rozwoju ekonomicznego z charakterem polityki prowadzonej przez władze miejskie.

Nazwa teorii, która stanowi zarazem tytuł książki pod redakcją T.N. Clarka, nawiązuje do opisanej w poprzednim podpunkcie popularnej teorii „miasta jako maszyny wzrostu” J.R. Logana i H. Molotcha. Uwypuklając czynniki socjologiczne związane z naturą ludzką, Clark przeciwstawia się dotychczasowym modelom opisującym przyczyny wzrostu i rozwoju różnych miejscowości (Swaniewicz, 2005, s. 18). Autor sugeruje, że w obecnych czasach rozwój 
gospodarczy ośrodków miejskich stracił moc przyciągania zasobów siły roboczej. Aktualnie jesteśmy świadkami zupełnie przeciwnego procesu. To wybór miejsca życia przez wysoko kwalifikowane rzesze pracowników implikuje rozwój ekonomiczny określonych terenów.

Stosunkowo zamożna klasa młodych specjalistów stanowi źródło zasilające najważniejsze gałęzie i sektory każdej nowoczesnej gospodarki. Społeczność ta stawia wysokie wymagania co do poziomu i oczekiwanej jakości życia. Często o wyborze miejsca zamieszkania decydują, w przypadku tej grupy osób, walory estetyczne lub aktualne trendy mody. Tak więc „miejsce maszyny wzrostu” zajęła „maszyna rozrywki”, która razem z możliwością dostępu do zdobyczy kulturalnych stanowią podstawę rozwoju gospodarczego. W dzisiejszych czasach to nie siła robocza przenosi się w poszukiwaniu pracy, ale miejsca pracy podążają za najbardziej wartościowymi pracownikami. Wykształceni ludzie otrzymali niewątpliwy przywilej decydowania o tym gdzie będą chcieli mieszkać.

Dopiero po dokonaniu tego wyboru, niejako w drugiej kolejności, mogą zacząć poszukiwanie stałego zajęcia zarobkowego (Swaniewicz, 2005, s. 18). Zatem, aby zagwarantować rozwój swojej miejscowości w dłuższym okresie, władze municypalne powinny skoncentrować uwagę na zwiększeniu atrakcyjności podległego im ośrodka oraz podnieść jednocześnie jakość egzystencji jego mieszkańców. Można to osiągnąć poprzez zapalenie „,zielonego światła” dla niezbędnych inwestycji w sferze infrastruktury usługowo-rozrywkowej. Clark daje przykłady miejsc, które przyciaggają młodych, wysportowanych i wykształconych ludzi. Wymienia takie placówki, jak: opera, piwiarnie, restauracje tematyczne, bary z napojami alkoholowymi i bezalkoholowymi, kawiarnie, teatry, kina, galerie, muzea, sale koncertowe. Nie zapomina przy tym o miejscach wypoczynku (także aktywnego), do których zalicza: parki, siłownie, stadiony sportowe, zagospodarowane ośrodki wodne położone nad brzegami jezior i rzek, góry i lasy (Clark, 2005, s. 103-139). Tak wyposażone miasta (wraz z otoczeniem) przyciagają atrakcyjną ofertą masy turystów i gości biznesowych. Dla tych ostatnich tworzone są centra kongresowe oraz hotele oferujące szeroki wachlarz usług. Teoria „maszyny rozrywki” eksponuje w rozwoju miasta znaczenie rozbudzonej konsumpcji, spychając na margines wagę i rolę dotychczasowych czynników lokalizacji, zwyczajowo łączonych z warunkami produkcji. Koncepcja tłumaczy również dynamiczny rozkwit sfery usług turystycznych oraz różnych instytucji rozrywkowych na określonych obszarach. W nowoczesnych państwach tworzy ona dominujący sektor gospodarki narodowej, dający zatrudnienie większej części obywateli.

Clark w swojej koncepcji użył ważnego pojęcia: amenities (tzn. przyjemności, uroków), spośród których wyróżnił:

- naturalne (klimat, woda, krajobraz),

- stworzone przez człowieka (biblioteki, teatry, antykwariaty, bary, imprezy kulturalne), 
- związane ze zróżnicowaniem i strukturą społeczną,

- związane wartościami wyznawanymi przez mieszkańców (otwartość, gościnność i tolerancja).

Według badań empirycznych przeprowadzonych przez Clarka w latach 1980-2000, na terenie Stanów Zjednoczonych, największy przyrost liczby ludności został odnotowany w miastach, w których znaleźć można było najwięcej amenities. Zarówno tych naturalnych, jak i tych stworzonych w wyniku celowej działalności człowieka. Natomiast pozostałe miasta odnotowały w tym samym czasie zróżnicowane modele wzrostu. Przyrost ludności z wyższym wykształceniem najbardziej dynamiczny był tam, gdzie powstało najwięcej stworzonych sztucznie atrakcji. Natomiast miastach, w których dominowały urozmaicenia i rozrywki związane w większej mierze ze środowiskiem naturalnym zanotowano najszybszy przyrost liczby dość specyficznej kategorii mieszkańców, a mianowicie - zamożnych emerytów (Swaniewicz, 2005, s. 20).

Dobrym przykładem polityki opisanej przez T.N. Clarka są działania podjęte przez władze Londynu, które zadecydowały, aby w miejscu doków portowych, opuszczonych w latach sześćdziesiątych i siedemdziesiątych XX wieku, powstał atrakcyjny teren mieszkaniowy potocznie zwany Docklands. Obejmuje on umiejscowione nad Tamizą cztery dzielnice: Greenwich, Newham, Southwark oraz Tower Hamlets. Stare dzielnice przemysłowe stały się nie tylko atrakcyjnym punktem do zamieszkania, lecz także miejscem rozrywki i spotkań towarzyskich oraz ośrodkiem sportów wodnych dla całej metropolii. Położony na tym terenie kompleks biurowy, Canary Wharf, wyrósł na poważnego rywala finansowobankowego londyńskiego City. Na jego terenie umiejscowione są najwyższe budynki w Wielkiej Brytanii oraz bardzo popularne, wielkie centra handlowe. W biurach Canary Wharf pracuje blisko 100 tys. pracowników. Jest ono także odwiedzane każdego tygodnia przez około pół miliona kupujących i szukających rozrywki. O osiągniętym sukcesie może świadczyć fakt, że ludność całego obszaru Docklands w przeciągu ostatnich dwudziestu lat uległa podwojeniu.

\subsubsection{Teoria reżimów Clarence Stone’a}

Fundamentalnym założeniem ogłoszonej w 1989 roku „teorii reżimów” (ang. regime theory) Clarence Stone'a, jest przeświadczenie, że aby osiągnąć stojące przed samorządem miejskim cele, niezbędna jest szeroko zakrojona współpraca pomiędzy sektorami publicznym i prywatnym. Współpraca ta może przebiegać drogą urzędową, ale równie dobrze przy użyciu nieformalnych powiązań.

Kluczową kategorią dla całej koncepcji jest samo pojęcie „reżimu”. Według autora, przez „reżim” należy rozumieć: „nieformalną i jednocześnie relatywnie stabilną grupę osób posiadających dostęp do organów instytucjonalnych, 
przez co mają one możliwość długotrwałego wpływu na podejmowane decyzje dotyczące realizowanej przez władze polityki publicznej" (Stone, 1989, s. 4). Teoria zakłada funkcjonowanie i równoczesne istnienie obok siebie wielu tworów sklasyfikowanych jako reżimy. Są one zainteresowane także wzajemnym współdziałaniem ze sobą, w zamyśle osiągnięcia interesujących je celów.

Reżimy tworzą niezwykle przydatny pomost, łączący kontrolę społeczną nad władzą samorządową i nadzór podmiotów prywatnych nad wykorzystaniem dostępnych zasobów ekonomicznych. Proces polega na włączeniu innych uczestników do procesu decyzyjnego leżącego w rękach władz samorządowych. Mogą nimi być przykładowo: koła biznesowe, różnego rodzaju średni i mali przedsiębiorcy, politycy, instytucje lokalne, przedstawiciele organizacji reprezentujących zamożną klasę średnią lub na przykład Afroamerykanów (Mossberger, Stoker, 2001, s. 813). Samo istnienie reżimów nie zależy bezpośrednio od samorządów. Organy lokalne mają w tej sprawie ograniczone możliwości. Przy niesprzyjających warunkach grupy reżimowe mogą w danym ośrodku miejskim w ogóle nie występować. W tym kontekście bardzo ważną staje się rola, jaką mogą odegrać pośrednio władze miasta. Poprzez stworzenie przyjaznej atmosfery oraz wykreowanie odpowiednich warunków mogą one pozyskać dla swoich zamierzeń określone grupy obywateli. Ograniczony wpływ władz samorządowych wynika $\mathrm{z}$ wysokiej nieprzewidywalności możliwych interakcji pomiędzy elementami całej układanki. Powstają one bardzo często przypadkowo i w dużej mierze spontanicznie.

W tym kontekście istotą działania władz miasta, zorientowanych na rozwój podległego im terenu, jest: mobilizacja i koordynacja dostępnych zasobów, wyznaczenie priorytetów, stworzenie odpowiednich warunków umożliwiających współpracę poszczególnych aktorów danego przedsięwzięcia na drodze do osiągnięcia pożądanego celu. Efektywność sektora publicznego, który reprezentują władze lokalne, jest budowana przez współpracę z sektorem prywatnym. W wyniku tego powstaje, dominujący nad wszystkimi pozostałymi, reżim wyznaczający kierunki wspólnego działania (Paczoski, 2010, s. 96). Skuteczność jego działania może zwiększyć umiejętne wykorzystanie potencjału intelektualnego i wiedzy całej społeczności (mieszkańców, inwestorów, przedsiębiorców, siły roboczej), dołączając do tej grupy kompetencje urzędników lokalnej administracji publicznej. Dodatkowe atuty mogą stanowić: efektywne spożytkowanie istniejących zasobów oraz korzystna sytuacja gospodarczo-ekonomiczna regionu.

Według niektórych, uznanych ekonomistów „teoria reżimów” nie stanowi spójnej całości. Przypomina raczej wielowątkową, zagmatwaną koncepcję, w której trudno jest się dopatrzeć jednolitego oblicza czy też spajającej wszystkie elementy wspólnej osi (Mossberger, Stoker, 2001, s. 814). Jednak pomimo braku jednoznaczności swojego przekazu, teoria Clarence Stone'a stanowi oryginalne podejście do zagadnień związanych ze znaczeniem miast w rozwoju regionalnym. 


\subsection{Teorie wzrostu egzogenicznego}

Przez cały wiek XIX i większość XX wieku najczęściej spotykanym wyjaśnieniem problemów rozwoju regionalnego były teorie wzrostu egzogenicznego. Zakładały one zasadniczy wpływ czynników zewnętrznych na tempo postępu ekonomiczno-społecznego na obszarach słabiej rozwiniętych. Według tych koncepcji obszary szybciej rozwijające się i wyżej zaawansowane gospodarczo wymuszały wzrost słabiej rozwiniętych regionów, niejako „pociągając” je za sobą. Dominujące gospodarki państw wysoko rozwiniętych narzucały prędkość oraz rytm postępu techniczno-cywilizacyjnego krajów i regionów zacofanych. Teorie egzogeniczne w sposób logiczny wyjaśniały zjawisko osiagania wyższych wskaźników wzrostu przez terytoria rozwijające się w relacji do wolniej rozwijających się państw wysoko uprzemysłowionych. Tłumaczono to korzystaniem z gotowych już wzorców i rozwiązań techniczno-organizacyjnych, podążanie „przetartymi” ścieżkami rozwoju, korzystaniem z wiedzy i doświadczenia zachodnich specjalistów oraz „dobrodziejstwem” napływu znacznych kapitałów pochodzących z zewnętrznych (zagranicznych) źródeł. Większość omówionych do tej pory modeli, teorii i koncepcji reprezentowała ten właśnie nurt. Do grupy teorii egzogenicznych należy zaliczyć zatem: klasyczne i neoklasyczne teorie ekonomii, model keynesowski oraz przede wszystkim teorie zrównoważonego i niezrównoważonego rozwoju regionalnego. Aż do początku lat osiemdziesiątych XX wieku teoretyczne założenia koncepcji egzogenicznych pokrywały się, w większości wypadków z przebiegiem zjawisk ekonomicznych, obserwowanych w praktyce gospodarczej. Jeszcze dzisiaj teoria ta znajduje potwierdzenie, jeśli weźmie się liczone w PKB tempo wzrostu gospodarczego naszego kraju i jego największego partnera handlowego, tzn. Niemiec. Słabsza i mniej zaawansowana ekonomicznie Polska skutecznie nadrabia od kilkunastu lat dystans, jaki dzieli ją od największej i najbardziej prężnej gospodarki Europy.

\subsection{Teorie wzrostu endogenicznego}

Pod koniec lat osiemdziesiątych XX wieku zaobserwowano zjawisko ekonomiczne wymykające się poza ustalone reguły rozwoju egzogenicznego. Gospodarka Stanów Zjednoczonych Ameryki Północnej wykazywała dużo szybsze tempo wzrostu niż powiązane z nią gospodarki krajów Ameryki Łacińskiej i rozwijających się krajów Afryki. Zgodnie z ustalonymi i obowiązującymi regułami, podążając „przetartymi szlakami”, słabsze kraje powinny rozwijać się szybciej niż USA. Tak jednak nie było. Stało się to podstawą hipotezy mówiącej, że istotne znaczenie dla rozwoju państw i regionów mogą mieć jeszcze inne niż tylko zewnętrzne czynniki. Uwaga została skierowana na czynniki wewnętrzne. 
Nowa idea opisywała wzrost tworzony własnymi siłami i możliwościami określonego systemu gospodarczego. Koncepcja rozwoju oparta na tej przesłance doprowadziła do powstania tzw. teorii wzrostu endogenicznego. W praktyce chodzi tu o kilka zbieżnych ze sobą koncepcji teoretycznych, które wykazują wyraźne podobieństwa i elementy wspólne.

Teoria wzrostu endogenicznego stara się udowodnić, że długofalowa stopa wzrostu gospodarczego zależy od kilku ważnych czynników (elementów) (rys. 11).

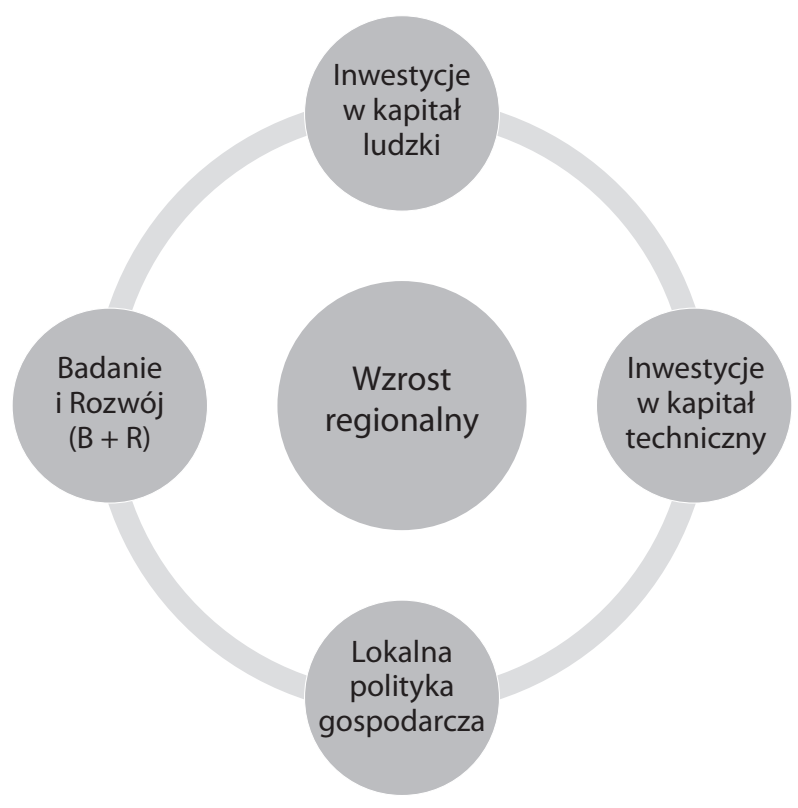

Rysunek 11. Główne czynniki endogenicznego wzrostu regionalnego

Źródło: opracowanie własne.

Najważniejsze z nich to: inwestycje w kapitał ludzki, inwestycje w kapitał techniczny, nakłady na badania i rozwój oraz polityka gospodarcza prowadzona przez władze samorządowe. Kapitał ludzki i zasoby rzeczowe (kapitał techniczny) tworzą razem siły wytwórcze regionu. W opisywanej teorii, po raz pierwszy tak wyraźnie w założeniach teoretycznych, została uwypuklona rola kapitału ludzkiego. Siła robocza nie jest, jak dotychczas tylko liczbą zatrudnionych, ale tworzy wartość samą w sobie. Poprzez inwestycje w naukę i dalsze kształcenie pracowników, wykorzystywanie ich specyficznych umiejętności i doświadczenia oraz zachęty do przejawiania inicjatywy twórczej zakłady pracy mogą zgromadzić unikatowe zespoły ludzkie kształtujące oblicze regionu. W tym kontekście najbar- 
dziej cenne jawią się zasoby wiedzy ludzkiej. To na ich podstawie, a nie na bazie surowcowej i zainwestowanych kapitałach, powinien opierać się rozwój różnych obszarów (Drucker, 1999, s. 14). Drugim ważnym elementem sił wytwórczych jest poziom i nowoczesność infrastruktury technicznej. Inwestycje w jego modernizację i rozbudowę tworzą nową wartość zgromadzonego majątku rzeczowego, zwaną kapitałem technicznym. Trzecim istotnym czynnikiem są nakłady na badania i rozwój $(B+R)$, w wyniku których powstają innowacje i dokonuje się postęp techniczno-technologiczny. Skierowanie odpowiednich środków finansowych na $\mathrm{B}+\mathrm{R}$ w odpowiedniej dziedzinie lub branży powinno po pewnym czasie spowodować powstanie szybko rozwijającego się i zaawansowanego technicznie sektora przemysłu. Elementem, który wszystko spaja i wyznacza kierunek zmian powinna być aktywna polityka władz samorządowych oparta na systemie zachęt finansowych, sprawnie działającej administracji oraz umiejąca zmotywować lokalne społeczeństwo do inicjatyw, podjęcia ryzyka i konkretnego działania.

Na zakończenie należy jeszcze dodać, że teoria wzrostu endogenicznego nie oznacza zupełnego wyeliminowania wpływów obcych. Opisywana koncepcja dopuszcza określone strumienie zewnętrze. Najważniejsze z nich stanowią wolny handel oraz przepływ kapitału ludzkiego i kapitału rzeczowego. Handel przyczynia się do wymiany rozwiązań innowacyjnych, służącej pozyskaniu nowatorskich technologii przez regiony zacofane. Badania dotyczące różnic w osiągniętym dochodzie $\mathrm{w}$ regionalnach ukazały, że handel może być czynnikiem prowadzącym do konwergencji lub też do dywergencji kooperujących ze sobą obszarów (Tondl, 2001, s. 7-33). Przykładami rozwoju endogenicznego z wykorzystaniem handlu i obcych rozwiązań, ale przy zastosowaniu i uwzględnieniu własnej specyfiki, był niespotykanie szybki rozwój grupy państw z Dalekiego Wschodu, nazywanych potocznie: azjatyckimi tygrysami. Należały do niej początkowo tylko cztery kraje: Korea Południowa, Hongkong, Singapur oraz Tajwan. W latach osiemdziesiątych XX wieku dołączyły do nich: Tajlandia, Filipiny, Malezja, Indonezja i Makau. Wspólnymi cechami łączącymi te organizmy państwowe były: niezwykle dynamiczny przyrost PKB, sięgający kilkunastu procent $\mathrm{w}$ skali roku oraz relatywnie bliskie wzajemne położenie w regionie Azji Południowo-Wschodniej. Zapaść ekonomiczna z 1997 roku, zwana „kryzysem dalekowschodnim" położyła kres przyspieszonemu rozwojowi tych krajów.

\subsection{Koncepcja rozwoju regionalnego oparta na klastrach przemysłowych}

Za autora koncepcji klastrów przemysłowych uważany jest amerykański uczony i profesor uniwersytecki - Michael Eugene Porter. Swoje rozważania zaprezentował w wydanej w 1990 r. książce pt.: Konkurencyjna przewaga narodów (ang. The Competitive Advantage of Nations). Jednak za twórcę samej idei 
skupisk przedsiębiorstw współdziałających ze sobą w jednej branży i na jednym terenie uważany jest brytyjski ekonomista - Alfred Marshall. Dokładnie sto lat wcześniej, w roku 1890, przedstawił on światu teorię okręgów przemysłowych. Zauważył i opisał dążenie zakładów wytwórczych w dziewiętnastowiecznej Anglii do umiejscawiania swojej produkcji w okręgach położonych niedaleko dostawców i klientów. Na tej bazie stworzył, opisane nieco wcześniej w tym rozdziale, pojęcie tzw. zewnętrznych korzyści (ang. external economies).

Pojęcie „klaster” pochodzi od angielskiego słowa cluster, które w zależności od kontekstu może oznaczać: grono, kiść, pęk, grupkę, kępkę, rój, gromadkę, skupisko lub zlepek. Jednakże istotę koncepcji Portera oddaje określenie: „klaster przemysłowy" (ang. industrial cluster). Ideę autora w przybliżeniu opisują polskie neologizmy: regionalne grono zakładów produkcyjnych, lokalny system wytwórczy czy branżowa wiązka przemysłowa.

„Klastry przemysłowe to geograficzna koncentracja konkurencyjnych firm w powiązanych sektorach, związanych ze sobą gospodarczo, dzielących te same umiejętności, technologię i infrastrukturę. W klastrze wielkie i małe przedsiębiorstwa osiągają znacznie więcej, niż gdyby miały pracować same, dzięki sieci związanych przedsiębiorstw, dostawców, usług, instytucji akademickich oraz producentów skoncentrowanych na tym samym obszarze. Koncentracja wspomaga tworzenie nowych przedsiębiorstw, produktów oraz nowych miejsc pracy dla wysoko wykwalifikowanych, dobrze opłacanych pracowników. Klastry stanowią o sile każdej gospodarki narodowej, regionalnej, stanowej, a nawet wielkomiejskiej, głównie w krajach gospodarczo rozwiniętych" (Porter, 1990, s. 36).

Koncepcja klastrów wyraźnie akcentuje znaczenie bezpośredniego otoczenia firmy dla osiągnięcia przez nią końcowego sukcesu. Podkreśla konieczność kształtowania środowiska, w jakim przychodzi funkcjonować podmiotom gospodarczym. Może to się powieść jedynie w przypadku współpracy lub co najmniej rzetelnej wymiany danych i informacji pomiędzy elementami składowymi grona. $\mathrm{W}$ powiązania $\mathrm{z}$ przedsiębiorstwami $\mathrm{w}$ obrębie klastra powinny być włączone jednostki naukowo-badawcze, wyższe uczelnie i inne związane $\mathrm{z}$ regionem organizacje, także prywatne. Wzajemne relacje wszystkich instytucji mogą mieć charakter zarówno formalny, jak i nieformalny. Specyfiką klastrów jest to, że współpraca pomiędzy poszczególnymi podmiotami nie neguje występowania pomiędzy nimi konkurencji. Konkurencja stanowi bezwzględnie siłę napędową całej grupy. Natomiast współpraca i kooperacja pomiędzy przedsiębiorstwami dają najlepsze rezultaty w tych obszarach, gdzie mogą zaistnieć wynikające z niej efekty synergetyczne. Tak jest w przypadku wspólnych przedsięwzięć inwestycyjnych lub badawczo-rozwojowych. Obecność zakładów i instytucji w gronie regionalnym umożliwia dostęp do pożądanych usług i zasobów, obniża koszty działalności, ułatwia znalezienie potrzebnych specjalistów, pozwala na szybkie dotarcie do potrzebnych danych i informacji, obniża koszty marketingu 
i zmniejsza ryzyko porażki na polu biznesowym. Najbardziej znanymi przykładami klastrów są:

- Dolina Krzemowa w Kalifornii w Stanach Zjednoczonych. Stanowi ona największy na świecie ośrodek przemysłu nowych technologii. Miejsce przyciąga jak magnes najlepszych specjalistów zaawansowanych technologii w skali całego globu. Ten proces sprawia, że podmioty gospodarcze działające w „dolinie”, konsekwentnie i z powodzeniem, powiększają swoją przewagę konkurencyjną nad resztą świata.

- Hollywood w Los Angeles (USA). Jest niekwestionowaną stolicą światowego przemysłu filmowo-telewizyjnego. Od początku XX wieku obiecuje sławę i pieniądze najlepszym reżyserom, scenarzystom, operatorom, aktorom i fachowcom od rozrywki. Klaster Hollywood opiera się z powodzeniem wszelkim kryzysom finansowym i ekonomicznym, jakie miały miejsce w okresie ostatnich stu lat.

- Bollywood w Bombaju (Indie). Największy, jeśli chodzi o ilość wyprodukowanych filmów, ośrodek produkcji kinematograficznej i telewizyjnej na świecie. Specyfika podobna do amerykańskiego Hoolywood, jednak przy zaangażowaniu znacznie mniejszych kapitałów. Realizacja mało ambitnych, z punktu widzenia Zachodu, projektów. Produkcja w większości na rynek rodzimy, azjatycki i afrykański. Wizytówka stanu Maharasztra w skali całego subkontynentu indyjskiego.

- Telecom City w Karskronie (Szwecja). Decyzją władz lokalnych na początku lat dziewięćdziesiątych XX wieku na samym południu Szwecji rozpoczęto tworzenie klastra o profilu teleinformatycznym. Zamysłem było zbudowanie jednego z wiodących w skali globu ośrodków wyspecjalizowanych w branży telekomunikacyjnej. Bazowymi elementami klastra stały się firma Ericson oraz Uniwersytet w Lund i Instytut Techniczny Blekinge. W w 2013 roku wiązka przemysłowa skupia ponad pięćdziesiąt firm związanych przede wszystkim z branżą telekomunikacyjną, a także specjalizujących się w problemach dotyczącymi biotechnologii i nanotechnologii. Zaplecze w postaci kapitału ludzkiego tworzą studenci pochodzący z całej Skandynawii.

Klastry powinny być traktowane przez władze lokalne jako instrumenty niezwykle istotne dla rozwoju regionalnego. Konieczne jest w tym wypadku stworzenie jasnych strategii działania na polu zadań gremiów samorządowych (Kozioł, Zalewska, 2009, s. 42). Zaangażowanie władz w działanie klastra sprzyja jego większej dynamice rozwoju niż w przypadku samorzutnych działań i oddolnych wysiłków uczestników grona produkcyjnego. Działanie to daje również poczucie bezpieczeństwa i stabilizacji podmiotom skupionym w wiązce regionalnej. Może ono ponadto prowadzić do uzyskania większego prestiżu przez 
przedsiębiorstwa oficjalnie współpracujące $\mathrm{z}$ władzami. Polityka samorządowa na polu rozwoju regionalnego powinna stworzyć zręby prawne działania klastra. Drugim ważnym zadaniem jest skoordynowanie działań na podległym władzy lokalnej obszarze,w dziedzinach aktywności: ekonomiczno-gospodarczej, naukowej, badawczej, politycznej i obywatelsko-społecznej.

\section{Najnowsze koncepcje rozwoju regionalnego}

W ciągu ostatnich kilkunastu lat zasadniczej zmianie uległa dotychczasowa tendencja, polegająca na tworzeniu zupełnie nowych teorii opisujących przesłanki rozwoju regionalnego. Działającym obecnie ekonomistom, zajmującym się zagadnieniami regionalnymi, relatywnie rzadko udaje się stworzyć zupełnie nowatorską koncepcję lub model rozwoju. Ze względu na niezmierzoną w tym obszarze teorię i praktykę jest to zadanie prawie niemożliwe. Dlatego dzisiejsza ich praca opiera się w dominującym stopniu na dostosowaniu oraz zaktualizowaniu znanych już koncepcji i poglądów do bieżących warunków społeczno-gospodarczych. Musi przy tym uwzględniać bieg aktualnych wydarzeń na arenie międzynarodowej, krajowej oraz lokalnej, a także brać pod uwagę istniejące i dostępne instrumenty polityki regionalnej. W większym stopniu niż do tej pory ma również obowiązek korzystać z wiedzy o możliwościach i specyfice funkcjonowania władz samorządowych.

Głównym celem działań specjalistów z tej dziedziny stało się tworzenie takich strategii rozwoju regionalnego, które opierając się na znanych już teoretycznych podstawach ekonomii rozwoju, mają zapewniać optymalny i zarazem bardziej efektywny rozwój regionalny. Przykładami w tej dziedzinie są: nowa teoria wzrostu oraz nowa geografia ekonomiczna korzystające z doświadczeń modeli zarówno neoklasycznych, jak i popytowych. Konsekwentnie, większą uwagę przywiązuje się $\mathrm{w}$ tych wysiłkach do roli czynników endogenicznych w rozwoju określonych obszarów (Churski, 2004, s. 31-45).

Nie należy jednak, tylko z powodu istniejących ograniczeń, marginalizować ani też umniejszać współczesnych dokonań na tym polu. Mają one w bardzo licznych przypadkach fundamentalne znaczenie dla obrazu i poziomu życia wielomilionowych społeczności lokalnych. Wywierają także zauważalny i niebagatelny wpływ na przyszłe oblicze terytoriów dostępnych do zamieszkania już dzisiaj oraz obszarów nadających się do tego celu dopiero w nadchodzącym czasie. 


\section{ROZDZIA IV}

\section{Polityka regionalna Unii Europejskiej}

Powojenny pomysł stworzenia zjednoczonej Europy nie był pierwszą w historii tego typu ideą na naszym kontynencie. Jednakże po raz pierwszy został zaprezentowany światu jako plan integracji oparty na zupełnie innych od dotychczasowych zasadach. Przedstawiciele dążących do zachowania pokoju narodów, w miejsce zmagań zbrojnych i fizycznej przemocy, znaleźli dużo lepszy sposób na realizację tego zamierzenia. $\mathrm{W}$ duchu demokracji i porozumienia zdecydowano o podjęciu kroków niezbędnych do stworzenia „wspólnego domu dla wszystkich pragnących tego Europejczyków".

\section{Geneza polityki regionalnej w Unii Europejskiej}

Po zakończeniu II wojny światowej najważniejszym zadaniem, jakie stanęło przed gremiami politycznymi na starym kontynencie, stało się zażegnanie zagrożenia wybuchu nowego konfliktu zbrojnego na dużą skalę. Drugim celem było zapewnienie stabilności gospodarczej w Europie Zachodniej. Zagwarantować to miała kontrola Francji nad odradzającym się potencjałem jej największego sąsiada. Aby osiagnnąc zakładany stan, niezbędne było połączenie w zakresie gospodarczym potencjałów rozwiniętych krajów odbudowującej się Europy. Szybko stało się jasne, że bez możliwości, jakie drzemały w gospodarce niemieckiej, żaden twór nie będzie w stanie ani politycznie, ani ekonomicznie konkurować $\mathrm{z}$ centralnie planowanym ZSRR, który podporządkował sobie dodatkowo kraje bloku wschodniego. Dlatego na podstawie międzynarodowej umowy, zawartej 18 kwietnia 1951 roku w Paryżu, powołano Europejską Wspólnotę Węgla i Stali (EWWiS) skupiającą: Francję, Republikę Federalna Niemiec, Włochy, Belgię, Holandię i Luksemburg. Celem wspólnoty było w pierwszej linii utrzymanie trwałego pokoju pomiędzy krajami członkowskimi. Miały to zapewnić międzynarodowe powiązania w dziedzinie przemysłu węglowego i przemysłu stalowego, które miały zasadnicze znaczenie, jak wtedy uważano, dla prowadzenia ewentualnej wojny. Zawarte porozumienie miało obowiązywać sygnatariuszy przez pięćdziesiąt lat od dnia wejścia w życie, to znaczy od 23 lipca 1952 roku. 
Krokiem milowym na polu integracji europejskiej stało się podpisanie, 25 marca 1957 roku, kolejnych dwóch umów międzynarodowych, zwanych zbiorczo traktatami rzymskimi. Wspólnie ze wspomnianym wcześniej traktatem paryskim z 1951 roku tworzyły one tzw. traktaty założycielskie. W stolicy Włoch, na Kapitolu państwa tworzące dotychczasową Europejską Wspólnotę Węgla i Stali: Francja, RFN, Włochy oraz Państwa Beneluksu podpisały dwa porozumienia:

- Traktat ustanawiający Europejską Wspólnotę Gospodarczą (EWG),

- Traktat ustanawiający Europejską Wspólnotę Energii Atomowej (EWEA lub potocznie: Euratom).

Przesłaniem, jakie niósł na swoich stronach traktat powołujący do życia EWG, było stworzenie europejskiego wspólnego rynku. W umowie zostały precyzyjnie wyznaczone cele i określone zasady działania ugrupowania integracyjnego oraz ramy instytucjonalne, w jakich miało ono działać. Podpisany w holenderskim Maastricht w 1992 roku Traktat o Unii Europejskiej, zmienił nazwę Europejskiej Wspólnoty Gospodarczej (EWG) na Wspólnotę Europejską (WE). W roku 2007 na mocy traktatu z Lizbony, Wspólnota Europejska uległa likwidacji, a w jej miejsce powołano dzisiejszą Unię Europejska (UE).

Zadaniem traktatu powołującego do życia Europejską Wspólnotę Energii Atomowej (EWEA) było stworzenie instytucji, której naczelnym zadaniem była kontrola i współpraca w sferze pokojowego wykorzystania energii jądrowej. Od momentu podpisania porozumień w Maastricht przez szesnaście lat traktat EWEA był integralnym elementem prawa unijnego. Umowa z Lizbony wyłączyła z prawa Unii Europejskiej ustalenia dotyczące Euratomu. Stanowi on w tym względzie od 2007 roku osobny dokument.

Już na samym początku procesów integracyjnych dostrzeżono występowanie pewnych nierówności w rozwoju regionalnym poszczególnych krajów członkowskich EWG. Chociaż sześć krajów-założycieli Europejskiej Wspólnoty Gospodarczej miało względnie jednorodny i zbliżony stopień rozwoju ekonomicznego przy ocenie całościowej, to występowały jednak na ich obszarze takie terytoria, które odstawały wyraźnie od pozostałych. Charakteryzował je niższy poziom życia mieszkańców, wysoka stopa bezrobocia i regres gospodarczy. Przykładem mogą być: południe Włoch (Sycylia, Sardynia, Kalabria, Apulia i Kampania), Bretania i Korsyka we Francji, Dolna Saksonia w Republice Federalnej Niemiec (a szczególnie Wyspy Fryzyjskie na Morzu Północnym) czy Prowincja Hainaut we francuskojęzycznej (walońskiej) części Belgii. Miały one hamujący wpływ na funkcjonowanie całego ugrupowania. Stało się jasne, że swobodna gra sił rynkowych nie jest w stanie doprowadzić do zatarcia istniejących negatywnych różnic w sferze ekonomicznej, społeczno-kulturowej i politycznej. Dlatego już na pierwszej stronie, w preambule do traktatów rzymskich z 1958 roku, znalazło się ważne zdanie, mówiące że: „Państwa członkowskie pragną wzmocnienia 
jedności swoich gospodarek i zabezpieczenia ich harmonijnego rozwoju przez redukowanie zróżnicowań istniejących między regionami oraz łagodzenie zacofania regionów mniej uprzywilejowanych".

Stwierdzenie to $\mathrm{w}$ wyraźny sposób eksponowało jedną z podstawowych dziedzin sfery ekonomiczno-społecznej życia, na którą państwa członkowskie będą chciały w przyszłości położyć szczególny nacisk. Odzwierciedlało również ugruntowane przekonanie władz unijnych o konieczności podjęcia środków zaradczych w zakresie wyeliminowania niekorzystnych zjawisk. Na początku lat sześćdziesiątych XX wieku problem nie wydawał się jednak jeszcze wielki. Dlatego niwelowanie różnic dotyczyło tylko sfery rolnictwa i przeciwdziałania bezrobociu. Pierwszym funduszem strukturalnym był utworzony na mocy traktatów rzymskich, już w 1960 roku, Europejski Fundusz Społeczny (EFS). Jego głównymi celami były walka z bezrobociem i promocja zatrudnienia. Od roku 1964 w ramach budżetu EWG działał dodatkowo Europejski Fundusz Orientacji i Gwarancji Rolnej (EFOiGR), mający na celu finansowe wsparcie przekształceń struktury rolnictwa oraz pomoc $\mathrm{w}$ rozwoju i zagospodarowaniu obszarów wiejskich. Sytuacja uległa zasadniczej zmianie wraz przystąpieniem do Wspólnoty nowych krajów. W roku 1973, EWG w rezultacie tzw. poszerzenia północnego, została powiększona o Danię, Wielką Brytanię i Irlandię. W dwóch pierwszych relatywnie wysoko rozwiniętych krajach istniały regiony odbiegające poziomem od rozwoju gospodarczego reszty ich terytoriów. W Danii były to Jutlandia Północna i pozostające pod administracją korony Wyspy Owcze na Atlantyku. W Wielkiej Brytanii do najsłabszych regionów należały: Walia, Kornwalia i północne hrabstwa w Szkocji. Irlandia w całości miała wyraźnie peryferyjny charakter, chociaż nawet na jej terenie można było zauważyć dysproporcje pomiędzy bardzo biednymi regionami zachodu i północnego zachodu, a nieco tylko bardziej zamożnym wschodem i południem kraju (Olejniczak, 2001, s. 104). To głównie odmienność i rzucające się w oczy zacofanie gospodarki „Zielonej Wyspy” wymusiły na organach i instytucjach EWG podjęcie konkretnych kroków by zintensyfikować działań na polu zacierania różnic rozwojowych.

Już od początku lat siedemdziesiątych XX wieku władze w Brukseli energicznie zajęły się tworzeniem zorganizowanej i ustrukturyzowanej polityki regionalnej Wspólnot Europejskich. W roku 1975 został powołany do życia kolejny z funduszy strukturalnych, Europejski Fundusz Rozwoju Regionalnego (EFRR). Jako cel działania funduszu wyznaczono: „Aktywne przyczynianie się do korygowania podstawowych dysproporcji regionalnych we Wspólnocie poprzez niwelowanie różnic w poziomach rozwoju oraz zacofania regionów" (Witkowska, Wysokińska, 2002, s. 281-283). W tym momencie niwelowanie różnic rozwojowych pomiędzy obszarami poszczególnych państw członkowskich Wspólnoty zostało oparte na formalnych instrumentach finansowych w ramach 
prowadzonej polityki strukturalnej i regionalnej. Określenia „polityka regionalna” oraz „polityka strukturalna” są dość często używane wymiennie, ponieważ zdecydowana większość (ponad 90\%) z puli środków przeznaczonych na politykę strukturalną jest ściśle powiązana z polityką regionalną (Ciepielewska, Jahns, 2004, s. 284-285). Przyjęcie takiego rozwiązania w praktyce miało w zamyśle umożliwić większą elastyczność wydatkowania zgromadzonych w poszczególnych funduszach środków finansowych.

\section{Główne etapy w kształtowaniu się polityki regionalnej UE}

W historii polityki regionalnej prowadzonej przez Unię Europejską (a wcześniej przez EWG) można wyróżnić trzy zasadnicze etapy (Jasiński, 2000, s. 34-39):

- I etap (1958-1974),

- II etap (1975-1987),

- III etap (od roku 1988).

I etap odnosi się do początkowej fazy działań na polu zacierania różnic regionalnych i poszukiwania skutecznych rozwiązań dla przyspieszenia rozwoju zidentyfikowanych obszarów problemowych oraz sektorów gospodarki o szczególnym znaczeniu. Od roku 1960 zaczyna działać Europejski Fundusz Społeczny (ang. European Social Fund). Za pochodzące z tego instrumentu finansowego pieniądze mają być kompensowane ewentualne negatywne następstwa integracji europejskiej. Na pierwszym miejscu wymienia się tutaj przeciwdziałanie utracie stałego zatrudnienia przez szerokie rzesze ludzkie w wyniku redukcji niektórych dziedzin i branż w gospodarce. Od kwietnia 1964 roku działania EFS skutecznie zwielokrotnia Europejski Fundusz Orientacji i Gwarancji Rolnej (ang. European Agriculture Guidance and Guarantee Fund). Przypisanymi mu naczelnymi zadaniami są: finansowanie pożądanych przekształceń w strukturze rolnictwa oraz pomoc i wsparcie dla przedsięwzięć państwowych i prywatnych dotyczących rozwoju obszarów wiejskich. Na tym etapie występował jeszcze jednak brak skoordynowanej polityki regionalnej.

Od samego początku wprowadzania w życie wspólnej polityki regionalnej można było zauważyć tarcia pomiędzy krajami członkowskimi. Zaczęło do nich dochodzić na tle wysokości wydatków na prowadzenie polityki regionalnej oraz sporów, które dotyczyły sposobu dystrybucji środków zgromadzonych w funduszach. Zakładana ekspansja przedmiotowa i podmiotowa Wspólnoty skłaniała do przypuszczeń, że na tle redystrybucji kolejnych pieniędzy w ramach prowadzenia polityki regionalnej mogą powstać coraz głębsze spory (Kawecka-Wyrzy- 
kowska, 2004, s. 473). Nadchodząca przyszłość miała potwierdzić z całą mocą ówczesne obawy.

II etap rozpoczyna się od momentu ustanowienia na próbny okres trzech lat Europejskiego Funduszu Rozwoju Regionalnego (ang. European Regional Development Fund). Działania tego instrumentu miały obejmować uporządkowanie struktury i zniwelowanie dysproporcji w rozwoju regionalnym na wybranych do interwencji finansowej, wydzielonych obszarach. Przyczyn powstałych różnic, które należało skorygować, upatrywano w przekształceniach w przemyśle i rolnictwie oraz wynikającym z tego bezrobociu strukturalnym. Pierwsze lata funkcjonowania funduszu polegały zasadniczo jedynie na finansowym wspieraniu krajowych rodzajów polityki regionalnej. W konsekwencji to głównie władze centralne ugrupowania rozdzielały środki finansowe pozostające w ich dyspozycji. Polityka regionalna z tego okresu przypominała bardziej odzyskiwanie pieniędzy wpłacanych przez poszczególne kraje do wspólnego budżetu, niż wprowadzanie spektakularnych zmian strukturalnych (Toczyński, Mikołajczyk, 2001, s. 22-23). Po trzyletnim okresie, w którym dokonano weryfikacji uznano, że EFRR stanowi skuteczne narzędzie na polu kształtowania rozwoju regionalnego i że należy utrzymać bezterminowo jego działanie. W roku 1979 wprowadzono poprawki do zasad działania Europejskiego Funduszu Rozwoju Regionalnego. Polegały one na tym, że w wyłącznej gestii Komisji Europejskiej z ogólnej puli pozostawiono 5\% środków, które można było przeznaczyć na ważne cele regionalne, wyznaczone przez tę instytucję. Prowadzona polityka regionalna nabrała jeszcze większego znaczenia w momencie przystąpienia w 1981 roku do ugrupowania Grecji. Słoneczna Hellada była krajem najbardziej odbiegającym od europejskiego wzorca rozwoju. Biedna i zacofana ekonomicznie została przyjęta niejako „na wyrost”. Po wielu latach okazało się, że stała się również zbyt dużym balastem i zagrożeniem dla całej Unii.

III etap należy uznać, że rozpoczął się w 1988 r., ponieważ faktycznie dopiero od tej daty zaczął się proces realnego wcielania w życie postanowień zawartych w Jednolitym Akcie Europejskim (JAE). Zapisy poczynione w wymienionej umowie ustanowiły nowe jakościowo podstawy prawne, umożliwiające realizację polityki regionalnej na Starym Kontynencie. Dokument nowelizował treść traktatów rzymskich z 1957 roku. Jednolity Akt Europejski został podpisany w 1986 roku, w dwóch turach. W pierwszej, w 17 lutego, został podpisany w Luksemburgu przez: Państwa Beneluksu, Francję, Irlandię, Hiszpanię, Republikę Federalną Niemiec, Portugalię i Wielką Brytanię. Początkowo niechętne nowej europejskiej umowie trzy kraje: Dania, Grecja i Włochy dołączyły do pierwszych dziewięciu sygnatariuszy w drugiej turze, 28 lutego tego samego roku, w Hadze. JAE wszedł w życie dopiero 1 lipca 1987 roku. Powodem tak długiego vacatio legis była konieczność zmiany konstytucji w Irlandii, umożliwiającej referendum w sprawie przyjęcia aktu. Ogól- 
nonarodowe głosowanie miało miejsce 26 maja 1987 roku i wypadło pomyślnie dla euroentuzjastów.

W artykule 130 ppkt A Jednolitego Aktu Europejskiego zostało zapisane ważne postanowienie dotyczące polityki regionalnej: „Aby wspomagać swój wszechstronny, harmonijny rozwój, Wspólnota podejmuje i kontynuuje działania prowadzące do wzmocnienia spójności społecznej i gospodarczej. W szczególności Wspólnota ma na celu zredukowanie dysproporcji pomiędzy różnymi regionami oraz zacofania regionów najmniej uprzywilejowanych".

To i inne sformułowania o podobnym przesłaniu umocniły wagę oraz znaczenie polityki regionalnej wewnątrz ugrupowania integracyjnego. Od daty wejścia dokumentu w życie bardziej skoncentrowano wysiłki na realizacji takich celów, jak (Brodecki, 2005, s. 37):

- urzeczywistnienie europejskiego rynku bez barier i granic,

- pogłębienie spójności społeczno-gospodarczej Wspólnoty,

- umocnienie europejskiego systemu walutowego,

- zreformowanie funkcjonowania funduszy strukturalnych.

Wdrażanie i urzeczywistnianie wyznaczonych celów polityki Wspólnoty opartych zostało na kilku ważnych normach. W odniesieniu do polityki regionalnej należy wymienić tutaj pięć wiodących zasad:

- pomocniczości (subsydiarności),

- koncentracji,

- partnerstwa,

- programowania,

- uzupełniania.

Zasada pomocniczości zwana również zasadą subsydiarności jest podstawową zasadą określającą funkcjonowanie ugrupowania integracyjnego $\mathrm{w}$ dziedzinie gospodarczej. Mówi, że polityka strukturalna jest jedynie uzupełnieniem działań na poziomie krajowym, regionalnym lub lokalnym. Finansowo wspierane powinny być jedynie te projekty i przedsięwzięcia, na których realizację brakuje pieniędzy. Stanowi również, że Wspólnota może podjąć działania nienależące do jej wyłącznej kompetencji. Może to mieć miejsce tylko i wyłącznie wtedy, gdy nie ma możliwości osiągnięcia wyznaczonych celów na szczeblu stowarzyszonych w ugrupowaniu krajów, natomiast wyznaczone cele, skala oraz skutki tych przedsięwzięć uprawniają do wniosku, że zostaną one lepiej zrealizowane przez Wspólnotę niż przez każde z państw członkowskich z osobna.

Zasada koncentracji określona została jako efektywne skoncentrowanie największej części pieniędzy wspólnotowych na obszarach znajdujących się w najtrudniejszej sytuacji ekonomicznej. Parametrem wyznaczającym regiony 
kwalifikujące się do wsparcia był średni poziom PKB na osobę. Podstawowym warunkiem skierowania pomocy finansowej dla danego regionu było osiagnięcie przezeń poziomu niższego niż $75 \%$ PKB per capita dla całej Unii. Od tej zasady możliwe były, w uzasadnionych przypadkach, odstępstwa. Występować o przyznanie środków z budżetu mogły również obszary słabo zaludnione oraz terytoria Wspólnoty oddalone od Europy w sensie geograficznym (tzw. regiony ultraperyferyjne - RUP). Za regiony słabo zaludnione w tej nomenklaturze uznano położone poza kręgiem polarnym tereny Finlandii i Szwecji. Do „regionów ultraperyferyjnych” zaliczono siedem terytoriów zamorskich byłych metropolii kolonialnych. Były to należące do Francji - Gujana, Gwadelupa; Martynika w obszarze Karaibów; Wyspa Reunion na Oceanie Indyjskim; położone na Oceanie Atlantyckim - Madera i Wyspy Azorskie należące do Portugalii oraz hiszpańskie Wyspy Kanaryjskie.

Zasada partnerstwa to innymi słowy ścisła współpraca Komisji Europejskiej, organu wykonawczego całej Wspólnoty (obecnie UE), z władzami w poszczególnych państwach. Dotyczy współdziałania Komisji z władzami publicznymi na poziomie: krajowym, regionalnym i lokalnym. Współpraca oparta na trójstopniowości powinna zapewnić lepszą organizację i wyższą efektywność wykorzystania przyznawanych środków finansowych, szczególnie w odniesieniu do niższych szczebli administracji samorządowej.

Zasada programowania nakłada obowiązek rozdysponowywania środków finansowych pochodzących $\mathrm{z}$ ugrupowania integracyjnego jedynie w oparciu o wieloletnie plany inwestycyjne i rozwoju lub inne dokumenty planistyczne zawierające niezbędne do tego celu informacje. Pozwala to na długofalową i skoncentrowaną realizację trwałego rozwiązania problemów określonego regionu, branży lub gałęzi gospodarki położonej na jego obszarze.

Zasada uzupełniania inaczej zwana także zasadą współfinansowania. Oznacza, że pieniądze skierowane z budżetu wspólnotowego na realizację określonego projektu muszą być każdorazowo uzupełniane środkami finansowymi pochodzącymi ze strony odpowiedniego kraju. W żaden sposób nie powinny ich zastępować. Stanowi również, że ze strony państwa nie może dochodzić do ograniczania wydatków publicznych w objętym pomocą regionie.

Uczestnictwo i wspólfinansowanie przez instytucje wspólnotowe długoletnich zintegrowanych i kompleksowych planów powinno w większym stopniu, niż dotychczas, sprzyjać osiaganiu trwałych i obliczonych na długie lata rezultatów. Zakładano też, że może przyczynić się do wywołania efektu synergetycznego, który będzie pożądaną wartością dodaną przy realizacji wielu przedsięwzięć o charakterze inwestycyjnym i społecznym (Głębicka, Grewiński, 2003, s. 66). Naczelne władze Wspólnoty konsekwentnie obstawały jednak przy zachowaniu „żelaznej” zasady subsydiarności we wszystkich swoich poczynaniach. 
Jeszcze kilka reguł, na których opiera się realizacja spójnej wspólnotowej polityki regionalnej, znajduje zastosowanie w praktyce. Należą do nich: zasada zgodności polityki regionalnej z innymi politykami wspólnotowymi, zasada zgodności polityki regionalnej państw członkowskich z ich polityką społeczną i makroekonomiczną, zasada koordynacji działań funduszy strukturalnych i pozostałych narzędzi finansowych, zasada koordynacji różnych rodzajów polityki regionalnej państw członkowskich. Stanowią one uzupełnienie naczelnych norm wyznaczonych przez pięć omówionych wcześniej zasad: pomocniczości, koncentracji, partnerstwa, programowania i uzupełniania.

\section{Cele realizowane $w$ ramach polityki regionalnej}

Realizacja przyjętych celów wspólnotowej polityki regionalnej przebiegała w czterech perspektywach czasowych:

- 1988-1992,

- 1993-1999,

- 2000-2006,

- 2007-2013.

W ramach pierwszej perspektywy czasowej (1988-1992) wyznaczono do wykonania pięć celów:

Cel 1 - wspieranie rozwoju i dostosowanie strukturalne regionów słabo rozwiniętych oraz zacofanych gospodarczo, w których PKB per capita nie przekracza $75 \%$ średniej wspólnotowej;

Cel 2 - restrukturyzacja regionów, w tym obszarów przygranicznych i tych części ich obszaru, które zostały dotknięte upadkiem przemysłu;

Cel 3 - walka i przeciwdziałanie długotrwałemu bezrobociu;

Cel 4 - pomoc w znalezieniu zatrudnienia ludziom młodym (od 14 do 15 lat);

Cel 5 - reformy Wspólnej Polityki Rolnej Wspólnoty;

a) dostosowanie agrarnych struktur produkcyjnych,

b) wspieranie rozwoju obszarów wiejskich.

Czynnikiem umożliwiającym przeprowadzenie ambitnych celów zebranych w pierwszej perspektywie czasowej było przyjęcie „pierwszego pakietu Delorsa”. Był to projekt reform finansowych, zakładający sześciokrotne zwiększenie środków funduszy regionalnych w porównaniu z 1987 rokiem. Sytuacja taka stawiała na uprzywilejowanej pozycji najsłabsze gospodarczo państwa Wspólnoty (Pietrzyk, 2001, s. 92). Główne znaczenie dla polityki regionalnej miały cele: 
1., 2. i 5b. Dotyczyły one pomocy i wsparcia finansowego dla wyodrębnionych obszarów problemowych. Natomiast cele: 3., 4. i 5a miały „,charakter horyzontalny”, co oznaczało, że dotyczyły w większym zakresie całego obszaru Wspólnoty.

Realizacja wyróżnionych celów została oparta na środkach pochodzących $\mathrm{z}$ istniejących funduszy strukturalnych: Europejskiego Funduszu Rozwoju Regionalnego (EFRR), Europejskiego Funduszu Społecznego (EFS) i Europejskiego Funduszu Orientacji i Gwarancji Rolnej (EFOiGR). Wszystkie trzy fundusze mogły być aktywne w ramach kilku celów jednocześnie. Należy przez to rozumieć, że jeden cel mógł być finansowany z kilku źródeł naraz (Szlachta, 1999, s. 27-29).

Druga perspektywa czasowa objęła lata 1993-1999. Okres ten został zdeterminowany przez zapisy traktatu z Maastricht, który został podpisany 7 lutego 1992 roku, a wszedł w życie w 1 listopada 1993 roku. Zawarte w Holandii porozumienie (w miejsce dotychczasowej EWG) ustanawiało Wspólnotę Europejską (WE) opartą na 3 filarach:

- Wspólnocie Europejskiej, Euratomie oraz Europejskiej Wspólnocie Węgla i Stali.

- prowadzeniu Wspólnej Polityki Zagranicznej i Bezpieczeństwa (WPZiB),

- współpracy Wymiaru Sprawiedliwości i Spraw Wewnętrznych krajów członkowskich.

Ustalenia były wyrazem dążenia państw ugrupowania integracyjnego w kierunku zintensyfikowania wysiłków mających na celu dalszą integrację. Narzędziem, które to umożliwi miała się stać polityka spójności. Zgodnie z zapisem art. 158 traktatu z Maastricht, Wspólnota Europejska ogłosiła, że: „Wspierając swój wszechstronny, harmonijny rozwój, będzie rozwijać i kontynuować działania prowadzące do zwartości ekonomicznej i społecznej, a w szczególności będzie dążyć do zredukowania różnic w stopniach rozwoju poszczególnych regionów, jak również zmniejszenia zacofania najmniej uprzywilejowanych regionów...".

Sposobem na przybliżenie do zakładanego przez władze WE stanu miała być realizacja sześciu celów:

Cel 1 - rozwój i strukturalne dostosowanie regionów zacofanych,

Cel 2 - konwersja regionów dotkniętych regresją przemysłu,

Cel 3 - zwalczanie długookresowego bezrobocia oraz ułatwianie młodzieży dostępu do rynku pracy,

Cel 4 - przystosowanie siły roboczej do zmian w systemie produkcji,

Cel 5 - wspieranie rozwoju obszarów wiejskich:

a) wspieranie obszarów rolniczych,

b) ułatwianie rozwoju i dostosowywanie strukturalne obszarów wiejskich,

Cel 6 - wspieranie regionów z bardzo niską gęstością zaludnienia. 
Przesłanie i treść celów: $1 ., 2$. oraz 5a i 5b pozostały zasadniczo bez zmian. Cel 3. powstał w wyniku połączenia celów 3. i 4., pochodzących z poprzedniego okresu programowania. Krok ten wykonano, aby zwiększyć i skoordynować skuteczność oddziaływania funduszy strukturalnych. Cel 6. został dodany po rozmowach akcesyjnych państw skandynawskich: Finlandii i Szwecji. Zakończyły się one w 1994 roku.

Absolutny priorytet uzyskał przy wdrażaniu cel 1 . „rozwój i strukturalne dostosowanie regionów zacofanych", na który przeznaczono ponad $63 \%$ pieniędzy pochodzących z funduszy strukturalnych oraz uzupełniające wsparcie z Funduszu Spójności. Europejski Fundusz Spójności (EFS) (ang. Cohesion Fund) był nowym instrumentem służącym wypełnianiu zadań WE. Został uchwalony w 1992 roku w Maastricht, zaczął zaś działać w dwa lata później, w roku 1994. EFS nie jest funduszem strukturalnym. Różnica pomiędzy Funduszem Spójności a funduszami strukturalnymi opiera się na tym, że polem jego działania jest poziom krajowy, a nie szczebel regionalny. Cel 1. objął swoim zasięgiem blisko 22\% obszaru całej Wspólnoty, powiększonej w międzyczasie do piętnastu członków (1995 r.) oraz o teren byłej Niemieckiej Republiki Demokratycznej, włączonej do RFN w 1990 roku.

Nowy w tym gronie - cel 6. - nakierowany był na udzielanie pomocy i wsparcia finansowego terenom słabo zamieszkałym. Dotyczył obszarów o gęstości zaludnienia poniżej 8 osób na $\mathrm{km}^{2}$. Objął swoim oddziaływaniem położone na dalekiej północy, subarktyczne tereny Finlandii i Szwecji. Znalazł zastosowanie dla prowadzonego w trudnych warunkach klimatycznych rolnictwa oraz specyficznego rodzaju hodowli (bydło i renifery). Jednakże z perspektywy czasu trzeba stwierdzić, iż skuteczność oddziaływania środków użytych w ramach celu 6 . (około $0,5 \%$ wszystkich pieniędzy) była niestety niedostrzegalnie niska.

Trzecia perspektywa czasowa dotyczyła lat 2000-2006. Jej oblicze zostało ukształtowane przez założenia przyjęte w perspektywie finansowej na lata 2000-2006 oraz w akcie znanym pod nazwą „Agenda 2000”. Drugi z wymienionych dokumentów był opracowywany już od 1997 roku. Określał on konieczne reformy w obszarach: finansów ugrupowania integracyjnego, Wspólnej Polityki Rolnej (WPR) oraz przedłużał na kolejny okres funkcjonowanie funduszy strukturalnych, to znaczy: Europejskiego Funduszu Rozwoju Regionalnego, Europejskiego Funduszu Społecznego, Europejskiego Funduszu Orientacji i Gwarancji Rolnej i Finansowego Instrumentu Orientacji Rybołówstwa oraz Funduszu Spójności (Kohezyjnego). Przewidywał także przystąpienie do dotychczasowej UE-15 sześciu nowych państw oraz wygospodarowanie dla nich środków finansowej pomocy przedakcesyjnej. Krajami, o których mówił dokument były: Cypr, Czechy, Estonia, Polska, Słowenia i Węgry. Ostatecznie liczba kandydatów do Unii została powiększona o dodatkowe trzy państwa: Litwę, Łotwę oraz Słowację. Zabieg ten nie został jednak połączony z jednoczesnym 
zwiększeniem środków oddanych do dyspozycji krajów dążących do wstąpienia do UE. Po roku 2002 ogólna kwota została nawet zmniejszona (KaweckaWyrzykowska, 2004, s. 472-473). Nieco później do grupy kandydatów dołączyła jeszcze niewielka Malta.

Trzecia perspektywa czasowa została ograniczona do trzech głównych celów:

Cel 1 - wsparcie regionów zapóźnionych w rozwoju,

Cel 2 - odbudowa terenów silnie uzależnionych od upadających gałęzi gospodarki,

Cel 3 - modernizacja rynku pracy.

Za najważniejszy uznano cel 1., na który zdecydowano przeznaczyć aż 69,7\% wszystkich pieniędzy pochodzących z funduszy strukturalnych. Na zadania objęte celem 2., rozdysponowano 11,5\% środków finansowych ze wspólnej puli. Cel 3. mógł liczyć na 12,3\% środków. Cele 1. i 2. miały „charakter regionalny”. Oznaczało to, że dany obszar, aby otrzymać wsparcie, musiał wypełniać określone warunki. Pomoc rozdzielana była w oparciu o przyjętą dla całej Unii jednolitą nomenklaturę NUTS. Cel 3. posiadał „charakter horyzontalny”, a środki finansowe były przyznawane bez względu na umiejscowienie potencjalnego beneficjenta. 0,5\% środków zostało przeznaczonych na inicjatywy Wspólnoty, prowadzenie działań innowacyjnych, pomoc techniczną oraz wsparcie dla rybołówstwa poza celem 1. W latach 2000-2006 państwa, które wchodziły w skład UE-15 otrzymały do swojej dyspozycji 183564 mln euro. Dla „nowych” dziesięciu krajów członkowskich od momentu ich akcesji - od 1 maja 2004 roku aż do końca trwania trzeciej perspektywy czasowej, przeznaczono 13 467,1 mln euro.

Czwarta perspektywa czasowa objęła swoim zasięgiem lata: 2007-2013. Do realizacji zawartych $w$ niej zamierzeń miały posłużyć cele finansowane z trzech funduszy: Funduszu Spójności (FS, Europejskiego Funduszu Rozwoju Regionalnego (EFRR) i Europejskiego Funduszu Społecznego (EFS). Cele zdecydowano skoncentrować na:

Cel 1 - konwergencji,

Cel 2 - konkurencyjności regionalnej i zatrudnieniu,

Cel 3 - europejskiej współpracy terytorialnej.

Cel 1., czyli konwergencja, został uznany za cel priorytetowy. W ramach puli przeznaczonej do rozdysponowania zostało nań przyznanych najwięcej, bo aż 81,54\% wszystkich środków finansowych. Stanowiło to kwotę 282,8 mld euro. Na etapie planowania miał dotyczyć 25 stowarzyszonych państw, został jednak rozszerzony na dwa dodatkowe - Bułgarię i Rumunię, które weszły do Unii 1 stycznia 2007 roku. Regionami objętymi celem 1. były obszary zakwalifikowane jako poziom NUTS 2, na których PKB per capita był niższy niż 75\% średniego PKB liczonego do UE-25. Dawało to w sumie 84 regiony o popula- 
cji ponad 154 milionów osób, położone na terenie 17 krajów członkowskich. Środki w ramach tego celu, miały powędrować jeszcze do tzw. regionów efektu statystycznego. W ten sposób zostały określone obszary, na których PKB na mieszkańca był wyższy niż 75\% średniego PKB dla UE-25, ale niższy od PKB dla wcześniejszej UE-15. Druga grupę stanowiło 16 regionów o populacji 16,4 mln mieszkańców, położonych na terenie 8 państw. W ramach celu 1. postanowiono zniwelować opóźnienie gospodarcze i cywilizacyjne najbardziej zacofanych terytoriów wspólnotowych. Zdecydowano się również na przeciwdziałanie bezrobociu w regionach najbardziej dotkniętych tym negatywnym zjawiskiem oraz aktywne popieranie przedsiębiorczości ze strony powołanych do tego celu instytucji i administracji samorządowej.

W puli przeznaczonej do rozdysponowania w ramach celu 2. zostało przyznanych 15,95\% środków finansowych. Stanowiło to kwotę około 55 mld euro. Zamysłem, jaki przyświecał celowi 2 . było wspieranie zmian strukturalnych na terenach niespełniających wymogów kwalifikujących je do celu 1. Dodatkowymi zadaniami było inicjowanie i przeprowadzanie pozytywnych zmian na rynku pracy. Położono w nim również nacisk na popieranie przedsiębiorczości i stymulację innowacyjności opartej na badaniach oraz upowszechnianiu wiedzy. Celem objętych zostało 168 regionów o populacji wynoszącej ponad 314 mln osób, położonych na terenie 19 państw członkowskich ugrupowania integracyjnego.

Ze wspólnej puli na cel 3. przyznano 2,52\% środków finansowych. Stanowiło to kwotę ponad 8,71 mld euro. Cel został ukierunkowany na pogłębianie integracji terytorialnej Unii Europejskiej w ramach harmonijnego i zrównoważonego rozwoju oraz wspieranie konkurencyjności objętych nim obszarów. Zaplanowano dokonać tego w ramach trzech wyróżnionych komponentów:

- transgranicznego - opartego na uaktywnieniu i wspieraniu działań społecznych i gospodarczych ze szczególnym uwzględnieniem sektora małych i średnich przedsiębiorstw; miał on obejmować regiony NUTS 3: wzdłuż wszystkich unijnych granic lądowych wewnętrznych i wyszczególnionych granic zewnętrznych oraz wszystkie regiony na wymienionym poziomie (NUTS 3) wzdłuż granic morskich, oddalone jednak od siebie maksymalnie o $150 \mathrm{~km}$;

- transnarodowego - opartego na nawiązaniu i pogłębianiu współpracy ponadnarodowej, zwiększaniu skuteczności polityki regionalnej oraz zacieśnianiu wzajemnej współpracy pomiędzy władzami samorządowymi (np. nadmorskich regionów bałtyckich w układach dwustronnych i wielostronnych);

- międzyregionalnego - wszystkie inicjatywy i przedsięwzięcia prowadzące do wzrostu homogeniczności i zwartości obszarów na terenie całej Unii Europejskiej. 
$\mathrm{Z}$ kwoty ponad 8,71 mld euro, na komponent transgraniczny zostało przeznaczone 6,44 mld euro, na komponent transnarodowy przekazano 1,83 mld euro, natomiast na komponent międzyregionalny - ponad 0,44 mld euro.

Cel trzeci objął swoim zasięgiem zakwalifikowane do wsparcia regiony z całego terytorium Unii w obrębie 27 krajów członkowskich. Na obszarach tych żyje blisko 182 mln mieszkańców, co stanowi około 37,5\% całej populacji Wspólnoty.

Realizacja trzech opisanych celów została zaplanowana z trzech głównych źródeł:

- cel 1. z Funduszu Spójności (FS), Europejskiego Funduszu Rozwoju Regionalnego (EFRR) oraz Europejskiego Funduszu Społecznego (EFS);

- cel 2. z EFRR i EFS;

- cel 3. tylko ze środków finansowych Europejskiego Funduszu Rozwoju Regionalnego.

Piąta perspektywa czasowa dotyczy nadchodzącej przyszłości w przedziale czasowym 2014-2020. Komisja Europejska w 2010 roku rozpoczęła debatę w sprawie przyszłości polityki spójności i jej instrumentów finansowych. Polityka ta, określona $\mathrm{w}$ traktacie $\mathrm{z}$ Lizbony, ma za zadanie wspierać realizację nowoprzyjętej strategii „Europa 2020”.

Według taktyki określonej $\mathrm{w}$ drugim $\mathrm{z}$ wyżej wymienionych dokumentów, w nadchodzących latach „stary kontynent” powinien wrócić na ścieżkę stabilnego rozwoju i na niej pozostać. Jest to główny cel strategii „Europa 2020”, której założenia to przede wszystkim: więcej miejsc pracy oraz wyższy standard życia społeczeństwa. Strategia zakłada również, że Europa powinna się rozwijać w sposób inteligentny i zrównoważony, sprzyjając włączeniu społecznemu wszystkich jej mieszkańców. Komisja Europejska proponuje pięć wymiernych celów Unii Europejskiej na rok 2020, które nadadzą kierunek całemu procesowi i zostaną przełożone na cele krajowe. Obejmują one zatrudnienie, badania i innowacje, zmiany klimatu i energię, edukację oraz walkę z ubóstwem pokazują kierunek, w którym powinniśmy zmierzać (Barroso, 2010, s. 2-3).

Realizacja celów strategii „Europa 2020” będzie wymagać aktywnego zaangażowania nie tylko poszczególnych krajów członkowskich, lecz także wszystkich regionów UE. Sprzyjać temu będzie pięć celów wymienionych w słowie wstępnym do „strategii” przez Przewodniczącego Komisji Europejskiej Jose Manuela Barroso, które mają zostać osiągnięte do 2020 roku:

- zatrudnienie - stałe miejsce pracy powinno mieć zapewnione $75 \%$ ludności w wieku od 20 do 64 lat (ciekawostką jest tutaj fakt, że założenia uwzględniają standardy europejskie, a nie te, które obowiązują w Polsce, gdzie trzeba pracować zarówno w przypadku kobiet, jak i mężczyzn aż do 67 roku życia - przyp. autora); 
- innowacje - co najmniej 3\% w odniesieniu do unijnego PKB poświęcone ma zostać na badania i rozwój, ze szczególnym wspieraniem inicjatyw innowacyjnych; kwota przeznaczona na ten cel to około 80 mld euro w latach 2014-2020;

- zmiana klimatu - wyznaczone zostały cele „20/20/20” w zakresie klimatu i energii; trzy liczby: 20/20/20, oznaczają ograniczenie do roku 2020 emisji gazów cieplarnianych na terenie Unii o co najmniej 20\% w stosunku do 1990 roku (a w sprzyjających warunkach nawet o 30\%), a także zwiększenie udziału odnawialnych źródeł energii w bilansie energetycznym ugrupowania o $20 \%$;

- edukacja - ilość osób przedwcześnie kończących naukę powinna być mniejsza niż 10\%; dodatkowo co najmniej $40 \%$ ludzi w średnim wieku (od 30 do 34 lat) powinno uzyskać wykształcenie wyższe (lub odpowiadające takiemu);

- ubóstwo - odczuwalne zmniejszenie liczby ludzi ubogich w wyniku uchronienia przed biedą lub zapobieżeniu wykluczeniu społecznemu, co najmniej 20 milionów osób.

Według Komunikatu Komisji do Parlamentu Europejskiego, Rady, Europejskiego Komitetu Ekonomiczno-Społecznego i Komitetu Regionów - Budżet z perspektywy „Europy 2020” (z dnia 29 czerwca 2011 roku), głównym narzędziem służącym urzeczywistnianiu w praktyce celów strategii, ma być polityka spójności. Komisja przewiduje przekazać w ramach piątej perspektywy czasowej około 376 mld euro, rozdzielając całą kwotę pomiędzy poszczególne obszary działań:

- 162,6 mld euro dla regionów w ramach celu konwergencji,

- 38,9 mld euro dla regionów w fazie przejściowej,

- 53,1 mld euro dla regionów w ramach celu konkurencyjności,

- 11,7 mld euro na współpracę terytorialną,

- 68,7 mld euro na Fundusz Spójności.

Z innych ważniejszych zadań, Komisja Europejska planuje prowadzić opartą na dwóch filarach Wspólną Politykę Rolną (WPR). Pierwszy filar będzie skoncentrowany przede wszystkim na zagadnieniach związanych z ekologią. Natomiast drugi - będzie się skupiać w przeważającym zakresie na konkurencyjności i innowacyjności w gospodarce rolnej. Przy okazji poświęci szczególną uwagę walce ze zmianami klimatu i środowiska. Przewidziane środki finansowe to:

- 281,8 mld euro dla pierwszego filaru WPR,

- 89,9 mld euro na rozwój obszarów wiejskich. 
Stosunkowo nowym instrumentem, działajaccym od 1 maja 2009 roku, jest Europejski Fundusz Dostosowania do Globalizacji (EFDG), który w perspektywie nadchodzących lat będzie dysponował środkami w wysokości około $500 \mathrm{mln}$ euro rocznie. Zamysłem jego utworzenia była chęć niesienia pomocy osobom, które zostały pozbawione pracy w wyniku światowego kryzysu gospodarczego. To czy wymienione kwoty rzeczywiście zostaną postawione do dyspozycji potencjalnych beneficjentów wydaje się obecnie kwestią niepewną. Będzie to zależało od wielu czynników, takich jak: potrzeby oszczędności w samej Unii, położenia ekonomicznego krajów południa naszego kontynentu, w tym: Grecji, Hiszpanii, Portugali i Włoch, przyszłości strefy wspólnej waluty europejskiej, zauważalnych sukcesów w walce z kryzysem, akceptacji Parlamentu Europejskiego dla ustaleń poczynionych przez polityków, ogólnej sytuacji międzynarodowej.

\section{Europejskie Fundusze Strukturalne}

Fundusze europejskie stanowią główny instrument służący realizacji unijnej polityki regionalnej i są istotną częścią wydatków wspólnotowego budżetu. Często ten dokument UE określany jest jako „budżetu wydatków”. Określenie wywodzi się stąd, że przez kraje członkowskie zasadniczo ustalany jest tylko poziom wydatków. Dochody i wydatki, w tym najważniejszym planie finansowym, muszą zostać zbilansowane. Tak więc zgodnie z obowiązującą w Unii zasadą dotyczącą zachowania równowagi budżetowej, wysokość wpłat państw członkowskich jest każdorazowo solidarnie dostosowywana do istniejących potrzeb. Nie mogą zostać zaplanowane wyższe wydatki niż przewidziane w przyjętej perspektywie finansowej.

\subsection{Fundusze jako element budżetu Unii Europejskiej}

Wszystkie środki przeznaczone w budżecie Unii Europejskiej na wydatki można podzielić na dwie zasadnicze kategorie (Oręziak, 2004a, s. 143-144):

- obligatoryjne,

- nieobligatoryjne.

Wydatki obligatoryjne wynikają z ustaleń zawartych w traktatach i wydanych na ich podstawie innych aktach prawnych. Ich alokacja odbywa się przede wszystkim w ramach prowadzenia przez ugrupowanie integracyjne Wspólnej Polityki Rolnej (WPR). Przykładem ich zastosowania jest finansowanie inter- 
wencji na rynku rolnym, w szczególności w odniesieniu do rynku zbóż, mleka, wołowiny i wieprzowiny. W dalszej kolejności ze środków pochodzących z Europejskiego Funduszu Orientacji i Gwarancji Rolnictwa (EFOiGR) dochodzi do realizacji ważnych dla rolników dopłat bezpośrednich (Sekcja Gwarancji) oraz wspierania zmian strukturalnych na wsi (Sekcja Orientacji). W wyniku zwiększenia dyscypliny finansowej w sferze rolnictwa wielkość wydatków obligatoryjnych spadła w ciągu ostatnich dziesięciu lat $\mathrm{z}$ około $65 \%$ do obecnego poziomu około $45 \% \mathrm{w}$ odniesieniu do całego budżetu Unii.

Zapewnienie sfinansowania wydatków obligatoryjnych posiada priorytet w stosunku do wydatków nieobligatoryjnych. Wynika to z faktu, że budżet stanowi niezbędny instrument realizacji określonych funkcji, które zostały Wspólnocie powierzone przez państwa członkowskie wraz ze środkami niezbędnymi do ich wypełnienia (Oręziak, 2004a, s. 144). Zapewnienie pieniędzy na wydatki obowiązkowe leży także w dobrze pojętym interesie kilkudziesięciotysięcznej rzeszy urzędników unijnych. I chociaż łączna kwota wynagrodzeń (a także w wielu przypadkach późniejszych emerytur) dla osób, które pracują w licznych organach i instytucjach Unii (Parlament, Rada Unii Europejskiej, Komisja Europejska, Komitet Regionów oraz w Komitet Ekonomiczno-Społeczny, Urząd Publikacji, Europejska Służba Działań Zewnętrznych, Trybunał Sprawiedliwości i Trybunał Obrachunkowy) została ustabilizowana na poziomie około 5\% wszystkich wydatków, to w każdej perspektywie finansowej pochłaniają one od kilkunastu do dziesiątków miliardów euro. Niektóre z pozostałych celów obowiązkowych wydatków to: wynikające z umów międzynarodowych, za wykonane usługi, świadczenia, rekompensaty i na pokrycie ewentualnych szkód, rezerwa monetarna, rezerwa na pomoc natychmiastową (zwana też rezerwą na pomoc nadzwyczajną, przeznaczona na przeprowadzenie operacji humanitarnych i zarządzania kryzysowego oraz zapewnienia ochrony ludności w państwach spoza UE w przypadku wystąpienia sytuacji nadzwyczajnych (przyp. aut.) oraz środki przeznaczone na potrzeby uczestnictwa przedstawicieli Unii w organizacjach międzynarodowych.

Wydatki nieobligatoryjne to wszystkie inne pozostałe wydatki, w tym środki przeznaczone na: finansowanie dalszego rozwoju regionalnego, dokończenie tworzenia jednolitego rynku wewnętrznego, działania Unii Europejskiej na korzyść państw trzecich (w Afryce, Ameryce Południowej i Środkowej oraz Azji), pomoc dla ludności na obszarach dotkniętych klęskami żywiołowymi czy kataklizmami naturalnymi oraz rezerwy budżetowe. Pewna część wydatków nieobowiązkowych przeznaczana jest na prowadzenie polityki badawczo-rozwojowej, unijnej polityki energetycznej, polityki ochrony środowiska, ochronę konsumentów, na cele kulturalne i informację. 


\subsection{Fundusze strukturalne $w$ ramach perspektyw finansowych UE}

W dotychczas obowiązujących perspektywach czasowych często zmieniała się liczba funkcjonujących funduszy strukturalnych. W poszczególnych latach wyglądało to następująco:

- pierwsza perspektywa czasowa (1988-1992):

- Europejski Fundusz Rozwoju Regionalnego (EFRR);

- Europejski Fundusz Społeczny (EFS);

- Europejski Fundusz Orientacji i Gwarancji Rolnej (EFOiGR);

- druga perspektywa czasowa (1993-1999):

- Europejski Fundusz Rozwoju Regionalnego (EFRR);

- Europejski Fundusz Społeczny (EFS);

- Europejski Fundusz Orientacji i Gwarancji Rolnej (EFOiGR);

- w czasie trwania tej perspektywy powstał Europejski Fundusz Spójności (EFS, ang. Cohesion Fund) -zupełnie nowy instrument służący wypełnianiu zadań WE; został on uchwalony w 1992 roku w Maastrich, a zaczął działać w dwa lata później; EFS nie jest funduszem strukturalnym; różnica pomiędzy Funduszem Spójności a funduszami strukturalnymi opiera się na tym, że polem jego działania jest poziom krajowy, nie zaś szczebel regionalny;

- trzecia perspektywa czasowa (2000-2006):

- Europejski Fundusz Społeczny (EFS);

- Europejski Fundusz Orientacji i Gwarancji Rolnej (EFOiGR):

- Europejski Fundusz Rozwoju Regionalnego (EFRR);

- Finansowy Instrument Orientacji Rybołówstwa (FIOR);

- jeszcze przed przystąpieniem do Unii kraje Europy Środkowej (w tym Polska) miały możliwość korzystania z pomocy finansowej pochodzącej z ugrupowania integracyjnego; świadczona ona była za pośrednictwem trzech funduszy przedakcesyjnych, których środki mogły być wykorzystane do 2006 r.:

- PHARE (ang. Poland and Hungary - Assistance In Restructuring in their Economies), instrument ten miał za zadanie wspomaganie państw Europy Środkowej w transformacji ich centralnego systemu ekonomicznego i politycznego w zdecentralizowaną gospodarkę rynkową i demokratyczne społeczeństwo; zakładał również reintegrację gospodarczą i społeczną z resztą świata, a szczególnie z Unią Europejską;

- SAPARD (ang. Special Accession Program for Agriculture and Rural Development), fundusz, dotyczący rolnictwa i rozwoju obszarów wiejskich, miał na celu lepsze przygotowanie krajów stowa- 
rzyszonych do członkostwa w Unii Europejskiej; brał pod uwagę specyfikę aktywności gospodarczej i potrzeby małych i średnich przedsiębiorców działających na terenach wiejskich;

- ISPA (ang. Instrument for Structural Policy for pre-Accession), zadaniem tego instrumentu było lepsze przygotowanie krajów stowarzyszonych do członkostwa w Unii Europejskiej w zakresie ochrony środowiska oraz szeroko rozumianego transportu;

- czwarta perspektywa czasowa (2007-2013):

- Europejski Fundusz Społeczny (EFS);

- Europejski Fundusz Rozwoju Regionalnego (EFRR);

- piąta perspektywa czasowa (2014-2020):

- Europejski Fundusz Rozwoju Regionalnego (EFRR);

- Europejski Fundusz Społeczny (EFS).

Z punktu widzenia rozważań prowadzonych w niniejszej pracy zasadnicze znaczenie mają dwie pespektywy czasowe: czwarta, obejmująca lata 2007-2013 oraz istotne detale tworzonej aktualnie piątej perspektywy, która dotyczy nadchodzących lat 2014-2020. Z tego względu zasadne wydaje się przybliżenie najważniejszych informacji dotyczących funduszy strukturalnych występujących w obu tych perspektywach:

- Europejskiego Funduszu Rozwoju Regionalnego,

- Europejskiego Funduszu Społecznego.

\subsection{Europejski Fundusz Rozwoju Regionalnego (EFRR)}

Europejski Fundusz Rozwoju Regionalnego (ang. European Regional Development Fund - ERDF) został utworzony w 1975 roku jako następstwo „północnego rozszerzenia” (lub inaczej „pierwszego rozszerzenia”) Unii Europejskiej o trzy kraje: Danię, Irlandię i Wielką Brytanię. Niektóre tereny Irlandii oraz Wielkiej Brytanii tak daleko odbiegały poziomem rozwoju od obszarów dotychczasowej „europejskiej szóstki”, że niezbędnym stało się stworzenie specjalnego instrumentu, który byłby w stanie te nierówności zniwelować. Decyzja o powołaniu do życia EFRR została podjęta już rok wcześniej - na początku grudnia 1974 roku, w czasie paryskiego szczytu ugrupowania integracyjnego.

Funkcjonowanie Europejskiego Funduszu Rozwoju Regionalnego zostało określone przez Traktat ustanawiający Wspólnotę Europejską w art. 160: „Europejski Fundusz Rozwoju Regionalnego ma na celu przyczynianie się do korygowania podstawowych dysproporcji regionalnych we Wspólnocie poprzez 
udział w rozwoju i dostosowaniu strukturalnym regionów opóźnionych w rozwoju oraz w przekształcaniu upadających regionów przemysłowych”.

Tym samym EFRR stał się, poprzez literę obowiązującego prawa wspólnotowego, najbardziej efektywnym narzędziem nakierowanym na wspieranie rozwoju regionalnego. Celem funduszu jest zwiększenie spójności obszaru Wspólnej Europy przez wspieranie rozwoju potencjału społeczno-gospodarczego krajów członkowskich.

Środki z tego funduszu miały w zamyśle przyczynić się do zmniejszenia dysproporcji regionalnych we Wspólnocie, dzięki pomocy w przemianach strukturalnych w regionach opóźnionych w rozwoju oraz przekształcaniu regionów przemysłowych przeżywających kryzys w dotychczasowej działalności. Środki funduszu zostały przeznaczone na finansowanie projektów dotyczących (Śliwa, Pawlicki, 2012, s. 64):

- tworzenia i ochrony miejsc pracy,

- modernizacji infrastruktury transportowej,

- tworzenia nowoczesnego zaplecza komunikacyjnego i energetycznego,

- ochrony środowiska naturalnego,

- wzrostu innowacyjności i konkurencyjności gospodarczej w regionie,

- rozwoju lokalnej przedsiębiorczości ze szczególnym uwzględnieniem sektora małych i średnich przedsiębiorstw,

- inwestycji w ochronę zdrowia oraz infrastrukturę społeczną,

- współpracy międzyregionalnej, transgranicznej i transnarodowej w dziedzinie społeczno-gospodarczej,

- inwestycji w kulturę i edukację,

- rozwoju społeczeństwa informacyjnego,

- tworzenia infrastruktury turystycznej.

Zasoby tego funduszu mogą być spożytkowane poprzez realizację kilku równoległych do siebie programów o określonych priorytetach oraz wyznaczonych kierunkach działania. Potencjalnymi beneficjentami mogącymi ubiegać się o wsparcie środkami finansowymi pochodzącymi z Funduszu Regionalnego, mogą być: władze samorządowe i lokalne, mali i średni przedsiębiorcy, administracja rządowa oraz instytucje pozarządowe, podmioty z otoczenia biznesu oraz instytucje naukowo-badawcze. Przypatrując się grupie wyliczonych projektów i ewentualnych beneficjentów EFRR, daje się zauważyć niezwykle szeroki wachlarz możliwych zastosowań dla środków zgromadzonych w ramach tego instrumentu finansowego. 


\subsection{Europejski Fundusz Społeczny (EFS)}

Europejski Fundusz Społeczny (ang. European Social Fund - ESF) jest najdłużej działającym funduszem strukturalnym. Powstał na podstawie zapisów traktatu rzymskiego z 1957 roku, ustanawiającego Europejską Wspólnotę Gospodarczą. Tworzy dynamiczne narzędzie, którego celem jest podnoszenie spójności społecznej i gospodarczej ugrupowania integracyjnego. Urzeczywistnienie tego zamierzenia ma zostać osiągnięte poprzez zwalczanie bezrobocia, poprawę stopnia zatrudnienia oraz rozwój zasobów ludzkich w krajach członkowskich Unii. Podjęte działania powinny wpłynąć na poprawę jakości dostępnego kapitału ludzkiego i podniesienie poziomu życia społeczeństwa we Wspólnej Europie. Strategia i budżet Funduszu określane są na szczeblu UE. Powstają w wyniku negocjacji pomiędzy Parlamentem Europejskim, Komisją Europejską i państwami członkowskimi. Wdrażaniem środków zajmują się kraje członkowskie i należące do nich regiony. Proces ten odbywa się za pomocą różnego rodzaju instytucji z sektora publicznego, jak również organizacji oraz podmiotów niepublicznych. Mogą to być władze samorządowe, organizacje pozarządowe, firmy prywatne, instytucje zajmujące się edukacją i szkoleniami, przedstawiciele przemysłu czy związki zawodowe.

W swoich założeniach EFS powinien koncentrować się na zadaniach wynikających bezpośrednio z Europejskiej Strategii Zatrudnienia. Określa ona działania zmierzające do zatrzymania procesu utraty miejsc pracy. Mogą to być szeroko rozumiane szkolenia i kursy, pobudzanie rozwoju przedsiębiorczości, wszelkie inicjatywy pracownicze czy aktywizacja zawodowa kobiet. Działania te mają na celu przede wszystkim stworzenie równych szans dla różnorodnych grup zawodowych. Pieniądze z EFS mogą wspierać przedsięwzięcia inwestycyjne dotyczące m.in. (Śliwa, 2008, s. 62):

- rozwoju i doskonalenia zawodowego zasobów ludzkich,

- redukowania bezrobocia i zapobiegania utracie miejsc pracy,

- rozwoju przedsiębiorczości,

- integracji społecznej osób mogących mieć problemy ze znalezieniem pracy (kobiet, młodzieży, ludzi starszych i niepełnosprawnych),

- kształcenia w sferze badań i zaawansowanych technologii,

- rozwoju szkolnictwa zawodowego i wyższego,

- wspierania inicjatyw na rzecz zatrudnienia,

- pomocy technicznej,

- tworzenia mechanizmów umożliwiających przewidywanie i planowanie zapotrzebowania na siłę roboczą.

Na przestrzeni lat charakter Funduszu Społecznego uległ zauważalnym zmianom. EFS ewoluował od stanu samodzielnego i w pewnym sensie niezależne- 
go, względem innych funduszy strukturalnych, instrumentu w kierunku środka finansowego opierającego się na koordynacji i współdziałaniu z pozostałymi narzędziami, służącymi urzeczywistnianiu polityki regionalnej Unii Europejskiej (Głąbicka, Grewiński, 2003, s. 121-124).

\subsection{Fundusz Spójności (FS)}

Łącznie z funduszami strukturalnymi wymieniany jest często także Fundusz Spójności (ang. Cohesion Fund - CF). Decyzja o jego powstaniu zapadła w czasie posiedzenia Rady Europejskiej w Edynburgu w grudniu 1992 roku, jednak funkcjonować w praktyce zaczął rok później. FS został utworzony, aby bardziej efektywnie wpływać na procesy prowadzące do rzeczywistej spójności społecznogospodarczej we Wspólnocie. Jednakże nie jest on funduszem strukturalnym, ze względu na odmienne procedury dostępu do zgromadzonych w jego ramach pieniędzy oraz zasad ich wydatkowania. Sposób zarządzania zgromadzonymi w jego ramach środkami jest bardziej scentralizowany i prostszy, niż w przypadku funduszy strukturalnych. Fundusz Kohezyjny stanowi instrument oddziaływania ekonomiczno-politycznego, zależny bezpośrednio od decyzji Komisji Europejskiej. Środki pochodzące z FS wdrażane są na poziomie wybranych państw członkowskich, a nie regionów. Do korzystania ze środków finansowych funduszu uprawnione są obecnie kraje, w których poziom PNB na jednego mieszkańca jest niższy od $90 \%$ średniego poziomu dla całego ugrupowania integracyjnego. W latach 1993-1999 kryterium to odnosiło się do średniego poziomu PKB per capita. Celem Funduszu Spójności jest przebudowa najbardziej zacofanych miejsc Starego Kontynentu w tereny połączone z miejscami lepiej rozwiniętymi najnowocześniejszą infrastrukturą transportową. W ramach funduszu szczególną uwagę poświęcono rozwojowi transeuropejskiej sieci drogowej, portów morskich i lotniczych oraz zagadnieniom związanym z ochroną środowiska. Założono, że dofinansowanie właśnie w tych sferach pozwoli słabiej rozwiniętym członkom Wspólnoty na szybsze nadrobienie dzielącego je od pozostałych krajów dystansu. Od początku istnienia funduszu z dobrodziejstw jego pomocy korzystały: Grecja, Hiszpania, Irlandia i Portugalia. Od roku 2004, ze względu na przekroczenie kryterium kwalifikującego do wsparcia ze strony funduszu, pomoc tę utraciła Republika Irlandii. W miarę procesu rozszerzania się Unii beneficjentami FS stały się także, wymieniając w kolejności alfabetycznej: Bułgaria, Cypr, Czechy, Kraje Bałtyckie, Malta, Polska, Rumunia, Słowacja, Słowenia oraz Węgry. W perspektywie finansowej 2007-2013 warunek 90\% średniego PNB przestała spełniać Hiszpania. Uwzględniając trudne położenie ekonomiczne tego kraju, otrzymuje on w dalszym ciągu środki pochodzące z omawianego źródła na szczególnych zasadach przejściowych. 
Finansowanie z Funduszu Spójności odnosi się do dużych (o minimalnej kwocie $10 \mathrm{mln}$ euro) projektów inwestycyjnych na szczeblu państwowym. Nie dotyczy programów rozwoju na poziomie regionalnym. Dziedziny wspierane ze strony Funduszu Kohezyjnego dotyczą projektów inwestycyjnych w obrębie (Śliwa, Pawlicki, 2012, s. 63):

- rozwoju transportu:

- budowy autostrad i dróg ekspresowych,

- modernizacji wybranych linii kolejowych,

- budowy i modernizacji portów morskich,

- budowy i modernizacji portów lotniczych,

- ochrony środowiska naturalnego:

- budowy i modernizacji kanalizacji zbiorczej,

- oczyszczalni ścieków,

- uzdatniania wody pitnej w miastach,

- zagospodarowania odpadów komunalnych,

- regeneracji systemów ekologicznych zdegradowanych w wyniku działalności przemysłowej,

- budowy zbiorników wodnych (głównie dla celów ochrony przeciwpożarowej).

Kraje członkowskie, korzystające ze środków Funduszu Spójności, zobligowane są do prowadzenia bieżącej kontroli oraz rzetelnej oceny wdrażanych projektów. Wyniki tych poczynań są przekazywane w formie raportów do KE. Po zakończeniu inwestycji beneficjenci mają jeszcze obowiązek zbadania rezultatów zrealizowanych projektów pod kątem zwiększania spójności objętych nimi obszarów, wyniki zaś przedstawiane są Komisji Europejskiej (Oręziak, 2004a, s. 161). Przyjęty system umożliwia sprawne monitorowanie efektywności prowadzonych działań.

\subsection{Europejski Fundusz Rolny na rzecz Rozwoju Obszarów Wiejskich (EFRROW)}

Europejski Fundusz Rolny na rzecz Rozwoju Obszarów Wiejskich (EFRROW) (ang. European Agricultural Fund for Rural Development) nie jest funduszem strukturalnym. Stanowi on główny instrument wspierania realizacji Wspólnej Polityki Rolnej Unii Europejskiej (WPR). Został ustanowiony przez Radę Unii Europejskiej we wrześniu 2005 roku (Rozporządzenie Rady (WE) nr 1698/2005).

Zadaniem funduszu jest poprawa skuteczności alokacji środków finansowych $\mathrm{z}$ budżetu unijnego w odniesieniu do obszarów wiejskich. Pochodzące z fundu- 
szu pieniądze miałyby zapewnić: tworzenie nowych miejsc pracy, zrównoważony i stały rozwój oraz wpłynąć na przyspieszony wzrost gospodarczy objętych nim terenów. Fundusz uzupełnia działania na poziomie krajowym, regionalnym i lokalnym, które wspierają priorytety Unii Europejskiej, takie jak spójność i konwergencja. Ma za zadanie efektywną realizację polityki niwelowania różnic rozwojowych pomiędzy poszczególnymi regionami Wspólnoty.

Fundusz umożliwia skuteczne wdrażanie krajowych planów strategicznych poprzez programy rozwoju obszarów wiejskich, obejmujących środki skupione wokół czterech głównych osi (http://europa.eu/legislation_summaries/agriculture/general_framework/160032_pl.htm):

- I. Poprawa konkurencyjności sektora rolnego i leśnego.

- II. Poprawa środowiska naturalnego i terenów wiejskich (krajobrazu).

- III. Polepszenie jakości życia na obszarach wiejskich oraz zwiększenie zróżnicowania działalności gospodarczej.

- IV. LEADER - projekty współpracy międzyterytorialnej, a także transnarodowej, które mogą wdrażać lokalne grupy działania i związki oparte na partnerstwie publiczno-prywatnym.

Rozdysponowanie środków EFRROW dotyczy bieżącej perspektywy finansowej obejmującej lata 2007-2013. Całkowity budżet funduszu wynosi ponad 96,31 bln euro. Stanowi to około $20 \%$ funduszy przeznaczonych na prowadzenie Wspólnej Polityki Rolnej realizowanej przez europejskie ugrupowanie integracyjne. Wsparcie finansowe następuje w odpowiedzi na inicjatywę poszczególnych krajów członkowskich. Ze środków funduszu można finansować do $4 \%$ całkowitej kwoty dla każdego przyjętego programu (http://ec.europa.eu/agriculture/ cap-post-2013/legal-proposals/com627/627_pl.pdf).

Europejski Fundusz Rolny na rzecz Rozwoju Obszarów Wiejskich stanowi istotne narzędzie wdrażające pomoc i wsparcie rozwoju obszarów wiejskich; jest jedną z podstaw Wspólnej Polityki Rolnej UE.

\subsection{Europejski Fundusz Orientacji i Gwarancji Rolnej (EFOiGR)}

Europejski Fundusz Orientacji i Gwarancji Rolnej (EFOiGR) (ang. European Agricultural Guidance and Guarantee Fund) został utworzony w 1964 roku, na mocy postanowień traktatów rzymskich podpisanych w marcu 1957 roku (powoływały one do życia Europejską Wspólnotę Gospodarczą). Fundusz istniał nieprzerwanie do 2006 roku.

Do głównych zadań EFOiGR należało: wspieranie przeobrażeń strukturalnych w rolnictwie i finansowanie przekształceń rozwojowych obszarów wiejskich w państwach należących do Wspólnoty. Fundusz składał się z dwóch sekcji: 
- orientacji, zaliczanej do funduszy strukturalnych,

- gwarancji, która nie była zaliczana do funduszy strukturalnych

Sekcja orientacji wspierała finansowo projekty inwestycyjne w gospodarstwach rolnych, budowę infrastruktury obszarów wiejskich oraz pomagała w rozwoju pozarolniczej działalności gospodarczej. Ze zgromadzonych w jej ramach środków działy rolnictwa oraz leśnictwa poddawane były nowoczesnym przeobrażeniom i wzmocnieniu istniejących struktur.

Sekcja gwarancji była odpowiedzialna za finansowanie Wspólnej Polityki Rolnej Unii Europejskiej. Jej działalność koncentrowała się na zakupach interwencyjnych produktów rolnych oraz przyznawaniu bezpośrednich dotacji dla rolników.

Na Europejski Fundusz Orientacji i Gwarancji Rolnej (EFOiGR) aż do 2000 r. przeznaczane było ponad 40\% środków pochodzących z budżetu Unii Europejskiej. Było to największe samodzielne przedsięwzięcie finansowane w ramach krajów należących do Wspólnoty (http://www.funduszestrukturalne. gov.pl). Jego beneficjentami byli m.in.: rolnicy indywidualni, prywatne podmioty gospodarcze, jak również małe i średnie przedsiębiorstwa.

W 2005 roku Komisja Europejska podjęła decyzję o przesunięciu w perspektywie finansowej, przypadającej na lata 2007-2013, całości finansowania rozwoju rolnictwa i obszarów wiejskich do Wspólnej Polityki Rolnej, co oznaczało likwidację Europejskiego Funduszu Orientacji i Gwarancji Rolnej. Dla celów finansowania rozwoju rolnictwa oraz obszarów wiejskich stworzono ${ }^{1}$ zupełnie nowy instrument - Europejski Fundusz Rolny na rzecz Rozwoju Obszarów Wiejskich (EFRROW) (http://mogilany.pl/node/954). W tej chwili stanowi on główne narzędzie wspierające finansowo realizację celów regionalnych Unii Europejskiej w zakresie rolnictwa i obszarów wiejskich.

1 Europejski Fundusz Rolny na rzecz Rozwoju Obszarów Wiejskich (EFRROW) został opisany w rozdz. IV, pkt 4.6 niniejszej publikacji. 


\section{ROZDZIA V}

\section{Rozwój Polski Wschodniej}

W wyniku reformy administracyjnej z 1999 roku, przeprowadzonej na podstawie ustawy o wprowadzeniu zasadniczego trójstopniowego podziału terytorialnego państwa (Dz.U. z 1998 r. Nr 96, poz. 603), obszar Polski został podzielony na 16 województw: dolnośląskie, kujawsko-pomorskie, lubelskie, lubuskie, łódzkie, małopolskie, mazowieckie, opolskie, podkarpackie, podlaskie, pomorskie, śląskie, świętokrzyskie, wielkopolskie, warmińsko-mazurskie i zachodniopomorskie.

Województwa, które przez Unię Europejską klasyfikowane są jako regiony, to najwyższy szczebel władzy samorządowej. Średni szczebel stanowią powiaty. $\mathrm{Na}$ najniższym szczeblu znajdują się gminy jako podstawowe jednostki samorządu terytorialnego.

Nowy podział administracyjny od chwili jego wprowadzenia, czyli od 1 stycznia 1999 roku, ulegał wprawdzie niewielkim, lecz ciagłym modyfikacjom. W roku 2002 utworzonych zostało 7 nowych powiatów i jedna nowa gmina. Równocześnie w tym samym roku likwidacji uległo aż 12 podstawowych jednostek samorządu terytorialnego. W roku $2003 \mathrm{z}$ mapy kraju usunięto jeden powiat, a w 2010 r. utworzono jedną nową gminę. W zasadzie co roku mają miejsce niewielkie korekty granic województw, powiatów i gmin. Dzieje się tak najczęściej na wniosek ich mieszkańców.

Aktualnie, według stanu na 1 stycznia 2012 roku, Rzeczpospolita Polska dzieli się na 16 województw, 379 powiatów i 2479 gmin (www.ksng.gugik.gov.pl).

Przystąpienie Polski do Unii Europejskiej uwidoczniło problem rażących nierówności w rozwoju większości regionów naszego kraju w porównaniu do podobnych obszarów w państwach ugrupowania integracyjnego. Najbardziej rzucające się w oczy różnice poziomu cywilizacyjno-ekonomicznego dotyczyły wschodnich terenów naszego kraju, które zacofane, jeśli chodzi o warunki życia ludności, i tradycyjnie słabiej zaawansowane w rozwoju gospodarczym określane były jako „Polska B”. Ich istnienie stanowiło poważną przeszkodę w realizacji polityki spójności w UE. Doprowadzenie do poprawy ich sytuacji stało się istotnym wyzwaniem zarówno dla władz krajowych, jak i unijnych. 


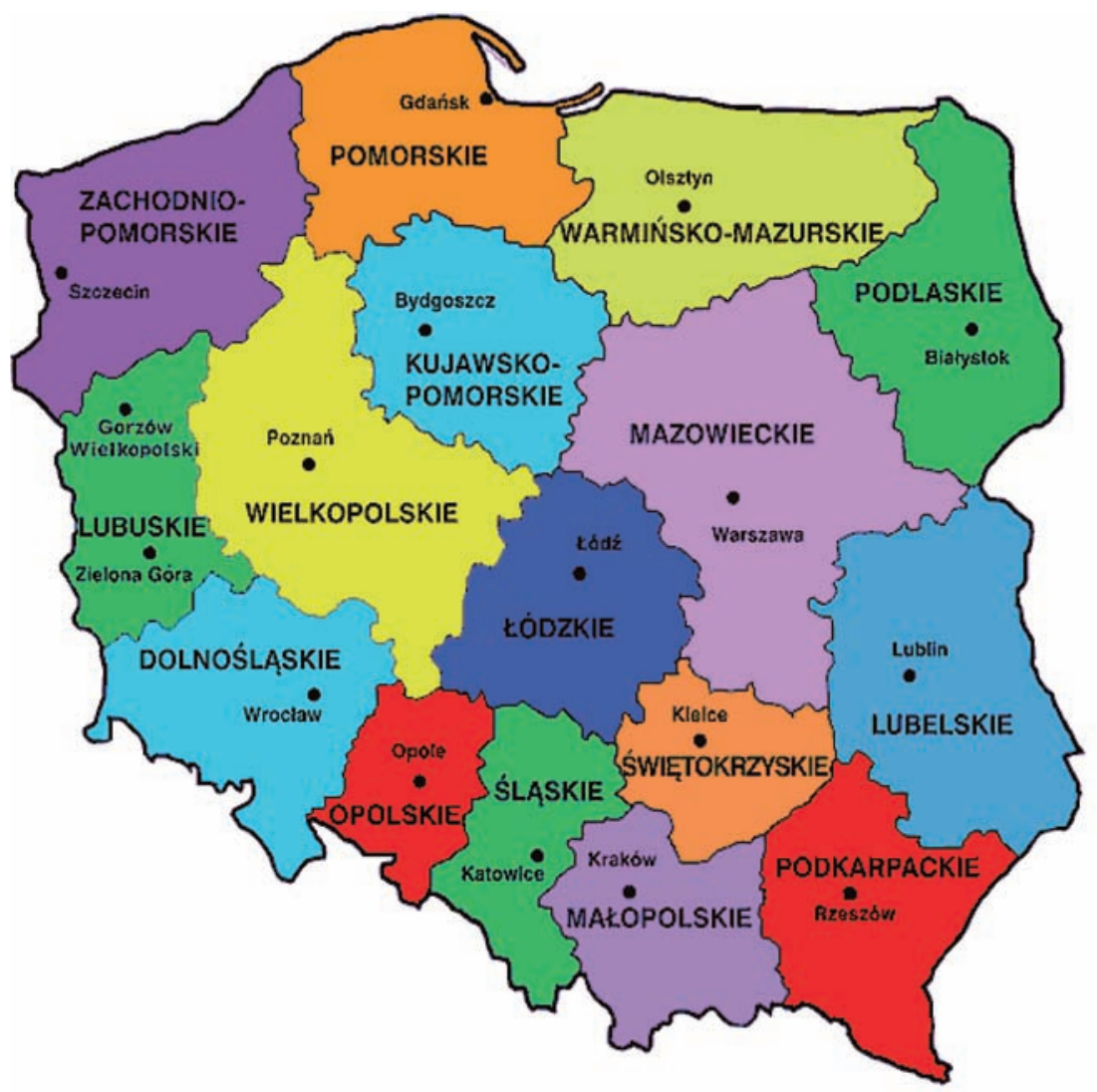

Rysunek 12. Podział administracyjny Polski (na województwa)

Źródło: www.encyklopedia.interia.pl.

\section{Charakterystyka Polski Wschodniej}

Polska Wschodnia to obszar położony na północno-wschodnich i południowo-wschodnich terenach Rzeczypospolitej. Obejmuje rubieże naszego państwa oraz jeden region umiejscowiony bliżej centrum (województwo świętokrzyskie). W potocznym użyciu funkcjonuje pojęcie „regionu Polski Wschodniej”, chociaż patrząc przez pryzmat Nomenklatury Jednostek Terytorialnych do Celów Statystycznych (NUTS), omawiane terytorium nim nie jest. Określenie to ma bardziej charakter geograficzny niż administracyjny. W sumie Polskę Wschodnią tworzy pięć województw (właściwych regionów według etymologii NUTS): 
lubelskie, podkarpackie, podlaskie, świętokrzyskie i warmińsko-mazurskie. Kryterium grupującym największe jednostki podziału terytorialnego wchodzące w jego skład jest PKB na jednego mieszkańca. W momencie wejścia Polski do Unii były to najbiedniejsze obszary nie tylko w naszym kraju, lecz także w całym ugrupowaniu integracyjnym. Ustępowały pod tym względem nawet zacofanym regionom Grecji, Hiszpanii, Irlandii, Portugalii czy Włoch. Żadne z wymienionych województw nie mogło się wykazać osiągnięciem poziomu nawet $40 \%$ PKB per capita w porównaniu do średniej unijnej. Dane dotyczące poziomu PKB na jednego mieszkańca pięciu województw Polski Wschodniej ukazuje tablica 5 .

Tablica 5. Regionalny PKB per capita dla pięciu województw Polski Wschodniej oraz dla całego kraju w momencie przystąpienia Polski do UE w 2004 r. (w porównaniu do średniej UE-27 $=100 \%$ )

\begin{tabular}{|c|l|c|}
\hline Lp. & \multicolumn{1}{|c|}{ Województwo } & $\begin{array}{c}\text { Dane dla 2004 roku } \\
\text { (w \%) }\end{array}$ \\
\hline 1. & Lubelskie & 35 \\
\hline 2. & Podkarpackie & 35 \\
\hline 3. & Podlaskie & 38 \\
\hline 4. & Świętokrzyskie & 39 \\
\hline 5. & Warmińsko-mazurskie & 39 \\
\hline 6. & POLSKA & 51 \\
\hline
\end{tabular}

Źródło: opracowanie własne na podstawie: http://epp.eurostat.ec.europa.eu.

Analizując tablicę 5 warto zwrócić uwagę, że Polska w 2004 roku jako kraj wykazywała się, jeśli chodzi o PKB na jednego mieszkańca, bardzo słabą wielkością tego wskaźnika, oscylującą zaledwie wokół połowy średniej unijnej.

Chociaż województwa Polski Wschodniej tworzą nieprzerwany ciąg połączonego ze sobą obszaru, nie stanowią jednak jednolicie zwartego terytorium. Uznając je dla celów badawczych za makroregion, można w nich wyodrębnić dwie grupy o charakterze podregionów:

- podregion północny, obejmujący województwa: podlaskie, warmińskomazurskie oraz słabiej rozwiniętą ekonomicznie północną część województwa lubelskiego;

- podregion południowy, który obejmuje województwa: podkarpackie świętokrzyskie oraz lepiej rozwiniętą gospodarczo południową część województwa lubelskiego. 
Polska Wschodnia rozciąga się na obszarze $99037 \mathrm{~km}^{2}$, co stanowi 31,7\% całkowitej powierzchni Rzeczpospolitej. Jej teren zamieszkuje ponad 8,2 mln obywateli naszego kraju. W rzeczywistości zaludnienie jest znacznie niższe. Wynika to z nierejestrowanego opływu dziesiątek tysięcy mieszkańców do innych regionów kraju i za granicę w poszukiwaniu pracy (Ignaciuk, 2010, s. 38-40). Regiony Polski Wschodniej przedstawia rysunek 13.

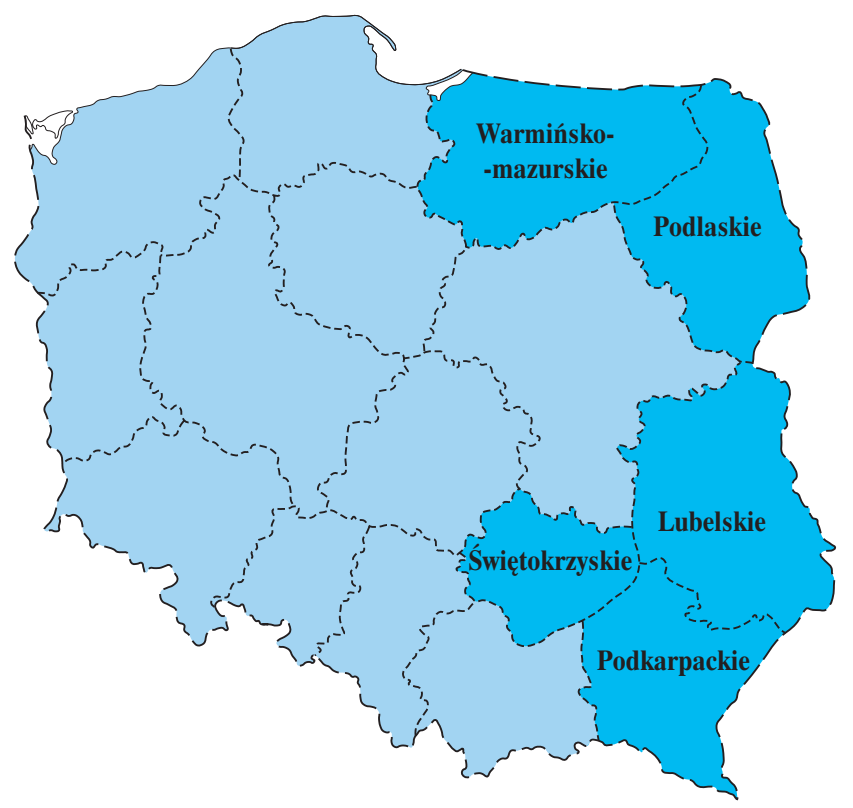

Rysunek 13. Pięć województw tworzących Polskę Wschodnią na mapie Polski Źródło: www.polskawschodnia.gov.pl.

Podregion północny jest jednym z najsłabiej rozwiniętych obszarów Polski pod względem ekonomicznym. Pozbawiony jest większych ośrodków przemysłowych i zakładów produkcyjnych, a występujące tu słabe gleby nie sprzyjają rolnictwu. Posiada natomiast niepodważalne walory turystyczne. W przeprowadzonym w 2011 roku ogólnoświatowym konkursie, mającym wyłonić nowe siedem cudów natury, położona na terenie Warmii i Mazur „Kraina tysiąca jezior" zajęła czternaste miejsce. Jest to ogromny sukces, jeśli wziąć pod uwagę, że we współzawodnictwie brało udział ponad 400 miejsc z więcej niż 200 krajów całego świata.

Podregion południowy jest bardziej uprzemysłowiony i dysponuje lepiej rozwiniętym rolnictwem. Jest mniej atrakcyjny, jeśli chodzi o walory krajobrazowe, niż podregion północny, ale posiada więcej ważnych obiektów związanych 
historią Polski, takich jak: zabytki architektoniczne, skarby kultury, skanseny i muzea. Na jego terenie znajduje się także stosunkowo duża liczba szkół i uczelni wyższych, w tym znany w Polsce i na świecie Katolicki Uniwersytet Lubelski (KUL).

\section{Województwa Polski Wschodniej}

Pięć najuboższych z szesnastu województw naszego kraju tworzy Polskę Wschodnią: lubelskie, podkarpackie, podlaskie, świętokrzyskie oraz warmińskomazurskie. Całą Polskę Wschodnią charakteryzuje: niski poziom życia mieszkańców, wysoka stopa bezrobocia, nasilona emigracja zarobkowa, zacofanie ekonomiczne, słaba aktywność gospodarcza, niewystarczające wyposażenie terenu w infrastrukturę techniczną, przemysłową oraz komunikacyjną.

\subsection{Województwo lubelskie}

Województwo lubelskie stanowi jednostkę samorządu terytorialnego i zarazem podziału administracyjnego naszego kraju. Dzieli się na 20 powiatów, 4 miasta na prawach powiatów oraz 213 gmin. Jest położone we wschodniej części Polski. Większość jego obszaru znajduje się w międzyrzeczu Bugu i Wisły. Wschodnie krańce stanowią granicę państwową Polski z Białorusią i Ukrainą. Pozostałymi sąsiadami są województwa: mazowieckie, podkarpackie, podlaskie i świętokrzyskie. Stolicą województwa jest Lublin, miasto liczące blisko 350 tysięcy mieszkańców.

Powierzchnia jaką zajmuje województwo wynosi: $25122,49 \mathrm{~km}^{2}$, co stanowi około $8 \%$ terytorium państwa i czyni go trzecim co do wielkości regionem. Według oficjalnych danych lubelskie zamieszkuje ogółem 2 171,9 tys. osób (GUS, 2012, s. 68). W styczniu 2013 roku zarejestrowanych w nim było ponad 140,9 tys. bezrobotnych, co przekłada się na liczbę 14,9\% wszystkich osób zdolnych do podjęcia pracy (www.forsal.pl). Gospodarka regionu ma charakter przemysłowo-rolniczy. Województwo lubelskie wykorzystując urodzajne gleby Wyżyny Lubelskiej i polskiej części Wyżyny Wołyńskiej, nastawione jest na rolnictwo. Uprawiane są tutaj: zboża (pszenica, jęczmień i żyto), a obok nich buraki cukrowe, rzepak, warzywa gruntowe i truskawki. Ważną rolę odgrywają plantacje drzew owocowych, tytoniu, chmielu oraz krzewów porzeczek i malin. Przemysł zlokalizowany jest głównie w okolicy największych ośrodków miejskich - elektromaszynowy w Lublinie, środków transportu w Lublinie i Świdniku, chemiczny (Zakłady Azotowe Puławy S.A.) w Puławach. W Bogdance koło 


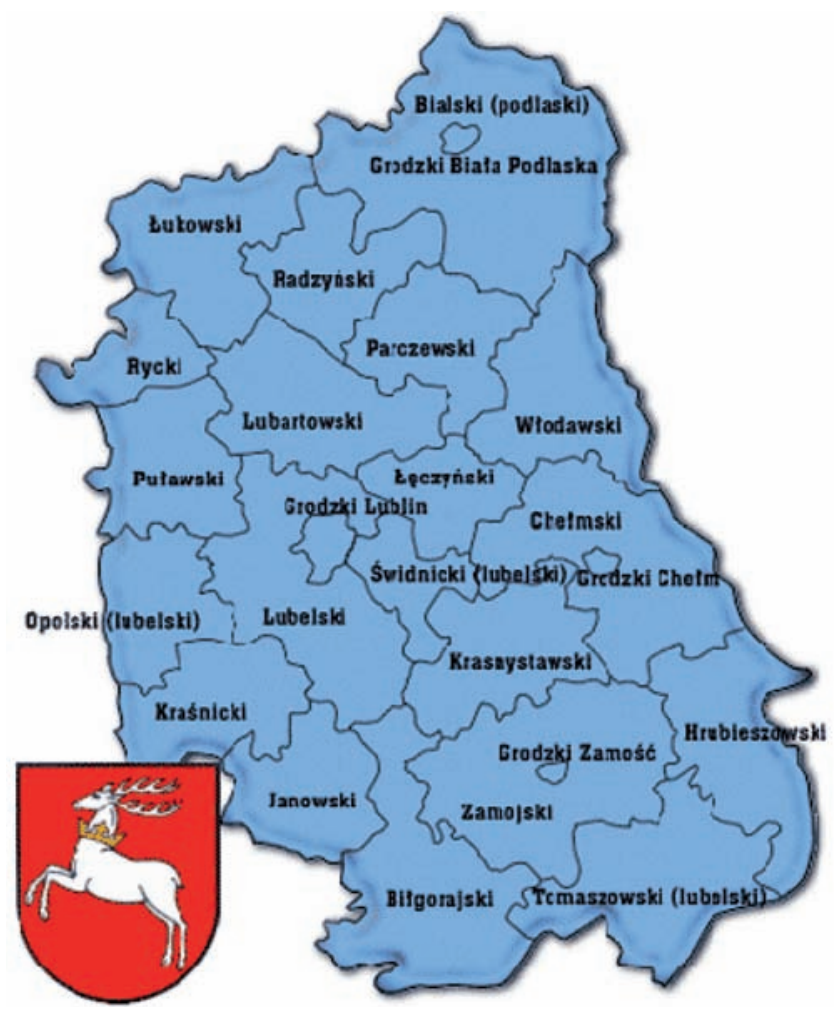

Rysunek 14. Podział administracyjny województwa lubelskiego (na powiaty) Źródło: www.albumpolski.pl

Łęcznej pracuje najbardziej dochodowa kopalnia węgla kamiennego w Polsce. Eksploatowane są także niewielkie złoża ropy naftowej i gazu ziemnego w Minkowicach i Ciecierzynie pod Lublinem i w okolicach Abramowa położonego w powiecie Lubartowskim. Najważniejszym przemysłem na terenie województwa jest spożywczy, swoją produkcję mają tu rozrzucone w różnych miejscach przedsiębiorstwa: przetwórstwa owocowo-warzywnego, mleczarskie, mięsne, piwowarskie i spirytusowe. Wobec spadającego z roku na rok popytu, coraz mniej produktów wytwarzają zakłady tytoniowe.

Wielkie znaczenie dla rozwoju ekonomicznego regionu mają usytuowane na jego terenie strefy i parki ekonomiczne oraz obszary aktywności gospodarczej, intensywnie wspierane przez władze lokalne. Obecnie na obszarze województwa działa z powodzeniem sześć Podstref Specjalnych Stref Ekonomicznych oraz cztery Obszary Aktywności Gospodarczej (www.lubelskie.pl):

- Specjalna Strefa Ekonomiczna Euro-Park Mielec - Podstrefa Lublin; 
- Tarnobrzeska Specjalna Strefa Ekonomiczna Euro-Park Wisłosan - Podstrefa Janów Lubelski;

- Starachowice S.A. - Podstrefa Puławy;

- Specjalna Strefa Ekonomiczna Euro-Park Mielec - Podstrefa Zamość;

- Tarnobrzeska Specjalna Strefa Ekonomiczna Euro-Park Wisłosan - Podstrefa Łuków;

- Tarnobrzeska Specjalna Strefa Ekonomiczna Euro-Park Wisłosan - Podstrefa Tomaszów Lubelski;

- Wolny Obszar Celny w Małaszewiczach;

- Suchy Port Przeładunkowy PKP w Gminie Terespol;

- Regionalny Park Przemysłowy w Świdniku;

- Bialska Strefa Aktywności Gospodarczej oraz teren po byłym lotnisku wojskowym w Białej Podlaskiej.

Region Lubelski jest miejscem działalności naukowo-dydaktycznej kilku znanych w całym kraju, a także za granicą wyższych uczelni. Rokrocznie wypuszczają one tysiące absolwentów, którzy znajdują zatrudnienie w przemyśle, szeroko rozumianym biznesie, administracji państwowej i samorządowej oraz szkolnictwie wszystkich szczebli. Do placówek tych należą:

- Katolicki Uniwersytet Lubelski (KUL),

- Politechnika Lubelska,

- Uniwersytet Marii Curie-Skłodowskiej w Lublinie,

- Uniwersytet Medyczny w Lublinie,

- Uniwersytet Przyrodniczy w Lublinie,

- Lubelska Szkoła Biznesu,

- Nauczycielskie Kolegium Języków Obcych w Chełmie,

- Wyższa Szkoła Oficerska Sił Powietrznych w Dęblinie (WSOSP),

- Puławska Szkoła Wyższa (PSW),

- Wyższa Szkoła Zarządzania i Administracji w Zamościu.

Dużym atutem Lubelszczyzny są walory przyrodnicze terenu. Na terenie regionu istnieje siedemnaście parków krajobrazowych oraz dwa parki narodowe:

- Poleski Park Narodowy,

- Roztoczański Park Narodowy,

które wraz z zabytkami architektury, takimi jak Kazimierz nad Wisłą, zespołami zamkowo-pałacowymi w różnym stopniu zachowania (Bochotnica, Czemierniki, Lublin, Zawieprzyce) oraz interesującymi obiektami sakralnymi różnych wyznań, przyciagają rokrocznie tysiące turystów i zwiedzających. 


\subsection{Województwo podkarpackie}

Województwo podkarpackie położone jest na samym południowo-wschodnim krańcu Polski. Zajmuje środkową część Podkarpacia, zachodni fragment Zewnętrznych Karpat Zachodnich oraz niewielki teren należący do Roztocza. Jego głównym ośrodkiem administracyjnym jest Rzeszów, liczący nieco ponad 180 tys. mieszkańców. Region dzieli się na 21 powiatów, 4 miasta na prawach powiatów oraz na 160 gmin. Od wschodu graniczy on z Ukrainą, a od południa - ze Słowacją. Pozostałymi sąsiadami są województwa: lubelskie, małopolskie i świętokrzyskie. Powierzchnia tej jednostki samorządu terytorialnego wynosi $17845,66 \mathrm{~km}^{2}$, co stanowi około 5,7\% powierzchni całego kraju i daje dopiero 11 pozycję w rankingu największych województw (www.stat.gov.pl).

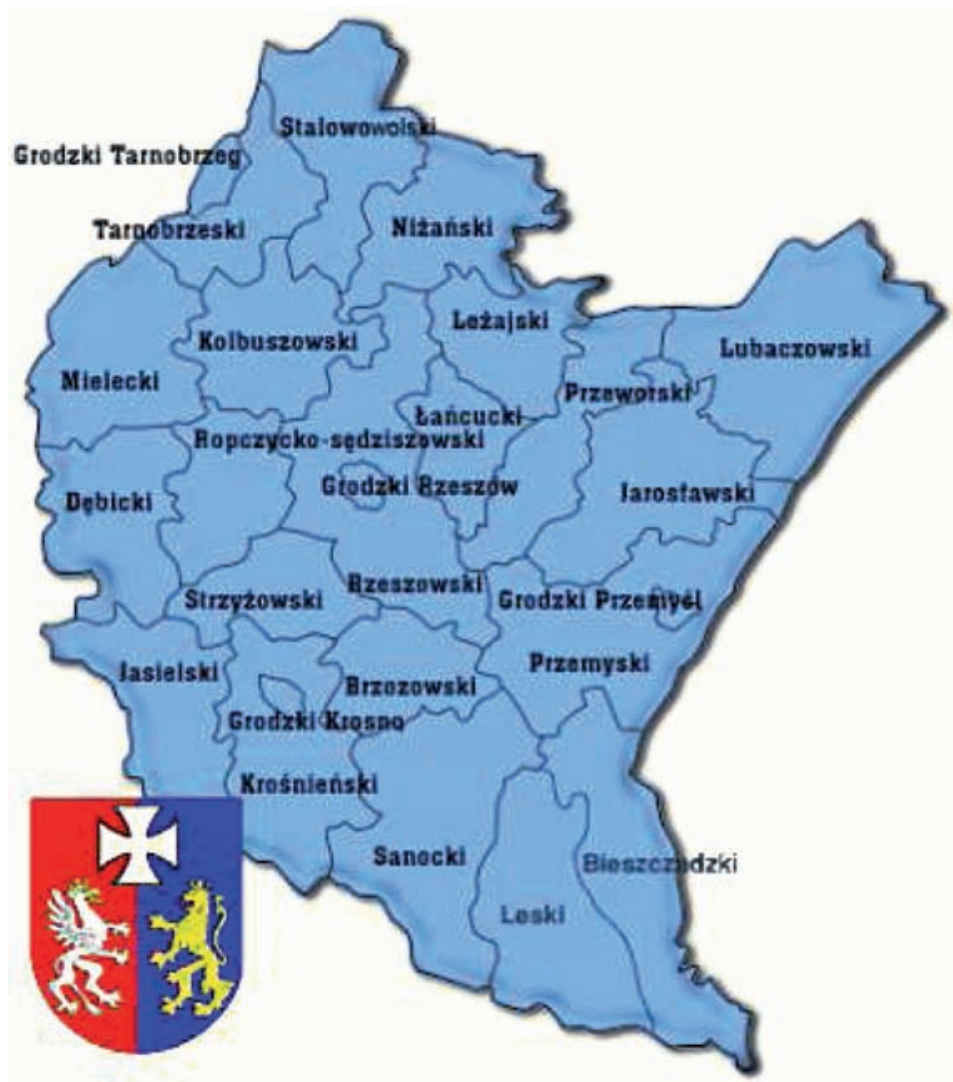

Rysunek 15. Podział administracyjny województwa podkarpackiego (na powiaty) Źródło: www.albumpolski.pl 
Według urzędowych danych województwo podkarpackie zamieszkuje 2128,7 tys. osób (GUS, 2012, s. 70). W styczniu 2013 roku zarejestrowanych w nim było ponad 163,0 tys. bezrobotnych, co przekłada się na liczbę 17,0\%, wszystkich osób zdolnych do pracy na tym terenie (www.forsal.pl). Liczba bezrobotnych jednak ustawicznie i szybko wzrasta. Stanowi to jeden z największych problemów społeczno-ekonomicznych dla władz samorządowych tego obszaru.

W gospodarce regionu istotne znaczenie ma rolnictwo. Udział użytków rolnych w stosunku do ogólnej powierzchni województwa podkarpackiego wynosi aż $44,1 \%$. Przy czym ponad $30 \%$ powierzchni województwa stanowią grunty orne. W strukturze zasiewów dominują zboża $(67,5 \%)$, a wśród nich pszenica (42,5\% zbóż ogółem). Lasy rosną tu na ponad $1 / 3$ całej powierzchni obszaru, co stanowi jeden z najwyższych wskaźników w naszym kraju. Struktura globalnej produkcji rolniczej rozkłada się prawie równo pół na pół, na produkcję roślinną oraz produkcję zwierzęcą (http://www.stat.gov.pl). Gospodarstwa rolne są jednak poważnie rozdrobnione i zajmują niewielką powierzchnię. W większości przypadków ich produkcja nie wystarcza, aby mogły stanowić jedyne źródło dochodów dla utrzymujących się z ich produkcji osób.

Ze względu na charakter gospodarki regionu ważną rolę odgrywa przetwórstwo rolno-spożywcze. $\mathrm{W}$ tej dziedzinie dominuje przemysł w branżach: mięsnej, mleczarskiej, zbożowej, owocowej, warzywnej oraz cukrowniczej (www. wrota.podkarpackie.pl).

Na terenie województwa podkarpackiego swą działalność prowadzi „Dolina Lotnicza”, czyli największy klaster przemysłowy w naszym kraju. Stowarzyszenie obejmuje 77 firm, w których zatrudnionych jest ponad 22 tys. wysoko wykwalifikowanych pracowników. Tworzą ją przede wszystkim przedsiębiorstwa związane z przemysłem lotniczym wraz z rozległym zapleczem edukacyjnoszkoleniowym. Współpracują z nimi ośrodki naukowo-badawcze w tym wiele uczelni wyższych. Ośrodkami, na których opiera się działalność „Doliny Lotniczej” są miasta wywodzące swą historię jeszcze z czasów tworzenia Centralnego Okręgu Przemysłowego (COP) w okresie międzywojennym, czyli Rzeszów, Dębica, Krosno, Mielec, Sędziszów Małopolski oraz Stalowa Wola (Grycuk, 2010, s. 3).

Na terenie województwa podkarpackiego zlokalizowane są trzy rafinerie: w Gorlicach w Jaśle i w Jedliczu. Obok ropy naftowej wydobywany jest tutaj gaz ziemny oraz występują nadające się do eksploatacji złoża siarki. Czynione są odwierty mające określić zasoby gazu łupkowego na tym obszarze.

W województwie funkcjonują dwie specjalne strefy ekonomiczne oraz trzy parki przemysłowe i ekonomiczne:

- Specjalna Strefa Ekonomiczna Euro-Park Mielec,

- Specjalna Strefa Ekonomiczna Wisłosan Tarnobrzeg,

- Mielecki Park Przemysłowy, 
- Strefa Przemysłowa „Stare Miasto Park” koło Leżajska,

- Podkarpacki Park Naukowo-Techniczny „Aeropolis” w Jasionce koło Rzeszowa.

Z licznych placówek o charakterze naukowo-badawczym i edukacyjnym działających na terenie opisywanego regionu należy wymienić:

- Uniwersytet Rzeszowski,

- Politechnikę Rzeszowską,

- Wyższą Szkołę Informatyki i Zarządzania w Rzeszowie,

- Wyższą Szkołę Prawa i Administracji w Przemyślu (WSPiA),

- Państwową Wyższą Szkołę Wschodnioeuropejską w Przemyślu,

- Podkarpacką Szkołę Wyższą w Jaśle,

- Wyższą Szkołę Gospodarki i Zarządzania w Mielcu,

- Nauczycielskie Kolegium Języków Obcych w Nisku.

Liczne zabytki sztuki sakralnej, dwory i dworki oraz wspaniałe zespoły pałacowo-zamkowe niezmiennie od wielu już lat przyciągają niezmierzone rzesze turystów i zachęcają do odwiedzenia województwa podkarpackiego. Najbardziej znanymi z tych obiektów są: późnorenesansowy zamek w Baranowie Sandomierskim oraz pałace w Łańcucie i Przeworsku. Dla miłośników zagadnień wojskowych niezwykłym przeżyciem jest możliwość obejrzenia umocnień Twierdzy Przemyśl.

Amatorów pieszych wędrówek latem, a narciarzy zimą, przyciagają swoim urokiem Bieszczady. Natomiast gratką dla przyjaciół przyrody są: Bieszczadzki Park Narodowy i leżąca w granicach regionu część Magurskiego Parku Narodowego. Do tego dochodzą tereny dziesięciu parków krajobrazowych oraz ponad dziewięćdziesiąt rezerwatów przyrody, chroniących unikalne zasoby geologiczne, wodne oraz fauny i flory.

\subsection{Województwo świętokrzyskie}

Województwo świętokrzyskie znajduje się w południowo-wschodniej Polsce. Położone jest stosunkowo blisko centrum kraju tak, że żadna z jego granic nie stanowi granicy państwa. Sąsiaduje za to aż z sześcioma województwami: mazowieckim, lubelskim, podkarpackim, małopolskim, śląskim i łódzkim. Umiejscowione na terenie Wyżyny Małopolskiej w lewostronnej części dorzecza Wisły. Od zachodu jego teren zamyka rzeka Pilica. Malowniczym elementem województwa są Góry Świętokrzyskie, najstarsza tego typu formacja w Polsce. Leżą one pośrodku Wyżyny Kieleckiej. Głównym ośrodkiem administracyjnym regionu są Kielce, liczące nieco ponad 200 tys. mieszkańców. Świętokrzyskie 
to jedna z najmniejszych obszarowo jednostek administracyjnych kraju. Na szesnaście miejsc, plasuje się dopiero na piętnastym, zajmuje bowiem powierzchnię $11710,50 \mathrm{kim}^{2}$. Jest to około 3,7\% powierzchni całego państwa. Region podzielony jest administracyjnie na: 13 powiatów, jedno miasto na prawach powiatu (Kielce) oraz 102 gminy (www.stat.gov.pl).

Według danych Głównego Urzędu Statystycznego, w województwie świętokrzyskim mieszka 1 278,2 tys. osób (2012, s. 74). W styczniu 2013 roku zarejestrowanych w nim było ponad 92,7 tys. osób bez stałej pracy, co oznacza stopę bezrobocia na poziomie 16,7\% (www.forsal.pl).

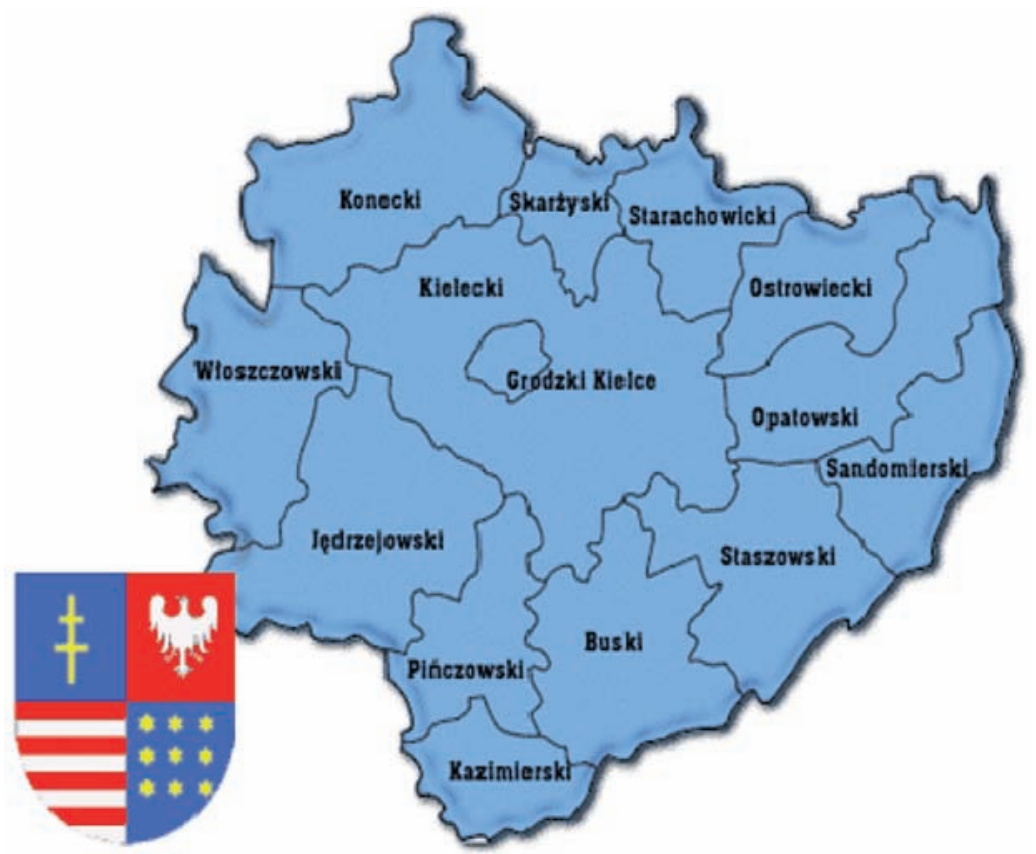

Rysunek 16. Podział administracyjny województwa świętokrzyskiego (na powiaty) Źródło: www.albumpolski.pl

Świętokrzyskie to region przemysłowo-rolniczy. Wśród gałęzi przemysłu, jakie rozwinęły się na tym terenie, można wymienić: hutniczy - Huta Ostrowiec w Ostrowcu Świętokrzyskim, maszynowy i samochodowy w Starachowicach, metalowy w Skarżysku-Kamiennej, materiałów budowlanych w Kielcach, ceramiczny wraz odlewniczym w Stąporkowie i Końskich oraz energetyczny, reprezentowany przez jedną z największych krajowych elektrowni cieplnych, położoną przy samej granicy województwa, w Połańcu. 
W Psarach pod Kielcami od 1974 roku działało jedyne w Polsce Centrum Usług Satelitarnych. Zapewniało ono kompleksową obsługę w zakresie przesyłania informacji głosowych. Jednakże jego właściciel, TP S.A, w związku z rozwojem nowych technologii przesyłania danych, zdecydował się w 2010 roku na jego likwidację.

Duże znaczenie dla pobudzania aktywności ekonomicznej w regionie ma Specjalna Strefa Ekonomiczna „Starachowice” S.A. w Starachowicach.

Województwo świętokrzyskie to również obszar, na którym prowadzone jest intensywne rolnictwo. Użytki rolne stanowią blisko 630 tys. ha. Pomimo rozdrobnienia gospodarstw i średniej jakości większości ziem, osiąga się tutaj relatywnie niezłe wyniki w zbiorach warzyw, owoców, jarzyn. W skali kraju Kielecczyzna jest również znaczącym na rodzimym rynku dostawcą: ziemniaków, zbóż, przetworów mlecznych, sera oraz masła. W regionie hoduje się duże ilości krów i trzody chlewnej, występują fermy drobiu oraz liczne stawy rybne (www.kielce.uw.gov.pl).

Na terenie województwa działają też liczne placówki naukowe kształcące przyszłych specjalistów dla biznesu, przemysłu i administracji. Tworzą je dwie państwowe uczelnie wyższe:

- Uniwersytet Jana Kochanowskiego w Kielcach,

- Politechnika Świętokrzyska w Kielcach.

Działa też kilkanaście wyższych uczelni niepublicznych, z których najbardziej znane to:

- Wyższa Szkoła Ekonomii i Prawa im. prof. Edwarda Lipińskiego w Kielcach,

- Wyższa Szkoła Umiejętności im. Stanisława Staszica,

- Wszechnica Świętokrzyska w Kielcach,

- Wyższa Szkoła Administracji Publicznej w Kielcach,

- Wyższa Szkoła Handlowa im. Bolesława Markowskiego w Kielcach,

- Wyższa Szkoła Telekomunikacji i Informatyki,

- Wyższa Szkoła Biznesu i Przedsiębiorczości w Ostrowcu Świętokrzyskim.

$\mathrm{Na}$ terenie regionu znajduje się Świętokrzyski Park Narodowy, Zespół Parków Krajobrazowych Gór Świętokrzyskich, 701 pomników przyrody, liczne rezerwaty przyrody oraz obszary chronionego krajobrazu.

Najbardziej zasobnym w zabytki sztuki i architektury jest główny ośrodek administracyjny regionu - Kielce. Jednakże w bliższej i dalszej okolicy tego miasta, można również natknąć się na ciekawe obiekty sakralne, pałacowozamkowe, muzea, skanseny oraz cmentarze należące do różnych wyznań. 


\subsection{Województwo warmińsko-mazurskie}

Województwo warmińsko-mazurskie położone jest w północno-wschodnim obszarze Polski. Zajmuje powierzchnię $24173,17 \mathrm{~km}^{2}$. Co do wielkości jest czwartym regionem naszego kraju. Podzielone jest na 19 powiatów, dwa miasta na prawach powiatów (Olsztyn i Elbląg) oraz 116 gmin. Głównym ośrodkiem administracyjnym jest Olsztyn, liczący ponad 175 tys. mieszkańców (www.stat.gov.pl).

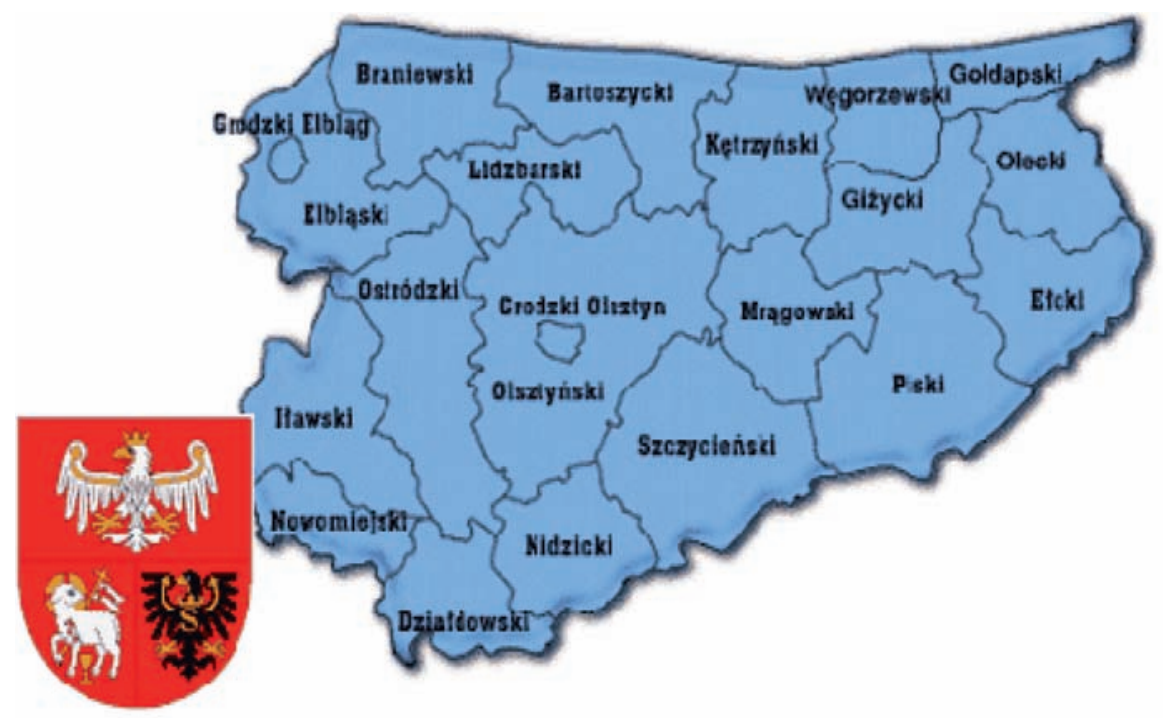

Rysunek 17. Podział administracyjny województwa warmińsko-mazurskiego (na powiaty)

Źródło: www.albumpolski.pl

Województwo warmińsko-mazurskie zamieszkuje 1 452,6 tys. osób, co stanowi około 3,8\% wszystkich obywateli Polski. Średnia gęstość zaludnienia jest jedną z najniższych w kraju i wynosi 60,06 osób na $\mathrm{km}^{2}$. Ludność jest stosunkowo młoda. Ponad 63,5\% znajduje się w wieku produkcyjnym (GUS, 2012, s. 71). W styczniu 2013 roku zarejestrowanych w nim było ponad 120,8 tys. bezrobotnych, co przekłada się na liczbę 22,2\%, wszystkich osób zdolnych do pracy na tym terenie (www.forsal.pl). Jest to najwyższa stopa bezrobocia w całym kraju. Brak pracy dotyka przede wszystkim osoby młode do 25 roku życia oraz te, które ukończyły już 50 lat.

Województwo jest najbardziej zróżnicowanym etnicznie regionem Polski. Obok siebie mieszkają i pracują liczne mniejszości narodowe i etniczne. Naj- 
więcej jest Ukraińców - około 100 000-85 000; osób deklarujących narodowość niemiecką zamieszkuje od 25000 do 30 000, Mazurów mieszka tu około 15000 , Warmiaków blisko 4000, Białorusinów jest szacunkowo od 3000 do 5000 , Romów 1000, Litwinów od 300 do 400 osób, polskich Tatarów i Rosjan po kilkadziesiąt osób. Zwyczajowo i w mowie potocznej wyróżnia się „Mazury właściwe” i „Mazury Zachodnie”, rozdziela je zaś Ziemia Warmińska. „Mazury właściwe" utożsamiane są z Krainą Wielkich Jezior Mazurskich, natomiast „Mazury Zachodnie” z Pojezierzem Iławskim (www.wojewodztwo_warminskomazurskie.info-polska.com.pl).

Południowa i wschodnia granica regionu warmińsko-mazurskiego przebiega w większości zgodnie z historycznie wyznaczoną linią oddzielająca nasz kraj od Prus Wschodnich, Prus Książęcych oraz Prus Królewskich. Na północy na odcinku ponad 200 kilometrów graniczy on z Okręgiem Kaliningradzkim, stanowiącym enklawę Federacji Rosyjskiej, wciśniętą pomiędzy Polskę i Litwę. Krajowymi sąsiadami tego obszaru są województwa, poczynając od zachodu: pomorskie, kujawsko-pomorskie, mazowieckie i podlaskie. Na północnym zachodzie region ma dostęp do Zatoki Wiślanej. Niestety nie oznacza to otwartego przejścia na Bałtyk. Ze względu na wyjątkowo nieprzychylną postawę władz rosyjskich w sprawie umożliwienia swobodnej żeglugi przez Cieśninę Piławską jednostkom pływającym z Polski, droga na pełne morze została zamknięta już kilkadziesiąt lat temu. Powoduje to powolne obumieranie portu w Elblągu. Rozwiązaniem może być od dawna rozważane przekopanie kanału przez Mierzeję Wiślaną. Jednak realizację tego pomysłu uniemożliwia brak wystarczających środków finansowych oraz sprzeciwy ekologów. W ten sposób ustanowiony całkowicie sztucznie po II wojnie światowej podział niemieckich Prus Wschodnich, rzutuje negatywnie na możliwości rozwojowe tej części obszaru, która została przyznana Polsce.

W gospodarce województwa warmińsko-mazurskiego przeważa uprawa ziemi i hodowla. Sektor rolny w regionie zajmuje 46,3\% dostępnego areału. W omawianym województwie ze względu na relatywnie słabe ziemie i surowy klimat produkuje się głównie zboża i ziemniaki, ponadto hoduje się tu: trzodę chlewną, bydło, konie, owce oraz drób. Duży nacisk położony został na produkcję proekologicznej żywności, rozwija się także gospodarkę leśną i związany z nią przemysł drzewny. Duże znaczenie ma turystyka. Na terenie Warmii i Mazur na przestrzeni ostatnich kilkunastu lat powstało wiele: stanic wodnych, ośrodków wypoczynkowych, gospodarstw ekoturystycznych, pensjonatów i eleganckich hoteli (www.wrota.warmia.mazury.pl). Wszystkie one wykorzystują unikatowe walory przyrodnicze tego terenu, nazywanego potocznie „Krainą Tysiąca Jezior”. Polodowcowe zbiorniki wodne, połączone niezliczonymi kanałami i rzeczkami, tworzą malownicze, wielokilometrowe szlaki, będące rajem dla początkujących wodniaków, jak również wymagających żeglarzy. Tutaj znajdują się największe jeziora polskie - Śniardwy i Mamry. Od 1860 roku funkcjonuje Kanał Elbląski 
stanowiący atrakcję inżynieryjną i historyczną na skalę światową. Mało kto wie, że zastosowany w nim system ,suchych śluz”, był rozważany jako ewentualne rozwiązanie dla powstałego pół wieku później Kanału Panamskiego. Ostatecznie zdecydowano się jednak w Strefie Kanałowej Stanów Zjednoczonych na wybudowanie ,śluz mokrych”.

Przemysł regionu skupia zaledwie 3\% krajowego zatrudnienia. Przeważa wytwarzanie maszyn do obróbki plastycznej metali oraz rozwinięte przetwórstwo rolno-spożywcze. Przemysł napojów alkoholowych, z ośmioprocentowym udziałem w produkcji krajowej, lokuje województwo na czwartym miejscu. Ponadto region znany jest $\mathrm{z}$ produkcji wyrobów gumowych (opony firmy Michelin w Olsztynie), mebli (IKEA w Lubawie) oraz wyrobów stolarskich, jak również, mieszczącego się w Elblągu, browaru należącego do znanej, holenderskiej firmy Heineken. Również w tym mieście produkcję turbin rozpoczął międzynarodowy koncern wywodzący się z Francji - Alstom Power. W Kętrzynie zlokalizowana jest natomiast fabryka należąca do branży elektromaszynowej - Philips Lighting. Jednakże wszystkie te zakłady razem dostarczają niecałe 2,6\% ogólnej wartości produkcji sprzedanej przemysłu w naszym kraju (www.money.pl).

Na terenie województwa usytuowana została Warmińsko-Mazurska Specjalna Strefa Ekonomiczna. Posiada ona 14 podstref w najważniejszych miastach regionu. Działają w niej obok polskich przedsiębiorców, inwestorzy zagraniczni reprezentujący: Francję, Holandię, Koreę Południową, Niemcy i Szwecję (http:// whyeasternpoland.eu).

Na terenie całego województwa znajduje się 110 rezerwatów przyrody, 71 obszarów chronionego krajobrazu, 18 zespołów przyrodniczo-krajobrazowych oraz 2576 pomników przyrody (Bochenek, 2012, s. 309).

Najbardziej znane uczelnie państwowe działające na tym terenie to:

- Uniwersytet Warmińsko-Mazurski w Olsztynie,

- Państwowa Wyższa Szkoła Zawodowa w Elblągu.

Z uczelni niepaństwowych i placówek naukowych na uwagę zasługują:

- Elbląska Uczelnia Humanistyczno-Ekonomiczna,

- Olsztyńska Wyższa Szkoła Informatyki i Zarządzania im. T. Kotarbińskiego,

- Wyższa Szkoła Informatyki i Ekonomii TWP w Olsztynie,

- Wszechnica Mazurska w Olecku,

- Wyższe Seminarium Duchowne Diecezji Elbląskiej w Elblągu,

- Instytut Rybactwa Śródlądowego w Giżycku,

- Instytut Rozrodu Zwierząt i Badań Żywności PAN w Olsztynie,

- Uniwersytecki Instytut Rozwoju Mleczarstwa w Olsztynie,

- Obserwatorium astronomiczne w Olsztynie,

- Stacja Hydrobiologiczna w Mikołajkach. 
Miłośników historii i architektury przyciągają liczne obiekty zgromadzone na tym terenie, m.in. zamki krzyżackie: w Olsztynku, Szczytnie i Węgorzewie, zamek biskupi w Lidzbarku Warmińskim, Zamek Kapituły Warmińskiej w Olsztynie, pole bitwy pod Grunwaldem, liczne katedry, kościoły i sanktuaria, cmentarze wojskowe i cywilne, dworki i pałace, interesujące budowle inżynieryjne (np.: most kolejowy w Pieniężnie, most gotycki w Reszlu, wiadukty w Stańczykach) odrestaurowana Starówka w Elblągu, miasto Mikołaja Kopernika - Frombork, mauzoleum von Farenheidów w kształcie piramidy w Rapie (ww.zabytki.mazury.pl). Jednak Warmia i Mazury kojarzą się w największym stopniu z nieograniczonymi możliwościami wodnej turystyki w obrębie licznie zgromadzonych na tym terenie jezior i rzek. W okresie zimowym do dyspozycji narciarzy stoją liczne trasy biegowe oraz trzy stacje narciarskie: Góra Czterech Wiatrów w Mrągowie, Piękna Góra koło Gołdapi, Morenowa Stacja Narciarska w miejscowości Okrągłe. Zajęcie w tym okresie znajdą dla siebie także miłośnicy: łyżew, wędkarstwa podlodowego, sportu bojerowego, sanek i karlingu.

\subsection{Województwo podlaskie}

Województwo podlaskie znajduje się w północno-wschodniej części naszego kraju. Położone jest na terenach: Niziny Podlaskiej, części Niziny Mazowieckiej oraz Pojezierza Suwalskiego. Przez środek regionu przepływa rzeka Narew. Wschodnie krańce jego obszaru stanowią granicę państwową z Litwą i Białorusią, w Polsce sąsiaduje natomiast z województwami: warmińsko-mazurskim, mazowieckim i lubelskim. Głównym ośrodkiem administracyjnym jest Białystok, liczący blisko 300 tys. mieszkańców. Region dzieli się na: 14 powiatów, trzy miasta na prawach powiatu oraz 118 gmin (www.stat.gov.pl).

Powierzchnia jaką zajmuje województwo wynosi $20187,02 \mathrm{~km}^{2}$. Podlaskie jest szóstym co do wielkości regionem w naszym państwie. Według oficjalnych danych, województwo zamieszkuje 1 201,0 tys. osób (GUS, 2012, s. 70). W styczniu 2013 roku zarejestrowanych w nim było ponad 73,8 tys. osób bez pracy, co oznacza 15,5\% wszystkich zdolnych do podjęcia zatrudnienia (www.forsal.pl). Wynik ten plasuje region na siódmym miejscu ze względu na odnotowaną stopę bezrobocia. Najważniejszym sektorem gospodarki opisywanego obszaru jest bez wątpienia rolnictwo. Działa tutaj około 120 tys. gospodarstw. Na występujących tu przeważnie lekkich glebach uprawiane są: zboża (przede wszystkim pszenica i żyto), ziemniaki, buraki cukrowe oraz kukurydza pastewna. Ważnym atutem wykorzystywanym przez rolników regionu jest największa w kraju powierzchnia użytków zielonych. Stanowią one $35,4 \%$ powierzchni upraw, z czego $13 \%$ to pastwiska, a $22,4 \%$ to łąki. Takie zagospodarowanie obszaru wyznacza kierunek 


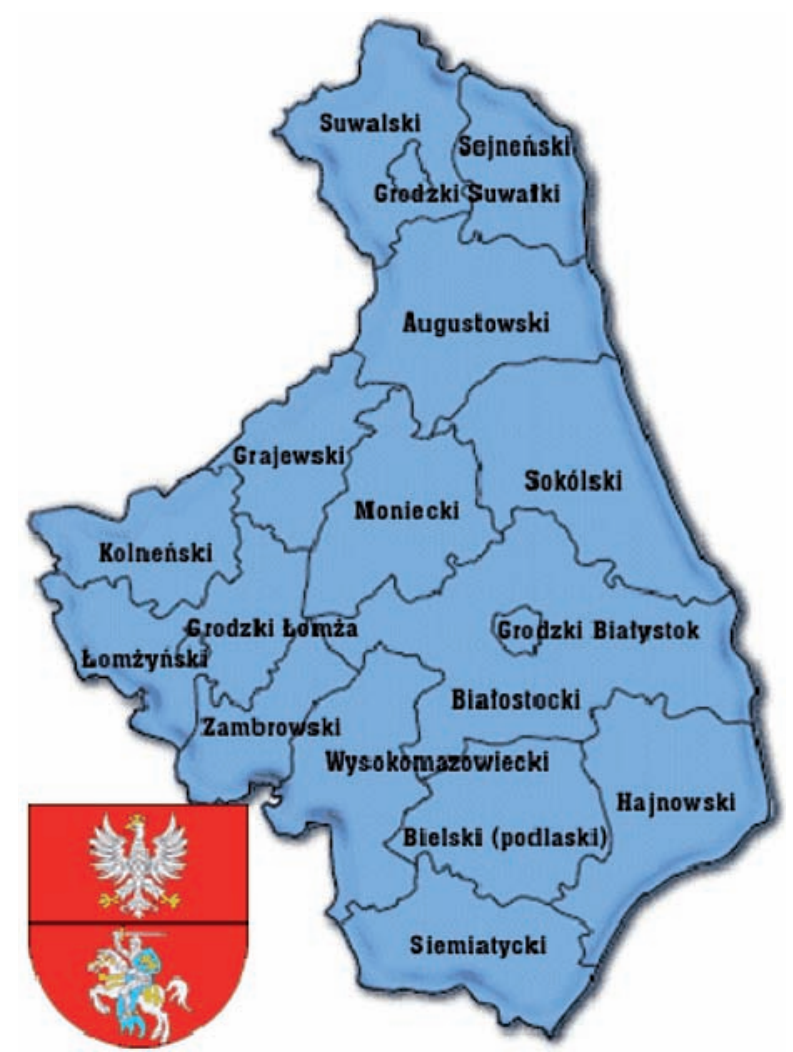

Rysunek 18. Podział administracyjny województwa podlaskiego (na powiaty) Źródło: www.albumpolski.pl.

rozwoju całego województwa. W podlaskim notuje się dynamiczny wzrost skupu mleka, na co wpływa, oprócz powierzchni użytków zielonych, stymulowanie produkcji mleka poprzez silne pozycje mleczarni. W podlaskim skupuje się około 20\% mleka w skali całego kraju (www.wrotapodlasia.pl). Powstają tutaj produkty pochodne mleka, takie jak: jogurty, kefiry i sery różnych gatunków. $\mathrm{Na}$ terenie regionu ważne znaczenie ma również przemysł przetwórczy mięsa. Znajdują się tutaj zakłady przerabiające drób, cielęcinę i wołowinę. Z innych gałęzi gospodarki, najbardziej widoczny jest przemysł drzewny. Na terenie województwa podlaskiego, głównie w oparciu na rodzimych surowcach, powstają nowoczesne i stylizowane meble, parkiety, sklejka, stolarka drzwiowa i stolarka okienna (w Sokółce), elementy konstrukcyjne niezbędne do budowy domów. Wiele $\mathrm{z}$ wytwarzanych tu produktów trafia na wymagające rynki zagraniczne, nie tylko w Europie, lecz także na innych kontynentach. 
Na terenie województwa funkcjonuje Suwalska Specjalna Strefa Ekonomiczna. Składa się na nią sześć podstref umiejscowionych w głównych miastach regionu: Suwałkach, Ełku, Gołdapi, Grajewie, Małkini Górnej i w Białymstoku. Obok polskich przedsiębiorców działają na jej terenie firmy zagraniczne reprezentujące: Austrię, Danię i Niemcy. Podmioty te należą do przemysłu: drzewnego, budowlanego, metalowego, spożywczego, tworzyw sztucznych, odzieżowego i mechaniki precyzyjnej (http://whyeasternpoland.eu).

Położone na terenie Podlasia Suwałki zostały uznane za „polski biegun zimna”. Inną ciekawostką regionu jest Geograficzny Środek Europy, umiejscowiony we wsi Suchowola w powiecie sokólskim. Znajduje się on na przecięciu linii łączących najdalej wysunięte punkty Północ-Południe i Wschód-Zachód na Starym Kontynencie. Jego położenie zostało wyznaczone w 1775 roku (www. bialystok.uw.gov.pl).

Prawdziwym bogactwem Podlasia jest zachowana w prawie nienaruszonym stanie przyroda. Aby utrzymać unikatowe w skali światowej skarby fauny i flory, ochrona prawną objęta została blisko jedna trzecia powierzchni regionu. Obok siebie istnieją tu cztery narodowe parki przyrody:

- Białowieski Park Narodowy,

- Biebrzański Park Narodowy,

- Narwiański Park Narodowy,

- Wigierski Park Narodowy.

Dodatkowo ochrona roztoczona została na trzy parki krajobrazowe:

- Suwalski Park Krajobrazowy,

- Park Krajobrazowy Puszczy Knyszyńskiej,

- Łomżyński Park Krajoznawczy Doliny Narwi.

Ponadto, staraniem władz utworzono jeszcze 88 rezerwatów przyrody, 15 obszarów chronionego krajobrazu oraz objęto opieką 2051 pomników przyrody. Województwo podlaskie zaliczone zostało do ekologicznie czystego obszaru zdefiniowanego jako: „Zielone Płuca Polski” (www.bialystok.uw.gov. pl). To określenie dobrze oddaje rangę regionu w życiu kraju.

Na terenie województwa swoja działalność edukacyjną i naukowo-badawczą prowadzi kilkanaście wyższych uczelni. Najbardziej zasłużone z nich w dziedzinie szerzenia oświaty, wiedzy i postępu to placówki państwowe:

- Uniwersytet w Białymstoku,

- Politechnika Białostocka,

- Państwowa Wyższa Szkoła Informatyki i Przedsiębiorczości w Łomży.

Istnieją tutaj również liczne uczelnie niepubliczne:

- Wyższa Szkoła Administracji Publicznej im. St. Staszica w Białymstoku, 
- Wyższa Szkoła Menedżerska w Białymstoku,

- Wyższa Szkoła Ekonomiczna w Białymstoku,

- Wyższa Szkoła Medyczna w Białymstoku,

- Wyższa Szkoła Matematyki i Informatyki Użytkowej w Białymstoku,

- Wyższa Szkoła Finansów i Zarządzania w Białymstoku,

- Wyższa Szkoła Agrobiznesu w Łomży,

- Wyższa Szkoła Wychowania Fizycznego i Turystyki w Białymstoku,

- Archidiecezjalne Wyższe Seminarium Duchowne w Białymstoku,

- Wyższa Szkoła Służby Społecznej im. ks. F. Blachnickiego w Suwałkach.

Ze względu na niezwykle bogatą mozaikę narodowościową Podlasia można zetknąć się tutaj z obiektami sakralnymi różnych wyznań takimi przykładowo, jak: kościoły i katedry rzymsko-katolickie (Białystok, Drohiczyn, Grajewo, Łomża, Sokółka, Sejny, Siemiatycze, Suwałki), cerkwie (Białowieża, Grabarka, Drohiczyn, Kleszczele, Łosinka), monastyry (Supraśl i Jabłeczna), synagogi (Ciechanowiec, Kolno, Krasnopol, Orla) oraz meczety (Bohoniki i Kruszyniany). Na opisywanym obszarze znajdują się także liczne zespoły pałacowozamkowe (Białystok, Choroszcz, Łomża, Tykocin), dwory (Chotycze, Gręzów, Korczew, Kownaty, Toporów) i dworki polskie (Chlewiska, Dąbrowa, Gałki, Nowe Iganie) (www.ciekawepodlasie.pl). Do zwiedzania zachęcają liczne szlaki turystyczne, trasy tematyczne i ścieżki rowerowe. Atutem jest także najkrótsza droga prowadząca z Polski na Litwę, jeśli ktoś ma ochotę zobaczyć zabytki Kiejdan, Kowna Taurogów, Poniewieża i Wilna.

\section{Polska Wschodnia w kontekście unijnej polityki spójności}

Dotychczasowe oddziaływanie unijnych środków finansowych na województwa należące do obszarów zdefiniowanych jako dzisiejsza Polska Wschodnia można podzielić na trzy zasadnicze okresy:

- przedakcesyjny trwający do 1 maja 2004 r.,

- od wstąpienia Polski do UE do końca trzeciej perspektywy czasowej, obejmujący lata 2004-2006,

- w obrębie trzeciej perspektywy czasowej, obejmujący lata 2007-2013.

Każdy z trzech wymienionych okresów różnił się od pozostałych poszczególnymi elementami jakie się nań składały. $Z$ najważniejszych należy tu wymienić: inną wielkość finansowych środków zaangażowanych w pomoc i wsparcie, ich przeznaczenie, efekty jakie przyniosły, specyfikację celów i zadań oraz wpływ, jaki miały na rozwój poszczególnych obszarów naszego kraju. 


\subsection{Okres przedakcesyjny}

Polska miała możliwość korzystania z pomocy finansowej pochodzącej ze wspólnotowego budżetu jeszcze przed przystąpieniem do Unii Europejskiej. Kraje kandydujące do UE od początku lat dziewięćdziesiątych objęte były programem PHARE, a od 2000 r. korzystały z trzech programów przedakcesyjnych: nowego PHARE, ISPA i SAPARD, mających przygotować nas do integracji z Unią. Programy przedakcesyjne stanowiły największe pod względem zaangażowanych kwot bezzwrotne wsparcie dla naszego kraju. Zasadniczy cel wykorzystania środków zgromadzonych w ramach pomocy unijnej stanowiła restrukturyzacja gospodarek krajów należących do ugrupowania. Przy poprzednich rozszerzeniach Unii największym problemem, jaki napotykały państwa po wstąpieniu do struktur europejskich, była mała skala zagospodarowania przyznanych do ich dyspozycji środków finansowych. Aby uniknąć nikłego procentowo wykorzystania pieniężnych środków wsparcia, władze Unii podjęły inicjatywę stworzenia trzech tzw. programów przedakcesyjnych. Pochodzące z nich środki mogły być wykorzystane do 2006 roku. Programami o których mowa były (Pluta, 2004, s. 198-212):

- PHARE (ang. Poland and Hungary - Assistance In Restructuring in their Economies), jego zadaniem było wspomaganie krajów Europy Środkowej w transformacji systemu ekonomicznego i politycznego w zdecentralizowaną gospodarkę rynkową i demokratyczne społeczeństwo oraz reintegracja gospodarcza i społeczna z UE i resztą „wolnego świata”;

- SAPARD (ang. Special Accession Program for Agriculture and Rural Development), fundusz ten działając w obrębie rolnictwa i rozwoju obszarów wiejskich, miał na celu lepsze przygotowanie krajów stowarzyszonych do członkostwa w UE; brał pod uwagę potrzeby i specyfikę małych i średnich przedsiębiorców działających na terenach wiejskich;

- ISPA (ang. Instrument for Structural Policy for pre - Accession), zadaniem tego instrumentu było przygotowanie krajów stowarzyszonych do członkostwa w Unii Europejskiej w zakresie ochrony środowiska oraz szeroko rozumianego transportu.

Obok trzech programów przedakcesyjnych pieniądze w postaci bezzwrotnych dotacji dostępne były dla zainteresowanych krajów jeszcze w ponad trzydziestu programach wspólnotowych, przeznaczonych na finansowanie różnorodnych celów, takich jak: badania naukowe, rozwój technologiczny i działania wdrożeniowe. Proces ich rozdysponowania koordynowany był centralnie przez Komisję Europejską przy wspólpracy krajowych punktów kontaktowych (Oręziak, 2004b, s. 21-32). 
Program Phare do 1999 roku dysponował w Polsce kwotą około $200 \mathrm{mln}$ euro rocznie. Wraz z uruchomieniem od 2000 roku trzech programów przedakcesyjnych, jego kwota wzrosła do ponad 900 mln euro, stąd często nazywany był „Nowym Phare”. W kolejnych latach kwoty środków finansowych pozostawione do dyspozycji programu wyniosły: w roku 2000 - 130 mln euro, w roku 2001 - 170 mln euro, w roku 2002 - 171,41 mln euro, w roku 2003 - 169,53 mln euro (Podstawy Wsparcia Wspólnoty..., 2003, s. 35-36).

W programie zostały wydzielone dwa komponenty (Nowicki, 2002, s. 48-49):

- rozwój instytucjonalny - 30\% dostępnej puli środków,

- projekty inwestycyjne - 70\% dostępnej puli środków.

Rozwój instytucjonalny to przede wszystkim stosowanie prawodawstwa do acquis communautaire (czyli: dorobek prawny UE), przygotowanie administracji do realizacji polityki Unii (w tym Funduszy Strukturalnych) oraz wzmocnienie organizacji pozarządowych. Wsparcie inwestycyjne to obok między innymi pomocy sektorowej pomoc różnym ministerstwom. Z punktu widzenia rozwoju regionalnego ważny był nowy komponent programu „Phare CBC” - spójność gospodarcza i społeczna, zwany też czasem „Phare regionalnym”, gdyż ukierunkowany był na rozwój polskich województw. Program objął w 2000 roku pięć województw (cztery wschodnie i śląskie), w 2001 - kolejne trzy, w 2002 roku było ich w sumie 11, a w roku 2003 realizowany był we wszystkich 16 województwach.

Projekty inwestycyjne to alokacja środków unijnych w zadania mające na celu przebudowę gospodarki z centralnie sterowanej w stronę wolnorynkowej oraz alokacja środków w przedsięwzięcia unowocześniające istniejącą infrastrukturę, rozwój małych i średnich przedsiębiorstw, rozwój zasobów ludzkich, program współpracy przygranicznej (Phare CBC - ang. Phare Cross-border).

ISPA jest programem w dużym stopniu scentralizowanym, który został skonstruowany na wzór Funduszu Spójności. Alokacja dla Polski wynosiła od 312 do $385 \mathrm{mln}$ euro rocznie, po połowie podzielonych na (Nowicki, 2002, s. 48-49):

- transport (główne sieci transeuropejskie),

- ochronę środowiska.

W jego ramach przeprowadzane były tylko bardzo duże projekty o wkładzie Wspólnoty powyżej $5 \mathrm{mln}$ euro. Z programu finansowane były między innymi: realizacja niektórych odcinków autostrady A4 oraz budowa nowoczesnych oczyszczalni ścieków w Krakowie i Warszawie.

Program SAPARD, jak już wspomniano, służył rozwojowi obszarów wiejskich i pomocy w przygotowaniu gospodarstw rolnych do członkostwa w Unii. Przewidziane środki dla Polski wynosiły rocznie blisko 170 milionów euro poczynając od 2000 roku. 
Programy przedakcesyjne nie $\mathrm{w}$ pełni spełniły pokładane $\mathrm{w}$ nich oczekiwania. Wskazały jednak dokładnie wszystkim zainteresowanym słabe miejsca na drodze pozyskiwania bezzwrotnych środków unijnych. Pozwoliły także na zdobycie bezcennego doświadczenia w poruszaniu się w gąszczu przepisów i procedur wspólnotowych. Zdobyta wiedza miała zaowocować w odniesieniu do podziału środków w ramach budżetu UE dopiero w nadchodzących perspektywach czasowych.

\subsection{Lata 2004-2006}

1 maja 2004 roku, wraz z przystąpieniem do Unii Europejskiej, Polska uzyskała dostęp do nowych instrumentów finansowych w ramach ugrupowania integracyjnego. Jako pełnoprawny członek rodziny krajów europejskich, otrzymaliśmy możliwość o ubiegania się o kilkukrotnie większe środki pomocowe i wsparcia, pochodzące ze wspólnego budżetu.

Nasze państwo w całości zostało zakwalifikowane do celu 1. („rozwój i strukturalne dostosowanie regionów zacofanych") ${ }^{1}$ jako obszar słabiej rozwinięty. Wyznacznikiem był wskaźnik PKB przypadający na jednego mieszkańca w odniesieniu do wszystkich województw (odpowiadających unijnemu poziomowi NUTS 2), który nie przekroczył w żadnym z regionalnych przypadków poziomu 75\% średniej unijnej w tym zakresie (Jóźwik, Sagan, 2012, s. 47). Taka ocena była dla Polski bardzo korzystna, ponieważ oznaczała, że przy korzystaniu z finansowych środków wspólnotowych wkład własny przy realizacji zaakceptowanych projektów wynosić będzie $15 \%$, zamiast $25 \%$, jak to miało miejsce przy wyższej wartości wskaźnika PKB per capita. Nasz kraj uzyskał dostęp do zasobnych w pieniądze czterech funduszy strukturalnych, przewidzianych w trzeciej perspektywie finansowej obejmującej lata 2000-2006.

Do wspomnianych funduszy strukturalnych (ang. Structural Funds) należały:

- Europejski Fundusz Rozwoju Regionalnego (ang. European Regional Development Fund - ERDF),

- Europejski Fundusz Społeczny (ang. European Social Fund - ESF),

- Europejski Fundusz Orientacji i Gwarancji Rolnej - Sekcja Orientacji (ang. European Agricultural Guidance and Guarantee Fund - EAGGF),

- Finansowy Instrument Wspierania Rybołówstwa (ang. Financial Instrument for Fisheries Suport - FIFS ).

Należy również wspomnieć, że wraz z funduszami strukturalnymi wymieniany jest często Fundusz Spójności (ang. Cohesion Fund - CF). Fundusz Spójności,

\footnotetext{
${ }^{1}$ Cel 1. został omówiony w rozdz. IV, pkt 3.
} 
nie jest jednakże funduszem strukturalnym, ze względu na odmienne procedury dostępu do zgromadzonych w jego puli środków oraz zasad ich wydatkowania. Od początku swojego istnienia ma on istotne znaczenie dla rozwoju regionalnego, ponieważ jego celem jest przebudowa najbardziej zacofanych miejsc w obrębie Europy w tereny połączone najnowocześniejszą infrastrukturą z lepiej rozwiniętymi obszarami. Szczególną uwagę zwraca on na rozwój sieci dróg oraz zagadnienia związane $\mathrm{z}$ ochroną środowiska.

Wdrażanie środków pochodzących z funduszy unijnych następowało za pomocą siedmiu sektorowych programów operacyjnych (SPO), ukierunkowanych na realizację następujących celów (Śliwa, 2006, s. 112-128):

- Wzrost konkurencyjności przedsiębiorstw (SPO WKP),

- Rozwój zasobów ludzkich (SPO RZL),

- Transport (SPO Transport),

- Rybołówstwo i Przetwórstwo Ryb (SPO RYBY),

- Zintegrowany Program Operacyjny Rozwoju Regionalnego (ZPORR),

- Pomoc Techniczna (SPO PT),

- Restrukturyzacja i Modernizacja Sektora Żywnościowego oraz Rozwój Obszarów Wiejskich (SPO ROL).

Obok programów wspólnotowych, funduszy przedakcesyjnych i strukturalnych oraz Funduszu Spójności, istniały cztery inicjatywy wspólnotowe (Community Initiatives - CI) w postaci programów pomocy bezzwrotnej dla wybranych środowisk i grup społecznych w krajach UE. Omawiane inicjatywy dotyczyły następujących problemów:

- $\boldsymbol{E Q U A L}$ - pomocy w zwalczaniu przejawów dyskryminacji i nierówności na rynku pracy oraz wspieraniu inicjatyw w kierunku integracji społecznej;

- URBAN - działaniu w ramach projektów mających jako cel rozwój infrastruktury miast europejskich liczących powyżej 100 tys. mieszkańców;

- INTERREG - rozwijaniu i wzmacnianiu współpracy transgranicznej, międzyregionalnej oraz międzynarodowej;

- LEADER - wspomaganiu wdrażania nowoczesnych strategii rozwoju terenów wiejskich.

Na inicjatywy wspólnotowe zostało przeznaczonych relatywnie niewiele środków finansowych pochodzących z budżetu Unii Europejskiej, dlatego też miały one stosunkowo niewielkie znaczenie i ograniczony zasięg. Natomiast największe i najważniejsze kwoty, służące do rozpoczęcia długotrwałego procesu integracji przyszłych państw członkowskich z pozostałymi krajami Unii, to pieniądze pochodzące z funduszy strukturalnych i z Funduszu Spójności. W Polsce były one wdrażane za pomocą Sektorowych Programów Operacyjnych (SPO). 
Tablica 6. Finansowe środki wsparcia i interwencji przeznaczone dla Polski w ramach funduszy i instrumentów unijnych na lata 2004-2006

\begin{tabular}{|l|c|c|}
\hline \multicolumn{1}{|c|}{ Pochodzenie środków unijnych } & $\begin{array}{c}\text { Wysokość } \\
\text { środków } \\
\text { finansowych } \\
\text { (w tys. euro) }\end{array}$ & $\begin{array}{c}\text { W odniesieniu } \\
\text { do całości } \\
\text { środków } \\
\text { finansowych } \\
\text { (ca) } \text { (w \%) }\end{array}$ \\
\hline Europejski Fundusz Rozwoju Regionalnego (ERDF) & 4.893 .400 & 39 \\
\hline Europejski Fundusz Społeczny (ESF) & 1.880 .400 & 15 \\
\hline $\begin{array}{l}\text { Europejski Fundusz Orientacji i Gwarancji Rolnej } \\
\text { (EAGGF) }\end{array}$ & 1.245 .000 & 10 \\
\hline Finansowy Instrument Wspierania Rybołówstwa (FIFS) & 257.000 & 2 \\
\hline Razem środki funduszy strukturalnych (SF) & 8.275 .800 & 66 \\
\hline Fundusz Spójności (CF) & 4.178 .800 & 34 \\
\hline $\begin{array}{l}\text { Razem środki wsparcia i interwencji w ramach funduszy } \\
\text { i instrumentów unijnych }\end{array}$ & 12.454 .600 & 100 \\
\hline
\end{tabular}

Źródło: opracowanie własne na podstawie danych z: Departament Wdrażania Programów Rozwoju Regionalnego (2006); Śliwa (2006).

Wielkość finansowych środków z funduszy Unii Europejskiej, rozdysponowanych za pomocą Sektorowych Programów Operacyjnych (SPO) ukazuje tablica 6.

Podobnie jak w przypadku Polski, zasadniczym problemem, który napotykały państwa wstępujące do ugrupowania integracyjnego (Grecja, a następnie Hiszpania i Portugalia), była mała skuteczność zagospodarowania przyznanych do ich dyspozycji środków finansowych. Aby uniknąć nikłego procentowo wykorzystywania środków wsparcia pochodzących z funduszy, Unia opierając się na doświadczeniach nabytych podczas „południowego rozszerzenia”, stworzyła „fundusze przedakcesyjne” (wymienione wcześniej: PHARE, SAPARD, ISPA). Oprócz wymiernych korzyści finansowych, miały one służyć do nabycia niezbędnych umiejętności przy skomplikowanych procedurach związanych z ubieganiem się o dofinansowanie ze środków wspólnotowych (Przygoda, 2008a, s. 35).

Łączna suma wszystkich środków finansowych zaangażowanych w realizację strategii rządowej ujętej w oficjalnym dokumencie sejmowym pt.: „Narodowy Plan Rozwoju na lata 2004-2006 ” (Dz.U. z 2004 r. Nr 116, poz. 1206), została określona na ponad 16 mmld euro. Przeważająca część tej kwoty miała pochodzić z funduszy strukturalnych, Funduszu Spójności oraz inicjatyw wspólnotowych (12 454600 tys. euro - co daje około 77,8\% wszystkich środków), reszta zaś (ponad 3500000 tys. euro - ca 22,2\%) ze środków krajowych i prywatnych. 
Zarówno treść, jak i struktura sektorowych programów operacyjnych (SPO) określona została w odniesieniu do celów i strategii opisanych w Narodowym Planie Rozwoju (NPR). Natomiast podział środków strukturalnych, użytych na realizację każdego z siedmiu programów sektorowych, był odbiciem stopnia ich ważności w dziele budowania podstaw wzrostu konkurencyjności i spójności Polski i jej regionów z regionami i krajami Unii Europejskiej (Przygoda, 2008a, s. 36).

Najwięcej środków miały zaabsorbować (Ministerstwo Rozwoju Regionalnego, 2006):

- Zintegrowany Program Operacyjny Rozwoju Regionalnego (ZPORR) 3996500 tys. euro;

- Wzrost Konkurencyjności Przedsiębiorstw (SPO WKP) - 1886700 tys. euro;

- Rozwój Zasobów Ludzkich (SPO RZL) - 1755500 tys. euro;

- Restrukturyzacja i Modernizacja Sektora Żywnościowego oraz Rozwój Obszarów Wiejskich (SPO ROL) - 1322900 tys. euro.

Do końca 2004 roku udało się Polsce wykorzystać jedynie około 24,8\% przyznanych jej pieniędzy unijnych. Daje to obraz kolosalnych kłopotów, na jakie natrafiali potencjalni beneficjenci podczas starania się o wspólnotową pomoc i wsparcie finansowe. Odpowiednio wczesne dostrzeżenie tego problemu przez stronę rządową umożliwiło podjęcie negocjacji z Unią Europejską na temat wydłużenia czasu wykorzystania postawionych do dyspozycji środków. Rozmowy zakończyły się sukcesem, umożliwiając czerpanie z zasobów wspólnotowych aż do 2008 roku, przy projektach rozpoczętych przed datą 31 grudnia 2006 roku. Tablica 7 ukazuje stopień wykorzystania środków unijnych przeznaczonych dla Polski na lata 2004-2006 (według danych Ministerstwa Rozwoju Regionalnego z końca 2006 roku).

W latach 2004-2006 z przyznanych środków udało się w naszym kraju wykorzystać około 8,6 mld euro. Pochodziły one z czterech funduszy strukturalnych (ERDF, ESF, EAGGF, FIFS). Posłużyły zaś jako współfinansowanie w postaci wsparcia dla siedmiu sektorowych programów operacyjnych. W kwocie tej zawarte zostały również środki finansowe pochodzące $\mathrm{z}$ dwóch programów inicjatyw wspólnotowych (EQUAL i INTERREG). Dodatkowe środki w kwocie około 4,2 mld euro zostały przyznane do dyspozycji naszego kraju w ramach Funduszu Spójności (FS). Największą i najbardziej efektywną grupę beneficjentów ubiegających się o dofinansowanie realizacji projektów ze środków funduszy strukturalnych stanowity jednostki samorządu terytorialnego. Drugą co do wielkości grupą były: administracja rządowa, jednostki wykonujące zadania zlecone administracji rządowej oraz państwowe jednostki budżetowe. Trzecią grupę stanowili przedsiębiorcy, przeznaczający uzyskane środki na przedsięwzięcia inwestycyjne i modernizacyjne (Przygoda, 2008b, s. 37). 
Tablica 7. Stopień wykorzystania środków finansowych pochodzących z funduszy strukturalnych oraz inicjatyw wspólnotowych w odniesieniu do sektorowych programów operacyjnych w latach 2004-2006 (w \%)*

\begin{tabular}{|r|l|c|}
\hline Lp. & $\begin{array}{c}\text { Nazwa sektorowego programu operacyjnego (SPO) } \\
\text { (lub środków pochodzących z inicjatyw wspólnotowych) }\end{array}$ & $\begin{array}{c}\text { Stopień wykorzystania } \\
\text { śodków (w \%) }\end{array}$ \\
\hline 1. & Wzrost Konkurencyjności Przedsiębiorstw & 18,0 \\
\hline 2. & Rozwój Zasobów Ludzkich & 27,7 \\
\hline 3. & Transport & 8,7 \\
\hline 4. & Rybołówstwo i Przetwórstwo Ryb & 34,4 \\
\hline 5. & Zintegrowany Program Operacyjny Rozwoju Regionalnego & 29,9 \\
\hline 6. & Pomoc Techniczna & 23,0 \\
\hline 7. & Restrukturyzacja i Modernizacja Sektora Żywnościowego & 33,6 \\
\hline 8. & EQUA Rozwój Obszarów Wiejskich & 13,5 \\
\hline 9. & INTERREG & 5,9 \\
\hline 10. & Razem & $\mathbf{2 4 , 8}$ \\
\hline
\end{tabular}

* Dotyczy wszystkich programów zgłoszonych i realizowanych o stopniu alokacji środków co najmniej 7,5\% do końca 2006 roku. Umożliwia to ich całkowite ukończenie do 2008 roku.

Źródło: opracowanie własne na podstawie danych z: Departament Wdrażania Programów Rozwoju Regionalnego (2006).

Wsparcie i pomoc przyznane przez Unię Europejską dla poszczególnych regionów były bardzo zróżnicowane. W omawianych latach 2004-2006 najwięcej środków finansowych otrzymały cztery najbogatsze polskie województwa: mazowieckie, śląskie, dolnośląskie oraz wielkopolskie. W sumie zostało im przyznanych około $45 \%$ pieniędzy ze wspólnotowego budżetu dla naszego kraju. Pięć województw Polski Wschodniej otrzymało tylko 17\% środków pochodzących z ogólnej puli (Jóźwik, Sagan, 2012, s. 49). Zamiast zniwelować, pogłębiło to jedynie istniejące dotychczas różnice rozwojowe. Ilość środków, jakie zostały przyznane najsłabiej rozwiniętym regionom naszego kraju, ukazuje tablica 8 .

Lubelszczyzna była trzecim w kolejności regionem w naszym kraju pod względem ilości dotowanych projektów przy wykorzystaniu unijnego wsparcia. W sumie na terenie tego województwa zostało zakwalifikowanych do realizacji 8796 przedsięwzięć. Świadczy to dobrze o skali mobilizacji wszystkich grup beneficjentów przy ubieganiu się o unijną pomoc i wsparcie finansowe oraz o dobrze wykorzystanym czasie na naukę procedur wspólnotowych w okresie przedakcesyjnym. 
Tablica 8. Ilość pomocowych środków unijnych przyznanych województwom Polski Wschodniej w latach 2004-2006

\begin{tabular}{|c|l|c|c|}
\hline Lp. & \multicolumn{1}{|c|}{ Województwo } & $\begin{array}{c}\text { Ilość przyznanych środków } \\
\text { unijnych } \\
\text { (w mld } \mathbf{~ z l})\end{array}$ & $\begin{array}{c}\text { Ilość przyznanych środków } \\
\text { unijnych } \\
(\mathbf{w} \%)^{*}\end{array}$ \\
\hline 1. & Lubelskie & 4,03 & 4,1 \\
\hline 2. & Podkarpackie & 3,58 & 3,7 \\
\hline 3. & Podlaskie & 2,70 & 2,7 \\
\hline 4. & Swiętokrzyskie & 2,60 & 2,6 \\
\hline 5. & Warmińsko-mazurskie & 3,88 & 3,9 \\
\hline 6. & Razem & 16,79 & 17,0 \\
\hline
\end{tabular}

* W przybliżeniu, w odniesieniu do puli środków krajowych.

Źródło: opracowanie własne na podstawie: Szafran (2012, s. 50).

\subsection{Czwarta perspektywa finansowa obejmująca lata $2007-2013$}

W ramach czwartej perspektywy finansowej Unia Europejska określiła główne cele do osiaggnięcia przez całe ugrupowanie integracyjne w ramach polityki regionalnej. Cele polskiej polityki pokrywają się w tym zakresie ze wspólnotowymi. W obu przypadkach mają one prowadzić do spójności społecznej, gospodarczej i terytorialnej w zjednoczonej Europie.

5 lipca 2005 roku Komisja Europejska opublikowała projekt dokumentu pt. „Polityka spójności wspierająca wzrost gospodarczy i zatrudnienie: Strategiczne Wytyczne Wspólnoty” (http://www.funduszeeuropejskie.gov.pl). Projekt zawierał najważniejsze wytyczne w sprawie spójności gospodarczej, społecznej oraz terytorialnej określające ramy interwencji wykorzystania środków zgromadzonych $\mathrm{w}$ funduszach. Projekt ten poprzedzily zapisy zawarte w strategii lizbońskiej, czyli dziesięcioletnim planie rozwoju przyjętym dla państw Unii przez Radę Europejską na posiedzeniu w stolicy Portugalii w roku 2000. $\mathrm{Na}$ podstawie strategii lizbońskiej oraz założeń Strategicznych Wytycznych Wspólnoty dla Spójności, Polska opracowała Narodowe Strategiczne Ramy Odniesienia 2007-2013, które integrują główne priorytety Wspólnoty z priorytetami polskimi. Dokument, dotyczący lat 2007-2013, został opracowany w celu realizacji na terytorium naszego kraju polityki spójności Unii Europejskiej. Narodowe Strategiczne Ramy Odniesienia (NSRO), stanowiły podstawę do programowania interwencji Europejskiego Funduszu Rozwoju Regionalnego, Europejskiego Funduszu Społecznego oraz Funduszu Spójności. 
W tym miejscu należy jeszcze wspomnieć, że pod koniec listopada 2006 roku Rada Ministrów przyjęła ważny dokument - Strategię Rozwoju Kraju na lata 2007-2015. Początkowo, podobnie jak Narodowe Strategiczne Ramy Odniesienia, dotyczył on lat 2007-2013, ale aby mógł być kompatybilny z unijną zasadą finansowania projektów $(n+2)$, jego horyzont czasowy został wydłużony o dwa lata. Daje to możliwość planowania przedsięwzięć rozpoczętych przed końcem 2013 roku. Strategia Rozwoju Kraju (SRK) jest nadrzędnym, wieloletnim dokumentem strategicznym, dotyczącym zagadnień rozwoju społecznogospodarczego naszego państwa. Stanowi platformę koordynacyjną dla innych strategii i programów rządowych, jak również zamierzeń i planów opracowywanych przez jednostki samorządu terytorialnego. Jest krajowym dokumentem o charakterze wewnętrznym (www.mrr.gov.pl). Cele wymienionych czterech dokumentów przedstawia tablica 9.

Tablica 9. Spójność celów w odniesieniu do dokumentów określających kierunki rozwoju regionalnego na lata 2007-2013

\begin{tabular}{|c|c|}
\hline $\begin{array}{c}\text { Nazwa } \\
\text { dokumentu }\end{array}$ & Cele szczegółowe w ramach dokumentu \\
\hline $\begin{array}{l}\text { Strategia } \\
\text { lizbońska }\end{array}$ & $\begin{array}{l}\text { - rozwój przedsiębiorczości } \\
\text { - poprawa spójności społecznej } \\
\text { - innowacyjność } \\
\text { - przeobrażenia telekomunikacji, energii, transportu i usług }\end{array}$ \\
\hline $\begin{array}{l}\text { Strategiczne } \\
\text { Wytyczne } \\
\text { Wspólnoty } \\
\text { dla } \\
\text { Spójności }\end{array}$ & $\begin{array}{l}\text { - uczynienie z Europy i jej regionów miejsca bardziej atrakcyjnego dla } \\
\text { inwestowania i pracy } \\
\text { - stworzenie większej liczby lepszych miejsc pracy } \\
\text { - rozwój wiedzy i innowacyjności na rzecz wzrostu gospodarczego } \\
\text { - działania polityki spójności w wymiarze terytorialnym }\end{array}$ \\
\hline $\begin{array}{l}\text { Strategia } \\
\text { Rozwoju } \\
\text { Kraju }\end{array}$ & $\begin{array}{l}\text { - wzrost konkurencyjności i innowacyjności gospodarki } \\
\text { - poprawa infrastruktury technicznej i społecznej } \\
\text { - wzrost zatrudnienia i podniesienie jakości miejsc pracy } \\
\text { - budowa zintegrowanej wspólnoty społecznej i jej bezpieczeństwa } \\
\text { - rozwój obszarów wiejskich } \\
\text { - rozwój regionalny i podniesienie spójności terytorialnej }\end{array}$ \\
\hline $\begin{array}{l}\text { Narodowe } \\
\text { Strategiczne } \\
\text { Ramy } \\
\text { Odniesienia }\end{array}$ & $\begin{array}{l}\text { - tworzenie warunków trwałego i wysokiego wzrostu gospodarczego } \\
\text { - wzrost zatrudnienia poprzez rozwój kapitału ludzkiego i społecznego } \\
\text { - podniesienie konkurencyjności polskich firm i sektora usług } \\
\text { - budowa i modernizacja infrastruktury technicznej regionów i kraju } \\
\text { - wzrost konkurencyjności Polski i jej regionów } \\
\text { - rozwój obszarów wiejskich i przeciwdziałanie ich marginalizacji } \\
\text { społecznej, gospodarczej i przestrzennej }\end{array}$ \\
\hline
\end{tabular}

Źródło: Czemiel-Grzybowska (2010, s. 31). 
Najważniejszy, w wymiarze krajowym, dokument - Narodowe Strategiczne Ramy Odniesienia dotyczy określenia zadań i środków, jakie rząd polski zamierzał podjąć w wyszczególnionym okresie dla zapewnienia ugruntowanego wzrostu gospodarczego, podniesienia konkurencyjności oraz zwiększenia zatrudnienia. NSRO stanowią również podstawę stworzenia skutecznej pomocy na rzecz regionów i grup społecznie marginalizowanych oraz realizacji wsparcia w restrukturyzacji sektorów i regionów problemowych.

Zaplanowana, łączna wielkość środków finansowych w ramach realizacji Narodowych Strategicznych Ram Odniesienia w latach 2007-2013 ma wynieść około 74,6 mld euro. Będą to zatem środki ponad 4,6 razy większe niż te, które dotyczyły lat 2004- 2006. Z kwoty 74,6 mld euro aż około 59,5 mld euro (co stanowi ca 79,7\% wszystkich pieniędzy) stanowić mają środki alokacji wspólnotowej pochodzące z trzech funduszy (Funduszu Spójności, Europejskiego Funduszu Społecznego oraz Europejskiego Funduszu Rozwoju Regionalnego).

Około 9,8 mld euro (ca 13,1\%) stanowić ma publiczny wkład krajowy (to jest środki pochodzące z budżetu państwa oraz budżetów jednostek samorządu terytorialnego) w projekty i przedsięwzięcia współfinansowane ze źródeł budżetu wspólnoty. Natomiast środki prywatne zaangażowane w realizację Narodowych Strategicznych Ram Odniesienia będą kwotą około 5,3 mld euro (co stanowić będzie ca 7,1\% całości). Przedsięwzięcia realizowane z budżetu polityki spójności zostaną dodatkowo uzupełnione wkładem ze środków Wspólnej Polityki Rolnej (około 11,8 mld euro) i Wspólnej Polityki Rybackiej (około 0,6 mld euro). Lącznie to około 12,4 mld euro (Przygoda, 2008b, s. 38).

Tablica 10. Wielkość środków finansowych z budżetu Unii Europejskiej przeznaczonych na politykę spójności do wykorzystania w ramach Narodowych Strategicznych Ram Odniesienia

\begin{tabular}{|c|l|c|}
\hline Lp. & Nazwa funduszu, z którego pochodzą środki finansowe & $\begin{array}{c}\text { Wielkość środków } \\
\text { w odniesieniu do całości } \\
\text { środków unijnych } \\
(\mathbf{w} \%)\end{array}$ \\
\hline 1. & Europejski Fundusz Rozwoju Regionalnego (ERDF) & 52 \\
\hline 2. & Europejski Fundusz Społeczny (ESF) & 15 \\
\hline 3. & Razem środki z funduszy strukturalnych & $\mathbf{6 7}$ \\
\hline 4. & Fundusz Spójności (CF) & 33 \\
\hline 5. & Razem środki z funduszy unijnych & $\mathbf{1 0 0}$ \\
\hline
\end{tabular}

Źródło: opracowanie własne na podstawie: Ministerstwo Rozwoju Regionalnego (2006). 
W ramach Narodowych Strategicznych Ram Odniesienia środki pochodzące z Europejskiego Funduszu Społecznego w wysokości aż 70\% zostały przeznaczone na wsparcie regionów. Pozostałe $30 \%$ pieniędzy zaplanowano wdrożyć w układzie sektorowym. Alokacja Funduszu Spójności w całości została skierowana na realizację przedsięwzięć w ramach programu Operacyjnego „Infrastruktura i Środowisko". Szczegółowy podział funduszy strukturalnych w Polsce przedstawiony został $\mathrm{w}$ tablicy 11 .

Tablica 11. Podział funduszy strukturalnych w Polsce na poszczególne programy operacyjne

\begin{tabular}{|c|l|c|c|}
\hline Lp. & \multicolumn{1}{|c|}{ Nazwa programu operacyjnego } & $\begin{array}{c}\text { Wielkość } \\
\text { środków } \\
\text { (w mld euro) }\end{array}$ & $\begin{array}{c}\text { Wielkość środków } \\
\text { w odniesieniu } \\
\text { do całości } \\
\text { zgromadzonej } \\
\text { w funduszach } \\
\text { strukturalnych (w \%) }\end{array}$ \\
\hline 1. & 16 Regionalnych Programów Operacyjnych & 15,9 & 26,8 \\
\hline 2. & PO Rozwój Polski Wschodniej & 2,2 & 3,6 \\
\hline 3. & PO Europejskiej Współpracy Terytorialnej & 0,6 & 1,0 \\
\hline 4. & PO Infrastruktura i Środowisko & 21,3 & 35,7 \\
\hline 5. & PO Innowacyjna Gospodarka & 7,0 & 11,7 \\
\hline 6. & PO Kapitał Ludzki & 8,1 & 13,7 \\
\hline 7. & PO Pomoc Techniczna & 0,2 & 0,4 \\
\hline 8. & Razem* & $\mathbf{5 5 , 3}$ & $\mathbf{9 2 , 9}$ \\
\hline
\end{tabular}

* Pozostałe środki (7,1\% całości - ca 4,2 mld euro) w ramach obu funduszy strukturalnych oraz Funduszu Spójności zostaną przeznaczone na utworzenie trzech rezerw na poziomie Narodowych Strategicznych Ram Odniesienia.

Źródło: opracowanie własne na podstawie: Ministerstwo Rozwoju Regionalnego (2006).

Podział środków z Europejskiego Funduszu Rozwoju Regionalnego i Europejskiego Funduszu Społecznego na poszczególne regiony w ramach 16 Regionalnych Programów Operacyjnych został wykonany przy zastosowaniu specjalnych algorytmów uwzględniających: zróżnicowanie wojewódzkie dotyczące poziomu życia, liczbę ludności, stopę bezrobocia w regionie.

Instrumentem realizacji Narodowych Strategicznych Ram Odniesienia (Narodowej Strategii Spójności - nazwa omawianego dokumentu umieszczona w podtytule - przyp. aut.) jest, obok 16 regionalnych (po jednym dla każde- 
go województwa), sześć programów operacyjnych, wymienionych w tablicy 11. W obecnej perspektywie finansowej są to następujące programy operacyjne:

- Infrastruktura i Środowisko (PO IiŚ),

- Kapitał Ludzki (PO KL),

- Innowacyjna Gospodarka (PO IG),

- Europejska Współpraca Terytorialna (PO EWT),

- Pomoc Techniczna (PO PT),

- Rozwój Polski wschodniej (PO RPW).

Tablica 12. Podział środków na województwa w ramach Regionalnych Programów Operacyjnych

\begin{tabular}{|l|c|c|c|c|}
\hline \multicolumn{1}{|c|}{ Województwo } & $\begin{array}{c}\text { Ludność } \\
\text { (w tys.) } \\
\mathbf{( 3 1 . 1 2 . 0 5 )}\end{array}$ & $\begin{array}{c}\text { Algorytm = udziat } \\
\text { (w \%) }\end{array}$ & $\begin{array}{c}\text { Europejski } \\
\text { Fundusz } \\
\text { Rozwoju } \\
\text { Regionalnego } \\
\text { (w mln euro) }\end{array}$ & $\begin{array}{c}\text { Europejski } \\
\text { Fundusz Rozwoju } \\
\text { Regionalnego } \\
\text { (w euro } \\
\text { per capita) }\end{array}$ \\
\hline Dolnośląskie & 2888,2 & 7,60 & 1213,2 & 420,0 \\
\hline Kujawsko-Pomorskie & 2068,2 & 5,95 & 951,0 & 459.8 \\
\hline Lubelskie & 2179,6 & 7,23 & 1155,9 & 530,3 \\
\hline Lubuskie & 1009,1 & 2,75 & 439,1 & 435,2 \\
\hline Lódzkie & 2577,4 & 5,40 & 863,8 & 335,2 \\
\hline Małopolskie & 3266,1 & 7,18 & 1147,7 & 351,4 \\
\hline Mazowieckie & 5157,7 & 11,46 & 1831,5 & 355,1 \\
\hline Opolskie & 1047,4 & 2,67 & 427,2 & 407,8 \\
\hline Podkarpackie & 2098,2 & 7,11 & 1136,3 & 541,6 \\
\hline Podlaskie & 1199,6 & 3,98 & 636,2 & 530,3 \\
\hline Pomorskie & 2199,0 & 5,54 & 885,1 & 402,5 \\
\hline Śląskie & 4685,7 & 9,82 & 1570,4 & 335,2 \\
\hline Świętokrzyskie & 1285,0 & 4,54 & 725.8 & 564,8 \\
\hline Warmińsko-Mazurskie & 1428,6 & 6,48 & 1036,6 & 725,6 \\
\hline Wielkopolskie & 3372,4 & 7,07 & 1130,3 & 335.2 \\
\hline Zachodniopomorskie & 1694,1 & 5,23 & 835,4 & 493,1 \\
\hline POLSKA & $\mathbf{3 8 1 5 7 , 0}$ & $\mathbf{1 0 0 , 0 0}$ & $\mathbf{1 5 9 8 5 , 5}$ & $\mathbf{4 1 8 , 9}$ \\
\hline (19,0 & & & \\
\hline
\end{tabular}

Źródło: Ministerstwo Rozwoju Regionalnego (2006). 
Wszystkie razem są opracowywane dopiero po zaakceptowaniu NSOR przez Komisję Europejską. W ramach tych prac wyznaczane są „osie priorytetowe”, zharmonizowane ze strategią społeczno-gospodarczą kraju. Opracowywana jest lista kroków niezbędnych do wdrożenia przyjętych priorytetów oraz diagnoza społeczno-ekonomiczna poszczególnych programów. Następnie zostaje przyjęty sposób monitorowania, kierunki interwencji oraz dokładny plan finansowy, który uściśla źródła pochodzenia środków potrzebnych do ich sprawnej realizacji. Kolejną, fazą, jest zatwierdzenie programu operacyjnego i jego ewentualne uzupełnienie przez Komisję Europejską, ostatni zaś etap to realizacja programów (Skorulska, 2005, s. 99).

\subsection{Poszczególne programy operacyjne}

W podrozdziale tym zostaną pokrótce opisane poszczególne programy operacyjne. Należy pamiętać, że działania w ramach 16 Regionalnych Programów Operacyjnych (RPO), powinny być ściśle koordynowane z przedsięwzięciami podejmowanymi w obszarze sześciu pozostałych (sektorowych) programów operacyjnych. Realizacja Programów Sektorowych może być finansowana tylko ze środków jednego funduszu strukturalnego (co nie wyklucza Funduszu Spójności). Podstawą finansowania wszystkich programów regionalnych są środki pochodzące z Europejskiego Funduszu Rozwoju Regionalnego (EFRR). Jednakże każde z szesnastu polskich województw realizuje swój własny program operacyjny.

\subsubsection{Regionalne Programy Operacyjne (RPO)}

Każdy z Regionalnych Programów Operacyjnych powinien powstawać przy szerokim udziale konsultacji społecznych, uwzględniając zarazem podstawowe cele, jakie zostały przed wszystkimi programami z tej grupy wyznaczone, czyli:

- podnoszenie konkurencyjności regionów,

- promowanie trwałego i zrównoważonego rozwoju,

- podnoszenie jakości życia mieszkańców.

Wyznaczone cele powinny zostać osiągnięte przy uwzględnieniu priorytetów w zakresie (http://www.tuv.com/akademia-polska/pl/projekty_europejskie_3_4.html):

- badań i rozwoju technologicznego, innowacji i przedsiębiorczości,

- wspierania rozwoju społeczeństwa informatycznego,

- wspierania inicjatyw lokalnych dotyczących zatrudnienia i rozwoju oraz pomocy dla struktur świadczących usługi lokalne w tworzeniu miejsc pracy, 
- rozwoju turystyki,

- ochrony środowiska i zapobiegania powodziom,

- wspierania kultury oraz ochrony dziedzictwa historycznego,

- wzmacniania funkcji miejskich i metropolitalnych,

- promowania regionalnych produktów i usług,

- zapobiegania i zwalczania zagrożeń przyrodniczych i technologicznych,

- rewitalizacji obszarów powojskowych i poprzemysłowych,

- inwestycji w transport,

- inwestycji energetycznych z uwzględnieniem źródeł odnawialnych,

- inwestycji w kształcenie (zwłaszcza zawodowe),

- inwestycji w ochronę zdrowia i infrastrukturę społeczną,

- wielofunkcyjnego rozwoju obszarów wiejskich.

Suma środków zaangażowanych w 16 RPO, wynosi 15 985,5 mln euro. Beneficjentami RPO mogą być przykładowo: jednostki samorządu terytorialnego, ich związki i zrzeszenia, organy administracji rządowej, publiczne zakłady opieki zdrowotnej, wyższe uczelnie, kościoły i związki wyznaniowe, sektor MSP, instytucje otoczenia biznesu.

\subsubsection{Program Operacyjny Infrastruktura i Środowisko (PO liś)}

Naczelnym priorytetem Programu Operacyjnego Infrastruktura i Środowisko (PO IiŚ) jest odczuwalne zwiększenie atrakcyjności inwestycyjnej Polski oraz jej regionów, poprzez rozbudowę infrastruktury technicznej przy jednoczesnej ochronie i polepszeniu stanu środowiska, poprawie zdrowia obywateli, zachowaniu tożsamości kulturowej oraz rozwijaniu spójności terytorialnej. Program jest największym, w historii realizowanych w ramach wspólnotowych, a zarazem ważnym narzędziem służącym urzeczywistnianiu założeń strategii lizbońskiej.

Łączna wielkość zaangażowanych środków finansowych wyniesie 37,6 mld euro. Z tego, ze źródeł unijnych pochodzi 27,9 mld euro, ze źródeł krajowych zaś 9,7 mld euro. W sumie zaangażowane w PO IiŚ środki stanowią blisko $42 \%$ całości pieniędzy przeznaczonych na wdrażanie założeń polityki spójności w naszym kraju. Wydatki na cele priorytetowe UE stanowią w ramach programu $66,23 \%$ całości wydatków ze środków unijnych. Inne ważne priorytety Programu Operacyjnego Infrastruktura i Środowisko stanowią (http://www.tuv. com/akademia-polska/pl/projekty_europejskie_3_2.html):

- gospodarka wodno- ściekowa,

- gospodarka odpadami i ochrona ziemi,

- zarządzanie zasobami i przeciwdziałanie zagrożeniom środowiska,

- przedsięwzięcia dostosowujące przedsiębiorstwa do wymogów ochrony środowiska, 
- ochrona przyrody i kształtowanie postaw ekologicznych,

- budowa sieci autostrad i dróg ekspresowych wchodzących w skład sieci transportowej TEN-T, łączącej główne aglomeracje Polski z resztą Europy,

- budowa nowych połączeń lotniczych,

- transport przyjazny środowisku,

- bezpieczeństwo transportu i krajowe sieci transportowe,

- infrastruktura energetyczna przyjazna środowisku i efektywność energetyczna,

- bezpieczeństwo energetyczne w tym dywersyfikacja źródeł energii,

- kultura i dziedzictwo kulturowe,

- bezpieczeństwo zdrowotne i poprawa efektywności systemu ochrony zdrowia,

- profilaktyka w dziedzinie zdrowia pracowników,

- infrastruktura szkolnictwa wyższego (rozwój nowoczesnych ośrodków akademickich),

- pomoc techniczna finansowana z Europejskiego Funduszu Rozwoju Regionalnego,

- pomoc techniczna finansowana ze środków Funduszu Spójności.

Najwięcej pieniędzy zostało przeznaczonych, biorąc pod uwagę środki unijne i krajowe łącznie, na (www.funduszestrukturalne.gov.pl):

1) transport przyjazny środowisku - $12062 \mathrm{mln}$ euro,

2) drogową i lotniczą sieć TEN-T - 10 548,3 mln euro,

3) bezpieczeństwo transportu i krajowe sieci transportowe $-3465,3 \mathrm{mln}$ euro,

4) gospodarkę wodno-ściekowa - $3275,2 \mathrm{mln}$ euro,

5) bezpieczeństwo energetyczne - 1693,2 mln euro.

Stosunkowo mało środków zostało skierowanych dla tak ważnych priorytetów, jak:

1) infrastruktura szkolnictwa wyższego - tylko 588,2 mln euro,

2) bezpieczeństwo zdrowotne i poprawa efektywności systemu ochrony zdrowia - 411,8 mln euro,

3) ochrona przyrody i kształtowanie postaw ekologicznych - 105,6 mln euro.

Przyglądając się wszystkim priorytetom ujętym w Programie Operacyjnym Infrastruktura i Środowisko można zauważyć, że największym zainteresowaniem Unii cieszyły takie dziedziny w obrębie gospodarki narodowej, jak: transport i energetyka. Uwaga została zwrócona także na sprawy dotyczące zachowania środowiska naturalnego. 
Potencjalni beneficjenci programu to: jednostki samorządu terytorialnego, Główny Inspektorat Ochrony Środowiska, Wojewódzkie Inspektoraty Ochrony Środowiska, Instytut Meteorologii i Gospodarki Wodnej, przedsiębiorstwa działające na terenie naszego kraju $\mathrm{z}$ wyłączeniem tych wyszczególnionych w osobnych przepisach, parki narodowe, instytucje oświatowe, instytucje naukowe oraz jednostki badawczo-rozwojowe w tym szkoły wyższe oraz ich jednostki organizacyjne (www.pois.gov.pl). Biorąc jednak pod uwagę chroniczne niedoinwestowanie polskiej nauki i szkolnictwa wyższego oraz publicznej służby zdrowia, środki przeznaczone na te priorytety w ramach PO IiŚ na lata 2007-2013 można uznać za niewystarczające i uniemożliwiające radykalną poprawę sytuacji w tych dwóch dziedzinach.

\subsubsection{Program Operacyjny Kapitał Ludzki (PO KL)}

Głównymi celami programu są: wzrost zatrudnienia połączony z pogłębieniem spójności społecznej. Dzięki pomocy struktur administracji publicznej powinno dojść do uzyskania kapitału ludzkiego o wysokiej jakości. Cały proces ma być rozłożony ma lata 2007-2013 w ramach bieżącej perspektywy finansowej.

Poprzez „kapitał ludzki” należy rozumieć zespół czynników, takich jak: wiedza, doświadczenie, umiejętności, predyspozycje oraz potencjał tak fizyczny, jak i umysłowy zawarty w każdej osobie i społeczeństwie złożonym z jednostek ludzkich. Poprzez naukę, przygotowanie do pełnionych funkcji oraz długoletni staż zawodowy indywidualne cechy pracownicze ulegają zmianom. Zatrudnieni ludzie pogłębiają swoją unikatową wiedzę, wchodzą w interakcje z podwładnymi i zwierzchnikami, a także otoczeniem. Wytwarza się pewien kapitał intelektualny w odniesieniu do pojedynczych osób i zbiorowości zakładowej, który umiejętnie wykorzystany stanowi o wyjątkowości danego podmiotu gospodarczego. Umiejętne kształtowanie na własne potrzeby kapitału ludzkiego często przesądza o możliwościach adaptacyjnych i zdolności do przetrwania zakładów usługowych, biur, przedsiębiorstw wytwórczych, fabryk i innych instytucji działających w sektorze publicznym i prywatnym. Dla polskiej gospodarki jednym z najważniejszych zadań w czasie narastającego kryzysu ekonomicznego będzie wzmocnienie zdolności adaptacyjnych pracowników. Powinno także nastąpić zwiększenie potencjalnej elastyczności pracodawców w obliczu zapaści na rynku pracy. Tym ważniejsze staje się właściwe rozdysponowanie środków finansowych pozostawionych do dyspozycji Polski w ramach Programu Operacyjnego Kapitał Ludzki.

Główne cele PO KL powinny zostać osiągnięte poprzez realizację sześciu celów strategicznych. Są nimi (http://www.tuv.com/akademia-polska/pl/projekty_europejskie_3_1.html): 
1) podniesienie poziomu aktywności zawodowej oraz zdolności do zatrudnienia osób bezrobotnych i biernych zawodowo;

2) zmniejszenie obszarów wykluczenia zawodowego;

3) poprawa zdolności adaptacyjnych pracowników i przedsiębiorstw do zmian zachodzących w gospodarce;

4) upowszechnienie edukacji społeczeństwa na każdym etapie kształcenia przy równoczesnym zwiększeniu jakości usług edukacyjnych i ich silniejszym powiazaniu z potrzebami gospodarki opartej na wiedzy;

5) zwiększenie potencjału administracji publicznej w zakresie opracowywania różnych rodzajów polityki i świadczenia usług wysokiej jakości oraz wzmocnienie mechanizmów partnerstwa;

6) wzrost spójności terytorialnej.

Program według założeń finansowany będzie w $85 \%$ z Europejskiego Funduszu Społecznego (EFS). Kwota pochodząca z budżetu unijnego to około 9,7 mld euro. Ze środków krajowych pochodzić ma około 1,7 mld euro, w tym komponent centralny wyniesie $40 \%$ środków, a komponent regionalny - $60 \%$ rozdysponowanych środków. Cała możliwa do wykorzystania kwota w ramach Programu Operacyjnego Kapitał Ludzki powinna wynieść ponad 11,4 mld euro (www.funduszestrukturalne.gov.pl).

Program dotyczyć ma dziesięciu priorytetów. Podobnie jak krajowy wkład finansowy, zostały one podzielone na dwie grupy: pięć priorytetów centralnych i pięć priorytetów regionalnych.

Priorytety PO KL (www.tuv.com/akademia-polska/pl/projekty_europejskie_3_1.html):

- priorytety centralne:

I. Zatrudnienie i integracja społeczna

II. Rozwój zasobów ludzkich i potencjału adaptacyjnego przedsiębiorstw oraz poprawa stanu zdrowia osób pracujących

III. Wysoka jakość systemu oświaty

IV. Szkolnictwo wyższe i nauka

V. Dobre rządzenie

- priorytety regionalne:

VI. Rynek pracy otwarty dla wszystkich

VI. Promocja integracji społecznej

VII. Regionalne kadry gospodarki

IX. Rozwój wykształcenia i kompetencji w regionach

$\mathrm{X}$. Pomoc techniczna.

Podział środków na poszczególne priorytety w ramach PO KL został ukazany w tablicy 13 . 
Tablica 13. Podział środków na dziesięć priorytetów Programu Operacyjnego Kapitał Ludzki

\begin{tabular}{|l|l|r|c|}
\hline \multicolumn{1}{|c|}{ Priorytety } & \multicolumn{2}{|c|}{$\begin{array}{c}\text { Lączna kwota } \\
\text { euro }\end{array}$} & $\begin{array}{c}\text { Do całości } \\
\text { środków } \\
\text { w ramach } \\
\text { PO KL }\end{array}$ \\
\hline \multicolumn{3}{|c|}{ priorytety centralne } \\
\hline I & Zatrudnienie i integracja społeczna & 506.189 .358 & $4,43 \%$ \\
\hline II & $\begin{array}{l}\text { Rozwój zasobów ludzkich i potencjału } \\
\text { adaptacyjnego przedsiębiorstw oraz poprawa stanu } \\
\text { zdrowia osób pracujących }\end{array}$ & 778.011 .906 & $6,81 \%$ \\
\hline III & Wysoka jakość systemu oświaty & 1.006 .236 .268 & $8,81 \%$ \\
\hline IV & Szkolnictwo wyższe i nauka & 960.366 .839 & $8,41 \%$ \\
\hline V & Dobre rządzenie & 610.854 .094 & $5,35 \%$ \\
\hline & \multicolumn{1}{|c|}{ priorytety regionalne } & 2.256 .929 .201 & $19,76 \%$ \\
\hline VI & Rynek pracy otwarty dla wszystkich & 1.552 .906 .053 & $13,60 \%$ \\
\hline VII & Promocja integracji społecznej & 1.588 .479 .612 & $13,91 \%$ \\
\hline VIII & Regionalne kadry gospodarki & 1.703 .425 .446 & $14,92 \%$ \\
\hline IX & Rozwój wykształcenia i kompetencji w regionach & 456.808 .282 & $4,00 \%$ \\
\hline X & Pomoc techniczna & 11.420 .207 .059 & $\mathbf{1 0 0 , 0 \%}$ \\
\hline Razem & &
\end{tabular}

Źródło: opracowanie własne na podstawie: http://www.mrr.gov.pl.

Projekty w ramach Programu Operacyjnego Kapitał Ludzki mogą być realizowane w dwóch równoległych trybach: systemowym i konkursowym.

W trybie systemowym projekty są wdrażane przez beneficjentów imiennie wymienionych w programie lub w innych dokumentach stanowiących jego uszczegółowienie.

W trybie konkursowym o realizację projektów przy wsparciu środków unijnych mogą się ubiegać następujące podmioty:

- jednostki administracji rządowej i samorządowej,

- instytucje prowadzące szkolenia zawodowe,

- instytucje rynku pracy,

- przedsiębiorcy indywidualni,

- instytucje otoczenia biznesu,

- organizacje i instytucje pozarządowe,

- instytucje należące do systemu oświaty, 
- placówki reprezentujące szkolnictwo wyższe,

- inne podmioty, realizujące założenia polityki edukacyjno-społecznej rządu.

Działalność wszystkich włączonych do programu podmiotów i instytucji powinna być ukierunkowana na wykształcenie społeczeństwa informacyjnego, posiadającego wiedzę z zakresu współczesnych instrumentów tworzenia i przesyłania danych elektronicznych, co w perspektywie powinno być bazą sprzyjająca osiągnięciu przez gospodarkę krajową zrównoważonego rozwoju.

\subsubsection{Program Operacyjny Innowacyjna Gospodarka (PO IG)}

Program Operacyjny Innowacyjna Gospodarka jest jednym z sześciu programów ujętych w dokumencie Narodowe Strategiczne Ramy Odniesienia. Dotyczy on rozwoju ekonomicznego oraz wzrostu zatrudnienia w sektorze przedsiębiorstw. Zagadnienia, którymi zajmuje się PO IG dotyczą innowacyjności i konkurencyjności w aspektach: produktowym, marketingowym i procesowoorganizacyjnym. Odnosi się także do zagadnień z zakresu sektora naukowobadawczego polskiej gospodarki.

Dokument swoją uwagę koncentruje na pięciu głównych celach, jakie powinny zostać osiągnięte do końca 2013 roku (www.funduszestrukturalne.gov.pl):

- zwiększeniu innowacyjności przedsiębiorstw,

- wzroście konkurencyjności polskiej nauki,

- zwiększeniu roli nauki w rozwoju gospodarczym,

- zwiększeniu udziału innowacyjnych produktów polskiej gospodarki w rynku międzynarodowym,

- tworzeniu trwałych i lepszych miejsc pracy.

Innowacyjna Gospodarka, tak jak w innych pięciu przypadkach programów operacyjnych, finansowany jest w 15\% ze środków krajowych i $85 \%$ z bezzwrotnych środków pochodzących z Europejskiego Funduszu Rozwoju Regionalnego. $\mathrm{Z}$ całej kwoty zgromadzonej w PO IG suma 9,7 mld euro pochodzi z budżetu Unii, a pozostała część - 1,8 mld euro to środki własne. Razem daje to wielkość ponad 11,5 mld euro (www.funduszestrukturalne.gov.pl). Program został poświęcony dziewięciu priorytetom:

I. Badania i rozwój nowoczesnych technologii

II. Infrastruktura sfery Badania i Rozwój $(\mathrm{B}+\mathrm{R})$

III. Kapitał dla innowacji

IV. Inwestycje w innowacyjne przedsięwzięcia

V. Dyfuzja innowacji

VI. Polska gospodarka na rynku międzynarodowym 
VII. Społeczeństwo informacyjne - budowa elektronicznej administracji

VIII. Społeczeństwo informacyjne - zwiększanie innowacyjności gospodarki IX. Pomoc techniczna.

Kwoty przeznaczone dla PO IG w ramach budżetu unijnego ukazuje tablica 14. Natomiast udział procentowy poszczególnych osi priorytetowych w dostępie do środków finansowych zgromadzonych w ramach Programu Operacyjnego Innowacyjna Gospodarka ukazany został na rysunku 19.

Wspomniany wyżej, nieco enigmatyczny, Priorytet V. Dyfuzja innowacji oznacza (www.dotacjeue.org.pl):

- zapewnienie przedsiębiorcom wysokiej jakości usług i infrastruktury służących wzmocnieniu oraz wykorzystaniu ich potencjału innowacyjnego;

- polepszenie pozycji konkurencyjnej przedsiębiorstw poprzez rozwój powiązań kooperacyjnych.

Tablica 14. Środki finansowe pochodzące z Europejskiego Funduszu Rozwoju Regionalnego, przeznaczone na PO IG z rozpisaniem na poszczególne osie priorytetowe

\begin{tabular}{|l|c|l|c|l|c|}
\hline \multicolumn{1}{|c|}{ Priorytet } & w mln euro & \multicolumn{1}{|c|}{ Priorytet } & w mln euro & \multicolumn{1}{c|}{ Priorytet } & w mln euro \\
\hline Priorytet I & $1.299,27$ & Priorytet IV & 3429,71 & Priorytet VII & 788,24 \\
\hline Priorytet II & $1.299,27$ & Priorytet V & 399,00 & Priorytet VIII & 1415,87 \\
\hline Priorytet III & 340,00 & Priorytet VI & 410,63 & Priorytet IX & 329,65 \\
\hline
\end{tabular}

Źródło: opracowanie własne na podstawie: www.dotacjeue.org.pl.
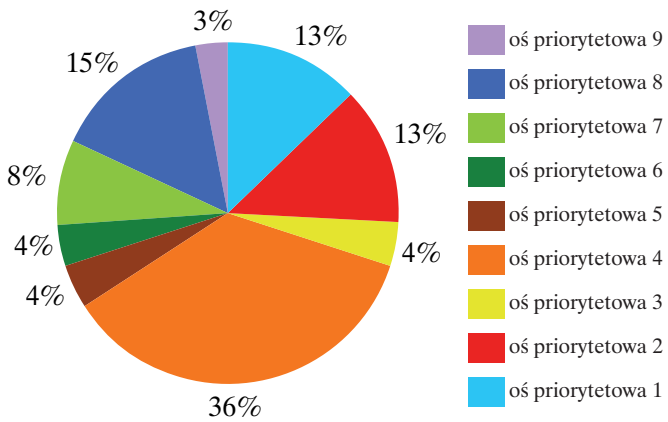

Rysunek 19. Podział środków finansowych Programu Operacyjnego Innowacyjna Gospodarka na dziewięć osi priorytetowych

Źródło: http://www.dotacjeue.org.pl. 
Jego beneficjentami mogą być: przedsiębiorcy sfery MSP, więksi przedsiębiorcy, układy klastrów (gron przemysłowych), jednostki naukowe, instytucje otoczenia biznesu o zasięgu ponadregionalnym i krajowym, instytucje świadczące wyspecjalizowane usługi dla firm, inkubatory technologii, centra zaawansowanych technologii i produktywności.

Wśród grup potencjalnych beneficjentów ramach całego Programu (to znaczy pozostałych ośmiu osi priorytetowych) należy natomiast jeszcze wymienić: wyższe uczelnie, konsorcja naukowo-przemysłowe, polskie platformy technologiczne, Fundację na Rzecz Nauki Polskiej, zespoły naukowców oraz badaczy indywidualnych, studentów, Narodowe Centrum Badań i Rozwoju, centra komputerów o dużej mocy, Ministerstwo Skarbu Państwa, Krajowy Fundusz Kapitałowy, Bank Gospodarstwa Krajowego, jednostki samorządu terytorialnego, jednostki administracji rządowej oraz jednostki im podległe, instytucje zaangażowane w zarządzanie oraz wdrażanie PO IG (http://www.dotacjeue.org.pl). Przyglądając się długiej liście podmiotów i instytucji, które mogą się ubiegać o sfinansowanie projektów ze środków zgromadzonych w PO IG, trzeba zauważyć ich szeroki wachlarz oraz wysoki stopień specjalizacji w wybranej dziedzinie.

\subsubsection{Program Operacyjny Europejska Współpraca Terytorialna (PO EWT)}

W wyniku prac nad wspólnotowym budżetem ustalono, że dla nadchodzącego okresu 2007-2013 współpraca w wymiarze transgranicznym, transnarodowym oraz międzyregionalnym będzie realizowana jako osobny cel polityki spójności Unii Europejskiej. Cel został określony jako Europejska Współpraca Terytorialna (EWT). Takie podejście jest konsekwencją rosnącego znaczenia polityki spójności dla przedsięwzięć z tego zakresu. Do uruchomienia realizacji zamierzeń w obrębie Programu Operacyjnego Europejska Współpraca Terytorialna niezbędne jest uczestnictwo co najmniej dwóch państw lub regionów, w tym jednego znajdującego się w obrębie ugrupowania integracyjnego. Finansowe środki wsparcia na realizację programu pochodzą w 85\% z Europejskiego Funduszu Rozwoju Regionalnego (EFRR), reszta zaś, czyli $15 \%$ z zasobów krajowych.

W latach 2007-2013 na rozwój współpracy terytorialnej z budżetu Unii Europejskiej przeznaczonych zostanie łącznie 7,75 mld euro. Polska alokacja na realizację programów w ramach Europejskiej Współpracy Terytorialnej wyniesie 557,8 mln euro. Dodatkowe 173,3 mln euro zostanie przeznaczonych przez Polskę na wspólpracę transgraniczną z państwami nienależącymi do Unii Europejskiej w ramach Europejskiego Instrumentu Sąsiedztwa i Partnerstwa (EISP). Programy Europejskiej Współpracy Terytorialnej (ang. European Territorial Cooperation) na lata 2007-2013 stanowią kontynuację programów wspólpracy transgranicznej, transnarodowej i międzyregionalnej realizowanych w ramach Inicjatywy Wspólnotowej INTERREG III w okresie programowania 
2000-2006 (w Polsce od 1 maja 2004 roku). EWT wdrażana będzie za pomocą trzech typów programów operacyjnych (www.interreg.gov.pl):

- współpracy transgranicznej jako kontynuacja INTERREG III A, której celem jest rozwijanie wspólnych inicjatyw lokalnych i regionalnych;

- współpracy transnarodowej jako kontynuacja INTERREG III B, ukierunkowanej na integrację terytorialną Unii Europejskiej poprzez wspieranie dostępności, zrównoważonego rozwoju obszarów miejskich, innowacyjność i ochronę środowiska naturalnego;

- współpracy międzyregionalnej (INTERREG IV C); jako kontynuacja INTERREG III C, polega na wymianie doświadczeń i praktyk w zakresie wspierania innowacyjności i gospodarki opartej na wiedzy oraz ochrony środowiska.

$\mathrm{Na}$ rysunku $20 \mathrm{w}$ ujęciu geograficznym zostały przedstawione subregiony nadgraniczne w Polsce, biorące udział w programach Europejskiej Współpracy Transgranicznej.

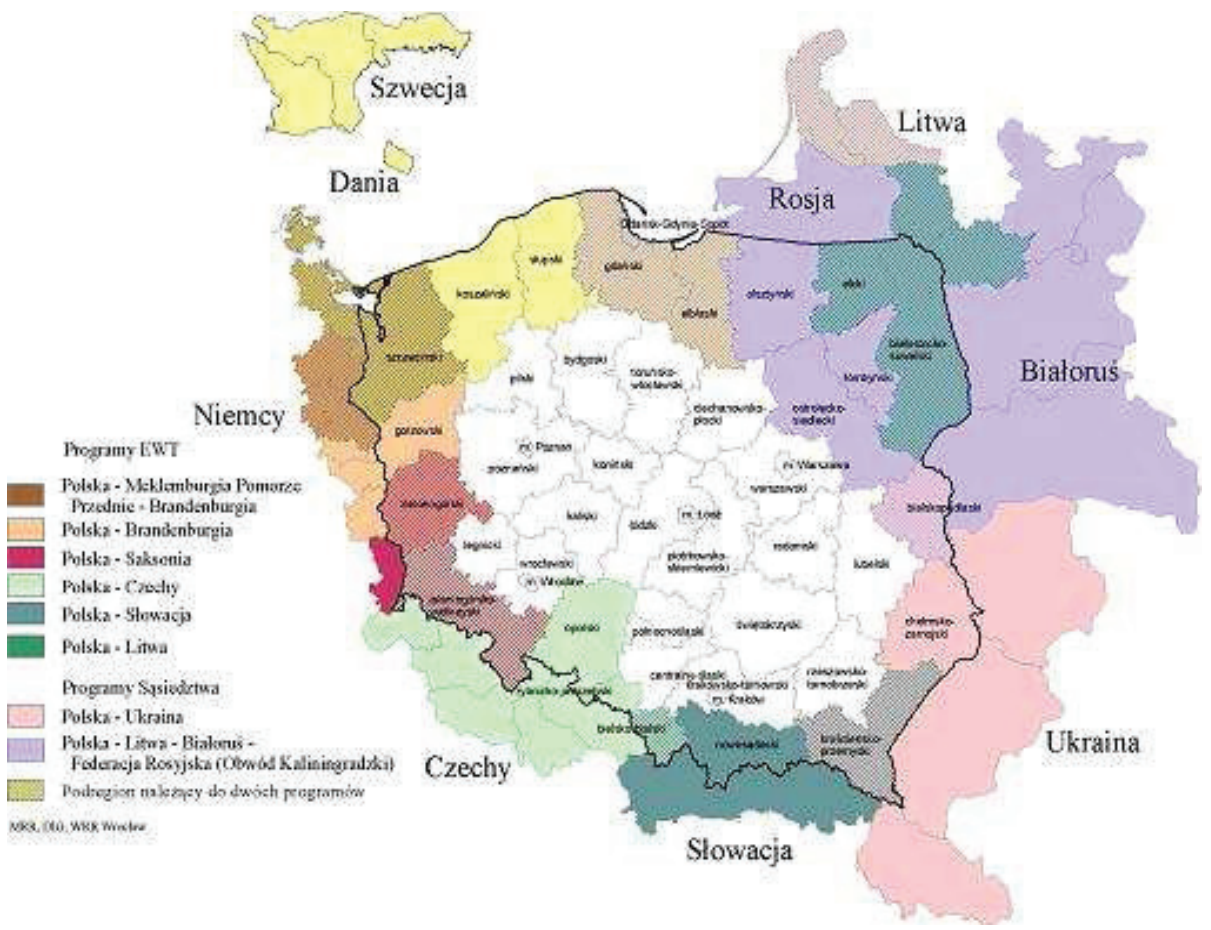

Rysunek 20. Obszary w Polsce objęte działaniami w ramach PO EWT Źródło: http://www.interreg.gov.pl/20072013/EWT/. 
Poszczególne typy programów są zróżnicowane nie tylko pod względem geograficznym, ale także w zakresie tematyki, którą poruszają (www.ewt.gov.pl):

- programy transgraniczne służą przede wszystkim budowaniu więzi łączących społeczności po obu stronach granicy; ich realizacja służy wzmocnieniu współpracy poprzez wzrost liczby wspólnych inicjatyw dotyczących między innymi: ochrony środowiska, rozbudowy infrastruktury, wymiany kulturalnej, czy wzajemnych kontaktów młodzieży;

- programy transnarodowe stanowią szansę dla wsparcia bardziej innowacyjnych projektów dotyczących zagadnień istotnych dla obszarów należących do kilku państw; sprzyjają zintegrowanemu rozwojowi UE poprzez inicjowanie planów i koncepcji prowadzących do realizacji ponadnarodowych przedsięwzięć;

- programy współpracy międzyregionalnej, które obejmują obszar całej UE, służą wymianie doświadczeń i dobrych praktyk, a tym samym wzmacnianiu potencjału instytucji i samorządów w zakresie mechanizmów wspierania rozwoju regionalnego.

Końcowymi beneficjentami projektów dofinansowywanych ze środków Europejskiego Funduszu Rozwoju Regionalnego w ramach PO EWT mogą być władze publiczne lub podmioty im równoważne takie na przykład, jak (http:// www.fundusze.malopolska.pl):

- władze regionalne i lokalne,

- agencje rozwoju regionalnego,

- uniwersytety, instytuty badań, instytuty na rzecz wyższej edukacji,

- obsługujący parki nauki i technologii, inkubatory przedsiębiorczości, centra innowacyjności,

- inne podmioty wspierające przedsiębiorców oraz organizacje reprezentujące społeczność przedsiębiorców zwłaszcza powiązane z MŚP,

- inne podmioty publiczne lub równoważne mające związek z rozwojem regionalnej innowacyjności oraz z gospodarką opartą na wiedzy,

- instytucje ochrony środowiska naturalnego,

- służby ratownicze i inne podmioty zarządzające ryzykiem,

- władze transportu publicznego,

- władze odpowiedzialne za ochronę krajobrazu i dziedzictwa kulturowego,

- władze w obszarze turystyki,

- inne publiczne lub równoważne podmioty mające związek ze środowiskiem i zapobieganiem zagrożeniom. 


\subsubsection{Program Operacyjny Pomoc Techniczna (PO PT)}

W obecnej perspektywie finansowej Program Operacyjny Pomoc Techniczna stanowi jeden z najistotniejszych komponentów umożliwiających sprawną realizację Narodowych Strategicznych Ram Odniesienia na lata 2007-2013. PO PT jest wymieniany jako oś priorytetowa we wszystkich programach operacyjnych.

Ponadto realizowany będzie horyzontalny program, a jego celem jest wsparcie tych procesów oraz instytucji wchodzących w system realizacji NSRO, których wsparcie na poziomie poszczególnych programów operacyjnych albo nie może być realizowane, albo jego realizacja byłaby niezasadna. Działania w obrębie samego Programu Operacyjnego Pomoc Techniczna obejmują wsparcie wszystkich horyzontalnych działań i procesów z zakresu przygotowania, zarządzania, wdrażania, monitorowania, oceny i kontroli wdrażania Narodowych Strategicznych Ram Odniesienia, jak również pomocy i wsparcia w przygotowywaniu projektów oraz rozpowszechnianiu informacji oraz promocji operacji funduszy strukturalnych w Polsce. Aby osiagnąć to zamierzenie, opracowano dwa cele szczegółowe (www.popt.gov.pl):

- zapewnienie sprawnej realizacji Narodowych Strategicznych Ram Odniesienia oraz wsparcie przygotowania przyszłych interwencji funduszy strukturalnych;

- skuteczne rozpowszechnianie informacji i promocja NSRO oraz zapewnienie odpowiedniego przepływu i wymiany informacji pomiędzy uczestnikami procesu realizacji Narodowych Strategicznych Ram Odniesienia.

Program Operacyjny Pomoc Techniczna został oparty na realizacji czterech priorytetów. Są nimi:

I. Wsparcie zasobów ludzkich

II. Wsparcie informatyczne dla Narodowych Strategicznych Ram Odniesienia

III. Wsparcie realizacji operacji funduszy strukturalnych

IV. Komunikacja i promocja.

Podział środków finansowych na poszczególne priorytety w ramach Programu Operacyjnego Pomoc Techniczna został przedstawiony w tablicy 15.

Najwięcej pieniędzy w programie skierowano do priorytetu I. Wsparcie zasobów ludzkich. W zamyśle. jaki tym kierował, chodziło przede wszystkim o przygotowanie oraz pozyskanie wysoko wykwalifikowanej kadry urzędników i specjalistów, która sprostałaby przygotowaniu, wprowadzeniu w życie, monitorowaniu, a następnie analizie poziomu wdrażania środków pochodzących z funduszy strukturalnych, pomagając zarazem realizować zadania przewidziane dla Narodowych Strategicznych Ram Odniesienia (NSRO). 
Tablica 15. Podział środków finansowych na cztery priorytety w ramach Programu Operacyjnego Pomoc Techniczna

\begin{tabular}{|c|l|c|c|c|}
\hline Lp. & \multicolumn{1}{|c|}{ Priorytet } & $\begin{array}{c}\text { Wkład } \\
\text { wspólnotowy } \\
\text { (w euro) }\end{array}$ & $\begin{array}{c}\text { Wkład } \\
\text { krajowy } \\
\text { (w euro) }\end{array}$ & $\begin{array}{c}\text { Ogółem } \\
\text { (w euro) }\end{array}$ \\
\hline I. & Wsparcie zasobów ludzkich & 357000000 & 63000000 & 420000000 \\
\hline II. & $\begin{array}{l}\text { Wsparcie informatyczne realizacji } \\
\text { NSRO }\end{array}$ & 18700000 & 3300000 & 22000000 \\
\hline III. & $\begin{array}{l}\text { Wsparcie realizacji operacji } \\
\text { funduszy } \\
\text { strukturalnych }\end{array}$ & 74800000 & 13200000 & 88000000 \\
\hline IV. & Komunikacja i promocja & 66200000 & 11682353 & 77882353 \\
\hline & Razem & $\mathbf{5 1 6 7 0 0 ~ 0 0 0}$ & $\mathbf{9 1 ~ 1 8 2 ~ 3 5 3}$ & $\mathbf{6 0 7} \mathbf{8 8 2 ~ 3 5 3}$ \\
\hline
\end{tabular}

Źródło: www.funduszestrukturalne.gov.pl.

\section{Program Operacyjny Rozwój Polski Wschodniej (PO RPW)}

Ze względu na szczególnie istotne znaczenie Programu Operacyjnego Rozwój Polski Wschodniej dla prowadzonych rozważań, został mu poświęcony osobny podrozdział.

Program Operacyjny Rozwój Polski Wschodniej stanowi niezwykle ważne narzędzie polityki regionalnej naszego państwa. $\mathrm{W}$ ramach programu sfera rządowa i władze regionalne podjęły zintensyfikowany wysiłek mający na celu przyspieszenie ogólnego tempa rozwoju społeczno-ekonomicznego obszarów objętych jego oddziaływaniem. Do programu zostało zakwalifikowanych pięć najmniej zamożnych regionów w Polsce, a mianowicie województwa: lubelskie, podkarpackie, podlaskie, świętokrzyskie i warmińsko-mazurskie. Zamysłem działań zaplanowanych w obrębie PO RPW jest przeciwdziałanie zjawiskom stagnacyjnym w usługach, przemyśle oraz rolnictwie, które mają wpływ na marginalizację i utrzymanie peryferyjnego charakteru obszaru określonego jako Polska Wschodnia. Program powinien pobudzić także wzrost gospodarczy omawianego terenu.

PO RPW został opracowany, podobnie jak strategia rozwoju Polski Wschodniej, przez specjalistów, naukowców, badaczy i ekspertów z różnych dziedzin życia społecznego oraz gospodarczego, przy ścisłej współpracy Rządu Rzeczypospolitej Polskiej.

Program zakłada umożliwienie sprawnej realizacji zamierzeń określonych w strategii rozwoju społeczno-gospodarczego wschodnich terenów Polski, 
a w rezultacie przyspieszenie tempa pozytywnych zmian tego obszaru. PO Rozwój Polski Wschodniej określa listę zadań i zamierzeń do końca 2013 roku. Cel główny określony został jako: „Przyspieszenie tempa rozwoju społeczno-gospodarczego Polski Wschodniej w zgodzie z zasadą zrównoważonego rozwoju”.

Zamierzenie zdefiniowane w celu głównym ma zostać osiągnięte poprzez realizację sześciu celów szczegółowych, do których należą (http://www.polskawschodnia.gov.pl):

- stymulowanie rozwoju konkurencyjnej gospodarki opartej na wiedzy,

- zwiększenie dostępu do Internetu szerokopasmowego na obszarze Polski Wschodniej,

- rozwój wybranych funkcji metropolitalnych miast wojewódzkich,

- poprawa dostępności i jakości powiązań komunikacyjnych województw Polski Wschodniej,

- zwiększenie roli zrównoważonej turystyki w gospodarczym rozwoju makroregionu,

- optymalizacja procesu wdrażania Programu Operacyjnego Rozwój Polski Wschodniej.

Instytucją zarządzającą zgodnie z przepisami ustawy o zasadach prowadzenia polityki rozwoju (Dz.U. z 2006 r. Nr 226, poz. 1658) jest Minister Rozwoju Regionalnego. Zgodnie z regulaminem wewnętrznym opracowanym przez wymienionego ministra, obowiązki instytucji zarządzającej Programem Operacyjnym Rozwój Polski Wschodniej pełni jednostka organizacyjna w ramach Ministerstwa Rozwoju Regionalnego. Aktualnie obowiązi te należą do Departamentu Koordynacji Programów Regionalnych. Instytucja zarządzająca powierza określoną część zadań do realizacji instytucji pośredniczącej. Dla PO RPW jako instytucja pośrednicząca wybrana została Polska Agencja Rozwoju Przedsiębiorczości (PARP). Program Operacyjny Rozwój Polski Wschodniej składa się z pięciu odrębnych programów, przeznaczonych dla poszczególnych pięciu województw. W ramach PO RPW zostało wyodrębnionych sześć osi priorytetowych (Ministerstwo Rozwoju Regionalnego, 2007, s. 75-98):

I. Nowoczesna gospodarka. Jej celem jest stymulowanie rozwoju konkurencyjnej gospodarki opartej na wiedzy. Jednym z jej zadań jest dokonanie poprawy jakości zasobów ludzkich, czyli wzrost umiejętności, jak również kwalifikacji aktualnych i przyszłych pracowników, a także przedsiębiorców. Sprzyjać ma temu poprawa warunków kształcenia oraz jakości wyposażenia bazy dydaktycznej i naukowo-badawczej uczelni oraz innych jednostek naukowych. Rezultatem działań mają być nowe inwestycje oraz efektywny transfer innowacyjnych rozwiązań i technologii.

II. Infrastruktura społeczeństwa informacyjnego. Główny cel drugiej osi priorytetowej stanowi zwiększenie dostępu do Internetu szerokopasmo- 
wego w całej Polsce Wschodniej. Do końca 2013 roku infrastrukturą informatyczną podwyższonej jakości, opierającą swoje działanie na szybkich łączach lub mediach o dużej przepływności, powinno zostać objętych ponad $90 \%$ gospodarstw domowych, $100 \%$ instytucji publicznych oraz $100 \%$ przedsiębiorców. Właścicielami sieci będą samorządy wojewódzkie.

III. Wojewódzkie ośrodki wzrostu. Cel tego priorytetu to rozwój wybranych funkcji metropolitalnych miast wojewódzkich. Regionalne obszary metropolitalne są głównymi ośrodkami dynamiki gospodarczej, technologicznej i kulturalnej. Charakteryzują się dużym zasięgiem oddziaływania na otoczenie. Rozwój metropolii ma znaczący wpływ na rozwój nie tylko głównego miasta, lecz także innych ośrodków miejskich, gmin i mniejszych skupisk ludzkich w promieniu nawet do $100 \mathrm{~km}$. Wzmocnienie infrastrukturalne miast wojewódzkich Polski Wschodniej: Lublina, Białegostoku, Rzeszowa, Olsztyna i Kielc, jest warunkiem wzrostu gospodarczego całych regionów, a tym samym poprawy warunków życia na obszarze Polski Wschodniej. Poprzez stworzenie i rozbudowę zintegrowanych systemów transportu zbiorowego zostanie osiągnięte zwiększenie mobilności mieszkańców. Powstanie obiektów kongresowych, wystawienniczych, targowych i konferencyjnych powinno podnieść atrakcyjność danych obszarów i przyczynić się do rozwoju turystyki rekreacyjnej i biznesowej.

IV. Infrastruktura transportowa. Głównym celem czwartej osi priorytetowej jest poprawa dostępności i jakości powiązań komunikacyjnych województw Polski Wschodniej. W jej ramach finansowane będą przedsięwzięcia dotyczące budowy i modernizacji dróg krajowych oraz wojewódzkich. Możliwość korzystania z wygodniejszej, bezpieczniejszej, szybszej i sprawniejszej komunikacji drogowej, przy zminimalizowaniu negatywnego wpływu na środowisko sprzyjać będzie poprawie jakości usług transportowych, a przez to mobilności społeczeństwa. Powinna także pozytywnie wpłynąć na zintensyfikowanie współpracy międzywojewódzkiej oraz międzynarodowej. Nowe połączenia zwiększą atrakcyjność terenów inwestycyjnych, skierują rzesze odwiedzających osób do atrakcji turystycznych oraz ułatwią dostęp do przejść granicznych.

V. Zrównoważony rozwój potencjału turystycznego opartego o warunki naturalne. Głównym celem tego priorytetu jest zwiększenie roli zrównoważonej turystyki w gospodarczym rozwoju makroregionu. Promowane będą zalety turystyki rowerowej. Podjęte będą również wysiłki w celu stworzenia wspólnej oferty turystycznej dla całej Polski Wschodniej. Oferta ma zachęcać do uprawiania zrównoważonych form turystyki, 
a szczególnie takich, które zmniejszają potrzebę korzystania z indywidualnej motoryzacji.

VI. Pomoc techniczna. Główny cel osi priorytetowej określony został jako optymalizacja procesu realizacji Programu Operacyjnego Rozwój Polski Wschodniej. Oznacza w praktyce wsparcie dla wszelkich działań mających na celu sprawne wdrożenie PO RPW. Ma to być osiagnięte m.in. poprzez:

- pokrycie kosztów zatrudnienia pracowników niezbędnych do sprawnej realizacji Programu oraz podnoszenie kwalifikacji personelu zaangażowanego w jego realizację;

- zakup i instalację sprzętu komputerowego, audiowizualnego, teleinformatycznego oraz wyposażenia biurowego przez jednostki zaangażowane w realizację Programu;

- zakup usług zewnętrznych niezbędnych do sprawnej realizacji Programu;

- wsparcie procesu oceny i selekcji projektów;

- wsparcie systemu monitoringu i procesu kontroli;

- przygotowanie ekspertyz, analiz, badań, sprawozdań i koncepcji na potrzeby procesu realizacji i oceny realizacji Programu;

- wsparcie działań związanych z udzielaniem zamówień publicznych;

- zakup długoterminowych kompleksowych usług doradczych;

- organizację spotkań komitetów, grup, zespołów zaangażowanych w realizację Programu;

- pomoc doradczą beneficjentom w przygotowaniu i wdrożeniu projektów;

- archiwizację dokumentacji zarówno w formie elektronicznej, jak i papierowej oraz pokrycie kosztów przekazywania jej do Komisji Europejskiej.

Podjęte działania powinny podnieść potencjał administracyjny instytucji zaangażowanych w realizację Programu Operacyjnego Rozwój Polski Wschodniej oraz przyczynić się do upowszechnienia stanu wiedzy na temat wsparcia ze środków Unii Europejskiej, a także pogłębić uspołecznienie prac nad przygotowaniem dokumentów na następny okres programowania (www.porpw.parp.gov.pl). Ostatecznie dzięki Pomocy technicznej powinien dokonać się szybszy wzrost poziomu spójności gospodarczej, społecznej i terytorialnej omawianego obszaru.

Program Operacyjny Rozwój Polski Wschodniej realizowany jest przy wykorzystaniu w 85\% środków unijnych i w 15\% środków pochodzenia krajowego. Środki wspólnotowe pochodzą z Europejskiego Funduszu Rozwoju Regionalnego (EFRR). W tym około $992 \mathrm{mln}$ euro płynnie do nas ze specjalnych środków przeznaczonych decyzją Rady Europejskiej dla najbiedniejszych regio- 
nów ugrupowania integracyjnego (UE-25). Pozostała część tej sumy, to znaczy około 1,3 mld euro, została przyznana przez Rząd RP z ogólnej puli środków z Europejskiego Funduszu Rozwoju Regionalnego przyznanych dla Polski. Publiczne środki krajowe dla PO RPW wyniosą 401,3 mln euro. Całościowo wkład unijny to ponad 2,27 mld euro. W sumie do dyspozycji regionów Polski Wschodniej zostało postawionych nieco ponad 2,67 mld euro (Ignatiuk, 2010, s. 50). Szczegółowy podział środków w ramach Programu Operacyjnego RPW na poszczególne osie priorytetowe został przedstawiony w tablicy 16.

Tablica 16. Podział środków finansowych w ramach Programu Operacyjnego Rozwój Polski Wschodniej na sześć osi priorytetowych

\begin{tabular}{|c|r|c|c|}
\hline Osie priorytetowe & Wkład UE (w euro) & Wkład krajowy (w euro) & Ogółem \\
\hline I & 789957284 & 139404227 & 929361511 \\
\hline II & 255119659 & 45021117 & 300140776 \\
\hline III & 452621636 & 79874407 & 532496043 \\
\hline IV & 660381359 & 116537887 & 776919246 \\
\hline V & 47500000 & 8382353 & 55882353 \\
\hline VI & 68213812 & $12037 \mathbf{7 3 2}$ & 80251544 \\
\hline Ogółem & $\mathbf{2} \mathbf{2 7 3 7 9 3 7 5 0}$ & $\mathbf{4 0 1 2 5 7 7 3 4}$ & $\mathbf{2} \mathbf{6 7 5} \mathbf{0 5 1} \mathbf{4 7 3}$ \\
\hline
\end{tabular}

Źródło: www.porpw.parp.gov.pl.

Najwięcej pieniędzy w ramach PO RPW zostało przeznaczonych na realizację osi priorytetowej I. Nowoczesna gospodarka i osi priorytetowej IV. Infrastruktura transportowa. W sumie jest to ponad 1,7 mld euro. Najskromniejsze środki finansowe płyną do osi priorytetowej V. Zrównoważony rozwój potencjału turystycznego opartego o warunki naturalne. Na tę ścieżkę przeznaczonych zostało niecałe 55,9 mln euro.

Beneficjentami programu w odniesieniu do poszczególnych celów szczegółowych i osi priorytetowych mogą być (http://www.polskawschodnia.gov.pl):

- jednostki samorządu terytorialnego oraz związki i stowarzyszenia z ich udziałem,

- organy administracji rządowej,

- organizacje pozarządowe,

- szkoły wyższe oraz jednostki naukowe, w tym podstawowe jednostki organizacyjne szkół wyższych,

- jednostki badawczo-rozwojowe, w tym jednostki zrzeszone w PAN,

- przedsiębiorcy sektora MSP, 
- Generalna Dyrekcja Dróg Krajowych i Autostrad,

- instytucje ważne dla zapewnienia rozwoju regionalneg, w tym:

- urzędy statystyczne, biura planowania przestrzennego,

- organizacje turystyczne,

- instytucje otoczenia biznesu i innowacji,

- agencje i fundacje rozwoju regionalnego i lokalnego,

- kluby biznesu, centra obsługi inwestorów, izby gospodarcze,

- centra transferu technologii i inkubatory przedsiębiorczości,

- parki przemysłowe i parki technologiczne,

- instytucje: zarządzająca programem i pośrednicząca, a także inne podmioty wyznaczone przez Ministra Rozwoju Regionalnego do wdrażania programu.

Środki Programu Operacyjnego Rozwój Polski Wschodniej zostały przyporządkowane poszczególnym regionom Polski Wschodniej przy użyciu specjalnego algorytmu uwzgledniającego takie czynniki, jak: gęstość zaludnienia, PKB per capita, stopa bezrobocia, powierzchnia i rozwój ekonomiczny danego obszaru. Podział ten obrazuje tablica 17.

Tablica 17. Algorytm podziału środków w ramach PO RPW na województwa Polski Wschodniej

\begin{tabular}{|l|c|c|c|c|c|}
\hline \multicolumn{1}{|c|}{ Województwo } & $\begin{array}{c}\text { Algorytm } \\
\text { dla kwoty } \\
\mathbf{9 9 2 , 1 9} \mathbf{~ m l n} \\
\text { euro }\end{array}$ & $\begin{array}{c}\text { Podzial } \\
\text { kwoty } \\
\mathbf{9 9 2 , 1 9} \\
\text { mln euro }\end{array}$ & $\begin{array}{c}\text { Algorytm } \\
\text { dla kwoty } \\
\mathbf{1 2 1 3 , 3 9} \\
\text { mln euro }\end{array}$ & $\begin{array}{c}\text { Podzial } \\
\text { kwoty } \\
\mathbf{1 2 1 3 , 3 9} \text { mln } \\
\text { euro }\end{array}$ & $\begin{array}{c}\text { Eączna } \\
\text { kwota } \\
\text { z EFRR } \\
\text { w mln euro }\end{array}$ \\
\hline Lubelskie & $25,69 \%$ & 264.85 & $20,09 \%$ & 243,72 & 508,57 \\
\hline Podkarpackie & $25,54 \%$ & 253,41 & $19,29 \%$ & 234,07 & 487,48 \\
\hline Podlaskie & $14,68 \%$ & 145,61 & $19,88 \%$ & 241,25 & 386,86 \\
\hline Świętokrzyskie & $15,74 \%$ & 156,21 & $18,06 \%$ & 219,09 & 375,30 \\
\hline Warmińsko-mazurskie & $17,35 \%$ & 172,11 & $22,69 \%$ & 275,26 & 447,37 \\
\hline Polska Wschodnia & $\mathbf{1 0 0 , 0 0 \%}$ & $\mathbf{9 9 2 , 1 9}$ & $\mathbf{1 0 0 , 0 0 \%}$ & $\mathbf{1 2 1 3 , 3 9}$ & $\mathbf{2 2 0 5 , 5 8}$ \\
\hline
\end{tabular}

Źródło: www.polskawschodnia.gov.pl.

Z ogólnej kwoty EFRR przeznaczonej na PO RPW 2,27 mld euro wydzielono z podziału kwotę 68,21 mln. euro przewidzianą na realizację Priorytetu VI: „Pomoc techniczna”

Największe środki w ramach Programu Operacyjnego Rozwój Polski Wschodniej zostały przyznane dla województwa lubelskiego - 508,57 mln euro. Z tej 
samej puli województwo świętokrzyskie otrzymało do dyspozycji najmniej pieniędzy - tylko 375,30 mln euro. Różnica pomiędzy środkami finansowymi z budżetu unijnego dla wymienionych dwóch regionów wynosi zatem 133,27 mln euro. Niewiele więcej otrzymało województwo podlaskie - tylko 386,86 mln euro (różnica w stosunku do lubelskiego wynosi - 121,71 mln euro). Stanowi to wielkość dającą relatywnie większe możliwość rozwojowe pierwszemu z wymienionych w tym zestawieniu regionów.

Dla pełnego powodzenia Programu Operacyjnego Rozwój Polski Wschodniej niezwykle istotne znaczenie będzie miało zapewnienie odpowiednich środków finansowych w wysokości $15 \%$, w ramach wkładu krajowego. Ich wygospodarowanie zapewni uruchomienie postawionych do dyspozycji potencjalnych beneficjentów $85 \%$ środków pochodzących z puli pieniędzy unijnych.

Należy zauważyć spore bogactwo zakresowe i dużą różnorodność programów operacyjnych (w tym szczególnie Programu Operacyjnego Rozwój Polski Wschodniej), a także szeroką tematykę osi priorytetowych oraz konkretność celów wyznaczonych dla zainicjowania rozwoju pięciu najbardziej zacofanych województw w Polsce. Dodając do tego wielomiliardowe kwoty pochodzące zarówno ze źródeł krajowych, jak i unijnych, można być przeświadczonym, że użyte środki wywołają dynamiczny proces uatrakcyjnienia inwestycyjnego słabo rozwiniętych regionów w naszym kraju. 


\section{ROZDZIA $\mathrm{VI}$}

\section{Atrakcyjność inwestycyjna regionów}

Atrakcyjność w szerokim rozumieniu jest szczególną cechą odnoszącą się do materii zarówno żywej, jak i nieożywionej. Może dotyczyć szerokiego spectrum rzeczy: organizmów, dóbr oraz zjawisk występujących w otoczeniu człowieka. Wyróżnia przedmiot ludzkiego zainteresowania spośród innych znanych już rzeczy i skłania do bliższego zainteresowania się jego specyfiką.

\section{Atrakcyjność w podstawowym znaczeniu}

Atrakcyjność jest oceniana jako cecha jednoznacznie pozytywna i pożądana. Utożsamiana jest zazwyczaj z niezaprzeczalnym walorem lub zbiorem unikalnych walorów charakterystycznych dla obserwowanego obiektu. W pewnej mierze jest zależna od subiektywnej opinii osoby zainteresowanej, chociaż może być także osądem reprezentującym określone grupy, społeczności i większe zbiorowiska ludzkie. W określonych granicach jej odbiór może być kształtowany przez działania marketingowe, przekazy medialne czy obiegowe opinie. Wynik tych działań zależy w dużej mierze od intensywności zastosowanych dla osiągnięcia ostatecznego celu metod i narzędzi.

Jako przykład konfiguracji, w jakiej występuje omawiana cecha, można podać atrakcyjne: pracę, locum, wyjazd wakacyjny, osobę czy też możliwość uczestnictwa w atrakcyjnej imprezie o charakterze masowym.

Atrakcyjna praca kojarzy się nam przede wszystkim z wysokimi zarobkami, możliwościami rozwoju intelektualnego, szansami na awans, urozmaiceniem zagadnień jakich dotyczy, brakiem ponadnormatywnych obowiązków i sprawowaniem władzy połączonym z zajmowaniem liczącego się w istniejącej hierarchii stanowiska.

Atrakcyjne locum oznacza dom lub mieszkanie o dogodnej lokalizacji, najlepiej w spokojnej i cichej okolicy, o przystępnej cenie, relatywnie dużym metrażu, ładnym widoku z okna, zadowalającym standardzie, położone niedaleko od miejsca zatrudnienia, posiadające dogodne połączenia komunikacyjne 
z centrum miejscowości, w której się znajduje oraz nadające się do natychmiastowego zamieszkania.

Atrakcyjny wyjazd wakacyjny powinien w swojej ofercie zawierać: dobrą, najlepiej słoneczną pogodę, umiarkowaną cenę, zdrowe i smaczne wyżywienie, bogaty program turystyczny, modne $\mathrm{w}$ danym sezonie miejsce destynacji oraz kulturalne towarzystwo w określonym, odpowiadającym nam wieku.

Atrakcyjna osoba to człowiek posiadający przyciągającą zainteresowanie urodę, połączoną najlepiej z wysokimi walorami intelektualnymi. Jednak ludzka atrakcyjność stanowi jedno z najbardziej subiektywnych kryteriów oceny. W dzisiejszych czasach za tego rodzaju jednostkę może uchodzić również osoba zajmująca eksponowaną pozycję w polityce lub posiadająca rozległą władzę. W wielu przypadkach zaciekawienie i podziw ludzi budzi duża ilość pieniędzy, jakimi dysponują inni, znaczne zasoby materialne lub rozgłos czy sława, jakie im towarzyszą. Atrakcyjne osoby nie zawsze i niekoniecznie muszą się przy tym wyróżniać pociągającym i młodym wyglądem.

Interesująca impreza, której można być świadkiem lub w niej aktywnie uczestniczyć, to najczęściej: przedstawienie teatralne, wydarzenie sportowe, koncert, wernisaż, spotkanie ze znaną osobistością z życia kulturalnego lub polityki. O atrakcyjności takiego spotkania decyduje elitarność środowiska, do którego jest adresowane, trudność w uzyskaniu nań zaproszenia lub cena biletu, wyjątkowość wydarzenia, a także zainteresowanie mass mediów.

Oto tylko kilka wybranych z niezliczonej ilości możliwych przykładów, określających w potocznym znaczeniu zjawisko atrakcyjności.

\section{Pojęcie atrakcyjności inwestycyjnej regionu}

W odniesieniu do określonych obszarów na ich postrzeganie wpływ ma znacznie więcej czynników, elementów i składowych o charakterze merytorycznym. Rozwój regionalny w dużej mierze uzależniony od zauważalnych zmian przede wszystkim o charakterze techniczno-ekonomicznym, dla wystąpienia których warunkiem koniecznym są sprzyjające wzrostowi inwestycje. Inwestycje zależą bezpośrednio od kapitału, który może być wygenerowany wewnątrz danego regionu lub być alokacją środków finansowych pochodzących z zewnątrz. W każdym przypadku wybrany obszar powinien wykazać się określonymi cechami zachęcającymi do inwestowania. Przy czym pod uwagę należy wziąć, obok czysto ekonomicznych i finansowych, także pozostałe istotne czynniki, takie jak: uwarunkowania społeczne czy kulturowe, walory ekologiczne, historyczne, demograficzne oraz geograficzne. W grę wchodziłoby nie tylko to, czym dysponuje region aktualnie, lecz także plany i zamierzenia dotyczące zagospodarowania danego obszaru w przyszłości. 
W ocenie należałoby zatem dodatkowo uwzględnić przewidywane scenariusze wydarzeń:

- możliwych do realizacji,

- najbardziej korzystnych dla regionu (a także dla kraju),

- oczekiwanych przez społeczeństwo,

- uzasadnionych ze strony ekonomicznej,

- mogących wystąpić samoistnie.

Kompleksowe rozpatrywanie uwarunkowań rozwojowych, mających wpływ na określenie atrakcyjności inwestycyjnej regionu, wydaje się zatem niezbędną przesłanką dla stworzenia wzorca służącego jego wiarygodnej ocenie. Trzeba przy tym uwzględnić wszystkie elementy i czynniki, które mogą przyczynić się do rozwoju danego terenu.

Pomocnym instrumentem w wyznaczeniu czynników, które odgrywają lub też będą odgrywały w nadchodzącej przyszłości istotną rolę, jest analiza obejmująca silne i słabe strony badanego obszaru oraz występujące szanse i zagrożenia dla jego sprawnego funkcjonowania (Wiatrak, 2006, s. 13-14).

\section{Ocena atrakcyjności inwestycyjnej Polski Wschodniej}

Istnieje kilka powszechnie stosowanych metod oceny atrakcyjności regionu. Różnią się od siebie podejściem do diagnozowanego obiektu, dokładnością przeprowadzonego badania, ilością czynników branych pod uwagę oraz sposobem prezentacji rezultatów.

\subsection{Analiza SWOT}

Jedną z najbardziej popularnych technik, które mogą zostać wykorzystane do oceny atrakcyjności inwestycyjnej regionu jest analiza SWOT. Stanowi ona relatywnie prosty, a przy tym szybki i skuteczny sposób stwierdzenia tego, co jest najważniejsze dla określenia bieżącej sytuacji badanego podmiotu i jego perspektyw. Dzięki zastosowaniu tego narzędzia, możliwe staje się uporządkowanie dostępnych informacji oraz przyjęcie ewentualnej strategii rozwoju. W naukach ekonomicznych ten rodzaj analizy ma szerokie zastosowanie. Wykorzystywany jest on przykładowo do ustalenia aktualnej pozycji: przedsiębiorstw, organizacji i instytucji, organów administracji, mniejszych i większych związków terytorialnych, poziomu konkurencyjności firm lub atrakcyjności produktu. Istotną rzeczą przy zastosowaniu analizy SWOT jest możliwie radykalne ograniczenie ilości 
branych pod uwagę kluczowych elementów, najlepiej do kilku najistotniejszych w każdym obszarze.

Nazwa SWOT pochodzi od pierwszych liter słów określających cztery czynniki, według których przebiega klasyfikacja możliwości podmiotu badania:

- Strengths, czyli mocne strony, które aktualnie w sposób pozytywny wyróżniają obiekt w otoczeniu. Jeśli zostaną one wykorzystane, będą atutami umożliwiającymi jego dalszy dynamiczny rozwój. Sprzyjają odniesieniu ostatecznego sukcesu; umożliwiają powstanie i pozwalają zachować przewagę rynkową w stosunku do konkurencji.

- Weaknesses, czyli słabe strony badanego obiektu. Istniejący obecnie obiektywny brak możliwości oraz wszystkie bariery i ograniczenia, które przeszkadzają w wykorzystaniu całego potencjału podmiotu dla osiągnięcia pożądanego rezultatu. Trzeba je możliwie szybko zidentyfikować, a następnie zdefiniować. W dalszej kolejności dążyć do wyeliminowania lub chociażby do ograniczenia ich niepożądanego wpływu.

- Opportunities, czyli szanse (lub inaczej możliwości) - tworzą je wszelkie uwarunkowania, które mogą generować pozytywne zmiany opisywanego obiektu. Właściwe ich wykorzystanie, pomaga podmiotowi w zapewnieniu sobie ciągłego i zrównoważonego rozwoju.

- Threats, czyli potencjalne zagrożenia - czynniki, które w przyszłości mogą stanowić zagrożenie dla przyszłości analizowanego obiektu. Należy do nich zaliczyć wszystko, co może być przyczyną wystąpienia niekorzystnych zmian oraz zjawisk osłabiających potencjał lub możliwości rozwojowe diagnozowanego podmiotu.

Najczęściej przyjmuje się, że mocne i słabe strony analizowanego obiektu uwarunkowane są czynnikami wewnętrznym, natomiast szanse i zagrożenia ściśle powiązane są z przyczynami zewnętrznymi. Dodatkowo mocne i słabe strony mogą występować jako czynniki zależne od podmiotu i odnoszące się do jego stanu obecnego, a szanse i zagrożenia to przyszłe obiektywne zjawiska, na które oddziaływanie podmiotu jest ograniczone.

Obrana przez władze podmiotu strategia działania powinna na podstawie przeprowadzonej analizy SWOT:

- wykorzystywać i jednocześnie eksponować jego silne strony;

- dążyć do wyeliminowania słabych stron lub maksymalnego zredukowania ich negatywnego oddziaływania;

- starać się wykorzystać wszelkie możliwości, których rezultatem byłoby wystąpienie pozytywnych zmian;

- zapobiegać zagrożeniom, a w przypadku gdy są nieuniknione, starać się na nie zawczasu przygotowywać. 


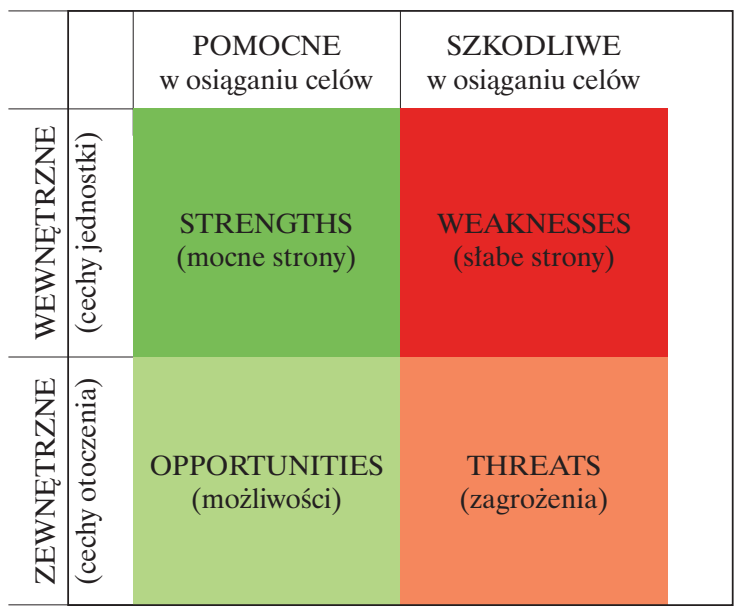

Rysunek 21. Podstawy założeniowe analizy SWOT

Źródło: http://zarzadzanieblog.blogspot.com.

Najważniejsze założenia składające się na analizę SWOT zostały ukazane na rysunku 21.

W odniesieniu do próby określenia atrakcyjności pięciu województw Polski Wschodniej za pomocą analizy SWOT można potraktować ich obszar jako wspólny przedmiot badania. Następnie w drugim etapie osobno przedstawić czynniki specyficzne dla poszczególnych regionów, według uprzednio przyjętego dla zastosowanej techniki wzorca.

Przy korzystaniu z analizy SWOT należy pamiętać o mogącym wystąpić subiektywnym podejściu sporządzających ją badaczy, do wyróżnionych czynników w zakresie mocnych i słabych stron, szans i zagrożeń. Konieczność ograniczenia ilości i zakresu wziętych pod uwagę danych może spowodować dodatkowo pominięcie pewnych istotnych dla stworzonego obrazu informacji. Niemniej jednak zastosowanie tej metody daje całościowy i relatywnie dokładny obraz analizowanego obiektu.

Na podstawie przeprowadzonej analizy SWOT dla Polski Wschodniej traktowanej jako całość (a nie pięć odrębnych regionów), można wysnuć ważne wnioski dotyczące atrakcyjności tego obszaru:

- Polska Wschodnia pozostaje obszarem peryferyjnym w stosunku do ważniejszych ośrodków rozwoju gospodarczego w Polsce oraz Europie Zachodniej (Unii Europejskiej);

- pomimo kampanii medialnej i wielu zachęt ze strony otoczenia biznesu oraz władz samorządowych, obszar ten jest w dalszym ciagu w oczach inwestorów mało zachęcający dla alokacji kapitału; 
Tablica 18. Analiza SWOT dla traktowanego jako całość obszaru Polski Wschodniej

\begin{tabular}{|c|}
\hline Mocne strony \\
\hline $\begin{array}{l}\text { 1) duża ilość atrakcyjnych terenów nadających } \\
\text { się pod inwestycje } \\
\text { 2) interesujące pod względem turystycznym } \\
\text { tereny, ze względu na ich walory: krajobra- } \\
\text { zowe przyrodnicze, historyczne, wypoczyn- } \\
\text { kowe oraz unikatowe środowisko naturalne } \\
\text { 3) prężnie działające specjalne strefy ekono- } \\
\text { miczne } \\
\text { 4) istnienie funkcjonujących z powodzeniem, } \\
\text { wybranych branż oraz działów gospodar- } \\
\text { ki, wytwarzających na potrzeby rynku } \\
\text { wewnętrznego i zagranicy } \\
\text { 5) relatywnie duża ilość firm należących do } \\
\text { kluczowego dla gospodarki sektora MSP } \\
\text { 6) ożywiona działalność ośrodków naukowo- } \\
\text { akademickich, liczących się w kraju i poza } \\
\text { jego granicami } \\
\text { 7) bliskość dużych rynków zbytu za wschodnią } \\
\text { granicą Polski } \\
\text { 8) ekologiczne rolnictwo }\end{array}$ \\
\hline
\end{tabular}

Stabe strony

1) niski poziom regionalnego $\mathrm{PKB}, \mathrm{PKB}$ per capita oraz wartości dodanej brutto

2) najwyższa w kraju stopa bezrobocia, szczególnie w dwóch grupach: do 25 lat oraz $50+$

3) słaba infrastruktura komunikacyjna (drogowa, wodna i kolejowa)

4) peryferyjne położenie w stosunku do głównych ośrodków rozwojowych w Polsce i w Europie Zachodniej

5) mało efektywna gospodarka oparta głównie na rolnictwie i związanym z nim przemyśle przetwórczym

6) niewielka liczba ośrodków miejskich o charakterze metropolitalnym, tworzących rozwinięte aglomeracje

7) brak szerszego wykorzystania ośrodków akademickich dla celów współdziałania z biznesem i prowadzenia badań na potrzeby różnych gałęzi gospodarki narodowej

8) niski poziom inwestycji krajowych i zagranicznych $w$ regionach

\begin{tabular}{|c|}
\hline \multicolumn{2}{|c|}{ Szanse (możliwości) } \\
\hline 1) liczące się wsparcie finansowe UE w ra-
\end{tabular}

1) liczące się wsparcie finansowe UE w ramach programów strukturalnych i operacyjnych

2) potencjalnie niewyczerpany rezerwuar taniej siły roboczej, pochodzącej zarówno z pięciu regionów Polski Wschodniej, jak i w dalszej kolejności z Ukrainy, Białorusi i Słowacji

3) zakrojona na szeroką skalę akcja medialna, reklamująca unikatowe cechy opisywanego obszaru

4) wzrost zainteresowania wśród turystów z Polski i z zagranicy

5) unikatowa przyroda, zabytki i walory krajobrazowe

6) rosnące efektywność współpracy międzyregionalnej i transgranicznej

7) zwiększająca się aktywność proinwestycyjna administracji samorządowej i instytucji działających w otoczeniu biznesu

8) Zauważalny wzrost potencjału w sektorze usług i wybranych gałęzi przemysłu (turystyka, mleczarstwo, meblarstwo, przetwórstwo spożywcze)

1) odpływ w poszukiwaniu pracy najbardziej kreatywnych i wykształconych osób do innych regionów i zagranicę

2) istnienie rozległych sfer ubóstwa i obszarów wystepowania „bezrobocia pokoleniowego"

3) duża wrażliwość całego obszaru na zjawiska związane $\mathrm{z}$ pogłębianiem się światowego kryzysu ekonomicznego

4) brak swobodnego przepływu kapitałów, siły roboczej i towarów pomiędzy Polską Wschodnią a graniczacymi $\mathrm{z}$ nią regionami państw spoza Unii Europejskiej (Rosją, Białorusią i Ukrainą)

5) unijne limity dotyczące produkcji w gałęziach gospodarki związanych ze specjalizacją regionalną

6) wynikające ze zmian otoczenia zagrożenia dla istniejącej przyrody

7) słaba efektywność wykorzystania środków finansowego wsparcia, pochodzących z UE

8) zagrożenia pochodzące od klimatu i sił przyrody, takie jak: wiosenne powodzie, srogie zimy, upalne lata

Źródło: opracowanie własne na podstawie: Ministerstwo Rozwoju Regionalnego (2007). 
- na ten stan wpływa szereg czynników, takich jak: nieefektywna struktura gospodarki z przewagą rolnictwa, słabo rozwinięty przemysł, nasilony odpływ wykwalifikowanej siły roboczej oraz brak rozwiniętej infrastruktury komunikacyjnej, znikoma ilość znaczących ośrodków metropolitalnych;

- przeszkodę w rozwoju może stanowić niski PKB per capita, rzutujący na małą zamożność społeczeństwa, a przez to na jego możliwości edukacyjne i rozwojowe, poziom konsumpcji oraz mobilność mieszkańców;

- istnienie ośrodków akademickich tylko w niewielkim stopniu stanowi wsparcie dla poczynań lokalnych usług i biznesu;

- Polska Wschodnia w dalszym ciągu nie może wykazać się infrastrukturą komunikacyjna i telekomunikacyjną porównywalną poziomem z resztą kraju, co stanowi poważna barierę w dostępności tych terenów.

Po przeprowadzeniu pierwszego etapu analizy SWOT oraz mając na uwadze założenia zaprezentowanych wcześniej programów pomocowych i wsparcia pochodzących z Unii Europejskiej, można uznać, że pięć regionów Polski Wschodniej w dalszym ciągu reprezentuje sobą obszar mało atrakcyjny inwestycyjnie dla kapitału polskiego i zagranicznego. Program Operacyjny Rozwój Polski Wschodniej stanowi krok w dobrym kierunku, jednakże ze względu na wielkie zapóźnienie techniczno-cywilizacyjne analizowanych obszarów, na jego skutki trzeba będzie czekać jeszcze długie lata. Rozwiązaniem byłaby dalsza intensyfikacja inwestycji w regionie, przy jednoczesnym wykorzystaniu endogenicznego potencjału istniejącego na opisywanym terytorium. Myśląc o niezbędnych inwestycjach, należy przede wszystkim mieć te na uwadze, które umożliwiłyby zatrzymanie niekorzystnych zjawisk demograficznych w tym szczególnie odpływu najlepiej wykształconej części siły roboczej i emigracji zarobkowej szerokiego społeczeństwa do innych regionów.

Drugi etap analizy SWOT będzie polegał na odnalezieniu indywidualnie rozpatrywanych mocnych i słabych stron, możliwości i zagrożeń dla każdego z pięciu województw Polski Wschodniej (tab. 19).

$\mathrm{Na}$ niską atrakcyjność inwestycyjną województwa lubelskiego zasadniczy wpływ mają słaba produktywność głównych sektorów gospodarki tworzonych przez rolnictwo i przemysł spożywczo-przetwórczy. Sytuację dodatkowo komplikuje spadający popyt na dwa inne produkty, które niegdý́ były mocną stroną regionu. Chodzi tu o tytoń i jego produkty pochodne oraz coraz mniej popularne wyroby spirytusowe. Główny atut tego obszaru, którym są urodzajne gleby, nie jest w pełni wykorzystany ze względu na słabą wydajność pracy. W roku 2005 zanotowano jeden z dwóch przypadków odpływu kapitału zagranicznego w Polsce. Tego stanu rzeczy nie będzie można w szybkim tempie zmienić, bez zaangażowania znacznych środków. Podsumowując rezultaty analizy, zauważalne są głównie czynniki zniechęcające potencjalnych inwestorów. 
Tablica 19. Województwo lubelskie. Analiza SWOT czynników specyficznych dla tego regionu

\begin{tabular}{|c|c|}
\hline Mocne strony & Slabe strony \\
\hline $\begin{array}{l}\text { - bezpośrednia linia graniczna z terenami } \\
\text { Białorusi i Ukrainy (oba państwa nie nale- } \\
\text { żą do UE) } \\
\text { - trzeci co do powierzchni region w naszym } \\
\text { kraju, posiadający wiele interesujących } \\
\text { terenów pod inwestycje krajowe i zagra- } \\
\text { niczne; zajmuje obszar porównywalny } \\
\text { z Macedonią lub Izraelem, natomiast } \\
\text { większy od Słowenii, Czarnogóry, Cypru, } \\
\text { Libanu czy Kuwejtu (liczonych osobno) }\end{array}$ & $\begin{array}{l}\text { - produkcja globalna na jednego mieszkań- } \\
\text { ca poniżej średniej krajowej, na poziomie } \\
\text { około } 60 \% \text { tego wskaźnika } \\
\text { - niska wartość obrotów handlowych regionu } \\
\text { z zagranicą } \\
\text { - duże bezrobocie wśród absolwentów szkół } \\
\text { wyższych } \\
\text { - niekorzystna struktura zatrudnienia oraz } \\
\text { słaba wydajność pracy } \\
\text { - słaba produktywność głównych sektorów } \\
\text { gospodarki województwa }\end{array}$ \\
\hline Szanse (możliwości) & Zagrożenia \\
\hline $\begin{array}{l}\text { - najsilniejszy ośrodek akademicki w Polsce } \\
\text { Wschodniej z prężnie działającym, zna- } \\
\text { nym w kraju oraz zagranicą, Katolickim } \\
\text { Uniwersytetem Lubelskim (KUL) } \\
\text { - długa lista zabytków, przykładów architek- } \\
\text { tury, skansenów oraz walorów krajobrazo- } \\
\text { wych i przyrodniczych na tym terenie } \\
\text { - najlepsze gatunkowo ziemie uprawne na } \\
\text { terenie kraju }\end{array}$ & $\begin{array}{l}\text { - najniższa produkcja sprzedana przemysłu, } \\
\text { w przeliczeniu na jednego mieszkańca } \\
\text { (poniżej } 8 \text { tys. zł) } \\
\text { - drugi po województwie podlaskim przypa- } \\
\text { dek odpływu kapitału zagranicznego z tere- } \\
\text { nu regionu w Polsce, szacowany na około } \\
\text { 26\% w roku } 2005 \\
\text { - słabe zaangażowanie bezpośrednich inwe- } \\
\text { stycji zagranicznych w regionie }\end{array}$ \\
\hline
\end{tabular}

Źródło: opracowanie własne na podstawie: Ministerstwo Rozwoju Regionalnego (2007).

Tablica 20. Województwo podkarpackie. Analiza SWOT czynników specyficznych dla tego regionu

\begin{tabular}{|c|c|}
\hline Mocne strony & Slabe strony \\
\hline $\begin{array}{l}\text { - istnienie „Doliny Lotniczej”, czyli najwięk- } \\
\text { szego klastra przemysłowego w Polsce; } \\
\text { w działających tutaj } 77 \text { firmach jest zatrud- } \\
\text { nionych ponad } 22 \text { tys. wysoko wykwalifi- } \\
\text { kowanych pracowników } \\
\text { - posiadanie bezpośredniej granicy ze } \\
\text { Słowacją (państwo należące do UE) oraz } \\
\text { z Ukrainą (kraj spoza UE) }\end{array}$ & $\begin{array}{l}\text { - niski stopień zurbanizowania obszaru } \\
\text { (przewaga mieszkańców wsi) } \\
\text { - gęstość zaludnienia poniżej średniej kra- } \\
\text { jowej } \\
\text { - duża ilość ziem nienadających się pod } \\
\text { intensywną uprawę (bardziej przydatnych } \\
\text { dla hodowli) } \\
\text { - niższy od średniej krajowej wskaźnik osób } \\
\text { posiadających wyższe wykształcenie }\end{array}$ \\
\hline Szanse (możliwości) & Zagrożenia \\
\hline $\begin{array}{l}\text { - cenne walory środowiska przyrodniczo- } \\
\text { krajobrazowego dla turystyki krajowej } \\
\text { i zagranicznej }\end{array}$ & $\begin{array}{l}\text { - niepokojąco wzrastająca liczba bezrobot- } \\
\text { nych i długotrwale pozostających bez pracy }\end{array}$ \\
\hline
\end{tabular}

Źródło: opracowanie własne na podstawie: Ministerstwo Rozwoju Regionalnego (2007). 
Analizując sytuację województwa podkarpackiego na pierwszy plan wysuwa się jego największy atut, czyli „Dolina Lotnicza”. Jest to wielkie koło zamachowe w dziedzinie badań, rozwoju i wprowadzania innowacji przemysłowych w ramach omawianego obszaru, jak również całego kraju. Słabą stroną jest słaby stopień urbanizacji obszaru połączony z brakiem wystarczającej liczby wysoko wykwalifikowanych kadr technicznych. Jednakże ten mankament można łatwo wyeliminować poprzez ściągnięcie odpowiednich ludzi z położonych w sąsiedztwie regionów.

Tablica 21. Województwo świętokrzyskie. Analiza SWOT czynników specyficznych dla tego regionu

\begin{tabular}{|c|c|}
\hline Mocne strony & Stabe strony \\
\hline $\begin{array}{l}\text { - najlepsza infrastruktura kolejowo-drogowa } \\
\text { na całym obszarze Polski Wschodniej (cho- } \\
\text { ciaż przestarzała i niedoinwestowana) } \\
\text { - cenne źródła leczniczych wód mineral- } \\
\text { nych w miejscowościach: Busko-Zdrój } \\
\text { i Solec-Zdrój } \\
\text { - bogate złoża kopalin mineralnych, przydat- } \\
\text { nych w produkcji podstawowych materiałów } \\
\text { szczególnie dla przemysłu budowlanego }\end{array}$ & $\begin{array}{l}\text { - brak bezpośredniej linii granicznej } \\
\text { z jakimkolwiek regionem spoza kraju } \\
\text { - najniższy w Polsce wskaźnik udzielonych } \\
\text { noclegów, kształtujący się na pozio- } \\
\text { mie } 1 \% \\
\text { - najniższe w kraju nakłady inwestycyjne } \\
\text { w sektorze przedsiębiorstw } \\
\text { - wydatki na badania i rozwój w sekto- } \\
\text { rze przedsiębiorstw poniżej średniej } \\
\text { krajowej }\end{array}$ \\
\hline Szanse (możliwości) & Zagrożenia \\
\hline $\begin{array}{l}\text { - zbliżona do poziomu krajowego wysoka } \\
\text { dynamika PKB per capita } \\
\text { - zwiększający się poziom nakładów inwesty- } \\
\text { cyjnych na działalność innowacyjną } \\
\text { - rozbudowa Kielc w kierunku prężnego } \\
\text { ośrodka akademickiego } \\
\text { - wysoka aktywność władz samorządowych } \\
\text { wszystkich szczebli na polu pozyskiwania } \\
\text { inwestorów }\end{array}$ & $\begin{array}{l}\text { - niepokojący brak zainteresowania ze stro- } \\
\text { ny turystów zagranicznych, który przekła- } \\
\text { da się na ostatnie miejsce w kategorii osób } \\
\text { spoza kraju odwiedzających ten region, } \\
\text { z liczby wszystkich piętnastu województw } \\
\text { w Polsce } \\
\text { - położenie województwa z dala od plano- } \\
\text { wanej sieci autostrad i krajowych dróg } \\
\text { szybkiego ruchu }\end{array}$ \\
\hline
\end{tabular}

Źródło: opracowanie własne na podstawie: Ministerstwo Rozwoju Regionalnego (2007).

Jak się wydaje, jest to „dość trudny przypadek” wśród pięciu regionów zakwalifikowanych do obszaru Polski Wschodniej. Można odnieść wrażenie, że przyporządkowanie (do Polski Wschodniej) zamiast przyczyniać się do rozwoju tego obszaru, hamuje jego postęp. Województwo świętokrzyskie ciąży bardziej w kierunku centrum kraju, szczególnie Mazowsza niż w kierunku wschodu. Z północnych powiatów regionu świętokrzyskiego bliżej jest do Radomia, leżącego już w innym województwie, niż do Kielc. Podobnie jest w przypadku 
powiatów położonych na południu i południowym zachodzie regionu, skąd dużo bliżej jest do Krakowa położonego w województwie małopolskim. Trasy komunikacyjne i tradycyjne kontakty handlowe tego terytorium zorientowane są bardziej w relacji północ-południe niż wschód-zachód. Pominięcie regionu świętokrzyskiego przy wytyczaniu sieci przebiegających przez Polskę autostrad może przynieść negatywne skutki, które się ujawnią już w przeciągu nadchodzących kilku lat.

Tablica 22. Województwo warmińsko-mazurskie. Analiza SWOT czynników specyficznych dla tego regionu

\begin{tabular}{|c|c|}
\hline Mocne strony & Slabe strony \\
\hline $\begin{array}{l}\text { - unikalne w skali światowej walory przy- } \\
\text { rodniczo-krajobrazowe Pojezierza War- } \\
\text { mińsko-Mazurskiego } \\
\text { - produkcja globalna na jednego mieszkań- } \\
\text { ca bliska średniej krajowej, na poziomie } \\
\text { około } 90 \% \text { tego wskaźnika; najwyższa } \\
\text { w Polsce Wschodniej }\end{array}$ & $\begin{array}{l}\text { - najniższa w Polsce gęstość zaludnienia } \\
\text { wynosząca 59,1 osoby na jeden km² } \\
\text { - mała przydatność terenów poza Olsztynem } \\
\text { i Elblągiem dla inwestycji typu przemysło- } \\
\text { wego ze względu na dużą ilość obszarów } \\
\text { chronionych } \\
\text { - brak otwarcia portu w Elblągu na potrzeby } \\
\text { gospodarki morskiej }\end{array}$ \\
\hline Szanse (możliwości) & Zagrożenia \\
\hline $\begin{array}{l}\text { - jeden z trzech najczęściej odwiedzanych } \\
\text { przez turystów regionów naszego kraju } \\
\text { (obok województw pomorskiego i zachod- } \\
\text { niopomorskiego) } \\
\text { - projektowana autostrada Via Baltica } \\
\text { będzie w przyszłości tworzyła oś komuni- } \\
\text { kacyjną regionu }\end{array}$ & $\begin{array}{l}\text { - najwyższy poziom stopy bezrobocia } \\
\text { w Polsce szacowany na 22,3\% na koniec } \\
\text { marca } 2013 \text { (dane GUS) } \\
\text { - odpływ kapitału ludzkiego do innych regio- } \\
\text { nów oraz za granice } \\
\text { - niski poziom inwestycji zagranicznych } \\
\text { i krajowych na obszarze województwa }\end{array}$ \\
\hline
\end{tabular}

Źródło: opracowanie własne na podstawie: Ministerstwo Rozwoju Regionalnego (2007).

Wielkim atutem województwa jest jego położenie geograficzne. Długa granica z należącym do Rosji, dynamicznie rozwijającym się Okręgiem Kaliningradzkim może przynieść w najbliższych latach znaczne korzyści gospodarcze. Usytuowanie na drodze tranzytowej z Litwy do centrum naszego kraju i na zachód Europy przynosi już takie korzyści obecnie. Zamierający port w Elblągu, wobec bierności naszych władz na polu otwarcia swobodnej drogi na Bałtyk, rokuje zdecydowanie źle. Najwyższa stopa bezrobocia w Polsce przysparza dodatkowych kłopotów. Niezwykle cenna jest specjalizacja regionu $\mathrm{w}$ rolnictwie ekologicznym i przemyśle przetwórczym. Atutem w skali światowej jest „Kraina Tysiąca Jezior”, przyciągająca jak magnes rzesze turystów z różnych stron świata. Wyspecjalizowanych kadr dla wszystkich dziedzin gospodarki powinien dostarczyć prężnie działający Uniwersytet 
w Olsztynie oraz inne szkoły wyższe. Oceniając drzemiący w tym obszarze potencjał, należy stwierdzić, że województwo warmińsko-mazurskie ma duże szanse na osiągnięcie spektakularnego sukcesu gospodarczego, szczególnie w turystyce.

Tablica 23. Województwo podlaskie. Analiza SWOT czynników specyficznych dla tego regionu

\begin{tabular}{|c|c|}
\hline Mocne strony & Slabe strony \\
\hline $\begin{array}{l}\text { - bezpośrednia granica z terenami Litwy } \\
\text { (należy do UE) i Białorusi (państwo spoza } \\
\text { UE) } \\
\text { - stosunkowo dobrze na tle kraju rozwinięta } \\
\text { infrastruktura turystyczna w postaci bazy } \\
\text { noclegowej (hotele i motele), sieci restau- } \\
\text { racji, ścieżek rowerowych } \\
\text { - Puszcza Białowieska - ostatni w Europie } \\
\text { przykład naturalnego kompleksu leśnego, } \\
\text { nietkniętego przez cywilizację }\end{array}$ & $\begin{array}{l}\text { - najmniejsza liczba zarejestrowanych pod- } \\
\text { miotów gospodarczych działających na } \\
\text { terenie tego regionu, w porównaniu do } \\
\text { całego kraju (niecałe } 89 \text { tys. w roku 2006) } \\
\text { - niski na tle innych regionów w naszym } \\
\text { kraju potencjał badawczo-rozwojowy } \\
\text { i znikome nakłady w tej dziedzinie } \\
\text { - peryferyjne położenie do głównych ośrod- } \\
\text { ków rozwojowych w Polsce i w Europie }\end{array}$ \\
\hline Szanse (możliwości) & Zagrożenia \\
\hline $\begin{array}{l}\text { - najwyższy w kraju napływ zagranicznych } \\
\text { inwestycji bezpośrednich per capita w latach } \\
\text { 2007-2010 (wyniósł 119\%) (www.mrr.gov. } \\
\text { pl) } \\
\text { - zainteresowanie władz w obszarze korzyści, } \\
\text { jakie może przynieść specjalizacja regionu } \\
\text { w dziedzinie nanotechnologii oraz innych } \\
\text { dziedzin zaawansowanej nauki i techniki } \\
\text { - projektowana autostrada Via Baltica }\end{array}$ & $\begin{array}{l}\text { - najwyższy w kraju odpływ kapitału inwe- } \\
\text { stycyjnego (ok. 50\% w } 2005 \text { r.) } \\
\text { - nasilająca się „ucieczka” najbardziej } \\
\text { wykwalifikowanej kadry pracowniczej } \\
\text { z województwa; z terenu Podlasia w ciągu } \\
\text { dekady 1999-2009, wyemigrowało ponad } \\
20 \text { tys. osób; w tej liczbie } 17 \text { tys. wybrało } \\
\text { inne województwa, natomiast ponad } 3 \text { tys. } \\
\text { opuściło kraj }\end{array}$ \\
\hline
\end{tabular}

Źródło: opracowanie własne na podstawie: Ministerstwo Rozwoju Regionalnego (2007).

Mocną stroną regionu jest rolnictwo. Szczególny wpływ na oblicze województwa podlaskiego wywiera przemysł przetwórczy mięsa i przemysł mleczarski. Niestety sektor rolniczy sprzyja jedynie rozwojowi gospodarczemu obszaru w wymiarze krajowym. W skali międzynarodowej Podlasie leży prawie na samych peryferiach Unii Europejskiej. Nie można, ze względu na skomplikowane uwarunkowania polityczne, wykorzystać jego granicy z Białorusią. Niewielka Litwa nie posiada odpowiedniego potencjału, aby „rozruszać” gospodarkę regionu. Niepokojem napawa zanotowany w 2005 roku najwyższy w naszym kraju odpływ kapitału inwestycyjnego. Wystąpienie tego rodzaju sytuacji wymaga wieloletnich działań naprawczych. Wielkim atutem regionu i niewątpliwą atrakcją turystyczną jest Puszcza Białowieska i trzy inne parki narodowe (Biebrzański, Narwiański i Wigierski). 
Na pierwszym etapie analizy SWOT, obejmującej obszar Polski Wschodniej, zostały zasugerowane kierunki działań mających na celu wykorzystanie potencjału endogenicznego obszaru oraz zatrzymanie bardzo niekorzystnej tendencji „ucieczki kapitału ludzkiego”.

Przeprowadzając drugi etap analizy, eksponujący specyfikę każdego z regionów, można stworzyć ranking atrakcyjności inwestycyjnej województw wchodzących w skład omawianego terytorium. W tym kontekście najbardziej atrakcyjne wydają się, kolejno województwa:

1) podkarpackie,

2) warmińsko-mazurskie,

3) świętokrzyskie,

4) lubelskie,

5) podlaskie.

Oczywiście lista mocnych i słabych stron, szans i możliwości może ewoluować w różnych kierunkach. Przykładowo, kryzys w przemyśle lotniczym może pogrążyć województwo podkarpackie, a zmiana rządów na Białorusi może otworzyć drogę handlową na Wschód i sprzyjać rozwojowi województw podlaskiego i lubelskiego. Podobnie jak specjalny status przyznany Okręgowi Kaliningradzkiemu przez UE, zdynamizuje rozwój województwa warmińsko-mazurskiego. Natomiast wejście w perspektywie kilku lat Ukrainy w struktury unijne ułatwi pełny rozkwit województw lubelskiego i podkarpackiego. Z pewnością radykalnych rozwiązań należy już dzisiaj szukać dla województwa świętokrzyskiego, zanim jego dystans do innych regionów tak naszego kraju, jak i Europy Zachodniej ulegnie powiększeniu.

\subsection{Atrakcyjność regionu mierzona poziomem inwestycji}

Dokładnym i dość nieskomplikowanym sposobem wyznaczenia atrakcyjności inwestycyjnej poszczególnych województw w naszym kraju jest określenie wielkości kapitału podstawowego, jaki został zgromadzony przy tworzeniu działających na ich terenie spółek handlowych z udziałem kapitału zagranicznego. Jednocześnie drugim pomocnym elementem w ramach tej analizy jest przedstawienie liczby funkcjonujących w danym regionie spółek, działających w oparciu o kapitał zagraniczny, jak również ich liczby ogółem.

W założeniach metody uwaga została skupiona głównie na inwestorach zagranicznych, ponieważ system zachęt, jaki jest im oferowany, działa w warunkach podlegających mniejszym zakłóceniom (bardziej sterylnych), niż ten, który ma wpływ na lokalizację przedsiębiorstw krajowych. Alokacja kapitału międzynarodowego w określonym miejscu w znacznie mniejszym zakresie 
w porównaniu do kapitału krajowego podlega uwarunkowaniom wynikającym: z przywiązania inwestora do danego terenu, kontynuacji rodzinnych tradycji, pobudek patriotycznych, mentalności miejscowej ludności, istnienia powiązań nieformalnych, znajomości lokalnych warunków, zaufania spotecznego.

Napływ bezpośrednich inwestycji zagranicznych (BIZ) do wszystkich 16 województw w Polsce w latach 2007-2010 został przedstawiony w tablicy 24.

Bezpośrednie inwestycje zagraniczne (ang. foreign direct investment - FDI) są tworzone na terenie Polski przede wszystkim przez przedsiębiorstwa działające w formie spółek prawa handlowego. BIZ oznacza kapitał o charakterze

Tablica 24. Napływ bezpośrednich inwestycji zagranicznych (BIZ) do poszczególnych województw w latach 2007-2010*

\begin{tabular}{|c|l|c|}
\hline Pozycja & \multicolumn{1}{|c|}{ Województwo } & $\begin{array}{c}\text { Napływ BIZ } \\
\text { (w mln euro) }\end{array}$ \\
\hline 1. & Mazowieckie & 4696 \\
\hline 2. & Śląskie & 1029 \\
\hline 3. & Dolnośląskie & 1001 \\
\hline 4. & Wielkopolskie & 912 \\
\hline 5. & Małopolskie & 675 \\
\hline 6. & Pomorskie & 654 \\
\hline 7. & Zachodniopomorskie & 507 \\
\hline 8. & Lódzkie & 370 \\
\hline 9. & Lubuskie & 250 \\
\hline 10. & Kujawsko-pomorskie & 233 \\
\hline 11. & Podkarpackie & 209 \\
\hline 12. & Opolskie & 171 \\
\hline 13. & Lubelskie & 133 \\
\hline 14. & Podlaskie & 106 \\
\hline 15. & Warmińsko-mazurskie & 104 \\
\hline 16. & Świętokrzyskie & 94 \\
\hline 17. & Razem Polska & 144 \\
\hline $5 t$ & & 1400 \\
\hline
\end{tabular}

* Kolorem szarym zostały zaznaczone województwa Polski Wschodniej.

Źródło: opracowanie własne na podstawie informacji GUS oraz NBP za: www.paiz.gov.pl. 
międzynarodowym alokowany przez podmiot zagraniczny działający jako bezpośredni inwestor (firma matka) w zamyśle zachowania długoterminowej kontroli i nadzoru w firmie innego kraju (firmie córce). Może także występować jako inwestycja osoby fizycznej lub prawnej w funkcjonujące już na rynku lub dopiero tworzone przedsiębiorstwo na terenie innego kraju. Inwestycja może zostać uznana jako BIZ pod warunkiem, że zaangażowanie finansowe inwestora bezpośredniego $\mathrm{w}$ danej firmie osiągnie minimalny poziom $10 \%$ zebranych kapitałów.

Tablica 24 pokazuje, że największą atrakcyjnością, jeśli chodzi o inwestycje zagraniczne cieszyły się województwa: mazowieckie, śląskie, dolnośląskie, wielkopolskie, małopolskie, pomorskie i zachodniopomorskie. Są to regiony, charakteryzujące się rozwiniętą infrastrukturą komunikacyjną, przemysłową, usługową oraz telekomunikacyjną. Wszystkie one posiadają także rozwinięte ośrodki miejskie o charakterze metropolitalnym, zapewniające inwestorom zbliżone do standardów zachodnich warunki życia, rozwoju intelektualnego oraz różnorodnej rozrywki. Znacznie większe nakłady inwestycyjne w województwach zaawansowanych gospodarczo wpływają na efekt utrwalania się i pogłębiania istniejących różnic rozwojowych pomiędzy regionami dobrze i słabo rozwiniętymi. W ten sposób kontynuowane są negatywne trendy, z którymi usiłują bezskutecznie walczyć władze rządowe i lokalne wszystkich szczebli.

Na samym końcu zestawienia znalazło się pięć województw Polski Wschodniej. Jedynie województwo podkarpackie w pewien sposób wyzwoliło się z utartego schematu, wyprzedzając nieznacznie (o jedno miejsce) województwo opolskie. Można przypuszczać, że na taki stan rzeczy na Podkarpaciu wpłynęło istnienie największego klastra przemysłowego w Polsce - „Doliny Lotniczej”, dwóch specjalnych stref ekonomicznych oraz trzech parków przemysłowych i ekonomicznych tworzących w sumie skutecznie działające „koło zamachowe” dla tego regionu. Jak można zauważyć, w dalszym ciągu większe znaczenie przy wyborze inwestycji ma nasycenie regionu przemysłem niż walory środowiskowe czy turystyczne.

W tablicy 25 zaprezentowany został napływ bezpośrednich inwestycji zagranicznych (BIZ) w spółkach prawa handlowego działających na terenie Polski na początku 2012 roku, z podziałem na poszczególne województwa.

Z tablicy 25 można wywnioskować, że ze wszystkich regionów Polski Wschodniej najbardziej wzrosła atrakcyjność inwestowania w województwie świętokrzyskim. Na początku roku 2012 był to dziesiąty obszar na terenie Polski pod względem zdolności do przyciągania kapitału zagranicznego. Warto przypomnieć, że w latach 2007-2010 województwo świętokrzyskie zajmowało w tym rankingu ostatnie miejsce. Województwo Podkarpackie utrzymało swoją 11. pozycję w kraju. Miejsca 14., 15. i 16. zajmują województwa Polski Wschodniej, kolejno: warmińsko-mazurskie, lubelskie i podlaskie. Ostatnie 
Tablica 25. Wielkość bezpośrednich inwestycji zagranicznych (BIZ) na początku 2012 roku w spółkach prawa handlowego działających w Polsce*

\begin{tabular}{|c|l|c|}
\hline Pozycja & \multicolumn{1}{|c|}{ Województwo } & $\begin{array}{c}\text { Napływ BIZ } \\
\text { (w mln euro) }\end{array}$ \\
\hline 1. & Mazowieckie & 2084,4 \\
\hline 2. & Śląskie & 393,2 \\
\hline 3. & Dolnośląskie & 356,7 \\
\hline 4. & Wielkopolskie & 348,2 \\
\hline 5. & Pomorskie & 259,2 \\
\hline 6. & Małopolskie & 246,5 \\
\hline 7. & Lódzkie & 103,8 \\
\hline 8. & Zachodniopomorskie & 103,6 \\
\hline 9. & Kujawsko-pomorskie & 67,5 \\
\hline 10. & Świętokrzyskie & 63,2 \\
\hline 11. & Podkarpackie & 49,3 \\
\hline 12. & Lubuskie & 45,5 \\
\hline 13. & Opolskie & 38,8 \\
\hline 14. & Warmińsko-mazurskie & 34,8 \\
\hline 15. & Lubelskie & 28,5 \\
\hline 16. & Podlaskie & 12,0 \\
\hline $\mathbf{1 7 .}$ & Razem Polska & $\mathbf{4 3 5 , 2}$ \\
\hline
\end{tabular}

* Kolorem szarym zostały zaznaczone województwa Polski Wschodniej.

Źródło: opracowanie własne na podstawie informacji GUS oraz NBP za: www.paiz.gov.pl.

z wymienionych regionów (lubelskie i podlaskie) w dalszym ciągu nie potrafiły skutecznie przeciwdziałać odpływowi kapitału zagranicznego z ich obszaru ani zachęcić podmiotów zagranicznych do inwestycji. O jedną pozycję w górę przesunęło się województwo pomorskie. Niebezpieczny spadek na sam koniec rankingu zanotowały województwo opolskie (o jedna pozycję) i województwo lubuskie (o trzy pozycje). Na miejscach środkowych zaszły tylko niewielkie zmiany.

Należy przypuszczać, że zaistniałe zmiany atrakcyjności regionalnej są w pewnym zakresie wynikiem dopływu dodatkowych środków finansowych pochodzących z Programu Operacyjnego Rozwój Polski Wschodniej. Innym 
ważnym czynnikiem jest z pewnością zaangażowanie władz lokalnych w promocję podległego im obszaru. Pewne zakłócenia może powodować zaostrzenie się symptomów kryzysu gospodarczego na terenie naszego kraju. Mogą one mieć wpływ na mniejszą atrakcyjność terenów bardziej nasyconych infrastrukturą usługowa i przemysłową (Opolskie i Zachodniopomorskie).

Na samym czele zestawienia mówiącego o atrakcyjności terenów pod inwestycje, rozpatrywanych w ujęciu regionalnym, plasują się dotychczasowi liderzy, czyli województwa: mazowieckie, śląskie, dolnośląskie i wielkopolskie.

Inwestycje zagraniczne w województwach: śląskim, dolnośląskim, wielkopolskim i małopolskim są znacznie większe niż w pozostałych regionach kraju. Powodują one rezultat przeciwny do zaplanowanego na szczeblu unijnym efektu pogłębiania spójności terytorialnej. Rozwarstwienie rozwojowe w obrębie gospodarki i poziomu życia mieszkańców staje się coraz bardziej społecznie odczuwalne, co powoduje negatywne następstwa, takie jak: niezadowolenie społeczne, niekontrolowane ruchy migracyjne, odpływ najbardziej wykształconych kadr za granicę, nastroje strajkowe w likwidowanych lub sprzedawanych zakładach pracy oraz protesty wobec zamykania szkół na prowincji.

Zestawienia z tablic 24 i 25 pokazują, że bardzo poważnym problemem w nadchodzącym czasie może stać się wykraczający poza krajową skalę rozwój regionu Mazowieckiego i całej aglomeracji warszawskiej. W tej chwili tempo i nakłady inwestycyjne tak krajowe, jak i zagraniczne są w stolicy kilkukrotnie wyższe niż na pozostałym obszarze państwa polskiego. Tworzy to prawdziwą przepaść ekonomiczną i cywilizacyjną pomiędzy Warszawą i otaczającymi ją miejscowościami satelickimi a słabiej rozwiniętymi regionami naszego kraju.

Aby dopełnić analizę ukazującą atrakcyjność poszczególnych regionów w Polsce przez pryzmat poziomu inwestycji, należy jeszcze przedstawić ilość funkcjonujących w poszczególnych województwach spółek działających w oparciu o kapitał zagraniczny (tab. 26).

Dane zawarte w tablicy 26 stanowią dość dokładne potwierdzenie rezultatów przedstawionych we wcześniej zaprezentowanych dwóch zestawieniach - tablicach 24 i 25. Ukazują, że atrakcyjność regionów według kryterium poziomu inwestycji, mierzona za pomocą ilości spółek handlowych działających przy udziale kapitału zagranicznego, zawiera informacje zbliżone do tych, które przyniosło określenie środków składających się na wielkość bezpośrednich inwestycji zagranicznych w poszczególnych województwach Polski.

Według utartego już schematu, największym powodzeniem wśród inwestorów zagranicznych cieszą się najbardziej rozwinięte gospodarczo województwa, tzn. mazowieckie, wielkopolskie, śląskie, zachodniopomorskie, pomorskie i małopolskie. Natomiast najmniejsze zainteresowanie, jako miejsce działalności dla przedsiębiorstw z udziałem kapitału zagranicznego, wzbudza pięć 
Tablica 26. Ilość spółek handlowych działających przy udziale kapitału zagranicznego w poszczególnych województwach Polski w 2012 roku*

\begin{tabular}{|c|l|c|c|}
\hline Pozycja & \multicolumn{1}{|c|}{ Województwo } & $\begin{array}{c}\text { Spółki handlowe z kapitałem } \\
\text { zagranicznym }\end{array}$ & $\begin{array}{c}\text { Spółki handlowe } \\
\text { ogółem }\end{array}$ \\
\hline 1. & Mazowieckie & 26920 & 95912 \\
\hline 2. & Wielkopolskie & 6059 & 30075 \\
\hline 3. & Śląskie & 5868 & 34738 \\
\hline 4. & Zachodniopomorskie & 4345 & 14479 \\
\hline 5. & Pomorskie & 4225 & 23051 \\
\hline 6. & Małopolskie & 3924 & 24282 \\
\hline 7. & Lódzkie & 2827 & 14945 \\
\hline 8. & Lubuskie & 2736 & 719935 \\
\hline 9. & Kujawsko-pomorskie & 1724 & 5578 \\
\hline 10. & Opolskie & 1410 & 9194 \\
\hline 11. & Lubelskie & 1118 & 7996 \\
\hline 12. & Podkarpackie & 1042 & 6409 \\
\hline 13. & Warmińsko-mazurskie & 963 & 26387 \\
\hline 14. & Dolnośląskie & 667 & 4934 \\
\hline 15. & Świętokrzyskie & 570 & 4739 \\
\hline 16. & Podlaskie & 560 & \\
\hline
\end{tabular}

* Kolorem szarym zostały zaznaczone województwa Polski Wschodniej.

Źródło: http://www.csr.szczecin.pl/pliki/prezentacje/Wozniak_Magdalena_CSR.pdf.

regionów należących do Polski Wschodniej. Pewne zdziwienie może budzić dopiero 14. miejsce województwa dolnośląskiego, które znalazło się w rankingu pomiędzy warmińsko-mazurskim a świętokrzyskim. Rezultat taki, może wynikać z bliskości terenów Republiki Czeskiej, gdzie od dawna warunki inwestycyjne są znacznie korzystniejsze niż w Polsce oraz bezpośredniego sąsiedztwa województwa wielkopolskiego, gdzie liczba przyciągniętych inwestycji zagranicznych jest na drugim miejscu w Polsce. Te dwa czynniki tworzą warunki „wysysania” kapitałów z regionu dolnośląskiego. Jednakże w tym przypadku należy odwołać się do ilości wszystkich spółek działających na tym terenie. W tym układzie okazuje się, że Dolny Śląsk zajmuje czwarte miejsce w naszym kraju, pod względem popularności inwestycyjnej. Wynik ten zwraca uwagę, że ograniczenie analizy tylko do podmiotów z udziałem kapitału 
zagranicznego nie we wszystkich rozpatrywanych przypadkach jest w pełni obiektywne.

Uzasadniony niepokój musi budzić również istniejąca różnica pomiędzy Mazowszem a Polską Wschodnią. Region Lubelski, znajdujący się na najwyższym - 11 miejscu w zestawieniu atrakcyjności inwestycyjnej mierzonej ilością spółek handlowych, posiada ich ponad dziesięciokrotnie mniej liczonych ogółem i aż ponad dwudziestoczterokrotnie mniej w odniesieniu do podmiotów z udziałem kapitału zagranicznego. Jeszcze gorzej zestawienie przedstawia się, kiedy obiektem porównania będzie pierwsze w zestawieniu województwo mazowieckie i ostatnie w rankingu województwo podlaskie. W tym przypadku proporcje kształtują się odpowiednio:

- dla spółek handlowych - 20:1,

- dla spółek handlowych z udziałem kapitału zagranicznego - 48:1.

Otrzymane wyniki dają rezultat zbliżony do otrzymanego za pomocą analizy SWOT, w którym województwo podlaskie jawiło się jako jeden z najmniej atrakcyjnych regionów inwestycyjnych w naszym kraju.

\subsection{Atrakcyjność polskich regionów według raportów Instytutu Badań nad Gospodarką Rynkową}

Instytut Badań nad Gospodarką Rynkową (IBnGR), nieprzerwanie już od 2005 roku, publikuje coroczne raporty dotyczące atrakcyjności inwestycyjnej województw i podregionów Polski. Wysoki profesjonalizm tych opracowań sprawił, że stanowią one jedno z najbardziej znanych i cenionych źródeł informacji wykorzystywanych przez szerokie grono odbiorców. Zainteresowanie rezultatami badań przejawiają inwestorzy zarówno krajowi, jak i zagraniczni, przedsiębiorcy reprezentujący wszystkie gałęzie gospodarki oraz władze samorządowe i centralne w naszym kraju.

Metoda używana do wyznaczenia atrakcyjności inwestycyjnej poszczególnych terenów opiera się na szeregu założeń, z których do najważniejszych należy zaliczyć (Godlewska-Majkowska, 2008, s. 20-21):

- występowanie potencjalnej i rzeczywistej atrakcyjności inwestycyjnej badanego obszaru;

- istnienie wprost proporcjonalnej zależności pomiędzy rzeczywistą atrakcyjnością inwestycyjną a efektywnością zaangażowanego kapitału;

- występowania stymulantów i destymulantów atrakcyjności inwestycyjnej, pomiędzy którymi nie zachodzą możliwe do zaobserwowania korelacje; 
- analiza atrakcyjności inwestycyjnej może być prowadzona dla regionów różnych szczebli taksonomicznych z zachowaniem zasady porównywalności;

- istnienie czynników mających znaczenie i wpływ na atrakcyjność badanych obszarów, którym przypisane zostały określone wagi.

Należy jeszcze zdefiniować pojęcia: „potencjalnej i rzeczywistej atrakcyjności inwestycyjnej badanego obszaru” (www.paiz.gov.pl). „Potencjalna atrakcyjność inwestycyjna” (PAI) oznacza zespół dających się wyróżnić potencjalnych walorów lokalizacyjnych, które mogą mieć wpływ na osiąganie celów inwestora. Przykładowo, można do nich zaliczyć: znaczne przychody ze sprzedaży, niskie koszty prowadzonej działalności gospodarczej, wysoką rentowność przedsięwzięcia oraz konkurencyjność rynkową realizowanej inwestycji.

„Rzeczywista atrakcyjność inwestycyjna” (RAI) rozpatrywana powinna być jednocześnie w dwóch płaszczyznach:

- skłonienia inwestorów do wyboru danego regionu jako miejsca dla przewidywanej inwestycji;

- zdolności regionu do absorbcji kapitału finansowego i rzeczowego.

Przy założeniach metody używanej do wyznaczenia atrakcyjności inwestycyjnej regionów poszczególnym czynnikom zostały przypisane wagi (tab. 27).

Największa waga została procentowo wyznaczona dla pozycji koszty pracy oraz wielkość i jakości zasobów pracy - 25\%; następnie dla: dostępność trans-

Tablica 27. Waga poszczególnych czynników wyznaczających atrakcyjność (klasę) regionów

\begin{tabular}{|c|l|c|}
\hline Lp. & \multicolumn{1}{|c|}{ Czynnik } & Waga czynnika (w \%) \\
\hline 1. & Dostępność transportowa & 20 \\
\hline 2. & Koszty pracy oraz wielkość i jakość zasobów pracy & 25 \\
\hline 3. & Chłonność rynku zbytu & 15 \\
\hline 4. & Poziom rozwoju infrastruktury gospodarczej & 10 \\
\hline 5. & Poziom rozwoju infrastruktury społecznej & 5 \\
\hline 6. & Poziom powszechnego bezpieczeństwa & 5 \\
\hline 7. & Aktywność regionów w stosunku do inwestorów & 20 \\
\hline $\mathbf{8 .}$ & Lącznie & $\mathbf{1 0 0}$ \\
\hline
\end{tabular}

Źródło: Kalinowski (2005, s. 15). 
portowa - 20\%; trzecia pozycja zaś to aktywność (władz) regionów w stosunku do inwestorów; na kolejnej pozycji występuje: chłonność rynku zbytu - 15\%. Należy tu zaznaczyć, że pod uwagę brana jest chłonność rynku detalicznego i instytucjonalnego. Na kolejnych miejscach plasują się poziom infrastruktury gospodarczej - 10\%; poziom powszechnego bezpieczeństw oraz poziom infrastruktury społecznej - po 5\%. Łącznie suma wszystkich czynników daje 100\%. Stwożono pięć klas regionów wyznaczanych przez wyróżnione czynniki. Zostały one oznaczone od A - klasa najwyższa (najlepsza) do E - klasa najgorsza sprawiająca największe problemy (tab. 28).

Tablica 28. Klasyfikacja atrakcyjności województw według pięciu klas* (w 2005 roku)

\begin{tabular}{|c|c|c|c|c|c|c|c|c|c|}
\hline \multirow{3}{*}{ Lp. } & Województwo & DT & ZiKP & $\mathbf{R Z}$ & IG & IS & PBP & ARwI & \multirow{3}{*}{$\begin{array}{l}\text { Atrakcyjność } \\
\text { inwestycyjna } \\
\text { regionów }\end{array}$} \\
\hline & Waga $\Rightarrow$ & 20 & 25 & 15 & 10 & 5 & 5 & 20 & \\
\hline & & \multicolumn{7}{|c|}{ KLASA } & \\
\hline 1. & Śląskie & A & A & A & A & A & $\mathrm{E}$ & $\mathrm{C}$ & $\mathbf{A}$ \\
\hline 2. & Mazowieckie & B & $\mathrm{D}$ & A & B & B & $\mathrm{E}$ & A & A \\
\hline 3. & Małopolskie & A & A & B & A & A & $\mathrm{D}$ & B & $\mathbf{A}$ \\
\hline 4. & Dolnośląskie & B & $\mathrm{B}$ & B & A & A & $\mathrm{D}$ & A & B \\
\hline 5. & Wielkopolskie & A & B & B & $\mathrm{C}$ & $\mathrm{C}$ & $\mathrm{C}$ & A & B \\
\hline 6. & Łódzkie & $\mathrm{C}$ & A & $\mathrm{C}$ & $\mathrm{D}$ & $\mathrm{C}$ & $\mathrm{C}$ & $\mathrm{C}$ & B \\
\hline 7. & Pomorskie & $\mathrm{D}$ & $\mathrm{C}$ & A & B & B & $\mathrm{E}$ & $\mathrm{C}$ & $\mathrm{C}$ \\
\hline 8. & Zachodniopomorskie & $\mathrm{C}$ & $\mathrm{C}$ & $\mathrm{C}$ & $\mathrm{D}$ & B & $\mathrm{D}$ & B & C \\
\hline 9. & Opolskie & $\mathrm{B}$ & $\mathrm{D}$ & $\mathrm{C}$ & $\mathrm{B}$ & $\mathrm{D}$ & B & $\mathrm{C}$ & $\mathrm{C}$ \\
\hline 10. & Lubuskie & $\mathrm{C}$ & $\mathrm{D}$ & $\mathrm{D}$ & $\mathrm{C}$ & $E$ & $\mathrm{C}$ & $\mathrm{B}$ & $\mathrm{C}$ \\
\hline 11. & Podkarpackie & $\mathrm{E}$ & $\mathrm{C}$ & $\mathrm{D}$ & $\mathrm{C}$ & $\mathrm{D}$ & A & $\mathrm{D}$ & D \\
\hline 12. & Kujawsko-pomorskie & $\mathrm{C}$ & $\mathrm{B}$ & $\mathrm{E}$ & $\mathrm{D}$ & $\mathrm{C}$ & $\mathrm{C}$ & $\mathrm{E}$ & D \\
\hline 13. & $\begin{array}{l}\text { Warmińsko- } \\
\text { mazurskie }\end{array}$ & $\mathrm{D}$ & $\mathrm{E}$ & $\mathrm{E}$ & $\mathrm{C}$ & $\mathrm{D}$ & B & $\mathrm{D}$ & D \\
\hline 14. & Świętokrzyskie & $\mathrm{D}$ & $\mathrm{C}$ & $\mathrm{E}$ & E & $\mathrm{C}$ & $\mathrm{B}$ & $\mathrm{E}$ & $\mathbf{E}$ \\
\hline 15. & Lubelskie & $\mathrm{E}$ & $\mathrm{E}$ & $\mathrm{C}$ & $\mathrm{E}$ & $\mathrm{E}$ & A & $\mathrm{E}$ & $\mathbf{E}$ \\
\hline 16. & Podlaskie & E & $\mathrm{E}$ & $\mathrm{D}$ & E & $\mathrm{E}$ & A & D & $\mathbf{E}$ \\
\hline
\end{tabular}

* A - najlepsza sytuacja pod względem badanego czynnika.

* E - najgorsza sytuacja pod względem badanego czynnika.

Legenda:

DT - dostępność transportowa

IG - infrastruktura gospodarcza

IS - infrastruktura społeczna

RZ - rynek zbytu

Źródło: Kalinowski (2005, s. 77).
ZiKP - zasoby i koszt pracy

ARwI - aktywność regionów wobec inwestorów

PBP - poziom bezpieczeństwa powszechnego 
Jeśli chodzi o obszar Polski Wschodniej, to atrakcyjność inwestycyjna województw z tego obszaru (tab. 28) kształtuje podobnie, jak zostało to ustalone przy zastosowaniu analizy SWOT. Ranking wygląda następująco:

1) województwo podkarpackie,

2) województwo warmińsko-mazurskie,

3) województwo świętokrzyskie,

4) województwo lubelskie,

5) województwo podlaskie.

Grupę najsłabszych pięciu regionów kraju przedziela województwo kujawsko-pomorskie, plasujące się na 12 miejscu (w przedostatniej klasie D) zaraz za województwem podkarpackim na 11 miejscu, sklasyfikowanym także w klasie D. Warto zauważyć, że klasę D uzyskał także region warmińsko-mazurski. Na samym końcu znajdują się najbardziej wysunięte na wschód województwa: lubelskie i podlaskie (oba w najgorszej klasie E). Potwierdza to obecne ciężkie położenie obu regionów i nikłe szanse na polepszenie ich sytuacji w przyszłości. Region świętokrzyski zajmuje, wśród 16 województw, 14 miejsce w klasie E. Relatywnie wysokie pozycje do innych zestawień zajmują województwa: łódzkie (szóste miejsce, klasa B) oraz opolskie (dziewiąte miejsce, klasa C). Chociaż nie jest to tematem niniejszej pracy, należy odnieść się do czołówki przedstawionego w tablicy 26 zestawienia. Pewne zdziwienie i uzasadnione zaskoczenie może budzić pierwsze miejsce województwa śląskiego jeszcze przed województwem mazowieckim. Przedstawione dotychczas metody oceny wskazywały, jako najbardziej atrakcyjny w skali całego kraju, region Mazowsza. Trudno się z tym ustaleniami nie zgodzić. Skąd w takim razie wynik z raportu Instytutu Badań nad Gospodarka Rynkową?

Można przypuszczać, że stosunkowo skomplikowana metodyka badań, opierająca się na dużej liczbie założeń, wskaźników i przeliczników, a także dodatkowo pewna subiektywność i „skąpość” w doborze czynników oddziaływujących na ocenę atrakcyjności inwestycyjnej regionów (było ich tylko siedem) oraz określenie a priori ich wagi wpłynęły na otrzymane przez IBnGR rezultaty. Kolejne lata przyniosły odejście od określania atrakcyjności regionów według klas (od A do E). Ze względu na zmianę standardów badawczych oraz składu ekipy specjalistów sporządzających raporty Instytutu, przyjęto schemat określania miejsca danego regionu w rankingu wszystkich 16 województw Polski. Zachowano przy tym zarówno ilość i specyfikację poszczególnych czynników wyznaczających atrakcyjność regionów, jak i ich wagę wyrażoną w procentach.

Ponownie w zestawieniu Instytutu Badań nad Gospodarka Rynkową pierwsze miejsce w klasyfikacji atrakcyjności inwestycyjnej polskich regionów zajęło województwo śląskie. Na drugim miejscu w przytoczonym rankingu uplasowało się województwo mazowieckie. 
Tablica 29. Klasyfikacja atrakcyjności inwestycyjnej województw według IBnGR (w 2011 roku)

\begin{tabular}{|c|l|r|r|r|r|r|r|r|r|c|}
\hline \multirow{2}{*}{ Lp. } & \multicolumn{1}{|c|}{ Województwo } & DT & ZiKP & RZ & IG & IS & PBP & ARwI & $\begin{array}{c}\text { Atrakcyjność } \\
\text { inwestycyjna } \\
\text { regionów }\end{array}$ \\
\cline { 2 - 10 } & & $\mathbf{2 0}$ & $\mathbf{2 5}$ & $\mathbf{1 5}$ & $\mathbf{1 0}$ & $\mathbf{5}$ & $\mathbf{5}$ & $\mathbf{2 0}$ & \multicolumn{7}{|c|}{ MIEJSCE W RANKINGU } \\
\hline 1. & Śląskie & \multicolumn{1}{|c|}{1} & 1 & 2 & 2 & 1 & 16 & 6 & $\mathbf{1}$ \\
\hline 2. & Mazowieckie & 5 & 14 & 1 & 3 & 4 & 13 & 2 & $\mathbf{2}$ \\
\hline 3. & Małopolskie & 2 & 5 & 4 & 1 & 3 & 15 & 1 & $\mathbf{3}$ \\
\hline 4. & Dolnośląskie & 8 & 2 & 5 & 6 & 2 & 9 & 7 & $\mathbf{4}$ \\
\hline 5. & Wielkopolskie & 3 & 3 & 8 & 5 & 10 & 6 & 4 & $\mathbf{5}$ \\
\hline 6. & Lódzkie & 4 & 9 & 9 & 9 & 6 & 12 & 3 & $\mathbf{6}$ \\
\hline 7. & Pomorskie & 11 & 8 & 3 & 11 & 5 & 14 & 5 & $\mathbf{7}$ \\
\hline 8. & Zachodniopomorskie & 9 & 4 & 11 & 7 & 7 & 11 & 8 & $\mathbf{8}$ \\
\hline 9. & Opolskie & 10 & 6 & 6 & 16 & 8 & 8 & 9 & $\mathbf{9}$ \\
\hline 10. & Lubuskie & 6 & 10 & 7 & 12 & 9 & 10 & 10 & $\mathbf{1 0}$ \\
\hline 11. & Podkarpackie & 7 & 12 & 10 & 4 & 15 & 7 & 12 & $\mathbf{1 1}$ \\
\hline 12. & Kujawsko-pomorskie & 14 & 7 & 13 & 8 & 13 & 1 & 14 & $\mathbf{1 2}$ \\
\hline 13. & Warmińsko-mazurskie & 12 & 11 & 15 & 14 & 11 & 2 & 15 & $\mathbf{1 3}$ \\
\hline 14. & Świętokrzyskie & 13 & 13 & 12 & 15 & 12 & 5 & 11 & $\mathbf{1 4}$ \\
\hline 15. & Lubelskie & 15 & 15 & 16 & 10 & 16 & 3 & 13 & $\mathbf{1 5}$ \\
\hline 16. & Podlaskie & 16 & 16 & 14 & 13 & 14 & 4 & 16 & $\mathbf{1 6}$ \\
\hline
\end{tabular}

Legenda:

DT - dostępność transportowa

IG - infrastruktura gospodarcza

ZiKP - zasoby i koszt pracy

IS - infrastruktura społeczna

ARwI - aktywność regionów wobec inwestorów

RZ - rynek zbytu

PBP - poziom bezpieczeństwa powszechnego

Źródło: Nowicki (2011, s. 65).

Taki stan rzeczy jest wynikiem przede wszystkim, jednych z najwyższych w Polsce, kosztów pracy w województwie mazowieckim (14 miejsce przy wadze $25 \%$ ). Wpływa na to bezpośrednie oddziaływanie Warszawy na cały region jako stolicy kraju, siedziby władz centralnych, przedstawicielstw i instytucji zagranicznych oraz placówek dyplomatycznych. Wszelkie koszty, w tym: utrzymania, wynajmu lokali, zakupu mieszkania i ziemi pod inwestycje czy ceny benzyny 
i usług, jak zwykle w takich sytuacjach wywindowane są radykalnie w górę w stosunku do reszty kraju. Zmusza to pracodawców do ponoszenia zwiększonych obciążeń, które muszą przeznaczyć na wynagrodzenia w celu pozyskania wykwalifikowanych pracowników. Inny ważny faktor w tym przypadku stanowi słaba dostępność transportowa (piąte miejsce, waga 20\%). „Komunikacyjny węzeł warszawski” od wielu lat czeka na ukończenie obwodnicy miasta, drugą nitkę metra, „odkorkowanie” centrum i zbudowanie tras wylotowych na północ, południe, wschód i zachód.

W roku 2011 najmniej atrakcyjnych, według rankingu Instytutu Badań nad Gospodarką Rynkową, było pięć regionów Polski Wschodniej. Podobnie jak w roku 2005, przedzielone one zostały województwem kujawsko-pomorskim (na 12 miejscu). Ponownie najbardziej atrakcyjne w tej grupie było województwo podkarpackie, pozostając na miejscu 11. Za nim znalazły się: warmińskomazurskie, świętokrzyskie, lubelskie i na końcu podlaskie. Na tle większości innych czynników branych w zestawieniu pod uwagę, rezultaty tych terenów były wyjątkowo słabe. Wyjątek stanowi poziom bezpieczeństwa powszechnego (waga jedynie 5\%). Polska Wschodnia to zasadniczo najbezpieczniejszy rejon naszego kraju. Natomiast za najbardziej niebezpieczne uznano województwa, kolejno: śląskie, małopolskie, pomorskie, mazowieckie i łódzkie. Zasadniczy wpływ na ten stan ma kryminogenność wielkich aglomeracji: połączonych w jeden system miast Górnego Śląska (w tym: Katowic, Bytomia, Chorzowa, Zabrza, Rudy Śląskiej, Świętochłowic i Mysłowic), Krakowa (z Nową Hutą), Trójmiasta (Gdańska, Gdyni i Sopotu), Warszawy (z Wołominem i Pruszkowem) oraz Łodzi.

Zabiegiem pozytywnym wydaje się być rezygnacja z pokazywania atrakcyjności inwestycyjnej poszczególnych regionów za pomocą skali literowej (od A do E), na korzyść bardziej czytelnego rankingu miejsc (od 1 do 16). Likwiduje to negatywne skojarzenia, co do obecnego stanu i przyszłych możliwości polskich województw, przedstawia zaś miejsce regionu na tle całego kraju, bez wartościowania czynników, które opisują lepszą lub gorszą sytuację w ich obrębie.

Innym interesującym zestawieniem jest ukazanie zmian, jakie zaszły w atrakcyjności inwestycyjnej poszczególnych województw Polski na przestrzeni pięciu lat (2007-2011) (tab. 30).

Na podstawie tablicy 30 można zauważyć, że w ciągu pół dekady (2007-2011), jeśli chodzi o przyciąganie kapitałów przez polskie województwa, nie zaszły żadne istotne zmiany. Dotyczy to zarówno najbardziej atrakcyjnych inwestycyjnie regionów, jak i tych, które jawią się jako nieatrakcyjne. Całej stawce przewodzi w dalszym ciągu województwo śląskie przed: mazowieckim, dolnośląskim, wielkopolskim i zachodniopomorskim. Najbardziej widoczne były w tym czasie: awans o dwa miejsca regionu zachodniopomorskiego i spadek o dwa miejsca województwa opolskiego (na 11 pozycję). Uwagę zwraca również przesunięcie się o dwie pozycje regionu kujawsko-pomorskiego ( $\mathrm{z}$ miejsca 11 na 9). 
Tablica 30. Zmiany atrakcyjności inwestycyjnej polskich województw w latach 2007-2011

\begin{tabular}{|c|c|c|c|c|c|c|}
\hline \multirow{2}{*}{ Województwo } & \multicolumn{5}{|c|}{ Pozycja $w$ rankingu } & \multirow{2}{*}{$\begin{array}{c}\text { Zmiana pozycj } \\
\text { 2011-2007 }\end{array}$} \\
\hline & 2007 & 2008 & 2009 & 2010 & 2011 & \\
\hline Śląskie & 1 & 1 & 1 & 1 & 1 & $\mathbf{0}$ \\
\hline Mazowieckie & 3 & 2 & 3 & 3 & 2 & +1 \\
\hline Dolnośląskie & 2 & 3 & 2 & 2 & 3 & -1 \\
\hline Małopolskie & 4 & 5 & 5 & 4 & 4 & $\mathbf{0}$ \\
\hline Wielkopolskie & 5 & 4 & 4 & 5 & 5 & $\mathbf{0}$ \\
\hline Zachodniopomorskie & 8 & 8 & 6 & 6 & 6 & +2 \\
\hline Pomorskie & 7 & 6 & 7 & 8 & 7 & $\mathbf{0}$ \\
\hline Łódzkie & 6 & 7 & 8 & 7 & 8 & -2 \\
\hline Kujawsko-pomorskie & 11 & 11 & 11 & 11 & 9 & +2 \\
\hline Lubuskie & 10 & 9 & 9 & 10 & 10 & $\mathbf{0}$ \\
\hline Opolskie & 9 & 10 & 10 & 9 & 11 & -2 \\
\hline Podkarpackie & 12 & 12 & 13 & 12 & 12 & $\mathbf{0}$ \\
\hline Świętokrzyskie & 14 & 14 & 14 & 14 & 13 & +1 \\
\hline Warmińsko-mazurskie & 13 & 13 & 12 & 13 & 14 & -1 \\
\hline Lubelskie & 15 & 15 & 16 & 15 & 15 & $\mathbf{0}$ \\
\hline Podlaskie & 16 & 16 & 15 & 16 & 16 & $\mathbf{0}$ \\
\hline
\end{tabular}

Źródło: Nowicki (2011, s. 67).

Natomiast w obrębie pięciu województw Polski Wschodniej nie wydarzyło się prawie nic. Po upływie pięciu lat tworzyły one zwartą grupę zajmującą ostatnie miejsca w rankingu. Zamiana pozycji pomiędzy województwem świętokrzyskim a warmińsko-mazurskim nie ma w tym przypadku większego znaczenia. Zwyczajowo stawce przewodzi region podkarpacki (12 miejsce w rankingu) przed województwami: świętokrzyskim (13 miejsce) i warmińsko-mazurskim (14 miejsce). Listę regionów zamykają: lubelskie na 15 pozycji i podlaskie na ostatniej. 


\section{Atrakcyjność Polski Wschodniej jako miejsca inwestycji}

Trzeba wyraźnie stwierdzić, że wyniki uzyskane za pomocą trzech zastosowanych sposobów (analizy SWOT, miary poziomu inwestycji zagranicznych i przeanalizowania raportów Instytutu Badań nad Gospodarka Rynkową) we wszystkich przypadkach napawają uzasadnionym niepokojem. Pomimo zróżnicowanego ujęcia zagadnienia, wybrania odmiennych elementów i czynników do pomiaru, mniej lub bardziej subiektywnego podejścia oraz niejednakowego stopnia skomplikowania technik badawczych, uzyskane rezultaty okazały się wyjątkowo zgodne i jednolite w swojej treści.

Pomimo wielu lat poświęconych prowadzeniu akcji promocyjnej, zaangażowaniu wielomiliardowych środków pochodzących z funduszy strukturalnych i Funduszu Spójności, usilnych starań władz krajowych i samorządowych w celu pozyskania inwestorów, mnogości inicjatyw społecznych, wysiłku przedsiębiorców, kół biznesowych oraz ośrodków akademickich i naukowych, nie daje się zauważyć wymiernych rezultatów tych działań. Polska Wschodnia, jak na samym początku procesu zmian, licząc od momentu wstąpienia naszego kraju w struktury unijne, aż do chwili obecnej, pozostaje obszarem omijanym przez inwestorów. Dotyczy to zarówno kapitału krajowego, jak i pochodzącego ze źródeł zagranicznych. Województwa Polski Wschodniej tradycyjnie okupują ostatnie miejsca w każdym zestawieniu i rankingu atrakcyjności inwestycyjnej.

W tym dość czarnym obrazie pewien jasny punkt stanowić może jedynie województwo podkarpackie, wyróżniające się pozytywnie na tle pozostałych regionów. Osią napędową tego regionu jest działająca ze sporym rozmachem „Dolina Lotnicza”. Natomiast województwa lubelskie i podlaskie w perspektywie nadchodzących lat pozostaną prawdopodobnie niełatwym problemem do rozwiązania dla władz państwowych i lokalnych oraz powodem trudnych decyzji Unii Europejskiej dotyczących nowych perspektyw finansowych. Środek grupy najsłabszych polskich regionów zajmują województwa warmińsko-mazurskie i świętokrzyskie. Pierwsze z wymienionych daje duże nadzieje na bardziej dynamiczny rozwój w nadchodzących latach ze względu na korzystne położenie geograficzne, unikatowe walory przyrodniczo-krajobrazowe oraz znaczne zainteresowanie turystów z kraju i ze świata. Natomiast województwo świętokrzyskie w konsekwencji odsunięcia decyzją władz państwowych od najważniejszych szlaków komunikacyjnych, może napotkać poważne problemy na drodze swojego rozwoju. Dodatkowo jego zdolność przyciaggania kapitałów zmniejsza położenie na pograniczu wpływów wielkich ośrodków metropolitalnych, jakie stanowią aglomeracje warszawska, łódzka i krakowska.

Polskę Wschodnią rozpatrywaną całościowo jako jeden obszar, pomimo pewnego postępu w rozbudowie infrastruktury w dziedzinie łączności i komu- 
nikacji, charakteryzuje w dalszym ciągu słabsza dostępność niż reszty Polski. Niska intensywność uprzemysłowienia i urbanizacji uniemożliwia wykorzystanie skali i potencjału „przyciągania” aglomeracyjnego. W obecnej sytuacji pięć najsłabszych ekonomicznie województw posiada zasadniczo niską atrakcyjność dla inwestorów. Dlatego są one stanie przyciągnąć do siebie znacznie mniej kapitału niż inne regiony naszego kraju. 


\section{ROZDZIA VII}

\section{Możliwości zwiększenia atrakcyjności inwestycyjnej regionów słabo rozwiniętych}

Aktualna perspektywa finansowa Unii Europejskiej dotyczy lat 2007-2013. W czasie jej trwania, w ramach Europejskiego Funduszu Rozwoju Regionalnego, zostało uruchomionych kilka istotnych programów operacyjnych. Z punktu widzenia najbardziej zapóźnionych pod względem społeczno-ekonomicznym regionów naszego kraju, najważniejszy jest Program Operacyjny Rozwój Polski Wschodniej (PO RPW). Program ten został uruchomiony po raz pierwszy w 2007 roku. Stanowi dodatkowy element specjalistycznego wsparcia funduszy strukturalnych, mający na celu wzmocnienie ich oddziaływania na wybrane regiony.

PO RPW jest narzędziem polityki regionalnej, którego inne części składowe tworzą 16 regionalnych programów operacyjnych realizowanych przez samorządy województw oraz pozostałe krajowe programy operacyjne. Są wśród nich: Innowacyjna Gospodarka, Kapitał Ludzki, Infrastruktura i Środowisko, Pomoc Techniczna oraz programy Europejskiej Współpracy Terytorialnej. Znaczne środki z budżetu Unii Europejskiej, przeznaczone na wyrównanie różnic rozwojowych poszczególnych obszarów Polski, obok EPRR, pochodziły z Europejskiego Funduszu Społecznego oraz Fundusz Spójności. Całość uzupełniały wielomiliardowe środki krajowe.

Biorąc pod uwagę, że 2013 stanowi ostatni rok w czasie bieżącej unijnej perspektywy finansowej, należy zadać sobie kilka pytań: na ile skuteczne okazały się wysiłki podjęte $\mathrm{w}$ ramach realizacji przyjętych przez polski rząd celów strategicznych; czy można już zauważyć jakieś pozytywne zmiany w postrzeganiu atrakcyjności najsłabiej rozwiniętych regionów naszego kraju; czy na obecnym etapie przemian, możliwe jest dostrzeżenie i poddanie obiektywnej analizie zaistniałych przeobrażeń, które w wypadku ich wystąpienia mogłyby się bezpośrednio przekładać na przyspieszony i pełniejszy rozwój opisywanych w pracy obszarów?

Odwołując się do kilku istotnych zestawień, rankingów i wskaźników, można podjąć próbę odpowiedzi na zadane pytania. 


\section{Wybrane wskaźniki opisujące sytuację gospodarczo-społeczną regionów słabiej rozwiniętych w Polsce}

Interesującym zestawieniem jest ukazanie zmian, jakie zaszły w atrakcyjności inwestycyjnej poszczególnych województw Polski na przestrzeni pięciu lat (2007-2011).

Na podstawie tablicy 31 można zauważyć, że w ciągu pół dekady (2007-2011) w procesie przyciągania kapitałów przez polskie województwa nie zaszły żadne zauważalnie zmiany. Dotyczy to zarówno najbardziej atrakcyjnych inwestycyjnie regionów, jak i tych, które jawią się jako nieatrakcyjne. W rankingu przewodzi

Tablica 31. Zmiany atrakcyjności inwestycyjnej polskich województw w latach 2007-2011

\begin{tabular}{|l|c|c|c|c|c|c|}
\hline \multirow{2}{*}{ Województwo } & \multicolumn{5}{|c|}{ Pozycja w rankingu } & \multirow{2}{*}{$\begin{array}{c}\text { Zmiana pozycji } \\
\mathbf{2 0 1 1 - 2 0 0 7}\end{array}$} \\
\cline { 2 - 7 } & $\mathbf{2 0 0 7}$ & $\mathbf{2 0 0 8}$ & $\mathbf{2 0 0 9}$ & $\mathbf{2 0 1 0}$ & $\mathbf{2 0 1 1}$ & $\mathbf{0}$ \\
\hline Śląskie & 1 & 1 & 1 & 1 & 1 & $\mathbf{+ 1}$ \\
\hline Mazowieckie & 3 & 2 & 3 & 3 & 2 & $\mathbf{- 1}$ \\
\hline Dolnośląskie & 2 & 3 & 2 & 2 & 3 & $\mathbf{0}$ \\
\hline Małopolskie & 4 & 5 & 5 & 4 & 4 & $\mathbf{0}$ \\
\hline Wielkopolskie & 5 & 4 & 4 & 5 & 5 & $\mathbf{+ 2}$ \\
\hline Zachodniopomorskie & 8 & 8 & 6 & 6 & 6 & $\mathbf{0}$ \\
\hline Pomorskie & 7 & 6 & 7 & 8 & 7 & $\mathbf{- 2}$ \\
\hline Lódzkie & 6 & 7 & 8 & 7 & 8 & $\mathbf{+ 2}$ \\
\hline Kujawsko-pomorskie & 11 & 11 & 11 & 11 & 9 & $\mathbf{0}$ \\
\hline Lubuskie & 10 & 9 & 9 & 10 & 10 & $\mathbf{- 2}$ \\
\hline Opolskie & 9 & 10 & 10 & 9 & 11 & $\mathbf{0}$ \\
\hline Podkarpackie & 12 & 12 & 13 & 12 & 12 & $\mathbf{+ 1}$ \\
\hline Świętokrzyskie & 14 & 14 & 14 & 14 & 13 & $\mathbf{- 1}$ \\
\hline Warmińsko-mazurskie & 13 & 13 & 12 & 13 & 14 & $\mathbf{0}$ \\
\hline Lubelskie & 15 & 15 & 16 & 15 & 15 & $\mathbf{0}$ \\
\hline Podlaskie & 16 & 16 & 15 & 16 & 16 & \\
\hline
\end{tabular}

Źródło: Nowicki (2011, s. 67). 
w dalszym ciągu województwo śląskie przed: mazowieckim, dolnośląskim, wielkopolskim i zachodniopomorskim. Najbardziej widoczne były w tym czasie: awans o dwa miejsca regionu zachodniopomorskiego i spadek o dwa miejsca województwa opolskiego (na 11 pozycję). Uwagę zwraca również przesunięcie się o dwie pozycje regionu kujawsko-pomorskiego (z miejsca 11 na 9).

Natomiast w obrębie pięciu województw Polski Wschodniej nie wydarzyło się prawie nic. Po upływie pięciu lat tworzyły one zwartą grupę zajmującą ostatnie miejsca w rankingu. Zamiana pozycji pomiędzy województwem świętokrzyskim a województwem warmińsko-mazurskim nie ma w tym przypadku większego znaczenia. Zwyczajowo stawce przewodzi region podkarpacki (12 miejsce w rankingu), przed województwami świętokrzyskim (13 miejsce) i warmińsko-mazurskim (14 miejsce). Listę regionów zamykają: lubelskie na 15 i podlaskie na 16 pozycji.

Sposobem na zweryfikowanie wyników z tablicy 31 będzie porównanie kilku ważniejszych wskaźników ekonomicznych dotyczących regionów należących do Polski Wschodniej oraz odnoszących się do województw przodujących w rozwoju i zarazem najbardziej atrakcyjnych inwestycyjnie w naszym kraju. Będą to wskaźniki nieuwzględniane w dotychczasowych rozważaniach badawczych niniejszej pracy. Latami, które posłużą do porównania będą 2006 i jeden rok z przedziału 2010-2012. Lata te zostały wybrane nieprzypadkowo. Rok 2006 jest ostatnim z poprzedniej unijnej perspektywy czasowej, ukazuje zatem stan gospodarki wybranych obszarów sprzed wdrożenia do realizacji Programu Operacyjnego Rozwój Polski Wschodniej. W tym przypadku za źródło danych posłużyły informacje publikowane przez Główny Urząd Statystyczny w Warszawie. W wybranym roku z przedziału 2010-2012 w grę wchodzi ich dostępność. W wielu miejscach dane za lata 2011 i 2012 zostaną opublikowane przez GUS dopiero w roku 2014. Dlatego w miarę możliwości użyte zostały najbardziej aktualne dane z serwisów tej instytucji oraz innych dostępnych portali o charakterze ekonomicznym, odnoszących się do polskiej gospodarki. W przypadku, gdy dane za lata 2011-2012 nie były jeszcze osiągalne, do porównania posłużyły informacje pochodzące $\mathrm{z}$ roku 2010.

W grupie wskaźników dotyczących sytuacji ekonomicznej poszczególnych regionów Polski, zostaną przeanalizowane:

- wysokość przeciętnego miesięcznego wynagrodzenia brutto w sektorze przedsiębiorstw;

- ruch naturalny oraz migracje ludności według województw (NUTS 2);

- wartość produktu krajowego brutto na jednego mieszkańca;

- wzrostu PKB per capita w złotych i jego dynamika;

- regionalny produkt krajowy brutto na jednego mieszkańca do średniej unijnej. 
Tablica 32. Wysokość przeciętnego miesięcznego wynagrodzenia brutto w sektorze przedsiębiorstw według województw (w zł). Porównanie lat 2006 i 2012 oraz dynamika*

\begin{tabular}{|c|l|c|c|c|}
\hline Pozycja & \multicolumn{1}{|c|}{ Województwo } & $\mathbf{2 0 0 6}$ & $\mathbf{2 0 1 2}$ (styczeń) & Dynamika (w \%) \\
\hline 1. & Mazowieckie & 3431,00 & $\mathbf{4 4 9 8 , 6 8}$ & 131,1 \\
\hline 2. & Śląskie & 2774,16 & $\mathbf{3 9 7 0 , 4 1}$ & 143,1 \\
\hline 3. & Pomorskie & 2711,62 & $\mathbf{3 7 2 3 , 7 8}$ & 137,3 \\
\hline 4. & Dolnośląskie & 2663,85 & $\mathbf{3 4 5 4 , 4 4}$ & 129,7 \\
\hline 5. & Lódzkie & 2439,10 & $\mathbf{3 3 8 3 , 5 9}$ & 144,6 \\
\hline 6. & Małopolskie & 2452,11 & $\mathbf{3 3 5 1 , 0 0}$ & 134,3 \\
\hline 7. & Wielkopolskie & 2325,27 & $\mathbf{3 3 2 5 , 8 3}$ & 135,6 \\
\hline 8. & Lubelskie & 2453,75 & $\mathbf{3 2 0 9 , 8 2}$ & 142,3 \\
\hline 9. & Zachodniopomorskie & 2441,83 & $\mathbf{3 1 7 9 , 8 5}$ & 130,8 \\
\hline 10. & Opolskie & 2367,04 & $\mathbf{3 0 3 9 , 4 5}$ & 128,4 \\
\hline 11. & Podlaskie & 2250,37 & $\mathbf{3 0 0 9 , 6 4}$ & 133,7 \\
\hline 12. & Warmińsko-mazurskie & 2316,54 & $\mathbf{3 0 0 3 , 5 3}$ & 129,6 \\
\hline 13. & Świętokrzyskie & 2324,54 & $\mathbf{2 9 9 8 , 3 5}$ & 128,9 \\
\hline 14. & Kujawsko-pomorskie & 2219,58 & $\mathbf{2 9 7 3 , 3 4}$ & 133,9 \\
\hline 15. & Podkarpackie & 2306,53 & $\mathbf{2 9 6 3 , 8 7}$ & 128,5 \\
\hline 16. & Lubuskie & $\mathbf{2 4 9 2 , 0 5}$ & $\mathbf{3 3 3 7 . 1 3}$ & $\mathbf{1 3 3 . 9}$ \\
\hline & Polska & & \\
\hline & & & & \\
\hline
\end{tabular}

* Kolorem szarym zaznaczono wiersze dotyczące województw Polski Wschodniej. Źródło: opracowanie własne na podstawie: GUS (2013).

Na najbardziej atrakcyjne stawki wynagrodzenia w sektorze przedsiębiorstw można liczyć tradycyjnie w województwach: mazowieckim, śląskim, pomorskim, dolnośląskim, łódzkim, małopolskim i wielkopolskim. Wysokie pozycje regionów: śląskiego (2 miejsce), pomorskiego (3 miejsce), łódzkiego (5 miejsce) wynikają z dynamiki przewyższającej dynamikę krajową wzrostu wynagrodzeń. Województwa Polski Wschodniej znajdują się na końcu zestawienia, nie osiągając wysokości średniego wynagrodzenia brutto w sektorze przedsiębiorstw dla Polski zarówno w roku 2006, jak i w styczniu 2012 roku. Najwyższą pozycję w rankingu osiągnęło województwo lubelskie (8 miejsce) ze względu na wysoką dynamikę wzrostu płac $(142,3 \%)$. Województwo podkarpackie ma dynamikę równą średniej krajowej, 
reszta regionów Polski Wschodniej notuje dynamikę niższą niż średnia dla Polski. Zajmują one lokaty: podlaskie (11 miejsce), warmińsko-mazurskie (12 miejsce), świętokrzyskie (13 miejsce) i podkarpackie (15 miejsce). Tak niska pozycja Podkarpacia nie może dziwić, jeśli zauważymy, że w 2006 roku w tym regionie wynagrodzenie brutto w sektorze przedsiębiorstw było najniższe w naszym kraju.

Następne zestawienie ukazuje napływ i odpływ ludności w odniesieniu do poszczególnych regionów oraz saldo tego procesu. W sposób syntetyczny ujmuje preferencje społeczne przy wyborze najbardziej atrakcyjnego miejsca dla osiedlenia się i podjęcia pracy w Polsce.

Tablica 33 wyraźnie ukazuje, gdzie mieszkańcy Polski widzą szanse na prowadzenie godziwego życia. Niezmiennie największym magnesem na mapie

Tablica 33. Zmiany w ruchu naturalnym oraz migracjach ludności według województw (NUTS 2) w 2006 roku oraz w 2011 roku*

\begin{tabular}{|r|l|r|r|r|r|r|r|}
\hline \multirow{2}{*}{ Pozycja } & \multirow{2}{*}{ Województwo } & \multicolumn{3}{|c|}{ 2006 r. } & \multicolumn{3}{c|}{ 2011 r. } \\
\cline { 3 - 8 } & & napływ & odpływ & saldo & napływ & odpływ & saldo \\
\hline 1. & Mazowieckie & 79901 & 63633 & 16262 & 68601 & 54901 & 13700 \\
\hline 2. & Małopolskie & 34225 & 30916 & 3309 & 32186 & 28403 & 3783 \\
\hline 3. & Pomorskie & 34107 & 31766 & 2341 & 30027 & 27409 & 2618 \\
\hline 4. & Wielkopolskie & 47451 & 45035 & 2416 & 42330 & 40443 & 1887 \\
\hline 5. & Dolnośląskie & 38494 & 38090 & 404 & 35615 & 419946 & 1559 \\
\hline 6. & Opolskie & 11140 & 11977 & -837 & 10212 & 10876 & -664 \\
\hline 7. & Lubuskie & 14491 & 15018 & -527 & 12625 & 13290 & -665 \\
\hline 8. & Zachodniopomorskie & 23130 & 24458 & -1328 & 21068 & 22039 & -971 \\
\hline 9. & Kujawsko-pomorskie & 27019 & 28642 & -1623 & 23172 & 24493 & -1321 \\
\hline 10. & Łódzkie & 26198 & 27969 & -1771 & 22693 & 24537 & -1844 \\
\hline 11. & Podlaskie & 13738 & 15732 & -1994 & 11862 & 13760 & -1898 \\
\hline 12. & Podkarpackie & 20827 & 22734 & -1907 & 18662 & 20874 & -2212 \\
\hline 13. & Świętokrzyskie & 12698 & 15493 & -2795 & 10705 & 13113 & -2408 \\
\hline 14. & Warmińsko-mazurskie & 18778 & 21906 & -3128 & 16220 & 9172 & -2952 \\
\hline 15. & Śląskie & 46718 & 50386 & -3668 & 43733 & 47385 & -3652 \\
\hline 16. & Lubelskie & 24633 & 29793 & -5160 & 20235 & 25195 & -4960 \\
\hline 17. & Polska & 473548 & 473548 & $x$ & 419946 & 419946 & x \\
\hline
\end{tabular}

* Województwa Polski Wschodniej zostały zaznaczone kolorem szarym.

Źródło: http://www.stat.gov.pl. 
Polski pozostaje województwo mazowieckie, a głównie aglomeracja warszawska. W stolicy kraju istnieje najwięcej możliwości zarówno wysokich zarobków, jak i znalezienia ciekawej pracy. Daje ona także największe szanse rozwoju intelektualnego, dalszego kształcenia się, wszechstronnej rozrywki, aktywnego wypoczynku oraz dostępu do zdobyczy cywilizacji. W dalszej kolejności popularnością cieszą się województwa o silnej gospodarce i znaczących w skali kraju ośrodkach miejskich, takie jak: małopolskie z Krakowem, pomorskie z Trójmiastem, wielkopolskie z Poznaniem i dolnośląskie z Wrocławiem. Wszystkie one, łącznie z Warszawą, notowały (w 2006 roku) i notują (w 2011 roku) dodatnie saldo migracji. Pozostałe jedenaście województw w Polsce odnotowuje stały ubytek w liczbie mieszkańców, czego nie udało się powstrzymać przez sześć lat objętych niniejszą analizą.

Cztery z pięciu województw Polski Wschodniej (podlaskie, podkarpackie, świętokrzyskie i warmińsko-mazurskie), zajmowały w 2006 roku i nadal zajmują te same miejsca: od 11 do 14 . Jedyną, niewielka zresztą, odnotowaną zmianą jest przesunięcie się województwa podlaskiego z miejsca 12 na 11 oraz spadek o jedną pozycję $\mathrm{w}$ przytoczonym zestawieniu województwa podkarpackiego (z miejsca 11 na 12). Grupę najbiedniejszych województw przedziela region Śląski - na 15 miejscu. Co ciekawe ujemne saldo migracyjne pozostaje cały czas na tym samym poziomie i kształtuje się w okolicach ponad 3600 osób w skali roku. Jest to wynikiem zamknięcia większości kopalń węgla kamiennego, hut oraz walcowni stanowiących dotychczasową oś napędową tego regionu. Brak pracy i pogarszające warunki bytowe, zmuszają mieszkańców Górnego Śląska do ucieczki w poszukiwaniu „chleba i pracy” z tego tradycyjnie przemysłowego obszaru.

Zupełnie katastrofalnie przedstawia się sytuacja w województwie lubelskim. Tutaj ujemne saldo migracji oscyluje wokół wartości 5 tys. osób rocznie. Liczba ta pokazuje, że wszystkie podjęte do tej pory wysiłki okazały się całkowicie nieskuteczne. Nie udało się powstrzymać niekorzystnych tendencji do wyludniania się opisywanego obszaru. Niepokojem może napawać fakt, że w skali roku z lubelskiego emigruje ilość mieszkańców mogących zasiedlić ze sporym nadkładem niewielkie miasto, takie jak np.: Hel (3720 mieszkańców), Chęciny (4304 mieszkańców), Jastarnię (3911 mieszkańców), Kazimierz Dolny nad Wisłą (3414 mieszkańców) czy Mikołajki na Mazurach (3734).

Kolejne zestawienie danych ukazuje wartość PKB przypadającą na jednego mieszkańca (PKB per capita) w ujęciu regionalnym. Ten miernik ekonomiczny jest jednym z najczęściej stosowanych wskaźników zamożności obywateli danego państwa. Umożliwia porównywanie poziomu dobrobytu obywateli wybranych państw lub, tak jak ma to miejsce w niniejszej pracy, standardu jakości życia społeczeństw pochodzących z różnych regionów w obrębie jednego kraju.

Wskaźnik PKB na jednego mieszkańca w ujęciu regionalnym wykazał, że jakość egzystencji mieszkańców Polski Wschodniej jest najniższa w całym kraju. 
Tablica 34. Porównanie wartości PKB przypadającej na jednego mieszkańca w Polsce w ujęciu regionalnym (ranking)"

\begin{tabular}{|c|c|c|c|c|c|c|}
\hline Województwo & $\begin{array}{c}\text { PKB } \\
\text { per capita } \\
\text { w zl } \\
(2006 \text { r. })\end{array}$ & $\begin{array}{c}\text { Pozycja } \\
\text { w roku } \\
2006\end{array}$ & $\begin{array}{c}\text { PKB } \\
\text { per capita } \\
\mathbf{w} \text { zl } \\
(2007 \text { r. })\end{array}$ & $\begin{array}{c}\text { Pozycja } \\
\text { w roku } \\
2007\end{array}$ & $\begin{array}{c}\text { PKB } \\
\text { per capita } \\
\text { w latach } \\
\mathbf{2 0 0 8 - 2 0 1 0}\end{array}$ & $\begin{array}{c}\text { Pozycja } \\
\text { w latach } \\
\text { 2008-2010 }\end{array}$ \\
\hline Mazowieckie & 36636 & 1 & 49415 & 1 & 56580 & 1 \\
\hline Dolnośląskie & 24632 & 2 & 33567 & 2 & 38708 & 2 \\
\hline Śląskie & 27177 & 3 & 32761 & 3 & 37858 & 3 \\
\hline Wielkopolskie & 26001 & 4 & 32266 & 4 & 37009 & 4 \\
\hline Pomorskie & 23616 & 5 & 30396 & 5 & 33883 & 5 \\
\hline Łódzkie & 22274 & 7 & 28371 & 6 & 32447 & 6 \\
\hline Zachodniopomorskie & 22494 & 6 & 27708 & 7 & 31137 & 7 \\
\hline Małopolskie & 20671 & 11 & 26456 & 10 & 30233 & 8 \\
\hline Lubuskie & 21641 & 8 & 27350 & 8 & 30035 & 9 \\
\hline Kujawsko-pomorskie & 21633 & 9 & 26801 & 9 & 29944 & 10 \\
\hline Opolskie & 20785 & 10 & 25609 & 11 & 28856 & 11 \\
\hline Świętokrzyskie & 18714 & 13 & 23741 & 12 & 27408 & 12 \\
\hline Warmińsko-mazurskie & 18778 & 12 & 22961 & 13 & 25988 & 13 \\
\hline Podlaskie & 18056 & 14 & 22896 & 14 & 25783 & 14 \\
\hline Podkarpackie & 16886 & 15 & 20829 & 16 & 24070 & 15 \\
\hline Lubelskie & 16777 & 16 & 20913 & 15 & 24002 & 16 \\
\hline Polska & 24181 & $\mathrm{x}$ & 30876 & $\mathrm{x}$ & 35262 & $\mathrm{x}$ \\
\hline
\end{tabular}

* Województwa Polski Wschodniej zostały zaznaczone kolorem szarym.

Źródło: dane GUS; www.forsal.pl; www.stat.gov.pl; www.mg.gov.pl.

Trudno tu nie zauważyć ścisłego powiązania z ruchami migracyjnymi (zob. tab. 33), których saldo jest ujemne dla pięciu najbiedniejszych regionów Polski. Ludzie uciekają z obszarów najmniej dla siebie przyjaznych i dających znikome szanse na odniesienie sukcesu życiowego. Od roku 2006 do 2010 województwa: świętokrzyskie, warmińsko-mazurskie, podlaskie, podkarpackie i lubelskie nieprzerwanie okupują ostatnie miejsca $\mathrm{w}$ rankingu. Niewielkie ruchy mają miejsce wyłącznie w obrębie zamkniętej grupy tych pięciu regionów. Polegają na wzajemnej wymianie pozycji, bez szans awansu na szczebel wyższy niż dwunaste miejsce. Najgorzej w zestawieniu przedstawia się sytuacja województwa 
lubelskiego, które zajmuje ostatnie miejsce. Co gorsza, PKB na jednego mieszkańca jest $\mathrm{w}$ tej $\mathrm{w}$ chwili $\mathrm{w}$ województwie lubelskim ponad dwukrotnie niższy niż w regionie mazowieckim. Chociaż wskaźnik wyrażony w złotych polskich nieprzerwanie rośnie, to i tak nie osiaggnął jeszcze dla lubelskiego poziomu miernika dla regionu dolnośląskiego z roku 2006.

Pewne zaskoczenie może budzić bardzo niska pozycja regionu podkarpackiego w rankingu. $\mathrm{W}$ badanym okresie województwo to zajmowało na przemian miejsca ostatnie i przedostatnie. Fakt ten można, podobnie jak w przypadku województwa lubelskiego, tłumaczyć skrajną peryferyjnością opisywanych obszarów, słabą urbanizacją i niskim nasyceniem infrastrukturą przemysłową. Trzecie miejsce od końca zajmuje niezmiennie województwo podlaskie (14 pozycja). Niestety nie chce ono lub nie potrafi wykorzystać swojego dogodnego położenia na trakcie z centrum Polski na Litwę i dalej ma Lotwę i do Estonii. Dwunaste miejsce zajmuje województwo świętokrzyskie. Wysokość PKB per capita (27 408 zł) jest w tym przypadku o ponad 1400 złotych wyższa niż trzynastego w rankingu województwa warmińsko-mazurskiego. Jeszcze raz można się zastanowić, czy przypisanie tego regionu do obszaru Polski Wschodniej było zabiegiem właściwym. Wydaje się, że, jak to zostało już wcześnie powiedziane, przypomina on bardziej regiony Polski Centralnej niż obecne kresy wschodnie.

Najlepszy standard życia w całym badanym okresie oferowało województwo mazowieckie. Patrząc na jego sytuację przez pryzmat wskaźnika PKB per capita, można zauważyć, że szybko oddala się od pozostałych regionów i głównie dzięki Warszawie, zajmuje nieprzerwanie pierwsze miejsce $\mathrm{w}$ rankingu. Niestety stolica stanowi pewną enklawę na mapie dobrobytu. Im większa staje się odległość od centrum, tym słabiej prezentują się możliwości ekonomiczne powiatów należących do regionu Mazowieckiego (Przygoda, 2008a, s. 21-35).

Podobną tendencję do Mazowsza wykazują, patrząc pod kątem PKB przypadającego na jednego mieszkańca, regiony, które znajdują się na miejscach od 2 do 5 . W okresie ujętym w zestawieniu w odniesieniu do tych województw nie nastąpiła żadna zmiana. Od roku 2006 do 2010 niezmiennie na drugiej pozycji znajdowało się dolnośląskie, następnie: śląskie (3 miejsce), wielkopolskie (4 miejsce) i pomorskie (5 miejsce). W grupie sześciu województw, plasujących się w środku tablicy 34, największy awans odnotowała Małopolska, przesuwając się w rankingu o cztery pozycje $\mathrm{z}$ miejsca jedenastego na ósme. W tym przypadku duży wpływ na klasyfikację miała atrakcyjność Krakowa.

Należy podkreślić, że szesnaście regionów Polski od momentu wstąpienia Polski do UE (2004 rok) i realizacji ostatniej finansowej perspektywy unijnej (od 2007 roku) odnotowuje regularny wzrost PKB per capita. Dotyczy to wzrostu bezwzględnego liczonego w złotych, jak również jego dynamiki. PKB per capita w ujęciu regionalnym dla lat 2006-2010 został ukazany w tablicy 35. 
Tablica 35. Wzrost PKB na głowę jednego mieszkańca dla Polski w ujęciu regionalnym oraz jego dynamika. Porównanie lat 2006-2010*

\begin{tabular}{|c|l|c|c|}
\hline Pozycja & \multicolumn{1}{|c|}{ Województwo } & Dynamika & $\begin{array}{c}\text { Wzrost } \\
\text { PKB per capita } \\
\text { w zlotych }\end{array}$ \\
\hline 1 & Mazowieckie & $154,4 \%$ & $\mathbf{1 9 . 9 4 4}$ \\
\hline 2 & Dolnośląskie & $157,1 \%$ & $\mathbf{1 4 . 0 7 6}$ \\
\hline 3 & Wielkopolskie & $142,3 \%$ & $\mathbf{1 1 . 0 0 8}$ \\
\hline 4 & Śląskie & $139,3 \%$ & $\mathbf{1 0 . 6 8 1}$ \\
\hline 5 & Pomorskie & $143,3 \%$ & $\mathbf{1 0 . 2 6 7}$ \\
\hline 6 & Lódzkie & $145,7 \%$ & $\mathbf{1 0 . 1 7 3}$ \\
\hline 7 & Małopolskie & $146,2 \%$ & $\mathbf{9 . 5 6 2}$ \\
\hline 8 & Zachodniopomorskie & $138,5 \%$ & $\mathbf{8 . 9 5 3}$ \\
\hline 9 & Świętokrzyskie & $146,4 \%$ & $\mathbf{8 . 6 9 4}$ \\
\hline 10 & Lubuskie & $138,7 \%$ & $\mathbf{8 . 3 9 4}$ \\
\hline 11 & Kujawsko-pomorskie & $138,4 \%$ & $\mathbf{8 . 3 1 1}$ \\
\hline 12 & Opolskie & $138,8 \%$ & $\mathbf{8 . 0 7 1}$ \\
\hline 13 & Podlaskie & $142,8 \%$ & $\mathbf{7 . 7 2 7}$ \\
\hline 14 & Lubelskie & $143,1 \%$ & $\mathbf{7 . 2 2 5}$ \\
\hline 15 & Warmińsko-mazurskie & $138,3 \%$ & $\mathbf{7 . 2 1 0}$ \\
\hline 16 & Podkarpackie & $142,5 \%$ & $\mathbf{7 . 1 8 4}$ \\
\hline $\mathrm{x}$ & Polska & $\mathbf{1 4 5 , 8} \%$ & $\mathbf{1 1 . 0 8 1}$ \\
\hline
\end{tabular}

* Województwa Polski Wschodniej zostały zaznaczone kolorem szarym.

Źródło: opracowanie własne na podstawie danych GUS.

Przy średniej dynamice wzrostu PKB na głowę jednego mieszkańca dla Polski, wynoszącego 145,8\% (od 2006 r. do 2010 r.), tylko nieliczne województwa w naszym kraju mogą poszczycić się osiągnięciem lepszego rezultatu. Należą do nich:

- dolnośląskie - 157,1\%,

- mazowieckie - 154,4\%,

- świętokrzyskie - 146,4\%,

- małopolskie - 146,2\%.

Pozostałe regiony kraju notują dynamikę wzrostu na poziomie pomiędzy 145,7\% (łódzkie) i 138,3\% (warmińsko-mazurskie, najgorszy wynik na 16 województw). Biorąc pod uwagę, że wśród szybko poprawiających poziom życia 
swoich mieszkańców znalazł się tylko obszar jednego regionu w Polski Wschodniej (było to świętokrzyskie), rezultat nie napawa entuzjazmem. W zaprezentowanym zestawieniu istotniejszą rolę odgrywa jednak wzrost PKB per capita wyrażony w złotych. To właśnie głównie dzięki temu ujęciu można stwierdzić właściwą stopę życia społeczeństw lokalnych. Tutaj różnice pomiędzy poszczególnymi województwami są już ogromne. W badanym okresie wynik pięciocyfrowego wzrostu PKB osiągnęły jak zwykle najbardziej rozwinięte regiony Polski, silnie zurbanizowane oraz posiadające ośrodki miejskie o charakterze regionalnych biegunów wzrostu:

- Mazowieckie = $19944 \mathrm{zl}$,

- Dolnośląskie $=14076$ zł,

- Wielkopolskie $=11008 \mathrm{zl}$,

- Śląskie = $10681 \mathrm{zl}$,

- Pomorskie $=10267 \mathrm{zl}$,

- Lódzkie = 10173 zł.

Interesujące jest, że w większości zaprezentowanych dotychczas zestawień danych (zob. tab. 32-35) tuż za czołówką plasuje się zazwyczaj województwo łódzkie. Może to oznaczać powolny powrót do znaczenia „polskiego Manchesteru" na ekonomicznej mapie kraju. Najniższy wzrost PKB per capita w złotych został zanotowany przez cztery województwa Polski Wschodniej: podlaskie, lubelskie, warmińsko-mazurskie i podkarpackie (miejsca od 13 do 16). Biorąc pod uwagę wykazywaną przez nie średnią dynamikę opisywanego procesu, można przypuszczać, że nigdy nie dogonią regionów z czołówki rankingu. Jedynie województwo świętokrzyskie, przy wysokiej dynamice oraz niezłym wyniku 8694 zł, ma w sprzyjających okolicznościach szansę na utrzymanie się na pozycji średniego regionu, mniej więcej w połowie stawki.

Regionalny PKB na jednego mieszkańca, wyrażony w procentach, w odniesieniu do UE-27 został zaprezentowany w tablicy 36. Wskaźnik ten ukazuje dystans pomiędzy poziomem życia w poszczególnych województwach Polski od średniej unijnej. Badany okres to czas od momentu wstąpienia Polski do europejskiego ugrupowania integracyjnego do 2010 roku.

Regionalny PKB per capita, w odniesieniu do średniej UE-27, ukazuje postęp, jaki nastąpił na polu zmniejszania dystansu w poziomie życia mieszkańców polskich województw do istniejących standardów na terenie regionów należących do wspólnej Europy. Okres wzięty pod uwagę obejmował lata 2004-2010.

W oczy rzuca się przede wszystkim znaczne przyspieszenie realizacji procesu regionalnej spójności pomiędzy latami 2006 i 2007. Stan taki jest nie tyle wyni kiem bardziej efektywnej konwergencji regionalnej, ile „bałkańskiego rozszerzenia" Unii Europejskiej od 1 stycznia 2007 roku o Rumunię i Bułgarię. Oba kraje w stosunku do 25 dotychczasowych państw ugrupowania integracyjnego były 
Tablica 36. Regionalny PKB per capita (w \%) do średniej UE-27 w okresie od 2004 do 2010 roku* $^{*}$

\begin{tabular}{|c|l|c|c|c|c|c|c|c|}
\hline Pozycja & \multicolumn{1}{|c|}{ Województwo } & $\mathbf{2 0 0 4}$ & $\mathbf{2 0 0 5}$ & $\mathbf{2 0 0 6}$ & $\mathbf{2 0 0 7}$ & $\mathbf{2 0 0 8}$ & $\mathbf{2 0 0 9}$ & $\mathbf{2 0 1 0}$ \\
\hline 1. & Mazowieckie & 78 & 81 & 83 & 87 & 89 & 97 & $\mathbf{1 0 2}$ \\
\hline 2. & Dolnośląskie & 51 & 53 & 55 & 59 & 60 & 66 & $\mathbf{7 0}$ \\
\hline 3. & Śląskie & 57 & 55 & 55 & 58 & 61 & 65 & $\mathbf{6 7}$ \\
\hline 4. & Wielkopolskie & 54 & 55 & 55 & 57 & 59 & 64 & $\mathbf{6 5}$ \\
\hline 5. & Pomorskie & 50 & 51 & 51 & 53 & 53 & 59 & $\mathbf{6 0}$ \\
\hline 6. & Lódzkie & 47 & 47 & 48 & 50 & 52 & 55 & $\mathbf{5 8}$ \\
\hline 7. & Zachodniopomorskie & 46 & 47 & 47 & 48 & 51 & 53 & $\mathbf{5 4}$ \\
\hline 8. & Małopolskie & 43 & 44 & 45 & 47 & 49 & 52 & $\mathbf{5 3}$ \\
\hline 9. & Lubuskie & 45 & 46 & 46 & 48 & 48 & 52 & $\mathbf{5 3}$ \\
\hline 10. & Kujawsko-pomorskie & 45 & 45 & 45 & 47 & 49 & 51 & $\mathbf{5 2}$ \\
\hline 11. & Opolskie & 43 & 42 & 42 & 45 & 48 & 49 & $\mathbf{5 0}$ \\
\hline 12. & Świętokrzyskie & 39 & 38 & 39 & 42 & 45 & 47 & $\mathbf{4 7}$ \\
\hline 13. & Warmińsko-mazurskie & 39 & 39 & 39 & 40 & 42 & 45 & $\mathbf{4 6}$ \\
\hline 14. & Podlaskie & 38 & 38 & 38 & 40 & 41 & 45 & $\mathbf{4 5}$ \\
\hline 15. & Lubelskie & 35 & 35 & 35 & 37 & 39 & 41 & $\mathbf{4 2}$ \\
\hline 16. & Podkarpackie & 35 & 36 & 36 & 37 & 39 & 41 & $\mathbf{4 2}$ \\
\hline
\end{tabular}

*Województwa Polski Wschodniej zostały zaznaczone kolorem szarym.

Źródło: http://forum.investmap.pl, za: Eurostat.

wyraźnie słabiej rozwinięte gospodarczo. Po akcesji ich niskie wartościowo wskaźniki miały wpływ na obniżenie ekonomicznych średnich unijnych (dla UE-27) w wielu dziedzinach, m.in. także w przypadku PKB na głowę jednego mieszkańca.

Równie godne uwagi jest przekroczenie przeciętnego PKB per capita dla Unii przez województwo mazowieckie (102\%). Warszawa i Mazowsze uciekają w tym względzie już nie tylko Polsce Wschodniej, lecz także zostawiają daleko w tyle pozostałe regiony. Wyniki osiągnięte przez województwa: dolnośląskie, śląskie i wielkopolskie (miejsca 2-4) można uznać za wielce obiecujące na drodze osiągnięcia średniego europejskiego poziomu życia mieszkańców. Gorzej wygląda to w przypadku województw: pomorskiego, łódzkiego, zachodniopomorskiego, małopolskiego, lubuskiego, kujawsko-pomorskiego i opolskiego. W porównaniu 
z Unią, oferowany standard życia społecznego wacha się na poziomie od 50 do $60 \%$. To mało zważywszy, że w odniesieniu do najbardziej rozwiniętych obszarów Europy Zachodniej różnica jest znacznie większa.

Obszarem niepokoju w dalszym ciągu pozostaje teren Polski Wschodniej. Województwa przypisane do tego terytorium zanotowały najmniejszy postęp w nadrabianiu dystansu ekonomiczno-cywilizacyjnego do zjednoczonej Europy. Gdy PKB per capita rósł w najbardziej atrakcyjnych inwestycyjnie regionach od 10 (małopolskie - zajmujące 8 miejsce) do ponad 20 punktów procentowych (mazowieckie - 1 miejsce), w najlepszym z opóźnionych województw (świętokrzyskie - zajmujące 12 miejsce) wzrósł o 8 punktów. Oznacza to, że dystans rozwojowy pomiędzy regionami Rzeczypospolitej uległ dalszemu, niekorzystnemu powiększeniu. Cztery pozostałe województwa Polski Wschodniej: warmińsko-mazurskie, podlaskie, lubelskie i podkarpackie odnotowały w badanym okresie (od 2006 do 2010 roku) zmniejszenie dystansu do Europy o 7 punktów procentowych. Dlatego od średniej dzieli je jeszcze duża „odległość” od 53 (świętokrzyskie) do 58 (lubelskie i podkarpackie) punktów procentowych. Prawie na samym końcu zestawienia miejsca zajmują województwa: podlaskie (14 miejsce) i lubelskie (15 miejsce), czyli regiony tradycyjnie problemowe. Pewnym zaskoczeniem może być ostatnie, szesnaste miejsce województwa podkarpackiego. Pomimo posiadania pewnej przewagi nad innymi słabo rozwiniętymi obszarami na polu zasobów infrastruktury industrialnej, region ten rozwija się słabo i powoli. W odniesieniu do średniej EU-27 nie osiągnął jeszcze poziomu województwa opolskiego z roku 2004 ani nawet połowy poziomu porównywanego wskaźnika dla województwa mazowieckiego z 2007 roku.

\section{Ocena zmian w atrakcyjności inwestycyjnej regionów Polski Wschodniej}

Analiza przedstawionych w rozdziale VI i VII (pkt 1) danych oraz zebranych na potrzeby pracy informacji wykazała, że od momentu wstąpienia Polski do Unii Europejskiej nastąpiło wiele istotnych zmian w rozwoju gospodarczo-społecznym polskich województw. W większości były to przeobrażenia pozytywne, przynoszące opisywanym regionom wzrost znaczenia na obszarze Wspólnej Europy. W wyniku zastosowanych rozwiązań oraz zaangażowanych środków finansowych, zapoczątkowany został długofalowy proces mający na celu przybliżenie naszego kraju do europejskich standardów życia i zapewnienie poszczególnym regionom państwa możliwości wszechstronnego rozwoju.

Nastąpił zauważalny w skali ogólnopaństwowej i regionalnej wzrost dostępności transportowej poszczególnych terenów, wynikający bezpośrednio z roz- 
budowy sieci komunikacyjnej opartej na autostradach, drogach ekspresowych oraz trasach o znaczeniu krajowym i lokalnym.

Do końca 2014 roku w naszym kraju ma być w użytku blisko 3100 km dróg szybkiego ruchu z czego $1605 \mathrm{~km}$ tworzyć będą autostrady, natomiast $1482 \mathrm{~km}$ drogi ekspresowe. Ostatecznie Polska do pierwszej połowy XXI wieku ma dysponować około 2000 kilometrami autostrad i 5300 kilometrami dróg ekspresowych. Realizacja tego zamierzenia może jednak zostać rozciągnięta na wiele lat z powodu kryzysu ekonomicznego. W tej chwili trudno jest dokładnie określić moment zakończenia całego procesu (www.regiomoto.pl). Na rysunku 22 przedstawiono aktualnie istniejącą i zaplanowaną sieć autostrad w Polsce.

Zamieszczona na rysunku 22 mapa ukazuje, że tylko nieliczne województwa w Polsce nie mają wytyczonego przebiegu autostrad przez swoje terytorium.

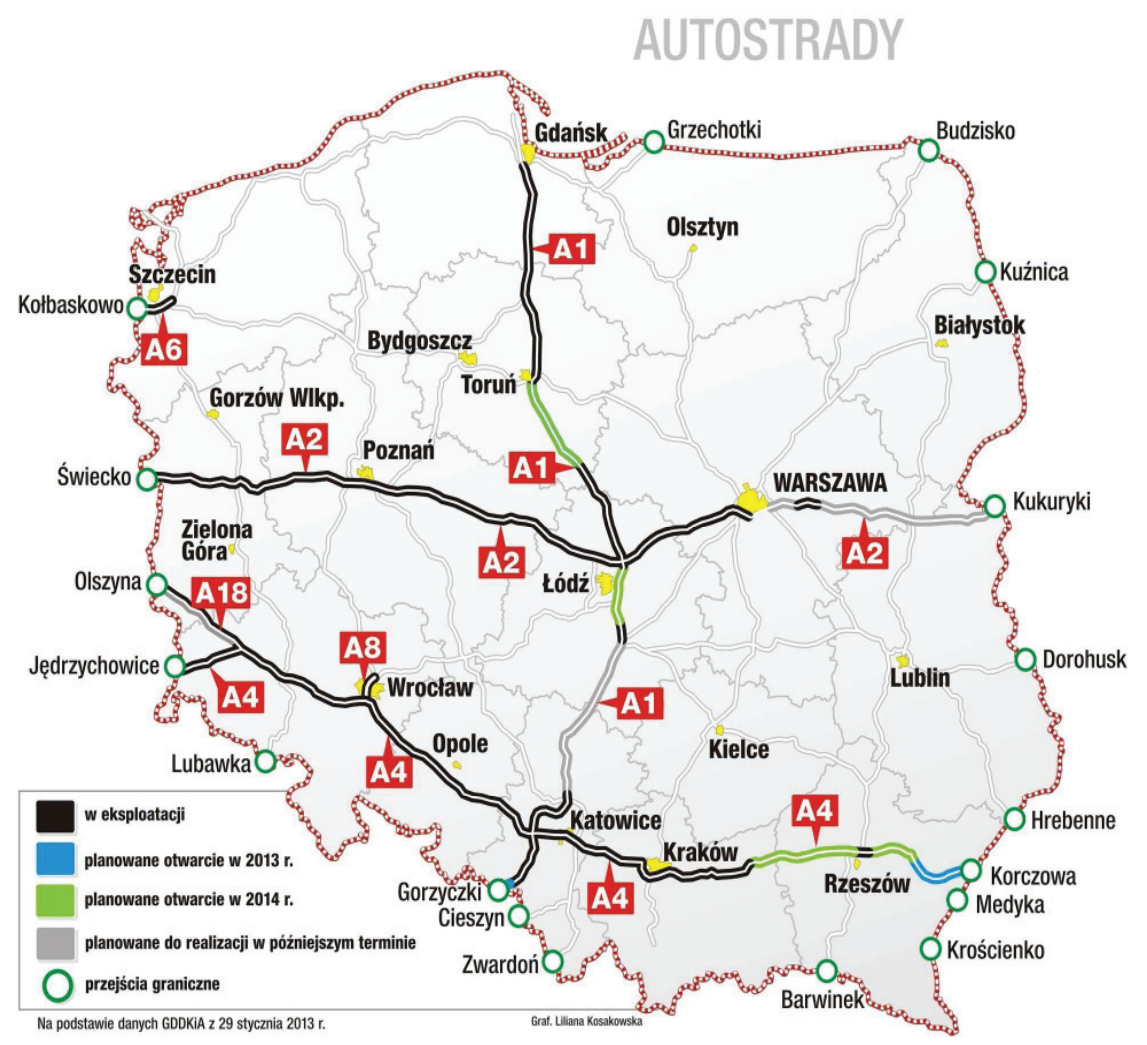

Rysunek 22. Sieć istniejących (i planowanych) autostrad w Polsce według danych z 2013 roku

Źródło: Dane Generalnej Dyrekcji Dróg Krajowych i Autostrad z dnia 29 stycznia 2013 roku. 
Dotyczy to już istniejącej infrastruktury drogowej, jak również tej zaplanowanej w nadchodzącej przyszłości. Decydenci zdają się nie dostrzegać kapitalnego znaczenia najbardziej bezpiecznych i wygodnych połączeń drogowych, jakimi są autostrady, dla zwiększenia atrakcyjności nie tylko inwestycyjnej danych obszarów. W tym kontekście pominięcie w krajowej sieci komunikacyjnej opartej na autostradach województw: świętokrzyskiego, podlaskiego i warmińsko-mazurskiego stanowi bardzo poważny, jeśli chodzi o konsekwencje, błąd planistyczny.

W tej chwili na terenie Polski działa czternaście cywilnych portów lotniczych dla zorganizowanego ruchu pasażerskiego. Istniejący system tworzą: najważniejszy - międzynarodowy port im. Fryderyka Chopina w Warszawie oraz trzynaście mniejszych placówek. Rysunek 23 ukazuje działające aktualnie w Polsce pasażerskie porty lotnicze.

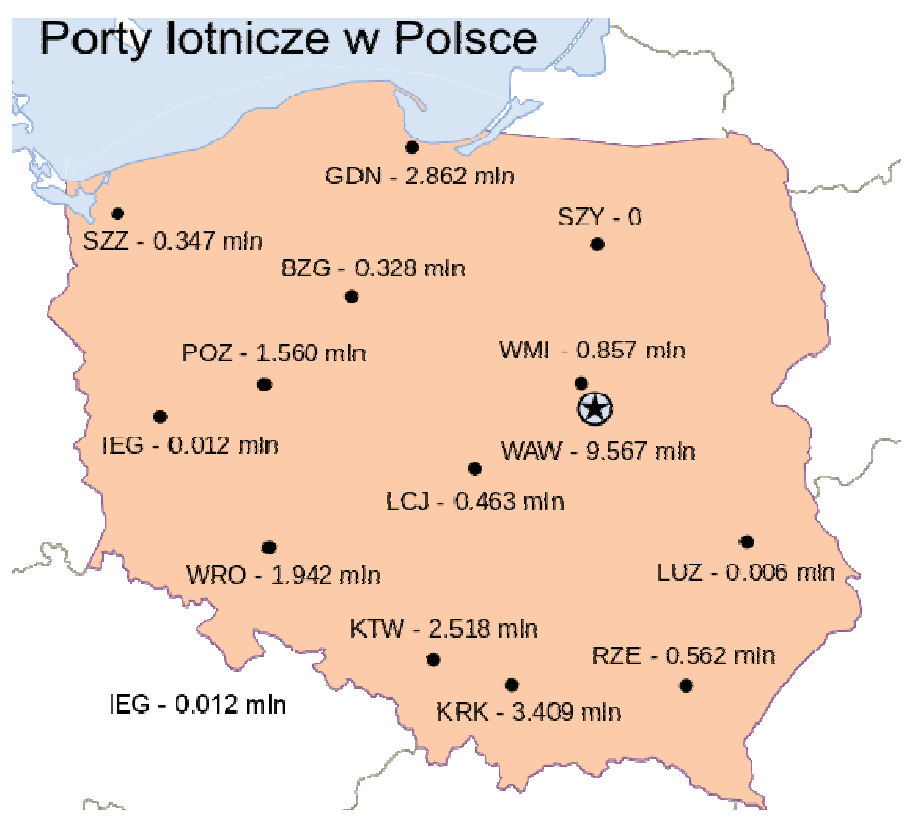

Legenda:

BZG - Bydgoszcz Szwederowo

POZ - Poznań Ławica

GDN - Gdańsk Rębiechowo

RZE - Rzeszów Jasionka

KRK - Kraków Balice

KTW - Katowice Pyrzowice

SZY - Szczytno Szymany

SZZ - Szczecin Goleniów

IEG - Zielona Góra Babimost

WRO - Wrocław Strachowice

LCJ - Łódź Lublinek

LUZ - Lublin Świdnik

WAW - Warszawa Okęcie

WMI - Warszawa Modlin

Rysunek 23. Istniejące w Polsce porty lotnicze o znaczeniu międzynarodowym i regionalnym wraz z liczbą odprawionych przy ich udziale pasażerów w 2012 roku Źródło: http://www.uk.gov.pl/_download/regulacja_rynku/statystyku/wg_portw_lotniczych_f.pdf. 
Od momentu przystąpienia Polski do UE powstało lub zostało w zasadniczy sposób zmodernizowanych kilka portów lotniczych na terenie kraju (m.in. Okęcie w Warszawie, Balice w Krakowie, Rębiechowo w Gdańsku, Pyrzowice na Górnym Śląsku, Modlin pod Warszawą, Ławica w Poznaniu, Goleniów pod Szczecinem, Świdnik pod Lublinem). Cywilnego portu lotniczego o statusie regionalnym nie posiadają cztery województwa i aż trzy z nich należą do obszaru Polski Wschodniej: podlaskie, świętokrzyskie i warmińsko-mazurskie (w rachubę nie wchodzi zamknięty w 2003 ro. Port Lotniczy Mazury w Szymanach koło Szczytna). Czwartym województwem bez własnej komunikacji lotniczej jest opolskie. Uciążliwość ta powinna jednak zniknąć po adaptacji przeznaczonego dla Opola powojskowego lotniska położonego w odległym o 24 kilometry od tego miasta Kamieniu Śląskim. W kolejnych latach zaplanowano budowę nowych regionalnych portów lotniczych: w Obicach dla Kielc, portu lotniczego Nowy Sącz - Stary Sącz oraz Olsztynek dla Olsztyna, chociaż inwestycje te mogą ulec znacznemu przesunięciu w czasie wobec spadku intensywności ruchu lotniczego na świecie.

W odniesieniu do infrastruktury społecznej najbardziej widoczny stał się wzrost popularności oraz dostępności szkół ponadpodstawowych i uczelni wyższych, co umożliwiło osiągnięcie lepszego poziomu edukacji szerokim rzeszom społeczeństwa. W okresie pomiędzy latami 2002 a 2011 odsetek osób z wykształceniem ponadpodstawowym zwiększył się z 66,9 do 78,7\%. Znaczący postęp dotyczy osób, które zdobyły wykształcenie wyższe. Ich udział w całej krajowej populacji osób powyżej trzynastego roku życia wzrósł w wymienionym okresie prawie podwójnie - z 9,9 do ponad 17,5\% (GUS, 2011).

Innym ważnym elementem określającym jakość i poziom infrastruktury społecznej jest upowszechnienie świadczeń medycznych, ilość szpitali oraz liczba łóżek stojących do dyspozycji pacjentów w publicznych placówkach ochrony zdrowia.

Chociaż pomiędzy rokiem 2005 a 2011 wzrosła w Polsce liczba szpitali ogólnych, świadczących najbardziej szeroką i wszechstronną paletę usług medycznych, o trzydzieści trzy - co daje wzrost o 4,2\%, to ogólna liczba łóżek jakimi dysponowały powiększyła się jedynie o 1113 miejsc (wzrost o 0,6\%). Jest to

Tablica 37. Liczba szpitali ogólnych wraz z liczbą łóżek w Polsce. Porównanie stanu w latach 2005 i 2011

\begin{tabular}{|l|c|c|}
\hline \multicolumn{1}{|c|}{ Wyszczególnienie } & $\mathbf{2 0 0 5}$ & $\mathbf{2 0 1 1}$ \\
\hline Szpitale ogólne & 781 & 814 \\
\hline Liczba łóżek w szpitalach ogólnych & 179.493 & 180.606 \\
\hline
\end{tabular}

Źródło: GUS (2012, s. 366). 
wynik niepokojąco słaby, biorąc pod uwagę wyjątkowo złą jakość publicznych usług zdrowotnych w naszym kraju, utrzymującą się na niezmienionym poziomie już od dziesiątków lat. Jeszcze gorzej sprawa przedstawia się, gdy weźmiemy pod uwagę, że w roku 2000 do dyspozycji pacjentów w publicznych szpitalach ogólnych były 190952 łóżka. Jest to o 10346 miejsc więcej (co stanowi ponad 5,7\%) niż w roku 2011. Przytoczone liczby pokazują głęboką zapaść polskiej służby zdrowia na polu hospitalizacji. Co więcej, na pomoc medyczną na zaawansowanym poziomie można liczyć tylko w największych, regionalnych ośrodkach miejskich. Im dalej od centrum kraju, tym opieka zdrowotna staje się mniej skuteczna. Dodając do tego czas oczekiwania na wizytę u lekarza specjalisty, który wynosi często od roku do ponad trzech lat, można śmiało stwierdzić, że Polska to kraj niezbyt bezpieczny dla ludzi o słabszym zdrowiu lub powyżej wieku średniego.

Jeśli chodzi o infrastrukturę gospodarczą, to w jej obrębie nastąpiła w skali kraju prawdziwa ewolucja. Zmienił się przede wszystkim charakter rodzimej gospodarki. W zasadzie z mapy Polski zniknęły największe, a zarazem najbardziej kapitałochłonne oraz energochłonne zakłady przemysłowe, takie jak: kopalnie węgla i huty, wielkie stocznie, Fabryka Samochodów Osobowych na Żeraniu czy Zakłady Produkcji Ciągników Rolniczych Ursus. W ich miejsce pojawiły się głównie podmioty gospodarcze należące do Sektora Małych i Średnich Przedsiębiorstw.

W Polsce według danych z 2011 roku działało ponad 1670 tys. firm. Liczba aktywnych przedsiębiorstw na rynku daje nam szóste miejscu w Unii Europejskiej. Aż 99,8\% z nich należało do sektora MSP. W tej liczbie aż 95,8\% to podmioty zatrudniające maksymalnie do 9 osób, które są zaliczane do mikroprzedsiębiorstw. Najpopularniejsze branże wśród najmniejszych firm to: kultura, rekreacja oraz rozrywka - $37 \%$, edukacja $-36 \%$ oraz działalność finansowa i ubezpieczeniowa - 34\%. Naprawdę niewielka liczba firm z tej grupy działa w przemyśle lub budownictwie. Wynik 1,6 mln działających mikroprzedsiębiorstw (w tym - 1,1 mln to osoby samozatrudnione) daje Polsce pod tym względem drugie miejsce w UE (Tarnawa, Zadura-Lichota, 2012, s. $18-47)$.

Sektor małych i średnich przedsiębiorstw tworzy w naszym kraju 48,4\% PKB. Wielkość ta pozostaje już od kilkunastu lat na prawie niezmienionym poziomie, nie przekraczając jednak $50 \%$. MSP stanowi miejsce pracy dla ponad $70 \%$ pracujących i $61 \%$ zatrudnionych. Szczególnym powodem do zadowolenia powinien być zaś stopień nasycenia przez MSP rodzimej gospodarki, znacznie wyższy niż w UE-27. Dla przypomnienia, w 2011 roku wynosił on dla Polski 99,8\%, natomiast dla Unii Europejskiej - 91,4\% (http://www.pi.gov.pl). Taki wynik świadczy dobrze o zmyśle przedsiębiorczości oraz zaradności w obszarze biznesowym polskich obywateli. Można przypuszczać, że był też jednym 
powodów dłuższego opierania się rodzimej gospodarki rozprzestrzeniającemu się kryzysowi finansowo-ekonomicznemu o zasięgu światowym.

Niewątpliwie wraz ze wzrostem wynagrodzeń zwiększyła się atrakcyjność polskiego rynku wewnętrznego. $\mathrm{Z}$ liczbą ponad $38 \mathrm{mln}$ konsumentów stanowi on interesujące miejsce dla inwestorów krajowych i zagranicznych. Jednakże jego chłonność dóbr drogich i luksusowych jest poważnie ograniczona, ze względu na dość nieliczną w naszym kraju klasę ludzi ponad przeciętnie zamożnych.

Jeśli chodzi o koszty pracy, to kształtują się one poniżej średniej dla UE-27, co stanowi zachętę dla podmiotów rozważających pod tym kątem inwestycje w Polsce. Dodatkowo, Polska dysponuje liczną, kilkuset tysięczną grupą młodych (do 25 lat), wykształconych i utalentowanych ludzi, gotowych do podjęcia każdej zaoferowanej im pracy.

Pozytywnym czynnikiem ściągającym kapitał do poszczególnych miejsc w Polsce jest w ostatnim czasie aktywna postawa władz lokalnych na polu pozyskiwania inwestorów. Poprzez akcje medialne, sympozja i konferencje oraz oferowane w Internecie wszechstronną informację i pomoc władze regionalne oraz reprezentujące niższe szczeble administracji starają się zachęcać potencjalnych inwestorów do lokowania pieniędzy na podległym sobie terenie.

Postrzeganiu Polski jako terenu atrakcyjnego dla różnorodnych inwestycji sprzyja także stosunkowo wysoki poziom bezpieczeństwa powszechnego wynikający z braku zagrożenia terroryzmem, zorganizowanych na większą skalę grup przestępczych, bandytyzmu czy niebezpieczeństwa wybuchu ewentualnego konfliktu zewnętrznego lub wewnętrznego.

Biorąc pod uwagę przytoczone informacje i dane, można stwierdzić, że nasz kraj stał się bardziej atrakcyjnym inwestycyjnie miejscem w przeciagu czasu, jaki dzieli datę jego wstąpienia do Unii Europejskiej do dzisiaj. Dystans jaki dzielił Rzeczpospolitą od średniej UE w wielu ważnych dziedzinach został radykalnie zmniejszony. Niestety dotyczy to grupy jedynie pięciu lub maksymalnie ośmiu najlepiej rozwiniętych gospodarczo województw. W tej liczbie należy przede wszystkim wymienić: mazowieckie, śląskie, wielkopolskie, pomorskie, małopolskie, dolnośląskie, łódzkie i zachodniopomorskie. Jeśli chodzi o Polskę Wschodnią to obszar ten rozwija się ekonomicznie znacznie wolniej niż pozostała część kraju. Chociaż wskaźniki ekonomiczne dla pięciu regionów tego obszaru rosną, to dzieje się to na tyle powoli, że osiągnięcie średniej unijnej może potrwać jeszcze kilkanaście lub nawet kilkadziesiąt lat.

Podjęte kroki w kierunku zwiększenia spójności i konwergencji tego obszaru nie przyniosły oczekiwanych efektów. Zaangażowane środki finansowe, pochodzące $z$ budżetu Unii i źródeł krajowych, nie dały nawet zadowalających rezultatów. Polityka spójności, programy regionalne, a w szczególności opisany wcześniej Program Operacyjny Rozwój Polski Wschodniej okazały się na tyle nieskuteczne, że dystans rozwoju gospodarczego pomiędzy najsłabszymi 
regionami a krajową czołówką uległ powiększeniu. Uzyskany wynik, okazał się odwrotny do zakładanego przez władze krajowe oraz zamysłu polityków z Brukseli. Przez badany okres kilkunastu lat tereny centralne, północno-zachodnie i południowo-zachodnie naszego kraju stały się znacznie bardziej atrakcyjne dla inwestorów niż obszar Polski Wschodniej. Co więcej zgodnie z „Koncepcją Przestrzennego Zagospodarowania Kraju 2030” (Monitor Polski, 2012, poz. 252), w Polsce wyodrębnionych zostało dziesięć ośrodków metropolitalnych, których rozbudowa ma inicjować przyspieszony rozwój regionalny. Tworzą je: Warszawa, Aglomeracja Górnośląska, Łódź, Trójmiasto, Poznań, Kraków, Wrocław, Bydgoszcz z Toruniem (traktowane jako duopol), Szczecin oraz Lublin (http://mac. gov.pl). Ośrodki te zostały wybrane za pomocą następujących kryteriów: liczba ludności ośrodka metropolitalnego wynosząca powyżej 300 tys. mieszkańców, zatrudnienie w sektorze usług rynkowych powyżej 40 tys. mieszkańców, liczba studentów kształcących się w danym mieście powyżej 60 tys., współpraca placówek naukowych z podobnymi instytucjami w UE, posiadanie regionalnego pasażerskiego portu lotniczego, lokalizacja na terenie miast hoteli cztero - i pięciogwiazdkowych oraz organizowanie międzynarodowych wystaw w obiektach specjalnie przeznaczonych do takiej działalności (MAC, 2012, s. 24). Zakłada się, że najdalej do roku 2030 roku przestrzeń Rzeczypospolitej powinna ulec bardziej intensywnej integracji w układach międzynarodowych. Stolica kraju oraz wymienione $\mathrm{w}$ dokumencie ośrodki metropolitalne powinny być silniej powiązane funkcjonalnie, a szczególnie gospodarczo, między sobą oraz z podobnymi obszarami w obrębie Wspólnej Europy.

Spośród stolic województw Polski Wschodniej tylko Lublin znalazł się w grupie ośrodków metropolitalnych. Pozostałe miasta nie zostały niestety objęte długoterminowym projektem przestrzennego rozwoju Polski. Wynika to bezpośrednio z wyznaczenia w rządowym dokumencie, pt.: „Koncepcje Przestrzennego Zagospodarowania Kraju 2030”, dość rygorystycznych kryteriów delimitacyjnych dla obszarów metropolitalnych. Jednym z najważniejszych okazał się w tym względzie wymóg posiadania liczby ludności powyżej 300 tys. dla takiego ośrodka. Ze wszystkich pięciu wschodnich województw warunek ten został spełniony jedynie przez stolicę regionu lubelskiego.

Zdziwienie może budzić brak uwzględnienia Białegostoku w rządowej „Koncepcji Przestrzennego Zagospodarowania Kraju 2030", któremu obecnie do liczby 300 tys. mieszkańców brakuje tylko nieco ponad 5 tys. osób. Niewątpliwie objęcie stolicy województwa podlaskiego założeniami ogólnokrajowego planu zagospodarowania mogłoby się przyczynić do bardziej dynamicznego rozwoju zarówno samego miasta, jak i całego regionu.

Barierą włączenia Białegostoku do grupy ośrodków metropolitalnych w Polsce są wyjątkowo niekorzystne przewidywania demograficzne dla całego obszaru. Zgodnie z opracowaną prognozą, dotyczącą okresu 2008-2035, w nadchodzą- 
Tablica 38. Największe miasta Polski pod względem liczby ludności według stanu na 31 grudnia 2011 r.*

\begin{tabular}{|c|c|c|c|}
\hline Lp. & Miasto & Województwo & Liczba mieszkańców ogółem \\
\hline 1. & Warszawa & mazowieckie & 1708491 \\
\hline 2. & Kraków & małopolskie & 759137 \\
\hline 3. & Łódź & łódzkie & 725055 \\
\hline 4. & Wrocław & dolnośląskie & 631235 \\
\hline 5. & Poznań & wielkopolskie & 553564 \\
\hline 6. & Gdańsk & pomorskie & 460517 \\
\hline 7. & Szczecin & zachodniopomorskie & 409596 \\
\hline 8. & Bydgoszcz & kujawsko-pomorskie & 363020 \\
\hline 9. & Lublin & lubelskie & 348567 \\
\hline 10. & Katowice & śląskie & 309304 \\
\hline 11. & Białystok & podlaskie & 294298 \\
\hline 12. & Gdynia & pomorskie & 248939 \\
\hline 13. & Częstochowa & śląskie & 235798 \\
\hline 14. & Radom & mazowieckie & 220602 \\
\hline 15. & Sosnowiec & śląskie & 215262 \\
\hline 16. & Toruń & kujawsko-pomorskie & 204921 \\
\hline 17. & Kielce & świętokrzyskie & 201815 \\
\hline 18. & Gliwice & śląskie & 186868 \\
\hline 19. & Zabrze & śląskie & 180332 \\
\hline 20. & Rzeszów & podkarpackie & 180031 \\
\hline 21. & Bytom & śląskie & 176106 \\
\hline 22. & Olsztyn & warmińsko-mazurskie & 175420 \\
\hline 23. & Bielsko-Biała & śląskie & 174503 \\
\hline 24. & RudaŚląska & śląskie & 143024 \\
\hline 25. & Rybnik & śląskie & 140944 \\
\hline 26. & Tychy & śląskie & 129322 \\
\hline 27. & Dąbrowa Górnicza & śląskie & 125475 \\
\hline 28. & Gorzów Wielkopolski & lubuskie & 124544 \\
\hline 29. & Płock & mazowieckie & 124318 \\
\hline 30. & Elbląg & warmińsko-mazurskie & 124257 \\
\hline
\end{tabular}

*Kolorem szarym zaznaczone zostały stolice pięciu województw Polski Wschodniej.

Źródło: www.stat.gov.pl. 
cych latach nastąpi proces odczuwalnego zmniejszania się liczby ludności województwa podlaskiego. Co gorsza, dynamika spadku liczby ludności ma zwiększać się systematycznie z roku na rok. Według przewidywań, w 2020 roku liczba mieszkańców Podlasia osiągnie poziom 1153,5 tys. osób, w 2035 roku będzie zaś wynosiła już tylko 1072,3 tys. Obecnie (2012 r.) populacja regionu wynosi 1201,0 tys. osób. Innymi słowy w okresie niecałego ćwierćwiecza (dokładnie 23 lat) liczba mieszkańców Podlasia może ulec zmniejszeniu o blisko 129 tys. osób. Przewidywany, szybki ubytek ludności w około 2/5 dotyczyć będzie mieszkańców miast (w tym także Białegostoku), natomiast w 3/5 osób zamieszkujących na stałe tereny wiejskie (Urząd Statystyczny w Białymstoku, 2011, s. 8).

Tablica 39. Liczba ludności Białegostoku od 2000 do 2012 roku. Dane na 31 grudnia każdego roku

\begin{tabular}{|c|c|c|}
\hline Lp. & Rok & Liczba ludności (w tys.) \\
\hline 1. & 2000 & 285,5 \\
\hline 2. & 2001 & 286,3 \\
\hline 3. & 2002 & 291,6 \\
\hline 4. & 2003 & 291,9 \\
\hline 5. & 2004 & 292,1 \\
\hline 6. & 2005 & 291,8 \\
\hline 7. & 2006 & 294,8 \\
\hline 8. & 2007 & 294,1 \\
\hline 9. & 2008 & 294,2 \\
\hline 10. & 2009 & 294,4 \\
\hline 11. & 2010 & 295,2 \\
\hline 12. & 2011 & 294,3 \\
\hline 13. & 2012 & 294,6 \\
\hline
\end{tabular}

Źródło: http://www.bialystok.pl.

W okresie od 2000 do 2012 roku liczba mieszkańców Białegostoku zwiększyła się jedynie o 9100 osób. Daje to dynamikę wzrostu na poziomie 103,2\%. Co więcej, w badanym okresie były nawet takie momenty, kiedy populacja miasta ulegała zmniejszeniu (w latach 2005, 2007 i 2011). Po zauważalnej fazie wzrostu 
na przełomie lat 2001-2002 oraz po raz drugi na przełomie 2005-2006 liczba ludności w stolicy Podlasia uległa ustabilizowaniu i oscyluje od 294,1 (2007) do 294,6 tys. osób (2012). Biorąc pod uwagę przedstawioną wcześniej niekorzystna prognozę demograficzną, można założyć, że Białystok ma niewielkie szanse na przekroczenie wymaganej granicy 300 tys. mieszkańców.

Poza opisaną sytuacją Lublina i Białegostoku, stolice trzech pozostałych regionów Polski Wschodniej, to znaczy: Kielce, Olsztyn i Rzeszów, ze względu na przewidywany proces „kurczenia się” ich populacji, nie mają szansy na osiągnięcie wymaganego minimalnego poziomu liczby mieszkańców ani do roku 2035, ani jak się wydaje nawet do końca obecnego stulecia. Można zatem już dzisiaj stwierdzić, że obserwowane aktualnie dysproporcje pomiędzy tempem rozwoju ekonomiczno-gospodarczego poszczególnych województw utrzymają się. Co gorsza, można śmiało prognozować, że w perspektywie roku 2035 mogą jeszcze narastać. Będzie to miało bezpośredni wpływ na postrzeganie atrakcyjności inwestycyjnej omawianych obszarów. Czołówkę najbardziej interesujących miejsc dla alokacji kapitałów, poszukiwania pracy oraz znalezienia miejsca zamieszkania, stanowić będą regiony z wyznaczonymi regionami metropolitalnymi. Natomiast coraz mniej w ujęciu krajowym będą znaczyć obszary Polski Wschodniej. Dotyczy to także województwa lubelskiego i samego Lublina w wypadku utrzymania się dotychczasowych bardzo niekorzystnych tendencji migracyjnych.

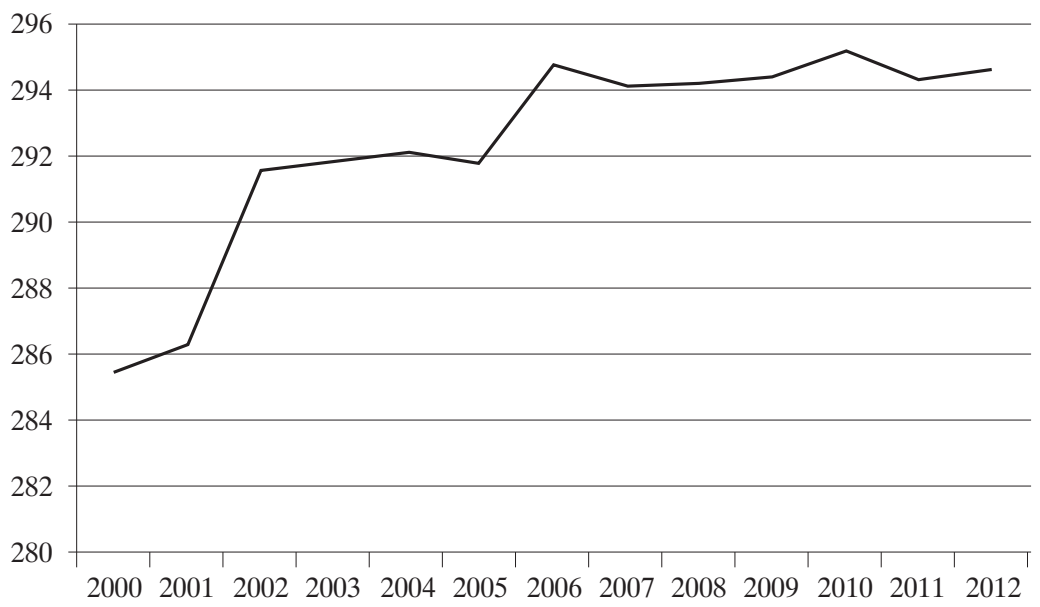

Rysunek 24. Zmiany w liczbie mieszkańców Białegostoku w latach 2000-2012 Źródło: opracowanie własne na podstawie danych z tab. 39. 


\section{Sposoby na zwiększenie atrakcyjności inwestycyjnej regionów słabiej rozwiniętych}

W celu pożądanego zwiększenia atrakcyjności inwestycyjnej regionów słabiej rozwiniętych można się odwołać do dwóch znanych i popularnych koncepcji: rozwoju egzogenicznego oraz rozwoju endogenicznego. Obecnie w Polsce, za sprawą pieniędzy pochodzących głównie z funduszy Unii Europejskiej, w większości przypadków forsowany jest model wzrostu egzogenicznego. Wzrost ten, oparty na napływie kapitału z zewnątrz i inwestycjach oraz dofinansowywaniu wybranych dziedzin gospodarki, został uznany za panaceum na rosnącą przepaść w poziomie rozwoju regionalnego poszczególnych obszarów. Przychylność władz krajowych dla zastosowania modelu egzogenicznego w budowaniu przyszłości regionów można zauważyć chociażby w odniesieniu do przyjętej „Koncepcji Przestrzennego Zagospodarowania Kraju 2030”, gdzie na pierwszy plan wysuwa się pomysł stworzenia dziesięciu ośrodków metropolitalnych. Takie rozwiązanie, to proste odwołanie się do czynników zewnętrznych wpływających na rozwój regionalny, które można znaleźć w opisywanych (zob. rozdz. III) koncepcjach, takich jak: teoria okręgów przemysłowych Alfreda Marshalla, teoria lokalizacji przemysłu Alfreda Webera, teoria ośrodków centralnych Waltera Christallera, koncepcja polaryzacji sektorowo-regionalnej Alfreda Hirschmana, teoria biegunów wzrostu François Perroux czy teoria centrum-peryferia Raula Prebischa.

Raz jeszcze z całym naciskiem należy przypomnieć wspomniany już wcześniej fakt, że we współczesnych czasach, w praktyce gospodarczej, nie występują, już „czyste" modele regionalnego wzrostu gospodarczego, co ma miejsce również w Polsce. Przykładowo, wielomiliardowe środki finansowe pochodzące z Unii Europejskiej można określić jako instrumenty reprezentujące egzogeniczny model rozwoju. Jednakże pieniądze z budżetu UE przeznacza się obecnie np. na cele wcielania w życie Programu Operacyjnego Innowacyjna Gospodarka, w ramach którego wspierane są działania w ramach Badań i Rozwoju $(B+R)$, wprowadzania nowoczesnych technologii czy popierana jest dyfuzja innowacji. Wymienione elementy jednoznacznie kojarzą się z czynnikami mającymi aktywizować rozwój regionalny, oparty na modelu endogenicznym. Także Program Operacyjny Kapitał Ludzki (PO KL) oraz Program Operacyjny Pomoc Techniczna (PO PT) należy zakwalifikować do sprawdzonych sposobów endogenicznego rozwojowi regionów. Jednakże, jeśli przyjrzeć się jednemu z głównych celów jakiemu służą, a mianowicie zwiększeniu konkurencyjności regionu, to pojawiają się wątpliwości. Zwiększenie konkurencyjności regionu w tym znaczeniu to: osiagnięcie $i$ utrzymanie trwatej przewagi ekonomicznej nad podobnymi jednostkami terytorialnymi. Oznacza to dążenie do wywalczenia lepszej pozycji w stosunku do innych województw. To z kolei jest jawnym zaprzecze- 
niem spójności gospodarczo-społecznej do której, przynajmniej w założeniu, dążymy.

W przypadku naszego kraju zastosowanie finansowych środków pomocy i wsparcia miało w założeniach przyczynić się do zwiększenia konwergencji najsłabszych województw państwa z najbardziej rozwiniętymi. Chociaż zamierzenie, jakim było nadrobienie dystansu cywilizacyjno-ekonomicznego do Zjednoczonej Europy, jest powoli realizowane, to innego ważnego celu, jakim było zwiększenie spójności obszaru Polski nie udało się osiągnąć. Oznacza to, że koncepcja ściągania kapitału na słabiej rozwinięte obszary za pomocą zwiększonych inwestycji pochodzących z finansowych środków krajowych i zagranicznych nie przyniosła oczekiwanych efektów. Okazała się w tym przypadku po prostu nieskuteczna.

Od momentu wstąpienia Polski do ugrupowania integracyjnego zauważalne różnice w poziomie rozwoju poszczególnych obszarów jeszcze się pogłębiły. Wpływa to bezpośrednio na wybór przez inwestorów miejsca dla alokacji kapitału. Inwestorzy konsekwentnie kierują swoje zainteresowanie przede wszystkim na obszary, które oferują im: lepszą infrastrukturę przemysłową, bardziej rozwinięte zaplecze techniczne, wyższy poziom życia, wszechstronne i szybkie połączenia komunikacyjne, dostęp do instytucji doradczych, finansowych i prawnych, szeroki wybór placówek o profilu kulturalnym i rozrywkowym, wygodne warunki zamieszkania oraz odpowiednie do ich zamierzeń zasoby siły roboczej o specjalistycznym wykształceniu. W efekcie, pomimo podejmowanej pracy i czynionych wysiłków, administracja samorządowa regionów słabiej rozwiniętych ma mniejsze możliwości skłonienia właścicieli kapitału do inwestowania na podległym sobie terenie $\mathrm{w}$ porównaniu $\mathrm{z}$ władzami reprezentującymi obszary metropolitalne.

Jak wykazuje nauka i praktyka, w wielu przypadkach to jednak nie ludzie podążają za kapitałem, lecz odwrotnie, to kapitał stara się znaleźć w miejscu, które dla swojej przyszłej egzystencji wybierają ludzie. Tego rodzaju wnioski przynoszą nam endogeniczne koncepcje wzrostu, a mianowicie (zob. rozdz. III): wybrane elementy teorii „maszyny rozrywki” Terry'ego Nocholasa Clarka oraz w mniejszym zakresie - teoria reżimów Clarence Stone'a. Przy przyjęciu takiej koncepcji rysuje się duża szansa na osiągnięcie pożądanego efektu, jakim jest ściągnięcie kapitału na określony teren. Proces ten odbywa się zazwyczaj przy wykorzystaniu koncepcji związanych z endogenicznym rozwojem regionalnym. Należy zatem zadać sobie kilka pytań: czy wykorzystane zostały już wszystkie możliwości leżące w modelu endogenicznego wzrostu regionalnego; czy istnieją uwarunkowania, w których udałoby się zwiększyć atrakcyjność regionu bez konieczności znacznych nakładów finansowych i czy można zachęcić szerokie rzesze społeczne do napływu na określone tereny, a w konsekwencji ściągnięcia przez nie kapitału i inwestycji? 
Znalezienie pozytywnej odpowiedzi na zdane pytania dawałoby teoretyczną szansę zniwelowania negatywnych skutków spowodowanych wyborem modelu wzrostu, kładącego przede wszystkim nacisk na koncepcje egzogeniczne. Byłoby także rozszerzeniem obszaru poszukiwań, a w przypadku ich znalezienia - eksploracji nowych sposobów umożliwiających zwiększanie atrakcyjności regionów słabiej rozwiniętych.

Poczynania te miałyby na celu osiągnięcie wyższej spójności oraz stanu pożądanej konwergencji przez poszczególne województwa naszego kraju. Gdyby rozwiązania miały charakter uniwersalny, można byłoby je także zastosować do innych regionów słabiej rozwiniętych w skali Europy.

\section{Bezpośredni udział społeczeństwa w kierowaniu rozwojem regionu}

Na samym początku trzeba zaznaczyć, że bezpośredni udział w kierowaniu rozwojem regionu oznacza przede wszystkim zdecydowanie większy wpływ społeczeństwa na decyzje administracyjne dotyczące obszaru, który ono zamieszkuje. Naturalnie, nie wyklucza to możliwego udziału mieszkańców w sensie finansowym, lobbystycznym czy świadczeniu nieodpłatnej pracy (społecznej) na rzecz określonego terytorium. Jednakże w prezentowanej koncepcji uwaga zostanie zwrócona głównie na rozwiązania leżące w sferze polityczno-ustrojowej, przekładające się na wzrost atrakcyjności inwestycyjnej regionów słabiej rozwiniętych. Efekt osiągnięcia bardziej dynamicznego rozwoju danego regionu implikuje niejako automatycznie wzrost jego atrakcyjności inwestycyjnej.

W przypadku, gdy instrumenty finansowe, jak to można zaobserwować w Polsce Wschodniej, straciły dużą część ze skuteczności swojego działania na polu zwiększenia atrakcyjności regionów, należy poszukać innych efektywnych rozwiązań. Oczywiście rozważając nowe sposoby przyciągania ludzi i kapitału na określone tereny, błędem byłaby rezygnacja z narzędzi ekonomicznych, które stosowane były do tej pory. Najwłaściwszym postępowaniem jest rozważenie możliwości zintensyfikowania osiąganych rezultatów przez zastosowanie nowych czynników dających w wyniku efekt wsparcia dotychczasowym dokonaniom. Taki pożądany efekt wsparcia, daje zastosowanie demokracji bezpośredniej. Jest to sposób sprawdzony i coraz częściej wykorzystywany w praktyce ze względu na swoją dowiedzioną skuteczność (Feld, Fischer, Kirchgaessner, 2006, s. 7-27).

Do najbardziej spektakularnych efektów stosowania demokracji bezpośredniej należy zaliczyć następujące fakty (Frey, 2010, s. 82-90):

- społeczeństwo przejawia większą spójność sąsiedzką oraz chęć do działań na rzecz swojego najbliższego otoczenia i regionu; 
- wydatki publiczne przeznaczone na edukację w przeliczeniu na głowę jednego mieszkańca są wyższe niż na innych terenach;

- budżety jednostek administracji lokalnej, gdzie z większą siłą występują mechanizmy współdecydowania mieszkańców o „własnym terytorium”, są wyraźnie „skromniejsze” zarówno po stronie wydatków, jak i dochodów;

- bez względu na: wykształcenie, wiek, płeć, wyznanie, status majątkowy oraz wysokość dochodów, mieszkańcy regionów z bardziej rozwiniętą demokracją bezpośrednią, wyrażają większą akceptację dla warunków życia, swobód obywatelskich oraz poczynań władz lokalnych;

- dochód per capita w regionach, gdzie w szerszym zakresie stosuje się demokrację bezpośrednią, jest znacznie wyższy niż na pozostałych terenach;

- rośnie zadowolenie ogółu społeczeństwa z życia (ang. life - satisfaction, niem. Lebenszufridenheit) wraz z pojawieniem się większego „nasycenia” elementami demokracji bezpośredniej; satysfakcja z bytowania (egzystencji) jest porównywalna nawet do efektu, jaki przynosi wzrost dochodów;

- stawki podatków i opłat leżących w gestii władz lokalnych ulegają zasadniczemu obniżeniu;

- skala uchylania się od podatków jest w społeczeństwie bardzo mała lub staje się wręcz marginalna;

- występuje zjawisko nasilonego napływu ludzi (zwiększonej imigracji) na obszary stosujące rozwiązania demokracji bezpośredniej;

- rosną ceny gruntów i nieruchomości w miejscach gdzie społeczeństwo współdecyduje o swojej przyszłości;

- rozwijana jest bogata infrastruktura socjalna ukierunkowana na zaspokojenie rosnących potrzeb społecznych;

- powstają nowe podmioty gospodarcze, a już istniejące, ale działające na innych obszarach, zakładają swoje filie lub przedstawicielstwa albo zmieniają miejsce głównej siedziby firmy, wybierając dla tego celu regiony legitymujące się wyższym stopniem demokracji bezpośredniej.

Naukowcy z niemieckojęzycznych ośrodków akademickich (uniwersytety w Kassel i Marburgu), zajmujący się zagadnieniami związanymi z demokracją bezpośrednią, dodają do wymienionego wyżej katalogu pozytywnych efektów jeszcze kilka istotnych faktów (Blume, Müller, Voight, 2007, s. 22-31):

- zwiększa się zrozumienie dla służebnej roli oraz misji, jaką ma do wypełnienia administracja publiczna;

- na terenach stosujących bardziej zaawansowane rozwiązania dotyczące demokracji bezpośredniej zauważalnemu wzrostowi ulega efektywność działania i skuteczność administracji publicznej (ang. higher goverment efficiecy); 
- zwiększa się poziom bezpieczeństwa na danym terenie;

- obniżeniu ulegają koszty funkcjonowania sektora publicznego gospodarki;

- zasadniczemu zmniejszeniu ulega deficyt budżetowy organów władzy i instytucji odpowiedzialnych za dany teren;

- przestają istnieć w praktyce negatywne zjawiska, takie jak: korupcja, nepotyzm i akty samowoli ze strony władzy.

Z przytoczonych przykładów efektów stosowania demokracji bezpośredniej wynika, że jej wdrożenie, w wypadku powodzenia takiego przedsięwzięcia, może wydatnie wspomóc wysiłki regionów w obszarze podwyższenia swojej atrakcyjności inwestycyjnej oraz skłonienia społeczeństwa do osiedlenia się na danym terenie. Sprzyjać temu będą przede wszystkim: niższe podatki, znaczny wpływ na przyjmowane rozwiązania w sferze gospodarczej, zwiększony napływ wykwalifikowanej siły roboczej, mniejsza biurokracja, atmosfera przychylna potencjalnym inwestorom, brak korupcji i nadużyć ze strony władz lokalnych, interesujące możliwości własnego rozwoju poprzez lepsze warunki edukacji, wzrost wartości nabytych gruntów i nieruchomości w dłuższym okresie, stabilna sytuacja polityczna, zwiększenie się liczby inwestycji, wzajemne zaufanie istniejące $\mathrm{w}$ społeczeństwie.

W tym kontekście, niezbędnym staje się wyjaśnienie, co w istocie oznacza demokracja bezpośrednia, w jakim zakresie i na jakim polu może funkcjonować oraz jakimi dysponuje narzędziami w wypadku jej zastosowania. 


\section{Koncepcja zwiększenia bezpośredniego udziału obywateli w zarządzaniu regionem}

Zasadnicze znaczenie dla prezentowanej koncepcji zwiększenia bezpośredniego udziału społeczeństwa w zarządzaniu regionem (a dokładnie w zarządzaniu rozwojem regionalnym), mającym na celu wzrost atrakcyjności inwestycyjnej określonych terenów, ma zrozumienie istoty demokracji. Stanowi ona podstawowy element, na którym oparte zostaną zręby całej teorii.

\section{Teoretyczne podstawy koncepcji}

Z punktu widzenia niniejszej pracy, demokracja to sposób realizacji określonych obowiązków, zadań oraz zadeklarowanych wcześniej celów na obszarze państwa, regionu lub gminy przez wybrane demokratycznie władze. Sposób urzeczywistniania przez ekipę sprawującą władzę (na każdym szczeblu) przyjętych koncepcji i idei jest nierozłącznie związany ze stosowaną przez nią metodą zarządzania.

W tym sensie zarządzanie stanowi najlepszy sposób administrowania istniejącym na danym terenie majątkiem, w celu realizacji określonych celów i zadań, przy zachowaniu troski o dobro społeczne, respektowaniu istniejącego prawa oraz poszanowaniu przywilejów obywatelskich.

Partycypacja społeczna w sprawowaniu władzy dotyczy zagadnień nie tylko politycznych. Coraz częściej i w zwiększającym się zakresie dotyczy także zagadnień: ekonomiczno-gospodarczych, socjalno-bytowych, ochrony środowiska, organizacji szkolnictwa, pracy służby zdrowia czy zagospodarowania terenu. Ujęcie w tym kontekście daje demokracji bezpośredniej jeden z jej najważniejszych atrybutów - przywilej obywatelskiego współzarząazania na poziomie współpracy z każdą funkcjonującą władzą. Współdecydowanie o najważniejszych sprawach może się odbywać zarówno na poziomie państwowym, jak i lokalnym (odnoszącym się do wszystkich szczebli). Zakres zjawiska, jakim jest współzarządzanie uzależniony jest wprost od: istnienia służących temu instrumentów ustrojowych, 
świadomości społecznej obywateli, organizacji państwa, przychylności władz dla występowania tego zjawiska, uwarunkowań historycznych, poziomu rozwoju, „kultury demokracji”, stopy życiowej mieszkańców, koniunktury gospodarczej panującej aktualnie w kraju i na świecie.

\section{Pojęcie i cele demokracji}

Demokracja oznacza system (ustrój) polityczny, w którym władza sprawowana jest przez społeczeństwo. Słowo „demokracja” wywodzi się z języka greckiego i powstało jeszcze w starożytności. Jego konstrukcja składa się z dwóch członów: demos $=$ lud oraz creatos $=$ władza. Te dwa elementy składają się na jedno pojęcie oznaczające „władzę sprawowaną przez społeczeństwo” lub inaczej „ludowładztwo”. Warto wiedzieć, że słowo demos posiada w języku greckim dwa znaczenia. W pierwszym znaczeniu może oznaczać „lud” jako naród, czyli ogół obywateli. W drugim zaś - „lud” oznacza niższą warstwę społeczną, którą można by w przybliżeniu określić jako „masy ludowe” lub zwykły plebs i pospólstwo (Węcowski, 2013, s. 9).

Termin „demokracja” używany jest obecnie w czterech znaczeniach. Może być rozumiany jako (Nowa Encyklopedia Powszechna PWN, 1998, s. 55-56):

- władza ludu, narodu, społeczeństwa;

- forma ustroju politycznego państwa, w którym uznaje się wolę większości obywateli jako źródło władzy i przyznaje się im prawa i wolności polityczne gwarantujące sprawowanie tej władzy;

- synonim samych praw i wolności politycznych, których podstawą jest równość obywateli wobec prawa oraz równość ich szans i możliwości;

- ustrój społeczno-gospodarczy zapewniający powszechny i możliwie równy udział obywateli we własności i zarządzaniu narodowym majątkiem produkcyjnym, dostęp do dóbr kultury, oświaty oraz ochrony zdrowia.

Ostatnie wymienione znaczenie posiada wyraźnie odciśnięty profil „demokracji społecznej”, która jest charakterystyczną cechą ruchów, ugrupowań i ideologii lewicowych oraz odnosi się do gospodarki centralnie sterowanej. W ramach gospodarki rynkowej jej ramy nie obejmują szerszego udziału społeczeństwa we własności i zarządzaniu majątkiem produkcyjnym podmiotów gospodarczych działających na terenie danego kraju. Jednakże ciągle aktualny pozostaje postulat równego dostępu obywateli do: dóbr kultury, możliwości nauki i oświaty oraz świadczeń przysługujących w ramach powszechnej ochrony zdrowia.

Główne cele, jakie wymienia się współcześnie w odniesieniu do szeroko rozumianej demokracji, to (http://www.qualityoflaws.com/government.aspx): 
- pełnienie służby w interesie publicznym;

- stanie na straży przestrzegania praw człowieka;

- zabezpieczenie obywatelom godnych warunków egzystencji;

- umożliwienie realizacji przez członków społeczeństwa ich planów i spełnienie wyższych aspiracji;

- zagwarantowanie przestrzegania obowiązujących w kraju przepisów prawa;

- zapewnienie społeczeństwu odpowiedniej jakości życia;

- utrzymanie równowagi sił pomiędzy organami państwa i pozostałymi instytucjami działającym w służbie publicznej;

- zagwarantowanie przez władze nienaruszalności własności prywatnej;

- troska gremiów rządzących o bezpieczeństwo wewnętrzne i zewnętrzne państwa.

Powstanie demokracji wiąże się nierozłącznie z Atenami. To właśnie tam w 510 r. p.n.e. za sprawą zręcznego polityka - Klejstenesa z rodu Alkmeonidów - doszło do obalenia panującej tyranii i stworzenia nowego ustroju społecznopolitycznego. $\mathrm{Z}$ nowego systemu usunięta została raz na zawsze dotychczas rządząca warstwa arystokratów, a władzę przekazano w ręce ludu.

Na przełomie lat 508/507 p.n.e. Klejstenes przeprowadził rewolucyjną reformę społeczno-ustrojową, która wprowadzała (http://portalwiedzy.onet.pl):

1) zastąpienie przez podział terytorialny, dotychczas przyjętego podziału społeczeństwa na plemiona i rody;

2) brak majątkowego kryterium dopuszczającego do głosowania na zgromadzeniu ludowym (obywatelskim);

3) podział Attyki ${ }^{1}$ na trzy okręgi (Ateny, Wybrzeże i Śródlądzie), a każdy okręg na dziesięć trytties (trójek); trzy trytties (po jednej z każdego okręgu), tworzyły fylę, czyli podstawową jednostkę terytorialną, na którą składały demy (lokalne wspólnoty); od czasu reformy nazwę demu umieszczano zamiast imienia ojca, aby pełniła ona funkcję nazwiska; dotychczas po imieniu ojca można było rozpoznać bardziej lub mniej szlachetne pochodzenie obywatela;

4) utworzenie Rady Pięciuset - instytucji, która miała decydujący wpływ na działanie państwa pomiędzy sesjami zgromadzenia ludowego (obywatelskiego);

5) kontrolę dotychczasowej działalności urzędników państwowych;

6) ocenę etyki i moralności przyszłych kandydatów na stanowiska i urzędy państwowe ${ }^{2}$;

1 Kraina historyczna w Grecji, której stolicą były Ateny.

2 Sprawdzano m.in. czy osoby takie opiekują się swoimi rodzicami w podeszłym wieku, a z braku takowych, czy dbają o ich groby. Chciano przez to zdobyć pewność czy będą wypełniali nałożone na nich obowiązki wobec państwa, zob. Węcowski, 2013, s. 10. 
7) nadanie praw obywatelskich cudzoziemcom osiadłym na stałe w Attyce, zwanym metojkami;

8) ustanawiała urząd dziesięciu wodzów - tzw. strategów;

9) wprowadzała „sąd skorupkowy” (ostracyzm).

Cele reformy, jakimi było: radykalne zmniejszenie dominującej roli arystokracji, zatarcie różnic społecznych wynikających z pochodzenia lub posiadanego majątku, swobodne wymieszanie ludności, jak również skłonienie obywateli do większej aktywności politycznej zostały stosunkowo szybko osiągnięte. Ustanowione zaś jeszcze w starożytności najważniejsze zasady demokracji ateńskiej obowiązują również w czasach współczesnych. Należą do nich: osobista wolność i gwarantowana wobec prawa równość wszystkich obywateli, a także instytucje publiczne wypełniające wolę narodu.

Obecnie wygląda to jednak znacznie mniej korzystnie, jeśli chodzi o zasadę obywatelskiej kontroli działalności urzędników państwowych. W praktyce brakuje bowiem w tej materii tak sprawnego instrumentu, jakim były ,sądy skorupkowe" znane także pod nazwą ostracyzmu. W języku greckim słowo: ostrakon oznacza glinianą skorupę, za pomocą której każdy pełnoprawny Ateńczyk (warunkiem było ukończenie 20 roku życia) mógł wziąć udział w głosowaniu w czasie eklezji - najwyższego organu władzy. Ostracyzm nakazywał obywatelom Aten coroczną ocenę dokonań oraz postawy obywatelskiej polityków. W razie bardziej lub mniej uzasadnionych podejrzeń o odejście od ideałów demokracji, przeprowadzane było głosowanie w tej sprawie. Miało ono charakter tajny i odbywało się poprzez zapisanie na skorupkach naczyń ceramicznych nazwisk osób, które należało wydalić z Aten za niewypełnianie powierzonych im obowiązków, sprzeciwiających się zasadom demokracji lub przejawiających dążenia do znienawidzonej przez lud tyranii. Obywatel Aten, wymieniony przez większość głosujących (stanowiło je co najmniej 6000 głosów), musiał udać się na długotrwałe wygnanie (początkowo na 10 lat, a w późniejszym okresie na 5 lat). Nie tracił on jednak ani życia, ani też praw obywatelskich i majątkowych. Przez surową decyzję sądu skorupkowego nie cierpiała także w żaden sposób rodzina skazanego. Prawdziwej zagładzie ulegała jednak jego pozycja polityczna. Wygnaniec $w$ razie potrzeby mógł być wcześniej odwołany z wygnania i zaangażowany ponownie $w$ realizację ważnych spraw państwowych Za pomocą ostracyzmu pozbywano się też często ludzi kłopotliwych oraz niepasujących do kierunków wyznaczonej przez większość obywateli polityki wewnętrznej, a także zagranicznej (portalwiedzy.onet.pl). W obecnych systemach demokratycznych nie ma niestety sprawnego narzędzia, służącego do oceny polityków i funkcjonariuszy państwowych. Można jednak śmiało przypuszczać, że gdyby istniało, cieszyłoby się w społeczeństwie dużą popularnością i było niewątpliwie dyscyplinujące dla ludzi związanych ze sprawowaniem władzy. 


\subsection{Cykliczność zmian demokratycznych}

Żyjący w IV wieku p.n.e. Arystoteles, uważany dzisiaj za jednego z trzech największych filozofów greckich (obok Sokratesa i Platona), część swoich rozważań poświęcił problemom sprawnej organizacji i kierowania państwem. Zebrane myśli zawarł w rozprawie pt.: „Polityka” - fundamentalnym dziele przedstawiającym, obok poglądów starożytnego myśliciela dotyczących spraw funkcjonowania organizmu państwowego, także zagadnienia: rodziny, stosunków pomiędzy panem a niewolnikiem, roli pieniądza, sztuki zarobkowania, definicji obywatela czy też zasad wychowania dzieci.

Dość istotny i obszerny zarazem pod względem treści wątek „Polityki” stanowią dociekania Arystotelesa dotyczące najlepszego ustroju państwa. Autor dzieła wyróżnia trzy „ustroje właściwe” i jako przeciwwagę do nich, taką samą liczbę „ustrojów zwyrodniałych” (Arystoteles, 2012, s. 83-156). Do pierwszej grupy zalicza: monarchię, arystokrację oraz politeję. Do ustrojów „zdegenerowanych" (gorszych), zalicza: tyranię, oligarchię i demokrację.

\section{Ustroje właściwe}

- Monarchia - to dożywotnia władza jednego człowieka, który za zgodą wyrażoną przez rządzonych, kieruje wspólnymi sprawami przy poszanowaniu istniejącego ładu i prawa oraz w celu zapewnienia dobra społecznego.

- Arystokracja - to ustrój polityczny oparty na wyłączności w kierowaniu państwem relatywnie niewielkiej i dość homogenicznej grupy rządzącej. Arystokracja, stanowiąc odrębną warstwę społeczną, tworzyła grupę „najlepszych” obywateli. Była niezwykle hermetyczna - przynależność do niej, wynikająca ze szlachetnego urodzenia, przekazywana była w zasadzie tylko dziedzicznie. Urzędy i najważniejsze stanowiska przyznawano członkom tej elity w drodze wewnętrznego wyboru. Sprawujący władzę nie byli odpowiedzialni za swoje poczynania przed resztą narodu.

- Politeja to, według Arystotelesa, najdoskonalszy ze wszystkich systemów dotyczących organizacji i zarządzania państwem. Łączy w sobie przede wszystkim cechy demokracji oraz oligarchii, chociaż pozytywne wzorce może czerpać także z najlepszych rozwiązań w obrębie: monarchii, tyranii oraz arystokracji. Stąd pochodzi nazwa ustroju. Dominuje w nim liczna klasa średnia. Siłą tej warstwy ludności jest ostrożność w działaniu, niechęć do radykalnych rozwiązań, spokój, rozwaga oraz zrównoważenie w podejściu do spraw publicznych. Klasa średnia stanowi trwałą barierę dla wygórowanych, a także często nieuzasadnionych ambicji ubogich obywateli. Potrafi jednocześnie w skuteczny sposób ograniczyć wybujałe aspiracje do przejęcia władzy, najzamożniejszych członków społeczeństwa. 
Swoimi rządami daje gwarancje: ogólnej sprawiedliwości, równowagi społecznej oraz stabilności, ciągłości i trwałości państwa.

\section{Ustroje zwyrodniałe}

- Tyrania to rządy jednej osoby (tyrana) dysponującej nieograniczoną władzą, zdobytą niezgodnie z prawem. Człowiek taki działa głównie w celu zapewnienia osobistych korzyści, nie dbając zbytnio o interes społeczny czy ogólny pożytek. Tyran włada wszystkimi - gorszymi, równymi, a także lepszymi od siebie. Według Arystotelesa był to najgorszy ustrój.

- Oligarchia stanowi formę rządów niewielkiego kręgu ludzi, legitymujących się wspólnym pochodzeniem lub przekonaniami. Mogą do niej należeć także osoby posiadające przykładowo wysoki status materialny. Uboższa większość społeczeństwa nie jest w tym ustroju dopuszczana do udziału w bezpośrednim rządzeniu krajem. Samozwańcza elita przywłaszcza sobie suwerenną pozycję i dominującą rolę w państwie, stwarzając pozory troski o dobro ogółu. Jest zamknięta dla innych grup społecznych. Konsekwentnie dąży do zawłaszczenia lub podporządkowania sobie najważniejszych stanowisk i urzędów w kraju. Nawet jeśli w obrębie oligarchii ma miejsce zjawisko zakulisowej walki o władzę i wpływy, to na zewnątrz występuje ona w postaci skonsolidowanego frontu, starając się stworzyć wrażenie monolitu politycznego. Ustrój oligarchiczny przypomina rządy dyktatorskie w kontekście dbania o własne interesy.

- Demokracja była według Arystotelesa ustrojem zwyrodniałym, ponieważ umożliwiała nieoświeconym członkom społeczeństwa pełnienie rządów w państwie. W skrajnych przypadkach władzę mógł przywłaszczyć sobie tłum, a nawet jego najgorsza część, czyli motłoch. Taki stan rzeczy filozof nazywał: ochlokracja. Decyzje, jakie w majestacie prawa były wtedy podejmowane, miały swoją genezę bardziej w emocjach, aniżeli w obiektywnej wiedzy. Za wielce szkodliwe grecki myśliciel uważał wypłacanie pensji za sprawowanie władzy. Twierdził, że może być to dla biedoty głównym motywem udziału w życiu publicznym, mającym na celu polepszenie własnego bytu i statusu majątkowego. Arystoteles w odniesieniu do każdego ustroju zdecydowanie opowiadał się za rządami sprawowanymi przez osoby najlepiej wykształcone i jednocześnie majętne. Tylko tacy obywatele, według niego, byli wolni od wszelakich pokus egzystencjalnych i mieli nie dopuszczać do chaosu w państwie. Arystoteles zwracał uwagę, że w skrajnych odmianach demokracji jej najwyższy organ - czyli zgromadzenie ludowe - stawiało się często ponad prawem. Jego uczestnicy zaś łatwo ulegali naciskowi stronnictw, do których należeli oraz obcym wpływom. Naczelna zasada demokracji - kryterium równości, teoretycznie miała zapewnić wszystkim obywatelom państwa (biednym i bogatym) jednakowy dostęp 
do władzy. Dawało to teoretycznie wielką liczbę osób mogących ubiegać się o władzę. W obliczu ograniczonej liczby stanowisk i urzędów, aby wszyscy mogli wziąć udział w rządzeniu, konieczne było zastosowanie zasady krótkiej kadencyjności i wymiany osób na stanowiskach. W efekcie mogło to wpływać niekorzystnie na zamierzenia dotyczące bardziej odległej przyszłości oraz przedsięwzięcia planowane długoterminowo.

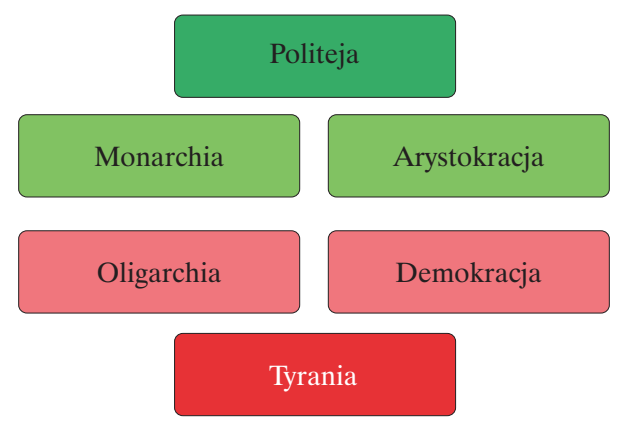

Rysunek 25. Hierarchia ustrojów wg Arystotelesa, ze względu na kryterium przydatności dla funkcjonowania i organizacji państwa

Źródło: opracowanie własne.

Według Arystotelesa najlepszym ustrojem państwowym była, wymyślona przez niego, politeja. Dwa pozostałe ustroje właściwe tworzą monarchia i arystokracja. Systemami zwyrodniałymi są oligarchia i demokracja, a najgorszy ze wszystkich ustrojów to tyrania, która jest najbardziej zdegenerowana i działa w interesie jednostki. Nie uwzględnia ona najczęściej ani prawa obywateli do szczęśsia, ani nie ma na celu dobra ogółu społeczeństwa.

Wyjątkowo istotnym elementem jest przekonanie sławnego filozofa o nieuchronności zmian ustrojowych. Arystoteles uważa za naturalne wyczerpywanie się możliwości funkcjonowania społeczeństwa opartego na jednym systemie. Za uzasadniony uważa proces zastępowania (obalania, wypierania) jednego systemu przez inny (Arystoteles, 2012, s. 110-146). Na zjawisko takie wpływ ma cały wachlarz czynników wewnętrznych i zewnętrznych, takich jak:: sprzeczność interesów poszczególnych warstw społeczeństwa, nadużywanie stanowisk publicznych przez urzędników, rozliczne błędy w sprawowaniu rządów, doprowadzenie do zubożenia narodu, powszechne naginanie i lekceważenie prawa, naruszanie zasad ustrojowych popełniane przez rządzących, wyrządzone krzywdy, korupcja i chciwość elit, ograniczanie wolności i przywilejów społecznych, złe intencje oraz negatywny wpływ silnych państw sąsiedzkich, wątpliwości obywateli co do rozwiązań wprowadzanych przez władzę, zła gospodarka, bezkompromisowa 
walka o przywództwo polityczne w łonie grupy panującej, brak perspektyw życiowych, rosnące niezadowolenie obywateli z sytuacji w kraju.

Lektura przyczyn, które doprowadzają do zmiany ustroju, powoduje mieszane uczucia. Patrząc na obecną sytuację w naszym kraju, a także na świecie, można odnieść wrażenie, że słabości ludzkie od czasu starożytnych Greków nie uległy żadnej zmianie. Nadużycia i wypaczenia w łonie władzy, mające miejsce kilkadziesiąt wieków temu są podobne do tych, z którymi mamy do czynienia obecnie. Oto kilka przykładów słuszności poglądów Arystotelesa na sprawę zmian ustrojowych.

Stosunkowo krótka historia Libii jako niepodległo państwa rozpoczyna się pod koniec 1951 roku. W grudniu tego roku, decyzją Organizacji Narodów Zjednoczonych, kraj ten uzyskuje niepodległość. Jeszcze w tym samym miesiącu królem zostaje ogłoszony Idris I (a zaprowadzony wówczas ustrój to monarchia). We wrześniu 1969 r. grupa młodych oficerów pod przewodnictwem ówczesnego kapitana - Muammara al-Kadafiego - dokonuje przewrotu, obalając monarchę i przejmuje władzę w kraju (oligarchia). W ciagu kilku lat al-Kadafi eliminuje dotychczasowych sprzymierzeńców, zastępując ich ludźmi ze swojej bliskiej rodziny oraz członkami plemienia. Sprawuje niepodzielną i despotyczna władzę dyktatora (tyrania). W roku 2011 na fali niezadowolenia społecznego dochodzi do zamieszek w kraju. W ich następstwie wybucha powstanie, które doprowadza do obalenia dyktatora. W lipcu 2012 roku w Libii mają miejsce wybory parlamentarne, w wyniku których wprowadzona zostaje demokratyczna władza (demokracja).

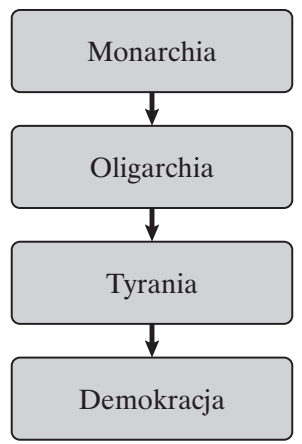

Rysunek 26. Cykl zmian ustrojowych na przykładzie postkolonialnej Libii Źródło: opracowanie własne.

Od VIII wieku n.e. aż do ostatniej dekady XVIII wieku Francja pozostawała monarchią (ustrój monarchia absolutna). W roku 1792, w wyniku krwawej rewolucji francuskiej, utworzona została I Republika Francuska (demokracja). Chociaż można polemizować czy ówczesne rządy spełniały demokratyczne 


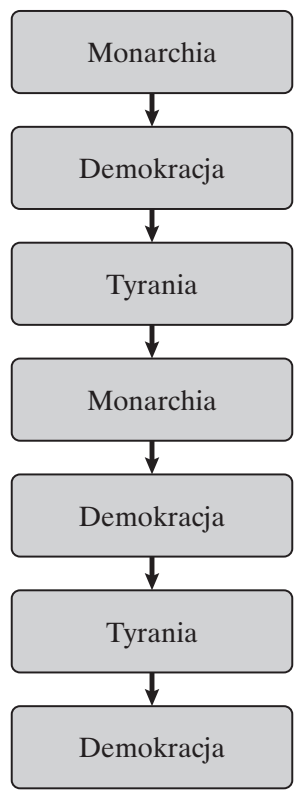

Rysunek 27. Cykl zmian ustrojowych na przykładzie Francji

Źródło: opracowanie własne.

kryteria, to nie ulega wątpliwości, że właśnie wtedy powstały zręby konstrukcji i organizacji nowoczesnego państwa dla współczesnych obywateli Francji. W roku 1799 Napoleon Bonaparte w wyniku wojskowego zamachu stanu przejął de facto władzę w państwie, przyjmując tytuł I Konsula. W 1804 roku koronował się na cesarza Francuzów, wprowadzając autorytarny sposób rządzenia (tyrania). W roku 1815 po ostatecznym upadku Napoleona, we Francji nastęąpiła restauracja monarchii (monarchia konstytucyjna). Po piętnastu latach, w 1830 roku, w odpowiedzi na próbę powrotu do absolutyzmu, przeprowadzoną przez Karola X z dynastii Burbonów, wybuchła tzw. rewolucja lipcowa. Następnie jako następstwo burzliwych wydarzeń powstała konstytucyjna Monarchia Lipcowa, usunięta z kolei w 1848 roku przez powołanie do życia II Republiki Francuskiej (demokracja). W roku 1852 Ludwik Napoleon (Napoleon III) proklamował się dziedzicznym Cesarzem Francuzów, przywracając autorytarne rządy oparte na wojsku, policji i administracji (tyrania). W wyniku przegranej wojny francusko-pruskiej w 1870 r. doszło do detronizacji władcy, likwidacji cesarstwa i powołania III Republiki (ponownie demokracja). Ustrój został utrzymany w formie IV Republiki (od II wojny światowej), a następnie V Republiki Francuskiej (od konfliktu algierskiego) do dnia dzisiejszego. 
Rysunek 27 ma charakter syntetycznego modelu. Takie ujęcie pociąga za sobą pewne zamierzone uproszczenia poczynione w celu uzyskania większej czytelności obrazu, a także uniknięcia zbytniej szczegółowości w przedstawianiu cyklu zmian ustrojowych na tle historii Francji. Przykładowo, nie została wzięta pod uwagę krótkotrwała zmiana ustroju $\mathrm{z}$ monarchii na tyranię, związana z przejęciem władzy w czasie „100 dni Napoleona”, nieuwzględniono także skomplikowanych zmian układów politycznych, jakie nastąpiły na ziemiach francuskich w okresie okupacji niemieckiej w czasie II wojny światowej.

$\mathrm{Z}$ przytoczonych do tej pory dwóch przykładów można wyciągnąć mylny wniosek, że niezależnie od intensywności i przebiegu zmian ustrojowych, ich początek zawsze stanowi monarchia, natomiast ostatni etap prowadzi do powstania systemu demokratycznego. W rzeczywistości tak nie jest. Chociaż cykl zmian ustrojowych jest procesem stałym, to przebiega często w zaskakujących kierunkach. Jego ostatecznego efektu nigdy nie można przwidzieć, ponieważ zbyt wiele niewiadomych i trudnych czynników wewnętrznych i zewnętrznych kształtuje jego ostateczną postać.

Kuba w okresie po II wojnie światowej jest przykładem dość szczególnego przebiegu zmian społeczno-ustrojowych w granicach tego organizmu państwowego położonego na Karaibach.

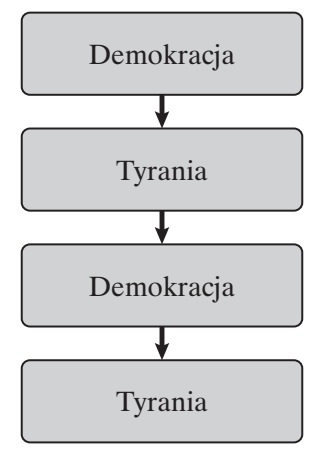

Rysunek 28. Cykl zmian ustrojowych na przykładzie powojennej Kuby Źródło: opracowanie własne.

Pierwszy okres (demokracja) to na Kubie rządy Carlosa Prio Socaraása. W latach 1945-1947 pełnił on funkcję premiera kraju, a w latach 1948-1952 sprawował urząd prezydenta. W marcu 1952 roku, zaledwie na trzy miesiące przed nowymi wyborami, został odsunięty od władzy w wyniku bezkrwawego zamachu stanu przeprowadzonego przez Fulgencio Batistę (poprzedniego prezydenta). W krótkim czasie, przy pomocy tajnej policji i brutalnych interwencji wojska, Batista stłumił wszelką opozycję, stając się niepodzielnym dyktatorem 
państwa (tyrania). 1 stycznia 1959 roku musiał jednak uciekać z Kuby w wyniku zwycięskiej rewolucji przeprowadzonej przez Fidela Castro. Po dokonanym przewrocie Castro na krótko odsunął się od władzy (demokracja). Jednakże poparcie i prawdziwe uwielbienie, szczególnie wśród najuboższych warstw społecznych, doprowadziło go do stanowiska premiera. W wyniku przeprowadzonych wyborów legendarny El Comendante został prezydentem. Walcząc z obcą interwencją (lądowanie 1500 kontrrewolucjonistów kierowanych przez CIA na plażach Zatoki Świń w 1961 roku - przyp. aut.), objął on pełnię władzy, całkowicie zmilitaryzował kraj i stłumił opozycję. Stał się dyktatorem (tyrania). Jako El Máximo Lider sprawuje autorytarne rządy przez 49 lat. Według opozycyjnych szacunków, na Kubie w niewyjaśnionych okolicznościach zginęło blisko 10000 osób. Istnieją też doniesienia o dziesiątkach tysięcy osób przetrzymywanych w więzieniach i poddawanych torturom (Skierka, 2008, s. 73-146). W roku 2008 z powodu choroby i podeszłego wieku Fidel Castro przekazał pełnię władzy w kraju swojemu młodszemu bratu, Raúlowi Castro.

Jeszcze innym interesującym przykładem specyficznego cyklu zmian ustrojowych jest historia niepodległego Singapuru.

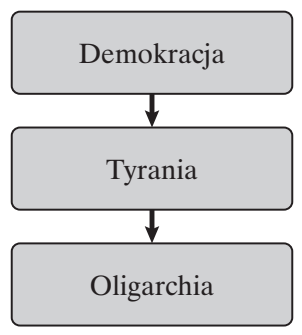

Rysunek 29. Cykl zmian ustrojowych na przykładzie Singapuru, od momentu uzyskania pełnej niepodległości w $1965 \mathrm{r}$.

Źródło: opracowanie własne.

W roku 1965 Singapur wystąpił z Federacji Malezyjskiej i uzyskał niepodległość. Przez okres trzech lat w obrębie tego miasta-państwa działało równolegle do siebie kilkanaście partii politycznych o różnorodnych programach (demokracja). W roku 1968 w wyniku wyborów do władzy doszła Partia Akcji Ludowej pod przywództwem Lee Kuan Yewa. Przez dwanaście kolejnych lat utrzymywała ona wszystkie miejsca w parlamencie. Jej charyzmatyczny przewodniczący, pełniąc jednocześnie funkcje premiera i członka Rady Bezpieczeństwa Singapuru, za pomocą drakońskich kar, jak: chłosta, długoletnie więzienie i wyroki śmierci, zlikwidował korupcję oraz przejawy jakiejkolwiek przestępczości w kraju. Wystąpił także zdecydowanie przeciw wpływom i działalności 
ugrupowań komunistycznych. Jako ciekawostkę nawiązującą do toczącej się w naszym kraju dyskusji o związkach partnerskich, można dodać, że w Singapurze homoseksualizm jest sprzeczny z prawem. Lee Kuan Yewa aż do roku 1990 był nieprzerwanie premierem państwa, który realizował konsekwentnie swoją wizję dobrobytu i rozwoju kraju za pomocą wszelkich dostępnych środków. Za granicą sposób sprawowania przezeń władzy określany był jako autorytaryzm albo reżim (tyrania). Po ustąpieniu ze sprawowanej funkcji premiera do rządzenia krajem dopuścił członków swojej partii. W 1999 roku prezydentem został Sellapan Rama Nathan, a tekę pierwszego ministra objął Goh Chok Tong. Lee Kuan Yewa, pomimo podeszłego wieku, nadal jednak pozostał w rządzie, pełniąc uprzywilejowaną rolę senior ministra. Okres rozdzielenia władzy pośród członków własnej partii można w przybliżeniu określić jako oligarchię. Od roku 2004 aż do dzisiaj funkcję premiera Singapuru sprawuje Lee Hsien Loong, najstarszy syn Lee Kuan Yewa, który specjalnie dla swojego ojca, stworzył w rządzie wpływowe stanowisko „ministra mentora”.

Przykład Singapuru pokazuje, że autorytarne rządy w pewnych okolicznościach mogą przynosić spektakularne sukcesy, szczególnie jeśli chodzi o gospodarkę. Na początku drugiej dekady XXI wieku, położony na samym końcu Półwyspu Malajskiego, Singapur był najszybciej rozwijającą się gospodarką na świecie. Podobnie sytuacja przedstawia się w Chinach, gdzie despotyczne rządy Partii Komunistycznej sprzyjają dynamicznemu wzrostowi ekonomicznemu kraju, przy znacznym ograniczeniu praw obywatelskich. $\mathrm{Na}$ ten pozorny paradoks zwrócił już uwagę Arystoteles w swojej rozprawie pt.: „Polityka”.

Najważniejszym wnioskiem z przeprowadzonych w tym punkcie rozważań jest stwierdzenie, że w obrębie każdego organizmu państwowego dochodzi do ewolucji ustrojowej. Jest to proces nieuchronny i stały w swej naturze. Może następować bardzo szybko w wyniku spontanicznych czynów rewolucyjnych albo rozwijać się jako rezultat zaplanowanych, długotrwałych przekształceń. Co więcej, nawet ustrój demokratyczny nie powinien być traktowany jako kres każdego cyklu zmian.

Istnieją wystarczające dowody, że nawet znaczne ograniczenia w demokracji mogą w pewnych okolicznościach prowadzić do rozwoju gospodarczego oraz wzrostu zamożności społecznej. Koronnymi przykładami są tutaj: Singapur, Chiny, Zjednoczone Emiraty Arabskie, Jordania czy też Arabia Saudyjska. W takich przypadkach jako końcowy wynik przekształceń systemowych, w miejsce demokracji, powstaje oligarchia albo dyktatura, określana przez Arystotelesa mianem tyrania. Nie należy jednak pewnych słabości, dotyczących samej nomenklatury zjawisk ustrojowych, traktować jako słabości całej starożytnej koncepcji. Po prostu, przez kilkadziesiąt stuleci niezwykłemu rozkwitowi uległa 
paleta systemów ustrojowo-politycznych kształtujących oblicze organizacyjnospołeczne organizmów państwowych.

\subsection{Potencjalna zdolność obecnego systemu demokratycznego do przekształceń}

Od momentu wystąpienia w 1997 roku pierwszych symptomów światowego kryzysu finansowego przybierają na sile ruchy społeczne, które mają na celu zwrócenie uwagi na wady oraz jaskrawo widoczne niedoskonałości obecnego systemu demokratycznego. Na fali wielomilionowych protestów członków: Ruchu Oburzonych, antyglobalistów, przeciwników ACTA i osób skrzywdzonych przez instytucje finansowe, do ogólnej świadomości społecznej zaczyna docierać, że dotychczasowe rozwiązania polityczne wymagają radykalnych zmian. Odnosi się to przede wszystkim do najbardziej rozpowszechnionego we współczesnym świecie ustroju demokratycznego. Można sformułować twierdzenie, że wszechobecna demokracja pośrednia zaczyna ustępować miejsca bardziej adekwatnej dla obecnych czasów demokracji bezpośredniej.

\subsubsection{System demokracji pośredniej}

Demokracja pośrednia jest najbardziej rozpowszechnionym i popularnym ustrojem, stosowanym w państwach rozwiniętych. Można nawet powiedzieć, że jest dominującym systemem społeczno-politycznym współczesnego świata. Inne jej określenia to: demokracja parlamentarna lub rzadziej stosowany termin, demokracja przedstawicielska. Podstawę, na której opiera się cały system, stanowi społeczeństwo obywatelskie. Jego członkowie posiadający czynne prawo wyborcze wybierają swoich reprezentantów do parlamentu, organów samorządu terytorialnego oraz innych ciał przedstawicielskich. Proces wyznaczania przedstawicieli przebiega za pomoca głosowania. Po odbytych wyborach, obywatele uczestniczą w sprawowaniu władzy już tylko w symbolicznym zakresie. Ich rola zostaje zredukowana do ograniczonej kontroli nad działalnością aparatu państwowego oraz samorządowego. Nie biorą już ani stałego, ani faktycznego udziału w podejmowaniu ważnych decyzji dotyczących polityki wewnętrznej i zewnętrznej kraju. Wszelkie rozstrzygnięcia realizowane są przez wyłonionych wcześniej mandatariuszy. Przedstawiciele, jeszcze jako kandydaci do stanowisk i urzędów, należą do różnych partii politycznych. Ugrupowania te agitują wyborców chwytliwymi hasłami oraz obietnicami atrakcyjnych programów, których urzeczywistnienie deklarują. Osoby niezrzeszone rzadko startują, a jeszcze rzadziej odnoszą sukces w wyborach. Przynależność do partii jest dobrowolna. Jednak brak członkostwa radykalnie zmniejsza szanse na wybór danego 
kandydata. Wyborom kandydatów na stanowiska i urzędy przyświeca idea, że powinni oni mieć wysokie morale i zasady etyczne, poszanowanie obowiązującego prawa, ponadprzeciętne wykształcenie lub/i zdolności oraz wykazywać troskę o przyszłość kraju i dobro społeczeństwa.

Sama idea demokracji parlamentarnej wywodzi się z teorii reprezentacji, której podstawowymi zasadami są (http://www.portalwiedzy.onet.pl):

- wolne wybory powszechne,

- kadencyjność ciał przedstawicielskich,

- odpowiedzialność reprezentantów w trakcie wykonywania powierzonego im mandatu przed wyborcami.

Najwyższym, a zarazem najważniejszym organem państwa w demokracji pośredniej jest parlament. Przysługuje mu wyłączność ustawodawcza. Według przyjętych norm parlament sprawuje dodatkowo kontrolę nad organami władzy wykonawczej, czyli rządem oraz urzędującą głową państwa. Demokracja parlamentarna opiera się na zasadzie podziału władzy. Głowa państwa, którą jest najczęściej prezydent (rzadziej król) powołuje premiera. Na wniosek tego ostatniego wyznaczeni zostają również pozostali członkowie rządu. Rząd musi uzyskać poparcie parlamentu, przed którym politycy odpowiadają za swoją działalność (http://www.portalwiedzy.onet.pl). Za złe decyzje i niefortunne kroki na arenie krajowej i międzynarodowej mogą zostać pociągnięci do odpowiedzialności zarówno głowa państwa, jak i członkowie rządu.

\subsubsection{Ustrój polityczny w Polsce}

Podstawy ustroju politycznego oraz systemu społeczno-gospodarczego, a dalszej kolejności prawa i obowiązki obywateli w Polsce określają przepisy zawarte w ustawie zasadniczej, czyli w Konstytucji. Stanowi ona akt nadrzędny w odniesieniu do całości porządku prawnego w naszym kraju (Dz. U. z 1997 r. Nr 78, poz. 483). Reguluje także sposób i organizację powoływania najważniejszych organów państwa. Według zawartych w niej zapisów Rzeczpospolita Polska jest republiką o charakterze parlamentarnym - krajem niepodległym, niezależnym i urzeczywistniającym zasady sprawiedliwości społecznej. W jego ramach realizowane są zasady suwerenności narodu oraz poszanowania praw i godności obywateli. Ustrój kraju oparty jest na demokracji i społeczeństwie obywatelskim. To ostanie oznacza, że obywatele mogą się samoorganizować i realizować ważne cele oraz przedsięwzięcia bez zachęt i inspiracji ze strony organów władzy. W układzie politycznym funkcjonuje pluralizm (czyli większa ilość partii politycznych) oraz zasada legalizmu (czyli poszanowania prawa). W stosunkach gospodarczo-ekonomicznych dominuje system gospodarki rynkowej. Zasadą systemu politycznego, jest trójpodział władzy na: 
- ustawodawczą,

- wykonawczą,

- sądowniczą.

Polska określona jest jako państwo charakteryzujące się wewnętrzną jednolitością i spójnością. Jednostki administracyjne, funkcjonujące na jej terytorium, są zorganizowane na jednakowych zasadach. Samorządowe organy władzy regionalnej są niezależne od rządu. Władze centralne podejmują tylko najważniejsze decyzje w skali całego kraju. Dobrze rozwinięty samorząd terytorialny, o wyraźnie określonych kompetencjach, zorganizowany jest na trzech szczeblach:

- gminnym (podstawowym),

- powiatowym (środkowym, średnim),

- wojewódzkim (regionalnym).

Organy samorządu terytorialnego poszczególnych poziomów nie są wzajemnie podporządkowane hierarchicznie. W podejmowaniu decyzji oraz realizowanej działalności pozostają niezależne od szczebli wyższych, chociaż mogą z nimi w uzgodnionych lub istotnych sprawach podejmować współpracę.

Władzę ustawodawczą w Polsce sprawują Sejm i Senat. Sejm liczy 460 posłów wybieranych na 4 lata. Jego kadencja w wyjątkowych i uzasadnionych przypadkach może zostać skrócona przez prezydenta kraju. Senat, druga (wyższa) izba polskiego parlamentu, składa się ze 100 senatorów wybieranych, podobnie jak posłowie, także na 4 lata. Jego kadencja rozpoczyna się i kończy jednocześnie z kadencją Sejmu. Inicjatywa ustawodawcza przysługuje posłom w Sejmie, Senatowi, osobie Prezydenta, Radzie Ministrów oraz „zwykłym obywatelom” kraju poprzez inicjatywę ustawodawczą. Ograniczona jest jednak w przypadku ustaw związanych z budżetem, które należą do wyłącznej kompetencji Rady Ministrów. Dotyczy to także zmian w Konstytucji. Władza wykonawcza należy do Rady Ministrów oraz Prezydenta. Rada Ministrów, zwana potocznie rządem, składa się z Prezesa Rady Ministrów (premiera) oraz podległych mu ministrów. Prezydent, wybierany na 5-letnią kadencję, jest natomiast najwyższym przedstawicielem władz polskich i gwarantem ciąłości władzy państwowej. Stanowisko swoje może piastować tylko przez dwie kadencje. Szczególną i rzadką stosunkowo formą obrad parlamentu jest wspólne posiedzenie posłów i senatorów w postaci Zgromadzenia Narodowego pod przewodnictwem Marszałka Sejmu. Parlament zbiera się jako gremium (Sejm łącznie z Senatem) w takich sprawach, jak: przyjęcie przysięgi nowego prezydenta, stwierdzenie niezdolność głowy państwa do sprawowania urzędu ze względu na stan zdrowia albo, aby postawić prezydenta przed obliczem Trybunałem Stanu (http:// www.politykanarodowa.pl). Ten ostatni przypadek nie miał jednak dotychczas w naszym kraju miejsca. 
W polskiej praktyce ustrojowej demokracja parlamentarna (pośrednia) może być sporadycznie wspierana wybraną formą demokracji bezpośredniej, jaką jest referendum. W sprawach ogólnokrajowych, dotyczących wszystkich obywateli, stosowane jest krajowe referendum powszechne. Zgodnie z literą prawa zawarta w ustawie zasadniczej (Dz. U. z 1997 r. Nr 78, poz. 483), referendum może zostać zarządzone przez:

- Sejm RP bezwzględną większością głosów w obecności przynajmniej połowy ustawowej liczby posłów;

- Prezydenta Rzeczypospolitej Polskiej za zgodą Senatu wyrażoną bezwzględną większością głosów w obecności co najmniej połowy ustawowej liczby senatorów.

W ważnych sprawach władze samorządowe mogą organizować referenda lokalne. Przeprowadzone w ich ramach głosowania mogą dotyczyć takich spraw, jak: odwołanie burmistrza, wójta, prezydenta miasta, rady gminy, rady powiatu czy też sejmiku województwa (dochodzi do tego jeszcze samoopodakowanie się obywateli). Referenda lokalne organizowane są w Polsce na poziomie: gmin, powiatów oraz województw.

Podstawą prawną dla możliwości przeprowadzania referendum jest Konstytucja Rzeczypospolitej Polskiej oraz dwie ustawy:

- ustawa o referendum lokalnym (Dz. U. z 2000 r. Nr 88, poz. 985),

- ustawa o referendum ogólnokrajowym (Dz. U. z 2003 r. Nr 57, poz. 507).

W okresie III Rzeczypospolitej miały miejsce tylko cztery referenda ogólnokrajowe (http://www.stop67.pl):

1) na temat powszechnego uwłaszczenia (18 lutego 1996 r.),

2) o niektórych kierunkach wykorzystania majątku państwowego (18 lutego 1996 r.),

3) na temat przyjęcia Konstytucji RP (25 maja 1997 r.),

4) w sprawie akcesji Polski do Unii Europejskiej, tzw. referendum europejskie (7-8 czerwca 2003 r.).

Referenda, dotyczące: powszechnego uwłaszczenia i niektórych kierunków wykorzystania majątku państwowego odbyły się wspólnie tego samego dnia. Interesującym szczegółem jest wzrastające uczestnictwo obywateli w tej formie demokracji.

Referendum daje wynik wiążący, jeśli uczestniczyła w nim ponad połowa ze wszystkich osób uprawnionych do głosowania (http://www.prawo24.pl). W referendum na temat powszechnego uwłaszczenia wzięło udział $32,40 \%$ osób uprawnionych. W referendum o niektórych kierunkach wykorzystania 


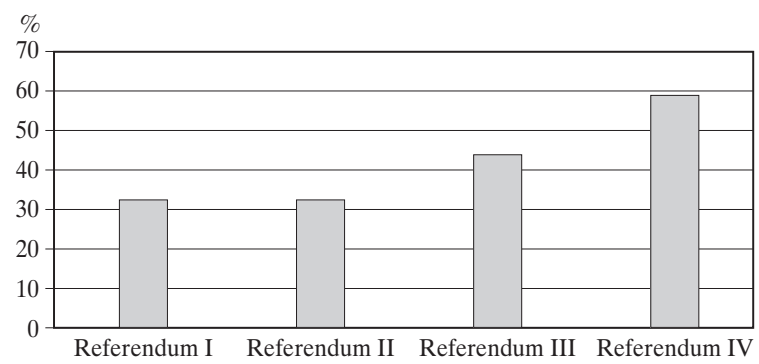

Rysunek 30. Frekwencja obywateli w referendach ogólnokrajowych w okresie III RP Źródło: opracowanie własne.

majątku państwowego wzięło udział 32,44\% obywateli. Frekwencja w obu głosowaniach była niemal identyczna $\mathrm{z}$ powodu przeprowadzenia ich w jednym terminie. W referendum na temat przyjęcia Konstytucji Rzeczypospolitej Polskiej uczestniczyło 42,86\% osób uprawnionych do głosowania. W ostatnim czwartym referendum, w sprawie wyrażania zgody na ratyfikację Traktatu dotyczącego przystąpienia Rzeczypospolitej Polskiej do Unii Europejskiej frekwencja wyniosła aż 58,85\%. Przytoczone liczby, dotyczące udziału obywateli w tej formie demokracji, świadczą o rosnącym zainteresowaniu i zaangażowaniu społecznym w sprawy kraju. Wyrażają także chęć bezpośredniego uczestnictwa szerokich mas ludności w sprawach o zasadniczym dla nich znaczeniu. Ukazują także potrzebę współuczestnictwa w rządzeniu krajem oraz rosnącej świadomości i „wyrobienia” politycznego ludności. Należy przypuszczać, że znaczna część obywateli uczestniczących w referendach ogólnokrajowych bierze także aktywny udział w referendach o charakterze lokalnym, organizowanych na wszystkich szczeblach.

\subsubsection{Demokracja bezpośrednia}

Bezpośredniego uczestnictwa obywateli w rządzeniu krajem (lub też w odniesieniu do niższego poziomu lokalnego) nie można jeszcze nazwać „w pełni odrębnym systemem demokracji”. Dzieje się tak dlatego, ponieważ w istniejącej rzeczywistości narzędzia demokracji bezpośredniej są, podobnie jak ma to miejsce w Polsce, jedynie elementami uzupełniającymi funkcjonowanie demokracji parlamentarnej (pośredniej). W takim przypadku można co najwyżej stwierdzić i określić większe lub mniejsze „nasycenie” obecnie działających systemów państwowych różnymi formami bezpośredniego uczestnictwa społecznego w sprawowaniu władzy.

Demokracja bezpośrednia polega na bezpośrednim podejmowaniu decyzji państwowych przez ogół obywateli. W jej ramach społeczeństwo ma większy wpływ na zapadające rozstrzygnięcia o istotnym znaczeniu dla kraju. Do zadań 
funkcjonującego nieprzerwanie aparatu administracyjnego należy przygotowywanie projektów decyzji o dużej wadze państwowej oraz podejmowanie decyzji wykonawczych lub mających charakter techniczno-administracyjny.

Formą demokracji bezpośredniej, zbliżoną do wymaganego ideału, była starożytna demokracja ateńska. Samo słowo „demokracja” dla obywateli greckiego polis oznaczało (Węcowski, 2012, s. 9-12):

- masowe uczestnictwo,

- rządy większości,

- równość wobec prawa,

- kadencyjność urzędników,

- rotacyjność stanowisk państwowych.

Wybieralność przedstawicieli w celu sprawowania przez nich władzy w imieniu społeczeństwa była całkowicie sprzeczna z zamysłem ustroju i nie była uważana za demokrację. Aspekt ten powoduje, że obecnie pojawia się coraz więcej głosów podważających prawo do określania istniejącego współcześnie systemu politycznego jako: demokracji. Zdaniem wielu, nasz obecny system stanowi w praktyce oligarchię, czyli władzę bogatych. Jednym z argumentów przytaczanych na potwierdzenie jest wniosek, że państwem rządzi zamknięta grupa osób. Aby móc do niej dołączyć, trzeba wkupić się pieniędzmi, przynależnością do partii, a także bezwzględnym posłuszeństwem wobec wyznawanych zasad (http://abeojeden.blox. pl/2012/03/Utopia-Demokracja-posrednia-i-bezposrednia.html).

Powracając do idei demokracji ateńskiej należy przypomnieć, że wszystkie najistotniejsze decyzje o znaczeniu ogólnopaństwowym mogły być podejmowane jedynie przez dorosłych mężczyzn (tych, którzy ukończyli 20 rok życia), posiadających status obywateli. Ich zebrania w celu debaty i podjęcia ważkich rozstrzygnięć nosiły miano: zgromadzeń ludowych (gr. ekklezja, pol. eklezja). Głosowania odbywały się w nadających się do tego celu, obszernych powierzchniowo miejscach publicznych na wolnym powietrzu, takich jak Agora, a później Pnyks. Najczęściej przybierały formę wyrażenia swojej woli za pomocą prostego podniesienia rąk lub podziału zebranych na osoby, które były „za” („udawały się na prawo”) i te, które były „przeciw” („przechodziły na lewą stronę"). Eklezje odbywały się systematycznie i prawie nieprzerwanie z częstotliwością ich zwoływania co 7-14 dni. Za sprawną organizację zgromadzeń ludowych odpowiedzialna była Rada Pięciuset (gr. Boule). Po zakończeniu eklezji, zadaniem Rady było wykonanie powziętych uchwał przy pomocy urzędników administracji. W przerwach pomiędzy sesjami zgromadzeń ludowych, Rada Pięciuset podejmowała decyzje w wielu zagadnieniach i sprawach wymagających bieżących rozstrzygnięć, ale leżących w kompetencji eklezji. Na najbliższym zebraniu obywateli musiały być one jednak zaakceptowane większością głosów. 
Obecnie za najważniejsze narzędzia demokracji bezpośredniej, które umożliwiają członkom społeczeństwa udział w sprawowaniu władzy oraz współuczestnictwo w zarządzaniu określonym obszarem, uważane są:

- referendum,

- plebiscyt,

- obywatelska inicjatywa ustawodawcza,

- weto ludowe,

- budżet partycypacyjny,

- odwołanie.

Za państwo, które stosuje w codziennej praktyce ustrojowej najwięcej elementów składających się na instrumenty demokracji bezpośredniej uważana jest niewielka terytorialnie Konfederacja Szwajcarska. Uwaga na temat małego terytorium jest uzasadniona, istnieje bowiem rozpowszechniona opinia, że demokracja bezpośrednia nadaje się najlepiej dla małych państw. Nie w pełni można się zgodzić z tą opinią, ponieważ w wielu przypadkach narzędzia demokracji uczestniczącej stosowane są na poziomie dużych obszarów, np. we Włoszech czy w poszczególnych stanach USA.

\subsubsection{Referendum}

Referendum to głosowanie ludowe o charakterze powszechnym, w którym obywatele państwa lub jego wydzielonej administracyjnie części (np. pojedynczego stanu w USA lub województwa, powiatu albo gminy w Polsce) mają możliwość wypowiedzenia się $\mathrm{w}$ istotnych sprawach dotyczących terytorium, jakie zamieszkują. Referendum wymaga podania tylko jednej z dwóch odpowiedzi: „TAK” lub „NIE” na postawione w nim pytania.

Sama idea instytucji referendum wywodzi się ze Szwajcarii, gdzie wraz z drugim ważnym instrumentem demokracji bezpośredniej, jaki stanowi inicjatywa ludowa (w użyciu od początku XIX wieku) stosuje się ją w sposób nieprzerwany już od XVI wieku (http://www.swisspolitics.org/politische-struktur/volksinitiative-und-referendum/).

Ze względu na przyjęte kryterium, referenda można podzielić na kilka różnych kategorii (Nowa Encyklopedia Powszechna PWN, 1998, s. 477):

- podział ze względu na zależność prawną władz danego szczebla od wyniku głosowania:

- referendum konstytutywne (inaczej wiążące), gdy decyzja powzięta przez ogół obywateli jest wiążąca;

- referendum konsultatywne (opiniodawcze), gdy jego wynik ma dla ekipy sprawującej władze jedynie informacyjny charakter, nieobligujący do wykonania powziętych przez społeczeństwo decyzji; 
- podział ze względu na obowiązek władz do zorganizowania głosowania ludowego:

- referendum obligatoryjne, ma miejsce wtedy, gdy odnośne władze są zobowiązane do jego przeprowadzenia;

- referendum fakultatywne, gdy przepisy prawne dopuszczają, lecz nie nakazują bezwzględnie jego przeprowadzenia;

- podział ze względu na przedmiot głosowania:

- referendum konstytucyjne, dotyczące aprobaty ustawy zasadniczej lub jej zmiany;

- referendum ustawodawcze, gdy dotyczy projektu legislacyjnego albo samej ustawy;

- podział ze względu na sposób sformułowania postawionych w nim pytań:

- referendum aprobatywne (inaczej afirmacyjne), w którym głosuje się za przyjęciem jakiegoś rozwiązania;

- referendum derogacyjne, w którym głosuje się za odrzuceniem jakiegoś rozwiązania (czasami równoznacznym z jednoczesnym przyjęciem nowego rozwiązania);

- podział ze względu na zasięg terytorialny:

- referendum ogólnokrajowe wtedy, gdy dotyczy terytorium całego państwa;

- referendum lokalne, gdy dotyczy jedynie wybranej części terytorium danego kraju (w Polsce: województwa, powiatu lub gminy).

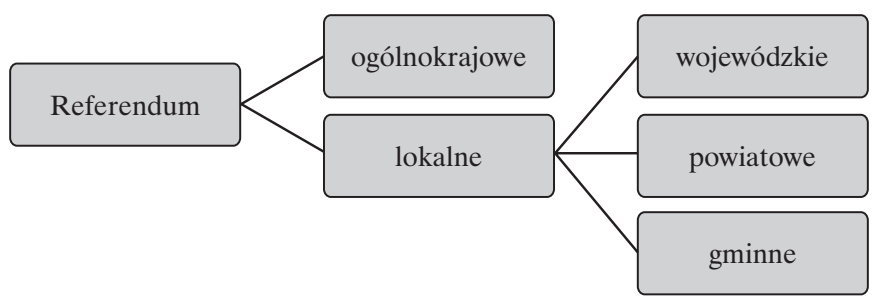

Rysunek 31. Podział referendów w Polsce, według kryterium terytorialnego Źródło: opracowanie własne.

Referendum lokalne może w Polsce odbyć się na szczeblu gminy, powiatu lub województwa. Najczęściej dotyczy sprawy odwołania organu stanowiącego administracji samorządowej, tj. rady gminy, rady powiatu, sejmiku województwa. Może także dotyczyć chęci odwołania organu wykonawczego gminy, tzn. wójta, burmistrza lub prezydenta miasta. Powodem przeprowadzeniu referendum lokalnego może być także chęć samoopodatkowania się mieszkańców bądź inne ważne problemy. 
Dzięki niedawnej nowelizacji przepisów ustawy o referendum lokalnym (Dz. U. z 2013 r. Nr 0, poz. 153), obywatele mogą również głosować w istotnych sprawach społecznych i gospodarczych. Poprzez włączenie spraw ekonomiczno-gospodarczych i społecznych wzrósł zakres, jaki może obejmować demokracja uczestnicząca w Polsce. Na podstawie znowelizowanych przepisów uprawnione do tego osoby mogą wziąć faktyczny udział we współzarządzaniu terenem, jaki zamieszkują.

Lokalne głosowanie ludowe może zostać zarządzone z inicjatywy organu stanowiącego lub na wniosek mieszkańców uprawnionych do głosowania w liczbie: $10 \%$ mieszkańców gminy (tak samo w przypadku powiatu) oraz 5\% mieszkańców województwa. Wymagana frekwencja na referendum wynosi $30 \%$. W przypadku odwołania organu jednostki samorządu terytorialnego pochodzącego z wyborów bezpośrednich, minimalna frekwencja musi wynieść minimum 3/5 liczby biorących udział w wyborze odwoływanego organu (Banaszak, 2010, s. 595-604).

Coraz częstsze korzystanie z możliwości, jakie daje referendum ukazuje, że społeczeństwo świadomie podejmuje decyzje w wielu sprawach oraz pragnie wywrzeć bezpośredni wpływ na jakość swojego życia. Swiadczy to dobrze o rosnącej świadomości politycznej obywateli Rzeczypospolitej oraz ulegającemu pozytywnej zmianie podejściu organów władzy do oczekiwań społecznych w tej materii.

\subsubsection{Plebiscyt}

Plebiscyt stanowi narzędzie demokracji bezpośredniej w formie głosowania, dotyczące najczęściej takich spraw, jak: przyłączenie spornego terytorium do któregoś z istniejących już państw lub utworzenie nowego, niezależnego państwa. Często w ramach plebiscytu zadawanych jest kilka pytań dotyczących np.: statusu danego obszaru lub pożądanej formy przyszłych rządów. W elementach rzymskiego ustroju politycznego można się dopatrywać początków plebiscytu. W czasach antycznych zgromadzenia obywateli przynależnych do komicji trybusowych (łac. comitia tributa), czyli określonych jednostek terytorialnych, mogły pod przywództwem trybunów ludowych podejmować decyzje dotyczące własnych spraw. Samo określenie pochodzi od łacińskiego zlepku dwóch słów: plebis + scitum, oznaczających uchwałę zgromadzenia ludowego.

Pierwszy plebiscyt w okresie nowożytnym miał miejsce w 1791 roku. Jego pozytywny wynik przyłączył do nowo powstałej Republiki Francuskiej leżące na terenach dzisiejszej Prowansji: Avignon oraz Hrabstwo Venaissin. Następne głosowania odbyły się w kolejnych latach, po zajęciu przez armię republikańską: Sabaudii oraz Nicei. Ciekawostką jest, że tak demokratyczne narzędzie, jakim jest plebiscyt zostało wykorzystane w sposób nieuczciwy. Prawo do głosowania w następnych plebiscytach na spornych terenach w Belgii oraz 
Nadrenii otrzymali wyłącznie zwolennicy Francji i Wielkiej Rewolucji Francuskiej.

W latach 1920-1921, na mocy postanowień traktatu wersalskiego, zostały przeprowadzone dwa plebiscyty terytorialne dotyczące obszarów Polski: Górnego Śląska oraz Warmii, Mazur i Powiśla. Wbrew niektórym kalkulacjom polskiej strony, plebiscyty w obu przypadkach skończyły się dla niej dotkliwą porażką. Większa część spornych terenów została przyznana Rzeszy Niemieckiej (Krasuski, 1975, s. 57-58).

Formę głosowania, zbliżoną do plebiscytu, miało również przeprowadzone w Polsce referendum ludowe z 30 czerwca 1946 roku. Odbyło się ono w oparciu o ustawę o przeprowadzeniu głosowania ludowego, uchwaloną przez Krajową Radę Narodową 28 kwietnia 1946 r. (Dz.U. Nr 15, poz. 105). Uczestnikom referendum zostały zadane trzy pytania:

1. Czy jesteś za zniesieniem Senatu?

2. Czy chcesz utrwalenia w przyszłej Konstytucji ustroju gospodarczego, zaprowadzonego przez reformę rolną i unarodowienie podstawowych gałęzi gospodarki krajowej, z zachowaniem ustawowych uprawnień inicjatywy prywatnej?

3. Czy chcesz utrwalenia zachodnich granic Państwa Polskiego na Bałtyku, Odrze i Nysie Lużyckiej?

Wyniki referendum zostały sfałszowane przez ówczesne siły totalitarne w Polsce, były bowiem niekorzystne dla ówczesnych władz prosowieckich, chociaż prawdziwych rezultatów nie uda się prawdopodobnie nigdy odtworzyć (Kersten, 1987, s. 249).

W niektórych krajach europejskich termin „plebiscyt” został zastosowany w szerszym ujęciu, dla wyróżnienia na tle innych form demokracji bezpośredniej, głosowań ludowych zbliżonych do referendum, nie dotyczących jednak spraw ani terytorialnych, ani ustrojowych.

We Francji i położonej obok Szwajcarii pojęcia tego używa się dla wyrażenia przez społeczeństwo poparcia dla określonego polityka lub ugrupowania politycznego, akceptującego jednocześnie przedstawione przez nich programy (Sarnecki, 2013, s. 302-306).

Przykłady powojennej Polski oraz Francji po Wielkiej Rewolucji ukazują dobitnie, że przeprowadzenie w pełni niezależnego głosowania w sprawach tak drażliwych, jak sporne terytoria nie jest w zasadzie możliwe. Można mieć tylko nadzieję, że głosowania ludowe dotyczące ewentualnej niepodległości Szkocji i Katalonii odbędą się na uczciwych zasadach. 


\subsubsection{Obywatelska inicjatywa ustawodawcza}

Obywatelska inicjatywa ustawodawcza jest rozwiązaniem ustrojowym pozwalającym społeczeństwu na wniesienie pod obrady parlamentu projektów ustaw stworzonych przez zorganizowane grupy obywateli. Jest to możliwość czynnego i bezpośredniego wzięcia udziału $\mathrm{w}$ procesie stanowienia prawa przez osoby niezajmujące się na co dzień polityką. Inicjatywa ustawodawcza funkcjonuje z powodzeniem w wielu państwach europejskich, między innym w Austrii, Hiszpanii, Szwajcarii czy we Włoszech. Obywatelską inicjatywę ustawodawcza dopuszczają także polskie uregulowania prawne. Mowa jest o niej w art. 118 ust. 2 Konstytucji Rzeczypospolitej (Dz. U. z 1997 r. Nr 78 poz. 483). Artykuł ten brzmi następująco:

Art. 118.

1. Inicjatywa ustawodawcza przysługuje posłom, Senatowi, Prezydentowi Rzeczypospolitej i Radzie Ministrów.

2. Inicjatywa ustawodawcza przysługuje również grupie co najmniej 100000 obywateli mających prawo wybierania do Sejmu. Tryb postępowania w tej sprawie określa ustawa.

3. Wnioskodawcy, przedkładając Sejmowi projekt ustawy, przedstawiają skutki finansowe jej wykonania.

Istotnym szczegółem artykułu 118 Konstytucji Rzeczypospolitej jest ustęp 3, który nakłada na inicjatorów nowych przepisów trudny obowiązek dokładnego oszacowania następstw finansowych proponowanych zmian w aktach normatywnych. Zmusza to grupy obywateli mających ambicje społeczno-polityczne do bardzo wnikliwego rozpatrzenia wszystkich aspektów związanych ze składanymi projektami. Ustawa, o której mowa w ostatnim zdaniu ust. 2 cytowanego artykułu, nosi tytuł „o wykonywaniu inicjatywy ustawodawczej przez obywateli” (Dz. U. z 1999 r. Nr 62, poz. 688). Pomijając pewną ilość zbędnych detali, dotyczących żmudnej procedury przedłożenia projektu proponowanej ustawy pod obrady Sejmu, trzeba zwrócić uwagę na kilka szczegółów.

Zapisy ustawowe określają, że specjalny komitet służący Obywatelskiej Inicjatywie Ustawodawczej może utworzyć grupa co najmniej piętnastu obywateli polskich posiadających prawo wybierania do Sejmu. Cały proces zbierania podpisów oraz przedłożenia projektu, wraz z załączonym wykazem popierających go osób, musi zakończyć się w terminie maksymalnie trzech miesięcy od wydania przez Marszałka Sejmu postanowienia o przyjęciu zawiadomienia o fakcie utworzenia komitetu. Innym ważnym szczegółem jest to, że Ustawa o wykonywaniu inicjatywy ustawodawczej przez obywateli, nie precyzuje wyraźnie zakresu spraw, które mogą być przedmiotem Obywatelskiej Inicjatywy Ustawodawczej. W art. 3 tego aktu normatywnego zostało jedynie zaznaczone, 
że projekt obywatelski nie może dotyczyć spraw, dla których Konstytucja RP zastrzega wyłączną właściwość innych podmiotów, którym przysługuje inicjatywa ustawodawcza (tj. posłom, Senatowi, Prezydentowi Rzeczypospolitej oraz Radzie Ministrów). Takimi zastrzeżonymi sprawami są np. przepisy ustawy dotyczącej poręczeń i gwarancji udzielanych przez Skarb Państwa (Dz. U. z 2009 r. Nr 65, poz. 545) oraz ustawa budżetowa konstruowana corocznie i przedstawiana Sejmowi przez każdy aktualny rząd (http://obywateledecyduja. pl). Pomimo nielicznych spraw zastrzeżonych dla Ustawowej Inicjatywy Obywatelskiej, polskie przepisy prawne idą znacznie dalej i dają większe możliwości grupom inicjatywnym niż ma to miejsce $w$ innych państwach. Przykładowo w Szwajcarii w ramach inicjatywy obywatelskiej, która w tym kraju nosi miano „inicjatywy ludowej” (niem. Volksinitiative), istnieje możliwość przeprowadzenia zmian tylko i wyłącznie w Konstytucji Federalnej Konfederacji Szwajcarskiej lub w jej części (niem. Bundesverfassung der Schweizerischen Eidgenossenschaft, fran. Constitution fédérale de la Confédération Suisse). Pozostałe sprawy są dla inicjatywy ludowej zastrzeżone i należą do kompetencjach organów państwa.

\subsubsection{Weto ludowe}

Weto ludowe po raz pierwszy zostało wprowadzone do systemu prawnego w 1831 r., w kantonie Sankt Gallen należącym do Konfederacji Szwajcarskiej. W Europie stosowane w praktyce jest obecnie jeszcze we tylko Włoszech. Poza starym Kontynentem używa się tego instrumentu demokracji w kilkunastu stanach USA i państwach Ameryki Południowej: Kolumbii, Peru, Urugwaju i Wenezueli (Jabłoński, 2002, s. 47-49). Weto ludowe jest rzadziej używanym w praktyce, jako wyraz sprzeciwu wobec przyjętych rozwiązań prawnych, narzędziem demokracji bezpośredniej, np. obowiązującej ustawy lub zawartej umowy międzynarodowej. Polega ono na tym, że określona przepisami liczba obywateli może wystąpić z wnioskiem o skierowanie budzącego sprzeciw aktu prawnego pod głosowanie ludowe. Odpowiedni organ administracji państwowej, którym jest najczęściej parlament, po rozpatrzeniu zasadności wniosku, przeprowadza jego kontrolę formalną (wymaganą ilość obywateli zgłaszających weto) oraz stronę merytoryczną (czy dana ustawa może być poddana pod głosowanie ludowe) (http://portalwiedzy.onet.pl). Jeśli wszystkie wymogi zostały spełnione, zarządza specjalne referendum w sprawie zakwestionowanego aktu prawnego. Obywatele wypowiadają się „za” albo „przeciw” w zorganizowanym w tym celu głosowaniu. W większości krajów rozstrzygnięcie ma charakter obowiązujący - w przypadku społecznego sprzeciwu wyrażonego na kartach do głosowania ustawa albo zawarte porozumienie międzynarodowe traci automatycznie swoją moc.

W Polsce rolę weta ludowego pełni, w pewnym sensie, referendum lokalne w sprawie odwołania organów stanowiących samorządu terytorialnego (rad gmin, rad powiatów, sejmików wojewódzkich). Nie istnieją natomiast konkretne 
regulacje kształtujące wprost instytucję weta ludowego w odniesieniu do aktów prawnych w naszym kraju (http://portalwiedzy.onet.p). Istniejącą w kilku krajach instytucję weta obywatelskiego należy uznać za bardzo skuteczny instrument kontrolny wobec poczynań władz krajowych i lokalnych. Szczególnie wyraziście potrzeba istnienia takiego instrumentu została wykazana przy okazji masowych protestów wobec podpisanego przez polski rząd w 2012 roku porozumienia ACTA (ang. Anti-Counterfeiting Trade Agreement). Fala podobnych protestów, jak naszym kraju, miała miejsce prawie w całej Europie.

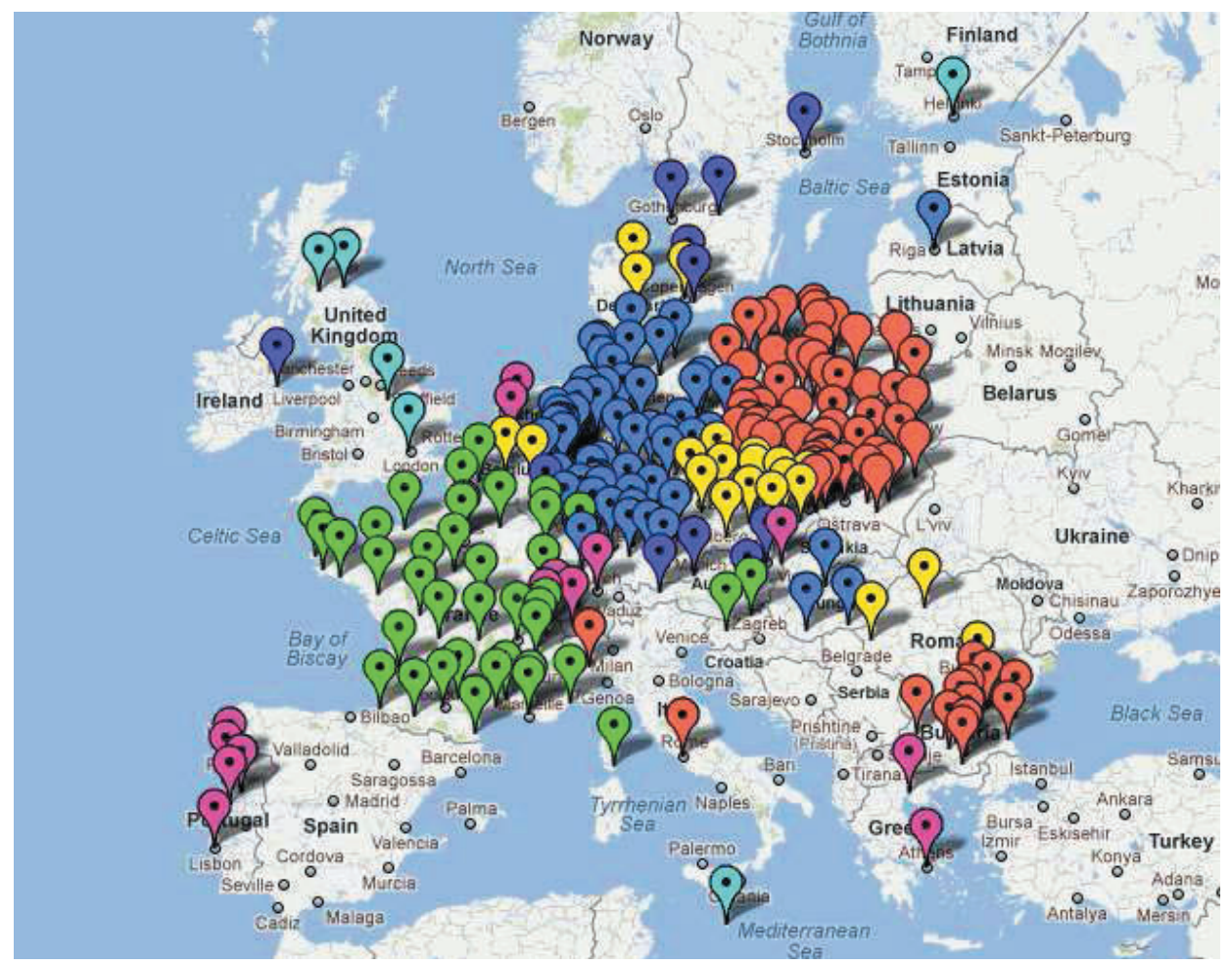

Rysunek 32. Mapa protestów przeciwko porozumieniu ACTA w Europie (2012 r.) Źródło: http://www.4thmedia.org/2012/02/06/europe-rises-up-against-acta/.

ACTA to międzynarodowa umowa handlowa dotycząca zwalczania obrotu towarami podrabianymi. Jej zadeklarowanym celem miało być stworzenie globalnych standardów w walce $\mathrm{z}$ naruszeniami własności intelektualnej. W rzeczywistości, według większości opinii publicznej, stanowiła próbę ustanowienia kontroli treści przekazywanych przez Internet. Niepokojów społecznych na uli- 
cach wielu miast w Polsce, związanych ze sprzeciwem młodych ludzi, można byłoby uniknąć, gdyby istniały w naszym kraju odpowiednie rozwiązania legislacyjne w tym zakresie. Podobne protesty młodzieży miały miejsce także w innych częściach Europy: w Niemczech, Bułgarii, we Francji, w Portugalii czy w Wielkiej Brytanii. Jak widać na rysunku 32, do wystąpień takich nie doszło prawie wcale na terenie Włoch i Szwajcarii, gdzie istnieje instytucja weta obywatelskiego. W każdym z tych krajów odnotowano tylko po cztery wystąpienia przeciwników tej umowy. Dla porównania w Niemczech, w Polsce czy we Francji odnotowano po kilkadziesiąt miejsc, gdzie doszło do protestów społecznych. W Austrii porównywalnej pod różnymi względami do Szwajcarii wystąpień było dziesięć (http://finchin.com/acta-sopas-bigger-brother/). Na szczęście polski rząd, biorąc przykład z Niemiec (które nie podpisały porozumienia) i ulegając naciskom społecznym, nie ratyfikował umowy ACTA. Zaistniała sytuacja pokazuje jasno, że dzisiejsze „społeczeństwo internetowe” domaga się udziału w podejmowaniu decyzji na wyższych szczeblach i w sprawowaniu władzy.

\subsubsection{Budżet partycypacyjny}

Budżet partycypacyjny to obecnie jedna z najskuteczniejszych praktyk mających na celu zaangażowanie mieszkańców w proces zarządzania miastami, w których żyją. Coraz więcej samorządów jest zainteresowanych wdrożeniem budżetu partycypacyjnego (zakładającego udział w jego formułowaniu obywateli) jako elastycznego, politycznie neutralnego narzędzia (lub zestawu niepowiązanych ze sobą narzędzi), które w oparciu o szereg otwartych spotkań mieszkańców skutecznie podnosi efektywność realizacji dotychczasowej, odgórnie ustalanej polityki miejskiej. Z wielu odkrytych już zalet budżetu partycypacyjnego (polska nazwa: obywatelskiego) należy przede wszystkim zwrócić uwagę, że (Kębłowski, 2013, s. 14-15):

- skutecznie legitymizuje politykę władz lokalnych wśród mieszkańców;

- promuje innowacyjność i przedsiębiorczość na danym terenie;

- umożliwia $\mathrm{w}$ porozumieniu $\mathrm{z}$ mieszkańcami podejmowanie trudnych i często kontrowersyjnych decyzji (np. dotyczących cięć budżetowych i poczynienia oszczędności);

- pozwala uzyskać od mieszkańców wiele szczegółowych i zarazem pożytecznych informacji dotyczących funkcjonowania ich miasta;

- naturalnie wspiera proces decentralizacji władzy;

- jest odpowiedzią na rosnący dystans pomiędzy rządzącymi i obywatelami;

- buduje zaufanie mieszkańców do samorządu i jego przedstawicieli;

- zwiększa popularność polityków, którzy angażują się we wprowadzenie na własnym terenie tego narzędzia demokracji bezpośredniej;

- aktywizuje liczne grono obywateli, którzy regularnie i aktywnie wspó1decydują o wybranych aspektach rozwoju miasta; 
- ma widoczny wpływ na proces tworzenia społeczeństwa obywatelskiego;

- służy demokratyzacji procesu decyzyjnego, dając czytelną odpowiedź na pogłębiający się kryzys demokracji reprezentatywnej (pośredniczącej);

- pozwala nawiązać dialog pomiędzy urzędnikami a organizacjami pozarządowymi i tzw. ruchami miejskimi - oddolnymi inicjatywami, które nierzadko wskazują na wiele często pomijanych problemów miasta i proponują alternatywne rozwiązania dotyczące jego funkcjonowania i zarządzania nim;

- zwiększa przejrzystość procesu zarządzania środkami publicznymi i ma wyraźny wpływ na zmniejszenie korupcji.

Budżet partycypacyjny powstał na fali szerokiej inicjatywy oddolnej na samym początku lat dziewięćdziesiątych ubiegłego wieku. Miejscem jego narodzin było, liczące ponad milion mieszkańców, miasto Porto Alegre będące stolicą Rio Grande do Sul - najdalej na południe wysuniętego stanu Brazylii. Twórcami

Tablica 40. Liczba mieszkańców biorących udział w tworzeniu budżetu partycypacyjnego w wybranych miastach Brazylii w latach 1990-2003

\begin{tabular}{|c|c|c|c|c|c|}
\hline \multirow{2}{*}{ Rok } & \multicolumn{5}{|c|}{ Nazwa miasta } \\
\cline { 2 - 6 } & Porto Alegre & Belo Horizonte & Ipatinga & Recife & São Paulo \\
\hline 1990 & 976 & b.d. & 630 & b.d. & b.d. \\
\hline 1991 & 3694 & b.d. & 470 & b.d. & b.d. \\
\hline 1992 & 7610 & b.d. & 483 & b.d. & b.d. \\
\hline 1993 & 10735 & b.d. & 563 & b.d. & b.d. \\
\hline 1994 & 9638 & 15216 & 572 & b.d. & b.d. \\
\hline 1995 & 11821 & 26823 & 581 & b.d. & b.d. \\
\hline 1996 & 10148 & 36508 & 604 & 30000 & b.d. \\
\hline 1997 & 11908 & 31795 & 683 & b. d. & b.d. \\
\hline 1998 & 13687 & 19418 & 1533 & 30000 & b.d. \\
\hline 1999 & 14776 & 21175 & 2136 & b.d. & b.d. \\
\hline 2000 & 14408 & 31369 & 2018 & 30000 & b.d. \\
\hline 2001 & 16612 & b.d. & 5015 & 42800 & 34 000 \\
\hline 2002 & 28549 & 28124 & 981 & 67100 & 55000 \\
\hline 2003 & 26807 & b.d. & 2374 & 69500 & 80000 \\
\hline
\end{tabular}

Źródło: Wampler (2007, s. 33). 
pomysłu budżetu partycypacyjnego byli działacze Związku Stowarzyszeń Sąsiedzkich Porto Alegre (por. União das Associações dos Moradores de PoA - UAMPA). Ruch wystąpił z projektem takiego przedsięwzięcia do władz miasta już w roku 1985. Jednak na akceptację trzeba było czekać aż do demokratyzacji kraju i zwycięstwa w wyborach powszechnych lewicującej Partii Robotników (por. Partido dos Trabalhadores). Po raz pierwszy, jako ustrojowe narzędzie współzarządzania miastem przez obywateli, budżet partycypacyjny został zastosowany w Porto Alegre, w 1990 roku. Szybko zyskał w Brazylii popularność wśród ludności.

Wszystkie, wymienione pięć brazylijskich miast, zanotowało dynamiczny wzrost liczby mieszkańców biorących udział tworzeniu budżetu partycypacyjnego w analizowanym okresie. Pewne zdziwienie może wywołać mała ilość osób, które na przestrzeni lat 1990-2003 zaangażowane były w planowanie gospodarczo-finansowe w mieście Ipatinga. Wyjaśnienie tego faktu jest proste. Ipatinga jest małym miastem w stanie Minas Gerais, bez dostępu do Oceanu Atlantyckiego. W 2009 roku liczyło nieco ponad 244 tys. mieszkańców (dane z 2010 r.). W porównaniu z pozostałymi miastami, tworzącymi olbrzymie aglomeracje, jest od każdego z nich od kilku do kilkudziesięciu razy mniejsze.

Tablica 41. Wybrane miasta w Brazylii pod względem liczby mieszkańców w 2010 r.

\begin{tabular}{|l|l|c|c|}
\hline \multicolumn{1}{|c|}{ Nazwa miasta } & \multicolumn{1}{|c|}{ Nazwa stanu } & $\begin{array}{c}\text { Populacja samego } \\
\text { ośrodka miejskiego }\end{array}$ & $\begin{array}{c}\text { Populacja całej } \\
\text { aglomeracji }\end{array}$ \\
\hline São Paulo & São Paulo & 11244369 & 19889559 \\
\hline Belo Horizonte & Minas Gerais & 2375444 & 5397438 \\
\hline Recife & Pernambuco & 1536934 & 4150004 \\
\hline Porto Alegre & Rio Grande do Sul & 1409939 & 4200413 \\
\hline Ipatinga & Minas Gerais & 244508 & brak aglomeracji \\
\hline
\end{tabular}

Źródło: (http://www.ibge.gov.br)

Dane zamieszczone w tablicy 41 pokazują, że stosowanie w praktyce narzędzia demokracji bezpośredniej, jakim jest budżet partycypacyjny, nie stanowi domeny największych ośrodków miejskich i ich aglomeracji. Z równym powodzeniem można wykorzystać chęci, entuzjazm oraz energię mieszkańców w kierunku współzarządzania małym miastem w celu optymalnego zagospodarowania powierzonych mu pieniędzy oraz majątku, jakim dysponuje.

Budżet partycypacyjny okazał się niezwykle udaną inicjatywą i w krótkim czasie odniósł ogromny sukces. Początkowo zafascynowanie jego możliwościami przeżyła Brazylia. W roku 2008 wprowadziło go około dwustu tamtejszych 
miast, obejmując ponad 44 mln mieszkańców. W dwa lata później liczbę miast stosujących zasady budżetu obywatelskiego szacowano na blisko dwieście sześćdziesiąt, przy ponad 54 mln obywateli. Następnym państwem, które podjęło eksperyment wspólnego zarządzania majątkiem przez władze municypalne i mieszkańców miast, było Chile. W roku 2010 odnotowano tam już czternaście przypadków zastosowania tego rozwiązania. Najszybciej i na największą skalę budżet partycypacyjny upowszechnił się w Ameryce Południowej. W ostatnim roku pierwszej dekady XXI wieku przynajmniej 510 ośrodków miejskich na tym kontynencie było zaangażowanych we wdrażanie idei współzarządzania obywatelskiego. Drugim miejscem, gdzie pomysł budżetu uczestniczącego został entuzjastycznie przyjęty jest Europa. W roku 2010 mieszkańcy około 200 miast na Starym Kontynencie korzystali z dobrodziejstw współdecydowania o własnych losach (Kębłowski, 2013, s. 12). Jak się szacuje w 2010 roku, na całym świecie można było znaleźć przynajmniej 795 miast, których budżet partycypacyjny był stosowany.

Jak obrazuje rysunek 33, rozwiązanie, które powstało w Ameryce Południowej, stosowane jest już na całym świecie. Swoim zasięgiem obejmuje w tej chwili: Europę, Azję, Amerykę Północną, Afrykę oraz Australię.

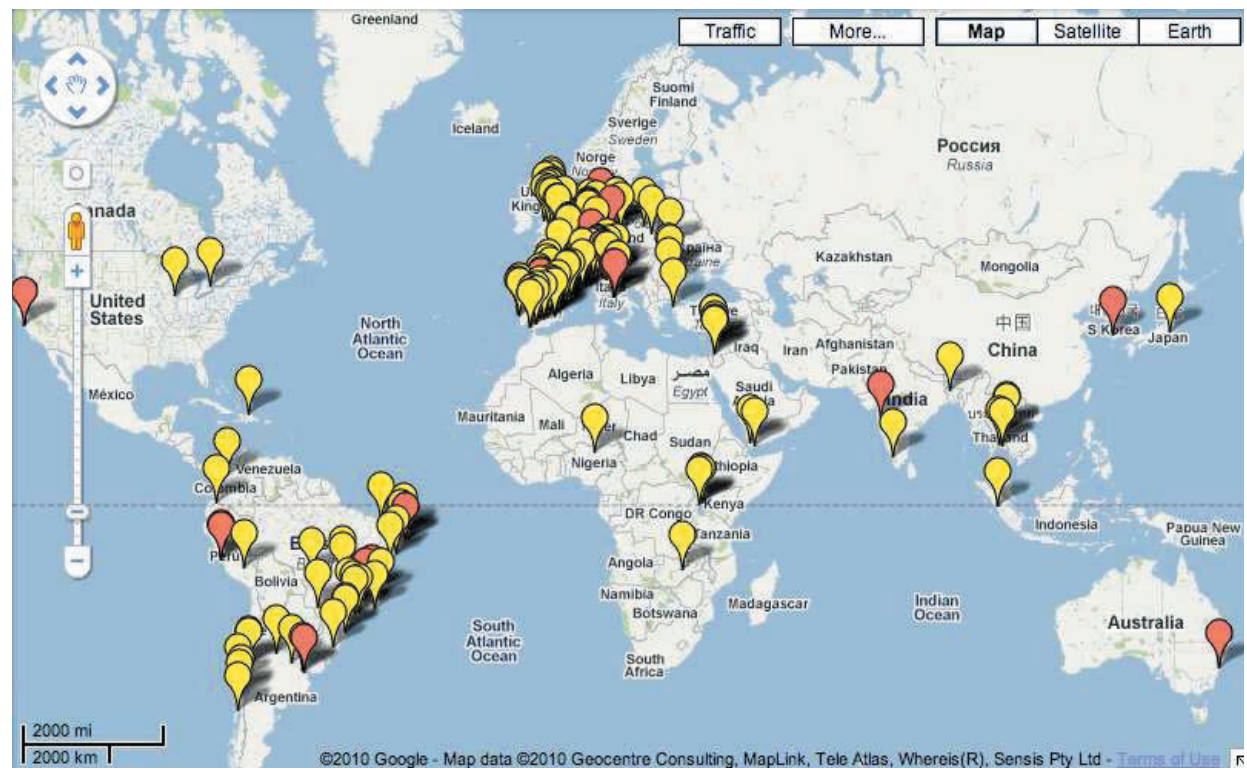

Rysunek 33. Wybrane miejsca na świecie, gdzie w 2010 roku, stosowane było zarządzanie ośrodkami miejskimi oparte na budżecie obywatelskim

Źródło: (http://www.google.com). 
Według pobieżnych szacunków ocenia się, że w obecnie budżet obywatelski może stosować od 1200 do 1500 ośrodków miejskich wraz z otaczającymi je przedmieściami oraz miejscowościami satelickimi (http://nicoleskibolaesq.wordpress.com). Na formułę budżetu partycypacyjnego decydują się władze zarówno wielkich aglomeracji, takich jak: Sewilla, Paryż (tylko niektóre dzielnice), Rzym, Lizbona czy Berlin, jak i średnich miast, takich jak: Emsdetten i Hilden w Niemczech, czy małych gmin, np. Grottamare (14 700 mieszkańców) oraz Altidona (2 600 mieszkańców) we Włoszech (http://siecobywatelska.pl/files/ budzet_partycypacyjny_w_europie_avt9.pdf). Tak więc, wielkość obszaru, jakiego dotyczy oraz liczebność populacji zamieszkującej daną jednostkę administracyjną nie są przeszkodami w zastosowaniu omawianego rozwiązania.

Także władze polskich miejscowości z biegiem czasu coraz śmielej oddają część własnych kompetencji w ręce obywateli, pozwalając im zadecydować na co powinny zostać wydane pieniądze pochodzące z miejskiej kasy. Budżety partycypacyjne (obywatelskie) powoli stają się stałym elementem naszej rzeczywistości lokalnej (Sikora, 2013, s. 22). Przykładami najbardziej znanych miejscowości w Polsce, w których znalazł zastosowanie budżet partycypacyjny są: Dąbrowa Górnicza, Elbląg, Gorzów Wielkopolski, Łódź, Karpacz, Płock, Poznań, Sopot, Wrocław, Zielona Góra. Na marginesie trzeba przyznać, że gospodarze stolicy nie wzięli pod uwagę tego wydarzenia w zarządzaniu miastem.

Jakie minimalne warunki powinien spełniać budżet obywatelski? Na oficjalnej, poświęconej temu zagadnieniu, stronie internetowej Ministerstwa Administracji i Cyfryzacji zostało wymienionych osiem niezbędnych elementów (https:// mac.gov.pl):

1) mieszkańcy mają możliwość zgłaszania propozycji wydatków;

2) pula środków wyodrębnionych na budżet obywatelski jest jednoznacznie określona;

3) projekty są, o ile jest to możliwe, precyzyjnie wycenione;

4) organizowane są debaty publiczne na temat zgłoszonych pomysłów;

5) projekty zgłoszone przez mieszkańców nie mogą zostać odrzucane przez urzędników lub radnych z powodów merytorycznych, a jedynie z przyczyn formalno-prawnych;

6) o wyborze projektów decydują sami mieszkańcy;

7) w głosowaniu mogą wziąć udział wyłącznie uprawnieni do tego mieszkańcy danej jednostki podziału administracyjnego kraju;

8) projekty wybrane przez mieszkańców są realizowane obligatoryjnie.

Dodatkowo podkreśla się, że aby można było uznać fakt działania instytucji budżetu obywatelskiego na danym terenie, musi mieć on charakter nieprzerwanie stosowanego instrumentu. Jednokrotne głosowanie, czy też odbycie jednej czy dwóch debat przez mieszkańców, w celu wyłonienia najlepszych 
pomysłów do realizacji nie przesadzają jeszcze o istnieniu budżetu partycypacyjnego.

W obrębie omawianego w tym podpunkcie narzędzia demokracji bezpośredniej, można wyróżnić kilka stałych etapów postepowania. Dobrze je można rozróżnić na przykładzie czwartego co do wielkości miasta w Hiszpanii - Sewilli (rys. 34).

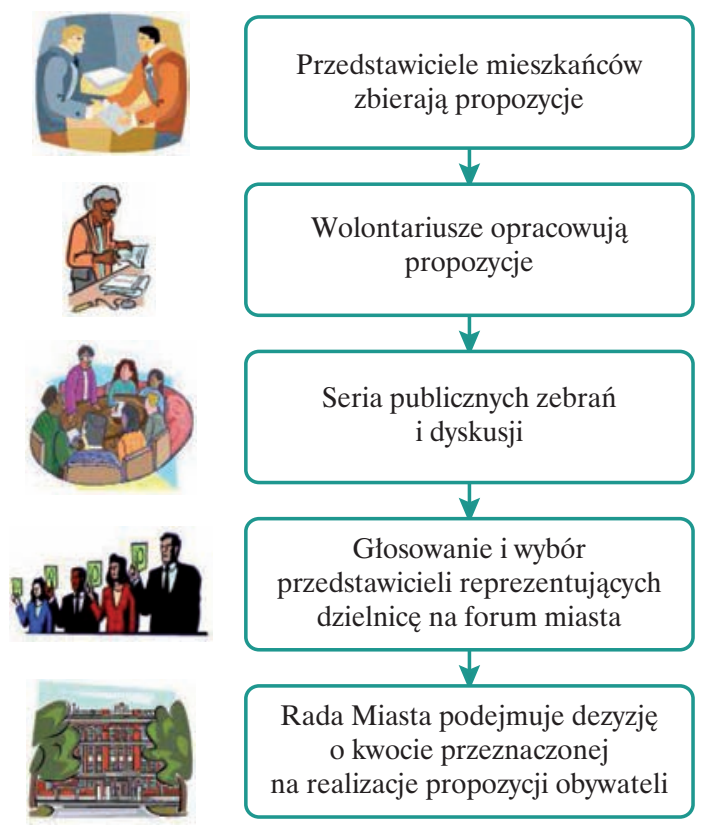

Rysunek 34. Etapy tworzenia budżetu obywatelskiego na przykładzie Sewilli w Hiszpanii

Źródło: https://mac.gov.pl/wp-content/uploads/2012/09/SEWILLA1.jpg

Jedną z trudności, jakie można napotkać przy korzystaniu z „budżetu uczestniczącego" jest niezbędny udział, w relatywnie czasochłonnych procedurach, obywateli oraz znalezienie odpowiedniej liczby wolontariuszy, którzy wezmą na swoje barki ciężar zbierania pomysłów do realizacji, opracowania propozycji do wyboru, a następnie zorganizowania i poprowadzenia serii publicznych spotkań.

Schemat kroków, które należy podjąć w celu stworzenia budżetu partycypacyjnego tym razem na podstawie Polski, przedstawia przykład zaczerpnięty z Dąbrowy Górniczej, ponad stutysięcznego miasta na prawach powiatu, leżącego na południu naszego kraju (w województwie śląskim) (rys. 35). 


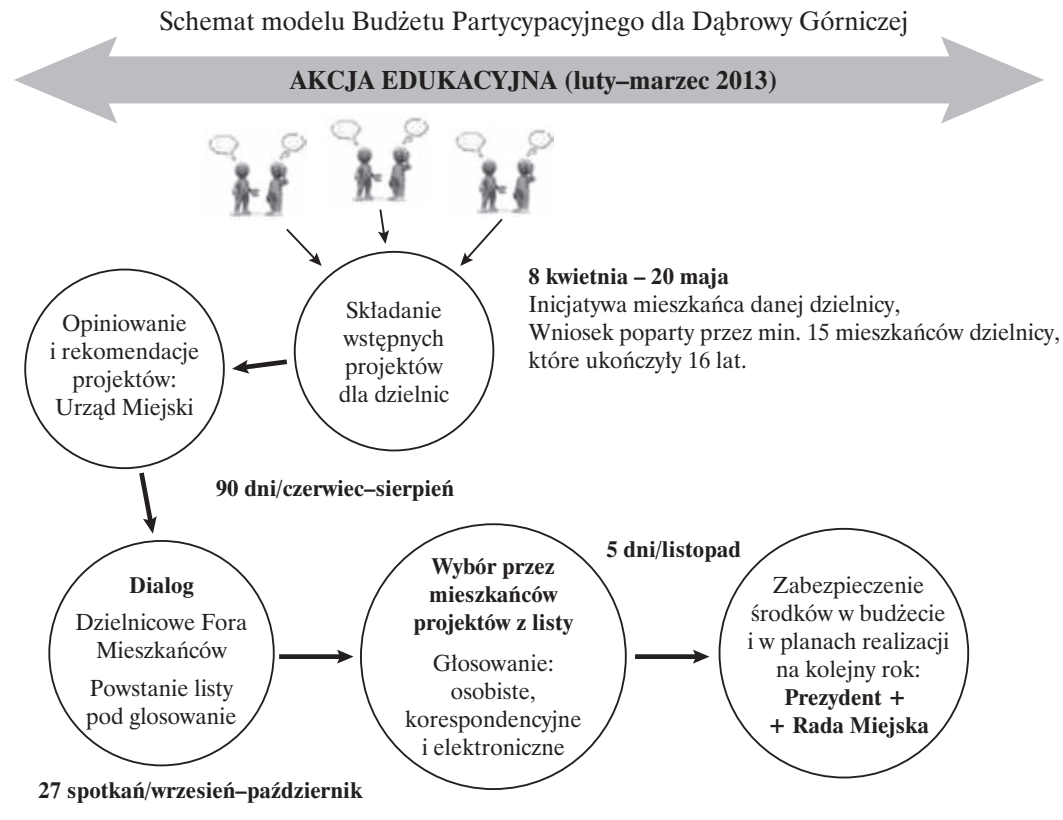

Rysunek 35. Procedura tworzenia budżetu obywatelskiego na przykładzie Dąbrowy Górniczej

Źródło: http://www.zaglebiedabrowskie.pl/2013/03/05/budzet-partycypacyjny-dabrowa-gornicza2013-spotkania/.

Od momentu swojego powstania w brazylijskim Porto Alegre, budżet partycypacyjny podlegał ewolucji i modyfikacjom. Poszukiwano również innych ścieżek partycypacji społecznej w decydowaniu o przeznaczeniu wspólnych pieniędzy. Obecnie różne modele budżetu obywatelskiego działają obok siebie niejako równolegle, różnią się jedynie założeniami oraz grupami adresatów, do których zostały skierowane. Dzisiaj uznaje się istnienie trzech podstawowych par modeli budżetu obywatelskiego (https://mac.gov.pl/dzialania/modele-budzetowania-partycypacyjnego/):

1) europejska wersja modelu Porto Alegre/uczestnictwo zorganizowanych grup interesów;

2) fundusz społeczności lokalnej na poziomie lokalnym i miejskim/negocjacje publiczno-prywatne;

3) partycypacja sąsiedzka/konsultowanie finansów publicznych.

Ad. 1) Europejska wersja modelu Porto Alegre. Nazwa pochodzi stąd, że brazylijskie rozwiązanie zostało po raz pierwszy zastosowane poza granicami Ameryki Południowej w hiszpańskiej Kordobie w 2001 roku. Opisywany model 
jest najbardziej zbliżony do swojego sławnego pierwowzoru. Skierowany do mieszkańców, koncentruje się głównie na konkretnych inwestycjach i projektach. Obywatelom dano do rąk realną możliwość współzarządzania. Po uprzednim dokładnym zweryfikowaniu strony formalno-prawnej wniosków, obowiązkiem władz samorządowych jest podporządkowanie się wyrażonym przez obywateli decyzjom, a następnie zastosowanie w praktyce, proponowanych przez nich rozwiązań.

Uczestnictwo zorganizowanych grup interesów. Ten model został skierowany, jak sama nazwa wskazuje, do zorganizowanych grup mieszkańców, takich jak: stowarzyszenia, komitety obywatelskie, grupy sąsiedzkie, organizacje pozarządowe, związki zawodowe. W ramach omawianego modelu, formułowane są jedynie ogólne wytyczne dla kierunków realizacji różnych rodzajów polityki lokalnej. Sugestie i propozycje powzięte $\mathrm{w}$ trakcie zebrań oraz zorganizowanych dyskusji, mogą dotyczyć na przykład sfer: mieszkalnictwa, szkolnictwa i edukacji, służby zdrowia, ochrony środowiska czy organizacji lokalnego transportu. Procedura postępowania przypomina konsultacje społeczne, mające jednak znacznie mniej sformalizowane zasady postępowania z propozycjami mieszkańców niż w klasycznym modelu Porto Alegre.

Wspólną cechą obu modeli jest możliwość szerokiej platformy dyskusji obywatelskiej przed wprowadzeniem propozycji i projektów do realizacji.

Ad 2) Fundusz społeczności lokalnej na poziomie lokalnym i miejskim. W modelu tym połączone zostały elementy opierające się na koncepcji bezpośredniego uczestnictwa mieszkańców, jak w rozwiązaniu z Porto Alegre, oraz stowarzyszeń lokalnych i sąsiedzkich. Bazą modelu jest istnienie specjalnego funduszu przeznaczanego na publiczne inwestycje oraz projekty. O docelowym przeznaczeniu środków na wybrany cel decyduje komitet, komisja lub zebranie delegatów mieszkańców. Procedura zarządzania funduszem wpisana jest w programy miejskie, np. program remontowy. Mieszkańcy zgodnie z przyjętymi zasadami decydują o funduszu samodzielnie. Model ten znalazł zastosowanie w angielskim Bradford, którego mieszkańcy zdecydowali o umiejscowieniu większości inwestycji do realizacji w najbiedniejszych dzielnicach miasta.

Negocjacje publiczno-prywatne. W tym rozwiązaniu duże firmy lub/i organizacje międzynarodowe wnoszą pokaźny wkład finansowy do funduszu przeznaczanego na publiczne inwestycje oraz projekty. Ten typ modelu znalazł zastosowanie na terenie Płocka. W przypadku byłej stolicy Mazowsza, fundusz opiewał na kwotę 300000 euro, z czego 150000 euro pochodziło od mającej swoją siedzibę w regionie firmy naftowej - Orlen S.A. Pozostała część środków finansowych została wyłożona przez miasto oraz z funduszu Programu Narodów Zjednoczonych ds. Rozwoju. Finansowe wsparcie sektora prywatnego sprawiło, że miał on znaczny wpływ na kształt procedury i ostateczne oblicze budże- 
tu partycypacyjnego. W końcowym efekcie rola mieszkańców, występujących niejako w roli petentów proszących o pieniądze dla swoich projektów, została zmarginalizowana (http://siecobywatelska.pl). Przypadek Płocka pokazuje, że finansowy udział wielkich firm, w rodzaju korporacji czy koncernów, w budżetach partycypacyjnych stwarza poważne niebezpieczeństwo faktycznego odsunięcia mieszkańców od możliwości współdecydowania o sposobie wydawania wspólnych pieniędzy i de facto stanowi zaprzeczenie szczytnej idei.

Elementem wspólnym dla obu przedstawionych modeli jest występowanie funduszu przeznaczanego na inwestycje o charakterze publicznym oraz na projekty dotyczące spraw społecznych, kulturalnych lub ekologicznych. Procedury postępowania w odniesieniu do tworzenia budżetu partycypacyjnego są relatywnie niezależne i niezawisłe od budżetu miasta. Fundusze przeznaczone do dyspozycji mieszkańców nie pochodzą ani od nich samych, ani z kasy miejskiej. Tylko sporadycznie i raczej w rzadkich wypadkach może zaistnieć częściowy wkład miasta do funduszu. W efekcie władze samorządowe nie biorą bezpośredniego udziału w podejmowaniu decyzji dotyczących docelowego przeznaczenia środków finansowych.

Ad 3) Partycypacja sąsiedzka w największym stopniu znalazła zastosowanie na terenie Francji. Opiera się na wypracowanym w praktyce sposobie polegającym na „selektywnym wysłuchaniu” preferencji przybyłych mieszkańców w trakcie otwartej sesji rady miasta. Partycypacja sąsiedzka, opiera się na formule konsultacji władz lokalnych z mieszkańcami danej miejscowości. Wpływ obywateli na podejmowane decyzje jest niewielki. Podział środków finansowych na realizację planowanych przedsięwzięć i potrzebnych inwestycji odbywa się bez ich udziału.

Konsultowanie finansów publicznych wzorowane jest na rozwiązaniach znanych z nowoczesnego zarządzania w sferze publicznej (ang. New Public Management). Model ten stosowany jest w wielu jednostkach terytorialnych w Niemczech. Pomysłem inspirującym jego twórców były doświadczenia miasta Christchurch w Nowej Zelandii. Elementy procedur pochodzących z idei Porto Alegre zostały wprowadzone później. Kluczową rolę w modelu, podobnie jak przy partycypacji sąsiedzkiej, odgrywa element konsultacji społecznych. Władze lokalne mogą wysłuchać sugestii mieszkańców, ale nie mają obowiązku zastosowania się do nich. Model stanowi bardziej narzędzie usprawniania administracji publicznej niż instrument wpływu mieszkańców na sferę publiczną (http://siecobywatelska.pl).

W przypadkach obu modeli główną rolę odgrywają konsultacje władz lokalnych z miejscowym społeczeństwem. W trakcie tych spotkań nie odbywają się żadne głosowania czy też inne formy wyrażenia woli przez obywateli, które miałyby wpływ na oblicze finansów samorządowych. Konsultacje nie wpływają na rozwiazywanie najbardziej istotnych dla miejscowej ludności problemów 
natury egzystencjonalnej czy socjalnej. Przedstawione propozycje obywatelskie zależą w dużej mierze od uznania urzędników. Chociaż zarówno partycypacja sąsiedzka, jak i konsultowanie finansów publicznych zaliczane są do narzędzi tworzących demokrację bezpośrednią, to jednak trudno w nich dostrzec jakiekolwiek większe elementy tradycyjnie utożsamiane z budżetem partycypacyjnym działającym według wzorca brazylijskiego.

Doświadczenia, jakie powstały w naszym kraju w odniesieniu do stosowania budżetu partycypacyjnego, wskazują na uzasadnioną potrzebę dalszego promowania tego rozwiązania. Wbrew obawom dużej grupy sceptyków, mieszkańcy polskich miast z powodzeniem unieśli ciężar odpowiedzialności i udowadniają, że swoimi pieniędzmi potrafią dysponować bardzo rozważnie. Pojawiają się sugestie znacznego rozszerzenia uprawnień obywatelskich dotyczących publicznych pieniędzy. Przykładowo, autorzy Obywatelskiej Strategii Konina na lata 2013-2020 chcą, aby do roku 2018 wszystkie wydatki inwestycyjne zależały bezpośrednio od decyzji obywateli (Sikora, 2013, s. 22). Motywują to lepszą od władz orientacją mieszkańców oraz umiejętnością zauważania spraw dotyczących własnego otoczenia i wpływających na poprawę życia w mieście.

\subsubsection{Odwołanie}

Odwołanie (ang. Recall) to prawo wywodzące się z anglo-saksońskiej doktryny prawnej. Obecnie jako instrument demokracji bezpośredniej stosowany jest w niektórych stanach USA oraz w kilku państwach Ameryki Południowej. Daje ono obywatelom możliwość odwoływania urzędników pochodzący z wyborów powszechnych. Procedura odwołania polega na zebraniu odpowiedniej liczby podpisów z okręgu polityka lub wypowiedzeniu się, co do przyszłości takiej osoby, w głosowaniu w ramach specjalnego referendum.

Recall dotyczy najczęściej przedstawicieli władz lokalnych. Może zostać zastosowane w przypadku, gdy: dany działacz zmieni barwy partyjne, nie wywiązuje się z danych uprzednio wyborcom przyrzeczeń, jest zamieszany w aferę finansową lub skandal obyczajowy. W niektórych krajach cofnięcie mandatu skompromitowanemu politykowi wiąże się z jednoczesnym pozbawieniem go immunitetu. Daje to natychmiastową możliwość postawienia takiej osoby przed wymiarem sprawiedliwości (http://db.org.pl). Odwołanie stanowi narzędzie bezpośredniej kontroli nad etyką i trzymaniem się przyjętych ogólnie zasad przez wybrańców społeczeństwa. Jest potężnym środkiem w rękach zwykłych ludzi, dającym im możność wyegzekwowania obietnic przedwyborczych. Całkowicie likwiduje ono „tarczę partyjną” chroniącą, w niektórych przypadkach, członków jakiegoś ugrupowania przed zasłużonymi konsekwencjami, co ważne pozbawia polityków uczucia bezkarności wobec prawa i wyborców. W Polsce funkcję Recall pełni w pewnym sensie referendum w sprawie odwołania organu wykonawcze- 
go samorządu terytorialnego. Może dotyczyć pozbawienia pełnionej funkcji: prezydenta miasta, burmistrza, starosty lub wójta. Niestety instrument ten nie ma mocy sprawczej odwołania w stosunku do posłów i senatorów naszego Parlamentu.

\subsubsection{Zalety demokracji bezpośredniej na tle systemu demokracji pośredniej}

Omówione instrumenty demokracji bezpośredniej pozwalają w wielu przypadkach na uniknięcie problemów, jakie niesie ze sobą system demokracji pośredniej. Do najważniejszych zalet systemu umożliwiającego szerokiemu społeczeństwu uczestniczenie w podziale stojących do dyspozycji środków finansowych, wyborze realizacji najważniejszych dla niego przedsięwzięć oraz współzarządzanie zamieszkałym przezeń terenem należy zaliczyć:

- wzrost zadowolenia mieszkańców z poziomu życia, porównywalny do efektu, jaki przynosi zwiększenie dochodów indywidualnych;

- zaproszenie społeczeństwa do aktywnego zarządzania wespół z władzami lokalnymi na danym terenie;

- obniżenie stawek podatków i opłat miejscowych leżących w gestii władz lokalnych;

- nie uchylanie się od podatków przez podmioty fizyczne i prawne lub występowanie tego zjawiska w bardzo niewielkiej skali;

- większa akceptacja przez społeczeństwo poczynań władz lokalnych;

- zjawisko intensywnego napływu ludzi (zwiększonej imigracji) w celu osiedlania się i podjęcia pracy na obszarach stosujących rozwiązania demokracji bezpośredniej;

- wzrost cen gruntów oraz nieruchomości na obszarach, gdzie demokracja bezpośrednia występuje w zwiększonym zakresie;

- powiększenie się liczby obiektów infrastruktury socjalnej różnego przeznaczenia, takich jak: szpitale, szkoły, przedszkola, biblioteki, muzea, kina, teatry, opery, filharmonie, kluby jazzowe, parki rozrywki, centra popularyzujące naukę, baseny, parki wodne ze Spa, ośrodki fitness, masowe obiekty sportowe, np. hale, stadiony, tory kolarskie, lodowiska;

- aktywizacja mieszkańców do wzięcia udziału w procesie aktywnego wspó1decydowania w sprawach własnego terytorium;

- wywieranie inspirującego wpływu na proces tworzenia prawdziwie obywatelskiego społeczeństwa.

- zwiększenie dynamiki wzrostu PKB na głowę mieszkańca;

- koncentrowanie się na sprawach najbardziej istotnych dla społeczeństwa w skali lokalnej;

- nakłonienie lokalnego społeczeństwa do przejawiania większej spójności sąsiedzkiej i działań na rzecz swojego najbliższego otoczenia; 
- zmniejszenie dystansu pomiędzy obywatelami i władzami lokalnym;

- legitymizacja wśród mieszkańców kierunku polityki realizowanego przez ekipę rządzącą;

- zwiększenie przejrzystości procesu zarządzania środkami publicznymi;

- skuteczne zwalczanie zjawiska korupcji, lobbingu i innych nadużyć władzy;

- promowanie innowacyjności i przedsiębiorczości na danym terenie;

- skoncentrowanie wszystkich sił na przezwyciężeniu problemów najbardziej dokuczliwych dla społeczności lokalnej (w tym przede wszystkim egzystencjonalnych i socjalnych);

- umożliwienie władzom podejmowania wspólnie z mieszkańcami trudnych i bardzo często niepopularnych decyzji;

- uzyskiwanie od mieszkańców, niejako z „pierwszej ręki”, szczegółowych i zarazem niezwykle pożytecznych informacji dotyczących funkcjonowania organizmu miasta w różnych aspektach;

- sprzyjanie powstawaniu nowych podmiotów gospodarczych;

- stworzenie bardziej „Zwartego” planu dochodów i wydatków publicznych;

- wyrażenie za pomocą referendum, opinii i preferencji mieszkańców w konkretnej chwili;

- poprawienie stopnia znajomości obowiązujących przepisów prawnych i ich wykładni przez szerokie rzesze społeczeństwa;

- szybsze reagowanie na „palące” problemy lokalne;

- w przypadku stosowania referendum uniknięcie podejmowania przez polityków decyzji sprzecznych z wolą wyborców;

- danie obywatelom poprzez zastosowanie instrumentu, jakim jest referendum, możliwości głosowania w każdej, ważnej dla mieszkańców sprawie;

- zwiększenie „odporności” obywateli na różnego rodzaju próby nacisków i sugestii władz oraz „ukierunkowywania” wyników rozstrzygnięć;

- postawienie jako priorytetu wzrostu poziomu życia mieszkańców;

- zwiększenie bezpieczeństwa publicznego w lokalnym wymiarze.

Oczywiście, ustrój używający instrumentów demokracji bezpośredniej nie jest pozbawiony pewnych niedoskonałości. Za możliwe do zaistnienia (chociaż nie zawsze muszą wystąpić) wady demokracji bezpośredniej uważa się:

- uczestnictwo w procesie decyzyjnym ludzi nieprzygotowanych do tego pod względem merytorycznym oraz posiadanych kwalifikacji (jednakże ten zarzut dotyczy także demokracji pośredniej);

- znaczne wydłużenie się procesu decyzyjnego ze względu na potrzebę konsultacji społecznych;

- uaktywnienie się w momentach kryzysowych radykalnych frakcji lub ugrupowań społecznych;

- możliwość zanarchizowania procesu decyzyjnego; 
- niechęć do „obcych”, szczególnie w niewielkich jednostkach podziału administracyjnego, gdzie wszyscy mieszkańcy znają się wzajemnie;

- w przypadku braku tolerancji wśród lokalnego społeczeństwa, możliwość podjęcia przez taką wspólnotę postanowień krzywdzących mniejszości narodowe, wyznaniowe, zagranicznych robotników sezonowych itp.;

- niechęć znakomitej większości obywateli do udziału w trudnych i długotrwałych przedsięwzięciach politycznych;

- tendencje autonomiczne w gminach zdominowanych przez obce nacje; przykładem może być tutaj gmina „Nova Germania” w Szwajcarii, gdzie jej mieszkańcy, będący w większości bogatymi Niemcami, którym pozwolono na osiedlenie się w kraju Helwetów, całkowicie zmarginalizowali prawa i interesy rdzennych mieszkańców; sytuacja miała miejsce w latach osiemdziesiątych ubiegłego wieku; podobnie było w przypadku mieszkańców duńskiego miasteczka Kokkedal, którzy dowiedzieli się, że z powodu oszczędności na Boże Narodzenie w 2012 roku nie będzie już miejskiej choinki; przyczyną takiej decyzji rady miejskiej było zdominowanie tego ciała samorządowego przez napływowych obywateli wyznających islam; kuriozalnie brzmi informacja, że znalazły się natomiast pieniądze (w kwocie dziesięciokrotnie wyższej niż zakup choinki) na miejskie obchody muzułmańskiego Święta Ofiarowania (http://www.wykop.pl);

- zaangażowanie w proces tworzenia demokracji bezpośredniej tylko najbardziej aktywnych jednostek (jednakże może to dotyczyć także demokracji pośredniej);

- brak odpowiedzialności personalnej za błędnie powzięte decyzje (dotyczy to także, choć w mniejszym stopniu, demokracji pośredniej);

- przekonanie, że system demokracji bezpośredniej nadaje się lepiej dla państw o małej powierzchni terytorialnej (ale dobrze sprawdza się w odniesieniu do regionów - np. referenda kantonalne w Szwajcarii przyp. aut.);

- wybrane formy demokracji bezpośredniej (np. inicjatywa ustawodawcza, budżet partycypacyjny), zamiast zwiększać wpływ mieszkańców na przebieg spraw na danym terenie, mogą wzmacniać np. pozycję i znaczenie opozycyjnych partii politycznych;

- zdominowanie lokalnych przedsięwzięć i inwestycji przez projekty „populistyczne".

Przy okazji przeprowadzonych rozważań trzeba skonstatować, że w systemie demokracji bezpośredniej lista zidentyfikowanych wad jest znacznie krótsza od przedstawionej nieco wcześniej listy zalet. 


\subsubsection{Kierunki zmian we współczesnej demokracji}

Obecnie jesteśmy świadkami poważnego kryzysu demokracji w jej dotychczasowej postaci. Zjawisko ogólnoświatowego kryzysu ekonomicznego uwidoczniło w jaskrawy sposób wady demokracji pośredniej. Alienacja grup rządzących, nieporadność oraz nieskuteczność stosowanych działań naprawczych, oczekiwanie władz na dramatyczne wyrzeczenia ze strony społeczeństwa, rosnące bezrobocie czy wreszcie brak pomysłu na przyszłość spowodowały w ostatnich kilku latach falę demonstracji na całym świecie. Protesty przeciwko prowadzonej przez rządy poszczególnych krajów polityce przetoczyły się przez Stany Zjednoczone i większość krajów Europy. Ludzie organizowali się, aby zamanifestować na ulicach miast swój sprzeciw wobec nowych rozwiązań państwa w sferze socjalnej i finansowej. Ruch ten był oddolny i całkowicie spontaniczny. Za narzędzia umożliwiające niezadowolonym obywatelom koordynację działań służyły popularne, internetowe portale społecznościowe, takie jak Facebook i Twitter. Skala zjawiska globalnego sprzeciwu przekroczyła wszelkie oczekiwania. Uzmysłowiła jednocześnie potrzebę zmian w obrębie działającego do tej pory ustroju demokratycznego.

Przypomniane zostały ideały demokracji ateńskiej oraz teorie nieuchronności zmian i ewolucji systemów politycznych. Wobec całego szacunku do ,instytucji” demokracji, pojawiły się głosy o konieczności powrotu do jej pierwotnych źródeł i podstawowych zasad. W tym momencie, społeczeństwo wyraziło swą chęć aktywnego udziału w rządzeniu, projektowaniu zmian, urzeczywistnianiu decyzji, jakie zapadły, realizacji ważnych dla ludności inwestycji oraz współzarządzania (gospodarowania) dobrami materialnymi i niematerialnymi na zamieszkiwanym przez siebie terenie. Odpowiedzią na te postulaty było wprowadzenie na szeroką skalę do praktyki polityczno-ustrojowej instrumentów utożsamianych z demokracja bezpośrednią.

Niejako przy okazji przyjrzano się tym organizmom państwowym, w których ideały udziału obywateli w zarządzaniu są cały czas kultywowane. Największe nasycenie elementami demokracji bezpośredniej przewidują systemy ustrojowe Szwajcarii i Lichtensteinu w Europie oraz Australii na antypodach. Przykładowo, w okresie od końca XVIII do przedostatniej dekady XX wieku na całym świecie odbyło się nieco ponad 500 referendów o charakterze ogólnokrajowym. Ponad 300, co daje około 60\% wszystkich tego typu głosowań, odbyło się w Szwajcarii. Zaraz na drugim miejscu plasuje się Australia, gdzie było ich 40. Daje to w skali globalnej 8\% (Frey, 2010, s. 82). Jeśli chodzi o referendum w Lichtensteinie, to ma ono specyficzną konstrukcję prawną pozwalająca zawetować jego wynik panującemu aktualnie Wielkiemu Księciu (http://www.spiegel.de). W tym, położonym pomiędzy Austrią a Szwajcarią, państewku odbywa się, z różnym nasileniem, kilka (od 2 do 5) głosowań referendalnych rocznie. Jednakże najciekawszą informacją 
jest, że wszystkie te państwa poradziły sobie bez kłopotu z panującym kryzysem, a ich gospodarka rozwija się obecnie w zrównoważony sposób, chociaż mówiąc o Australii trzeba tu użyć raczej słowa - rozkwita.

Australia znajduje się na czele listy krajów uprzemysłowionych, w których pracuje i żyje się najlepiej. Dane pochodzą z rankingu sporządzanego przez Organizację Współpracy Gospodarczej i Rozwoju (OECD), przy użyciu tzw. indeksu lepszego życia (ang. Better Life Index). Wskaźnik OECD bierze pod uwagę takie kryteria, jak: zatrudnienie, dochody, stan środowiska naturalnego, bezpieczeństwo, służba zdrowia oraz zadowolenie z życia obywateli. Wynik Australii, w każdej z 11 kategorii stanowiących podstawę naliczania indeksu, wysuwa ją na trzecie miejsce na świecie po Szwecji i Kanadzie. Gospodarce australijskiej w znacznej mierze udało się uniknąć kłopotów, jakie dotknęły w następstwie kryzysu finansowego inne kraje rozwinięte. Ten najmniejszy z kontynentów kontynuuje rozwój gospodarczy i ma już za sobą 21 lat bez recesji. Bezrobocie wynosi w tym kraju 5,5\% (dane z kwietnia 2013 roku), podczas gdy w strefie euro wynosi on 12,1\% (http://wiadomosci.gazeta.pl). Bardzo ciekawie prezentuje się porównanie wybranych elementów cytowanego indeksu dla Australii, Szwajcarii i Polski.

Tablica 42. Porównanie wybranych kategorii Better Life Index dla Australii, Szwajcarii i Polski

\begin{tabular}{|l|c|c|c|}
\hline \multicolumn{1}{|c|}{ Kategoria* } & Australia & Szwajcaria & Polska \\
\hline Zadowolenia z życia & 8,1 & 10,0 & 3,8 \\
\hline Satysfakcja z pracy i pewność jej zachowania & 7,6 & 8,9 & 5,2 \\
\hline Poziom dochodów & 4,5 & 7,8 & 1,0 \\
\hline
\end{tabular}

* Odczucia ankietowanych liczone były w skali: 0-10 (dane za 2012 r.).

Źródło: opracowanie własne na podstawie: http://www.oecdbetterlifeindex.org.

Przytoczone elementy Better Life Index ukazują brak zadowolenia Polaków z dochodów, jakie osiągają oraz bardzo niską satysfakcję (zadowolenie) z życia jakie wiodą. Obywatele naszego kraju są za to relatywnie zadowoleni z zawodu, jaki wykonują, chociaż według danych tego z samego źródła, czas ich pracy jest znacznie dłuższy od średniego dla 34 krajów należących do OECD. Każdy obywatel Rzeczypospolitej pracuje statystycznie w ciągu roku 1937 godzin, przy średniej OECD wynoszącej 1776 godzin. Daje to w ciągu dwunastu miesięcy liczbę 161 godzin więcej. Dzieląc to przez długość dnia pracy, wynosząca 8,5 godziny, Polacy pracują w rezultacie prawie 19 dni w roku dłużej niż obywatele innych państw uprzemysłowionych. 
Nie można jednoznacznie określić, jak duży wpływ na poziom zadowolenia życiowego, jakość wykonywanej pracy oraz ostateczny sukces gospodarczy ma demokracja bezpośrednia w tych krajach. Wiadomo jednak, że co roku dziesiątki tysięcy ludzi starają się o możliwość osiedlenia i podjęcia pracy w Szwajcarii, Lichtensteinie i Australii. O ile Australia chętnie przyjmuje młodych i wykształconych imigrantów, o tyle w pozostałych krajach panują w tym względzie dość surowe ograniczenia. Polityka władz australijskich opiera się na założeniu, że pozyskiwanie wartościowych specjalistów przyczynia się w efekcie do rozwoju całego kraju. Podobnie jest w Szwajcarii, gdzie dużą szansę na znalezienie dla siebie miejsca na stałe mają przede wszystkim ludzie młodzi i wykształceni lub też specjaliści, najlepiej w poszukiwanych zawodach (np. informatycy i inżynierowie, ale także wybitni artyści). W Lichtensteinie, uważanym dodatkowo za jeden z rajów podatkowych, szansa na otrzymanie obywatelstwa jest wyjątkowo nikła. Istnieją jednakże okoliczności, w których można to osiągnąć. Wielki Książę Franciszek Józef II - poprzednik obecnie panującego Jana Adama II - wprowadził dekret, na mocy którego obywatelstwo może otrzymać każdy obcokrajowiec, który poślubi najstarszą, niezamężną córkę w rodzinie i będzie mógł się wykazać przykładną troską o małżeństwo przez co najmniej dziesięć lat jego trwania. $\mathrm{Z}$ pozoru dość zabawny przepis zapewnia w praktyce brak niezamężnych kobiet w tym kraju i jednocześnie zjednuje potomkom rodziny panującej nieustającą przychylność ze strony wszystkich obywatelek Lichtensteinu. Niedobór siły roboczej Księstwo rozwiązuje „importując” potrzebnych ludzi przede wszystkim z innych państw niemieckojęzycznych: Niemiec i pobliskich Austrii oraz Szwajcarii.

Powracając do zagadnień demokracji bezpośredniej, w trakcie organizacji wystąpień społecznych i protestów w Europie, okazało się, że przezwyciężona została największa bariera, czyli problem prawie jednoczesnego i bezpośredniego udziału wielosettysięcznej liczby obywateli w podejmowaniu ważnych decyzji i rozstrzygnięć. Problem rozwiązuje korzystanie z Internetu. Można założyć, że tzw. e-demokracja (poprzez elektroniczne głosowanie) jest już dzisiaj w pełni realna. Przykład Dąbrowy Górniczej, gdzie wybór projektów do realizacji w ramach budżetu partycypacyjnego umożliwiony został, obok konwencjonalnych sposobów, za pomocą przesłania informacji w formie elektronicznej, wskazuje, że jesteśmy już tylko krok od powszechnego udziału obywateli w rządzeniu na danym terenie. Istnieje jednak pewien problem dotyczący osób, które w nie mają jeszcze dostępu do Internetu. W tych stosunkowo nielicznych przypadkach musiałyby one oddać swoje głosy w tradycyjny sposób lub za pośrednictwem komputera w wyznaczonym do tego urzędzie miasta lub gminy, po uprzednim potwierdzeniu własnej tożsamości. To, że otaczający nas świat uległ bezpowrotnym zmianom i ewoluuje w kierunku demokracji bezpośredniej, wykorzystującej zdobycze obecnej nauki i techniki, staje się na naszych oczach faktem. 
Nieuchronność kierunku zmian jest już jakby przesądzona. Ludzie żyjący w dzisiejszych czasach coraz bardziej zdają sobie sprawę nie tylko z obowiązków obywatelskich, jakie na nich ciążą, lecz także z pragnień i planów, które chcieliby zrealizować na zamieszkanym przez siebie terenie. Umożliwia im to posiadana wiedza życiowa, nabyte $\mathrm{w}$ toku pracy zawodowej doświadczenie i zdobyte wykształcenie. Biorąc odważnie sprawy w swoje ręce, odsuwają na bok nieudolną administrację, opieszałych urzędników, karierowiczów i tych wszystkich, którzy gonią za wymiernymi korzyściami. Dobrym przykładem takiej postawy jest ruch, jaki powstał po kryzysie finansowym na Islandii.

Islandczycy inicjatywą oddolną doprowadzili do dymisji rządu, który aprobował sugestie światowego lobby finansowego zmierzające do radykalnych oszczędności, wyrzeczeń i zubożenia społeczeństwa (zgodnie ze scenariuszem aktualnie „przerabianym” przez Grecję). Główne banki w Islandii zostały znacjonalizowane, a mieszkańcy wyspy zdecydowali w referendum o zadeklarowaniu niewypłacalności długu (około 93\% głosujących było za takim rozwiązaniem), który został zaciągnięty przez prywatne banki w Wielkiej Brytanii i Holandii. Doprowadzono również do powołania nowego Zgromadzenia Narodowego w celu ponownego spisania konstytucji. Tworzą ja obywatele, którzy zyskali poparcie społeczne, są pełnoletni i, co najważniejsze, nie należą do żadnej partii politycznej (http://www.zbuntowaniobywatele.pl). Praca nowej rady konstytucyjnej ma się zakończyć przedstawieniem przygotowanej ustawy zasadniczej, a następnie poddaniem jej pod głosowanie w najbliższych wyborach. W tej chwili obywatele tego skandynawskiego państwa aktywnie uczestniczą $\mathrm{w}$ unikatowym procesie legislacyjnym za pomocą swoich komputerów i łączy internetowych. Jak twierdzą eksperci, Islandia, ze swoimi zaledwie 320 tys. mieszkańców, jest idealnym miejscem dla szerokiej i wyrażonej w bezpośredni sposób ustawodawczej inicjatywy obywatelskiej (http://www. guardian.co.uk/world/2013/apr/25/reykjavik-mayor-digital-democracy). W ciagu zaledwie trzech lat od ciężkiego załamania finansowo-ekonomicznego mały kraj, położony na północnym Atlantyku, wszedł na ścieżkę szybkiego wzrostu gospodarczego. Obywatele Islandii pokazali dobitnie, że ci, którzy się nie sprawdzili, nie mogą dalej zarządzać państwem, a metody, które zawiodły, powinny być raz na zawsze zmienione.

Wiele osób zadaje sobie słuszne pytanie, dlaczego rozwiązanie, które z powodzeniem zadziałało na północnym krańcu Europy nie znajduje zastosowania w położonej na samym południu tego samego kontynentu bankrutującej Grecji. Niektórzy upatrują tutaj obawy przed „złym przykładem”, jaki mógłby mieć katastrofalne skutki dla całej Unii Europejskiej i związanego z jej strukturami establishmentu. 


\section{Wzmocnienie atrakcyjności inwestycyjnej regionów słabiej rozwiniętych}

Regiony słabiej rozwinięte posiadają wiele zalet i unikatowych wartości, które sprawiają, że mogą być bardzo atrakcyjne jako miejsce inwestycji krajowych i zagranicznych. Inwestycje gwarantują terenom, na których powstają, dynamiczny rozwój oraz stałe zwiększanie się poziomu życia mieszkańców, co powoduje, że są elementem bardzo pożądanym. Dzięki nim tworzone są nowe miejsca pracy, rośnie konsumpcja, następuje postęp cywilizacyjny, powstają lokalne bieguny wzrostu, ludzie wyrażają większe zadowolenie i satysfakcję z życia. Posługując się przykładem pięciu województw Polski Wschodniej, udało się zidentyfikować czynniki, które mają wpływ na podniesienie atrakcyjności inwestycyjnej regionów. Należą do nich, przede wszystkim:

- niższe koszty pracy (niskie koszty zatrudnienia);

- praktycznie niewyczerpany rezerwuar siły roboczej;

- przychylność władz lokalnych dla potencjalnych inwestorów;

- istnienie dużej liczby relatywnie tanich i atrakcyjnie położonych terenów pod inwestycje;

- duża ilość firm poszukujących inwestorów strategicznych;

- występowanie w każdym z pięciu województw specjalnych stref ekonomicznych oferujących inwestorom zwolnienie z podatku dochodowego, wyższe stawki amortyzacji, a także możliwość zakupu lub wynajmu już istniejących na danym obszarze nieruchomości;

- chęć podjęcia współpracy z biznesem miejscowych wyższych uczelni reprezentujących każdy profil;

- specjalizacja regionalna w niektórych branżach, np. przemyśle lotniczym oraz maszynowym w województwie podkarpackim, przemyśle spożywczym w lubelskim, mleczarstwie w regionie podlaskim czy przemyśle meblarskim w województwie warmińsko-mazurskim;

- przyszłe możliwości rozwojowe, np. rozwój przemysłu gazowniczego i wydobywczego istniejących zasobów gazu łupkowego na terenie wszystkich regionów Polski Wschodniej;

- niewielka w skali zjednoczonej Europy odległość od wiodących w naszym kraju ośrodków metropolitalnych, takich jak: Trójmiasto, Warszawa, Łódź czy Kraków;

- zwiększająca się liczba autostrad i dróg szybkiego ruchu przecinających regiony słabo rozwinięte;

- istnienie krajowych i międzynarodowych portów (połączeń) lotniczych;

- unikatowe walory krajobrazowe;

- liczne zabytki i pomniki architektury; 
- bogata historia oparta na burzliwej i barwnej przeszłości;

- duża atrakcyjność turystyczna;

- edukacja na każdym poziomie i możliwość rozwoju intelektualnego;

- istnienie potrzebnej infrastruktury kulturalnej, takiej jak: teatry, kina, biblioteki, imprezy regionalne, wyposażenie sportowe (stadiony, hale, kluby), hotele oferujące każdy standard usług i wypoczynku;

- odnotowywany stały wzrost PKB w poszczególnych regionach i na głowę jednego mieszkańca;

- relatywnie duża ilość firm należących do kluczowego dla gospodarki sektora małych i średnich przedsiębiorstw;

- znacząca pomoc finansowa pochodząca z funduszy unijnych dla przedsięwzięć publicznych oraz prywatnych;

- bliskość dużych rynków zbytu za wschodnią granicą Polski (Ukraina, Białoruś, Litwa, Łotwa, Estonia, Rosja, a także Słowacja);

- zakrojona na szeroką skalę akcja medialna reklamująca unikatowe cechy opisywanego obszaru;

- rosnąca efektywność współpracy międzyregionalnej i transgranicznej omawianych terenów;

- duża liczba działających instytucji z otoczenia biznesu;

- ekologiczne rolnictwo;

- bogaty wachlarz dostępnych surowców naturalnych;

- cenne źródła leczniczych wód mineralnych (np. Busko-Zdrój i SolecZdrój);

- zróżnicowanie etniczne i bogactwo folklorystyczne;

- stosunkowo dobrze rozwinięta infrastruktura turystyczna w postaci bazy noclegowej (hotele, motele, zajazdy, noclegi prywatne), sieci restauracji, ścieżek rowerowych, zabytkowych linii kolejowych;

- dłuższy statystycznie o dziewiętnaście dni (161 godzin) czas pracy (średnia dla Polski) na tle krajów uprzemysłowionych, należących do OECD;

- korzystne dla pracodawców formy zatrudnienia (np. „umowy śmieciowe);

- będąca w trakcie realizacji sieć Internetu szerokopasmowego;

- przychylność i zainteresowanie władz centralnych sprawami Polski Wschodniej.

Wśród wymienionych powyżej znalazły się tylko czynniki mające znaczenie dla postrzegania pięciu najsłabiej rozwiniętych województw jako atrakcyjnego miejsca pod inwestycje. Należy jeszcze do nich dodać ustawiczny proces zmniejszania się dystansu w rozwoju gospodarczym pomiędzy EU-27 a Polską Wschodnią, liczony takimi wskaźnikami, jak: regionalny PKB dla opisywanych obszarów i PKB per capita, napływ bezpośrednich inwestycji zagranicznych (BIZ) czy wzrost ilości spółek handlowych działających przy udziale kapitału 
zagranicznego na tym terenie. Jednocześnie trzeba przypomnieć, wykazany w niniejszej pracy, postępujący wzrost różnic rozwojowych (w sensie ekonomicznym) pomiędzy województwami centralnym i pięcioma regionami Polski Wschodniej. Jest to tendencja dokładnie przeciwna do, zakładanego przez polskie władze i najwyższe gremia w Unii Europejskiej, procesu mającego na celu wzrost spójności społeczno-ekonomicznej i konwergencji gospodarczej Wspólnoty. Zainwestowane wielomiliardowe środki finansowe, pochodzące z zasobów państwowych oraz z budżetu Unii Europejskiej, okazały się w tym wypadku mało skuteczne. Co więcej spora grupa eurosceptyków wykazuje, opierając się na oficjalnych informacjach, że przez dziewięć lat poprzedzających wstąpienie Polski do struktur Wspólnoty nasz kraj rozwijał się szybciej niż w okresie członkostwa naszego państwa w Unii Europejskiej (Cukiernik, 2013, s. 14-18). Na poparcie tych faktów przytaczają oni interesujące dane (tab. 43).

Tablica 43. Wybrane dane i wskaźniki dotyczące okresów przed i po wstąpieniu Polski do Unii Europejskiej

\begin{tabular}{|c|l|c|c|}
\hline Lp. & \multicolumn{1}{|c|}{ Kategoria } & $\mathbf{1 9 9 5 - 2 0 0 3 / 4}$ & $\mathbf{2 0 0 4 - 2 0 1 2 / 1 3}$ \\
\hline 1. & Wzrost PKB & $46,2 \%$ & $38,8 \%$ \\
\hline 2. & Inflacja & $108,0 \%$ & $31,2 \%$ \\
\hline 3. & $\begin{array}{l}\text { Wzrost handlu zagranicznego } \\
\text { z uwzględnieniem inflacji }\end{array}$ & $130,0 \%$ & $58,0 \%$ \\
\hline 4. & Wzrost inwestycji z uwzględnieniem inflacji & $22,0 \%$ & $60,0 \% *$ \\
\hline 5. & $\begin{array}{l}\text { Wzrost średnich wynagrodzeń } \\
\text { z uwzględnieniem inflacji }\end{array}$ & $56,0 \%$ & $18,0 \%$ \\
\hline 6. & Bezpośrednie inwestycje zagraniczne (BIZ) & 48,4 mld euro & 97,8 mld euro \\
\hline 7. & Lączny deficyt budżetowy & 256,5 mld złotych & 547 mld złotych \\
\hline
\end{tabular}

* Według danych za rok 2011.

Źródło: Cukiernik (2013, s. 17).

Wśród zaprezentowanych w tablicy 43 danych ogromny niepokój wzbudza rosnący już lawinowo łączny deficyt budżetowy państwa. Można przypuszczać, że nawet drastyczne oszczędności i przyjście koniunktury gospodarczej nie zmienią faktu, że jeszcze następne pokolenia będą musiały spłacać ten dług. Ponad trzykrotne zwolnienie wzrostu średnich wynagrodzeń odczuwamy wszyscy bardzo dotkliwie. Zjawisko to ogranicza konsumpcję oraz jest barierą budowy zamożnego społeczeństwa. Mniejszą dynamikę polskiego PKB w latach 2004-2012/13 można wytłumaczyć, nasilającym się już od 2007 roku, świato- 
wym kryzysem w dziedzinie finansów. Cieszyć natomiast może wzrost inwestycji, w tym bezpośrednich inwestycji zagranicznych (BIZ), oraz spowolnienie tempa narastania inflacji pochłaniającej w okresie poprzednich dziewięciu lat (1995-2003/4) oszczędności obywateli naszego kraju. Średnie wynagrodzenie w okresie od 2004 do 2012 roku wzrosło o blisko 54\%. W roku 2004 wynosiło 2289 zł, a w 2012 r. zwiększyło się do kwoty 3521 złotych. W czerwcu 2013 r. średnie wynagrodzenie wyniosło 3740 złotych.

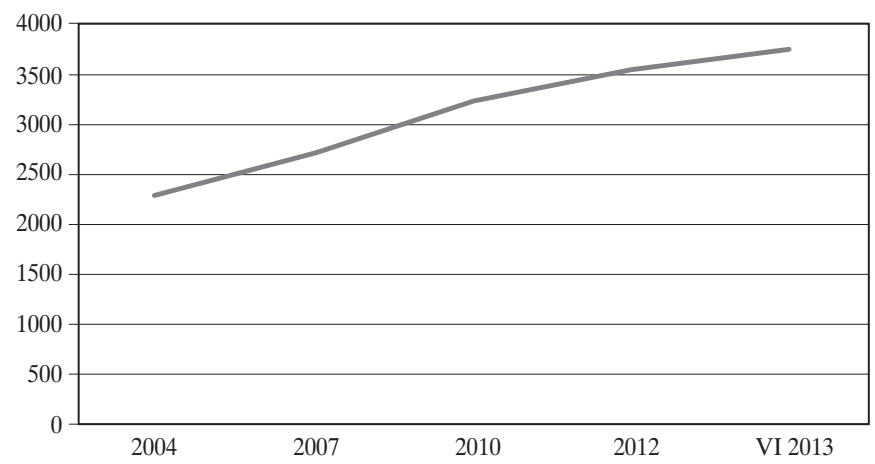

Rysunek 36. Wzrost średniego wynagrodzenia w Polsce, od 2004 do czerwca 2013 r. (w zl)

Źródło: opracowanie własne na podstawie danych GUS.

W Polsce odnotowuje się stały wzrost średnich wynagrodzeń. Jednakże, jak można to zauważyć na rysunku 36, przebiegał on szybciej w latach 2004-2010 niż w późniejszym okresie. Analizując dane z rysunku 36, warto jest się przyjrzeć, ile można kupić za średnią pensję (na przykładzie wybranych towarów) w latach 2004 i 2013 (tab. 44).

Przytoczone za Głównym Urzędem Statystycznym dane uwidaczniają, że Polska rozwijała się jednak szybciej w okresie dziewięciu lat przed wstąpieniem do UE niż w ciągu dziewięciu lat po wstąpieniu do europejskiego ugrupowania integracyjnego. Niestety średnie wynagrodzenie w Polsce pozwala na coraz skromniejsze życie. Widać to wyraźnie na podstawie danych umieszczonych w tablicy 44. Jedynie mięsa drobiowego (kurczak) i wieprzowiny w roku 2013 można nabyć większą ilość niż w 2004 roku. Za takie towary, jak: benzyna, ON, papierosy, prąd, gaz, cukier, chleb czy mleko trzeba dzisiaj zapłacić od kilku do kilkudziesięciu procent więcej niż w momencie wstąpienia Polski do Unii.

W tym miejscu należy powrócić do pytań zadanych w punkcie 3. rozdz. VII: czy wykorzystane zostały już wszystkie możliwości leżące w modelu endogenicz- 
Tablica 44. Ile można kupić za średnią płacę w Polsce. Porównanie lat 2004 i 2013

\begin{tabular}{|r|l|c|c|c|}
\hline Lp. & \multicolumn{1}{|c|}{ Artykul } & $\mathbf{2 0 0 4}$ & $\mathbf{2 0 1 3}$ & Różnica (w \%) \\
\hline 1. & Mieszkanie $\left(\mathrm{m}^{2}\right)$ & 0,89 & 0,88 & $-1,9$ \\
\hline 2. & Grunty rolne (ha) & 0,50 & 0,13 & $-73,1$ \\
\hline 3. & Benzyna 95 oktan (litry) & 715 & 661 & $-7,8$ \\
\hline 4. & ON (litry) & 818 & 663 & $-18,9$ \\
\hline 5. & Papierosy (ilość paczek) & 498 & 304 & $-39,0$ \\
\hline 6. & Prąd (kWh, Warszawa) & 5723 & 5103 & $-10,8$ \\
\hline 7. & Gaz ziemny (m³) & 1990 & 1386 & $-30,4$ \\
\hline 8. & Woda i odprowadzanie ścieków $\left(\mathrm{m}^{3}\right)$ & 293 & 283 & $-3,5$ \\
\hline 9. & Chleb (szt.) & 1761 & 1531 & $-13,1$ \\
\hline 10. & Wołowina (kg) & 208 & 134 & $-35,4$ \\
\hline 11. & Wieprzowina (kg) & 186 & 220 & $+18,3$ \\
\hline 12. & Kurczak (kg) & 458 & 476 & $+3,9$ \\
\hline 13. & Mleko (litry) & 1761 & 1354 & $-23,1$ \\
\hline 14. & Cukier (kg) & 1205 & 927 & $-23,1$ \\
\hline
\end{tabular}

Źródło: Cukiernik (2013, s. 17).

nego wzrostu regionalnego; czy istnieją uwarunkowania, w których udałoby się zwiększyć atrakcyjność regionu bez konieczności znacznych nakładów finansowych; czy można zachęcić szerokie rzesze społeczne do napływu na określone tereny, a w konsekwencji ściągnięcia przez nie kapitału i inwestycji?

Odpowiedź na pierwsze pytanie brzmi „tak”. Co więcej, jak się wydaje, obecnie większe możliwości leżą w modelu endogenicznego wzrostu regionalnego niż w modelu egzogenicznym stosowanym w Polsce. W przypadku naszego kraju model egzogeniczny zakłada przede wszystkim nieustanne finansowanie rozwoju regionalnego oparte na wielomiliardowych środkach finansowych pochodzących z kraju i z zagranicy. Jak wykazała przeprowadzona analiza, model ten staje się coraz mniej efektywny, a w niektórych przypadkach przynosi skutki przeciwne do założonych.

Odpowiedź na drugie pytanie również jest twierdząca. W tym przypadku „tak” oznacza sukcesywną zmianę ustroju z niewydolnej i przeżywającej dotkliwy kryzys demokracji pośredniej w kierunku demokracji zakładającej zwiększony udziału obywateli w życiu publicznym. Odnosi się to zarówno do inicjatywy 
oddolnej, jak i przywileju podejmowania decyzji dotyczących zarządzania danym terenem przez osiadłych na nim mieszkańców.

Odpowiedź na trzecie pytanie to również „tak”. Przykłady takich państw, jak: Szwajcaria, Lichtenstein, Australia czy Brazylia pokazują, że istnieje związek pomiędzy panującym ustrojem a napływem imigrantów do wymienionych krajów. Brazylia, znana na świecie z eksperymentu zapoczątkowanego w Porto Alegre, stała się w ostatnich kilku latach „portem docelowym” dla dziesiątek tysięcy młodych Hiszpanów i Portugalczyków szukających miejsca do pracy i życia. Nie można oczywiście przesądzać czy o decyzji osiedlenia się w wymienionych państwach w większej mierze zdecydował rozkwit gospodarczy, czy rozszerzone prawa obywatelskie. Można jednak założyć, że takie czynniki, jak zwiększone zapotrzebowanie na wszelkich specjalistów ${ }^{3}$ oraz demokracja bezpośrednia tworzą w sumie pożądany efekt wzrostu atrakcyjności określonych terenów. Dlatego należy się na nich spodziewać przyspieszonego rozwoju infrastruktury społecznej oraz „inwestycji wynikowych” związanych z dynamicznym napływem ludności oraz zaistnieniem wymienionych w poprzednim zdaniu zjawisk.

\section{Zarys koncepcji zwiększenia udziału obywateli w zarządzaniu regionem}

Należy stwierdzić, że istnieje jeszcze duży potencjał w rozwiązaniach endogenicznych, który może zadziałać stymulująco na wzrost atrakcyjności obszarów Polski Wschodniej. Procesem, który to umożliwia, jest wprowadzenie do funkcji administracyjnej regionów zwiększonej ilości elementów demokracji bezpośredniej. Proces ten można rozłożyć na dwa etapy

Etap I polegałby na wprowadzeniu, na wszystkich poziomach samorządu terytorialnego, systemu opartego na budżecie partycypacyjnym. Oczywiście wdrożenie nowych rozwiązań powinno bezwzględnie zostać poprzedzone szeroką akcją edukacyjną, przeprowadzaną za pomocą mediów publicznych. $\mathrm{Na}$ niższych szczeblach samorządu mógłby być on wprowadzany najpierw w gminach miejskich, potem zaś w miejsko-wiejskich. Dopiero trzecim krokiem byłoby zaprowadzenie go w gminach wiejskich. Pomocnym instrumentem umożliwiającym głosowanie na większych obszarach (na przykład całego województwa) byłby Internet. Osoby nieposiadające dostępu do komputera mogłyby oddać swój głos w urzędach (miasta, miejskim lub gminy). Żadne zmiany konstytucyjne nie są w tym przypadku konieczne, ponieważ strukturę organizacyjną oraz zasady

3 Związane ze zbliżającymi się mistrzostwami świata w piłce nożnej, w 2014 roku oraz Igrzyskami XXXI Olimpiady w Rio de Janeiro w 2016 r. 
funkcjonowania urzędu określa regulamin (nadany przez wójta, burmistrza lub prezydenta miasta) w drodze zarządzenia (Dz. U. z 2001 r. Nr 142, poz. 1591). $\mathrm{Na}$ wyższych szczeblach samorządu nie ma przeszkód, aby głosowanie mogło się odbywać w starostwie powiatowym (Dz. U. z 1998 r. Nr 91, poz. 578) lub w urzędzie wojewódzkim (Dz. U. z 1998 r. Nr 91, poz. 576). Prostsza byłaby możliwość skorzystania z Internetu sąsiadów lub rodziny, jednakże takie rozwiązanie wymaga opracowania dodatkowego systemu weryfikującego tożsamość wyborców.

Jeśli chodzi o sam instrument, jakim jest budżet partycypacyjny, to jego wprowadzenie na szeroką skalę jest już w tej chwili możliwe i zgodne z obowiązującym w Polsce prawem. Mieści się w ramach przepisów legislacyjnych jako „umowa społeczna” zawierana pomiędzy mieszkańcami i radnymi. Może być więc legalnie wprowadzany $w$ gminach, dzielnicach i innych jednostkach samorządu. Przychylni radni mogą określić kwotę wydzieloną z ogólnego budżetu własnej jednostki. Uzyskane w ten sposób pieniądze zostaną przeznaczone na określone cele, zgodnie z wolą mieszkańców wyrażoną w otwartym głosowaniu. Procedura podejmowania decyzji może być tak dostosowana do lokalnych warunków, aby mogła wyłonić te propozycje mieszkańców, które mają największe poparcie społeczne i mogą zostać wpisane do budżetu (https://mac. gov.pl). Nasuwają się tutaj trzy uwagi:

1) wdrożenie budżetu partycypacyjnego uzależnione jest w naszym kraju w dużej mierze od świadomości obywatelskiej i dobrej woli radnych;

2) trudno spodziewać się przychylności dla takiego rozwiązania na poziomie jednostek samorządu terytorialnego, często borykających się z poważnymi problemami natury finansowej;

3) to radni określają kwotę wydzielona z ogólnego budżetu jednostki.

Aby więc to narzędzie demokracji bezpośredniej mogło być w Polsce szerzej stosowane, powinno zostać wprowadzone na drodze obowiązującego powszechnie prawa (ustawy sejmowej), a nie dobrej woli urzędników.

Pierwszy krok etapu II polegałby na zmianach ustawowych, które dawałyby referendom ogólnokrajowym moc wiążącą dla władzy wykonawczej przy jednoczesnym obowiązku ich zorganizowania, w przypadku zebrania odpowiedniej ilości podpisów pod wnioskiem o ich przeprowadzenie. Zmiana przepisów w tym zakresie stała się już niejako obowiązkiem naszego parlamentu, ze względu na coraz bardziej stanowcze próby dochodzenia swoich praw przez obywateli. W ostatnim czasie $\mathrm{z}$ masowym poparciem spotkały się inicjatywy społeczne służące próbom zorganizowania głosowań ludowych na temat: wieku emerytalnego (około 2,5 mln podpisów pod wnioskiem) oraz obowiązku szkolnego dla sześciolatków (950 tys. podpisów). Należy również wspomnieć o referendach 
lokalnych, przy czym tylko w ciągu ostatnich kilku miesięcy doszło do wszczęcia kilkunastu procedur z nimi związanych. Najbardziej medialne były: odwołanie władz Elbląga, referendum w sprawie odwołania burmistrza Zakopanego, zbieranie podpisów w celu zorganizowania referendum odwołującego prezydentów Łodzi, Warszawy i Rzeszowa.

Jeśli chodzi o sama literę przepisów dotyczących referendów w Polsce, to powinny one dotyczyć każdej istotnej sprawy, której rozstrzygniecie leży w interesie społecznym. Chodzi tu również o rozwiązania gospodarcze i konstytucyjne.

Krok drugi to stworzenie, na wzór szwajcarski (Sarnecki, 2013, s. 306), odpowiedników wszelkich rozwiązań stosowanych na szczeblu ogólnokrajowym, również w regionach. Oznaczało by to znaczne zwiększenie autonomii poszczególnych województw albo ich związków, np.: makroregionów według nomenklatury unijnej - NUTS 1, albo przy udziale innego kryterium podziału (chociażby traktowane razem pięć województw Polski Wschodniej). Należy tylko przypomnieć, że w polskich uregulowaniach prawnych istnieje już instrument, jakim jest obywatelska inicjatywa ustawodawcza. Natomiast w rozszerzonym zakresie referendum można by objąć takie instrumenty, jak weto ludowe i odwołanie.

Z rysunku 37 wyraźnie wynika, że podział dla celów statystycznych NUTS 1 nie pokrywa się z pojęciem Polski Wschodniej, stworzonym dla celów pomocy i wsparcia finansowego (krajowego oraz unijnego). W przedstawionym na mapce regionie wschodnim nie ma województwa warmińsko-mazurskiego. Zostało ono według nomenklatury NUTS przypisane do regionu północnego.

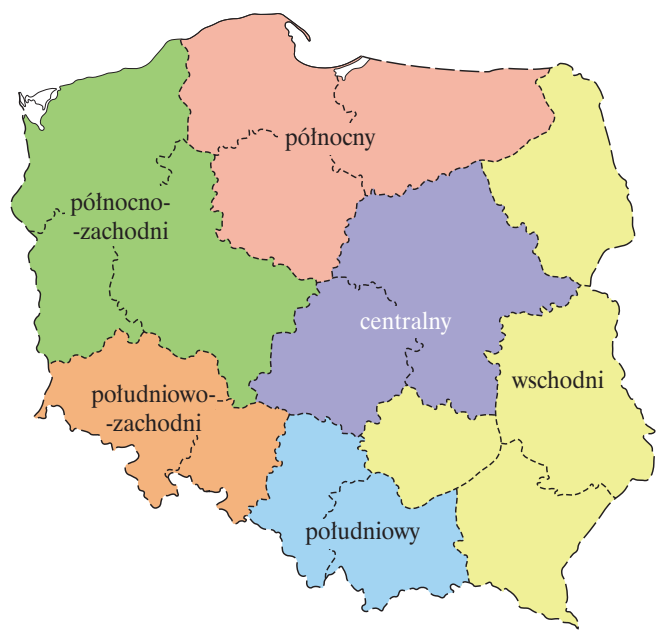

Rysunek 37. Makroregiony w Polsce (NUTS 1) według unijnej nomenklatury dla celów statystycznych

Źródło: http://www.iluminaci.pl/info/nuts-i-polska. 
Przyznanie zwiększonej autonomii poszczególnym regionom może przebiegać przez kontynuowanie procesu zrzekania się kompetencji przez władze centralne na rzecz samorządów albo poprzez szukanie rozwiązań federacyjnych. W tej chwili model ustroju federacyjnego przyjęło kilka najbardziej liczących się lub przodujących w sferze gospodarczej państw na świecie, m.in. Australia, Stany Zjednoczone Ameryki, Kanada, Meksyk, Indie, Argentyna, Rosja czy Brazylia. Argumentowi, że federacyjność sprawdza się jedynie w przypadku dużych krajów przeczą przykłady dużo mniejszych organizmów państwowych opartych na wymienionej zasadzie ustrojowej, takich jak: Republika Federalna Niemiec, Belgia, Austria, Szwajcaria, Zjednoczone Emiraty Arabskie, Bośnia i Hercegowina czy Nepal. W tej chwili na całym świecie jest około trzydziestu państw opartych na związku federacyjnym. Jest to z pewnością rozwiązanie nowoczesne, dające znacznie większe możliwości i różnorodność stosowania rozwiązań o charakterze ekonomiczno-społecznym i prawnym, nawet na sąsiadujących ze sobą terenach jednego państwa. Warto wspomnieć, że samo rozwiązanie znane jest ze starożytności. Po raz pierwszy zostało zastosowane w starożytnej Helladzie, gdzie greckie polis podporządkowały się w sprawach zagranicznych rosnącej w siłę Macedonii ${ }^{4}$, zachowując jednak niezależność w sprawach wewnętrznych.

Państwa federalne posiadają wspólny (federalny) rząd i niektóre służby publiczne (na przykład: FBI w USA) oraz jednolitą walutę krajową. Wspólna pozostaje także: polityka zagraniczna, polityka obronna oraz bardzo często polityka finansowa $\mathrm{w}$ tych krajach. Państwa związkowe (albo: stany, landy, kantony, kraje, prowincje) cieszą się zazwyczaj szeroką autonomią wewnętrzną, własnym rządem i parlamentem oraz tworzą w bardzo wielu kwestiach własne uregulowania prawne. Warto tu przypomnieć niezrealizowaną koncepcję Ignacego Paderewskiego dotyczącą kształtu ustrojowego odradzającej się Rzeczypospolitej. Ten wielki patriota, a zarazem muzyk i polityk, widział naszą ojczyznę jako Stany Zjednoczone Polski. W skład tego organizmu państwowego wchodziłyby następujące kraje: ziemie polskie, Litwa, Polesie, Galicja-Podole i Wołyń. Taki ustrój Polski pozwalał zapobiec, zdaniem autora koncepcji, napięciom na tle narodowym i etnicznym, dominacji ośrodków centralnych oraz tendencjom odśrodkowym. Przemyślenia swoje zawarł w dokumencie znanym jako „Memoriał Paderewskiego”, który przedstawił prezydentowi Stanów Zjednoczonych Ameryki, Thomasowi Woodrowowi Wilsonowi, jeszcze w 1917 roku (Sukiennicki, 1973, s. 166-185). Inspiracją dla koncepcji Paderewskiego była historia naszego państwa, które od momentu zawarcia Unii Lubelskiej w 1569 roku aż do III rozbioru w 1795 roku istniało jako Rzeczpospolita Obojga Narodów, scalająca w jeden twór państwowy Wielkie Księstwo Litewskie i Królestwo Polskie. W ostatecznym rozrachunku zwyciężyła idea państwa

\footnotetext{
${ }^{4}$ W Macedonii władał wtedy przez Filip II, ur. 382 p.n.e. - zm. 336 p.n.e.
} 
centralistycznego, lansowana przez Józefa Piłsudskiego i jego zwolenników. $\mathrm{Z}$ dzisiejszej perspektywy trudno osądzić, która z koncepcji mogła okazać się lepsza.

Intersującym przykładem stworzenia państwa federalnego we współczesnych czasach jest Belgia. Istniejąca odmienność językowa i kulturowa oraz pogłębiające się różnice w poziomie życia stały się zalążkiem dążeń związanych z późniejszą przebudową ustroju w tym kraju. Kończąca długotrwały proces zmian nowa konstytucja utworzyła państwo o charakterze federalnym. Zmienioną ustawę zasadniczą parlament przyjął w 14 lipca 1993 roku. Była ona ukoronowaniem prac nad reformą ustroju Królestwa Belgii rozpoczętych ponad dwadzieścia trzy lata wcześniej (http://brussels.trade.gov.pl). Obecnie Belgia podzielona jest na trzy strefy językowe: francuską, niderlandzką i niemiecką, administracyjnie zaś na regiony: Flamandzki, Waloński oraz Stołeczny Region Brukseli.

Zmiany, których jesteśmy świadkami w łonie Unii Europejskiej również zdają się wskazywać na dążenie całego ugrupowania integracyjnego do modelu organizacji opartego na wzorcach federacyjnych.

Zanim zostanie podjęty drugi krok na drodze przemian demokratycznych w Polsce, należy się zastanowić, jak daleko powinny one prowadzić. Trzeba bowiem wspomnieć, że organizmy słabe, oparte na zasadzie federalizmu, łatwo mogą się rozpaść, jak miało to miejsce w przypadku Federacyjnej Republiki Jugosławii czy Republiki Czechosłowacji. Wydaje się, że nasilający kryzys gospodarczy nie sprzyja ideom federacyjnym. Jednakże większa autonomia regionalna i wprowadzenie w jej ramach sprawdzonych już narzędzi demokracji bezpośredniej może przyczynić się do wielu pozytywnych zmian w Polsce. Proces zmian, umożliwiający obywatelom aktywniejszy udział w życiu politycznym oraz podejmowanie wespół z władzami decyzji dotyczących zarządzania określonym terenem, będzie nieść ze sobą pozytywne efekty. Proponowane przeobrażenia powinny doprowadzić do realnego oraz świadomego współuczestnictwa mieszkańców w zarządzaniu terenem, na którym wiodą życie i pracują. Innymi rezultatami przemian idących w kierunku demokracji bezpośredniej powinny być osiągnięcie sukcesu na polu wzrostu spójności i konwergencji naszego kraju oraz zwiększenie atrakcyjności inwestycyjnej najsłabszych regionów.

Pomimo że przy poszukiwaniu rozwiązań umożliwiających bardziej dynamiczny rozwój określonych obszarów uwaga skoncentrowana została na przykładzie Polski Wschodniej, proponowane sposoby mogą zostać z powodzeniem zastosowane w przypadku każdego słabiej rozwiniętego obszaru. 


\section{ROZDZIA IX}

\section{Współudział mieszkańców w zarządzaniu regionem na tle wybranych teorii zarządzania}

Aby można było określić kategorię naukową zaprezentowanej w rozdziale VIII koncepcji zwiększonego uczestnictwa obywateli w zarządzaniu regionem pod kątem współudziału mieszkańców, należy ukazać jej miejsce na tle wybranych teorii zarządzania, a także przypomnieć, co należy rozumieć w sensie naukowym przez „zarządzanie”.

\section{Nauki o zarządzaniu}

Zarządzanie (a dokładnie cała grupa nauk o zarządzaniu - przyp. aut.) określane jest jako jedna z trzech głównych dyscyplin należących do dziedziny nauk ekonomicznych (Uchwała Centralnej Komisji do Spraw Stopni i Tytułów z dnia 23 czerwca 2003 r.). Pozostałe dwie dyscypliny tworzące tę grupę to:

- ekonomia,

- towaroznawstwo.

Zarządzanie zaczęto traktować jako samodzielną dyscyplinę naukową stosunkowo późno (na przełomie XIX i XX wieku) i to głównie w wyniku zmian wynikających $\mathrm{z}$ rewolucji przemysłowej. Jest ono jedną z najbardziej interdyscyplinarnych nauk współczesnych, ponieważ oprócz czerpania z bogatych źródeł ekonomii, odwołuje się do skarbnicy wielu innych dyscyplin naukowych, takich jak:

- matematyka i informatyka,

- historia,

- etnologia,

- geografia,

- psychologia,

- automatyka,

- geofizyka, 
- prawo,

- socjologia,

- transport,

- nauka o administracji itp.

W obrębie zarządzania nie rodzą się zupełnie niezależne i całkiem abstrakcyjne teorie. Rozwiązania oraz koncepcje, jakie powstają w ramach nauk o zarządzaniu, odnoszą się najczęściej do istniejących w rzeczywistości zjawisk i zauważonych tendencji wykazywanych przez jednostki, zbiorowości i grupy społeczne, organizacje, instytucje czy przedsiębiorstwa. Odkrycia, jakie mają w tej dyscyplinie miejsce, umożliwiają najczęściej albo optymalne, albo jeszcze bardziej efektywne niż dotychczas wykorzystanie stojących do dyspozycji zasobów: ludzkich, pieniężnych, kapitałowych, naturalnych, energetycznych lub też takich, które można zaliczyć do kategorii użytecznych informacji.

Zaprezentowana zatem w rozdz. VIII koncepcja zwiększonego udziału obywateli w zarządzaniu regionem, opisująca możliwe metody polepszenia skuteczności administrowania istniejącym na danym terenie majątkiem w celu realizacji określonych celów i zadań, przy zachowaniu troski o dobro społeczne, respektowaniu istniejącego prawa oraz poszanowaniu przywilejów obywatelskich, wpisuje się mocno w ramy określone dla nauki o zarządzaniu.

\section{Koncepcja "obywatelska" na tle wybranych teorii zarządzania}

Koncepcja zwiększonego udziału obywateli w zarządzaniu regionem, którą w uproszczeniu można nazywać: koncepcją obywatelską, dość wyraźnie nawiązuje do kierunku administracyjnego w ramach klasycznej teorii zarządzania. Jeden z głównych twórców tego nurtu, Henri Fayol (1841-1925), wyróżnił pięć głównych funkcji administracji, nazywanych obecnie funkcjami zarządzania (rys. 38).

Obecnie liczba funkcji Henriego Fayola pozostała taka sama i funkcjonuje w dalszym ciągu, jednakże została nieco inaczej opisana. Pewnej niewielkiej, acz dość istotnej zmianie, uległy trzy określenia (zob. rys. 39).

Pierwsza zamiana polega na zastąpieniu słowa „przewidywanie” „planowaniem", co oznacza przejście od biernej obserwacji występujących procesów do aktywnego ich kształtowania. Druga to zmiana terminu „rozkazywanie” na „decydowanie", podkreślająca większy wpływ na ostateczne rozstrzygnięcia uczestników pochodzących z niższych szczebli organizacji. Natomiast trzecia różnica to zamiana: „koordynowanie” na „motywowanie”, zakładająca wyższą świadomość wszystkich uczestników przebiegającego procesu, a także zmniejszenie roli jednostek na kierowniczych stanowiskach, wyposażonych w atrybut władzy. 


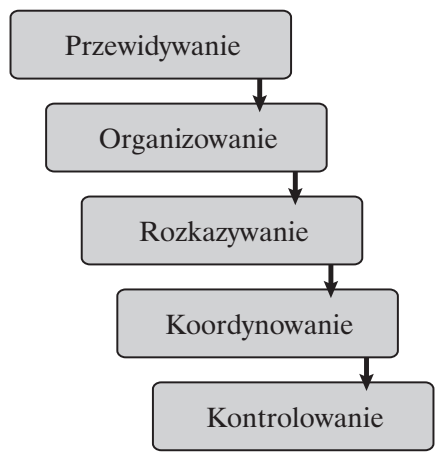

Rysunek 38. Pięć głównych funkcji administracji (zarządzania) według Henriego Fayola

Źródło: Kurnal (1970, s. 47).

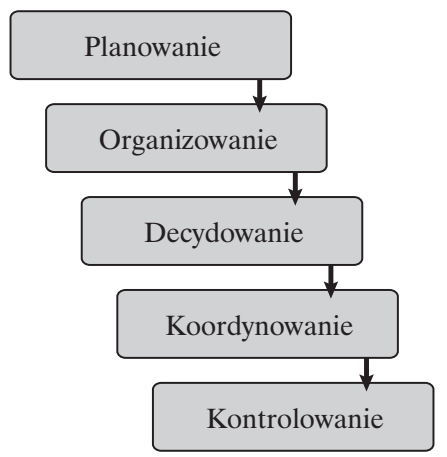

Rysunek 39. Współczesne określenie pięciu funkcji administracji (zarządzania) Henriego Fayola

Źródło: Lendzion, Stankiewicz-Mróz (2005, s. 16).

Jeśli biorąc pod uwagę pięć funkcji zarządzania, przyjrzymy się procesowi tworzenia (planowanie, organizowanie) i realizacji (decydowanie, motywowanie, kontrolowanie) budżetu partycypacyjnego, okaże się, że wszystkie one występują przy jego praktycznym urzeczywistnianiu. Nie może to dziwić, ponieważ główne kanony pracy administracji od czasów Henriego Fayola do dzisiaj tylko w niewielkim stopniu uległy zmianom.

Zaprezentowana idea oparcia budżetów samorządowych na zwiększonej partycypacji mieszkańców wychodzi także zwycięsko z walki z najcięższymi zarzutami, jakie kierowane były wobec koncepcji organizacji biurokratycznej. Wymieniona teoria została stworzona w obszarze klasycznego podejścia do nauk o zarządzaniu, przez innego przedstawiciela nurtu administracyjnego - Maxa 
Webera (1864-1920). Zarzutami podważającymi uniwersalność wymienionej koncepcji były (Kurnal, 1970, s. 391-392):

- skupienie się na wykładni (często) niedoskonałego prawa;

- brak elastyczności i przyjazności, istotne szczególnie w administracji samorządowej;

- koncentracja na kontaktach pomiędzy komórkami urzędu z pominięciem interesu klienta;

- tworzenie urzędu dla samego siebie.

Kolejnym przedstawicielem nurtu klasycznego, który wywarł wpływ na kształt przedstawionej koncepcji zwiększonego udziału obywateli w zarządzaniu regionem był inny Francuz - Henri Louis Le Chatelier (1850-1936). Jego dokonania koncentrowały się na sposobach racjonalizacji pracy. Na podstawie poczynionych przez siebie obserwacji, Le Chatelier stworzył cykl organizacyjny, który składał się z pięciu etapów (Sokołowska, 2009, s. 19):

1) wyboru celu, jaki chce się osiągnąć;

2) zbadania środków i warunków, których trzeba użyć (stworzyć), aby osiągnąć zamierzony cel;

3) przygotowania środków i warunków uznanych za potrzebne;

4) wykonania zgodnie z powziętym planem;

5) kontroli otrzymanych wyników.

Jakie odbicie miały przytoczone wskazówki w zaprezentowanym w rozdz. VIII opracowaniu? Celem, jaki przyświecał w trakcie pisania pracy, było wykazanie atrakcyjności inwestowania w regionach słabo rozwiniętych i, jeśli okaże się to możliwe, znalezienie sposobu na jej podniesienie. Jest to zarazem punkt pierwszy w cyklu organizacyjnym Le Chateliera. Punkt drugi (zbadanie środków i warunków, których trzeba użyć (stworzyć), aby osiagnąć zamierzony cel) znalazł odbicie w stworzeniu nowej koncepcji współuczestnictwa (współudziału) obywatelskiego w zarządzaniu regionem. Punkt trzeci zaś (przygotowanie środków i warunków uznanych za potrzebne), potraktowano jako nakreślenie (w zarysie) kolejnych etapów wdrażania elementów demokracji bezpośredniej do ustroju demokratycznego (zob. rozdz. VIII, pkt 4) oraz przedstawienie możliwych do zastosowania w tym procesie narzędzi (zob. rozdział VIII, pkt 2.2.3). Punkty czwarty i piąty cyklu organizacyjnego możliwe są do realizacji tylko przy założeniu podążania przez nasz kraj ścieżką proponowanych w rozdz. VIII przemian.

Propozycja wprowadzenia elementów demokracji bezpośredniej w dwóch etapach wynika $\mathrm{z}$ dorobku naukowego najbardziej znanego przedstawiciela i propagatora kierunku naukowego zarządzania w Polsce, badacza żyjącego na przełomie wieków - Karola Adamieckiego (1866-1933). Stwierdził on, w sformułowanym przez siebie prawie przekory, że: „Jakiekolwiek działania zmienia- 
jące stan faktyczny powodują powstanie oporów (przeciwdziałania), mających na celu utrzymanie tego stanu. Dlatego wszelkie zmiany należy wprowadzać stopniowo, aby nie doprowadzić do ich odrzucenia" (Zimniewicz, 1984, s. 62).

Wnioski z prac australijskiego psychologa i socjologa, Eltona Mayo (1880-1949), reprezentującego „szkołę stosunków międzyludzkich” (ang. Human Relations), potwierdziły istotne znaczenie koncepcji czynników pozaekonomicznych, według niego bowiem (Lendzion, Stankiewicz-Mróz, 2005, s. 24-25):

- „Jednostka jest motywowana nie tylko czynnikami ekonomicznymi, lecz także psychospołecznymi.

- Wysoki poziom zadowolenia można osiąnąć dzięki stosowaniu technik zarządzania, które prowadzą do decentralizacji procesu decyzyjnego i włączenia w jego przebieg wszystkich grup społecznych".

Oba spostrzeżenia podkreślają najważniejsze z dokonań szkoły Human Relations, jakim jest określenie czynników pozaekonomicznych, wpływających na satysfakcję jednostek społecznych $\mathrm{w}$ większym stopniu niż wynagrodzenia $\mathrm{w}$ formie finansowej. Znalazło to odbicie w zarysie zaprezentowanej w rozdz. VIII koncepcji1.

Szkoła Human Resources (szkoła potencjału ludzkiego) zaczęła nabierać dużego znaczenia w dziedzinie nauk o zarządzaniu w połowie lat pięćdziesiątych XX wieku. Jej przedstawiciel, Amerykanin, Abraham Harold Maslow (1908-1970) stworzył teorię hierarchii potrzeb ludzkich zobrazowaną przez tzw. piramidę Maslowa.

Stawia ona na najwyższych szczeblach konstrukcji (potrzeb wyższego rzędu): pragnienie samorealizacji, potrzebę uznania społecznego i potrzebę przynależności do grupy. Wszystkie te potrzeby mogą być w dużej mierze urzeczywistnione w obrębie zorganizowanych grup mieszkańców, biorących aktywny udział w pracach na rzecz regionów zamieszkania.

Szkoła neoklasyczna (zwana także szkołą empiryczna) w zarządzaniu rozwijała się od początku lat pięćdziesiątych XX wieku. Jeden z jej najbardziej znanych przedstawicieli, uważany za ojca współczesnych metod zarządzania, Peter F. Drucker (1909-2005), wyróżnił siedem cech, które powinny charakteryzować dobre zarządzanie (Lendzion, Stankiewicz-Mróz, 2005, s. 40-45):

1) zarządzanie dotyczy przede wszystkim ludzi;

2) zarządzanie jest głęboko osadzone w kulturze;

3) zarządzanie wymaga prostych i zrozumiałych wartości, celów działania i zadań, jednoczących uczestników organizacji;

1 Por. rozdz. VIII, pkt 2.2.4. Zalety demokracji bezpośredniej na tle systemu demokracji pośredniej. 


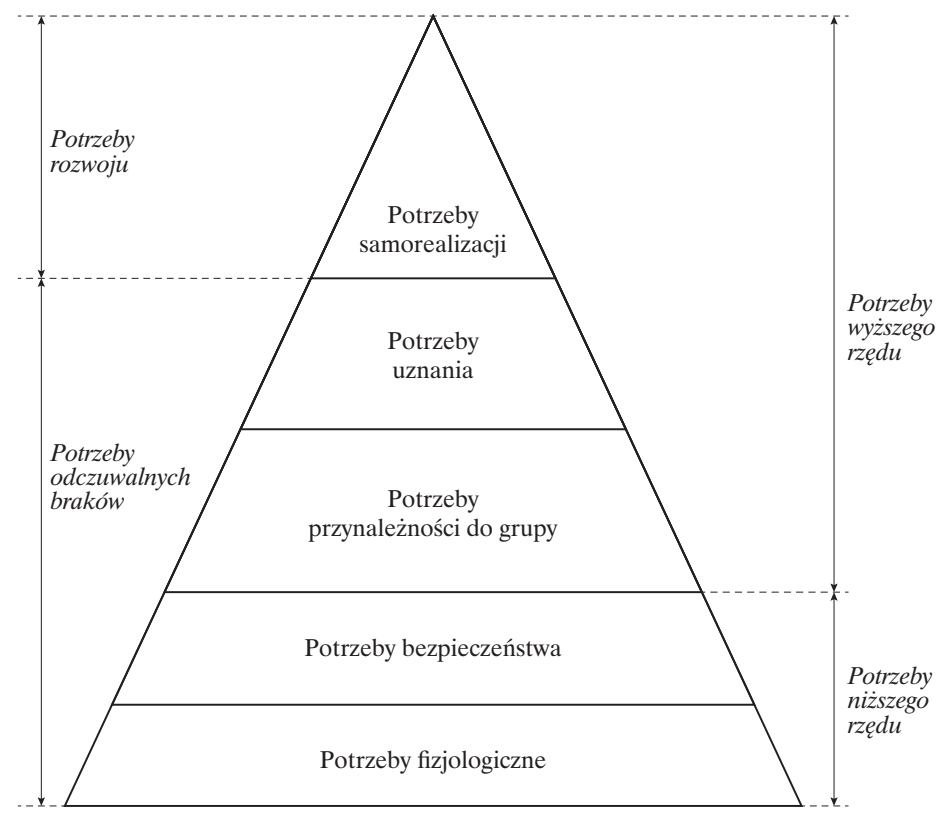

Rysunek 40. Piramida potrzeb Maslowa

Źródło: http://mfiles.pl/pl/index.php/Potrzeby.

4) zarządzanie powinno prowadzić do tego, aby każda organizacja była zdolna do uczenia się;

5) zarządzanie wymaga komunikowania się;

6) zarządzanie wymaga rozbudowanego systemu wskaźników;

7) zarządzanie musi być jednoznacznie zorientowane na podstawowy i najważniejszy rezultat, jakim jest zadowolenie jednostki społecznej.

Patrząc na zarys przedstawionej koncepcji zwiększonego uczestnictwa obywateli w zarządzaniu regionem, trzeba przyznać, że wychodzi ona naprzeciw większości cech wymienionych przez Petera Druckera. Można mieć jedynie tylko pewne obawy, czy przy zastosowaniu demokracji bezpośredniej uda się w pełni zrealizować punkty 4 i 6 .

Peter F. Drucker wysunął jeszcze wiele postulatów pod adresem organizacji, która powinna dobrze funkcjonować. Jednym $\mathrm{z}$ nich był postulat decentralizacji, zgodnie z którym rozstrzygnięcia powinny być podejmowane na jak najniższym szczeblu. Inny postulat - zarządzania przez cele - zakładał, że członkowie organizacji zajmujący wyższe i niższe stanowiska powinni wspólnie wyznaczać cele do realizacji oraz ustalać kryteria oceny osiągniętych wyników. Sugestie te całkowicie pokrywają się z założeniami współudziału mieszkańców w zarządzaniu regionem. 
Podejście systemowe do zarządzania, które powstało $\mathrm{w}$ drugiej połowie XX wieku, podkreśliło jeszcze wyraźniej jego interdyscyplinarny charakter. Usankcjonowało zarazem możliwość korzystania nauk zarządzania z dorobku innych dziedzin wiedzy. Przejawia się ono w poglądach na oblicze natury rzeczywistości, w metodologii jej badania oraz sposobach oddziaływania na tę rzeczywistość. Jego istota polega na traktowaniu badanych obiektów jako systemów otwartych, czyli zbiorów elementów powiązanych w taki sposób, że tworzą one pewna nową całość wyróżniającą się w otoczeniu (Koźmiński, Piotrowski, 1998, s. 699). Sam system to pewien wyodrębniony układ, który zakłada wzajemne powiązanie składających się nań różnorodnych elementów, występowanie pomiędzy nimi związków, wzajemnych zależności i interakcji.

W ramach podejścia systemowego zostało ustalone, że skuteczne i sprawne zarządzanie powstaje dzięki obserwacji otaczającej nas rzeczywistości, jest więc poprzez ten fakt nauką opartą na praktyce, a nie tylko bazująca na teorii. Założenia te przyświecały procesowi powstawania niniejszej pracy na wszystkich jej etapach.

Teoria chaosu, jako próba wytłumaczenia nieregularności zjawisk, pojawiła się w latach siedemdziesiątych XX wieku, równolegle i niemal jednocześnie w wielu dziedzinach nauki takich przykładowo, jak: matematyka, fizyka, biologia, chemia i zarządzanie. $\mathrm{Z}$ punktu widzenia niniejszej publikacji, jej najważniejszym elementem jest doprowadzenie do zlikwidowania tradycyjnych podziałów między istniejącymi dyscyplinami naukowymi oraz postulat możliwie jak najbardziej uniwersalnego podejśca do zjawisk obserwowanych $\mathrm{w}$ organizacjach i zachodzących w społeczeństwie.

Nowa fala (ang. New Wave) to jedna z najbardziej popularnych teorii w zarządzaniu, jakie pojawiły się w drugiej połowie XX wieku (koniec lat osiemdziesiątych). W obliczu poważnego kryzysu gospodarczego, zamiast do rozwiązań mających swoje korzenie w wiedzy akademickiej, odwoływała się do doświadczenia i praktyki (Piotrowski, 1995, s. 575). Była podejściem koncentrującym się na dążeniu do doskonałości. Niektóre z postulatów, jakie wysunęła ona w odniesieniu do działania sprawnej organizacji, wykorzystano na potrzeby koncepcji zwiększonego udziału obywateli w zarządzaniu regionem. Oto one:

- uwaga powinna koncentrować się na pracy zespołowej i zaufaniu;

- dla osiągnięcia zamierzonych celów powinna zaistnieć delegacja uprawnień zarządczych w dół piramidy organizacyjnej;

- organizacje „doskonałe” powinny stanowić wzór do naśladowania dla mniej sprawnych i efektywnych przedsięwzięć;

- ważne jest przekazywanie istniejącej tradycji;

- powinno się popierać i wprowadzać autonomię poszczególnych części składowych organizacji;

- w podejmowanych działaniach należy kierować się nadrzędnymi wartościami. 
Sugerowane we wcześniejszych rozdziałach wprowadzenie większej autonomii regionalnej, oparcie się na tradycji demokracji ateńskiej, udział obywateli w zarządzaniu zamieszkanym przez siebie terenem, czerpanie z doświadczeń rozwiniętych państw o strukturze federalnej oraz nadrzędny interes społeczny pokrywają się z wymienionymi w Teorii New Wave postulatami.

Jak można się przekonać na podstawie przytoczonych wyżej przykładów, koncepcja współudziału (współuczestnictwa) mieszkańców w zarządzaniu regionem oparta została na solidnych podstawach teoretycznych.

\section{Znaczenie wybranych teorii zarządzania dla koncepcji zwiększonego udziału obywateli w zarządzaniu regionem}

Przy konstruowaniu koncepcji zwiększonego udziału obywateli w zarządzaniu regionem, posłużono się najbardziej przydatnymi, w przekonaniu autora, teoriami oraz koncepcjami zaczerpniętymi z bogatego skarbca nauk o zarządzaniu. Okazało się, że wiele dawnych teorii nie utraciło nic ze swojej aktualności. Natomiast nowe, stanowiące częstokroć rozwinięcie istniejących już koncepcji, w sposób bliski idealnemu wkomponowały się w zaprezentowaną ideę.

Oczywiście wykorzystanie całej wiedzy skumulowanej w dyscyplinie nauki zwanej zarządzaniem nie było możliwe. Niektóre z teorii nie zostały wykorzystane, ponieważ albo były tylko w małym stopniu spójne ze ścieżką poczynań badawczych, albo dotyczyły bardzo odległych zagadnień. Jeszcze inne z koncepcji zarządzania były niepotrzebnie skomplikowane lub przedstawiały sobą zbyt wysoki poziom abstrakcji. Dlatego też nie znalazły miejsca w niniejszej monografii elementy należące do: teorii przedstawicieli nurtu naukowej organizacji pracy (Henry Laurence Gantt, Frank Bunker Gilbreth i Lilian Moller Gilbreth czy Harrington Emerson); założeń podejścia sytuacyjnego w zarządzaniu, idei prezentowanych przez Fredericka Herzberga w jego koncepcji dwuczynnikowej, czy teorii X i Y autorstwa Douglas McGregora. Jako zbyt utopijny potraktowano nurt postmodernistyczny w zarządzaniu, negujący wszystkie prawdy i definicje, które udało się do tej pory stworzyć w nauce. Wiele innych podejść i kierunków zaliczanych do nauk o zarządzaniu nie zostało nawet wymienionych. Nie jest to w praktyce ani możliwe, ani uzasadnione potrzebami zaprezentowanej koncepcji obywatelskiej. Jednak mogły być one pozostającym w głębokim tle, źródłem inspiracji podjętych dociekań, badań i zaprezentowanych rozwiązań. 


\section{Zakończenie}

Przedstawiona praca wpisuje się w nurt aktualnych obecnie rozważań dotyczących uwarunkowań rozwoju regionalnego. Koncentruje się na zagadnieniu atrakcyjności inwestycyjnej określonych obszarów. Zamysłem, który skłonił do jej napisania była chęć wykazania, że tereny słabo rozwinięte mogą również stanowić bardzo interesujący teren do alokacji kapitału, podejmowania wszelkiego rodzaju przedsięwzięć oraz jako miejsce pracy, spędzania wolnego czasu i prowadzenia godziwego życia. Założenie takie stoi niejako w sprzeczności z panującymi trendami, które na miejsca najkorzystniejsze dla inwestycji wyznaczają zazwyczaj obszary dobrze rozwinięte, posiadające bogatą infrastrukturę usługową oraz zaplecze w postaci istniejących i działających już firm z różnych gałęzi gospodarki. Potencjalni inwestorzy pomimo wyższych kosztów zatrudnienia, większej konkurencji i drogich terenów nadających się pod zabudowę, ciągle jeszcze bardziej skłonni są wybierać regiony „bogate” i już eksploatowane, niż te obszary, które w mniejszym stopniu dotknięte zostały piętnem cywilizacji i znajdują się w pewnym oddaleniu od najważniejszych ośrodków przemysłowych. Magnesami, które przyciągają w najskuteczniejszy sposób kapitał oraz ludzi pozostają niezmiennie wielkie miasta wraz z aglomeracjami i otaczające je terytoria.

Punktem wyjścia konstrukcji struktury pracy była lista zalet i atutów terenów słabo rozwiniętych, ukazująca ich realną atrakcyjność. Następnie obiektem zainteresowania stały się zagadnienia zależności rozwoju regionalnego od lokowania inwestycji na nadających się do tego obszarach. Rozważania dotyczące podjętego tematu dorowadziły do przeświadczenia, że za atrakcyjny uważany może być każdy teren, na który jesteśmy w stanie sprowadzić inwestycje. Stąd już tylko mały krok dzielił od ustalenia czynników, które mogą sprzyjać alokacji kapitału na wybranych do tego terenach.

Szczególną uwagę zwrócono również na teorie wzrostu regionalnego, z którymi można się zetknąć, studiując koncepcje prezentowane przez Artura Lewisa, Gunnara Myrdala, Paula Petersona i Clarensa Stone'a. Wskazywały one na spore szanse oraz duże możliwości rozwojowe regionów słabo rozwiniętych. Jednak dopiero teoria „maszyny rozrywki” opisana przez Terrego Nicholsa Clarka zakła- 
dała, że wzrost gospodarczy i inwestycje podążają za społecznościami ludzkimi, które jako „pierwsza fala przypływu” znajdują najbardziej atrakcyjne tereny dla swojej egzystencji. Teorie wzrostu endogenicznego, które ujrzały światło pod koniec lat osiemdziesiątych XX wieku, jako jeden z najważniejszych czynników długotrwałego wzrostu gospodarczego wzrostu uznawały także pozyskiwanie wybitnych specjalistów i siły roboczej. Peter Drucker przekonuje natomiast, że największe dobro w obecnych czasach stanowią zasoby wiedzy ludzkiej. To na ich podstawie, a nie jak do tej pory na bazie surowcowej i zainwestowanych kapitałach, powinien opierać się rozwój różnych obszarów (Drucker, 1999, s. 14). Trzeba jeszcze tylko przypomnieć, że teoria wzrostu endogenicznego nie oznacza wyeliminowania wpływów zewnętrznych - są one w niej uznawane i jak najbardziej pożądane. Koncepcja ta przedstawia ważne impulsy, które są w stanie pobudzić siły wewnętrzne, skumulowane na danym obszarze, do bardziej dynamicznego działania.

Analiza przytoczonych powyżej koncepcji i zjawisk doprowadziła do wniosku, że obecnie coraz większe rzesze społeczeństwa pragną wziąć aktywny udział w kształtowaniu swojego otoczenia i mieć wpływ na zarządzanie środkami finansowymi oraz zasobami, które są do dyspozycji na terenach przez nie zamieszkiwanych. Chęć zmian i wykazywana nieudolność na wszystkich szczeblach władzy doprowadziły do niezadowolenia i sprzeciwów społecznych w wielu miejscach na świecie, a także w naszym kraju. Zarysował się ostry kryzys ustroju demokratycznego w jego obecnej formule. Jednocześnie dostrzec można inne formy w ramach systemu demokracji, które dają możliwość udziału w rządzeniu każdemu obywatelowi i przyczyniają się do lepszych efektów zarządzania istniejącymi zasobami. Przykłady sukcesu gospodarczego takich krajów, jak: Australia, Niemiecka Republika Federalna, Austria, Kanada, Brazylia, Meksyk, Szwajcaria czy Indie, skłaniają do poważnego zastanowienie się nad tym, w jakiej mierze jest to zbieg okoliczności, a w jakiej - zasługa wybranego przez te organizmy państwowe systemu politycznego. Wszystkie wymienione kraje opierają podstawy swojego funkcjonowania na ustroju demokratycznym, zawierającym dużą ilość elementów demokracji bezpośredniej. Według przeprowadzonych w Kraju Helwetów badań (Frey, 2010, s. 82-90), umożliwienie mieszkańcom bezpośredniego udziału w podejmowaniu decyzji dotyczących zamieszkiwanego przez nich terenu przynosi, obok efektów społecznych, rezultaty czysto ekonomiczne. Należą do nich: obniżenie lokalnych stawek podatkowych, zwiększenie się dochodów na głowę jednego mieszkańca, wzrost cen gruntów i nieruchomości, napływ inwestycji i kapitału na danym terenie, brak uchylania się od podatków, większe bezpieczeństwo ogólne, mniejsze wydatki władz lokalnych, nasilona imigracja (w tym specjalistów i osób w poszukiwanych zawodach), powstawanie nowych podmiotów gospodarczych, rozbudowa infrastruktury rozrywkowej i usługowej. Tak więc czynnik o charakterze czysto 
endogenicznym, jakim jest ustrój polityczny, a w tym wypadku demokracja bezpośrednia, skłania ludzi do osiedlania się na danym terenie, przestrzegania przepisów prawa, daje określone efekty dla gospodarki oraz co bardzo ważne, podwyższa uczucie satysfakcji z życia. Oczywiście wnioskiem płynącym z przeprowadzonych rozważań nie jest nawoływanie do przejścia z unitarnego systemu panującego w naszym kraju do systemu federacyjnego. Sugestią jest raczej niewielkie rozszerzenie uprawnień władz samorządowych w granicach istniejącego prawa lub taka zmiana wybranych przepisów, aby mogły przyczynić się do wzrostu atrakcyjności terenów uznawanych dotychczasowo za zacofane i mało interesujące.

W pracy wystrzegano się prób określania sposobów przebudowy istniejącej litery prawa oraz zakresu nowelizacji przepisów. Jest to domeną specjalistów w dziedzinie legislacji. Skupiono się na efektach, jakie propozycje oraz sugestie mogą wywołać w dziedzinie sprawowania władzy i zarządzania na danym terenie. W przeprowadzonych rozważaniach, oparto się na bogatych danych statystycznych dostępnych z oficjalnych źródeł, a końcowe wnioski w dużej mierze oparto na podejściu heurystycznym, które ze względu na charakter pracy, najbardziej nadawało się do tego celu.

Myśli i propozycje działań przedstawione w koncepcji zwiększonego udziału obywateli w zarządzaniu regionem stanowią uzupełnienie oraz rozwinięcie dotychczas istniejącej wiedzy $\mathrm{w}$ dziedzinie rozwoju regionalnego, jednakże w obszarze do tej pory jeszcze nie eksplorowanym. Mam nadzieję, że wzbudzi ona zainteresowanie i znajdzie życzliwe zrozumienie u czytających.

Zamiarem, jaki przyświecał $\mathrm{w}$ trakcie pisania pracy, było znalezienie rozwiązań, które przy ograniczonym nakładzie finansowym oraz możliwych do przeprowadzenia zmianach prawa dawałyby pożądane społecznie i gospodarczo efekty dla naszego kraju. 


\section{Bibliografia}

Andrews, R.B. (1953), Mechanism of the Urban Economic Base: Historical Development of the Base Concept, Land Economics, Madison, Wisconsin.

Arystoteles, (2012, (C2006), Polityka, tłum. L. Piotrowicz, Warszawa: Wydawnictwo Naukowe PWN.

Banaszak, B. (2012), Prawo konstytucyjne, wyd. VI, Warszawa: C.H. Beck.

Barbag, J., Galon, R. (1967), Stany Zjednoczone, w: A. Jahn (red.), Geografia powszechna, T. V: Arktyka, Ameryka, Australia i Oceania, Antarktyda, Ocean Światowy, Warszawa: PWN.

Barroso, J.M. (2010), EUROPA 2020, Strategia na rzecz inteligentnego i zrównoważonego rozwoju sprzyjającego wtaczeniu społecznemu, Komunikat Komisji, Bruksela: Komisja Europejska.

Bartkowiak, R. (2003), Historia myśli ekonomicznej, Warszawa: PWE.

Białas, T. (1983), Liga Morska i Kolonialna 1930-1939, Gdańsk: Wydawnictwo Morskie.

Blume, L., Müller, J., Voight, S. (2007), The Economic Effects of Direct Democracy - A First Global Assessment, CESifo Working Paper No. 2149, category 1: Public choice, Munich, Germany: CESifo Group,.

Bochenek, D. (red.) (2012), Ochrona środowiska 2011, Warszawa: Główny Urząd Statystyczny.

Brodecki, Z. (2005), Regiony, Warszawa: LexisNexis.

Broza, C., Sowa, A. (2007), Historia Polski 1918-1945, Kraków: Wydawnictwo Literackie.

Budner, W. (2004), Lokalizacja przedsiębiorstw, aspekty ekonomiczno-przestrzenne i środowiskowe, Poznań: Wydawnictwo Akademii Ekonomicznej w Poznaniu.

Bullman, U. (1997), The Politics of the Third Level, w: The Regional Dimension of the European Union, Towards a Third Level in Europe, London: Frank Cass \& Co Ltd.

Chojnacki, Z. (1997), Region jako terytorialny system społeczny, w: Kukliński A. (red.), Problematyka przestrzeni europejskiej, Warszawa: EUROREG.

Churski, P. (2004), Rozwój regionalny w warunkach transformacji gospodarczej i integracji europejskiej, w: S. Ciok, D. Ilnicki (red.), Przeksztatcenia regionalnych struktur funkcjonalno-przestrzennych. Regionalny wymiar integracji europejskiej, T. VIII/1, Wrocław: Instytut Geografii i Rozwoju Regionalnego, Uniwersytet Wrocławski.

Churski, P. (2005), Czynniki rozwoju regionalnego w świetle koncepcji teoretycznych, Zeszyty Naukowe Wyższej Szkoły Humanistyczno-Ekonomicznej we Włocławku, Nauki Ekonomiczne, T. XIX, z. 3.

Ciepielewska, M., Jahns, H. (2004), Polityka regionalna i strukturalna, w: E. Synowiec, E. Kawecka-Wyrzykowska (red.), Unia Europejska, T. I, Warszawa: Instytut Koniunktur i Cen Handlu Zagranicznego. 
Clark, T.N. (2005), Urban Aniemities: Lakes, Opera, and Juice Bars: Do They Drive Development?, w: The City As an Entertainment Machine, Research in Urban Policy, Vol. 9, San Diego, Califonia, USA: Elsevier Ltd.

Cukiernik, T. (2013), Temat tygodnia: Bilans. Zbiednieliśmy przez Unię, Uważam Rze, 3-9 czerwca, nr 22(122), Warszawa: Gremi Media sp. z o.o.

Czekanowski, J. (1963), Rasy i ludy, w: J. Barbag (red.), Geografia Powszechna, T. II: Człowiek $i$ jego działalność gospodarcza, Warszawa: PWN.

Dąbrowski, A. (1995), Wybrane teorie rozwoju regionalnego i ich znaczenie $w$ polityce ekonomicznej, w: H. Ćwikliński, G. Szczodrowski (red.), Dylematy i osiagniecia polskiej polityki transformacji gospodarczej, Gdańsk: Wydawnictwo Uniwersytetu Gdańskiego.

Departament Wdrażania Programów Rozwoju Regionalnego (2006), Biuletyn Informacyjny Ministerstwa Rozwoju Regionalnego, vol. 2, nr 6, Warszawa: Departament Wdrażania Programów Rozwoju Regionalnego.

Dickinson, J.A., Young B. (2003), A Short History of Quebec, $3^{\text {rd }}$ edition, Montreal: Press McGill - Queen's University.

Drucker, P. (1999), Społeczeństwo pokapitalistyczne, Warszawa: Wydawnictwo Naukowe PWN.

Duesennberry, J.S. (1950), Some Aspects of the Theory of Economic Development, Explorations in Entreprneurial History, ind. III, Richmond, Virginia.

Fajferek, A. (red.) (1999), Polityka ekonomiczna, Kraków: Wydawnictwo Akademii Ekonomicznej w Krakowie.

Falkowski, J. (2005), Struktura regionalna świata, w: J. Falkowski, J. Kostrowicki (red.), Geografia rolnictwa świata, wyd. I, Warszawa: Wydawnictwo Naukowe PWN.

Fawcett, L. (2004), Exploring Regional Domains: A Comparative History of Regionalism, International, No. 3, London: The Royal Institute of International Affairs, Chatham House.

Feld, L., Fischer, J., Kirchgaessner, G. (2006), The Effect of Direct Democracy on Income Redistribution: Evidence for Switzerland, CESifo Working Paper No. 1837, category 1: Public finance, Munich, Germany: CESifo Group.

Feser, J., Malizia, E. (1999), Understanding Local Economic Development, Rutgers, New York: Center for Urban Policy Research.

Flis, J. (1967), Kraje himalajskie, w: A. Zirhoffer (red.), Geografia powszechna, T. IV: ZSRR, Azja, Afryka, Warszawa: PWN.

Freeman, O. (1993), Regionalizm i regionalizacja w Hiszpanii, we Francji i we Włoszech, Kultura i Spoteczeństwo, nr 4, Warszawa: Instytut Studiów Politycznych PAN.

Frey, S.B. (2010), Glück. Die Sicht der Ökonomie, Zürich - Chur, Schweiz: Rüegger Verlag.

Gawlikowska-Huesckel, K. (2003), Procesy rozwoju regionalnego w Unii Europejskiej, Konwergencja czy polaryzacja?, Gdańsk: Wydawnictwo Uniwersytetu Gdańskiego.

Głębicka, K., Grewiński, M. (2003), Europejska polityka regionalna, Warszawa: Dom Wydawniczy Elipsa.

Głuchowski, J. (1996), Oazy podatkowe, Warszawa: Dom Wydawniczy ABC.

Godlewska-Majkowska, H. (2008), Atrakcyjność inwestycyjna polskich regionów - zatożenia $i$ wstępne wyniki, w: W. Szczęsny (red.), Atrakcyjność inwestycyjna polskich regionów, Warszawa: Polskie Towarzystwo Ekonomiczne Oddział Warszawski, Drukarnia cyfrowa Elpil. 
Gorzelak, G. (1989), Rozwój regionalny Polski w warunkach kryzysu i reform, Warszawa: Wydawnictwo Uniwersytetu Warszawskiego, Instytut Gospodarki Przestrzennej.

Goverde, H.J.M. (1996), Innowacja regionalnego sprawowania władzy, Samorzad Terytorialny, nr 1-2, Warszawa: Wolters Kluwer Polska Sp. z o.o.

Grycuk, A. (2010), Klastry jako element polityki regionalnej, Warszawa: „Infos”, Biuro Analiz Sejmowych Kancelarii Sejmu.

Grzenkowicz, N., Kowalczyk, J., Kusak, A., Podgórski, Z., Ambroziak, M. (2008), Podstawy funkcjonowania przedsiębiorstw, Warszawa: Wydawnictwo Naukowe Wydziału Zarządzania UW.

GUS (2011), Spis powszechny, Warszawa: GUS.

GUS (2012), Rocznik Statystyczny Rzeczypospolitej Polskiej, Warszawa: GUS.

GUS (2013), Zatrudnienie $i$ wynagrodzenia w Gospodarce Narodowej, Warszawa: GUS.

Hirschman, A.O. (1958), The Strategy of Economic Development, New Haven, Connecticut: Yale University Press.

Ignaciuk, S. (2010), Polska Wschodnia - szanse i możliwości rozwoju, w: W. CzemielGrzybowska (red.), Finansowanie rozwoju regionalnego z funduszy strukturalnych 2007-2013, Polska Wschodnia, szanse i możliwości rozwoju, Białystok: Oficyna Wydawnicza Politechniki Białostockiej.

Jabłoński, M. (2002), Referendum i inne instytucje demokracji bezpośredniej, Przeglad Prawa i Administracji, T. LI, Wrocław: Uniwersytet Wrocławski.

Jałowiecki, B. (1992), Kwestia regionalna. Regionalizacja versus regionalizm, Studia socjologiczne, nr 1/2, Warszawa: Polska Akademia Nauk, Komitet Socjologii.

Jasiński, P. (2000), Europa jako szansa: Polityka regionalna Unii Europejskiej i jej instrumenty a wtadze lokalne $i$ regionalne, Warszawa: Dom Wydawniczy Elipsa.

Jezierski, A., Leszczyńska, C. (2003), Historia gospodarcza Polski, Warszawa: Wydawnictwo: KeyText.

Jóźwik, B., Sagan, M. (red.) (2012), Rozwój Polski Wschodniej, Ograniczenia i wyzwania, Warszawa: Difin S.A.

Jureczko, A., Wac, E. (2007), Historia Lichtensteinu, w: J. Laptos (red.), Historia matych krajów Europy, wyd. II popr. i uzup., Warszawa: Ossolineum.

Kacewicz, M. (2012), Niepodległy Ural, Newsweek, Historia, nr 4.

Kalinowski, T. (red.) (2005), Atrakcyjność inwestycyjna regionów i podregionów Polski 2005, Gdańsk: Instytut Badań nad Gospodarką Rynkową.

Kawecka-Wyrzykowska, E. (2004), Unia Europejska, Warszawa: Instytut Koniunktur i Cen Handlu Zagranicznego.

Keay, J. (2000), India: A History, New York: Grove Press,.

Kębłowski, W. (2013), Budżet partycypacyjny. Krótka instrukcja obstugi, Warszawa: Instytut Obywatelski.

Kersten, K. (1987), Narodziny system wtadzy: Polska 1943-1948, Warszawa: Most.

Kieniewicz, J. (1980), Historia Indii, Warszawa: Ossolineum.

Klusek, J. (1992), COP w gospodarce i obronności II Rzeczypospolitej, Warszawa: Wydawnictwo Oświata.

Kondracki, J. (1995), Fizycznogeograficzna regionalizacja Europy Wschodniej w układzie dziesiętnym, Przeglad Geograficzny, T. LXVII, z. 3-4.

Korenik, S. (2004), Dysproporcje w rozwoju regionów Polski. Wybrane aspekty, Wrocław: Wydawnictwo Akademii Ekonomicznej we Wrocławiu. 
Korenik, S., Zakrzewska-Półtorak, A. (2011), Teorie rozwoju regionalnego - ujęcie dynamiczne, Wrocław: Wydawnictwo Uniwersytetu Ekonomicznego we Wrocławiu.

Kozioł, W., Zalewska, M. (2009), Doświadczenia struktur klastrowych we Francji $i w$ Belgii oraz możliwość ich wykorzystania do wspierania przedsiębiorczości lokalnej na Mazowszu, w: A.Z. Nowak, M. Szałański (red.), Czynniki i bariery rozwoju przedsiębiorstw na Mazowszu, Warszawa: Wydawnictwo Naukowe Wydziału Zarządzania UW.

Koźmiński, K.A., Piotrowski, W. (1998), Zarzadzanie. Teoria i praktyka, wyd. IV popr. i rozsz., Warszawa: Wydawnictwo Naukowe PWN.

Krasuski, J. (1975), Stosunki polsko-niemieckie 1919-1932, Poznań: Wydawnictwo Instytutu Zachodniego.

Kudłacz, T. (2011), Efektywność zarządzania rozwojem regionalnym w nowym okresie Programowania po 2013 r., wystąpienie na sympozjum: OPEN DAYS 2011 LOCAL EVENTS „Świętokrzyskie w UE - Zacznijmy od strategii”, Uniwersytet Ekonomiczny w Krakowie, Kielce 16.112011 r.

Kundera, J., Szmyt, W. (2008), Leksykon polityki regionalnej UE, Kraków: Wolters Kluwer Business.

Kurnal, J. (1970), Zarys teorii organizacji i zarządzania, Warszawa: PWE.

Lemańska, J. (2006), Koncepcja samorządu województwa na tle porównawczym, Kraków: Wydawnictwo Uniwersytetu Jagiellońskiego.

Lendzion, P.J., Stankiewicz-Mróz, A. (2005), Wprowadzenie do organizacji i zarządzania, Kraków: Oficyna Ekonomiczna.

Lepecki, M. (1962), Parana i Polacy, Warszawa: PWN.

Łepkowski, T. (1986), Historia Meksyku, Warszawa: Ossolineum.

Lewis, A. (1954), Economic Development with Unlimited Supplies of Labor, Manchester School of Economic and Social Studies, Vol. 22, Manchester, England.

Logan, J.R., Molotch, H. (1987), Urban Fortunes: The Political Economy of Place, Berkeley: University of California Press.

Lubiński, M. (2004), Analiza koniunktury i badanie rynków, Warszawa: Dom Wydawniczy Elipsa.

MAC (2012), Zielona Księga dotycząca obszarów metropolitalnych, Warszawa: Ministerstwo Administracji i Cyfryzacji, pobrano z: https://mac.gov.pl/wp-content/uploads/2012/04/ Zielona-ksi\%c4\%99ga.pdf.

Malecki, E.J., (1997), Technology and Economic Development: The Dynamics of Local, Regional and National Competitiveness, 2nd edition, London-Boston: Addison Wesley Longman.

Mandel, E. (1995), Long Waves of Capitalist Development, A Marxist Interpretations, London - New York: Verso.

Marciniak, R. (1996), Gurkhowie, Warszawa: Wydawnictwo Bellona, Oficyna Wydawnicza Rytm.

Markowski, T. (2008), Teoretyczne podstawy rozwoju lokalnego i regionalnego, w: Z. Strzelecki (red.), Gospodarka regionalna i lokalna, Warszawa: Wydawnictwo Naukowe PWN.

Markusen, A. (1987), Regions: The Economics and Politics of Territory, New York: Rowman and Allanheld, Totowa.

Ministerstwo Rozwoju Regionalnego (2006), Polska. Narodowe Strategiczne Ramy Odniesienia 2007-2013 wspierajace wzrost gospodarczy $i$ zatrudnienie. Narodowa Strategia Spójności, Warszawa: Ministerstwo Rozwoju Regionalnego, sierpień. 
Ministerstwo Rozwoju Regionalnego (2007), Program Operacyjny Rozwoju Polski Wschodniej 2007-2013, Narodowe Strategiczne Ramy Odniesienia 21007-2013, Warszawa: Ministerstwo Rozwoju Regionalnego, 2 października.

Misztal, M. (2007), Historia Malty, w: J. Laptos (red.), Historia matych krajów Europy, wyd. II popr. i uzup., Warszawa: Ossolineum.

Morris, W. (red.) (1975), The American Heritage Dictionary of the English, za: M. Malendowski, M. Ratajczak (2000), Euroregiony. Polski krok do Integracji, Wrocław: Wydawnictwo Alta 2, s. 41.

Mossberger, K., Stoker, G. (2001), The Evolution of Urban Regime Theory, The Challenge of Conceptualization, Urban Affairs Review, Vol. 36, No. 6, July, University of Illinois at Chicago, USA: Sage Publications.

Myrdal, G. (1967), The Theories of ,stages of Growth”, Scandynavian Economic History Review, No. 1, 2, Odense, Danmark: Routledge.

North, D.C., (1955), Location Theory and Regional Economic Growth, The Journal of Political Economy, Vol. 63, No. 3, The University of Chicago Press.

Nowa Encyklopedia Powszechna PWN (1998), T. D-H, Warszawa: Wydawnictwo Naukowe PWN.

Nowicki, M. (2002), Fundusze europejskie - programy przedakcesyjne, Miesięcznik Społeczności Akademickiej, nr 4-5(6-7), Zielona Góra: Wydawnictwo Uniwersytetu Zielonogórskiego.

Nowicki, M. (red.) (2011), Atrakcyjność inwestycyjna regionów i podregionów Polski 2011, Gdańsk - Warszawa: Instytut Badań nad Gospodarką Rynkową, Fundacja Konrada Adenauera w Polsce.

Nurske, R. (1966), Problems of capital formation in underdeveloped countries, Oxford University Press.

O'Shea, S. (2009), Morze Wiary, islam i chrześcijaństwo $w$ świecie śródziemnomorskim doby średniowiecza, wyd. I, Poznań: Dom Wydawniczy REBIS.

Olejniczak, K. (2001), Wykorzystanie funduszy strukturalnych w Republice Irlandii, Studia Regionalne i Lokalne, nr 2-3(6), Warszawa: Centrum Europejskich Studiów Regionalnych i Lokalnych UW.

Oręziak, L. (2004a), Finanse Unii Europejskiej, Warszawa: Wydawnictwo Naukowe PWN.

Oręziak, L. (2004b), Finanse matych $i$ średnich przedsiębiorstw, Warszawa: PWE.

Paczoski, A. (2010), Kreowanie regionalnej i lokalnej polityki gospodarczej na podstawie teorii $i$ koncepcji rozwoju terytorialnego, Gdańsk: Wydawnictwo Uniwersytetu Gdańskiego,.

Pasieczny, J. (2008), Profile gmin w Polsce - zarzadzanie rozwojem i zmianami, Warszawa: Wydawnictwo Naukowe Wydziału Zarzadzania UW.

Peterson, P.E. (1981), City limits, The University of Chicago Press.

Piotrowski, W. (1995), Organizacje i zarzadzanie - kierunki, koncepcje, punkty widzenia, w: A.K. Koźmiński, W. Piotrowski (red.), Zarzadzanie. Teoria i praktyka, Warszawa: Wydawnictwo Naukowe PWN.

Pluta, W. (red.) (2004), Finanse matych i średnich przedsiębiorstw, Warszawa: PWE.

Podstawy Wsparcia Wspólnoty. Promowanie rozwoju gospodarczego i warunków sprzyjających wzrostowi zatrudnienia (2004), dokument przyjęty przez Radę Ministrów w dniu 23 grudnia 2003 roku oraz zatwierdzony przez Komisję Europejską w dniu 22 czerwca 2004 roku, Warszawa-Bruksela. 
Porter, M.E. (1990), The Competitive Advantage of Nations, Hampshire - London: Macmillan Press.

Przygoda, M. (2008a), Efektywność wykorzystania środków finansowych z funduszy unijnych $w$ podregionie ciechanowsko-ptockim, w: A.Z. Nowak, M. Szałański (red.), Pozyskiwanie $i$ wykorzystanie funduszy unijnych $w$ regionie mazowieckim, Warszawa: Wydawnictwo Naukowe Wydziału Zarządzania UW.

Przygoda, M. (2008b), Zarys priorytetów rozwoju gospodarczego Mazowsza na lata 2007-2013, w: A.Z. Nowak, M. Szałański (red.), Region ptocki w strategii rozwoju Mazowsza, Warszawa: Wydawnictwo Naukowe Wydziału Zarządzania Uniwersytetu Warszawskiego.

Przygoda, M. (2009), Wykorzystanie funduszy unijnych w podregionie ciechanowskopłockim w latach 2004-2006, Rocznik Naukowy Wydziału Zarzadzania w Ciechanowie, Ciechanów: Wyższa Szkoła Menedżerska w Warszawie.

Przygoda, M. (2012), Skutki kryzysu strefy euro dla Europy Środkowej i Wschodniej, w: S. Partycki (red.), Kryzys finansowy, przebieg i skutki spoteczno-gospodarcze w Europie Środkowej $i$ Wschodniej, Lublin: Wydawnictwo Katolickiego Uniwersytetu Lubelskiego Jana Pawła II.

Puri, M. (2010), Economics of Development and Planning - Theory and Practice, Mumbai, Maharashtra, India: Himalaya Publishing House.

Pysiewicz-Jędrusik, R., Pustelnik, A., Konopska, B. (1998), Granice Śląska, Wrocław: Wydawnictwo Rzeka.

Rabska, T. (1992), Refleksje na temat układu przestrzennego administracji publicznej i jego konsekwencje w zakresie administrowania, Ruch Prawniczy, Ekonomiczny i Socjologiczny, z. 2, Poznań: Uniwersytet im. Adama Mickiewicza i Uniwersytet Ekonomiczny w Poznaniu.

Richardson, H.W. (1973), Regional growth theory, London, UK: Edition: Macmillan.

Rosenstein-Rodan, P. (1959), Uwagi o „teorii wielkiego pchnięcia”, Ekonomista, nr 2, wydane staraniem Komitetu Nauk Ekonomicznych Polskiej Akademii Nauk i Polskiego Towarzystwa Ekonomicznego, Warszawa.

Rostow, W. (1960), The Stages of Economic Growth, Cambridge, England: Cambridge University Press.

Roszkowski, J.M. (1995), Rola Kościoła na Spiszu i Orawie w podtrzymywaniu polskości oraz $w$ stowakizacji, w: T.M. Trajdos (red.), Spisz i Orawa $w$ 75. rocznice powrotu do Polski pótnocnych części obu ziem, Kraków: Towarzystwo Przyjaciół Orawy, Wydawnictwo i Drukarnia „Secesja”, Związek Polskiego Spisza.

Sagan, I. (2007), Teorie rozwoju regionalnego i ich praktyczne zastosowanie, w: G. Gorzelak, A. Tuchomska (red.), Rozwój, region, przestrzeń, Warszawa: Ministerstwo Rozwoju Regionalnego, EUROREG.

Sarnecki, P. (2013), Ustroje konstytucyjne państw wspótczesnych, wyd. 5, Warszawa: Lex, Wolters Kluwer Polska S.A.

Schaffer, F. (1979), Abriss der Schweizergeschichte, Huber, 12 Auflage, Frauenfeld.

Schumpeter, J. (1960), Teorie rozwoju gospodarczego, Warszawa: PWN.

Secomski, K. (1982), Ekonomika regionalna, Warszawa: Państwowe Wydawnictwo Ekonomiczne.

Sikora, K. (2013), Brazylijski wynalazek podbija Polskę, Angora, 24 marca, nr 12(1188.

Skierka, V. (2008), Fidel Castro. Biografia, tłum. M. Słabicka, Wrocław: Wydawnictwo Dolnośląskie. 
Skorulska, J. (2005), Fundusze strukturalne jako źródto finansowania polityki strukturalnej Unii Europejskiej, w: S. Naruszewicz (red.), Fundusze strukturalne w polityce regionalnej, Białystok: Wydawnictwo Politechniki Białostockiej.

Skrzeszewski, C. (1976), Integralny rozwój gospodarczy, Warszawa: Ośrodek Dokumentacji i Studiów Społecznych.

Śliwa, J. (2006), Fundusze unijne - rodzaje i sposoby wyboru. Finanse i rachunkowość zarządcza, Problemy Zarządzania, nr 4(14), Warszawa: Wydawnictwo Naukowe Wydziału Zarządzania UW.

Śliwa, J. (2008), Fundusze unijne bez tajemnic, Warszawa: Wydawnictwo Naukowe Wydziału Zarządzania UW.

Śliwa, J., Pawlicki, R. (2012), Zarzadzanie funduszami unijnymi dla przedsiębiorców, Warszawa: Wydawnictwo Naukowe Wydziału Zarządzania UW.

Słodczyk, J. (2003), Przestrzeń miasta i jej przeobrażenia, Opole: Wydawnictwo Uniwersytetu Opolskiego.

Smolorz, M. (2012), Śląsk wymyślony, Katowice: Wydawnictwo Regionalne Studia: Antena Górnośląska.

Sobczyński, M., Zawadzka, B. (1988), Orawa polska. Problemy geograficzno-polityczne i spoteczne, Łódź: Zarząd Wojewódzki PTTK, Regionalna Pracownia Krajoznawcza.

Sokołowska, S. (2009), Organizacja i zarzadzanie. Ujęcie teoretyczne, wyd. III, Opole: Uniwersytet Opolski.

Sprawozdanie Ministerstwa Rozwoju Regionalnego dla potrzeb Komisji Europejskiej, grudzień 2006 r., Warszawa.

Sprawozdanie okresowe z realizacji Zintegrowanego Programu Operacyjnego Rozwoju Regionalnego (ZPORR) - stan na dzień 31.10.2006 r., Ministerstwo Rozwoju Regionalnego, grudzień 2006 r., Warszawa.

Stone, C. (1989), Regime Politics: Governing Atlanta, 1946-1988, Lawrence: University Press of Kansas.

Strzelecki, Z. (2008), Polityka regionalna, w: Z. Strzelecki (red.), Gospodarka regionalna i lokalna, Warszawa: Wydawnictwo Naukowe PWN.

Sukiennicki, W. (1973), Amerykański memoriał Paderewskiego, Zeszyty Historyczne, nr 26(235), Paryż: Instytut Literacki.

Swaniewicz, P. (2005), Nowe interpretacje polityki miejskiej, Studia Regionalne i Lokalne, nr 4, Warszawa: Uniwersytet Warszawski.

Szafran, J. (2012), Polska Wschodnia w polityce spójności Unii Europejskiej, w: B. Jóźwik, M. Sagan (red.), Rozwój Polski Wschodniej. Ograniczenia i wyzwania, Warszawa: Difin S.A.

Szlachta, J. (1992), Interwencjonizm państwa w przebieg procesów rozwoju regionalnego świetle doktryny neokeynesowskiej $i$ neoliberalnej, w: B. Winiarski (red.), Polityka regionalna $w$ warunkach gospodarki rynkowej, Wrocław: Zakład Narodowy im. Ossolińskich, Wydawnictwo Polskiej Akademii Nauk.

Szlachta, J. (1999), Programowanie rozwoju regionalnego w Unii Europejskiej, Warszawa: Wydawnictwo Naukowe PWN.

Szul, R. (2007), Teorie i koncepcje w polityce regionalnej, w: G. Gorzelak, A. Tuchomska (red.), Rozwój, region, przestrzeń, Warszawa: Ministerstwo Rozwoju Regionalnego, EUROREG.

Tarnawa, A., Zadura-Lichota, P. (2012), Raport o stanie sektora małych i średnich przedsiębiorstw w Polsce w latach 2010-2011, Warszawa: Polska Agencja Rozwoju Przedsiębiorczości (PARP). 
Tiebaut, C. (1962), The Community Economic Base Study, New York: Committee for Economic Development.

Tiebout, C. (1956a), Exports and Regional Economic Growth, Journal of Political Economy, Vol. 64, No. 2, Chicago, Illinois: University of Chicago Press.

Tiebout, C. (1956b), A Pure Theory of Local Expenditures, Journal of Political Economy, Vol. 64, No. 5, Chicago, Illinois: University of Chicago Press.

Toczyński, W., Mikołajczyk, A. (2001), Polityka Regionalna, Gdańsk: Gdańska Wyższa Szkoła Humanistyczna.

Toczyński, W., Sartorius, W., Zaucha, J. (red.) (1997), Międzynarodowa wspótpraca regionów. Wybór ekspertyz, Warszawa: Zespół Zadaniowy ds. Polityki Strukturalnej w Polsce.

Todl, G. (2001), Convergence After Divergence? Regional Growth in Europe, Wien, Heidelberg, New York: Springer Verlag.

Trojanek, M. (1994), Oddziaływanie władzy lokalnej na efektywność przedsięwzięć inwestycyjnych, Zeszyty Naukowe Akademii Ekonomicznej w Poznaniu, seria 2, z. 137, Poznań.

Trudgill, P. (1988), Norwich Revisitred: Recent Changes in a English Urban Dialect, English World - Wide, No. 9, London.

Tschirschnitz, A. (1994), Dzieje ludów biblijnych, Warszawa: Wydawnictwo: Sarden i S-ka.

Tyloch, W. (1974), Bliski Wschód, w: M. Jaczynowska (red.), Historia starożytna, wyd. II popr. i uzup., Warszawa: Wydawnictwa Szkolne i Pedagogiczne.

Tymowski, M. (red.) (1996), Historia Afryki do poczatku XIX wieku, Kraków - Warszawa - Wrocław: Zakład Narodowy im. Ossolińskich.

Urbański, J. (1962), Świat zwierzęcy, w: A. Malicki (red.), Geografia Powszechna, T. I: Ziemia środowisko naturalne człowieka, Warszawa: PWN.

Urząd Statystyczny w Białymstoku (2011), Perspektywy rozwoju demograficznego - prognoza do 2035 r., Białystok: Urząd Statystyczny w Białymstoku.

Vernon, R. (1966), International Investment and International Trade in the Product Cycle, Quartely Journal of Economics, No. 80(2), Cambridge, Massachusetts: Harvard University's Department of Economics.

Wallance, H., Ridley, A. (1985), Europe: The Chalenge of Diversity, London, Boston, Henley: Routledge \& Kegan Paul.

Wampler, B. (2007), Introduction to Participatory Budgeting. State of the Debate, w: A. Shah (red.), Participatory Budgeting, Washington D.C.: The International Bank for Reconstruction and Development, The World Bank.

Weber, A. (1929), Theory of the Location of Industry, Chicago, Illinois: University of Chicago Press.

Węcowski, M. (2013), Dlaczego Grecy wymyślili demokrację?, Fokus, Historia, nr 3, Warszawa: Gruner \& Jahr Polska Sp. z o.o.

Weyand, S. (1997), Inter-Regional Associations and the European Integration Process, w: The Regional Dimension of the European Union, Towards a Third Level in Europe, London: Frank Cass \& Co Ltd.

Wiatrak, A.P. (2006), Skala regionalna i lokalna - istota, rozwój i zarządzanie, Problemy Zarzadzania, nr 3(13), Warszawa: Wydawnictwo Naukowe Wydziału Zarządzania UW.

Witkowska, J., Wysokińska, Z. (2002), Integracja europejska. Rozwój rynków, Warszawa - Łódź: Państwowe Wydawnictwo Naukowe. 
Wlaźlak, K. (2010), Rozwój regionalny jako zadanie administracji publicznej, Warszawa: Wolter Kluwer Polska Spółka z o.o.

Wojtasiewicz, L. (1997), Czynniki rozwoju lokalnego - nowe ujęcia metodologiczne, w: W. Maik (red.), Problematyka rozwoju lokalnego $w$ warunkach transformacji systemowej, Biuletyn KPZK, z. 177, Warszawa: Wydawnictwo Naukowe PWN.

Wojtaszczak, K.A. (2004), Fundusze strukturalne i polityka regionalna UE, Warszawa: Oficyna Wydawnicza ASPRA - JR.

Ziewiec, G. (2011), Druga fala globalizacji (1950-1973), Studia Ekonomiczne, nr 1(LXVIII), Warszawa: Instytut Nauk Ekonomicznych Polskiej Akademii Nauk.

Zimmerman, L.J. (2003), Indianie Ameryki Pótnocnej. Dzieje i plemiona, wierzenia i rytuały, Warszawa: Świat Książki.

Zimniewicz, K. (1984), Nauka o organizacji i zarzadzaniu, Warszawa - Poznań: PWN.

\section{Akty prawne}

Konstytucja Rzeczypospolitej Polskiej z dnia 2 kwietnia 1997 roku, Dz. U. z 1997 r. $\mathrm{Nr} 78$, poz. 483.

Rozporządzenie Rady (WE) nr 1698/2005 z dnia 20 września 2005 r. w sprawie wsparcia rozwoju obszarów wiejskich przez Europejski Fundusz Rolny na rzecz Rozwoju Obszarów Wiejskich (EFRROW).

Uchwała Nr 239 Rady Ministrów z dnia 13 grudnia 2011 roku w sprawie przyjęcia Koncepcji Przestrzennego Zagospodarowania Kraju 2030, Monitor Polski z dnia 27 kwietnia 2012 r., poz. 252.

Uchwała Centralnej Komisji do Spraw Stopni i Tytułów z dnia 23 czerwca 2003 r. w sprawie określenia dziedzin nauki i dziedzin sztuki oraz dyscyplin naukowych i artystycznych, Monitor Polski z 2003 r. Nr 40, poz. 586.

Ustawa z dnia 27 marca 2003 r. o planowaniu i zagospodarowaniu przestrzennym, Dz. U. z 2003 r. Nr 80, poz. 717 z późn. zm.

Ustawa z dnia 14 marca 2003 r. o referendum ogólnokrajowym, Dz. U. z 2003 r. Nr 57, poz. 507.

Ustawa z dnia 15 września 2000 r. o referendum lokalnym, Dz. U. z 2000 r. Nr 88, poz. 985.

Ustawa o samorządzie gminnym z dnia 8 marca 1990 r., tekst jednolity Dz. U. z 2001 r. Nr 142, poz. 1591.

Ustawa z 13 listopada 2003 r. o dochodach jednostek samorządu terytorialnego, Dz. U. z 2003 r. Nr 203, poz. 1966.

Ustawa z dnia 14 grudnia 2012 r. o zmianie ustawy o referendum lokalnym oraz ustawy o samorządzie gminnym, Dz. U. z 2013 r. Nr 0, poz. 153.

Ustawa z dnia 2 kwietnia 2009 r. o zmianie ustawy o poręczeniach i gwarancjach udzielanych przez Skarb Państwa oraz niektóre osoby prawne, ustawy o Banku Gospodarstwa Krajowego oraz niektórych innych ustaw, Dz. U. z 2009 r. Nr 65, poz. 545.

Ustawa z dnia 20 kwietnia 2004 r. o Narodowym Planie Rozwoju, Dz. U. z 2004 r. Nr 116, poz. 1206.

Ustawa z dnia 24 czerwca 1999 r. o wykonywaniu inicjatywy ustawodawczej przez obywateli, Dz. U. z 1999 r. Nr 62, poz. 688.

Ustawa z dnia 28 kwietnia 1946 r. o przeprowadzeniu głosowania ludowego, uchwalona przez Krajową Radę Narodową, Dz. U. Nr 15, poz. 105; zm. Dz. U. Nr 26, poz. 166. 
Ustawa z dnia 5 czerwca 1998 r. o samorządzie powiatowym, Dz. U. z 1998 r. Nr 91, poz. 578.

Ustawa z dnia 5 czerwca 1998 r. o samorządzie województwa, Dz. U. z 1998 r. Nr 91, poz. 576.

Ustawa z dnia 6 grudnia 2006 r. o zasadach prowadzenia polityki rozwoju, Dz. U. z 2006 r. Nr 226, poz. 1658.

Ustawa z dnia 24 lipca 1998 r. o wprowadzeniu zasadniczego trójstopniowego podziału terytorialnego państwa, Dz. U. z 1998 r. Nr 96, poz. 603.

\section{Strony internetowe}

2013-spotkania/

http://abeojeden.blox.pl/2012/03/Utopia-Demokracja-posrednia-i-bezposrednia.html http://db.org.pl

http://ec.europa.eu/agriculture/cap-post-2013/legal-proposals/com627/627_pl.pdf.

http://epp.eurostat.ec.europa.eu

http://europa.eu/legislation_summaries/agriculture/general_framework/160032_pl.htm

http://finchin.com/acta-sopas-bigger-brother/

http://forsal.pl

http://forum.investmap.pl

http://mac.gov.pl

http://mac.gov.pl/dzialania/modele-budzetowania-partycypacyjnego/

http://midwig.pomorskie.eu/assets/files/INWESTYCJE/ATRAKCYJNOSC_2011.pdf

http://mogilany.pl/node/954

http://pl.wikipedia.org

http://pl.wikipedia.org/wiki/Stany_Zjednoczone_Polski

http://portalwiedzy.onet.pl

http://siecobywatelska.pl/files/budzet_partycypacyjny_w_europie_avt9.pdf

http://whyeasternpoland.eu

http://wiadomosci.gazeta.pl

http://www.4thmedia.org/2012/02/06/europe-rises-up-against-acta/

http://www.bialystok.pl

http://www.csr.szczecin.pl/pliki/prezentacje/Wozniak_Magdalena_CSR.pdf

http://www.fundusze.malopolska.pl

http://www.funduszeeuropejskie.gov.pl

http://www.google.com

http://www.guardian.co.uk/world/2013/apr/25/reykjavik-mayor-digital-democracy

http://www.ibge.gov.br

http://www.iluminaci.pl/info/nuts-i-polska

http://www.kas.de/wf/doc/kas_29767-1522-8-30.pdf?111219113219

http://www.mg.gov.pl

http://www.mrr.gov.pl

http://www.oecdbetterlifeindex.org

http://www.pi.gov.pl

http://www.politykanarodowa.pl

http://www.prawo24.pl

http://www.qualityoflaws.com/government.aspx 
http://www.regiomoto.pl

http://www.stat.gov.pl/cps/rde/xbcr/gus/pkb_rachunki_regionalne_w_2006.pdf

http://www.stop67.pl

http://www.stopjanosikowe.pl

http://www.swisspolitics.org/politische-struktur/volksinitiative-und-referendum/

http://www.tuv.com/akademia-polska/pl/projekty_europejskie_3_4.html

http://www.ulc.gov.pl

http://www.wykop.pl

http://www.wzp.pl/ewt/ewt_2007-2013/europejska_wspolpraca_terytorialna_2007-2013. htm

http://www.zaglebiedabrowskie.pl/2013/03/05/budzet-partycypacyjny-dabrowa-gorniczahttp://www.zbuntowaniobywatele.pl

http://zarzadzanieblog.blogspot.com

www.albumpolski.pl

www.bialystok.uw.gov.pl

www.ciekawepodlasie.pl

www.dotacjeue.org.pl

www.encyklopedia.interia.pl

www.ewt.gov.pl

www.fundusze strukturalne.gov.pl

www.geodezja.kielce.pl

www.interreg.gov.pl

www.kielce.uw.gov.pl

www.ksng.gugik.gov.pl

www.lubelskie.pl

www.money.pl

www.paiz.gov.pl

www.pois.gov.pl

www.polskawschodnia.gov.pl

www.popt.gov.pl

www.porpw.parp.gov.pl

www.stat.gov.pl

www.wojewodztwo_warminsko-mazurskie.info-polska.com.pl

www.wrota.podkarpackie.pl

www.wrota.warmia.mazury.pl

www.wrotapodlasia.pl

www.zabytki.mazury.pl 


\section{Spis tablic}

Tablica 1. Zestawienie zalet stosowania polityki intraregionalnej i polityki interregionalnej ...................... 27

Tablica 2. Zestawienie wad i zagrożeń związanych ze stosowaniem polityki intraregionalnej i polityki interregionalnej ........... 28

Tablica 3. Powiaty wraz z miastami na prawach powiatów, które są głównymi wpłacającymi na fundusz solidarności (tzw. janosikowe) . . . . . 110

Tablica 4. Gminy w Polsce, które w 2012 r. wpłaciły najwyższe kwoty na rzecz obciążenia ,janosikowego".................... 111

Tablica 5. Regionalny PKB per capita dla pięciu województw Polski Wschodniej oraz dla całego kraju w momencie przystąpienia Polski do UE w 2004 r. (w porównaniu do średniej UE-27 = 100\%) . . . . . 149

Tablica 6. Finansowe środki wsparcia i interwencji przeznaczone dla Polski w ramach funduszy i instrumentów unijnych na lata 2004-2006. . 170

Tablica 7. Stopień wykorzystania środków finansowych pochodzących z funduszy strukturalnych oraz inicjatyw wspólnotowych w odniesieniu do sektorowych programów operacyjnych w latach 2004-2006

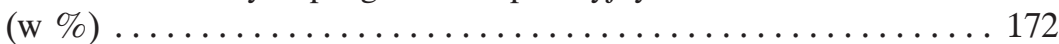

Tablica 8. Ilość pomocowych środków unijnych przyznanych województwom Polski Wschodniej w latach 2004-2006 ................. 173

Tablica 9. Spójność celów w odniesieniu do dokumentów określających kierunki rozwoju regionalnego na lata $2007-2013 \ldots \ldots \ldots \ldots \ldots 174$

Tablica 10. Wielkość środków finansowych z budżetu Unii Europejskiej przeznaczonych na politykę spójności do wykorzystania w ramach Narodowych Strategicznych Ram Odniesienia ............ 175

Tablica 11. Podział funduszy strukturalnych w Polsce na poszczególne progra-

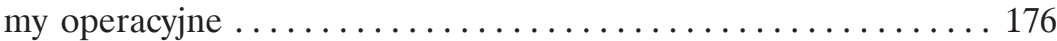

Tablica 12. Podział środków na województwa w ramach Regionalnych Programów Operacyjnych.................... 177

Tablica 13. Podział środków na dziesięć priorytetów Programu Operacyjnego Kapitał Ludzki.............................. 183

Tablica 14. Środki finansowe pochodzące z Europejskiego Funduszu Rozwoju Regionalnego, przeznaczone na PO IG z rozpisaniem na poszczególne osie priorytetowe $\ldots \ldots \ldots \ldots \ldots \ldots \ldots \ldots \ldots \ldots \ldots \ldots \ldots \ldots \ldots \ldots \ldots \ldots$ 
Tablica 15. Podział środków finansowych na cztery priorytety w ramach Programu Operacyjnego Pomoc Techniczna.............. 190

Tablica 16. Podział środków finansowych w ramach Programu Operacyjnego Rozwój Polski Wschodniej na sześć osi priorytetowych ........ 194

Tablica 17. Algorytm podziału środków w ramach PO RPW na województwa Polski Wschodniej......................... 195

Tablica 18. Analiza SWOT dla traktowanego jako całość obszaru Polski Wschodniej........................... 202

Tablica 19. Województwo lubelskie. Analiza SWOT czynników specyficznych dla tego regionu . . . . . . . . . . . . . . . . . . . . . . 204

Tablica 20. Województwo podkarpackie. Analiza SWOT czynników specyficznych dla tego regionu. . . . . . . . . . . . . . . . . . . . . . . 204

Tablica 21. Województwo świętokrzyskie. Analiza SWOT czynników specyficznych dla tego regionu..................... 205

Tablica 22. Województwo warmińsko-mazurskie. Analiza SWOT czynników specyficznych dla tego regionu ................... 206

Tablica 23. Województwo podlaskie. Analiza SWOT czynników specyficznych dla tego regionu ....................... 207

Tablica 24. Napływ bezpośrednich inwestycji zagranicznych (BIZ) do poszczególnych województw w latach $2007-2010$. . . . . . . . . . . 209

Tablica 25. Wielkość bezpośrednich inwestycji zagranicznych (BIZ) na początku 2012 roku w spółkach prawa handlowego działających w Polsce $\cdots 211$

Tablica 26. Ilość spółek handlowych działających przy udziale kapitału zagranicznego w poszczególnych województwach Polski w 2012 roku. . 213

Tablica 27. Waga poszczególnych czynników wyznaczających atrakcyjność

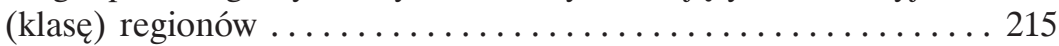

Tablica 28. Klasyfikacja atrakcyjności województw według pięciu klas (w 2005

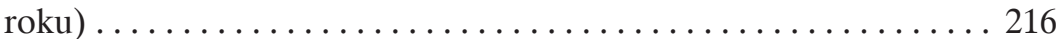

Tablica 29. Klasyfikacja atrakcyjności inwestycyjnej województw według IBnGR

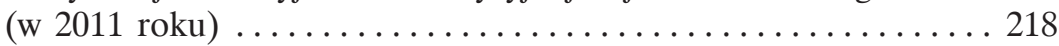

Tablica 30. Zmiany atrakcyjności inwestycyjnej polskich województw w latach

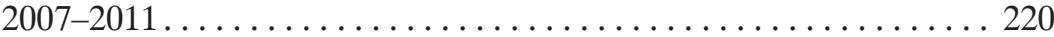

Tablica 31. Zmiany atrakcyjności inwestycyjnej polskich województw w latach

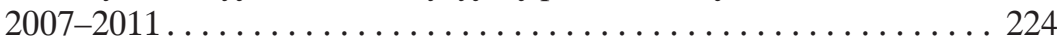

Tablica 32. Wysokość przeciętnego miesięcznego wynagrodzenia brutto w sektorze przedsiębiorstw według województw (w z1). Porównanie lat 2006 i 2012 oraz dynamika . . . . . . . . . . . . . . . . 226

Tablica 33. Zmiany w ruchu naturalnym oraz migracjach ludności według województw (NUTS 2) w 2006 roku oraz w 2011 roku ........ 227

Tablica 34. Porównanie wartości PKB przypadającej na jednego mieszkańca w Polsce w ujęciu regionalnym (ranking) . . . . . . . . . . . 229

Tablica 35. Wzrost PKB na głowę jednego mieszkańca dla Polski w ujęciu regionalnym oraz jego dynamika. Porównanie lat 2006-2010 . . . 231 
Tablica 36. Regionalny PKB per capita (w \%) do średniej UE-27 w okresie od 2004 do 2010 roku . . . . . . . . . . . . . . . . . . . . . . . . 233

Tablica 37. Liczba szpitali ogólnych wraz z liczbą łóżek w Polsce. Porównanie

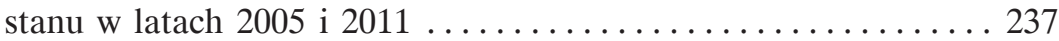

Tablica 38. Największe miasta Polski pod względem liczby ludności według stanu na 31 grudnia 2011 r........................ 241

Tablica 39. Liczba ludności Białegostoku od 2000 do 2012 roku. Dane na 31 grudnia każdego roku ................... 242

Tablica 40. Liczba mieszkańców biorących udział w tworzeniu budżetu partycypacyjnego w wybranych miastach Brazylii w latach 1990-2003. . 275

Tablica 41. Wybrane miasta w Brazylii pod względem liczby mieszkańców w 2010 r. ................................ 276

Tablica 42. Porównanie wybranych kategorii Better Life Index dla Australii, Szwajcarii i Polski ....................... 288

Tablica 43. Wybrane dane i wskaźniki dotyczące okresów przed i po wstąpieniu Polski do Unii Europejskiej. . . . . . . . . . . . . . . . 293

Tablica 44. Ile można kupić za średnią płacę w Polsce. Porównanie lat 2004 i $2013 \ldots \ldots \ldots \ldots \ldots \ldots \ldots \ldots$. . . . . . . . . . . . . . . . . 295 


\section{Spis rysunków}

Rysunek 1. Czynniki sprzyjające powstawaniu regionów............ 36

Rysunek 2. Czynniki etniczne warunkujące powstawanie regionów ....... 44

Rysunek 3. Czynniki gospodarcze kreujące regiony............... 57

Rysunek 4. Cele rozwoju regionalnego ujęte w czterech głównych płaszczy-

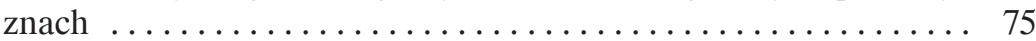

Rysunek 5. Czynniki i przesłanki mające wpływ na lokalizację inwestycji według ogólnego kryterium społeczno-ekonomicznego........ 81

Rysunek 6. Układ jednostek w hierarchii ośrodków centralnych Waltera Christallera.............................. 84

Rysunek 7. Cztery fazy (etapy) cyklu życia produktu ............. 92

Rysunek 8. Pięć bazowych (podstawowych) stadiów rozwoju regionalnego według modelu Walta Rostowa.................... 94

Rysunek 9. Błędne koło ubóstwa według teorii zrównoważonego wzrostu Ragnara Nurske'a ........................... 100

Rysunek 10. Schematyczne ukazanie wspólnych pól działania trzech rodzajów „polityki miejskiej" .............................. 109

Rysunek 11. Główne czynniki endogenicznego wzrostu regionalnego . . . . . 118

Rysunek 12. Podział administracyjny Polski (na województwa) ........... 148

Rysunek 13. Pięć województw tworzących Polskę Wschodnią na mapie Polski....................................... 150

Rysunek 14. Podział administracyjny województwa lubelskiego (na powiaty). 152

Rysunek 15. Podział administracyjny województwa podkarpackiego (na powiaty) ................................ 154

Rysunek 16. Podział administracyjny województwa świętokrzyskiego (na powiaty) .............................. 157

Rysunek 17. Podział administracyjny województwa warmińsko-mazurskiego (na powiaty)............................... 159

Rysunek 18. Podział administracyjny województwa podlaskiego (na powiaty). . 163

Rysunek 19. Podział środków finansowych Programu Operacyjnego Innowacyjna Gospodarka na dziewięć osi priorytetowych.............. 185

Rysunek 20. Obszary w Polsce objęte działaniami w ramach PO EWT..... 187 Rysunek 21. Podstawy założeniowe analizy SWOT ................. 201 
Rysunek 22. Sieć istniejących (i planowanych) autostrad w Polsce według danych z 2013 roku. . . . . . . . . . . . . . . . . . . . . 235

Rysunek 23. Istniejące w Polsce porty lotnicze o znaczeniu międzynarodowym i regionalnym wraz z liczbą odprawionych przy ich udziale pasażerów w 2012 roku . . . . . . . . . . . . . . . . . . . . . . 236

Rysunek 24. Zmiany w liczbie mieszkańców Białegostoku w latach 2000-

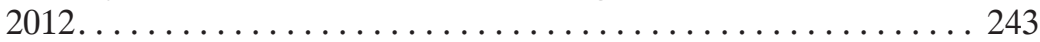

Rysunek 25. Hierarchia ustrojów wg Arystotelesa, ze względu na kryterium przydatności dla funkcjonowania i organizacji państwa . . . . . 255

Rysunek 26. Cykl zmian ustrojowych na przykładzie postkolonialnej Libii . . 256

Rysunek 27. Cykl zmian ustrojowych na przykładzie Francji........... 257

Rysunek 28. Cykl zmian ustrojowych na przykładzie powojennej Kuby...... 258

Rysunek 29. Cykl zmian ustrojowych na przykładzie Singapuru, od momentu uzyskania pełnej niepodległości w 1965 r. . . . . . . . . . 259

Rysunek 30. Frekwencja obywateli w referendach ogólnokrajowych w okre-

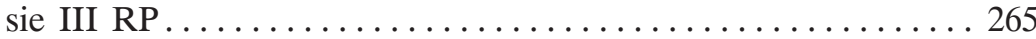

Rysunek 31. Podział referendów w Polsce, według kryterium terytorialnego . 268

Rysunek 32. Mapa protestów przeciwko porozumieniu ACTA w Europie

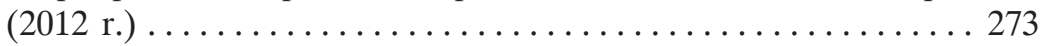

Rysunek 33. Wybrane miejsca na świecie, gdzie w 2010 roku, stosowane było zarządzanie ośrodkami miejskimi oparte na budżecie obywatel-

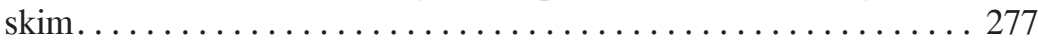

Rysunek 34. Etapy tworzenia budżetu obywatelskiego na przykładzie Sewilli w Hiszpanii . . . . . . . . . . . . . . . . . . . . . . . . . . . . 279

Rysunek 35. Procedura tworzenia budżetu obywatelskiego na przykładzie Dąbrowy Górniczej ..................... 280

Rysunek 36. Wzrost średniego wynagrodzenia w Polsce, od 2004 do czerwca 2013 r. (w zl) . . . . . . . . . . . . . . . . . . . . . . . . . . . . . 294

Rysunek 37. Makroregiony w Polsce (NUTS 1) według unijnej nomenklatury dla celów statystycznych..................... 298

Rysunek 38. Pięć głównych funkcji administracji (zarządzania) według Henriego Fayola ............................ 303

Rysunek 39. Współczesne określenie pięciu funkcji administracji (zarządzania)

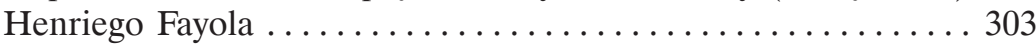

Rysunek 40. Piramida potrzeb Maslowa . . . . . . . . . . . . . . . 306 



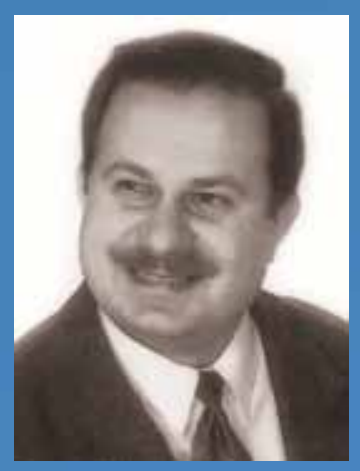

Mirosław Przygoda - doktor nauk ekonomicznych w dziedzinie zarządzania. Jest adiunktem w Katedrze Finansów i Rachunkowości na Wydziale Zarządzania Uniwersytetu Warszawskiego. Specjalizuje się w zagadnieniach dotyczących finansów przedsiębiorstwa oraz metod i instrumentów zarządzania finansami. Stypendysta szkół wyższych w Austrii, w Niemczech, w Szwajcarii i w Wielkiej Brytanii. Wieloletni doradca w Ministerstwie Przekształceń Własnościowych (obecnie Ministerstwo Skarbu Państwa), członek licznych rad nadzorczych, współpracownik firm konsultingowych, wykładowca wielu renomowanych uczelni. Posiada bogaty dorobek naukowy w zakresie wykorzystania unijnych środków finansowych. 